Universidad Nacional de La Plata

Facultad de Ciencias Jurídicas y Sociales

Director: Prof. Dr. Alberto Guillermo Ranea

\title{
LEGITIMIDAD Y LEGITIMACIÓN EN LA ARGENTINA
}

1853-1930

Una relación dialéctica que no siempre resulta condición veritativa

María Cristina Linchetta

LA PLATA-2013 


\section{INDICE.}

Prólogo

Introducción.

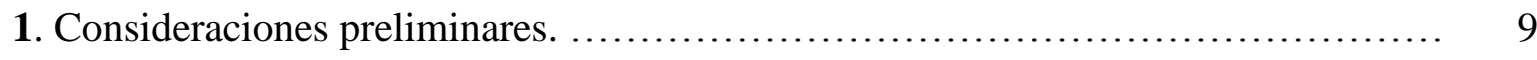

2. Identidad nacional. .................................................. 11

3. Poder y obediencia.................................................... 12

4. La legitimidad como problema político: fuentes y conceptos $\ldots \ldots \ldots \ldots \ldots \ldots \ldots, 14$

a) Punto de vista politológico:

Guglielmo Ferrero................................................ 15

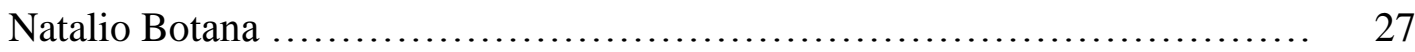

b) La mirada sociológica:

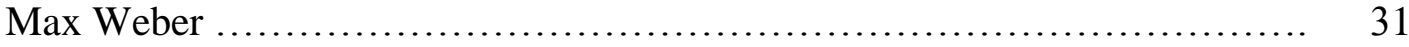

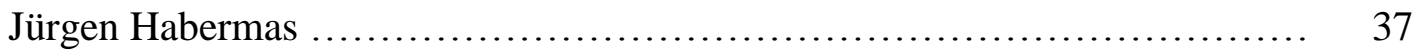

David Easton ...................................................... 38

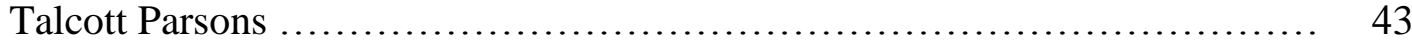

Carlos Barbé ........................................................ 44

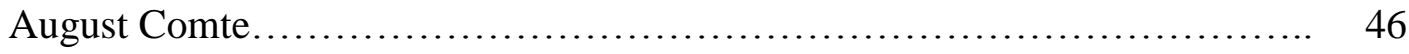

c) Enfoque jurídico:

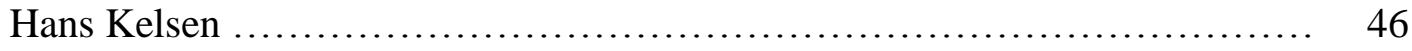

George Burdeau............................................... 48

d) El análisis filosófico:

Raymond Polin ...................................................... 52

5. El proceso de legitimación: fuentes y conceptos.......................... 52

a) Desde la Politología:

Maurice Duverger............................................... 53

Carl J. Friedrich ................................................ 58

b) Visión de la Sociología:

Carlos Barbé....................................................... 62

Jürgen Habermas............................................... 71

Seymur M. Lipset............................................. 75

Talcott Parsons....................................................... 78 
c) Perspectiva filosófico-jurídica:

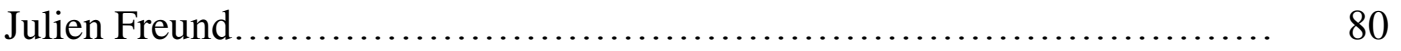

Carl Schmitt....................................................... 81

6. Algunas inferencias en torno a la teoría................................ 85

Capítulo I. Legitimidad vigente y la adoptada $\ldots \ldots \ldots \ldots \ldots \ldots \ldots \ldots \ldots \ldots \ldots, 92$

Génesis de la formación política: Sociedad Civil y Estado.

1. A modo de introito............................................ 92

2. Espacio y población............................................. 95

3. La formación social argentina.................................... 97

4. La formación política como expresión de sistema de alianzas sociales.... 99

4.1. Hitos: Años 1810-1820 y 1826-1837............................ 101

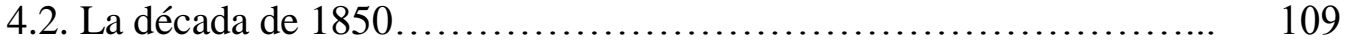

4.2.1. Aparición de ideas fuerzas............................. 110

4.2.2. Los hombres de la Asamblea Constituyente.................. 111

4.2.3. El Acuerdo de San Nicolás................................. 114

4.3. Año 1852 - Las Elecciones - Análisis de la Asamblea General

Constituyente.............................................. 117

4.3.1. Los Diputados Constituyentes.......................... 121

4.3.2. Comisión de Asuntos Constitucionales...................... 123

4.3.3. Las sesiones - Análisis de la Minuta - Intervenciones significativas: Huergo - Presidencia de la Asamblea - Aprobación de la Constitución Nacional..................................... 126

4.3.4. La Constitución Nacional llega a la Provincia de Buenos Aires Panorama político, social y económico - La Convención de la Provincia de Buenos Aires - Las sesiones............... 140

4.4. Reforma Constitucional de 1860 - La Convencional Nacional ad hoc -

Los Diputados - Las sesiones............................... 150

\section{Addenda Capítulo I.}

1. 1860- La República Argentina y el "Estado" de Buenos Aires: normalidadnormatividad................................................. 157

2. La formación social como base de la formación política (1862/1868, 1868/1874, 


\section{Capítulo II. 1890 - Crisis por déficit de legitimidad.}

1. La década.

2. Esbozo de revolución. 2.1. La Unión Cívica. 2.2. Revolución del parque.

2.3. U.C.N-U.C.R. 183

3. 1893-1895: nuevos intentos revolucionarios

4. Roca y su segunda presidencia. 4.1. Sistema electoral: Ley $\mathrm{N}^{\circ} 4.161$ (1903).

4.2. 1905 - Revolución 193

5. Las coyunturas revolucionarias 196

6. Años 1910-1914: regímenes electorales - Censo de 1914 200

Capítulo III. 1916. Nueva legitimidad por legitimación del sistema y de los elementos del sistema.

Principio electivo-democrático. Sistema de Partidos. Primer gobierno popular.

1. El principio electivo-democrático................................ 204

1.1. Aplicación de la Ley Sáenz Peña................................... 205

1.2. El rol de los partidos políticos y de la UCR. El surgimiento del ciudadano y de la voluntad popular como elementos del sistema político................... 207

2. Hipólito Yrigoyen: primer gobierno popular y legítimo................ 209

3. Ejercicio del concreto poder............................................. 211

4. Sentido ético y establecimiento de políticas de estado. .................. 213

5. Nuevo gobierno popular: Alvear................................. 228

6. 1928 - Segunda Presidencia de Yrigoyen ........................... 236

\section{Capítulo IV. 1930. Deslegitimación del sistema. Fractura institucional. Gobierno de}

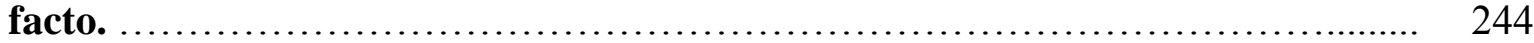

1. El "golpe". Prisión y reclusión de Yrigoyen .......................... 247

2. La conspiración ¿sólo ensayo fascista-corporativo? El contubernio........... 249

3. Acordada de la Corte Suprema de Justicia. Validez del gobierno de facto... 253

4. José E. Uriburu. Manifiesto del $1^{\circ}$ de octubre de $1930 \ldots \ldots \ldots \ldots \ldots \ldots \ldots . . . . . .255$

5. El periodismo y la opinión pública............................... 256

6. Respuestas del accionar corporativo............................. 257

7. Los intelectuales y la sociedad civil............................... 259 
8. Agustín P. Justo: segunda fase del contubernio...................... 262

9. Regreso y muerte de Yrigoyen.................................. 265

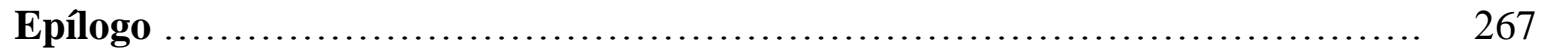

Conclusiones.................................................... 271

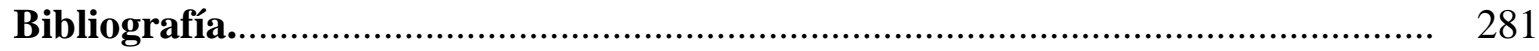

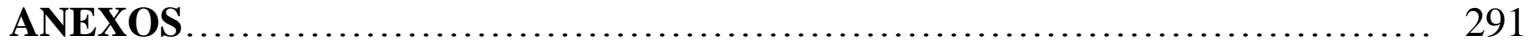

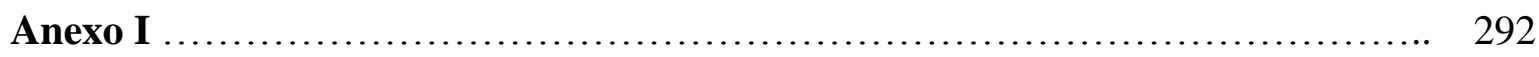

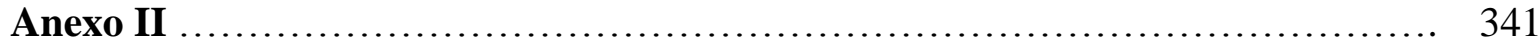

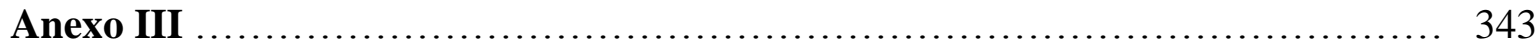


A la memoria de mis padres. $Y$ en reconocimiento a quienes, incondicionalmente, supieron acompañarme.

\section{PROLOGO}

Si en las democracias, como en las monarquías, el poder viene de arriba, en las monarquías como en las democracias, la legitimidad viene de abajo, puesto que únicamente el consentimiento de aquellos que tienen el deber de obedecer puede crearla. Por lo tanto, en todos los regímenes, es en el punto donde se encuentran las dos líneas -la una descendente, el poder, y la otra ascendente, la legitimidad-que se realiza la plenitud del Estado. (Ferrero, 1943:193)

La humanidad toda registra desde el inicio de los tiempos distintos "pactos y/o contratos" -en la Biblia: Moisés; en los Reinos Germánicos: Carlomagno; en la Edad Media: los contratos de vasallaje; en la Revolución Inglesa de 1688: la monarquía constitucional y el "Bill of Rights de 1689; en la Revolución Francesa de 1789: Luis XIIIpor medio de los cuales los hombres han bregado en la consecución de formas de vida, vida en forma y formas que nacen de la vida.

Si estamos contestes en la importancia que han revestido y revisten los acuerdos y contratos, es porque surgen cuando los hombres se unen, actúan juntos, de común acuerdo, vinculados por la fuerza de las "promesas" que los han llevado a concretarlos (la llamada 
memoria de la voluntad, Nietzche, $1980\left(1972^{1}\right)$, p.66). Convenciones que desaparecen cuando los hombres se dispersan, pues entonces pierden la fuerza que los mantuvo unidos: la fuerza del contrato. (Arendt, 2012) ${ }^{1}$

Y es, precisamente, en la búsqueda por armonizar la dialéctica entre libertad-poder, que el concepto, la idea, de legitimidad, recupera el sentido y la significación que los hombres han dado y dan a la relación de poder. (Botana, 1968: 13)

Dialéctica que se integra con el esquema de legitimación que implica una "imagen o representación” generada en la internalización de valores (no inmutables) por parte de un grupo o sector de hombres que -en tanto antecedente de la creencia- es lógica consecuencia de aquella representación. Paradigma que, en definitiva, es el resultado de la institucionalización de valores que, articulados, delinean todo un modo de vida o proyecto de vida o diseño de vida (Barbé, 1973:42-43)

Si bien el hecho de la legitimidad es universal, vale decir que se encuentra ampliamente atestiguado, los principios que la sustentan son diferentes en todos los casos. $\mathrm{Su}$ carácter analítico-operacional, está insoslayablemente unido a la valoración, a la 'historia de vida', de cada actor social en tanto integrante de una sociedad civil acotada espacio temporalmente.

El acontecer humano se da, acaece en lo substancial, de manera ininterrumpida. Existe, pues, 'una continuidad de fondo'. Vale decir que, no obstante las variables que formalmente se multiplican en la humanidad, subsiste, se mantiene, una unidad que hace a la esencia vital y que se reproduce a lo largo de la existencia. (Bobbio, 1985: 11) ${ }^{2}$

Y es en este "acontecer humano" en donde se concreta el proceso de legitimación.

\footnotetext{
${ }^{1}$ Sostiene Arendt (2012: 263) como contrapartida, y en la lógica que encierra la imposibilidad de 'predecir' y el poder de la 'promesa' que: "El peligro y la ventaja inherente a todos los cuerpos políticos que confian en contratos y tratados radica en que, a diferencia de los que se atienen al gobierno y la soberanía, dejan tal como son el carácter de no-predicción de los asuntos humanos y la desconfianza de los hombres, usándolos simplemente como el expediente, por decirlo así, en el que se arrojan ciertas islas de predicción y se levantan ciertos hitos de confianza. En el momento en que las promesas pierden su carácter de aisladas islas de seguridad en un océano de inseguridad, es decir, cuando esta facultad se usa mal para cubrir todo el terreno del futuro y formar una senda segura en todas direcciones, pierden su poder vinculante y, así, toda la empresa resulta contraproducente".

${ }^{2}$ El autor cita, en tal sentido, a Maquiavelo (Discorsi, III, 43): 'Suelen decir los hombres prudentes, y no a bulto ni sin mérito que quien quiera ver lo que ha de ser, que considere lo que ha sido: porque todas las cosas del mundo tienen en todo tiempo su correspondencia con los antiguos tiempos. Lo que procede de que, al ser aquéllas realizadas por los hombres que tienen y han tenido siempre las mismas pasiones, resulta de necesidad que les siga el mismo efecto".
} 
Generador -a la par que debido correlato- de la legitimidad atribuida a un poder. Proceso, interacción, por cuyo intermedio se manifiesta, el proyecto, el diseño de vida pergeñado "desde abajo" por la sociedad civil. Fundamentando esta postura, intentaremos brindar algunas aproximaciones que, desde nuestra óptica, proporcionaron el marco que rodeó la configuración de la formación política argentina a partir de su origen. Ello reconociendo las limitaciones y los obstáculos que significó interpretar el devenir histórico.

De modo que, si la legitimidad es propia de la sociedad política -porque justifica el poder público y a quien o quienes lo detentan- y la legitimación es propia de la sociedad civil en tanto sistema de creencias, objetivos, modos de vida, valores y principios compartidos, o no, por el colectivo social, esclarecer el concepto de una y otra, constituyó nuestro insoslayable desafío.

Así, al reconstruir distintos escenarios, recurriendo a las coordenadas de tiempo y de espacio, buscamos demostrar la existencia de una deslegitimación latente en el entramado social argentino, que, entendemos, resultó producto de una sociedad civil débil -por déficit de legitimación- generadora, a su turno, de una formación política (sistema político) débil, por crisis de legitimidad. 


\section{INTRODUCCIÓN.}

\section{Consideraciones preliminares.}

Al leer por primera vez a G. Ferrero, pensamos, como él, que sólo era posible comparar los variopintos regímenes políticos que existieron, existen y existirán, utilizando inferencias (falaces o no) y conjeturas, como también explicaciones tal vez inconsistentes per se, por lo que no resultaría viable comparar la realidad efectivamente acaecida con deducciones intelectuales.

Sin embargo, en un intento por comprender los llamados genios invisibles de la ciudad" como generadores de los principios de legitimidad y su gravitación en la construcción del Estado argentino, compartimos también su idea sobre que -al interior de las sociedades- existen ciertas fuerzas que, al igual que los seres humanos nacen, se desarrollan y mueren pero que resultan intangibles cual si fueran genii (palabra con la que los romanos designaban a los genios). Seres estos que ocupaban un lugar intermedio entre los dioses y los hombres y que, invisibles, se encuentran omnipresentes en el colectivo para ayudar o atormentar. Condición ésta, "ser intangibles", que llevó a ignorar no solo su presencia, sino su existencia, sin reparar que esos genios invisibles rigen para bien o para mal la vida y el comportamiento de los hombres. Y no es que existan "buenos" y "malos" ya que lo son sucesivamente. Vale decir, el que ayuda hoy, mañana puede atormentar y viceversa. (Ferrero, 1943: 29)

También sabíamos que el humanismo acompañado de movimientos como el Renacimiento, los descubrimientos y avances científicos, así como la colonización de América, despertó el espíritu crítico de los hombres, al aumentar su confianza en ellos mismos, en la fuerza de su voluntad y en su inteligencia. Circunstancias éstas, que poco a poco fueron atenuando ese primigenio determinismo -señalado por la existencia de los genios- favoreciendo la aparición, aunque -deber es reconocerlo- muy despaciosamente de individuos que, primando el raciocinio y la razonabilidad, intentaron una praxis agonista, 
superando el mero antagonismo, para, de ese modo, favorecer el bienestar y el progreso.(Ferrero, 1943: 71).

Considerando a la política no solo como natural sino también como una actividad netamente social, la individualidad que caracterizó -y caracteriza- lo que debió ser un tejido social gestado, como sostuvo Santo Tomás de Aquino, en la "amistad política" dando origen al Estado (Sabine, 1990:189-194 y cc.), no tuvo lugar en nuestro caso, por la sola razón que, en el período de conformación del pacto social, no se habló del concreto poder, de la legitimidad como problema político, de la legitimación como resultado y origen de aquella, sino que el tema preocupante, al momento de darse una Constitución -"el" pacto fundacional- y como lógico corolario de la guerra fratricida, fue resolver la secular porfía de la organización nacional bajo el ideario unitario o federal.

Si la Historia no es sólo un conjunto de fechas, batallas y grandes personajes, ¿cómo conocer realmente qué pasó con los conflictos, expectativas y demandas que estuvieron en debate y las circunstancias en que acontecieron? ¿Cómo reconstruir hechos y procesos del pasado, acaecidos en el entramado social, si faltan las voces de los testigos y de los auténticos protagonistas de la ciudadanía, verdaderos actores sociales? Esto es, ¿cómo lograrlo, sin contar con la "objetiva certeza” de la acción comunicativa que existió 'allá y entonces'?

$\mathrm{Si}$, además, la cultura, fundamentalmente, y el condicionamiento cultural con que el ser humano enfrentó los problemas existenciales, otorgaron respuestas en este sentido y descartando el llamado "estado de naturaleza"- la solidaridad, la creación de lazos fraternos, definitivamente la cooperación, resultaron la principal condición humana, esta affectio societatis producto de un sentir racional y "razonable" -antes que jurídico- provocó la evolución, como también la involución, de las organizaciones humanas. Extremos estos conducentes a la denominada, democracia consentida (Botana, 1968)

Un pensador del siglo XIV, al analizar esta problemática, descubrió la existencia en las sociedades de una pauta recurrente: un "destino común" o asabiyah. El sentido de pertenencia grupal, de solidaridad, es, pues, lo que permitió a distintas organizaciones sociales (familias, dinastías, civilizaciones, formaciones políticas) el ascenso colectivo y, consecuente con ello, a la riqueza generalizada. Por el contrario, la inexistencia del sentido de pertenencia, vale decir, de compartir un “destino común”, desembocó, inexorablemente, 
en el descenso del colectivo y un masivo y generalizado descontento.

De donde, si

“...la cooperación como condición humana primordial está asociada a la 'asabiyah' como práctica ciudadana..." (Tokatlian, 2005:.21), ello pareciera no haber acontecido en nuestro caso.

\section{La identidad nacional.}

Sin duda que el haber enfocado estudios que poseen cierto grado de abstracción, dificultaron operacionalizar la realidad. De allí que buscaremos describir, para luego lograr la debida síntesis.

La apropiación territorial -ideológicamente hablando, creación de identidad nacional- es un requisito que todo estado -que pretenda ser "fuerte"- debe tener como obligada télesis. A cumplimentar ese objetivo debieron entonces volcarse tanto los estados provinciales, cuanto sus elites dirigenciales en búsqueda de la organización nacional.

Para ello fue necesario que políticos e intelectuales se situaran frente a la cuestión de la identidad nacional y de sus formas de constitución. La formación de una elite internalizada en los valores sociales de este bloque hegemómico, estuvo conformada por hombres provenientes de familias de "nombre" acompañados por antecedentes históricos que trasvasaron la hegemonía política llegando a la cultural para, de este modo, llegar a la sociedad civil toda, utilizando, por ejemplo, la primegenia prensa, los periódicos fieles a su ideología.

No solo no se "quitó la vista" de Europa, sino que -en muchos casos- se ignoró la propia realidad, olvidando la búsqueda y análisis de peculiaridades regionales. No mediaron acciones comunes aglutinantes, sino que, muy por el contrario los "localismos" se exacerbaron, a no dudar por carencia -de la que aún estamos faltos y que necesitamos conseguir- de "capital social". Genéricamente hablando, el incipiente entramado social careció de "virtud republicana", no se interesó por la res publica, condiciones estas que, de modo cuasi inexorable y cual hilo conductor, conducen a la debida participación institucional. Participación que genera el necesario "capital social", permitiendo que la interacción se construya sobre la base de relaciones de confianza (Putnam, 1993) lo cual hubiera superado, quizás y en principio, la desconfianza, resolviendo en cualquier caso, el enigma de la "acción colectiva".

Nos preguntamos ¿cuál fue el "proyecto” político en acción? ¿existió un "modelo" 
político? ¿Lo hubo en el '53, en el '60, en el '80, en 1916? ¿acaso podemos hablar de ello a partir de 1930, con la primer fractura del estado legitimado en 1916? ¿o se trató, de un mero artilugio político?

Veamos. La complejidad se hizo presente a poco que comenzamos con el análisis del proceso de "conformación del estado argentino": mezcla de diversos grupos étnicos, convivencia de burguesía-terrateniente-hacendada con "peonadas" y procesos de ascenso social sólo para algunos. Esto, a no dudar, evidenció una "lógica" de organización política y social bien diferenciada y, a decir verdad, poco virtuosa.

La aceptación de la forma "federal" para la articulación del sistema político formalmente hablando, nunca en la praxis- no impidió la preeminencia de las provincias que habían tenido éxito desde el punto de vista económico. Por lo que, la oligarquía terrateniente-hacendada no estuvo dispuesta a someter sus intereses específicos de clase a los intereses nacionales, sino, por el contrario, buscó establecer su prevalencia.

\section{Poder y obediencia.}

Para deslindar la problemática del poder y la obediencia, esto es de la relación dialéctica y conflictiva entre quienes detentaron roles de autoridad y aquellos que debieron obedecer y que, al igual que ocurriere en el orbe todo, signara también nuestra república desde su nacimiento, hemos de imbricar la teoría política con nuestra praxis histórica, analizando, para ello, la vigencia de las categorías conceptuales en los sistemas de poder de la formación política argentina durante el período 1853/1930.

La aseveración de $\mathrm{N}$. Botana, que señaláramos en nuestras primeras palabras, nos permitió abordar -para el análisis de la problemática- diferentes perspectivas de investigación. Por ello, en una primera aproximación, los enfoques metodológicos de Joseph Vialatoux y David Easton habrán de auxiliarnos en nuestra tarea.

i) Desde una visión normativa, J. Vialatoux encuentra el fundamento de la legitimidad en el derecho natural que consiste en la obtención del "bien común".

Un poder no será racional y razonablemente legitimo más que por su finalidad, sus objetivos, definitivamente, su razón de ser. De modo que, el poder de gobernar un pueblo tiene como fundamento racional y de derecho natural el bien de la comunidad, estar al servicio de ese pueblo, bregar en la consecución del 'bien común'. (Vialatoux, 1945:28) El poder legítimo de un pueblo es el que, acogido y llevado por el consentimiento popular, 
procura servir el bien común. Así entendido y legitimado, el principio supremo del Poder deviene del Creador, ya que el Poder legítimo está en Dios. (Vialatoux, 1945:12)

ii) Por su parte David Easton, sostiene desde la óptica explicativa, que la idea de legitimidad será siempre empleada en un sentido psicológico además de moral.

Desde el punto de vista psicológico, una acción es legítima cuando es aceptada como tal por el pueblo. De manera que una acción no será moral, cuando no se conforme a una regla dada y consentida como tal (Easton, 1964:159) en la medida en que, la legitimidad, es un concepto empleado para describir y explicar un fenómeno político recurrente. En ese sentido, diremos que la noción de legitimidad encierra, en un sentido amplio, la aceptación generalizada de una acción situada al interior del colectivo político.

Ambos autores están de acuerdo en que, el consentimiento del pueblo o la aceptación popular, constituyen la condición del ejercicio legítimo del poder.

No obstante, Vialatoux va un poco más lejos ya que se basa en la cuestión filosófica del primer fundamento y del destino esencial del poder que "encierra una concepción general del hombre y del mundo”. (Maritain, 1957, II: 37)

Analizando una y otra, entiende Botana que entre las dos posturas existe un lazo indisoluble.

Mientras que para Easton (explicativa) se trata, de la elaboración de un concepto que permite comprender la lógica interna de un conjunto de fenómenos políticos; para Vialatoux (normativa) se trata de la elaboración doctrinal de un principio (ó principios) desde el que pueden establecerse las condiciones ideales de legitimidad del poder y el consecuente deber de obediencia de los ciudadanos (sea en razón de su origen -o "por qué"; sea -“en vista de”- esto es, en razón de su finalidad). (Botana, 1968:16) ${ }^{3}$

Comparar estos contenidos permitirá conocer el significado que esos fenómenos

\footnotetext{
${ }^{3}$ El autor cita a B. de Jouvenel (1947:36) y sostiene que el punto de vista de este último, es un poco diferente del suyo ya que -de Jouvenel- reserva el campo de aplicación de la noción de legitimidad a los fenómenos de obediencia que derivan de la perspectiva del "por qué". En tal sentido dice B. de Jouvenel: "[...] afirmamos que el Poder debe ser obedecido, sea 'por qué' sea 'en vista de'. En relación al 'por qué' hemos desarrollado las teorías de la Soberanía. La causa eficiente de la obediencia, decimos, reside en un derecho ejercido por el Poder derivado de la 'Majestas' que posee, encarna o representa. Detenta ese derecho por la condición necesaria y suficiente de ser 'legítimo', es decir, en razón de su origen[...] Respecto al otro punto de vista hemos desarrollado teorías de la Función del Estado. La causa final de la obediencia, a nuestro juicio, consiste en el 'fin' que persigue el Poder, que es el 'Bien Común', del modo que, además, lo concibe. Para merecer la docilidad de los sujetos, es necesario y suficiente que el Poder busque y procure el Bien Común."
} 
tienen para el actor, a la par que conocer la "multiplicidad de significaciones".

De tal modo, para la óptica explicativa la realidad política está compuesta por un conjunto de significaciones en medio de las cuales, los hombres valorizan la configuración que toma el poder en el seno de una colectividad. Significaciones éstas que parten de la propia realidad, de esa peculiar "efectividad humana", por lo que, no podemos dejar de conocerla. Esta "explicación" tampoco puede desentenderse de la relación "sujetos/valores", ya que, definitivamente es la persona-humana la que integra el campo de análisis de esa realidad.

N. Botana analiza la legitimidad como problema político, considerando la categoría tematizada, como un concepto operacional -valorativo, axiológico- en la intención de volver perceptibles una serie de fenómenos políticos y, al propio tiempo, en la búsqueda por determinar la lógica interna de los mismos, dada su complejidad, teniendo en cuenta que, el proceso de atribución de legitimidad puede alcanzar diferentes grados. (Botana, 1968:201-202) ${ }^{4}$

El grado de legitimidad de un régimen político resultará difícil de establecer a raíz de todos los matices que puede presentar la expresión concreta de la creencia y del acuerdo compartido por gobernantes y gobernados. Esto es, la significación, la valoración axiológica que el actor social atribuye a esos fenómenos, lo cual implica una referencia al comportamiento político y la directa relación del poder y la legitimidad. (Botana, 1968:213) ${ }^{5}$

\section{La legitimidad como problema político. Fuentes y conceptos.}

Un primer interrogante se impone ab initio si nos remontamos a la doctrina clásica.

Cuando hablamos de legitimidad, ¿lo hacemos en relación a las formas de gobierno: monarquía-aristocracia-democracia?; al poder: ¿quién y cómo lo ejerce?; a las instituciones:

\footnotetext{
${ }^{4}$ Botana define la noción de legitimidad como "[...] la cualidad que puede revestir un régimen político cuando: a) existe una creencia compartida por los gobernantes y los gobernados con respecto a la traducción institucional de un principio de legitimidad; b) existe un acuerdo entre gobernantes y gobernados con respecto a las reglas que rigen la solución de los conflictos nacidos en ocasión de la transferencia del gobierno."

5 Para este autor, ambas categorías, creencia y acuerdo, tienen directa referencia con los dos momentos en que se perfecciona el proceso de legitimación, originando grados de legitimidad y de paralelos regímenes políticos, a saber: a) legitimidad plena- régimen estable; b) legitimidad parcial- régimen inestable y c) ilegitimidad- régimen en crisis. La creencia valoriza la traducción institucional de un principio de legitimidad (característico de un régimen monocrático). A su turno, el acuerdo valoriza las reglas que rigen la solución de los conflictos generados en el momento de la transferencia del gobierno (propio de las poliarquías). De ello deriva que cada régimen tiene un mecanismo de legitimación prioritario y un mecanismo de legitimación secundario.
} 
¿para qué existen, quiénes les dan vida? ó a las normas: ¿son justas, para quiénes y por qué se dictaron?

La teoría toda gira en torno a que la noción de legitimidad está indisolublemente unida al significante-significado del Poder.

Sentada esta premisa, y compartiendo la noción operacional de legitimidad hemos de analizar sus principios a la luz de distintas fuentes que, entendemos, constituyeron las que nos permitirán demostrar la hipótesis desde la cual encaramos nuestro trabajo por lo que, a no dudar no revestirán una visión total, toda vez que no es pretensión nuestra agotar la cuestión heurística. ${ }^{6}$

a) Punto de vista politológico:

\section{- Guglielmo Ferrero}

Cuando corría el año 1942, para este autor, la cuestión incursionaba en torno a “QQué son los principios de legitimidad?” entendiendo que, mediante ellos se justificaba el poder, el derecho de mandar. Tema que revestía -considerando la natural desigualdad humana- suma importancia por las consecuencias que generaba ante la necesidad de justificar racionalmente su ejercicio.

Tales principios, resultaban idóneos para proteger al poder del mal más temible: $e l$ miedo de sus súbditos [...] (Ferrero, 1943a:50) ${ }^{7}$, de allí que, en todas las sociedades aún las imperfectas, los hombres más fuertes desistan de infundir terror a los más débiles, siendo este el método universal del mandato que regla la convivencia social.

En tal sentido, enuncia los cuatro principios -y sus respectivos procedimientos para lograrlo y ejercerlo- que se han operativizado en occidente: el electivo, el hereditario, el aristocrático-monárquico y el democrático (sobre los que volveremos más adelante).

La legitimidad de un poder, depende del procedimiento seguido para obtenerlo y llevarlo a la práctica. Podrá discutirse si es justo o razonable, pero la legitimidad es la que instituye el derecho de mandar, desde que es una "constante" cuya verificación no ofrece

\footnotetext{
6 El orden dado para enumerar a los autores citados, tanto respecto a "legitimidad" cuanto a "legitimación", fue adoptado aleatoriamente y obedece a la especialidad de cada uno: politólogos, sociólogos, filósofos y juristas.

${ }^{7} \mathrm{Y}$ continúa “[...] el poder está condenado a vivir en perpetuo terror, porque para gobernar emplea la fuerza física y la violencia, pero no obstante su miedo será siempre más fuerte que todas las rebeliones que estallen contra él, porque su existencia, como su miedo, están de conformidad con la naturaleza humana.".
} 
mayor dificultad y esos principios son los genios invisibles de la ciudad y los fundamentos del orden universal. Cuando existan problemas de coexistencia entre los dos genii la discordia surgirá y la potencial rebelión existente en el entramado social, estallará desapareciendo el respeto por las reglas y principios (Ferrero, 1943a:153-154,156)

Los cuatro principios son limitados y las reglas de ellos extraídas son convencionales, por lo cual, cuando el egoísmo o la inconsciencia de los actores sociales introduzca variables, unos y otras se tornarán inadmisibles, paradójicas, pues no resultarán aptos para responder a las demandas del colectivo.

De estas advertencias, surgen algunas consecuencias que permiten comprender, más profundamente, la entidad de los principios de legitimidad:

i. Dado que no responden a un "estado de naturaleza", sino que resultan de un esforzado proceso humano, por ende, cultural y artificial, pueden fracasar o malograrse.

ii. Todo poder legítimo, está precedido por un estadío previo, llamado prelegitimidad o legitimidad en pañales. Esto obliga a los gobiernos a someterse a una ardua experiencia ya que -aunque legítimos- no cuentan, al comenzar, con un consentimiento generalizado, por lo que debe luchar en su consecución. Son legítimos a partir del momento en que logran desbaratar las oposiciones existentes al asumir el poder. (Ferrero, 1943a:159) ${ }^{8}$

iii. Si bien es necesario el transcurso de 'tiempo' para que el poder pase de la pre-legitimidad a la legitimidad, no resulta suficiente, sino que es preciso que medie 'adhesión pasiva'. Comportamiento éste que atesora una activa conformidad -amalgama de gratitud y fervor- hacia ese principio de legitimidad, por parte de grupos elitistas y minoritarios, mediante el cual la legitimidad alcanza su madurez, su plenitud. (Ferrero, 1943a:160) ${ }^{9}$

\footnotetext{
${ }^{8} \mathrm{Y}$ añade, “La pre-legitimidad es la más difícil de las pruebas a las cuales puede ser sometido un estado[...] El poder tiene, por lo tanto, razón de tener miedo, es decir de temer a la oposición y a la posible rebelión de la mayoría o de algunas minorías poderosas, capaces de aprovechar en beneficio propio el descontento de la mayoría. Pero al mismo tiempo es necesario que resista su propio miedo en la medida necesaria para no dejarse arrastrar a combatir a las oposiciones por medios de violencia, que harían muy difícil, si no imposible, la cristalización definitiva del consentimiento universal. Esta es la situación más difícil en que puede hallarse un poder que desea ser serio[...]"

${ }^{9}$ Se pregunta entonces “¿Por qué medios puede materializarse esa plenitud de la legitimidad? Los medios utilizables son numerosos: el arte (la pintura, la escultura y la arquitectura); de la misma manera el oro, la plata, el marfil, los diamantes, las piedras preciosas, las pieles, las riquísimas telas fueron mucho más
} 
Para Ferrero, la literatura (poesía e historia) y por fin la religión, también actuaron como soportes del principio de legitimidad. Ello no significa que fuesen elementos persuasivos capaces de generar esa veneración propia del poder que, definitivamente, es el que deviene idóneo al brindar determinados servicios respetados por aquellos llamados a obedecer y que se encuentran satisfechos con su accionar, permitiendo de esa manera que la adhesión hacia la legitimidad brote y permanezca.

También la eficacia desempeña un rol en el escenario de la legitimidad, pero ésta no depende de la eficacia del poder -que puede aumentar o disminuir- sin afectar la legitimidad. Por el contrario, la legitimidad puede, de algún modo, sustituir a la eficacia. (Ferrero, 1943a: 162) ${ }^{10}$

Si la legitimidad es el principio que surge, como lógico resultante de un acuerdo tácito y sobre-entendido- entre el poder y el pueblo mediante el que se fijan reglas estableciendo atribuciones y límites, los denominados principios son las variopintas fórmulas de ese contrato sobreentendido, entre las cuales pueda elegir el gobernante y los gobernados de cada lugar y de cada época. Al aceptarse uno de ellos -activa o pasivamenteel compromiso de obedecer configura un verdadero contrato que debe ser aceptado voluntariamente o por la fuerza. (Ferrero, 1943a:55)

El poder se siente precario pues sabe que la revolución se encuentra en estado potencial, de allí que apele al monopolio de la fuerza.

Como ya mencionáramos, los principios de legitimidad, auténticos "genios de la ciudad", surgieron -como creación humana- para atenuar la extrema tensión "obedienciamiedo" existente entre los actores sociales, vale decir, para combatir y coordinar el latente espíritu revolucionario, siempre dispuesto a la reprobación y a la censura.

\footnotetext{
importantes que como atributos o elementos de seducción (de las mujeres): se convirtieron en instruments regni, esplendores con los cuales se cubría el poder para abrir ante los ojos de sus súbditos feéricos ventanales que hacían entrever una hipotética vida superior. Añádanse a eso los desfiles, las procesiones, las revistas militares, los triunfos, los campos de maniobras, las grandes fiestas públicas y las fastuosas magnificencias de las grandes ceremonias religiosas o civiles. Todos esos esplendores han ayudado a las legitimidades todavía encerradas en la crisálida de la pre-legitimidad a alcanzar su plena madurez. ”.

${ }^{10}$ Afirma Ferrero que "[...] Los servicios por los cuales un gobierno legítimo demuestra su eficacia pueden ser muy diferentes: el orden y la prosperidad en el interior, la seguridad en el exterior [...] En la larga lista de servicios a prestar cada gobierno legítimo se esfuerza por elegir aquellos que sabe más preciados por el pueblo y que se cree más capacitado para prestar [...] Si demandas y expectativas coinciden [...] se produce la combinación ideal y la probabilidad menos incierta de un período feliz de la historia. Cuando el pueblo exige servicios que sobrepasan poco o mucho la capacidad de poder legítimo, es posible el advenimiento de grandes dificultades.”. Pensamos -junto con J.C. Rubinstein- que, si bien la eficacia no constituye fuente del poder legítimo, sí es seguro o garantía para su existencia.
} 
Pero, reiteramos, en tanto contingentes, los principios de legitimidad están despojados de toda trascendencia: son justos y racionales bajo ciertas condiciones, dado que pueden devenir absurdos si esas condiciones son defectuosas. Entonces se convierten en instrumentos de los que la razón se vale para crear un poder eficaz, en caso de flaquear, de debilitarse, dichas "condiciones".

Tal aserto incorpora un nuevo elemento a nuestro análisis: la eficacia. Conceptos que no deben confundirse, pues mientras la legitimidad políticamente constituye una "constante", la eficacia es una "variable".

Así, en tanto la eficacia del poder puede aumentar o disminuir, la legitimidad, cual fiel guardián de aquel, busca paliar los errores y asimetrías en que ineluctablemente cae el poder. De modo que, si se trata de aggiornar la relación "mando-obediencia", resulta incuestionable que el principio de legitimidad elegido no está aislado y no se impone tan sólo por su fuerza. (Ferrero, 1943a:65) ${ }^{11}$

De modo que, establecidas estas relaciones que devienen contingentes, es que la humanidad no ha vivido, vive ni vivirá, más que organizada de esa manera. No obstante, los descubrimientos geográficos y exploraciones de los siglos XV y XVII, lograron acrecentar la certidumbre de la humanidad en relación a su inteligencia y en la capacidad de su voluntad, moviendo e incitando el espíritu crítico, llevándolos a delinear incipientes planes de reforma. (Ferrero, 1943a:69)

Por otra parte con la Reforma, que significó la declinación de la teología -ciencia considerada como la más importante del medioevo- emergió “el pueblo" junto al concepto de "legitimidad". (Ferrero, 1943a:69) ${ }^{12}$

El siglo XVIII marcó un cambio de opinión, disminuyendo la subordinación de las clases sometidas y demostrando que la legitimidad del poder guarda una directa dependencia tanto del grupo cuanto de la cultura, reconociendo que cada principio de legitimidad se explica en función de los valores culturales propios de la sociedad civil al

\footnotetext{
${ }^{11}$ Esto es, que el principio debe armonizarse de modo insoslayable "[...] con las costumbres, cultura, ciencia, religión, e intereses económicos de una época; con la orientación general de los espíritus, para emplear la expresión de Mme. Gina Lombroso. Cuando las costumbres, la cultura, la ciencia, la religión, los intereses económicos -en una palabra: la orientación general- cambian, el principio de legitimación se modifica también".

12 Dice el autor, que germinó "[...] la idea de que el poder tiene necesidad de contar con la sanción del pueblo para ser legítimo [...] pero incipientemente, vale decir [...] como un perfeccionamiento del principio dominante y como un remedio a sus abusos siempre posibles. ”.
} 
que es aplicado.

Sobre esos razonamientos, sostuvo Ferrero, que la situación conflictiva planteada entre dos "Genios" opuestos: el "genio" del Ancien Regime y el "genio" de la Revolución originaron las dos grandes crisis que sacudieron el mundo, la de 1789/1814 y la de 1914/1943, conmoviendo el orbe todo ya que las mismas surgieron de la lucha entre el principio de legitimidad hereditario, aristocrático, monárquico y el principio de legitimidad electivo y democrático (simbolizando, por entonces, el "genio" de la Revolución).

Los cuatro principios de legitimidad que han sido reconocidos y aplicados por Occidente pueden ser representados de la manera esquemática que sigue:

-Principio electivo-principio democrático

-Principio hereditario- principio aristo-monárquico

En rigor estamos refiriéndonos a dos principios de legitimidad, cada uno de los cuales presenta dos caracteres:

- el electivo y el hereditario, guardan relación con el método de legitimación, (entendido como un proceso que acontece en la SC), en tanto

- el democrático y el aristo-monárquico, se refieren al titular legítimo del Poder (en tanto cualidad del Poder)

El principio hereditario, aristo-monárquico, deriva de la supremacía ejercida por una ó un grupo de familias. Ferrero cavila sobre un tipo concreto y definido de legitimidad monárquica, acotado en tiempo y espacio, que es el de las "Casas" (v.g.: la Casa de Francia o la de Austria) las que resultaron representativas del sistema de poder prevalente en el devenir histórico europeo, durante el período que corre desde el medioevo hasta el año1918. (Ferrero, 1943a:35,166-167) ${ }^{13}$

Esto en virtud del principio de legitimidad aceptado, el cual, dejando de lado la inteligencia y resultando el menos racional y el más absurdo, consolidó la sumisión y el respeto al poder real durante siglos.

Sin embargo, hubo un momento "clave" en la historia, en que este principio de legitimidad (hereditario-aristo-monárquico) entró en conflicto con el principio electivo-

\footnotetext{
${ }^{13}$ Destaca que, la superioridad de unos sobre otros lleva a "[...] que la herencia ha sido aceptada, por muchos pueblos y desde hace tiempo, como una regla razonable y justa de transmisión del poder [...], indicada, con exclusión de toda forma y de toda consideración de capacidad personal, por la heredad biológica".,"
} 
democrático, toda vez que, al elegir a sus gobernantes, la sociedad no hacía más que delegar en ellos -sus representantes- la posibilidad de resolver los problemas por los que atravesaba el poder, pero democráticamente.

Esto llevó a Ferrero a decir que, si bien la democracia moderna se justificaba por la delegación del Poder, adjetivándolo en tanto tal, en rigor se impone de la misma manera que el poder monárquico se imponía anteriormente, es decir como un poder preestablecido después de generaciones. (Ferrero, 1943a:191) ${ }^{14}$

Va de suyo que ningún principio se impone per se. Se trate de monarquías o democracias, ambas son instauradas por una energía que viene desde "arriba", es decir, originadas por minorías organizadas.

De todos modos, fuerza es destacar que si bien tienen un origen similar -desde arriba- el principio democrático no se impone de la misma manera que el principio monárquico, toda vez que el quehacer democrático está caracterizado por la delegación por “elección”. Ello implica que el pueblo constituye un colectivo dotado de soberanía, calidad necesaria para que la fuente del poder resida en él, al menos teóricamente.

Con esta afirmación Ferrero buscó impedir una interpretación superficial de la doctrina de J.J.Rousseau sobre la soberanía, al afirmar que, de acuerdo a la naturaleza de las cosas, en todas las cuestiones, la voluntad del pueblo se divide en una mayoría y una minoría que constituyen los pilares de la legitimidad democrática. (Ferrero, 1943a:196)

Es necesario que tanto la mayoría como la minoría operen en distintas esferas de acción, aunque complementarias: el poder -y el consecuente derecho de mandar- y la oposición -y el derecho a ejercerla- posturas que deben ser respetadas por ambas partes.

El poder y la oposición constituyen un dualismo, y todo dualismo tiende a modelarse conforme a su opuesto, engendrando ruptura y lucha. Por ello, la necesariedad de destruirse mutuamente, origina un Estado no legítimo si no logra conquistar a todos los sujetos por un acuerdo, que vele lo que de irracional y convencional se oculta en ese principio.

\footnotetext{
${ }^{14}$ En tal sentido, considera Ferrero que “[...] En las democracias, los jóvenes aprenden a ejercer su parcela de soberanía, como aprendían, en las monarquías, a servir al rey, porque a ello les obligaban instituciones preexistentes." De manera que no encuentra diferencia alguna -desde ese punto de vista- entre la democracia y la monarquía.
} 
Pero, si ese dualismo es generador de ruptura ¿cómo conciliar esta postura con el pensamiento roussoniano de la 'voluntad general'? ¿Cómo armonizar esa "unidad” -que supone la voluntad general- con el "dualismo" del poder y de la oposición?

Sostiene Ferrero que para lograr que el "mando y la obediencia" cooperen en el mantenimiento de la legitimidad democrática, deben darse tres extremos:

I) una mayoría "real" y "verdadera" (no camuflada), que exige costumbres políticas caracterizadas por la corrección y la lealtad: el denominado "fair play" británico, ya que en él se funda la virtud cardinal de la democracia legítima.

II) una mayoría consciente de su capacidad de movilidad. Es decir que, esa mayoría además de ser real debe tener conciencia de su naturaleza móvil y que no debe eternizarse en el poder impidiendo -mediante la violencia y/o el fraude- que la minoría logre ser mayoría.

III) finalmente, una minoría que, ejerciendo su rol de oposición, sea capaz de respetar el derecho que posee la mayoría de mandar. Oposición capaz de admitir el libre juego que supone el régimen democrático: "el que gana (la mayoría) gobierna y el que pierde (la minoría) controla" (Ferrero, 1943a:200) ${ }^{15}$ recurriendo para ello a un sistema de divergencias superables sobre una base consensual.

Lo expuesto, no significa olvidar que, instalada la discrepancia, la minoría deberá ser capaz de devenir en mayoría, representando un movimiento portador de un criterio amplio y sólido. Esto es, no debe tratarse de un pequeño grupo al que solo guía un sentimiento de odio que lo lleva a no aceptar el régimen y cuya única finalidad es lograr subvertir el orden jurídico, la legalidad vigente.

$\mathrm{Y}$ es precisamente, en el respeto por esos límites o condiciones que fundan la legitimidad democrática, que el poder y la oposición se convierten solidariamente en voceros de la voluntad general, dotados, pues, de la capacidad de liberar el poder de los sujetos de sus miedos recíprocos.

Considerando que Ferrero se refiere a dos principios de legitimidad alternativos y variables, semeja que enuncia un comportamiento deseable tendiente a que el principio democrático alcance su plena madurez, para, de tal modo, ingresar en un sendero de reflexión pleno en perspectivas.

\footnotetext{
${ }^{15}$ Para, de esa manera, evitar "[...] el peligro de que la libertad degenere en una denigración feroz e injusta que sacuda la legitimidad del régimen al hacerlo aborrecer o menospreciar, es decir,[...] romper la unidad de la voluntad general, en la cual deben basarse el poder y la oposición, aún en la lucha".
} 
Consecuente con ello, inferimos que no es posible comprender la legitimidad del poder como un privilegio exclusivo de un solo tipo de régimen político que, como corolario, será el único que merezca el título de legítimo.

Es así que Ferrero, en función de la alternativa monarquía-democracia y abandonando la interpretación que los legitimistas franceses daban al problema - "sólo la monarquía absoluta puede ser reconocida como el poder legítimo”- presenta una visión más amplia aunque limitada al fin.

Desde el punto de vista de las relación entre poder y legitimidad, debemos reconocer prima facie, que un sistema de poder es legítimo si el principio de legitimidad que lo justifica es capaz de vivir dentro del consentimiento de los gobernados y dentro del respeto que los gobernantes deben a las reglas aceptadas e interiorizadas por todos los actores pertenecientes al régimen.

Si cada principio de legitimidad establece determinado número de reglas, tanto para la adquisición, cuanto para el ejercicio del poder, cabe el interrogante acerca de si, jurídicamente, la legalidad no permitirá confrontar con mayor precisión y en virtud del orden constitucional vigente, el principio de legitimidad que justifique el poder. (Botana, $1968: 34)^{16}$

Analizados los principios de legitimidad y su impacto en el régimen democrático moderno, Ferrero se vuelca al estudio de las crisis de legitimidad.

Discurriendo en los casos históricos por él analizados, las crisis de legitimidad tienen tres modos de manifestarse: a) poderes pre-legítimos, b) poderes cuasi-legítimos y c) poderes ilegítimos.

i. Con referencia al primer caso -poderes pre-legítimos- entiende que si los principios de legitimidad tienen un dinamismo, que les es propio, y dominan en más un ciclo histórico determinado, ellos deben ser normalmente precedidos por un estado preparatorio que denomina la pre-legitimidad.

Así, para ilustrar la noción de pre-legitimidad, recurre a ejemplos, como la República de Weimar -entre 1920 y 1930-; la tercera república en Francia desde 1870 a 1900- y la República Española de 1931. Ninguna de ellas constituyeron, por entonces, regímenes legítimos, dada la existencia de una

\footnotetext{
${ }^{16}$ Agrega Botana que, para confrontar la cuestión tematizada, le resulta importante comparar el pensamiento de Hans Kelsen con el de George Burdeau.
} 
violenta oposición y la paralela carencia de un consentimiento colectivo generalizado, forjador de legitimidad. (Ferrero, 1943a:158)

Esto significa que en el estado pre-legítimo, si bien el poder debe respetar el principio de legitimidad que lo justifica, no puede pretender lo propio del pueblo porque una parte importante de la sociedad civil -la mayoría- no reconoce aún el principio de legitimidad invocado por el poder, mediando en ella, cuanto menos, un estado de potencial desobediencia.

Recordemos que Ferrero piensa que, el consentimiento restringido obliga al poder a oscilar entre la represión y la búsqueda de la cristalización más o menos definitiva de un consenso, capaz de formar la unidad en torno al principio de legitimidad.

Desde el punto de vista explicativo, la hipótesis es razonable ya que solo ve, en las minorías de mediación que sostienen un poder pre-legítimo, un esfuerzo creciente y sincero por respetar el principio de legitimidad que lo funda y por hacer que ese principio sea también reconocido por aquellos a los que se dirige.

Analizada ya esta problemática y su principio de solución (tiempo-adhesión), Ferrero nos dice que no basta con examinar la crisis desde el punto de vista de los gobernantes acerca de cuya honestidad no se duda y que creen efectivamente en un principio de legitimidad.

ii. $\quad$ Al referirse a los por él denominados poderes cuasi-legítimos (designación sugerida por una nota de Metternich sobre la "Monarquía de Julio" en Francia) relata que, el no contar con sufragio popular -como tampoco con "el derecho histórico"- y el no tener fuerza popular, llevó a Luis Felipe a intentar conciliar dos principios de legitimidad opuestos. Ese estado, sólo podía lograrse por medio de la costumbre (acompañada de prosperidad), pero ¿acaso de hubiere alcanzado rodeado de instituciones republicanas? Evidentemente no. Las circunstancias que rodearon la designación de Luis Felipe no fueron el producto de norma, de derecho alguno, por lo que fue un 'rey de facto'. (Ferrero, 1943a:261)

Por las situaciones señaladas, los gobiernos 'cuasi legítimos' ofrecen 
múltiples dificultades para su comprensión, ya que no se trata de estar en presencia de regímenes dualistas en los que cohabitan el principio democrático con el monárquico (v.g.: las monarquías constitucionales estables, como el caso de Inglaterra) (Ferrero, 1943a:115) ${ }^{17}$ de donde, aún reconociendo la superioridad del principio democrático, todos se someten, al menos tácticamente, al principio monárquico obedeciendo la oculta coyuntura del poder real. De allí que, la circunstancia de intentar justificarse mediante dos principios contradictorios los obliga a fingir, por lo que usufructúan de la legitimidad sólo en la medida en que logran camuflarse.

De manera que, dentro de un régimen cuasi-legítimo, el poder (derecho de mandar) no está protegido por ningún principio de legitimidad -ni el monárquico ni el democrático- por lo que mantiene un equilibrio inestable entre una apariencia parlamentaria (justificando el principio democrático) y el sustento que le proporciona la monarquía la que no admitirá ser controlada, pues ello significaría la efectiva limitación de sus antiguos poderes.

Después de establecer esta categoría conceptual, analizando los extremos que justifican la precariedad de esos poderes, Ferrero proporciona una serie de ejemplos transitando medio siglo de historia europea- para abarcar una sucesión de regímenes que, estima, se encuentran en la categoría que venimos analizando y en los que nos hallamos ante 'situaciones fortuitas' (recordemos la señalada nota de Metternich) de 'hecho' y no de 'derecho'. (Botana, 1968:208) ${ }^{18}$

Sin compartir dicha generalización, Botana rescata de dichas inferencias un elemento importante: la situación de incertidumbre que se puede constatar en todos esos regímenes en relación a la legitimidad y que dificulta la posibilidad de orientar el régimen

\footnotetext{
${ }^{17}$ Explica el autor que: "Hasta entonces los dos principios habían luchado en Inglaterra, pero sin llegar nunca a una ruptura definitiva. Los comunes habían defendido los derechos del pueblo como derechos empíricos, establecidos por textos y leyes que limitaban, pero no negaban, en nombre de un principio superior y absoluto, los derechos de la corona y de la nobleza. Fue eso lo que había permitido y permitirá a las libertades inglesas desarrollarse por transacciones sucesivas y llegar a un entendimiento y colaboración de los dos genios invisibles, de la corona, la nobleza y el pueblo."

18 Botana cita palabras de Ferrero, en que éste señala: “[...] (estos regímenes cuasi-legítimos) fueron numerosos, Italia de 1878 a 1922; España, tras 1870 y hasta la revolución de 1931; los países balcánicos. Todos estos Estados han sido gobernados como Francia bajo Louis-Philippe, por las Cortes y por el poder ejecutivo; con la colaboración subordinada de parlamentos, soberanos en teoría y en apariencia.".
} 
ya sea hacia la monarquía, pues carece de legitimidad tradicional, o hacia la democracia, desde que el parlamento está sometido al poder del rey. (Botana, 1968: 209) ${ }^{19}$

iii. Las crisis de legitimidad visualizadas bajo el sesgo de 'poderes ilegítimos', surgen, en el agónico trance por el que atravesó el poder monárquico o en la impronta que provocaron la aparición de los poderes pre-legítimos o cuasilegítimos.

Los regímenes legítimos envejecen por dos motivos: a) porque abusan del poder y del prestigio conferido por el principio y b) porque una nueva orientación de los espíritus surge en las tendencias de opinión que nutren las fuerzas políticas. Lo cual conduce a indagar nacientes ideas que permitan reemplazar la vieja legitimidad por una legitimidad nueva.

De tal modo, el poder ilegítimo se presenta, como una prolongación del derrumbamiento del antiguo régimen ya que, éste, al perder su prestigio, vale decir, su poder, deja su lugar a otro, nacido en el imaginario colectivo de aquellos que habían propiciado un cambio político.

Sin embargo puede ocurrir que estas recientes ideas no resulten suficientes para cimentar, una legitimidad nueva. Apta, por consiguiente, para suplir el principio antiguo que ha sido desmoronado por el accionar del movimiento revolucionario.

Lo dicho podría hacer pensar que existe alguna confusión entre el poder prelegítimo y el poder ilegítimo, pero, teniendo en cuenta el juicio de valor lanzado por Ferrero en relación a todo poder ilegítimo, podríamos hablar del

\footnotetext{
${ }^{19}$ Aclarando el concepto, recurre a palabras de M. Duverger -a quien considera netamente influenciado por Ferrero-: "El desarrollo progresivo del régimen parlamentario en Gran Bretaña y en otros países de Europa permite superar el conflicto Antiguo Régimen-Revolución: el poder es compartido entre el rey y una asamblea aristocrática (órganos basados sobre la legitimidad tradicional) y una asamblea democrática y un gobierno emanado de ella (órganos fundados sobre la nueva legitimidad). Progresivamente, las prerrogativas de los segundos fueron desarrollados y las primeras fueron atenuándose: esta evolución siguió la declinación de la legitimidad monárquica y el ascenso de la legitimidad democrática. Finalmente, la Corona y los Lores devienen sólo órganos de 'pompa', privados de todo poder real. En ciertos momentos, en la Francia del siglo XIX, se tiene otro compromiso, basado sobre la doble investidura: Napoleón I tiene la investidura democrática, por el voto de la nación, y la investidura monárquica, por la consagración y por el matrimonio con una heredera de la más antigua dinastía de Europa; Luis Felipe tiene la investidura democrática, por el voto de la Cámara de Diputados llamándolo al trono, y la investidura monárquica, por el hecho de ser de sangre real. Subterfugios que no logran buen resultado".
} 
"buen" poder pre-legítimo y el "mal” poder ilegítimo.

Específicamente la ilegitimidad, es la ausencia de aceptación del principio por ambos extremos de la relación. Esto es, el principio no es admitido ni por gobernantes ni por gobernados. De allí que Ferrero juzgue de maniquea la intención de los gobernantes ilegítimos, al manipular el principio que invocan, como una fórmula de mistificación. Suministra entonces, y según esta convicción, ejemplos típicos de ilegitimidad. Menciona un continuo de malogrados regímenes acaecidos tras la revolución de 1789, comenzando por la propia Convención que -habiendo violado los principios cardinales (derecho de la mayoría y libertad de sufragio)- no podía ser más que un gobierno revolucionario.

Señala en este mismo sentido, lo que llama sus consecuencias inmediatas: la Salud Pública y el Terror elementos que configuraron la insoluble contradicción existente entre, por un lado, los principios democráticos enunciados por la Revolución -prácticamente erigidos en religión secular- y, por el otro, la violación constante de esos mismos principios en su efectividad fáctica.

Pero es la Constitución del año VIII, obra de Siéyés, la que logrará que el poder ilegítimo alcance su plenitud al no otorgar satisfacción a ninguno de los principios en lucha. Ya que, al liquidar la oposición, se tergiversó el texto constitucional, implementando un concentrado gobierno revolucionario, considerado como el más absurdo e imposible...” (Ferrero, 1943a: 219)

Además de un sofisticado sistema electoral, generador de un Senado (emanado de las clases altas) -y por su intermedio una Asamblea Legislativa (también elitista) en los que radicaba la soberanía nacional- sin oposición, sin libertad de prensa ni de sufragio, el falseamiento de la denominada soberanía de la nación resultaba aplicado en sentido contrario.

La voluntad nacional no creaba el poder sino que era "creada" por él, por lo que su pretensa legitimidad caía estrepitosamente, ilegitimizándose a sí mismo al construirla en la forma que le apetecía.

Obedeciendo tal artilugio, el Consulado fue el primer gobierno que -en el 
marco de esa constitución- intentó clara e intencionalmente, revestir de legalidad la flagrante violación del principio de legitimidad democrática y, sobre dicho soporte es que Bonaparte instauró su poder.

Ferrero no vacila en sostener que el gobierno revolucionario, en tanto gobierno ilegítimo, es el "régimen del miedo por excelencia". Para sostenerlo, para su defensa, solo le resta aumentar sus poderes, con lo que se convierte en totalitario, cuyo instrumento más eficaz es "la propaganda" (comenzando por la periodística).

Si el poder legítimo es consentimiento más coacción, el resultado a que llegamos luego de estas especulaciones es que el poder ilegítimo resulta sinónimo de fuerza pero sin consentimiento. En consecuencia, debe poseer un efecto multiplicador sobre los sujetos a los que la fuerza se aplica para lograr el consentimiento.

Tal es la significación profunda, del miedo que sacudió el paso de la monarquía a la democracia en, por ejemplo, Italia y Alemania. Se trató de un dualismo difícil de dilucidar y que glosando a Ferrero diríamos, un enigma insoluble; de un temor aciago, causado por los poderes subyugados por un denodado esfuerzo para convencer que debían ser obedecidos. Esto es, "Poderes que gobiernan como si pudieran ser obedecidos." (Ferrero, 1943a:237) ${ }^{20}$

\section{- Natalio Botana.}

En directa relación con los fundamentos de la legitimidad y con sus principios, toca ahora abordar el tema de la relación existente entre poder-creencia (u obediencia).

Por ello y luego de esta apretada visión de aquello que el significante-significado de legitimidad encierra, y considerando a la legitimidad en tanto que causa eficiente de un sistema de poder, siguiendo a Botana hemos de referirnos a los "sistemas de legitimidad", los que en principio están integrados por esferas íntimamente relacionadas, a saber: i) un centro, constituido por el régimen político; ii) dos partes esenciales en relación al régimen, los gobernantes y los gobernados; iii) un mecanismo de funcionamiento, la creencia compartida por gobernantes y gobernados en el valor de los principios y las reglas que ese régimen invoca y, iv) la "creencia" compartida por gobernantes y gobernados.

Existen, pues, posiciones de legitimidad si, con antelación, esta cualidad resulta

\footnotetext{
${ }^{20}$ Palabras que el autor toma de las Confesiones de San Agustín.
} 
esencial, inherente, a un sistema de poder institucionalizado. (Botana, 1968:129)

Un sistema de poder institucionalizado, está sometido a lo que podemos llamar momentos "fuertes" y momentos "débiles": unos resultan de la continuidad que media entre el hecho acumulativo de la atribución de legitimidad con la atribución de autoridad, mientras otros son producto de la ausencia de una posición de autoridad al interior de un sistema de poder ya legitimado.

Si bien el modelo teórico adoptado, se ubicó en el nivel del proceso de atribución de legitimidad, ello no significa desconocer la relevancia que reviste el hecho de autoridad en tanto fuente posible de un sistema de legitimidad de reemplazo; al propio tiempo que reconocer la potencial trascendencia adjudicable a la ausencia de autoridad, como fuente de erosión de un sistema de legitimidad preexistente.

Ese hecho ó esta ausencia, configuran factores capaces de esclarecer el por qué, tanto de los movimientos de mantenimiento, cuanto los de contestación de un régimen político.

Una especulación sobre la legitimidad, debe analizar los factores que benefician o atentan respecto a la posibilidad de lograr un acuerdo entre gobernados y gobernantes en relación al principio que determina la forma constitutiva de un régimen político, sin mediar preocupación alguna por la presencia o la ausencia de la variable atribución de autoridad y su posible relación con los mencionados factores. (Botana, 1968:130) ${ }^{21}$

El tema de la "creencia" nos permite también ingresar al estudio de las relaciones que median en la relación "mando-obediencia" a efectos de presentar distintas "posiciones" según guarden relación con "legitimidad", "poder" o "autoridad".

Refiere entonces el autor que mediarán: a) posiciones de 'legitimidad' cuando el gobernante goce -en un sistema de poder- de una presunción de legitimidad por parte del colectivo; b) posiciones de 'poder' cuando los gobernantes -dentro del sistema de poderdisponen de los medios de sanción para imponer su decisión y c) posición de 'autoridad' cuando los gobernantes -ubicados en el sistema de poder- se hagan acreedores a la confianza en su autoridad por parte del colectivo.

Las posiciones de legitimidad (sistema de poder institucionalizado) y de autoridad

\footnotetext{
${ }^{21}$ Y cita a Burdeau, G., (1959:248) quien sostiene -en relación a la institución monárquica- que, si es necesario que el rey cambie, que al menos la corona 'se fije' para simbolizar la permanencia del destino común.
} 
(titulares de roles de poder) suponen creencia por parte del colectivo. (Botana, 1968: 125 y ss.)

Existen sin embargo diferencias, ya que, mientras la posición de legitimidad está fundada sobre la valorización impersonal de un principio -lo que supone una serie determinada de reglas y mecanismos, que establecen una forma constitutiva de regímenes políticos- las posiciones de autoridad están fundadas sobre la valorización personal de un gobernante que -por el hecho de atribución de una cualidad- es capaz de imponer válidamente sus decisiones al colectivo, en virtud de la confianza que desarrolla de su propio valor y no por la creencia en la posición institucional que detenta.

De manera que, las posiciones de legitimidad y de autoridad se unen en un vivaz proceso según el cual, el sistema de poder institucionalizado por una parte, y los titulares de roles de poder por otra, están en tren de perder o de ganar -como dice B.de Jouvenel- en estatura y en peso. (Botana, 1968:126)

Contrariamente, las posiciones de poder no se desarrollan desde un proceso efectivo, sino desde un orden provisoriamente establecido aunque, también, institucionalizado, dotando, a quienes detentan roles de poder, de la capacidad necesaria para cumplir sus fines en virtud de los medios de sanción. Capacidad que, por otra parte, es independiente de la doble atribución de legitimidad y de autoridad.

A su turno, las posiciones de autoridad y de legitimidad pueden ser independientes o interdependientes. Si media independencia entre una y otra, el sistema de roles de poder dependerá del titular que los desempeñe. De donde, la autoridad del gobernante (su legitimidad) no dependerá de la creencia en relación al sistema institucionalizado de poder, sino que el régimen se fundará sobre la creencia en el principio personal de gobierno y no sobre la creencia en el principio institucional de gobierno. Por el contrario, si la posición de autoridad es interdependiente de la posición de legitimidad, al sistema de roles de poder legitimado por la creencia de parte del colectivo en el principio institucional de gobiernose agrega la creencia, de parte del colectivo, en el principio personal de gobierno.

Queda explicitado así el 'efecto multiplicador' al que se refiere B. de Jouvenel: en el interior de un régimen que goza de una presunción de legitimidad, el político que se alce al sometimiento de la jerarquía en virtud de las reglas de transferencia de gobierno aceptadas sin discusión, agrega -además- una presunción favorable de autoridad.

Similar lectura podemos realizar respecto a las posiciones de legitimidad: si son 
independientes de una posición de autoridad, el régimen se basará sobre la creencia en el principio institucional de gobierno. Gobernante y gobernados expresan su confianza, consensuada respecto al principio, a la forma del régimen y a las reglas, por lo que la obediencia está asegurada. Confianza que, a su vez, constituye el soporte de una posición de legitimidad. De mediar interdependencia de la posición de legitimidad respecto a una posición de autoridad, el efecto será contrario. (Botana, 1968:127-128) ${ }^{22}$

Las posiciones de autoridad como las posiciones de legitimidad, constituyen dos formas de mando que armonizan con tres formas de obediencia toda vez que -esas posiciones de mando- reflejan posiciones de poder.

Las dos primeras posiciones se ejercen por la doble atribución, de modo que, si esas posiciones se ejercen en ausencia del doble tipo de atribución, ellas resultarán posiciones de poder stricto-sensu.

Toda situación de poder supone la existencia de consentimiento y presión, dado que resultan variables combinadas y no aisladas la una de la otra. Por ello, ante la carencia de autoridad y legitimidad, las posiciones de poder serán vistas como fundadas sobre los medios coercitivos que los gobernantes acentuarán -para hacer efectiva la obediencia- en desmedro del consentimiento.

Rota la unión entre los valores del colectivo y el régimen donde se asienta el mandato, para sostener el régimen existente, la relación de poder recurrirá más a medios que van desde la violencia hasta el miedo, que a las acciones de que dispone para hacer efectiva la obediencia. Ante la inexistencia de la doble atribución -de autoridad de los gobernantes y de legitimidad del régimen- el pueblo será avasallado por los gobernantes ya que no reconoce ni su capacidad de generar el orden que comprometa efectivamente su

\footnotetext{
${ }^{22}$ Menciona Botana en tal sentido, conceptos de Acton H.B. (1957, t.II:83 y ss.) quien hace una distinción muy importante entre posiciones de autoridad y posiciones de poder: "[...] las posiciones de autoridad no pueden existir en tanto que un orden social dado esté aceptado sin discusión por todos, o por casi todos los que viven en su seno. Si este mismo orden social comienza a ser puesto en duda; la 'posición de autoridad' será considerada cada vez más, como 'posición de poder'.” “[ ..]. (el tipo puro de obediencia a la autoridad) será acompañamiento voluntario de órdenes considerados como legítimos a la vez por el superior y el subordinado. Las dos partes actuarán según los términos de un orden social que consideran o suponen legítimo." Dichos a los que Botana agrega que: "Está claro que la noción de posición de autoridad de Acton se une a nuestra noción de posición de legitimidad. Si el tipo puro de obediencia está fundado sobre la relación triangular que tipifica la confianza al régimen (órdenes considerados como legitimas a la vez por el superior y el subordinado) habrá una presunción favorable de legitimidad, pero no habrá una presunción favorable de autoridad, si junto a la relación triangular, no existe la relación vertical de confianza según la cual el superior (en nuestro caso el gobernante) goza de una presunción favorable de autoridad de parte de los subordinados ( en nuestro caso los gobernados).”
} 
destino, ni el principio institucional en virtud del cual pretenden justificar su derecho a mandar. (Botana, 1968: 128-129)

b) La mirada sociológica

- Max Weber.

La legitimidad obtenida a través de la legalidad ocupa un puesto privilegiado en la tipología weberiana, siendo sus fuentes: carismática, tradicional, legal (esta última característica del estado moderno).

Nutrido en la tradición neo-kantiana de la filosofía alemana, y de neto corte explicativo, Weber concibe un "tipo ideal" toda vez que las cadenas causales que la justifican, no se presentan a los ojos del observador en su realidad empírica. Media, en él, una inferencia subjetiva e idealista de lo existente y efectivo, de donde, el orden y la causalidad son otorgados por el sujeto mismo. (Botana, 1968:81) ${ }^{23}$ Enunciado que tiene como corolario remitirnos a la base de sustento de la teoría sociológica weberiana, la acción.

Vale decir que, en relación a los objetos, la acción -que involucra todo tipo de comportamiento humano- puede ser manifiesta o subjetiva; activa o pasiva, pero la acción es siempre social en tanto que, como cuenta con el comportamiento de los otros, éstos influyen su orientación. (Botana, 1968:77-78) ${ }^{24}$

${ }^{23}$ Cita Botana que R. Aron (1950:104) manifiesta que, mientras la definición weberiana es "[...] del tipo ideal como una 'imagen mental' obtenida no por generalización de los rasgos comunes a todos los individuos sino por racionalización utópica. Nosotros reunimos los caracteres más o menos presentes aquí y allá, señalamos, eliminamos, exageramos: finalmente, sustituimos un conjunto coherente, racional a la confusión y a la incoherencia de lo real".

${ }^{24}$ Ampliando la noción, sostiene el autor que J.Freund, al abordar el estudio de la sociología política weberiana, no vacila en adjetivarla como una sociología de la dominación (Herrschaftssoziologie), añadiendo que Weber considera a la dominación como el corazón de la política y que las fuerzas políticas se encuentran delante de los grupos dominantes, por lo que la dominación será la manifestación del poder (Macht). Concepto que es definido por Weber como la posibilidad que tiene un individuo de imponer en una relación social su voluntad, aún contra las resistencias que le presenten, y la dominación (Herrschaft) como una acción capaz de encontrar personas dispuestas a obedecer las órdenes dadas. Por el contrario, autores como A.M.Henderson y T.Parsons, traducen los términos "Macht" y "Herrschaft", por sus equivalentes en inglés "Power" e "Imperative Control", respectivamente. A su turno, R.Bendix traduce el término "Herrschaft" por el de "Domination", añadiendo que el término "Herrschaft" designa dos cosas a la vez: por una parte un sistema de poder que se ejerce y, por otra, la aceptación de los sujetos que tienen ese ejercicio como legítimo. Tal interpretación discrepa pues, con la proporcionada por Henderson y Parsons, para quienes "Imperative Control" será sinónimo de poder institucionalizado que ejerce una capacidad de sanción, y "Authority" será sinónimo de poder legítimo. Continuando con las interpretaciones, Friedrich, entiende que "Herrschaft" es sinónimo de la palabra inglesa "Rule", que indica el poder político institucionalizado. Por lo tanto "Rule" constituye, analíticamente considerado, un concepto diferente a "Legitimacy" y "Authority", no obstante 
Manifiesta al respecto Parsons, que el "tipo ideal" no describe una acción individual, sino más bien una acción "específica”, ya que sus manifestaciones comprenden un número indefinido de casos particulares. Por lo que ese tipo ideal, describe aquello que Weber llama un "curso de acción objetivamente posible", toda vez que -en su encuadramiento referencial- se hallan los datos necesarios para un caso o una acción concreta.

Importa destacar que los elementos que componen ese tipo son generalmente variables independientes, que, a su vez, generan una serie de relaciones establecidas, entre esa serie de variables.

Esto permite llegar al fundamento de legitimidad de un poder institucionalizado, basándose, por una parte, en las condiciones de solidaridad -derivadas de los intereses individuales- y por otra, en el 'orden', definido por un sistema de control imperativo sobre la base de la acción que se relaciona con la creencia en su legitimidad. En tal sentido y más allá de su simplicidad o complejidad, Weber admite la existencia de un origen uniforme en todo agrupamiento político. Ese elemento, que puede caracterizarse como esencial y que lo distingue de los otros grupos, es el monopolio del uso legítimo de la fuerza en tanto que capacidad de sanción. (Weber, 1963: 100 y ss.) ${ }^{25}$

A partir de este factor diferencial habrá tres elementos comunes a todo agrupamiento político:

1) el jefe individual o colegiado (ubicado en la cima de la jerarquía gubernamental);

2) el aparato administrativo (que aplica las normas y reglas y que ejerce una función subordinada) y

3) los miembros ordinarios que obedecen.

Sin embargo, esta uniformidad $\mathrm{u}$ homogeneidad no es incompatible, con una variación significativa en el carácter de la estructura de mando y de obediencia. Diferenciación que deriva de la legitimidad invocada por cada sistema, de manera que habrá diferencias de fondo en los tipos de obediencia, en la estructura formal del cuerpo administrativo y en el modo de ejercicio del poder.

existir entre las tres nociones mutua interdependencia.

${ }^{25}$ Entiende Weber que "Es necesario concebir el Estado contemporáneo como una comunidad humana que, dentro de los límites de un territorio determinado -la noción de territorio es una de sus característicasreivindique por su propia cuenta 'el monopolio de la violencia fisica legitima “" (cit. en Botana, 1968:83) 
Esta perspectiva de análisis, se comprende mejor a partir de la distinción que formula Bendix (1970) entre dos enfoques -dentro del ámbito de las ciencias socialescuales son, la sociología y la ciencia política.

Desde el punto de vista sociológico, las instituciones a través de las cuales se organiza formalmente la sociedad política -poder ejecutivo, poder legislativo, poder judicial- deben ser entendidas a través del análisis de la interacción entre agentes que resultan socialmente condicionados. De manera que los problemas políticos, de igual modo, pueden ser observados como un proceso de interacción (v.g.: el comportamiento electoral o los mecanismos de deliberación y decisión dentro de los cuerpos colegiados).

Así, las instituciones políticas formales son desplazadas en el método de análisis como un elemento exterior y no integrado realmente al proceso de interacción.

Desde otro ángulo, la ciencia política entiende a las instituciones políticas formales, como el marco necesario para la articulación de toda sociedad compleja. Es precisamente esa complejidad y la necesidad de la ciencia política de recurrir a otras disciplinas, lo que conduce a Weber a sostener que el análisis debe centrarse sobre la organización y sobre la interacción.

Dado que cada tipo de poder institucionalizado depende de un aparato administrativo -dirigido por un jefe o un cuerpo colegiado- y de una creencia en la legitimidad de las normas y las decisiones, Weber no se contenta con encarar un sistema de poder como el que está fundado exclusivamente sobre la sumisión exterior. De manera que agrega, a ese hecho, el esfuerzo permanente que realiza toda dominación política, por “...despertar entre los miembros la fe en esa legitimidad, es decir, transformar la sumisión en adhesión a la verdad que ella representa” (Freund, 1967:200) Vale decir que comprende el fundamento de legitimidad de un sistema de poder, a partir de la orientación que toma un tipo determinado de acción social. Los actores no solo persiguen el interés de orden ideal, sino que también buscan intereses de orden material (guiados no solamente por las consideraciones de utilidad o afinidad, sino también porque la existencia de un orden legítimo de poder es reconocido por los que participan).

El pensamiento weberiano ha querido distinguir claramente, entre las relaciones sociales que son mantenidas por la reciprocidad de los que esperan, por ejemplo la oferta y la demanda -en tanto que relaciones puras de mercado- y las relaciones sociales que son 
mantenidas por el ejercicio del poder. Estas últimas comprenden siempre, en tanto elementos constitutivos, la creencia en la existencia de un orden legítimo, y las personas identificables capaces de mantener ese orden por el ejercicio del poder.

Esta concepción "bipartita" de un orden legítimo, permite inferir que las acciones orientadas en función de él, pueden afectar la consecución de los intereses particulares; al igual que el logro de los intereses particulares puede tener efectos múltiples sobre el ejercicio del poder que este orden define. Esto supone, asimismo, una diferencia cualitativa basada en el hecho que, la acción, se orienta sobre un orden legítimo en virtud de una creencia dividida por lo que adopta una significación específica en relación a la distinción que hace Weber entre la “conservación” y la "atribución” de legitimidad.

De modo que, la legitimidad de un orden político puede ser conservada tanto por motivos de orden social, es decir, de interés general, como por motivos de orden particular. Por el contrario, hay atribución de legitimidad, solo a partir de motivos que no dependen de situaciones de orden particular.

Así, la conservación de legitimidad combina dos tipos de acción social: la primera orientada en función de motivos que trascienden intereses de orden particular- puede expresarse por una actividad afectiva o por una actividad racional, por finalidad o por valor; la segunda depende de la situación de cada actor particular y ella toma en consecuencia, una significación neutra desde el punto de vista moral.

La atribución de legitimidad, pone de manifiesto, a su turno, la existencia de motivos orientados por la actividad tradicional, por la actividad afectiva, o por el doble tipo de actividad racional, es decir, por finalidad y por valor.

La diferenciación que Weber manifiesta entre conservación y atribución de legitimidad, permite visualizar más certeramente las diferentes razones por las que se recurre a un orden político.

Por una parte, la conservación de legitimidad, que combina la búsqueda de tipo particular, releva de toda consideración del orden de la conformidad: se mantiene el orden en cuestión porque ciertas consecuencias son capaces de satisfacer una búsqueda particular.

La atribución de legitimidad, a su turno, releva más del orden de la convicción que del orden de la conformidad. Encontramos aquí, el hecho privilegiado de la creencia tradicional -afectiva o racional- que buscando en el corazón de las relaciones entre mando y 
obediencia, determina una armonía entre el sistema de valores y el sistema de poder. De donde, la atribución de legitimidad está fundada, pues, sobre una actividad que une una visión de la "buena" sociedad o, si se quiere, del "mejor" régimen.

Esta tipología de motivaciones -tanto para el análisis de las actividades de conservación como para las de atribución- permite ver más claramente cuál es el tratamiento sociológico que Weber da a la legitimidad de un sistema de poder.

Desde una óptica sociológica y aplicando su propia metodología de tipos ideales, Weber establece tres formas puras de legitimidad que, si bien no llegan a caracterizar la totalidad de las formas históricamente dadas, "expresa las posibilidades objetivas que resultan, según los casos, más o menos típicas, o más o menos próximas a una causalidad adecuada o a una acción débilmente favorable”. (Aron, 1950:104 y ss) ${ }^{26}$

En virtud de lo expuesto tres son los tipos de legitimidad para el pensamiento weberiano:

a) Racional-legal.

Es considerado como 'técnicamente superior' a los otros, puesto que descansa en la creencia en la legalidad de las normas y en la estructura de jerarquía y de sanción que desarrollan esas normas. Se caracteriza: a) por un 'estatuto' sobre el cual descansa todo el sistema legal; b) por la limitación de los roles de poder y c) la temporariedad de los sujetos que tienen la responsabilidad de su ejercicio y cuya 'superioridad' es reconocida. (Bourricaud, 1964:391) ${ }^{27}$

\footnotetext{
${ }^{26}$ En ese sentido señala Weber (1963:102 y ss.), “Existe en principio [...] tres razones internas que justifican la dominación, y en consecuencia existen tres fundamentos de la 'legitimidad'. Desde luego la autoridad 'eterna', es decir, la de las costumbres santificadas por su validez inmemorial y por la costumbre enraizada en el hombre al respecto. Tal es el 'poder tradicional' que el patriarca o el señor terrateniente ejercían antiguamente. En segundo lugar la autoridad fundada sobre la gracia personal y extraordinaria de un individuo (carisma); ella se caracteriza por el sacrificio personal de los sujetos a la causa de un hombre y por su confianza en esa sola persona en tanto que ella se caracteriza por sus cualidades prodigiosas, por el heroísmo u otras particularidades ejemplares que posee el jefe. Este es el poder 'carismático' que el profeta ejerce, o -en el dominio político- el jefe de la guerra electo, el soberano plebiscitado, el gran demagogo o el jefe de un partido político. Hay una autoridad que se impone en virtud de la 'legalidad', en virtud de la creencia en la validez de un estatuto legal y de una 'competencia' positiva fundada sobre reglas establecidas racionalmente, en otros términos, la autoridad fundada sobre la obediencia que se recibe de acuerdo a las obligaciones existentes en el estatuto establecido. Este es el poder que ejerce el 'servidor del Estado' moderno, o los detentadores del poder que se están bajo esa relación" [...] por lo que "[...] cada vez que nos interroguemos sobre los fundamentos que 'legitiman' la obediencia, encontraremos siempre sin duda [...] estas tres formas 'puras' que hemos indicado”. (cit. en Botana,1968:87-88)

${ }^{27}$ Bourricaud entiende que: "El jefe 'racional-legal' no está de ningún modo habilitado a tomar cualquier cosa que sea 'bajo su gorro'; para 'cubrirse' frente a sus jefes, como frente al público, debe medirse ante toda requisitoria, de justificar sus decisiones. La única forma de personalización que le está permitida, es la
} 
El orden no es impuesto por presión o violencia, pero tampoco deriva de un acuerdo unánime- pues cuenta con mayorías y minorías dentro del entramado social encargadas de establecerlo, en principio, (Botana,1968:90) ${ }^{28}$ mediante el voto y por la presencia permanente e indispensable de una organización burocrática, en la base de los conflictos entre mayorías y minorías.

b) Tradicional.

Este sistema está legitimado por la creencia en aquellos individuos que ocupan roles de poder en virtud de la tradición, o porque han sido elegidos sobre una base tradicional. Tradiciones estas, que determinan el contenido del orden y la extensión de su poder de mando, otorgándole una esfera propia de autonomía y de decisión personal. El acto de 'justicia' aparece, entonces, como un 'don', una 'gracia', una concesión que aquel que detenta el poder otorga, fundado en razones éticas o utilitarias.

Comprende tres sub-tipos: la gerontocracia, el patriarcado y el patrimonialismo. Los dos primeros tienen en común no contar con aparatos administrativos fuera de sus jefes (en un caso los de más edad: el consejo de ancianos; en el otro: el poder se legitima porque el patriarca es elegido por una norma de herencia tradicionalmente aceptada); así como, que el poder de mando se ejerce en nombre de todo el grupo y en aras del interés común.

El patrimonialista difiere de los anteriores, pues cuenta con un aparato administrativo que depende del jefe y con una fuerza armada organizada, lo cual le permite ejercer un poder de orden personal y absoluto, no en nombre de los miembros del grupo. De manera que, en la medida en que se torne arbitrario, se transformará en sultanismo.

Otra característica del sistema, la constituye la obediencia tradicional de los actores, por lo que se impone contemplar la cuestión de aquellos factores que pueden originar resistencia. De efectivizarse, ella se dirige contra la persona del jefe o un miembro del aparato administrativo, es decir, nunca contra el sistema tradicional considerado en su todo.

identificación con las leyes. El jefe 'racional-legal' puede aparecer como mediador entre ellas y el pueblo o el público. Pero no es el que las hace, no es por su prestigio que ellas tienen autoridad. No las aventaja, y es la conformidad de su conducta con las obligaciones que ellas le imponen que legitima su conducta." (cit.en Botana, 1968:89)

${ }^{28}$ Menciona Botana, citando a M. Weber (1947:131 y ss) que "Mientras el voto sea empleado como medio legal para cambiar un orden, será corriente que la voluntad de una minoría alcance una mayoría formal, y que la mayoría se someta. En ese caso el gobierno de la mayoría es una ilusión." 
Esta 'personalización' del conflicto, aún en el caso de adoptar formas de violencia, no es capaz de destruir el fundamento de legitimidad sustentado sobre la creencia en la fuerza de la tradición o de la costumbre. (Botana, 1968:77-80)

\section{- Jurgen Habermas.}

Para este autor, "la legitimidad es la capacidad de un régimen político de ser reconocido". Aserto éste, que ilustra claramente acerca del alcance de la definición, al establecer que la legitimidad es un imperativo insoslayable, substancial, para la validez del régimen, constituyendo -su efectivo reconocimiento- factor determinante en tanto garantía de estabilidad del sistema político. (Habermas, 1985:250) ${ }^{29}$

Si bien es misión del sub-sistema político preservar la sociedad de su disgregación, él no dispone libremente de potenciales de integración social, ni del poder normativo que prescriba cuál debe ser la identidad de ese entramado social, para, de ese modo, mantener la cohesión.

Las fases de evolución sobre los que se han constituido las sociedades organizadas en Estados, encontraron diferentes formas elaboradas de identidad: imperios, comunidades urbanas, estados nacionales. Pero, un imperio, una Ciudad (polis), una comunidad medieval, una Nación expresan una constelación de diferentes órdenes políticos, cada uno ligado a una determinada forma de vida (ethos). Esto porque el significado aristotélico de polis es una creencia de identidad, antes que una noción constitucional. (Rittert, 1969:106-132)

Es por ello, que la investigación histórica de la modernidad trata la formación de los Estados y la formación de las naciones como dos procesos que aun siendo diferentes, también son interdependientes.

Quienes sostienen que la extensión de la categoría 'legitimidad' no puede limitarse a las sociedades estatales, piensan que el poder legítimo y la dominación política pueden colocarse sobre un mismo plan. Ello no los conduce necesariamente a admitir, que ningún sistema político no pueda -en un tiempo prolongado- lograr, asegurarse, la confianza de la

\footnotetext{
${ }^{29}$ Y continúa: "Esto porque, tanto desde una perspectiva histórica como sobre el plan de análisis, el concepto se aplica ante todo a las situaciones donde la legitimidad de un orden político es litigioso, es decir a las situaciones donde surgen los llamados problemas de legitimación: algunos niegan entonces esta legitimidad, otros la reafirman" [...] "Se trata de 'procesos': Talleyrand, por ejemplo, se esfuerza por 'hacer reconocer la legitimidad' de los Borbones. En el marco de los Estados constitucionales modernos (la oposición está también institucionalizada), los procesos han tenido una suerte de vuelco desdramatizándolos, es decir, se encuentran destrabados y normalizados. Esto porque hoy, no significa faltar a la realidad considerar la cuestión de la legitimación como un problema permanente.".
} 
población, o sea, la obediencia de quienes integran el entramado social, sin tener que recurrir a ciertas legitimaciones. (Habermas, 1974:253)

El tema de la legitimidad, tampoco es "extraño" a la lucha de clases, ya que, si bien es cierto que antes de la modernidad no puede hablarse de una distribución de la población en diferentes grupos socio-económicos, sí es posible, comprobar la existencia de un sistema de privilegios constituido por corporaciones, castas, estratos sociales, etc. Por lo que se constata que han existido en el seno de las sociedades tradicionales, conflictos estructurales que han generado crisis de legitimación.

\section{- David Easton.}

Este autor, no define la legitimidad conforme las condiciones morales que determinan el ejercicio legítimo del poder, sino que trata de explicar por qué una acción política puede ser tenida como legítima, sin preguntarse si existen criterios morales capaces de determinar la legitimidad de esa acción. Criterio que, como veremos, origina ciertas dificultades.

Tanto Easton como Vialatoux, comparten similar postura en cuanto a que, el consentimiento del pueblo o la aceptación popular, constituyen la condición del ejercicio legítimo del poder. Easton descansa sobre ese punto y al abordar de esta manera la cuestión de la legitimidad, persigue una finalidad explicativa toda vez que la legitimidad es un concepto empleado para describir y explicar un fenómeno político recurrente, ya que encierra, en un sentido amplio, la aceptación generalizada de una acción situada al interior de un colectivo político.

De modo que, pareciera mediar, entre ambas ópticas -explicativa y normativa- un lazo indisoluble.

Así, para la óptica explicativa se tratará, de la elaboración de un concepto operacional a partir del cual la lógica interna de un conjunto de fenómenos políticos pueden comprenderse.

Para la óptica normativa, por el contrario, estaremos en presencia de la elaboración doctrinal de un principio ó de una serie de principios a partir de los que podemos determinar las condiciones ideales de la legitimidad del poder y del deber de obediencia de los ciudadanos.

Es al establecer ese cotejo de donde surge que la realidad política -que la óptica 
explicativa trata de acercar- se integra por un conjunto de significaciones en torno de las cuales los hombres otorgan valor a la forma que asume el poder en el seno de una sociedad.

Significaciones las señaladas, que parten de la realidad misma y de su efectivo conocimiento, por lo que no puede desconocerse su incorporación dentro del escenario de análisis por ella establecido, toda vez que, la elaboración de un concepto operacional, no puede dejar de considerar la diversidad de significaciones que cada uno de los actores otorgan a estos acontecimientos.

Tampoco podemos dejar de pensar que dicha dilucidación, no debe ni puede prescindir de la relación que media entre los sujetos y los valores, ya que son los sujetos los que, finalmente, integran el campo de análisis sobre el que ella se sustenta.

$\mathrm{Si}$ bien en principio, la doctrina es conteste en aceptar que el concepto de "obediencia" guarda íntima relación con el de Poder, ¿hasta dónde alcanza esa relación? Además, ¿ocurre lo propio respecto a las categorías "Autoridad” y "autoridad”?

Se trata de dos conceptos distintos. Mientras Autoridad es un concepto estático, autoridad es un concepto dinámico que tiene por función describir la efectividad del proceso político, en virtud del cual -y como mencionásemos antes-, las personalidades están constantemente en tren de ganar en 'estatura' y en 'peso' '. (de Jouvenel, 1963:147) ${ }^{30}$

Considerando que las palabras generan acción y por ende, relación, su eficacia se multiplica si son pronunciadas con autoridad, pero adquieren más ventaja si son dichas desde una posición de Autoridad”. (de Jouvenel,1963:148) ${ }^{31}$

\footnotetext{
${ }^{30}$ Menciona Botana (1968:118-119) que las fuentes del concepto 'autoridad' empleado por B. de Jouvenel cambian en una obra precedente del mismo autor (1955). de Jouvenel llama allí 'autoridad' a "[...] la facultad de atraer el consentimiento de otros". En ese sentido autoridad constituye "[...] la causa eficiente de reuniones voluntarias" (p.45). Enseguida, agrega: Llamo 'Autoridad' (propia o natural) al don de hacer aceptar las propuestas formuladas" (p.47). En este orden de ideas es importante señalar que: "[...] el poder difiere mucho de la autoridad. Es propio de la autoridad no ser ejercida más que sobre los que la aceptan voluntariamente: al contrario, es suficiente para los dirigentes tener autoridad sobre una parte de los sujetos para pretender ser fuerzas capaces de ordenar también a otros bajo su poder. Los medios de violencia pertenecen de este modo al poder en virtud de la autoridad parcial que les resta [...] Lo peor de los Estados es lo que dan los dirigentes sin la suficiente autoridad universal para ser seguidos por todos de buen grado, [...]” (p.48 s.). Subraya Botana, que el autor designa autoridad, como una cualidad imputable al que tiene la capacidad de atraer el consentimiento de otros. El análisis se ubica, pues, más sobre la perspectiva del polo que comienza a hacer un acto, que sobre el polo receptor que consiente respecto las proposiciones formuladas tanto a partir del género de autoridad atrayente (le $d u x$, es decir, el conductor), que a partir del género de autoridad pacificadora (le rex, o sea, el rectificador).

${ }_{31}$ Continua Botana (1968:119) diciendo, que esto nos conduce a investigar la muy bella imagen sobre la estatua y el rostro, que expresa claramente nuestra distinción entre régimen político y gobierno; imagen que es reproducida por otra parte por Léo Hamon (1966) con estas palabras: "En el museo de Corintio, se encuentran dos estatuas desprovistas de valor artístico, que testimonian la costumbre que tenían, bajo la
} 
Consecuente con lo expuesto, para Botana, el concepto de "autoridad" utilizado por B. de Jouvenel, coincide con su concepto de autoridad (atributo perteneciente a los gobernantes en su calidad de titulares de roles de poder), mientras que, la categoría conceptual "Autoridad", se relaciona con su concepción de sistema de poder.

De donde, su concepto de legitimidad no se corresponde con el de régimen político.

El análisis que efectúa D. Easton, resulta disímil al desarrollado por B. de Jouvenel, toda vez que en aquel comprobamos la ausencia del factor "autoridad" en tanto que condición atribuible a los titulares de roles de poder.

Así, para Easton la palabra "Autoridad" se relaciona con un concepto que no solo designa a los ocupantes de roles de poder, sino a los ocupantes de roles de autoridad. Ello le facilita indagar acerca de la legitimidad, considerándola un factor de sostén tanto para el régimen político como para los titulares de roles de autoridad. (Botana, 1968: 121-122) ${ }^{32}$

De modo que, teniendo en consideración las relaciones existentes entre aquellos que mandan y quienes obedecen, podemos hablar de posiciones de legitimidad, posiciones de poder y posiciones de autoridad.

Al bosquejar un cuadro sobre las fuentes y el objeto de la legitimidad D. Easton, toma los "tipos de legitimidad" caracterizados desde su fuente, a saber: ideología, estructura y cualidades personales y los relaciona con los objetos de legitimidad: régimen y autoridad.

- Con relación al primer tipo - la legitimidad ideológica- y refiriéndose al régimen, encuentra su fundamento sobre la base de la creencia en la validez del

\footnotetext{
dominación romana, de erigir en un lugar de más valor, la estatua en pie del gobernador. El escultor ha reproducido, con una exactitud poco inspirada, cada detalle del traje militar revestido en las ocasiones oficiales por el representante de la 'civitas imperans'. Solo la cabeza falta, pero no es accidental: un hueco entre los hombros revela las ranuras destinadas a permitir fijar una cabeza móvil sobre el cuerpo macizo. Así, los ciudadanos podían evitar el gasto que significaría edificar una nueva estatua para un nuevo gobernador; el viejo rostro es levantado y reemplazado por un rostro nuevo. He ahí el símbolo de la autoridad establecida. La estatua ha sido erigida en una época muy anterior y dura a través de numerosas generaciones; pero el rostro debe ser el de un magistrado en vida y en ejercicio. El fin de una vida o de un mandato levanta la cabeza pasajera de los hombros duraderos. Existe en adelante una vida a cumplir, una ocasión para un hombre nuevo de levantar su cabeza hasta los hombros de la estatua. El político resuelto que busca subir su rostro a la cima de la estatua, emprende una operación que exige menos esfuerzos y talentos diferentes que el que supone levantar la estatua misma”. (de Jouvenel, 1963:171 y ss).

${ }^{32}$ Destaca Botana, que T. Parsons (1964:197) parece orientarse hacia un esquema de análisis similar a su noción de atribución de legitimidad y añade: "Sin embargo, nosotros agregamos que la noción de autoridad no se relaciona con un modelo institucional, es decir, a un principio institucional de gobierno ya que -desde nuestra terminología- ese principio institucional se comprende en relación a la de poder institucionalizado, sinónimo de régimen político”.
} 
régimen; y en el caso de las autoridades, sobre la creencia en la validez de quienes resultan titulares de los roles de autoridad.

- La legitimidad estructural está definida, por la confianza en la validez de dicha estructura -así como de las normas establecidas por el régimen- convicción que hace extensiva a los titulares de roles de autoridad. Circunstancia que habla de una relación dialéctica entre ambos, dado que la legitimidad de los titulares depende de la legitimidad del régimen.

- El caso de la legitimidad personal nos ubica frente a una relación inversa a la anterior. Esto así, pues, la credibilidad en la validez de las autoridades en razón de sus cualidades personales, comprende también el régimen, ya que su legitimidad, deriva de esos titulares de roles de autoridad.

Como corolario de lo expuesto, para Easton, la legitimidad es un atributo que, efectivamente aplicada, constituye uno de los factores de sustento difuso de los gobernantes y del régimen, junto a la creencia en el interés común. Esta propiedad se divide en función de su atribución, tanto al régimen cuanto a los gobernantes.

De modo que considera legítimo al gobernante al que se le atribuye legitimidad, tanto como titular de roles de un régimen ya legitimado, cuanto como fuente personal que comprende también al régimen político.

Advierte Easton, que la pérdida de sostén puede estar determinada, ya sea porque los miembros faltan a la confianza frente a las autoridades -otorgando su crédito al régimen- o, en el caso inverso, es decir, porque los miembros pierden confianza frente al régimen, depositando su credibilidad en las autoridades. La situación "límite" estaría dada por una revolución social, tipificada por la ausencia de legitimidad tanto en el caso del régimen, como en el de las autoridades.

Botana por su parte entiende, que la legitimidad considerada como una cualidad imputable al régimen, permite eliminar el caso donde los miembros faltan a la confianza frente a los gobernantes, dando su confianza al régimen. Mediará entonces ausencia de autoridad de parte de los gobernantes, y esta ausencia de autoridad, si se prolonga en el tiempo, puede jugar como fuente de erosión del régimen que perderá de más en más la cualidad de legitimidad que se le había atribuido antes.

De manera que, cuanta menos autoridad se atribuye a los gobernantes más tiende a 
deteriorarse la legitimidad del régimen.

El caso contrario, en que, según Easton, se atribuye la legitimidad a los gobernantes y no al régimen, presenta la hipótesis según la cual la atribución de autoridad frente a los titulares de roles de poder, se inscribe dentro de un régimen político que no posee -para una fracción del colectivo- el atributo de la legitimidad. De manera que, la autoridad del gobernante puede actuar como el factor que origina una legitimidad de reemplazo. (Botana, 1968:123-124) ${ }^{33}$

Si no hay confianza frente al régimen se presume que la legitimidad es incierta. Pero si, a esa ausencia de atribución de legitimidad se agrega que un gobernante se levanta ante el sometimiento de la jerarquía de roles de poder y goza de la cualidad de autoridad junto a una gran fracción del colectivo, diremos que el régimen en cuestión funda su existencia más bien sobre el principio personal de gobierno -al que se une la legitimidadque sobre el principio institucional.

El problema de un régimen fundado sobre la atribución de autoridad en detrimento de la atribución de legitimidad, se expresa en toda su amplitud en el problema de la

\footnotetext{
${ }^{33} \mathrm{Al}$ respecto, señala: "Puede ser útil esbozar una breve interpretación del pasaje de la IVa. a la Va. República francesa, teniendo en cuenta nuestra distinción entre autoridad y legitimidad. De Gaulle llega al poder en el momento en que el régimen de la IVa. República es puesto en duda de manera manifiesta por la extrema derecha y de un modo latente por la extrema izquierda. Es la autoridad atribuida a De Gaulle por una extensa fracción del personal político y del cuerpo electoral, que permite el pasaje pacífico de la IVa. a la Va. República. En el período transitorio así como en el período que sigue el establecimiento de la Va. República, el régimen político francés es inseparable de la estatura de autoridad atribuida al presidente De Gaulle. Después de 1958 Francia continua siendo gobernada más bien en virtud de la aceptación de un principio de autoridad, que en virtud de la aceptación de un principio de legitimidad. La cuestión de saber en qué medida las instituciones de la Va. República fueron capaces de dejar atrás sus fundadores queda abierta, pues la sucesión efectiva al sometimiento de la jerarquía gubernamental (ocupación de roles por titulares sucesivos) no tiene todavía lugar. Paralelamente a este hecho, la puesta en duda latente del principio institucional queda, y la confianza institucional depende en cierto sentido de la integración progresiva de las fuerzas contestatarias. Esta desconfianza deviene menos presente, pues la Va. República, gracias a su fundador, goza, al menos, de una presunción favorable de autoridad, presunción que falta al personal político del régimen anterior, que había franqueado, desde 1947, el umbral de admisión al sometimiento de la jerarquía gubernamental: "Bajo la IVa. República las tres Asambleas de 1946, 1951 y 1956 no han contado jamás con menos de un tercio de diputados que no gozan del juego, hostiles al régimen, ese tercio de extremistas representa una fracción de votantes que regularmente es superior al 40\%, superior al 45\% en 1951. La IVa. República jamás ha rehusado reunir al conjunto de ciudadanos: en cada elección, han votado por o contra el 'sistema' al propio tiempo que para una política en el marco de la Constitución establecida" (Aron, 1959:48). Además de cierta ausencia de legitimidad, la ausencia de autoridad podría unirse a la falta de estabilidad gubernamental resultante de la tendencia del personal político "[...] a ampliar los desacuerdos reales multiplicando las disputas de la profesión parlamentaria" (Aron, 1959:59). En razón de la falta de estabilidad en el nivel de los equipos gubernamentales, los roles de poder están, en un sentido, viciados de contenido efectivo, lo que impide a los gobernantes ver un objeto frente al cual la imputación de autoridad es posible. A la crisis en el nivel del principio institucional de gobierno se agrega, pues, la crisis en el nivel del principio personal de gobierno."
} 
sucesión.

El interrogante se impone: ¿En qué medida la confianza personal puede transformarse en una nueva confianza de tipo impersonal, que permita superar la limitación personal que toda acción política individual comporta? (Botana, 1968: 125)

\section{- $\quad$ Talcott Parsons.}

Según T.Parsons, el principio que unifica los tres elementos motivacionales que se refieren a la legitimidad -la tradición, el afecto y la racionalidad referida a los valores últimos- se expresa en el concepto de carisma.

Ahora bien, pareciera que esta interpretación está orientada en el sentido de reconocer el hecho del carisma, tanto al interior del sistema racional-legal como en el seno del sistema tradicional.

El carisma, lejos de ser para Parsons una entidad metafísica, constituye por el contrario una cualidad observable en relación con los actos humanos y las actitudes que desarrollan. Por lo que apunta a recubrir bajo la categoría de carisma, los hechos humanos relacionados al principio personal de autoridad.

Ratificando la concepción weberiana, Parsons sostiene que el carisma será la fuente de legitimidad "en general", tanto como la legitimidad en un sentido "restringido", constituyendo de tal modo, la aplicación institucional o el marco de incorporación del carisma. El diario acontecer sucede de la manera que el pueblo considera como "buena", por lo que así debe seguir. Aún en una estructura racional-burocrática, el colectivo debe contar con un orden social cuya fuente de legalidad sea carismática.

De donde, substituyendo la idea de elemento carismático por la del elemento personal, encontramos que el sentido dado por Parsons al concepto de carisma, guarda relación con el elemento personal que, necesariamente, debe encontrarse al interior de cualesquiera sistema de poder, racional-legal o tradicional.

Ello así, el margen de acción que poseen los gobernantes al interior del sistema tradicional es más amplio que el que surge al interior del sistema racional-legal, pero ello no es indicativo que deba incluir el principio personal en la categoría carismática. No obstante y tal como lo ha sostenido Weber, si bien ocupar roles de poder es necesario, ello no significa que quienes los poseen detentarán la calidad de jefes carismáticos.

El carisma es un atributo concedido a los hombres políticos natural y comúnmente o 
proveniente de un orden ambiguo. En cualquier caso, cualesquiera fuere el origen de esa cualidad, ambas concepciones aceptan, por igual, la presencia de jefes carismáticos. Sea que resulten incorporados dado su fortaleza a un sistema de legitimidad, sea que aparezcan gobernantes a quienes no se les aquilatan poderes o cualidades excepcionales.

Siendo que el principio personal de gobierno constituye el hecho previo, el marco de referencia es único: todos los sistemas de poder son sistemas carismáticos rutinarios, (argumento que posibilita comprender la marcha del carisma hacia una fase de rutina).

Con referencia a la interpretación del la categoría racional-legal, si bien se reconoce la existencia en la teoría weberiana, de un elemento esencial en cada tipo -el aparato administrativo- innegable resulta que éste, logra marcada supremacía en el tipo racionallegal.

Aparente ambigüedad (¿ó contradicción?) que además de caracterizar el pensamiento weberiano, fue, tal vez, precursora del pensamiento occidental ante el fenómeno burocrático, que es particularmente sensible en la literatura desarrollada por la corriente pesimista revolucionaria, desde Rosa Luxemburgo y de León Trotsky a Bruno Rizzi, Simone Weil y C. Wright Mills; cuanto en pensadores conservadores como James Burnham y W.H.Whyte Jr., sin dejar de lado la ley de hierro de la oligarquía burocrática de Robert Michels, según la cual los movimientos que débilmente quieren producir intensos cambios en el entramado social, se encuentran cercados por el aparato burocrático, cuya incompatibilidad con los valores de la democracia resultan manifiestos. (Crozier, 1963:234235) ${ }^{34}$

- Carlos Barbé.

Ante el vuelco doctrinario hacia la legalidad, su enfoque consiste en analizar el tema legitimidad-legitimación en otros niveles de investigación, por lo que -con el agregado de un nuevo elemento: efectividad- se plantea tres interrogantes:

\footnotetext{
${ }^{34}$ Expresa Crozier que, "Por un lado, la mayor parte de los grandes pensadores entiende que el desarrollo de las organizaciones burocráticas corresponde al advenimiento de la racionalidad al mundo moderno y que la burocracia es de hecho intrínsecamente superior a todas las otras formas posibles de organización. Por el otro, muchos autores, a menudo los mismos, consideran las organizaciones como una suerte de Leviatán a través de las que se pretende esclavizar la raza humana. El acento que cada uno de ellos pone sobre uno u otro aspecto, depende de su optimismo natural. Pero cualesquiera sea el resultado al que lleguen, descubrimos siempre que ellos creen a la vez en la superioridad de la racionalidad burocrática, en el dominio de la eficacia y en sus implicaciones amenazantes para los valores tradicionales de la humanidad" (cit. en Botana,1968:104)
} 
a) ¿Un poder efectivo es siempre legitimo?

b) ¿A través del análisis de la efectividad de un poder, podemos buscar el mecanismo por medio del cual el Poder tiende a presentarse como aceptado o consensuado?

c) ¿Cuál es la esencia de la legitimidad?

Respecto a la primera de las cuestiones, estima que un poder no es legítimo por el solo hecho de su ejercicio, aún siendo eficaz. De modo que eficacia no es sinónimo de legitimidad, aún para aquellos que sostienen que la primera se basa en el que cree en el consenso como fundamento del poder. (Barbé, 1973:21 y ss.) ${ }^{35}$

En cuanto al "mecanismo" que permita visualizar que el poder es producto del consenso, menciona que N. Bobbio otorga una primera respuesta: a la legitimidad se llega a través de un proceso circular, consistente en: i) un poder se establece como poder de facto y su instauración comporta la violación y ruptura de la legalidad de un poder precedente; ii) a ese estado de cosas, le sigue un nuevo poder que restablece la legalidad y iii) habrá que aguardar un tercer momento que complete el círculo y en el cual el poder formule e infunda su propio título de legitimidad.

Pero, ¿cuál es el mecanismo a través del cual se desarrolla este proceso?, ¿cómo puede desarrollarse en una forma diferente? Es decir, ¿previo al establecimiento de un nuevo poder, es posible comenzar el proceso de inculcar y plantear su futura legitimidad?

El tercer cuestionamiento, conduce al autor a considerar que un poder es más efectivo en la medida en que es considerado justo o responde a la necesidad y expectativa de la comunidad. (Barbé, 1973:23) ${ }^{36}$

Siendo que la idea de justicia, como cualquier otra, es variable, también varía su contenido según las coordenadas de tiempo-espacio. Tal corolario lo lleva a considerar que -teniendo en cuenta que el fundamento de la legitimidad, como su esencia, cambian de comunidad en comunidad, de situación histórica en situación histórica, de grupo social en grupo social- el ámbito propio del concepto de legitimidad es el de los valores.

\footnotetext{
${ }^{35}$ Proporciona ejemplos al respecto: a) gobiernos en el exilio que han invocado la legitimidad aún no constituyendo un gobierno efectivo; b) para quienes se basan en el consenso para sostener su postura, menciona que éste no se expresa siempre por medio de elecciones, como en el modelo democrático parlamentario; c) se ocupa luego de los gobiernos de ocupación como el nazi con relación a Italia durante la 2da. Guerra mundial; d) las relaciones de poder en una cárcel proporcionan otro ejemplo, dado que el Director de la cárcel deja de ser obedecido en el momento de producirse la excarcelación.

${ }^{36}$ En idéntico sentido, ver infra cita 10 in fine.
} 
Así como la legalidad no resultó suficiente para individualizar la legitimidad, tampoco la efectividad es un criterio suficiente, de modo que e1 verdadero criterio será el que surja no de un valor u otro, sino de todo un sistema de valores.

\section{- $\quad$ Augusto Comte.}

Cabe señalar que este autor, ha pasado de un rechazo de la idea de legitimidad -que interpretaba como una concepción metafísica- a afirmar que una organización social se funda sobre un sistema filosófico y que es él, el que determina el perfeccionamiento al cual el estado social -indicado por la "marcha de la civilidad"- debe ajustarse en cada época histórica.

Si bien la mayoría de la doctrina comparte hoy día que la legitimación de un sistema de poder es el fruto de un sistema de valores, para Comte, cada época histórica tuvo su objetivo espontáneo, toda vez que existe un orden "natural” de la sociedad.

Por tanto, la función de la estructura política, no es otra que respetar y reflotar aquel orden, regulando también la estratificación espontánea que se produce el interior de la trama social. De donde, su competencia, será la regulación de la división "natural” del trabajo.

Inevitable, entonces, deviene considerar el vínculo que establece entre los subsistemas económico y político. Toda vez que -esta división del trabajo socialpresupone, asimismo, la institucionalización de una autoridad que deberá definir los “fines u objetivos de actividad" de la sociedad. (Parsons, 1962) ${ }^{37}$

Considera Comte que las fuerzas sociales "preponderantes" o "prevalentes" terminarán inevitablemente por devenir también “dirigentes", por lo que la función de la esfera política o del sistema político se limitará a regular aquella jerarquización espontánea que se produce al interior de la sociedad. Justifica, entonces, el poder político de aquella familia que ya detenta el poder económico. (Arnaud, 1967:195-210)

b) Enfoque jurídico.

\section{- Hans Kelsen.}

\footnotetext{
${ }^{37}$ Menciona Barbé (1973:55) que, en esto, la semejanza entre la concepción de la autoridad de Comte y la de Parsons de 1963, es impresionante; también en el Parsons de veinticinco años antes que había basado toda su teoría de la acción social, en el rechazo a la concepción positivista y utilitarista.
} 
Para Kelsen el sistema jurídico constituye un sistema "independiente" del sistema político, social o cultural en el que esas normas se aplican.

En tal sentido S. Cotta, sostiene que la noción kelseniana de constitución está rigurosamente inspirada en el derecho positivo, permitiéndole obrar con imparcialidad de toda organización estatal. (Cotta, 1965:148)

Siendo su visión puramente "formal", la norma fundamental (Grundnorm) es la que proporciona validez a todo el ordenamiento jurídico.

Tal argumentación, habilita ubicar la tesis del principio de legitimidad en el corazón de la teoría de Kelsen, toda vez que el fundamento de validez de una norma está constituido por una norma superior que es la Constitución. Aceptado que la validez de las normas legales puede ser acotada en el tiempo, y que el orden legal del cual ellas emanan es susceptible de determinar el comienzo y el fin de su validez: éste es el principio de legitimidad.

El principio de legitimidad, en el pensamiento kelseniano, se mantiene bajo ciertas condiciones. Por ejemplo, no permanece en el caso de una revolución, categoría conceptual que es utilizada por Kelsen en un sentido "social", por ende, mucho más amplio que el correspondiente a una revolución de tipo rigurosamente político.

Así, el razonamiento que posibilita comprender el hecho revolucionario es aquel de contenido legal que deviene reemplazado por un orden nuevo y mediante otros medios que los establecidos por el orden legal vigente.

Sin embargo, gran parte del viejo orden queda en vigor, por lo que es solamente el contenido de normas siempre similares y de ningún modo la razón de su validez, ya que la parte reemplazada lo ha sido utilizando un orden legal que esas mismas normas no han anticipado. En consecuencia, el principio de legitimidad no está más en vigor, por lo que, a las normas del viejo orden, les falta validez.

Kelsen completa el análisis uniendo al principio de legalidad el análisis del principio de eficacia. (Botana, 1968:36) ${ }^{38}$ Es necesario que el orden legal sea eficaz como tal,

\footnotetext{
${ }^{38}$ Para ilustrar sus manifestaciones, menciona Botana que Kelsen se vale de un ejemplo: un grupo rebelde ubicado al interior de un estado monárquico toma el poder por la fuerza con la finalidad de reemplazarlo por una forma republicana de gobierno. Si el conjunto logra su cometido y se apodera del mando, las estructuras políticas del antiguo régimen son reemplazadas por nuevas estructuras, y, sin más, el orden nuevo deviene eficaz, pues la conducta del colectivo -reglada por un nuevo orden- se muestra conforme, dispuesto para con dicho orden, por lo que resulta un orden legal valedero. Merced a la eficacia del nuevo orden, el
} 
no solo eficiente, para que sus normas sean válidas dado que devienen concebidas de acuerdo con la constitución.

Si el principio de legitimidad establece la razón por la cual respetamos la jerarquía de las normas como valederas -ser hechas por el procedimiento que preceptúa el orden constitucional vigente- y si el principio de eficacia es la condición necesaria para la validez de cada norma del orden legal, como también para la validez del orden legal globalmente considerado (por ejemplo el caso de la revolución), estamos en condiciones de sostener que, para Kelsen, hay tantos principios de legitimidad como órdenes legales.

Cabe destacar, que esos órdenes legales se sucederán, tanto en el espacio cuanto en el tiempo, y su habilidad para sostenerse estará condicionada por el principio de eficacia.

De lo expuesto, pareciera que el principio de legitimidad es equivalente al principio de legalidad. No obstante, ello no es así ya que, el principio de legitimidad, no puede ser considerado independientemente de un principio de rendimiento funcional que es el de eficacia.

La utilidad del principio de eficacia radica en que es capaz de medir la autoridad del sistema normativo, para concertar adecuadamente con el comportamiento de los actores -a los que el sistema direcciona- y viceversa.

A su turno, el principio de legitimidad, siempre que se ensamble con el criterio de legalidad, señalará el modo, por el cual el comportamiento de los sujetos debe estar de acuerdo con él.

\section{- $\quad$ George Burdeau.}

Si bien Burdeau comienza a desgranar sus ideas de manera similar a la tesis kelseniana, los desarrollos posteriores de su análisis tienden a demostrar que el encuadramiento formal no es suficiente para comprender en toda su dimensión, la problemática que presenta la complejidad de los principios de legitimidad.

Respecto al origen de la legitimidad de los gobernantes -y al igual que el positivismo kelseniano- en un principio Burdeau considera, que es la constitución la que la

comportamiento actual de los individuos será interpretado como legal o ilegal con relación a él. Por el contrario, si los revolucionarios son vencidos, o si el orden legal que pretenden establecer deviene ineficaz, su acción será juzgada no en el sentido de un acto que llega para establecer una constitución, sino como un acto ilegal, "un crimen de traición" -dice Ferrero- a la constitución del antiguo régimen y a su norma de base específica. 
instituye, toda vez que cierra el enigma secular en torno a: de dónde proviene el poder de los gobernantes, cuál es su naturaleza, las condiciones de su ejercicio, así como su finalidad y límites.

No obstante, y si bien parte de la premisa que todo reside en la autenticidad de la idea de derecho que la constitución consagra, plantea la dificultad, por una parte, que significa definir la esencia de esa "idea" sin ser arbitrario; sugiriendo, por la otra, y con referencia a la "movilidad" o "alternancia" los beneficios para obtener un orden social deseable, que presenta, prima facie, un régimen liberal -y la posibilidad de lograr una legitimidad real-frente a un régimen en el que todos los elementos devienen inmutables, sin permitir cambios, ni la posibilidad de introducir variables.

Así entendidas, las nociones de legalidad y legitimidad resultan relativas. Relatividad que deriva de la pluralidad de principios de legitimidad, obligados referentes a la hora de consultar acerca de la regularidad que ofrecen las distintas formas de gobierno.

Surge de lo expuesto que, para justificar la legitimidad de un régimen, Burdeau no admite ceñirse solo a su legalidad formal. Ello, porque comprueba que no es posible establecer la legitimidad sobre un principio complejo, válido universalmente y para todos los tiempos. Por el contrario, debe tomarse como legítimo la conducta, el acto o la situación que pueda reclamar para sí, la idea de derecho válida para un colectivo acotado témporo y espacialmente.

Dado que la legitimidad, necesita una constante adaptabilidad de la acción política a los cambios que se producen en la idea de derecho que la justifica, sostiene el autor que la legitimidad -si bien lograda en el momento de su investidura- no es para los gobernantes una atributo permanente, indisoluble, sino que es un principio expuesto a las lides de la política plenaria y en cuya custodia y defensa debe luchar constantemente. (Burdeau, 1950:138)

Motivo por el cual y en orden a las reflexiones enunciadas, es que bosqueja la situación de los gobernantes en relación a la legitimidad, a partir de las siguientes conjeturas:

a) El gobierno legalmente establecido, debe respetar los principios que dieron origen a la constitución, tanto en lo contemplado al organizar el Poder, cuanto en la distribución de su ejercicio. El gobierno así establecido es legal en lo formal y legítimo 
materialmente hablando, de modo que la idea de derecho válida es la establecida en la constitución.

b) Un gobierno regladamente investido puede encaminar, "de una manera sistemática y continua, según una línea política contradictoria, la idea de derecho incluida en la constitución” (Burdeau, 1950:143)

Las referencias de que se vale para demostrar sus dichos pertenecen a gobiernos totalitarios -el fascismo en Italia o el nacional-socialismo en Alemania- que aparecieron en la esfera de gobierno en los parlamentos.

De modo que la constitución asegura la legitimidad de los gobernantes, siempre y cuando éstos actúen y respondan, conforme su letra y su espíritu.

c) Asimismo, un gobierno puede estar constituido legalmente según los procedimientos establecidos por la constitución, pero si reemplaza esas condiciones en la práctica política, puede ser calificado como ilegítimo.

Burdeau proporciona ejemplo de ello al examinar dos casos.

-En el primero, al momento de asumir los gobernantes, la constitución no guarda armonía con la idea de derecho válida en el país.

Vale decir que, quizás, la carta magna sea la resultante de un poder constituyente usurpado. Opinión que facilita fijar límites precisos a tal afirmación, cuando manifiesta que la constitución otorga a los gobernantes, no solo la legalidad extrínseca, sino también la legitimidad de fondo. Por lo cual, la constitución pone coto a esa subterfugio de los usurpadores que -revestidos de un barniz de legalidad- pretenden detentar un gobierno regular, legítimo.

-En el segundo caso, puede acontecer que la ilegitimidad del gobierno emane de la propia constitución. Tal probabilidad se presenta cuando la idea de derecho evoluciona, por lo que la constitución ya no proporciona el debido marco de referencia. Evolución que puede ser lenta, por lo que la carta fundamental poco a poco se aggiorna con los nuevos datos que representan el orden social reclamado por el colectivo y el paralelo alejamiento de los órganos por ella previstos.

También y en lugar de resultar producto de una "evolución”, puede darse como fruto de una ruptura que subvierte la institucionalización existente, instalando una nueva idea de derecho que, suficientemente consolidada, desplace la anterior. 
De modo que, en el pensamiento de Burdeau, "Evolución-Reforma" y "RevoluciónRuptura" son vislumbradas como posibilidades. Ambos casos presentan el ascenso de una idea de derecho, que comenzó siendo minoritaria (oposición) para culminar nucleando un colectivo de voluntades individuales, paulatinamente desgajadas de la idea de derecho oficial. (Burdeau, 1950:145)

De darse tal extremo, el poder legítimo es el que aglutina las energías de la idea del nuevo derecho, pero no deja de ser un Poder de hecho. Poder que, pese a ser ilegal, su legitimidad no se ve menoscabada, ya que es el derecho el que establece la condición de legítimo, por lo que puede estar tanto a favor de los revolucionarios, cuanto amparar a los gobernantes legales.

Lo expuesto pone en evidencia que el enfoque que Burdeau realiza de los principios de legitimidad, va más allá de un encuadramiento meramente jurídico en la conceptualización de la problemática.

Cierto es que, para su análisis, parte de la indagación formal que le proporciona la teoría constitucional, sin embargo, más adelante amplía esa visión incorporando contenidos de la Ciencia Política. (Burdeau, 1959:235) ${ }^{39}$

Es entonces que Burdeau, en su Método de la Ciencia Política, al situar la problemática de los principios de legitimidad dentro del marco de la relación política entendiéndola como elementos intrínsecos y componentes de la misma- condensa muchas de las inferencias bosquejadas con anterioridad.

Considerando que los principios de legitimidad conforman referencias obligadas de las que deviene la estabilidad del sistema de poder, y que la multiplicidad de principios guardan relación con la armonía o la controversia que la acción política contenga en sí misma, perduran como uno de los elementos constitutivos de la relación política, o sea, como la justificación del mando y de la obediencia. Justificación que, por otra parte, no puede suplir su origen más allá del marco que le ofrecen "las tablas de referencia múltiples", que, además, se encuentran en decidido proceso de transformación.

\footnotetext{
${ }^{39}$ Explica Botana (1968:41) que, en el nuevo desarrollo, Burdeau sostiene que "[...] no hay ningún sistema político que no elija legitimar la obediencia, es decir que explique su necesidad de otro modo que por la incapacidad o el sometimiento al orden dado [...] La Ciencia Política debe tener conocimiento de este hecho. Ella debe considerar las explicaciones dadas sobre la obediencia no como teorías venales, apresuradas, sino legitimar la subordinación de los gobernados, pero como elementos intrínsecos de la relación política [...] que comportan su justificación".
} 
Concluye que, en ausencia de los principios de legitimidad no puede mediar contestación ni adaptación. De igual modo, sin principios de legitimidad no se logrará revelar, siquiera vislumbrar, la tirantez existente entre el equilibrio y la disolución que caracteriza el proceso dialéctico resultante de un doble movimiento: el de "evoluciónreforma" y el de "revolución-ruptura."

d) El análisis filosófico.

- Raymond Polin.

Dejando de lado la legalidad como 'medida' de la legitimidad, un sector de la doctrina filosófica, relaciona esta última con la efectividad, reiterando posturas que, como ya hemos sostenido, en mayor o menor medida, han sido sustentadas por otros autores.

Así, este autor considera que la legitimidad es un valor absoluto. No hay proporción en la legitimidad, tampoco límites: ella es total y absoluta, o no es. Pero, si la existencia de un poder es la condición necesaria de su legitimidad, no es condición suficiente. Un poder que se ejerce no es legítimo sólo por el hecho de ejercerlo. Eficacia no quiere decir legitimidad. No se puede medir la legitimidad de un poder en proporción de aquellos que lo obedecen y de los que lo resisten, o del grado de eficacia de sus emprendimientos. (Polin, 1967) En consecuencia, poder legítimo será aquel que -invocando un título de legitimidadal requerir obediencia ésta le es efectivamente admitida.

Es evidente que la postura de Polin resulta opuesta a la de Ferrero ya que, mientras Guglielmo Ferrero decía en 1943 que una época tiene sólo "un principio de legitimación" y lo cambia, ya establecido o en vías de formación, por otro- Raymond Polin indica, veinticinco años después, que una "norma de legitimidad" corresponde a "una afirmación", una convicción histórica; de modo que es un hecho de civilidad, que resulta incomprensible si se pretende analizarlo independientemente de la sociedad a la cual pertenece.

\section{El proceso de legitimación. Fuentes y conceptos.}

La categoría conceptual que toca abordar, hace referencia al desarrollo y la trasformación que acaece en el nivel infraestructural, como lógica consecuencia del relacionamiento que -en las distintas instancias regionales- traban los actores sociales. 
Relaciones que generan revulsivos en la sociedad civil y que, impactan en la esfera del Poder otorgándole consenso, creencia, confianza, conceptos éstos que suponen la preexistencia de una evidente carga axiológica.

Por ello, al igual que lo hicimos en la sección anterior, y en orden a deslindar el proceso de legitimación que acompaña el establecimiento de la legitimidad, hemos de abordar el tratamiento de algunos autores. ${ }^{40}$

a) Desde la politología:

- Maurice Duverger.

El tema de la legitimación, como no podía ser de otro modo, se encuentra en directa liaison con la legitimidad, circunstancia por la que deberemos comenzar por conocer qué significa, para este autor -sociólogo y politólogo- la categoría "legitimidad".

Sostiene que la legitimidad, se encuentra en el centro de las creencias inherentes al poder y, por ende, puede ser considerada como la cualidad que presenta un régimen de estar conforme a la teoría del poder que se estima verdadero. (Botana, 1968:131) ${ }^{41}$

Comprende dos elementos:

a) la coacción material (coacción) y

b) la creencia de que esta coacción está bien fundada (legitimidad).

Dicha creencia se funda en un factor ideológico que refleja, en más o en menos, los "intereses de aquellos que las desarrollan y que creen en ellas".

Las doctrinas sobre la legitimidad se refieren tanto al origen del poder como a su forma. Es por ello, que Duverger enfatiza la trascendencia que poseen, a la luz de la legitimidad, las teorías de la soberanía.

Desde ese punto de vista examina las doctrinas teocráticas de la soberanía divina proclives a conceptuar una legitimidad autocrática- y las doctrinas de la soberanía del pueblo que buscan definir una legitimidad democrática. Esto, en tren de deslindar los tipos de doctrina que se corresponden con los diferentes regímenes políticos, toda vez que, genéricamente hablando, la legitimidad es la conformidad con un sistema de valores. (Duverger, 1962:32-39)

\footnotetext{
${ }^{40}$ Con similar aclaración a la señalada ut supra n. 6.

${ }^{41}$ Menciona Botana que, ya al día siguiente de la liberación, Duverger tiene el mérito de situar el conflicto de sucesión -resultante del reemplazo del gobierno de Vichy por el gobierno provisorio del General De Gaulleen el marco de una teoría sobre la legitimidad. (Ver Duverger, 1945, T.60).
} 
Sociológicamente, un régimen es legítimo cuando la ideología sobre la que se sustenta armoniza con la creencia que es común al colectivo. Si bien el concepto de ‘creencia común' es difícil de precisar, resulta aplicable a sucesos fáciles de reconocer en la praxis ya que se asimila, en mayor o menor grado al 'consenso'. Es una creencia cuasigeneral, aceptada masivamente, contra la que se levantan las doctrinas minoritarias que aparecen como más o menos 'anormales' (por lo que en realidad son ‘dos'). (Duverger, 1963, vol.II: 12 y ss.) ${ }^{42}$

De modo que, si bien la noción de creencia es el corazón del problema, ella es puesta en directa congruencia con el consenso.

Distintos sociólogos analizan la temática, explicando el consenso a través de la investigación de rasgos culturales comunes, que se expresan resaltando organizadamente los usos, sentimientos y actitudes sociales. Por ejemplo, para Durkheim las "representaciones colectivas" constituyen el meollo de la totalidad de los problemas sociológicos. En el mismo sentido, también Duverger entiende que la sociedad es el conjunto de representaciones de los estados de conciencia y de las "creencias". De lo dicho se desprende que la legitimidad se encuentra directamente relacionada con las ideologías y los mitos de una sociedad. ${ }^{43}$

El consenso al que se refiere Duverger no es otro, entonces, que el acuerdo cuasigeneral existente entre quienes constituyen una sociedad, con relación a una forma de gobierno que conceptualizan como legítima.

En virtud de ello, esa forma de gobierno está establecida por una ideología que opera en el seno del tejido social como una imagen propulsora frente a la cual, la cuasi-

42 También acerca Botana (1968:132) la siguiente definición tomada de Duverger, 1961a:35: "En un país dado, en un momento dado, existe generalmente un cierto 'consenso' con respecto a la forma y el origen del poder, de la estructura y de la investidura del gobiernos: es legitimo, en el sentido positivo del término, el gobierno que corresponda a ese 'consenso'. Así, la legitimidad releva de análisis científico. Ello no impide que, para un demócrata, solo el poder de origen popular sea legítimo: pero esa legitimidad descansa sobre un juicio de valor, sobre una adhesión personal, y no releva de un análisis sociológico".

${ }^{43}$ Sostiene Botana que las creencias descansan en "[...] opiniones subjetivas. Esas creencias pueden constituir conjuntos elaborados y sistematizados, o bien conjuntos más vagos, menos sistematizados, el primer tipo de creencia se relaciona con las ideologías, el segundo con los mitos. Las ideologías y los mitos definen los sistemas de valores que expresan las definiciones morales, las concepciones del bien y del mal, de justicia e injusticia, sobre las que descansa toda sociedad [...]" Y cita a Duverger, 1966:147 (Botana, 1968:133) quien expresa: "Cada ideología busca definir la imagen de un gobierno ideal. Ella considera como legítimos les gobiernos que se acercan a esa imagen y como ilegítimos los otros [...] determina así un tipo de legitimidad: hay una legitimidad monárquica, una legitimidad democrática, una legitimidad comunista, etc. La legitimidad no se define en abstracto, [...] sino en concreto, en relación a cada una de las concepciones históricas del tipo ideal de gobierno, es decir a cada una de las ideologías políticas." 
totalidad de los ciudadanos orienta su confianza.

Si los actores abandonan la creencia en esa ideología, sin que medie una ideología de reemplazo, existirá ruptura del consenso. De modo que -al interior del colectivo- las ideologías entrarán en conflicto y, en tanto que una de ellas no obtenga unidad en torno a su 'modelo', esa sociedad ingresará en una crisis de creencia.

Es aquí donde incuestionablemente el análisis de Botana coincide con el esquema formulado por Duverger, en lo referente a la doble distinción de la legitimidad considerada como causa formal, por una parte, y eficiente, por otra, de un régimen político.

También entiende Duverger que, si los principios de legitimidad devienen principios constitutivos de un régimen político, resulta incuestionable su relación con las distintas ideologías políticas. Ideologías estas que, en tanto contingentes y cambiantes intentan determinar la imagen de un gobierno ideal (entendiendo gobierno como forma de un régimen).

Considerada como causa eficiente, la legitimidad se relaciona al hecho del maridaje de la ideología con la creencia de la población a la que esta ideología y, consecuentemente, el tipo de régimen por ella determinado, se aplican.

Evidente resulta entonces, la doble función que la ideología cumple en el análisis weberiano: por una lado, plasma el principio de conformación de un régimen político y, por otro, estipula el funcionamiento del régimen, concertando o no, con la ideología que lo determina. Si no concuerda, es porque una parte de los gobernados deja de creer en una ideología de 'mantenimiento', confiando, por el contrario, en una o varias ideologías de 'rechazo'.

Basándose en esta distinción, Duverger determina los límites que tipifican el pluralismo de las democracias occidentales, el cual no interviene al interior de la ideología legítima, la que no resulta cuestionada, aceptando, además, el marco constitucional y las reglas de juego establecidas (con la sola excepción de Francia e Italia). (Duverger, vol.II, 1963:12 y ss.) ${ }^{44}$

\footnotetext{
${ }^{44}$ Señala Botana (1968:134) que esta distinción permite a Duverger determinar los límites del pluralismo de las democracias occidentales, aclarando que "en todas las naciones del Oeste, salvo en Francia e Italia, los diferentes partidos no se oponen al régimen existente [...] Aceptan el marco constitucional y las reglas de juego establecidas. En Francia e Italia solamente, el pluralismo pasa esos límites, y juzga a los partidos opositores al régimen, entonces la ideología es incompatible con ellos: fascistas en la extrema-derecha, comunistas en la extrema-izquierda."
} 
Claramente expone, poniendo de relieve la importancia de la ideología, que es a partir de ellas que lograrán desgajarse los principios de legitimidad que devienen determinantes de las formas constitutivas de los regímenes políticos.

También, y en paralelo a la categoría de las ideologías, el examen de la noción de conflicto resulta central, ya que es el primer elemento de la política, pues todo poder pretende eliminar o reducir, o por lo menos lo intenta, la problemática que ofrece la integración. Concepto este último que, directamente vinculado a la legitimidad, lo lleva a diferenciar la lucha "sobre" el régimen y de la lucha "en el" régimen. (Duverger, 1966:284) ${ }^{45}$

De tal modo, los estilos que adopta la lucha sobre el régimen, diferencian entre los fines y los medios empleados por las fuerzas contestatarias. Por lo que, conformando una estrategia de acuerdo a la relación de fuerzas que presente un determinado régimen, las fuerzas contestarias pueden rechazar las reglas de juego que rigen el régimen para arribar al objetivo a largo plazo, o aceptar esas reglas como un medio necesario para cumplir ese mismo fin. Posibilitando, la segunda conjetura, percibir un principio de integración progresiva.

Al respecto, revela Duverger la hipótesis de cierto umbral contestatario susceptible de ser cuantificable: "no hay problema" por la estabilidad del régimen, si una fuerza contestataria -que subordina, el fin a largo plazo al del corto plazo- no reúne más que 5 o $10 \%$ de los sufragios; "situación intermedia", donde la incertidumbre en relación a la legitimidad aumenta, si ella reúne 20 o $30 \%$ de sufragios, dado que todo se estabiliza en ese porcentaje; "situación de crisis", en fin, si ella se acerca al umbral del 50\%, las condiciones de legitimidad están rotas, el régimen se encamina hacia una dictadura de derecha o una dictadura de izquierda. (Duverger, M., 1966:284)

La ideología y el conflicto, constituyen pues, la base del diseño sobre el cual,

\footnotetext{
${ }^{45}$ Ver también M. Duverger, 1964:268 ss. (cit, en Botana, N., 1968:135) donde sostiene: "La lucha queda en el marco del régimen, si la mayor parte de los ciudadanos lo considera legítimo, si hay consenso sobre su propósito. La lucha va sobre el régimen, si ese consenso se rompe, si ciertas clases, ciertos grupos, ciertos partidos tan solo juzgan legítimo el régimen existente, entonces las otras clases, grupos o partidos tercian por otra forma de legitimidad. En consecuencia, la lucha en el régimen o la lucha sobre el régimen no son estrategias por las que se busca cohibir en general. Una y otra se imponen por la situación. Si el consenso político está quebrado, esta situación revolucionaria entraña una lucha sobre el régimen. Se puede mantener la lucha en el marco del régimen si hay consenso sobre la legitimidad. La elección no es posible en situaciones intermedias, o el consenso está en vía de ruptura sin estar todavía dañado muy profundamente, o bien en vía de restablecimiento total restando aún contestatarios. Entonces solamente los partidos tienen elección entre aceptar las reglas del régimen o, cuestionar esas reglas"
} 
Duverger, desarrolla su análisis. Esto así, las interferencias habidas entre las ideologías sean las que determinan el tipo de régimen, sean las que se manifiestan al interior de la sociedad- generan un proceso susceptible de ser medido en relación al fenómeno del conflicto y a través de la diferenciación entre fines a "corto" y a "largo" plazo. (Botana, 1968:136) ${ }^{46}$

¿Es real que Duverger se conforma con una primera concepción del consenso, que resulta de una comunión de sentimientos y creencias? Vale decir: los actores participan de una misma conciencia colectiva, de manera que el consenso es una unidad hecha. Circunstancia que, por otra parte, es exterior a la conciencia individual e independiente de ella.

Esto no es así, ya que, en una segunda postura conceptualiza el consenso, como resultante de un acuerdo elaborado bajo la conducción de una voluntad reflexiva que -sin ejercer ningún tipo de violencia- concibe una norma común a todos que, no solo les es ventajosa, sino que, al propio tiempo, los obliga.

En ese sentido, el conflicto constituye, una variable que permite entrever cómo el acuerdo debe ser jugado dinámicamente. Ello, toda vez que, recién después del proceso, es que se llegará a medir el grado de ese acuerdo -acaecidos la discusión y el enfrentamientofrente a las reglas que rigen la solución de esos conflictos.

Este acuerdo podrá unirse a una forma pura como es el caso -ya señalado por Weber- de una asociación voluntaria o, en una grado intermedio. En este último caso, no acaece este pacto pues la unión, lejos de darse voluntaria y activamente, se da a través de un proceso conflictivo y mediante las reglas que un orden político determinado presenta al elegir la acción.

De modo que -cuando el pacto se relaciona a un orden- debe existir por parte de los actores que participan del mismo, la atribución de una cualidad al régimen, que no es otra que la de la legitimidad.

Ello implica, por un lado, reconocer el orden como legítimo e intentar, por el otro,

\footnotetext{
${ }^{46}$ En ese orden de ideas, manifiesta Botana, que el esquema trazado puede adoptar, un modo de funcionar circular: “[...] el consenso sobre la legitimidad, es decir sobre la ideología que determina el régimen, permite integrar el conflicto en el régimen, tanto como la ausencia del consenso sobre la legitimidad tiende a llevar a los actores a un conflicto sobre el régimen. Lo contrario es por tanto posible: el conflicto en el régimen permite entrever como los actores se ponen de acuerdo para mantener un régimen, es decir para elaborar un consenso al respecto; en tanto, el conflicto sobre el régimen permite entrever, como los actores no llegan a elaborar un consenso capaz de sostener el régimen en cuestión."
} 
elaborar un acuerdo que tiene por finalidad las reglas invocadas por el régimen.

Fácticamente, ambas ideas del consenso son interdependientes una de la otra. (Botana, N., 1968:137) ${ }^{47}$

En lo que a las crisis se refiere, Duverger, reconoce que las crisis de legitimidad crean una situación revolucionaria donde ningún gobierno es reconocido como legítimo por el conjunto del país. (Duverger, M., 1961:54 ss.) ${ }^{48}$

\section{- $\quad$ Carl J. Friedrich.}

Se pregunta este autor, ¿si la mayor parte de los individuos que están sometidos a un gobierno dado, creen que él está fundado sobre un título válido?

De tal interrogante, se colige que la problemática de la legitimidad es para Friedrich, un problema de hecho. De manera que, un acto político está legitimado, si se hace conforme a la creencia que el mayor número de quienes integran el colectivo tiene al respecto. (Friedrich, 1963:234, cit. en Botana, 1968:144)

La legitimidad será entonces, la cualidad que tendrá un gobierno si los sujetos creen en el título que él invoca. La legitimidad se mide, pues, a partir de aquellos que ocupan los roles de poder. Sin embargo, el objeto de la legitimación no es el gobierno sino el título que él invoca. Por esa vía, la legitimidad está directamente ligada al régimen político. (Friedrich, 1963: 232)

Esto no sucede si el colectivo social se encuentra dividido respecto a la autenticidad de los títulos de aquellos que tienen el derecho a gobernar, puesto que se opera una división en la sociedad política en relación a qué se entiende, qué es, qué constituye la legitimidad. (Friedrich, 1963:237) ${ }^{49}$

Cuestión ésta, que nos introduce en la fórmula "chère” al pensamiento anglosajón: "the agreement on fundamentals". Friedrich entiende que debe existir cierta cuota de

\footnotetext{
${ }^{47}$ De donde, "[...] hay consenso porque se es parte de una misma cultura, pero hay consenso también porque los actores llegan a elaborar un acuerdo que tiene por objeto las reglas del régimen. Una definición de la legitimidad debe tener en cuenta las dos perspectivas pues la primera resulta de un consentimiento que valoriza las ideologías en tanto que representación unitaria del mundo histórica, mientras que la segunda surge de un consentimiento que valoriza un mecanismo procedimental capaz de reglar la discusión y el conflicto".

${ }^{48}$ Duverger refuerza entonces su argumento resaltando que: "El poder pierde asidero en el espíritu y el corazón de muchos ciudadanos: él se debilita, y arriesga no ser más respetado. Entonces, la tentación deviene grande para cada facción, de emplear la violencia para imponer su concepción de autoridad a otra fracción”. (Botana, 1968:205)

${ }_{49}$ Piensa Botana (1968:144) que el autor tiende a distinguir esta situación a partir de lo que pensamiento griego llama "anomia".
} 
acuerdo sobre lo que es fundamental, es decir, sobre el tipo de régimen que es válido y la suerte del gobernante que tiene el título para gobernar. (Friedrich, 1963:238)

La elaboración de tres proposiciones concernientes a la legitimidad, nos habilita para concluir en que, Friedrich, enfoca la legitimidad en tanto que causa eficiente de poder. $\mathrm{Su}$ argumento, pues, privilegia la 'creencia', como el elemento que determina la legitimidad, rebatiendo expresamente el rol de la legitimidad como constitutivo de un régimen político.

Señalará, sin embargo, la hipótesis que resulta de abordar -en lo atinente- la división que se opera en el seno del colectivo social en relación a la autenticidad del título del que reclama el derecho a gobernar. A no dudar, este hecho señala la presencia de principios de legitimidad antagónicos. Existe un proceso según el cual, en forma paralela al tipo de creencia reclamada por el sistema de poder vigente, se levanta un tipo de creencia que califica un sistema de poder emergente. Esta ruptura no encuentra sus raíces únicamente en el hecho de la oposición de dos o varias maneras de concebir una organización institucional. Detrás de esta postura, a nuestro juicio, se puede entrever el conflicto entre dos principios, cada uno valoriza un tipo de régimen que permitirá a los gobernantes revertir el título legítimo para reclamar obediencia. Pero un "principio" de legitimidad todavía no es un "sistema" de legitimidad.

Reiteramos, el principio de legitimidad tan solo supone una pretensión de legitimidad. El soberano que lo invoca dice a los ciudadanos: este debe ser obedecido porque es la ley que tenemos como válida.

A eso es necesario agregar la respuesta del colectivo que reacciona frente a esa demanda; o bien es la creencia efectiva, y se tiene como válida puesto que el gobierno que la propone ocupa un rol y reclama un título que es reconocido como legítimo; o bien es un universo de creencias fragmentadas al interior del cual, circulan distintas pretensiones de legitimidad sin que el autor de ellas pueda efectivamente lograr el acuerdo de los ciudadanos en conflicto. Por lo expuesto, ningún gobernante es capaz de garantizar con el sello de la legitimidad el sistema de poder en vigencia, ya que, una fracción del colectivo social relaciona su confianza a un principio antagónico que invoca una pretensión de legitimidad alternativa. (Botana, N., 1968:145 ss.)

Sobre la base de estos argumentos Friedrich propone una clasificación de los tipos 
de legitimidad, diferenciando cuatro tipologías:

a) el tipo religioso, que permite la existencia de sub-tipos (teniendo en cuenta la interpretación que las distintas religiones han otorgado al concepto y sentido de mando y obediencia, en el devenir histórico).

b) el tipo jurídico y filosófico, que se refiere a las variopintas ideas respecto a las formas que puede adoptar un poder institucionalizado.

c) el tipo tradicional que -si bien guarda relación con las formas de poder institucionalizado- lo hace desde el punto de vista de una creencia generada en la costumbre, en cambio de una creencia fundada sobre el discurso filosófico.

d) por último, los tipos procedimentales y pragmáticos, referidos: i) a los disímiles sistemas electivos -entendidos como mecanismos de legitimación- y ii) a las preferencias basadas sobre la perfomance o el resultado obtenido (v.g.: la victoria en una guerra, ó el mantenimiento de la prosperidad ó de la seguridad interna). (Friedrich, 1963:236) ${ }^{50}$

Queda claro que, en la totalidad de los casos, la legitimidad está vinculada a una determinada concepción de poder (el tipo religioso ó el tipo jurídico-filosófico); de tal modo, el tipo de creencia solo puede cambiar para bien.

Por lo tanto, existe legitimidad tanto desde la perspectiva de una creencia basada en la lógica filosófica, cuanto observándola desde el ángulo de una creencia asentada en la costumbre.

Esto así, no cabe duda alguna que para Friedrich, es el tipo de creencia la que determina el tipo de legitimidad. El tipo de régimen sobre el que descansa el consentimiento puede ser el mismo, sin embargo diversos tipos de creencias pueden determinar la suerte de la legitimidad que se le atribuye.

Distingue entonces, una óptica que concibe la legitimidad del poder a partir de una aproximación de tipo igualitaria; de otra, que la interpreta, sea a partir de una aproximación aristocrática (legitimidad fundada sobre la creencia en un título hereditario), sea a partir de una aproximación plutocrática (legitimidad fundada sobre la creencia que tiene a la

\footnotetext{
50 Destaca Botana (1968:147) que : "En lo que concierne a las formas que puede revestir un poder institucionalizado (kinds of rule) conforme al tipo de legitimidad jurídico-filosófica, Friedrich nos presenta una tipología bastante amplia que se escalona en trece categorías: "1) Anarquía [...]; 2) Tribal rule [...] 3) Monarquía despótica[...] 4) Oligarquía [...] 5) Oligarquía (otra forma) [...] 6) Oligarquía (otra) [...] 7) Democracia directa; 8) Tiranía; 9) Burocrática; 10) Parlamentaria [...] 11) Presidencial [...] 12) Militardictatorial; 13) Totalitarismo dictatorial [...]”
} 
adquisición de la riqueza como el único factor capaz de conferir un título para gobernar).

De modo que el punto de vista igualitario, es ilustrado en relación a tres cuestiones: a) una señala el rol de legitimación tenido por el logro de ciertas metas valorizadas por el colectivo como tales, por ejemplo, la prosperidad y la seguridad; b) otra, destaca el rol de las ideologías en relación a su capacidad -en un mundo secularizado con relación a la tradición y a la religión- para determinar el derecho de gobernar y el deber de obediencia: ese rol está más limitado en una sociedad democrática que en una sociedad totalitaria y c) una tercera, subraya el rol del nacionalismo contemporáneo en tanto que mecanismo de legitimación de los líderes de las naciones independientes. ${ }^{51}$

Por lo que, en Friedrich,

"La legitimidad de tipo igualitario se explica en relación a las preferencias populares que vienen de las bases. La legitimidad de tipo aristocrático o de tipo plutocrático se explica, por el contrario, por la capacidad intrínseca que se le reconoce a una capa social (por ejemplo, la aristocracia) de ejercer el derecho a gobernar... ${ }^{52}$

${ }^{51}$ Para Botana (1968:148): "Friedrich se refiere explícitamente aquí a la legitimidad personal [...] La cuestión más importante que, según nosotros, desarrolla desde esta hipótesis es la siguientes: los libertadores no derivan su legitimidad de la voluntad del grupo para devenir una nación independiente, sino por el contrario de su autoridad. Pensamos sobre todo en el caso de Simón Bolívar en América latina. El jefe victorioso fue capaz de derivar su autoridad de la voluntad de independencia -más o menos consciente- de las colonias españolas [...] Solamente cuando Bolívar, después de las guerras de la independencia, ensaya construir un orden institucional monocrático que constituirá la armadura capaz de consolidar su deseo de unidad continental, cae. Las fuerzas centrífugas desarticularon el edificio y la Gran Colombia fue partida en una serie de pequeños estados. Hay aquí un hecho importante: el fracaso de los hombres políticos, que encarnan la voluntad de independencia de una colectividad sin por tanto ser capaces de construir un orden institucional que les trascienda. La efectividad para consolidar la independencia no es suficiente para crear un sistema de legitimidad interna. Junto a esta efectividad, es necesario unir la voluntad nacional en la aceptación de un principio institucional de gobierno. El elemento característico de las naciones emergentes es precisamente ése. Se construye un Estado a partir, al menos, de criterios determinados por la ley internacional. Sólo al interior de los Estados la sucesión casi ininterrumpida de regímenes diferentes, la ausencia de normas capaces de reglar los conflictos de sucesión, demuestran que la legitimidad es aún una cualidad que no se puede hallar, en ausencia de una creencia, en los valores de un principio institucional de gobierno."

${ }_{52}$ Y continúa diciendo (1968:148-149) que: "Un mismo tipo de legitimidad -el tipo igualitario- puede aplicarse en relación a los tres tipos de creencia: creencia en una ideología, en una meta de seguridad o de prosperidad, o bien en el objetivo mayor de la independencia nacional. Nadie podrá negar que el tipo igualitario hallará diferentes tipos de legitimación según que se trate de una ideología igualitaria que justifique el poder de una minoría dominante en un régimen monocrático (para Friedrich totalitario), o bien del dominio del crecimiento económico en un régimen democrático de una sociedad industrial próspera, o aún de una nación emergente, donde el gobierno depende más de la autoridad personal del líder, que ha cristalizado en él la voluntad de la colectividad de lograr una nación que dé estabilidad a las instituciones que están todavía en tren de construirse. En los tres casos el mecanismo de legitimación difiere: en los dos primeros porque el mecanismo de legitimación depende del principio constitutivo del régimen; en el tercero, porque la legitimidad es aún una cualidad que falta a los gobernantes. Faltan instituciones capaces de fijar 
Diferenciando ambos tipos de legitimidad (igualitario y aristocrático), Friedrich considera que, el primer tipo se contrapone con el segundo toda vez que la legitimidad de los gobernantes, es el resultado de su mérito o de su perfomance, más que de su sabiduría para ejercer las funciones de gobierno. Toda vez que, puestos los ciudadanos en la tarea de elegir a los gobernantes, el tipo igualitario otorga más confianza al entramado social, que el tipo aristocrático.

Cierto es, también, que ambos tipos plasman dos criterios de legitimidad bien diferenciados y que no resultan ajenos al distinto matiz con que Ferrero caracteriza los principios de legitimidad monárquico y democrático.

Sin embargo, cuando tipifica ambas categorías conceptuales, Friedrich esclarece la cuestión, al plantear que el tipo de creencia depende del tipo de legitimidad que se pretende implantar: i) en el caso de un principio igualitario, la creencia que se reclama valoriza o desvaloriza la perfomance de los gobernantes, en tanto, ii) en el principio aristocrático, la creencia valoriza o desvaloriza el potencial de una estrato social para ejercer el mando.

En los dos casos la creencia se genera desde abajo, así como la versión institucional de un principio de legitimidad viene desde lo alto. Es entonces, en el encuentro de las dos líneas, que se podrá prefigurar un sistema de legitimidad, en el marco de las dimensiones del poder y de la justicia. ${ }^{53}$

b) Visión de la Sociología.

- Barbé Carlos.

Para este autor el meollo de la legitimidad -criterio que también comparten algunos tratadistas como Comte y Polin- guarda íntima relación con la elección de un "diseño de vida" por parte de quienes conforman el colectivo.

Esto así, ¿Cuál es ese diseño de vida? ¿Es sólo uno? Acaso ¿Es sólo a través de la

\footnotetext{
un tipo de organización de poder, esos colectivos de naciones emergentes prueban, experimentan, ensayan, su roles, confiando en la autoridad personal de los líderes, antes que en la traducción institucional de un principio de legitimidad aún no encontrado. Aquí [...] la doble perspectiva de la legitimidad en tanto que causa formal y eficiente del poder aparece más comprensiva, el mecanismo de legitimación (causa eficiente) depende del principio de legitimidad (causa formal) que valoriza un modo de distribución y de transferencia del poder en el seno del colectivo."

${ }^{53}$ Precisa además Botana, (1968:150) la importancia del relacionamiento que hace Friedrich entre la idea de legitimidad y la idea aristotélica de justicia distributiva [...] entendiendo que, para este autor, ese punto particular toma sentido no sólo en relación a la ciencia política sino también y más, en relación a la filosofía política.
} 
institucionalización de todo un proyecto de vida que se produce la legitimación de un sistema de poder?

La expresión 'proyecto de vida', debe considerarse como definición de la situación que no solo significa relación, acción, interacción, valores y símbolos, sino también, posición, status y rol- y de la habilidad del sistema de poder, y del concreto poder, para manifestarse como perteneciente al modelo ideal (caracteres, éstos, que corresponden al proceso en su forma "pura" o ejemplar). ${ }^{54}$

E1 modelo de vida (o proyecto de vida o diseño de vida) implica pues, el lugar que ocupa el hombre en la naturaleza y la articulación que media entre los hombres. Lo que anhelan, lo que esperan alcanzar, o no, en el escenario en el que se reproducen esos vínculos humanos. (Smelser, 1968: 237) ${ }^{55}$

Y si un particular diseño de vida, es fundamental en el proceso de legitimación de un específico sistema, dentro de la estructura "legitimación" -que tiene lugar en toda 1a sociedad humana- el contenido de un diseño de vida es, por lo tanto, contingente.

Por el contrario, como hemos visto supra, D.Easton, prefiere llamar todo "legitimidad", involucrando así, la "legitimidad del gobierno", la "legitimidad del régimen" y la "legitimidad de la comunidad".

Tal postura supone, de alguna manera, camuflar las disímiles peculiaridades que presentan uno y otro fenómeno, refutando la esencia misma del fenómeno legitimación, que se encuentra ínsito en el mecanismo de institucionalización de un determinado diseño de vida.

Incuestionablemente, la sociología electoral ha favorecido esta confusión, al admitir un proceso electoral como vía de legitimación. Ello toda vez que, la mayoría electoral -que, a no dudar, implica un marcado consenso hacia un grupo de candidatos del partido al cual están vinculados- es tomada como prueba de la legitimación de todo un sistema de poder. Esto, más allá que el resultado satisfactorio sea solo momentáneo.

Para aclarar la génesis y el proceso de formación de la legitimación, es preciso delimitar los fines -e implicancias- de ambos fenómenos.

Una interpretación mecanicista de ella, indicará que, si el proceso de legitimación se

\footnotetext{
${ }^{54}$ Sostiene Barbé, (1973:43), que la expresión 'proyecto de vida' está tomada de Clyde Kluckhohn (1951); ver también Kluckhohn C. y Kelly W. (1945.)

${ }^{55}$ Y agrega Barbé (1973:43) que Smelser adopta esta frase para definir la 'creencia basada en los valores'.
} 
produce así, esto significaría que, a un estadio del desarrollo de las fuerzas productivas correspondería un núcleo tipo de superestructura política, cosa que la experiencia histórica no siempre confirma. Ello, toda vez que no resultaría razonable imaginar una formación política organizada bajo un sistema democrático-parlamentario, en una sociedad donde las relaciones de producción fueran de tipo feudal ya que, la unión entre los valores del colectivo y el régimen donde se asienta el mandato, se han quebrado.

No obstante, la problemática no es tan clara. Tal como sucede en muchos países latinoamericanos en los que, aún cuando se encuentran organizados políticamente como una democracia-parlamentaria, las relaciones económicas que se dan son de tipo feudal. (Romano, 1972)

Barbé, al analizar la cuestión referida a consenso, diseño hegemónico y tipos de legitimación y, aludiendo puntualmente a legitimación y consenso, sostiene -con algunas reflexiones que, se nos ocurre, resultan cercanas a la postura de N. Botana- que:

a) Los actores del proceso de legitimación son por una parte, e1 legitimado -un sistema de poder, sobre todo a través de un concreto poder- y, por la otra, el legitimante aquel que concede legitimación a un determinado sistema de poder, o a un elemento de él. (Barbé, 1973:41)

Así, la interiorización en el actor de un conjunto de valores, constituye el primer momento para lograr o no la buscada legitimación.

El segundo momento, vale decir, el que lleva a la concesión de la legitimación, supone, por parte del agente-legitimante, de una previa representación del ideal interiorizado respecto a determinado elemento del sistema de poder. Representación que, en consecuencia, constituye el fundamento de 1a creencia en determinado sistema de poder, o en un elemento de él, en virtud del paradigma ideal interiorizado.

b) De tal modo, la legitimación es el producto del mencionado proceso de interacción entre poder y legitimante que -pese a contar con variopintas especificidades, poseen mecanismos similares- se repite en la totalidad del conjunto humano (como también en subgrupos de determinada sociedad; o sea, también en particulares "sistemas sociales" según el decir parsoniano). ${ }^{56}$

56 Dice Barbé, (1973:42) que el sistema social para Parsons, “[...] no es equivalente en términos de
estructura-funcional a la noción de sociedad. El equívoco pudo originarse en el hecho que voluntariamente
Parsons proporciona ejemplos de sociedades concreta e históricamente existentes cuando habla de sistema 
c) De manera que, el concepto de legitimidad -como momento adquirido o definitivo- si bien no existe en el proceso anterior, sí, aparece en éste para dar nombre al contenido de aquella representación, en tanto germen de la misma y que el actor internaliza respecto a una época de la historia.

d) Como corolario resulta que, la representación es el resultado de la institucionalización de una serie de valores que, articulados, delinean todo un modelo de vida (o proyecto de vida o diseño de vida). Categorías conceptuales que difieren de "ideología", dada la gran carga afectiva que la caracteriza -sea positiva o negativa- y que será motivo de interpretaciones contrapuestas. (Barbé, 1973:42) ${ }^{57}$

Perfilada la legitimación toca ahora interrogarnos, con mayor énfasis, acerca de ¿cuáles son las semejanzas y cuáles las diferencias respecto del consenso?

Aunque tanto uno como otro tienen múltiples significados, algunos autores consideran ambos vocablos como sinónimos, entre ellos TH. Newcomb y L. Lipsitz.

El significado con el que lo ha identificado la tradición romana es el de consensus gentium, es decir, como convergencia de opiniones entre dos o más personas; acepción que, posteriormente, fuera receptada en el medioevo en el sentido más amplio de "consentimiento" o acuerdo (conf. F. Barbano).

De modo que, mientras el consenso es la adhesión que una parte de los actores, manifiesta respecto a la actividad desarrollada por el soberano -sea en su totalidad o con referencia a una parte de la misma- la legitimidad, es el status que ocupa un poder en virtud de un título -derecho divino, sucesión dinástica- por el cual dicho poder es ejercido. De modo que el soberano podrá ser legítimo, aunque carezca de consenso sobre su obrar. (Barbé, 1973:45).

social. El concepto de sistema social fue mencionado la primera vez por Pareto para indicar el equilibrio social, o sea el equilibrio de una sociedad. Para Parsons en cambio, no solo la sociedad es un sistema social, sino que cualesquiera conjunto de relaciones sociales lo es, independientemente de la dimensión. Por tanto, un sistema social puede coincidir con un grupo experimental de dos o tres personas, o con un hospital, o también con el imperio chino antiguo o con la sociedad americana contemporánea" (v. Barbano, 1966:118 ss.).

${ }^{57} \mathrm{Y}$ añade, "La historia de la legitimidad será entonces, la historia de la utopía política; pero no de toda la utopía, sino de aquella que, en un concreta sociedad, fue considerada el modelo que respetaba la conformación de esa sociedad", ya que la legitimidad varía según el momento histórico. Y, en orden al concepto de ideología, dice que en el lenguaje habitual y también en el técnico, ideología, según Gramsci, es utilizada "[...] no simplemente como elemento de conocimiento, como noción, etc., sino también como proceso de simbolización, de transposición mítica, de "gusto", de "estilo", de "moda", en síntesis, el "modo de vida" en general [...] p.28-29"), sea en el sentido de sistema conceptual o conjunto de ideas y creencias, ya con la connotación marxiana de falsa conciencia. 
Más adelante, la aparición de la teoría contractualista dentro de la estructura "legitimación", incorporó como elemento contingente -o criterio de legitimación- la soberanía popular.

Aclara Barbé al respecto que, a su juicio, la fórmula política de Gaetano Mosca, se identifica con la expresión criterios de legitimación y no con el concepto de legitimidad tal como es usada . (Barbé, 1973:46) ${ }^{58}$

De modo que la atención pasa del poder al legitimante, de allí la razón por la que los autores terminaron por adoptar ambos términos como sinónimos, o al menos como pertenecientes a una misma categoría de fenómenos.

Finalmente, la legitimación, que posee un origen muy distinto, terminó siendo entendida como una forma, aunque específica, de consenso.

Ante la complejidad, que restó operatividad al concepto, algunos autores utilizaron distintas categorías en un intento por precisar el espacio de la legitimación. Mientras E. Shills prefiere referirse a "croyances fundamentales", D. Easton, prefirió englobar los fenómenos en el concepto "legitimidad".

Para Parsons, la legitimación es sólo legitimación de la acción, dado que los valores están "institucionalizados" en un sentido único. Consecuente con su percepción, no contempla la posibilidad de la des-legitimación o de la legitimación de valores alternativos, sino sólo del hecho que

"[...] la oposición bajo forma de tendencia a la no conformidad nace ahora de una

\footnotetext{
${ }^{58}$ Dice Mosca (1966:85-87) "[...] ocurre a menudo, o al menos ha sucedido hasta ahora en toda sociedad numerosa y apenas llega a un cierto grado de cultura, que la clase política no justifica exclusivamente su poder sólo con la posesión de hecho, sino que busca dar una base moral y también legal, haciéndola surgir como consecuencia necesaria de la doctrina y la creencia generalmente reconocida y aceptada por la sociedad que dirige [...] Esta base jurídica y moral, sobre la cual una sociedad apoya el poder de la clase política, es aquella que en otro trabajo hemos llamado, y que ahora llamaremos "fórmula política", y que el filósofo del derecho denomina generalmente "principio de soberania". Ella difícilmente es idéntica en sociedades diversas, y dos o varias fórmulas políticas tienen notables puntos de contacto, o una semejanza fundamental, solo cuando es profesada por el pueblo que tiene el mismo tipo de civilización, o [...] pertenece al mismo tipo social. Las diversas fórmulas políticas, según el diverso grado de civilización de la gente sobre la cual están vigentes, pueden fundarse sobre una creencia sobrenatural o sobre un concepto que, si no es positivo, o sea fundado sobre la realidad de los hechos, parecen al menos racionales. Diremos que, tanto el primer caso como el otro, responden a una verdad científica; es más, debo confesar que, si ninguno ha visto jamás el acto auténtico con el cual el Señor ha dado facultad a cierta persona o familia privilegiada de regir por cuenta suya el pueblo, un observador concienzudo puede también fácilmente constatar una elección popular, por cuanto el sufragio [...] no es comúnmente la expresión de la voluntad de la mayoría".
} 
incompleta institucionalización [...]" (Barbé, 1973:48-49) ${ }^{59}$

Por el contrario, a juicio de Barbé, existe legitimación cuando la articulación de los valores permiten un diseño de vida. Lo que resulta legitimado es el diseño (o alguno de sus elementos) no la acción.

El consenso, entonces, ocupa un tercer nivel, encontrándose entre ambos uno intermedio al que denomina poder residual de legitimación. ${ }^{60}$

Por lo tanto, el consenso a un concreto poder o a sus acciones, puede ser consecuencia indirecta de la legitimación del sistema de poder -del cual el concreto poder

${ }^{59}$ Barbé, ejemplificando, señala: “El día en que, en una monarquía hereditaria, el hijo del soberano fallecido
es coronado, tendrá consenso de parte de quienes han legitimado el poder monárquico. Este consenso deriva
directamente de aquella legitimación (consenso residual de legitimación). Pero aquel mismo día, un grupo de
republicanos que luchaban activamente contra la monarquía dan también consenso a la coronación en virtud
del hecho que, en ese estado, el peligro era que fuese coronado un primo del nuevo rey que, por su personal
idiosincrasia, hubiera podido iniciar una persecución más violenta contra los republicanos. Este consenso no es un cambio legitimante del sistema monárquico sino solo contingente [...]".

${ }^{60}$ En busca de esclarecer aún más la diferencia entre consenso y legitimación, Barbé (1973:49) recurre a un fragmento de Weber, quien señala: "Entendemos definir el contenido de sentido de una relación social con el término 'ordenamiento', cuando la conducta está orientada, principalmente, en vista del dato 'máximo'. Hablamos entonces de 'validez' de este ordenamiento para el caso que la orientación del hecho en vista de tal máximo adviene por lo menos también (en una medida prácticamente relevante) de manera que sea considerada válida para actuar, vale decir vinculante, sino ejemplar. De hecho la orientación del actuar en vista de un ordenamiento tiene luego, parte de aquellos que participaron, por motivos muy diferentes. Pero la circunstancia que, junto a otros motivos, una parte al menos de los individuos que tenían delante como modelo o como obligación -cualesquiera cosa que debe valer- también el ordenamiento, aumenta naturalmente la posibilidad que el actuar sea orientado en vista de eso, y, a menudo en medida muy relevante. Un ordenamiento mantenido por lo tanto sobre la base de motivos racionales respecto al objeto y, en general, de la gran fragilidad de una orientación en vista de lo que está simplemente fundado sobre la costumbre, mediante un comportamiento adquirido -que es la especie más frecuente de conducta interna. Pero esta orientación es todavía más frágil que otra que se presente rodeada de prestigio, de ejemplaridad o de obligatoriedad, es decir, del prestigio de la 'legitimidad'. El traspaso de la orientación meramente tradicional, se da motivada por lo tanto sobre la base racional respecto al objeto, en vista de un ordenamiento, a la creencia en su legitimidad, [...] jamás fluye de la realidad." (Weber, 1968:9, par.2) у continúa 'La 'legitimidad' de un poder puede, naturalmente, ser considerada, tan solo como la posibilidad que él sea retenido como tal en una medida relevante, y que de esto derive una correspondiente acción práctica. No es de ninguna manera cierto que cada disposición a obedecer a un poder sea orientada en modo primario (o incluso tan solo generalmente) en base a esta creencia. La disposición a obedecer puede ser simulada por el particular o por el grupo, solamente por motivos de oportunidad, puede ser asumida como inevitable por debilidad y por necesidad de protección. Todo esto no es decisivo para la clasificación de un poder. Decisivo es en cambio, el hecho que su propia pretensión de legitimidad 'valga' según el tipo, en una medida relevante, garantizando su subsistencia y al mismo tiempo determinando la especie de los medios de poder seleccionados. Un poder puede además -y este es un caso frecuente en la práctica- ser asegurado en modo casi absoluto, por la evidente comunidad de intereses, a través del señor y su aparato administrativo (guardia del cuerpo, pretorianas, guardia "roja" o "blanca") en la confrontación de los súbditos, y de la falta de defensa de estos, que eso puede incluso hacer a menos la pretensión de 'legitimidad'. Además, la especie de la relación de legitimidad entre el detentador del poder y el aparato administrativo, siempre se configura en modo muy diverso según el fundamento de autoridad que los une, y resulta al máximo grado decisiva -como se mostrará- para la estructura del poder." (Weber, 1968 vol.I: 209 par.3). 
es la resultante-, pero, de igual forma, puede irrumpir -y esta es su característica especialde la simple "situación de intereses".

Queda entonces claro, que el consenso puede exteriorizarse sin que ello implique legitimación (como sucede en aquellos países que cuentan, o contaron, con escasa estabilidad política, v.g.: algunos países de América Latina).

Comúnmente y como resultado del acontecer propio de la socialización, el modelo a legitimar, es el democrático-liberal. Pero, ¿acaso no existen golpes militares que generan indudable consenso desde el comienzo de su cometido? El entramado social manifiesta así, su resistencia al gobierno anterior que, aunque fruto de una elección, por ejemplo, no satisface la expectativa de desarrollo económico. (Barbé, 1973:52)

Este es precisamente el caso, de un poder que logra conquistar un circunstancial consenso pero que, sin embargo, aún no consigue legitimar el sistema de poder que trata de imponer. Según Barbé, transcurridos escasos meses, el gobierno militar, fallido, intentará restituir '1a papa caliente' a un gobierno civil, y no será raro, que -en la elección- triunfe el grupo político que encarna el proyecto más opuesto a la dictadura militar instaurada.

A contrario sensu, puede mediar legitimación sin consenso, situación que deviene observable en los regímenes democrático-parlamentarios estables. En ellos, puede quebrantarse una cuota parte de consenso pero -si bien ello obliga a formar un nuevo gobierno- la legitimación del sistema no cambia.

Por lo expuesto, queda claro que consenso y legitimación no son sinónimos. Pero, resta todavía, agregar una peculiaridad que habilita diferenciarlos aún más: mientras el consenso lleva ínsito el sentido de cosa mensurable, la legitimación carece de ello pues no puede medirse la quantía de interés divino, la creencia, que es necesaria para fundar un poder. (Barbé, 1973:52-53) ${ }^{61}$

\footnotetext{
${ }^{61}$ El autor amplía esta idea al sostener que “[...] dentro de esta conceptualización numérica [... ] para tener consenso es necesario el sostenimiento de al menos el $75 \%$ de la población. Recordemos que ya Locke equiparaba el concepto de consenso y de 'mayoría' ". Pero, reitera: "La legitimación no es una categoría del consenso, aunque sí viceversa, muchas veces este último es una consecuencia de la primera; es decir, existe un consenso al cual hemos llamado 'consenso residual de legitimación', que se da en un concreto poder simplemente porque es ejercitado dentro de los parámetros del sistema de poder legitimado [...] Y continúa, diciendo, "Pero la confusión entre uno y otro concepto se ve frecuentemente en investigaciones empíricas e las que el consenso es considerado como una especie de indicador empírico de la legitimación. De este error derivan cierta perplejidad sobre la supervivencia del sistema político de la República italiana que es considerado falto de legitimidad por que la mayoría parlamentaria solo tiene un consenso limitado. Esto conduce al frecuente cambio de la coalición en el Parlamento. De allí la permanente predicción sobre
} 
Eso sí, cuando el consenso ingresa en la estructura de la legitimación, resulta fundamental su mutua y recíproca asimilación. Lo cual no supone que se trate del mismo elemento. Menos aún, cuando afirmamos que también la legitimación puede ser medida, pero mediante la utilización de parámetros y técnicas distintas a las empleadas con relación al consenso.

Toca ahora referirnos a dos conceptos distintos, que ciertos teóricos pretenden presentar como sinónimos, "legitimación" y "hegemonía".

La progresiva laicización del concepto de "legitimidad", así como la concepción marxiana de la ideología, le han restado a la legitimación, características sacramentales.

No es difícil arribar hoy, a una definición según la cual, la "legitimidad" -conforme A. Negri (1970)-,

"representa la función política de la ideología de la clase dominante, el signo ideológico de su hegemonía” (Barbé, 1973:60).

Sin embargo y aún semejando certeras, estas definiciones no investigan la complejidad que encierra el fenómeno "legitimación".

El análisis de la concepción gramsciana de hegemonía, posibilitará comprobar que la existencia de una supuesta semejanza conceptual entre ambas, es sólo aparencial o, al menos, parcial.

Distingue Gramsci (1971:94) entre el grupo social que solo ejerce dominio, de aquello que constituye la "dirección intelectual y moral". Este último es designado, en ciertos casos, como sector dirigente, en otros, como sector hegemónico. (Barbe, 1973:60 y ss.) ${ }^{62}$

En principio, una primera aproximación al fenómeno identificaría al "dominio" con el poder de facto, reservando la categoría "poder hegemónico" en directa correspondencia con el poder legitimado.

Necesario es aclarar que se trata de una aproximación sumamente prudente, toda

derrumbamiento inminente del sistema político italiano y el estupor ante la malograda predicción, [...] pues todavía está en pie. Y esto no se comprenderá sin la distinción de aquellas dos categorías..."

${ }^{62}$ En el desarrollo de su pensamiento, considera Gramsci que: "El criterio metodológico sobre el que fundaré el examen es este: que la supremacía de un grupo social se manifiesta en dos momentos, como "dominio" y como "dirección intelectual y moral”. Un grupo social es dominante del grupo adversario que tiende a "liquidar" o a someter también con la fuerza armada y es "dirigente” del grupo afín o aliado. Un grupo social puede y así debe ser, dirigente ya antes de conquistar el poder gubernativo (y esta es una de las condiciones principales para la conquista del poder); después, cuando ejercita el poder y también se lo tiene fuertemente en un puño, deviene dominante, pero debe continuar siendo también "dirigente" [...] un poder para ser dirigente debe antes ser dominante [...]). 
vez que el poder "hegemónico" concebido por Gramsci, sólo es una de las formas posibles de poder legitimado. En definitiva, se alude a 'una' de las manifestaciones de esa forma especial de legitimación -legitimación activa- que exterioriza una división de los valores del "modelo de legitimar".

Consecuente con lo expuesto, no podemos identificar "hegemonía" con las diversas formas en que se manifiesta la "legitimación activa". Ello, por cuanto la "hegemonía" permite, una participación política portadora -en cuanto a contenido se refiere- de un preciso diseño de vida. (Barbé, 1973:62) ${ }^{63}$

De modo que si hegemonía y legitimación activa no constituyen una misma cosa, deviene aún más distante una identificación entre el concepto de hegemonía y el de legitimación en general. Ello, toda vez que la legitimación no se engendra porque todos compartan un proyecto de vida.

La legitimación también puede presentarse bajo formas más indirectas, configurando la denominada "legitimación pasiva". Esta es la forma menos imprecisa en que se manifiesta la legitimación y, en rigor, en la mayoría de las oportunidades, es e1 denominado producto o "factor secundario de legitimación", es decir, la que justifica la existencia misma del poder, la interiorización de su símbolo, la permanencia de su legalidad y la potencialidad de su coerción. Es mediante este factor secundario de legitimación, que adviene la indirecta legitimación del diseño “oficial”. Es aquí, y sólo aquí, en el manifestarse de la legitimación pasiva, que la 1egalidad de un poder aparece como un elemento mediador y coadyuvante -pero sólo coadyuvante- de la legitimación.

Adquiere entonces importancia la aseveración de Huntington en el sentido que un poder se institucionaliza en la medida en que tiende a prevalecer en el tiempo. (observación que ya había hecho G. Ferrero cuando hablaba del principio cuestionado que, por obra del mero transcurso del tiempo, tiende a disfrutar de la adhesión de sus súbditos). (Barbé, 1973:6,11)

Cabe señalar que el esquema de legitimación no debe contemplar solamente el caso de "legitimación activa", dado que el modelo a legitimar, adquiere una cierta autonomía respecto al poder que lo provoca, como consecuencia de la dinámica propia del proceso (no

\footnotetext{
${ }^{63}$ Menciona el autor, que Gramsci indica que se es dirigente de los "grupos afines y aliados". La situación de "hegemonía" es conocida por un grupo restringido de legitimantes. Esto se entiende bien si se recuerda aquello que Gramsci tiene en mente, "la hegemonía revolucionaria”.
} 
existe una correlación mecánica entre diseño de vida del sector dominante de un sistema de poder y el modelo oficial de legitimación de un mismo sistema).

Piensa Barbé que, entre los valores que fundan la legitimación, se encuentra la sobrevivencia de los valores y el modelo surgido, superado ya el momento conflictivo de 1a interacción.

El esquema que ha delineado implica por tanto:

“a) la existencia de más diseños de vida -y no sólo del "oficial"- dentro de una determinada sociedad;

b) la eventual coexistencia de más de un modelo a legitimar, y consecuentemente, de más de una legitimación posible;

c) el hecho que estas legitimaciones puedan sin embargo, convergir en virtud de la acción del poder y en virtud de diversas interpretaciones, de una misma circunstancia de hecho. (Este último punto aparentemente irrelevante, al final del modelo general, tiene sin embargo, su importancia en la investigación empírica). ” (Barbé, 1973:63)

La legitimación se manifiesta, entonces, en el legitimante y no en el poder, admitiendo toda una gama decreciente de legitimaciones posibles -en calidad y en cantidad- según los elementos del sistema que son legitimados.

Diferenciándose de la "legitimación pasiva", la "apatía" también es una gama dentro del proceso de legitimación. Así, en determinadas situaciones críticas pueden presentarse comportamientos desviados o apáticos. Sin embargo, tales conductas no constituyen per se, no resultan sinónimo de “des-legitimación”. Para serlo, deberíamos estar frente a concretos y efectivos comportamientos desviados o deslegitimantes, portadores de un "modelo alternativo de vida".

Por lo tanto, la existencia, la interiorización en el colectivo de un concreto modelo de vida alternativo, implica, conjeturar como posible un modelo -no preciso, pero distinto- del “oficial”. Por ello, no todos los comportamientos desviados o apáticos son des-legitimantes. De modo que, la circunstancia de entrever como factible un modelo alternativo, traza la línea divisoria entre los comportamientos desviados des-legitimantes y aquellos que no lo Son. (Barbe, 1973:64-65)

\section{- $\quad$ Jurgen Habermas.}


Continuando con lo manifestado supra en torno a la legitimidad, para este autor no es extraño que existiera lucha de clases $y$, por ende, diferentes fenómenos de deslegitimación. Ello no debe sorprender ya que, la organización estatal de la sociedad es la condición primordial de la existencia de una estructura de clases, en el sentido de Marx. Si bien los conflictos de legitimidad no se expresan regularmente bajo la forma de conflictos económicos, son solapados entre las doctrinas que aseguran la legitimación. Esas doctrinas llevan necesariamente a las definiciones de identidad colectiva, y esos axiomas, a su turno, no pueden sostenerse sino en las estructuras que aseguran una cohesión y garantizan un consenso: el idioma, la pertenencia étnica, la tradición.

"Por legitimación -dice Habermas- entiendo el reconocimiento del cual se beneficia un orden político. La exigencia de legitimidad se refiere a la garantía de integración social, a la identidad de una sociedad definida por las normas. (Habermas, 1985:257) ${ }^{64}$

Necesario es, además, establecer una distinción entre las razones destinadas a asegurar la legitimación y las diferentes institucionalizaciones del poder, ya que las justificaciones no se apoyan tan solo sobre una argumentación.

La idea de un acuerdo anterior entre todos los miembros de la sociedad -en tanto individuos libres e iguales- caracteriza el tipo procedimental de legitimidad, propia de la época moderna. Por tanto, a este nuevo tipo de legitimidad corresponde una transformación del status de los sujetos. La voluntad general no tiene por única función explicitar las razones de validez de la legitimidad, sino que también define el lugar de la soberanía. Pero la existencia de una sociedad democrática no indica una preferencia, a priori, de ese tipo de organización, de allí la discusión entre los representantes de una teoría normativa de la democracia y aquellos que participan de una concepción empirista o 'realista'.

Es evidente, entonces que, en lo que concierne al Estado moderno, la distinción entre las justificaciones de la validez del poder y de sus instituciones genera dificultades. Actualmente solo tienen poder de legitimación las reglas y las propuestas de la comunicación que permiten distinguir una unanimidad o un acuerdo realizado entre

\footnotetext{
${ }^{64}$ Y prosigue, "Las legitimaciones tienen por función responder a esta exigencia, es decir de mostrar cómo y por qué las instituciones establecidas (o preconizadas) están en condiciones de disponer el poder político de tal suerte que los valores constitutivos de identidad social informen efectivamente la realidad [...]
} 
hombres libres e iguales acerca de un consenso contingente. (Habermas, 1985:265) ${ }^{65}$

Establecer, pues, una relación entre las estructuras propias de la formación de los Estados y su transformación en Nación, puede resultar útil para comprender los problemas de legitimación que caracterizaron la aparición del Estado burgués.

Diferentes momentos expresan los cambios habidos en las estructuras sociopolíticas. Al interior de los Estados, los temas relacionados con los procesos de secularización y el surgimiento del 'derecho racional', guardan relación con la elaboración de niveles de justificación propios de la era moderna; el capitalismo y el derecho abstracto, la soberanía y la nación, se vinculan con la estructura de la formación política moderna, vale decir, del estado moderno y de la nación.

También revisten importancia los conflictos habidos entre los artesanos, los obreros de la industria y el proletariado agrícola durante el siglo XIX, puesto que generaron nuevos problemas de legitimación, tendientes a dilucidar los conflictos inherentes al sistema económico y aquellos propios del sistema político, institucionalizando -bajo la forma de un debate sobre la distribución de la riqueza- el 'Estado-social' o 'Estado providencia', a la par que originaron la democracia de masa.

Fenómeno éste, caracterizado por una convivencia reglada entre los partidos políticos, que institucionalizó los roles de la oposición; formalizó los procesos de legitimación a largo plazo; instituyó un ciclo de alternancia de legitimación, canalizando los niveles de legitimación en los límites de cambio de gobernantes; para, finalmente, establecer la participación de todos los ciudadanos en los procesos de legitimación de los electores.

Estimó, además, que las amenazas que pesan sobre la legitimidad no pueden prosperar ante un Estado capaz de transmitir credibilidad en su rol de Estado-social, capaz de neutralizar los efectos perturbadores que acompañan los procesos económicos, enfrentando las amenazas que pesan sobre los individuos.

En tal sentido, desarrolló un sistema de garantías sociales para atenuar los riesgos fundamentales ligados a las situaciones de mercado y, preventivamente, estableció un

\footnotetext{
${ }^{65}$ Habermas añade que "[...] es accesorio conocer si esas reglas y esos presupuestos de la comunicación son mejor explicitados e 'interpretados' con la ayuda de teorías del contrato y del derecho natural, o por conceptos de una filosofía trascendental, por una pragmática del lenguaje, vista en el marco de una teoría de la evolución de la conciencia moral."
} 
sistema de garantía de las condiciones de existencia que funcionan, ante todo, asegurando el acceso igualitario a una formación escolar organizada.

Va de suyo que un sistema económico relativamente estable es la condición requerida para cumplir ese programa; por lo que, en el seno de las democracias de masa, esas funciones propias del Estado social, constituyen, sino las bases, por lo menos una condición necesaria de la legitimidad.

La capacidad de los gobernantes se mide, pues, por: a) una política coyuntural que tiene por fin garantizar el crecimiento, b) el control de la estructura de producción cuya finalidad es responder a los deseos de la colectividad y c) la corrección de las desigualdades sociales.

En cualquier caso, en materia de legitimación, hoy por hoy, la problemática que pasa al primer plano se sitúa en la intersección de las tesis tecnocráticas y los modelos de participación.

Concluye, sosteniendo que, toda vez que el análisis que realizan las ciencias sociales sobre los procesos de legitimación, sufren aún la influencia de Max Weber, la legitimidad de un orden político se mide conforme a la credibilidad que beneficia a aquellos que están sometidos a esa dominación.

En tal sentido, cita a R. Merelman (1966:548) para quien la legitimidad, significa

"la creencia que las estructuras, los procedimientos, las acciones, las decisiones, las políticas, los funcionarios o los jefes de Estado poseen las cualidades de justicia, de oportunidad, de corrección moral, y que esas cualidades valen porque son reconocidas”. (Habermas, 1985:283)

De allí que, H. Busshoff (1975) considere, que la preocupación de la teoría de sistemas -Parsons, Easton, Luhman- resida en saber qué mecanismos deben ser movilizados para producir un quantum suficiente de legitimación, o qué equivalencias funcionales pueden reemplazar una legitimación deficiente. (Habermas, 1985:283-284) ${ }^{66}$

Reconstruir las legitimaciones dadas consiste, entonces, en rever el sistema de justificación que autoriza la evaluación de las mismas, permitiendo juzgarlas válidas o no en relación al sistema. 'Válidas en relación al sistema' significa, simplemente, que toda persona que otorga su consentimiento al sistema -es decir un mito, una cosmología o una

\footnotetext{
${ }^{66} \mathrm{Al}$ respecto y compartiendo la idea, sostiene Habermas que: "Los teóricos del aprendizaje se preguntan en el marco de un análisis de las motivaciones a la obediencia, sobre las condiciones socio-psicológicas que permiten la formación de una credibilidad de la legitimidad." (cit. OPP, 1975:214-243).
} 
teoría política- debe igualmente aceptar las justificaciones propuestas por las legitimaciones válidas. Este contraste, traduce la estructura de coherencia que resulta de las relaciones internas del sistema de justificación. Lo cual permite, no solo interpretar una forma de creencia en la legitimidad, sino, y al propio tiempo, posibilita testear su consistencia, además de juzgarla como 'aquella en la que creemos'.

Admitiendo que 'ideas' y 'realidad' no están determinadas a enfrentarse, no existe una sola dirección para realizar una investigación fecunda. De manera que la teoría rendirá cuenta estructuralmente de la sucesión de los diferentes niveles de justificación -que observa la historia-, reconstruyendo, a la vez, esta 'sucesión' desde la perspectiva de una lógica de la evolución. (Habermas, 1985:293) ${ }^{67}$

\section{- $\quad$ Seymur M. Lipset.}

El pensamiento que desarrolla Lipset, gira en torno al por qué de las causas que favorecen la estabilidad de un régimen democrático. Pero su atención no solo se concentra sobre las causas que se relacionan con el nivel del desarrollo económico de una sociedad, sino también sobre las que atañen tanto a la legitimidad, cuanto a la eficiencia y la eficacia.

Sostiene que la legitimidad reside en la creencia popular en los valores sociales que constituyen las instituciones existentes, como también en la capacidad del régimen para garantizar el mantenimiento de esa "creencia".

Para tal cometido, analiza la importancia que revisten la eficacia -en cuanto al logro de resultados esperados por el colectivo- y la eficiencia, en clara referencia con la capacidad del régimen en lo que se refiere a la satisfacción de las funciones de base del gobierno y que posee un carácter instrumental que tanto los individuos, cuanto los grupos, evalúan por motivos de orden interesado.

A su turno, la legitimidad designa una relación mucho más efectiva toda vez que, los grupos estiman el régimen como legítimo o ilegítimo según sus valores se ajusten, o no, con los invocados por el régimen.

Ciertamente, la distinción de Lipset entre legitimidad y eficacia guarda relación con

\footnotetext{
${ }^{67}$ Añadiendo que : "La psicología genética del conocimiento, que beneficia con resultados concluyentes, y que ha reconstruido en cierta manera los estados de la conciencia moral en su evolución ontogenética, puede ser considerada al menos como una guía de heurística para alentar fuertemente nuestras investigaciones". (cit. L. Kohlberg, 1975).
} 
la postura weberiana en orden a la liaison existente entre mantenimiento y atribución de legitimidad.

La legitimidad de un régimen se conserva cuando se reconoce que las expectativas individuales son satisfechas. Esto, más allá de creer o no, en los principios que establecen la estructura institucional del régimen. De modo que la atribución de la legitimidad al régimen se admite tras un juicio de valor.

No obstante el enfoque dado a la cuestión tematizada -eminentemente sociológicoLipset sufre la influencia, al menos desde el punto de vista terminológico, del normativismo positivista de Kelsen.

Sostiene, entonces, que el principio de legitimidad -que en la visión kelseniana es igual al de legalidad- está condicionado por el principio de eficacia, que, él, por el contrario, relaciona al hecho de una relación sociológica.

De donde, el principio de eficacia-eficiencia mide el grado de conformidad de la conducta de los actores frente a la estructura normativa del ordenamiento jurídico. Por ejemplo, en períodos de crisis, cuando hay un pasaje -por medios no previstos en la estructura normativa anterior- de un principio de legitimidad a otro, este principio permite medir las chances (probabilidades) de éxito o de fracaso del nuevo orden instaurado.

Ambos tipos de relaciones, constituyen, pues, solo "un" tipo de relación: la que resulta de la aquiescencia que los individuos prestan a la norma que estipula un tipo de conducta, conformidad ésta que es tributaria de la eficiencia del orden en cuestión.

Por lo que, cuando mediaren situaciones de cambio o crisis, habrá mantenimiento de legitimidad si el sistema satisface las expectativas de orden que interesa a los individuos y a los grupos; en tanto, hay atribución de legitimidad si el orden incorpora en sí una creencia de parte de sus miembros que se relaciona a una evaluación moral, independientemente de las expectativas particulares de cada individuo ó de cada grupo.

Según las correlaciones y el valor positivo existente entre legitimidad y eficaciaeficiencia, se sostendrá que una sociedad es beneficiaria de un régimen estable. Según el valor negativo de los dos criterios, se manifestará que una sociedad es presa de la crisis y de la inestabilidad. Los dos casos intermedios posibles (legitimidad (+), eficacia (-), y viceversa permiten, a su turno, juzgar las chances de éxito o de fracaso en períodos de crisis. 
Desde todo punto de vista, el esquema es, pues, operacional.

Está claro que el criterio de legitimidad se relaciona al régimen, es decir a las instituciones políticas. Pero, no está de igual modo claro -al menos la cuestión no está decididamente promovida- si el criterio de eficacia se relaciona al régimen político en cuestión -conjunto de roles de poder organizados e institucionalizados-, o al gobierno, es decir, al conjunto de ocupantes sucesivos de esos roles de poder. (Botana, 1968:142) ${ }^{68}$

De modo que, el criterio de eficacia dependerá, en principio, del criterio de legitimidad. Si, a partir de 1930 medió una crisis de creencia generada en una fracción de la sociedad alemana que no aceptó el principio de legitimidad (policrático) al ser cuestionada la eficiencia de los distintos equipos de poder en el marco del régimen, pareciera -ab initioque la eficacia cualifica a quienes, temporariamente, ocupan roles de poder. Y es precisamente esta "ausencia" de eficacia, la que actuará sobre el régimen, comprometiendo su legitimidad.

Indudable que el principio, cualifica a los gobernantes y no al régimen, por lo que se relaciona de manera insoslayable con los roles de autoridad, toda vez que es atribuida a quienes gobiernan. (Botana, 1968:142 y ss.) ${ }^{69}$

Ahora bien, en un escenario político de las características a que nos estamos refiriendo, existe un factor constante representado por el poder y dos factores que resultan variables: la legitimidad y la autoridad.

Enfocando la cuestión bajo dos ángulos, el primero nos permite visualizar que la relación de eficacia respecto a la relación de autoridad guarda ligazón con la facultad de satisfacción que se manifiesta en los "resultados” de determinada acción.

El segundo aspecto, es aquel que relaciona autoridad con la facultad de

\footnotetext{
${ }^{68}$ Botana menciona que, en el caso de los regímenes situados en las categorías intermedias -legitimidad (+), eficacia (-); o bien, legitimidad (-), eficacia (+), Lipset, (1963:94 y ss.) formula las siguientes observaciones históricas: "Después de 1920, importantes capas de sus respectivas poblaciones consideraron la República alemana y la República austríaca como ilegítimas. Los regímenes de esos Estados conservaban aún una razonable eficacia. Ellas entran pues en nuestra categoría C [Legitimidad (-), Eficacia (+)]. Cuando la eficacia de diversos gobiernos se encuentra comprometida después de 1930, las sociedades donde los coeficientes de legitimidad se elevaban permanecieron democráticas, mientras que los países como Alemania, España, conocieron la dictadura y Francia estuvo bastante cerca de hacer la experiencia.". Y complementa Lipset, indicando: "Si se trata de juzgar a corto término la estabilidad de un régimen, podemos decir que si posee la capacidad de obrar sin legitimidad -caso de una colonia bien gobernada- está más amenazado que un régimen en el que la eficacia es débil, pero donde la legitimidad no es puesta en duda"

${ }^{69}$ Expresa este autor que: "Hay aquí un proceso de atribución porque, desde luego, los miembros del régimen (privilegiados o no) definen las funciones de gobierno, y enseguida, el "pattern" (modelo) que determina la capacidad de satisfacción de esos mismos miembros".
} 
interpretación. Esto es, a la aptitud que el colectivo concede a un gobernante en el sentido de elaborar órdenes razonables. Capacidad que se ubica en el nivel de los "medios" empleados por la autoridad, con el objeto de satisfacer las expectativas definidas en el seno del entramado social, obteniendo así el resultado buscado. (Botana, 1968: 143) ${ }^{70}$

Realizando un último examen al criterio de eficacia, solo queda por subrayar, el aporte más significativo que realiza Lipset a la teoría de la legitimidad, ya que se sitúa en la tradición weberiana, con relación a la atribución de legitimidad. Lipset piensa pues, que una crisis de legitimidad constituye desde luego un proceso de cambio de creencia que se manifiesta por la amenaza que pesa sobre el estatuto de las grandes instituciones tradicionales. (Botana, 1968:143 y 205) ${ }^{71}$

\section{- Talcot Parsons.}

Entiende este autor, que la legitimación cumple un rol análogo al que la 'confianza' posee al interior de un sistema monetario. (Barbé, 1973:30) ${ }^{72}$

La legitimación es, en definitiva, la valoración de la acción, en tanto forma parte del proceso de compartir valores comunes entre aquellos que integran el entramado social.

En otros términos, "la acción" es legitimada, en tanto se ajusta al valor con el que la comunidad concuerda. Así, la legitimación comprende el proceso de mediación entre la institución -concebida como un todo articulado de valores que conforman el marco regulatorio- y la acción.

De lo expuesto se desprende que tres son los elementos que emergen del modelo

\footnotetext{
70 Sostiene Botana que: “[...] en todo gobernante hay una pretensión de eficiencia ya que, desde luego, ese gobernante invoca una pretensión de autoridad. La noción de autoridad nos parece más comprensiva que la de eficiencia y preferimos entonces mantener nuestra correlación entre autoridad y legitimidad." Agregando: "Bien entendido, Lipset no podrá examinar el criterio de autoridad en el lugar del de eficiencia ya que para él autoridad es una cualidad imputable al principio institucional de gobierno: ella es igual a la suma de poder más legitimidad."

71 Así, dicha atribución "será determinada por la conformidad que existe entre los valores propuestos por un sistema de poder y los valores asumidos por los individuos y los grupos en el seno de la sociedad. En este proceso evaluativo, la creencia popular en el valor social de las instituciones determina el encuentro entre los dos niveles de valores". Añadiendo Lipset, (1963:89) que: "Las crisis de legitimidad, fenómeno histórico reciente, son la consecuencia directa de opiniones existentes en el seno de los grupos, donde el poder de los medios de información provocan una remisión en cuestiones de valores que, antes eran aceptados sin reserva".

72 Destaca entonces, que, "Esto es muy claro, si se tiene presente que para Parsons, el poder en un sistema político desempeña el mismo rol de la moneda en un sistema económico (y por tanto no existe el poder de A sobre B como en la teoría clásica, sino mayor o menor cantidad de poder, como elemento circulante en el interior del sistema)"
} 
parsoniano:

a) el mundo de los valores y de las instituciones;

b) los miembros del sistema en el cual dichos valores son interiorizados;

c) un proceso de mediación-valorización entre los valores y las acciones sociales: la legitimación.

Sujetos de este proceso serán, pues, los miembros del sistema en el cual las valores -o mejor la "institución"- está interiorizada. Sin embargo, señala Parsons que ningún sistema de valores está cabalmente interiorizado, por lo que su subsistencia dependerá, de manera insoslayable, de una serie de dispositivos de institucionalización, de socialización y de control social.

Si a ello le agregamos -como lo afirma la totalidad de la teoría funcionalista- que los valores constituyen los elementos determinantes de la acción, un 'verdadero' cambio de valores, implica una profunda, radical, modificación del tipo de sistema y no un mero “cambio social". Pero, ¿Quién socializa? ¿Quién ejercita el control social? Parsons responde el interrogante, en su definición de "autoridad", al sostener que la autoridad es, ella misma, un valor, o más exactamente un conjunto articulado de valores, una "institución". Agregando que dos son los componentes de la autoridad:

i) la institucionalización de formas y niveles de integración de la colectividad (integración cultural) y

ii) 1a institucionalización del derecho del líder de contar con el sostenimiento de los miembros de la colectividad (integración de roles o integración social) ó, en el decir parsoniano, "responsabilidad".

Según Parsons (1963), debido a la división del trabajo y dado que, de "hecho", diferentes grupos desempeñan funciones especializadas, se producen las llamadas "responsabilidades diferenciales", las que son ejercidas -en el mundo occidental- por agentes profesionales del sistema. (Barbé, 1973, 32-33) ${ }^{73}$

La autoridad es, en sí misma, una “institución”, y como tal, el lugar primario de integración de un sistema social. Lo cual permite mantener el conflicto interno dentro de

\footnotetext{
${ }^{73}$ Por lo que "es esencialmente el código institucional dentro del cual, el uso del poder como instrumento, viene organizado y legitimado”. Y agrega, "la función principal de la autoridad superior [...] es claramente la de definir la situación por el estrato inferior de la colectividad. El problema de superar la oposición bajo forma de tendencia a la no conformidad nace ahora de una incompleta institucionalización del poder de la unidad superior".
} 
límites que resultan tolerables.

Cabe señalar que, no obstante reconocer los aportes realizados por Parsons al fenómeno de la legitimación, Barbé mantiene algunas divergencias con el esquema parsoniano -diferencias que compartimos- (v.g.: el considerar como dos momentos distintos la institucionalización y la legitimación; el pensar el poder como un elemento circulante que implica la imposibilidad de concretar la esencia y génesis de la legitimación (Barbé, 1973:35-36) ${ }^{74}$; la circunstancia que, en el mencionado esquema, la institución "autoridad" comprende dos elementos: a) institucionalización de formas y niveles de integración de la colectividad y b) la institucionalización del derecho del líder de recibir apoyo de parte de los miembros de aquella). (Barbé, 1973:36) ${ }^{75}$

b) Perspectiva filosófico-jurídica.

- Julien Freund.

Dando testimonio de la importancia que suscitó en Francia el pensamiento de G. Ferrero, J. Freund (1965:259-260) manifiesta,

"Es necesario saber el grado en que G. Ferrero llama nuevamente la atención de la ciencia política sobre la importancia de la noción de legitimidad”. (Botana, N., 1968:137).

\footnotetext{
${ }^{74}$ Señala Barbé: "Por consiguiente, en Parsons la verdadera legitimación será la legitimación de la acción y cuando se habla de poder legitimado se refiere a la legitimación de la atribución de una cuota de poder a un actor determinado. Todo esto tiene luego un modo que podría resumirse en estas palabras: hacemos como si [...] Y esto hace que Parsons deba excluir de su esquema la categoría del poder de hecho. Esta no es nuestra interpretación. Él dice expresamente: "asegurarse la adhesión a un deseo, sea definido como una obligación del objeto o menos, con la simple amenaza de la mayor fuerza, no constituye el uso del poder" (Parsons, 1963) Ciertamente esta afirmación es coherente con su concepción del poder. No es que Parsons niegue la existencia de la coerción, niega el status de la forma de manifestación de poder político, ya que este es poder legitimado. Pero todo esto sería verdadero si existiese solo una serie de institucionalización coherente y, en consecuencia, solo una posible legitimación [...]".

${ }^{75}$ Barbé amplía el concepto manifestando: "Este 'derecho' de los líderes, como se ha dicho, proviene de la división del trabajo social del que deriva la asunción "de facto" de funciones diferentes de parte de los diversos grupos. Pero limitarse a decir que la asignación de esta "responsabilidad" adviene "de facto", implica dejar entre paréntesis toda la sociedad civil (cuando decimos sociedad civil entendemos referirnos a una categoría de análisis que comprende la vida asociada pre-política o pre-estatal esto es, del ámbito de las relaciones de poder de hecho), operación esta que puede ser lícita si la finalidad es analizar ciertas variables políticas significativas, pero que no es provechosa cuando se trata de conceptualizar el poder. Y aún, si se deja entre paréntesis la sociedad civil, ¿cómo se hace para explicar el origen de los valores que deben ser institucionalizados- socializados? Supongamos, [...] que la institucionalización sea tarea de la leadership, la cual en la concepción de Parsons tiende a ser compuesta, en los modernos estados occidentales, por un staff de encargados de los trabajos. Pero incluso si esto fuera verdad, y la leadership fuese el elemento decisivo (como si ver el modelo corresponde a aquello constitucional o del "estado de derecho") cómo explicamos el hecho de haber una leadership y no otra?"
} 
Por ello y entendiendo a la legitimidad como un elemento regulador del orden, ubica su estudio en el capítulo dedicado a la dialéctica del mando y la obediencia, cuyo resultado es aquel.

"Ella (la legitimidad) consiste en el consentimiento durable y cuasi unánime que los miembros y las capas sociales acuerdan en un tipo de jerarquía y en una clase dirigente en vista de reglar los problemas interiores por otros vías que las de la violencia y el miedo [....]" (Botana, 1968:138).

En esta definición, existen dos elementos a analizar. Interpretamos con Botana, que el primero de ellos -el tipo de jerarquía de la que habla Freund (1965:345) - no es otro que el régimen. Y le asiste razón, pues, más adelante en una discusión sobre el sentido aristotélico de la constitución política esta hipótesis aparece confirmada ya que, si una formación política existe por su voluntad, no tiene necesidad de tener otra legitimidad ( jurídica o ética) toda vez que se justifica por su propia existencia.

El objeto de la legitimación, es únicamente el régimen (la existencia de una postura antagónica irreductible entre el principio absolutista y el principio democrático, se da por la naturaleza de las cosas: el primer principio considerará siempre como ilegítimo el segundo y recíprocamente). (Botana, 1968:138). ${ }^{76}$

El segundo elemento, es el de la clase dirigente que constituye un hecho nuevo en relación a las fuentes analizadas precedentemente -pero que no es extraño al pensamiento de G. Mosca- y sobre la que Freund hace recaer el consentimiento. Consecuente con su pensamiento, considera que la legitimidad es esencialmente un fenómeno político no jurídico, que resulta de la relación vertical -que tipifica el consenso sobre los gobernantesy no la que surge de la relación triangular, que tipifica el consenso sobre el régimen.

\section{- Carl Schmitt.}

Dejando de lado la "neutralidad", a que lo conduce la dialéctica "legalidadlegitimidad" y decididamente ubicado en el ámbito político, Schmitt realiza la ya conocida bifurcación conceptual entre amigo y enemigo, por lo que la enemistad, se constituye en

\footnotetext{
${ }^{76}$ Con referencia a los principios de legitimidad, Freund se sitúa en la línea de pensamiento de Ferrero: “[...] un principio de legitimidad no se impone autoritariamente, sino que nace de la unión entre las aspiraciones políticas y las costumbres, tradiciones del sistema económico, de la religión y del espíritu general de la civilización de un colectivo dado" (p.260). "Ningún régimen es auténticamente legítimo,[...] deviene con el tiempo si resultará aceptado como el más conveniente y adecuado.” (p.261).
} 
uno de los conceptos cardinales de su pensamiento.

De ello se desprende que -aun considerando el "estado de naturaleza" propio del individuo hobbesiano que integra, como, la también "natural" condición social del hombreSchmitt descarta de manera "perversa" -tal como la califica G. Bidart Campos- todo tipo de convivencia que transite fuera de los parámetros señalados. Convivencia que, aunque dialógicamente divergente, ubica a los hombres -en su individualidad- en situación de alteridad, de relacionamiento con el otro. En esa especial "nostridad" entendida como integración de la persona humana en la convivencia con su prójimo. (Bidart Campos, 1997:6) ${ }^{77}$

De manera que la noción schimittiana de legitimidad se sitúa, conforme la teoría weberiana, en una legitimidad de tipo 'carismática', por lo que esa "agrupación humana" a que hace referencia -que no es otra cosa que el "pueblo"- precisa alguien que lo "guíe" en sus apetencias, que le sirva de "mentor" en sus deseos, definitivamente, un "intérprete" de su voluntad, toda vez que las masas deben reconocerse en el 'guía'.

Ello toda vez que

“El pueblo sólo puede decir sí o no, pero no puede asesorar ni deliberar, ni discutir; no puede gobernar ni administrar. ${ }^{78}$

Varios interrogantes se generan, pues, al analizar la denominada “obligación

\footnotetext{
${ }^{77}$ Expresan Bertin-Corbetta (1997:49-50) que Schmitt define 'a la esencia de la política' como la relación amigo-enemigo, y en en tal sentido, la relación muestra, conforme lo expone en uno de sus textos (1932:57), "el grado de máxima intensidad de una unión o separación, de una asociación o disociación [...] El enemigo no necesita ser moralmente malo, o estéticamente feo, simplemente es el otro, el extraño, y para determinar su esencia basta con que sea existencialmente distinto y extraño, en un sentido particularmente intensivo[...] Sólo es enemigo el enemigo público, pues todo cuanto hace referencia a un conjunto tal de personas, o en términos más precisos a un pueblo entero, adquiere 'eo ipso' carácter público [...] (1932:58-59) [.... “Todo antagonismo u oposición religiosa, moral, económica, étnica o de cualquier clase se transforma en oposición política cuando gana la fuerza suficiente para agrupar de un modo efectivo a los hombres en amigosenemigos [...] Por eso es siempre la agrupación humana que marca la pauta, y de ahí que, siempre que existe unidad política, ella sea decisiva, y sea 'soberana' en el sentido de que siempre, por necesidad conceptual, posea la competencia para decidir en el caso decisivo, aunque se trate de una caso excepcional", (1932:67$68)$.

${ }^{78}$ Continúa Schmitt desarrollando la idea: "Tampoco puede hacer preguntas, sino únicamente sancionar con su sí el proyecto que se le presenta. Sobre todo tampoco puede hacer preguntas sino que tiene que limitarse a responder con un sí o un no a la pregunta que se le somete". (cit. en Bertín, H.D.-Corbetta, Juan C., 1997:4950). Mencionan Bertin-Corbetta (1997:55-56) lo señalado al respecto por Gomez Orfanel (1986: 187): “[...] En la concepción de Schmitt, teóricamente el pueblo ocupa una posición de portador del poder supremo, pero a ello acompaña una visión amorfa y desorganizada, proclive a fáciles manipulaciones de quienes, apoyándose en la aclamación y plebiscitos populares, toman las decisiones. El pueblo aparece como incapaz de gobernarse. La voluntad general democrática iría asociada con el poder de un individuo o una minoría para plantear cuestiones al pueblo, que dependería totalmente de tales iniciativas, siendo su facultad la de refrendar o rechazar".
} 
política“. Por ejemplo, desde el punto de vista de aquellos que "deben” obediencia: ¿por qué y a quién obedecer? Y, desde el ángulo de aquel que pretende ser obedecido, ¿quién hace que se lo obedezca?, ¿cómo proceder para lograr obediencia?

Si la legitimidad carismática "funde" las relaciones de mando y obediencia y las deposita en el "líder" y en su "misión”, solo él -el soberano- es el encargado de identificar al amigo-enemigo.

El enfoque acerca de cómo se encuentra organizada la estructura de la dominación, permite observar que, el esquema schmittiano, coloca en el vértice del poder al soberano con poderes extraordinarios en los momentos de excepción.

Esto así, si el líder o el soberano es quien detenta el poder sustentado en la ‘creencia' que lo legitima, se impone deslindar la relación soberanía-legitimidad.

En tal sentido, entiende Kriele (1980:13-14) que,

“[...] En una primera y provisional caracterización, el problema de la soberanía hace referencia a la fuerza de imposición del poder estatal; el problema de la legitimidad, a su justificación. (Bertin, H.D.-Corbetta, J.C., 1997:76) ${ }^{79}$

Partiendo no solo del decisionismo sino también realizando frecuentes remisiones a Hobbes, manifiesta Schmitt -alejado del positivismo y de las tradiciones- que en momentos extraordinarios o de excepción, solo el soberano -considerando los atributos que detenta- es capaz de aplicar o reformar el ordenamiento legal utilizando para ello variables puramente discrecionales.

De modo que el soberano, se encuentra 'por encima' del ordenamiento jurídico formal o tradicional, por lo que no es posible la representación política nacida de elecciones libres (Vertretung), resultando la misma, la mera identificación del pueblo con su líder en razón de un acto aclamatorio o del mero asentimiento (Reprësentation).

Consecuente con tal sistema de representación, la democracia schmittiana es

\footnotetext{
${ }^{79}$ Y prosigue: “Ambas preguntas están íntimamente entrelazadas, pues forman, en cierto modo, dos lados del mismo problema. Pues la fuerza de imposición del poder estatal sólo existe mientras es considerada como justificada en términos generales por lo menos por los miembros del estado. Cuando se conmueve el fundamento de la legitimidad del poder del Estado, surge la resistencia activa y pasiva, la negación a obedecer las normas jurídicas, el sabotaje, y finalmente la polarización total y la guerra civil, [...] La soberanía del Estado depende de su legitimidad y la legitimidad fundamenta su soberanía. En este sentido, el problema de la legitimidad es el lado interno del problema de la soberanía. Lo que se presenta desde afuera como mera cuestión de fuerza, es -visto desde dentro- un complejo de problemas morales, psicológicos, antropológicos, económicos, históricos".
} 
plebiscitaria y está basada en una 'creencia' que se sustenta en una "misión” propia del soberano. Y decimos 'propia' para destacar que posee caracteres que únicamente él posee y de la cual se nutre, naturalmente, la soberanía tanto al interior del Estado -bregando por la conservación de su unidad en cuanto tal-; cuanto en lo que hace al sostén del mismo -en tanto sistema político diferenciado- ante el resto de los estados que conforman el escenario mundial.

\section{Sostienen Bertin-Corbetta que}

"Es evidente que el modelo schmittiano está lejos de suponer que el fundamento de la validez del poder se apoya en factores jurídico-formales o tradicionales-sanguíneos o tradicionales-religiosos". (Bertín-Corbetta, 1997:79) ${ }^{80}$.

Modelo éste en el cual, más adelante, y conforme lo señala Gómez Orfanel (1986:96), Schmitt culmina acoplando la legitimidad carismática -siempre como elemento central- con elementos burocráticos -como la burocracia y el ejército- para la administración del Estado. (Bertin- Corbetta, 1997:79-80.) ${ }^{81}$

Por el contrario, y siempre en relación a los "ordenamientos", entiende Schwab (1986:182) -según las manifestaciones que Schmitt vierte en "I Tre tipi di pensiero

\footnotetext{
${ }^{80}$ Apuntan, asimismo, que "[...] recordando la inclinación que tiene Schmitt por el mito -como fuente motriz. de los procesos- la relación que identifica al soberano con el pueblo está apoyada o exige una "entrega" de abajo hacia arriba. Si bien la misma supone un interés (protección-obediencia), la relación está dominada por una identificación "total" del pueblo (sujeto global) con la ideología dominante que impone el soberano y no permite, tampoco, ningún espacio de pluralismo que rescate al individuo como ser único, distinguible, poseedor de derechos anteriores y superiores a cualquier organización política. En este sentido, la presencia del mito implica una transposición hacia el exterior del individuo y la exclusión de la participación real en la formación de la voluntad estatal". Refieren además que Berlin, (1974:127), observa que: "La pasión, el prejuicio, el miedo y el nerviosismo nacen de la ignorancia y toman la forma del mito y la ilusión [...] cualesquiera sea la causa emergente, lo cual "[...] significa ser dominado por factores externos y falsamente empujados en una dirección que no es necesariamente la deseada"

${ }^{81}$ En su análisis, Gómez Orfanel, vincula la legitimidad carismática a 'lo extraordinario', es decir, aquello que no acontece habitualmente, señalando que: "[...] La solución podrá residir en aceptar las tendencias racionalizadoras sin renunciar totalmente al elemento carismático, que actuaría como contrapeso, y ello en conexión con lo que Weber denomina 'glorificación carismática de la razón', en cuanto última forma que adopta el carisma en su evolución. Su idea es la de una democracia autoritaria de tipo plebiscitario apoyada por un aparato administrativo [plebiszitäre Führerdemokratie mit Maschine] capaz de ejercer una verdadera dirección [echte Führung] mediante la selección de jefes o líderes apoyados democráticamente en las masas". En idéntico sentido, Freund, (1967:217), advierte sobre la problemática que suscita este tipo de legitimidad en torno a la sucesión, cuando manifiesta: "[...] ¿Cómo perpetuar el sistema tras la muerte del jefe, considerando que el carisma no se enseña ni se inculca, sino que se despierta y se siente y que los partidarios, así como el estado mayor del jefe, tienen un interés material e ideal en que dure la dominación? La dificultad radica en que la obediencia de los partidarios es pura sumisión a la persona del jefe y que carece de la continuidad que es la fuerza de la tradición y de la legalidad"
} 
giuridico"- que la legitimidad es de tipo tradicional. (Bertin- Corbetta, 1997:80) ${ }^{82}$

6. A no dudar, los autores hasta aquí tratados han permitido acercarnos a la conceptualización del fenómeno de la legitimidad y la legitimación, con la finalidad de lograr una caracterización operativa que nos habilite a concretar una investigación, aplicada a la formación política argentina.

Sin embargo antes de ingresar a ella indagaremos acerca de un criterio en que la mayor parte de la doctrina reciente coincide: la legitimación de un sistema de poder es el fruto de un sistema de valores que supone compartir todo un "diseño de vida".

Probado está que, al interior de cada sociedad -obviamente dotada de un determinado ordenamiento- y tal como lo investigara Weber (1968, vol.1:29-30), subsisten más diseños de vida que incluyen diversas orientaciones. (Barbé, 1973:56-57) ${ }^{83}$

En cualquier caso, el "diseño de vida" (oficial) será el que resulte del proceso “oficial” de legitimación. (Barbé, 1973:57-59, nota 21) ${ }^{84}$

\footnotetext{
${ }^{82}$ Entiende Schwab que, en lo referente a la burocracia alemana y el ejército, "[...] aparece claramente como Schmitt, elaborando el modelo de ordenamientos concretos, no había logrado inspirarse en el principio carismático [...] También había considerado la legitimación jurídica de inspiración normativa alternativa [...] No quedaba, ahora, más que la legitimidad tradicional, personificada en la alta burocracia tedesca, en el ejército y en el poder local. Pero existe una contradicción fundamental en el pensamiento de Schmitt. Más allá de la constante referencia a las instituciones tradicionales, él menciona al pasar en 1933 las SA y las SS como instituciones potenciales. Pero de estas dos fuerzas derivaba aún la razón de ser del carisma, y Schmitt no resuelve en realidad la contradicción creada entre la legitimidad racional y la carismática".

${ }^{83}$ Expresa Weber que: "Se puede 'orientar' el propio obrar en base a la validez de un ordenamiento no solamente mediante la 'observación' de su sentido (cuál tiene acuerdo en promedio). También en el caso de una 'elusión' o de una 'infracción' de tal sentido (acuerdo en promedio), puede todavía operar la chance de su validez en cualquier ámbito (como norma vinculante): y esto, dicho de manera puramente racional respecto al fin. El ladrón orienta su propio obrar en base a la 'validez' de la ley penal, y por eso busca disimularlo. La validez de tal 'ordenamiento' en el ámbito de los hombres viene a manifestarse precisamente por el hecho que el debe ocultar su falta. Pero, prescindiendo de este caso-límite, a menudo la infracción del ordenamiento se limita a faltas parciales más o menos numerosas, o bien busca afirmarse -como medida de buena fe-como legitima. También coexisten de hecho diferentes concepciones del sentido del ordenamiento, el cual puede -para la sociología- 'valer' en el ámbito que determina el comportamiento efectivo. Esto no impide a la sociología reconocer la aceptación, dentro del mismo ámbito de los hombres, de diversos ordenamientos entre ellos contradictorios. Y en los hechos, hasta cada individuo puede orientar su obrar en base a ordenamientos contradictorios -y no solamente en tiempos sucesivos- como sucede cotidianamente, sino con la misma acción. Quien acepta batirse a duelo orienta el propio hacer en base al código de honor, y disimula tal hacer o bien, por el contrario, se presenta al tribunal, y se orienta en base al código penal. Esto es cierto, pero, cuando la elusión o la infracción del sentido (en promedio aceptado) de un ordenamiento deviene la regla, el ordenamiento 'vale' ahora tan sólo en medida limitada, o bien no 'vale' más en absoluto. Entre la validez y la no validez de un determinado ordenamiento, no existe pues, para la sociología -como existe a veces para la jurisprudencia- una alternativa absoluta. Existe en cambio un tránsito incierto entre los dos casos, teniendo a la vez 'valor' ordenamientos contradictorios. Cada uno, en el ámbito en que subsiste la posibilidad que el obrar sea de hecho orientado en vista de eso".

${ }^{84}$ Indica Barbé que "Después de dos siglos de constitucionalismo no podemos poner en duda la existencia de un diseño de vida 'oficial' que es el que 'inspira' el texto constitucional de cada estado. Aunque aquel diseño
} 
Esto así, resulta claro, que la totalidad del entramado social debe compartir -sino todo- por lo menos, parcialmente, los elementos por el cual se articula. Esto explica que al interior de esa misma sociedad, pueda generarse, simultáneamente, la legitimación de un proyecto de vida alternativo. De tal modo, una persona, un grupo social, o un estrato social, tratarán de infundir su diseño de vida propio. Por lo que, si visualizamos la legitimación como un proceso que va del legitimante hacia el poder legitimado, es porque, a priori, existe un proceso de "socialización de valores", que va del sistema de poder -que persigue su propia legitimación- hacia aquellos que aparecen como eventuales "legitimados". Proceso que, formalmente, se desarrolla a nivel del sistema político; pero, puede suceder que un proceso "oficial" de legitimación tenga su raíz en un "momento pre-político" (o preestatal) que es el de la sociedad civil.

Para finalizar esta introducción teórica respecto al estado del arte y habiéndonos referido a la existencia de distintos principios de legitimidad -entendida ésta como atributo de un sistema de poder- toca ahora asumir similar actitud con referencia a los denominados tipos de legitimación.

Sintetizando: la legitimación es un proceso por el cual se produce la aceptación de un sistema de poder -o de alguno de sus elementos- por parte de los legitimantes, generada en el hecho de reconocerse en los valores que "comparten", y que, además, resultan

no permanece cristalizado, sino que cambia permanentemente como consecuencia de la interacción podersúbdito. A nivel jurídico lo demuestra la constante mutación (o reinterpretación, sea expresa o tácita) de le constitución escrita. Diseño oficial y diseño del 'sector dominante' no son sinónimos. A propósito utilizamos la categoría proceso oficial de legitimación en vez de 'dominante'. El término 'dominante' fue adoptado por K. Marx en una nota en L'Ideologia tedesca cuyo contenido puede considerarse actualmente aceptado por buena parte de la literatura no marxista. También es cierto que se presentaron no pocas dificultades, más que sobre el pensamiento de fondo, sobre algunas afirmaciones paralelas. Sobre todo una interpretación de corte 'historicista' de esta nota por conducir a una conceptualización no muy distante de la comteana. La nota a que nos referimos dice: "La idea de la clase dominante es en cada época la idea dominante; es decir, la clase que tiene la potencia material dominante de la sociedad y al propio tiempo la potencia espiritual dominante. La clase que dispone de los medios de producción material dispone, asimismo, de los medios de la producción intelectual, de modo que en conjunto someten a la idea a los que les faltan los medios de producción intelectual. La idea dominante no es otra que la expresión ideal de las relaciones materiales dominantes, son las relaciones materiales dominantes como idea: son, por lo tanto, la expresión de las relaciones que precisamente hacen de una clase la clase dominante, y por tanto son la idea de su dominio. Los individuos que componen la clase dominante poseen sobre los otros también la conciencia, y por consiguiente piensan en cuanto dominantes como clase y determinantes de todo el ámbito de una época histórica, es evidente que eso lo hacen en toda su extensión, y, por eso, entre los otros dominantes también como pensantes, como productores de ideas que regulan la producción y la distribución de las ideas al propio tiempo; es pues evidente que la misma idea es la idea dominante de la época. Por ejemplo: en un período y en un país cuyo poder monárquico, aristocracia y burguesía luchan por el poder, el cual por eso se divide, aparece como idea dominante la doctrina de la división de los poderes, doctrina que ahora es enunciada como 'ley eterna' (Editori Riuniti, 1969, pp.35-36)'. 
fundantes del sistema de poder.

Una conceptualización de este orden permite esbozar tres tipos de clasificación: 1) una fundada sobre el "tipo de participación" generada por la legitimación; 2) otra basada en el "carácter de los valores socializados" y 3) una última, que logra sustento en la jerarquía de los elementos legitimados. (Barbé, 1973:65)

1) En cuanto al tipo de participación, y como señaláramos antes, existe "legitimación activa", cuando media una relativa participación política dentro del canal legitimado del sistema, esto es, en el marco del diseño de vida 'oficial'.

Por su parte, la "legitimación pasiva" abarca sectores más vastos del entramado social, los que -si bien no están fuera del diseño 'oficial' - lo aceptan como algo que acontece lógica y naturalmente, resultando su participación política fortuita y limitada por factores contingentes. Vale decir que no tienen suficientemente asimilado el modelo de vida 'oficial' parsoniano. (Barbé, 1973:66)

En lo que hace la deslegitimación, a la que hiciéramos referencia al diferenciarla de la apatía, se llega a tal comportamiento "desviado", cuando, en relación al modelo "oficial” de legitimación, los actores sociales intuyen, al menos como factible, la existencia de un sistema de poder alternativo. ${ }^{85}$

Comportamiento ‘desviado' que no siempre fue considerado legitimante por buena parte de la literatura, sin que, previamente, estuviere determinado si estos actores conciben como factible un sistema de poder alternativo. También porque la tesis de una participación política muy difusa sería a la recíproca contraproducente para el sistema. Por lo cual, si bien resulta erróneo hacer de cada comportamiento apático un indicador de deslegitimación, no está menos equivocada la corriente opuesta. (Barbé, 1973:67) ${ }^{86}$

2) Respecto al "carácter que revisten los valores socializados", el tema de la legitimación y legitimación revolucionaria -bastamente abordado por Guglielmo Ferreroconstituye un intento por sortear las galimatías que aparecen ante la existencia de una "legitimación" surgida de un proceso revolucionario. Cuestión esta que problematiza el concepto mismo de "legitimidad", al no resultar claro el carácter que revisten los valores

\footnotetext{
${ }^{85}$ Así lo manifiesta Barbe, refiriéndose a investigaciones que, en cierto momento político, afirmaban "que esta categoría comprende en Italia estratos cada vez más vastos de la población, caracterizada por la cuasi absoluta falta de participación. (Cfr. Donolo, C., Politicizzazione e crisis di legitimità, in Cuaderni di Sociologia, n. 3-4, 1970).

${ }^{86}$ Menciona el autor que ésa es una de las críticas que C. Pateman (1971) formula a la producción de Almond.
} 
socializados durante el proceso, toda vez que -la legitimación que se propone- no se referirá a un sistema de valores ya institucionalizados ó en proceso de institucionalización, sino a un conjunto de valores que se quieren vivir. (Barbé, 1973:68)

Materia distinta al de un acto revolucionario, supone un acto contestario ó de restauración, pues, en este último, la legitimación precedente ha sido quebrada por la instauración de un nuevo poder de facto, que propone el restablecimiento de valores legitimantes de un sistema anterior sin que medie una reproducción exacta del mismo.

En consecuencia, revolución y restauración devienen antagónicas, puesto que, en la revolución no existe relación alguna con los valores precedentemente institucionalizados.

Sin embargo, lo dicho no impide que Parsons entienda que también la autoridad carismática está caracterizada en Weber en términos de legitimación. De donde, se infiere que, también la legitimación carismática es precedida por un proceso de institucionalización y socialización de valores. Por lo tanto y siguiendo ese orden de ideas, el mecanismo de legitimación de un poder revolucionario no discrepa -en lo que a dirección del proceso se refiere- de aquello que funda un poder tradicional o legal, desde que la legitimación también se hace a través de un proceso previo de institucionalización y socialización de los valores. El poder revolucionario es una cabal formulación de un diseño de vida alternativo que se produce en el interior de un subgrupo de la sociedad total.

La diferencia existente entre uno y otro tipo de legitimación, no reside pues, en lo referente a la dirección del proceso de legitimación, sino en lo que hace al arquetipo de valores a socializar (en el caso revolucionario se discurre sobre nuevos valores, ó aquellos que aún no revisten actualidad en una sociedad determinada). Es por ello que, antes de la toma del poder, la institucionalización del nuevo diseño de vida aparece como preocupación fundamental de los líderes revolucionarios, manifestada a través de sus enunciados y manifiestos.

Acaecido, entonces, el acto revolucionario, la socialización y el mecanismo de institucionalización, detentan un rol privilegiado ya que legitiman el nuevo poder, desencadenando la movilización política.

Por el contrario, en la restauración, el proceso de institucionalización no tiene un puesto relevante ya que, el nuevo poder se referirá a un modelo precedente de legitimación. No es necesario socializar un nuevo diseño, sino que es suficiente negar la legitimación del 
poder inmediatamente antecedente, esto es, "hacer" anti-fascismo; anti-nazismo; antiliberalismo ó anti-comunismo.

3) Con relación a la legitimación del sistema y de los "elementos del sistema", en rigor lo que se produce es la legitimación articulada de uno o más elementos del sistema de poder al interior del cual, uno de sus subsistemas, e1 "sistema político" desempeña un importante rol. De allí que el análisis se realice sobre un "elemento" del sistema político y no sobre todo el sistema, dado que esa participación se produce dentro del canal institucional, que implica, per se, la legitimación de uno de los elementos claves del propio sistema.

El mensurar la legitimación del sistema político a través de la legitimación de sus elementos presupone una jerarquización de ellos, ya que algunos resultan más relevantes dado que, su legitimación, repercute en todo el sistema.

Dicha jerarquización obedece, por ejemplo, a la circunstancia que -ya antes de la toma del poder- la legitimación del canal de aumento de la demanda política -los partidos políticos, los sindicatos- parece más importante en lo interno de la estructura total de legitimación, que la mera legitimación de los outputs económicos del sistema, los cuales son contingentes. Una legitimación fundada sobre un bienestar económico -que puede resultar solo transitorio- resultaría así muy frágil. También si, la sola permanencia de aquel bienestar en el tiempo, da juego a los "factores secundarios de legitimación”, vale decir, la presencia de legalidad, coerción, prestigio, etc. (Barbé, 1973:71)

Como conclusión y considerando que la temática de la participación política se genera a nivel de grupo ó estructura de solidaridad, es en ese mismo nivel que tiene lugar el proceso de legitimación. Por lo que, queda claro, que la legitimación se verifica a través de concretos y efectivos comportamientos, los cuales -en su mutuo y recíproco contralorconstituyen la auténtica "historia de vida" o "diseño de vida".

Estamos hablando de una medida "cualitativa" no "cuantitativa" de legitimación. Si aplicamos un principio de nuestros días, aceptado por todos, al menos declarativamente -el de "la mayoría"- podremos decir que un elemento de sistema de poder está "legitimado" cuando recibe la legitimación de la mayoría de la población. Sin embargo, se trataría de una afirmación genérica, ya que, debería deslindarse, cuál formación de tal legitimación está constituida por una legitimación activa y cuál otra, por una legitimación pasiva. 
Por ello, si el objeto de una indagación sobre legitimación es determinar la posibilidad de estabilidad (o permanencia) de un sistema de poder o de alguno de sus elementos, se debe tener en cuenta que no todos los eventuales legitimantes tienen el mismo peso a1 interior de un determinado sistema de poder. Esto es, no todas las des-legitimaciones significan el mismo peligro para un sistema de poder. Así, la estabilidad de una democracia dada, no depende solamente del desarrollo económico sino también de la eficacia y la legitimidad de su sistema político. E insistimos en ello, por eficacia se entiende 1a verdadera conducta, el grado en que el sistema tiende a satisfacer las fundamentales funciones de gobierno, tal como lo consideran la mayor parte de la población y, al interior de ella, por poderosos grupos como lo son las altas finanzas y las fuerzas armadas. (Lipset, 1977:57)

Ahora bien, siendo la legitimidad una cuestión de grado, determinar el "grado" de legitimidad de un régimen político presenta serias dificultades, a causa de todos los matices que puede presentar la expresión concreta de la "creencia" y del "acuerdo" compartido por gobernantes y gobernados. Prueba de ello, lo constituyen las nociones prelegitimidad, cuasi-legitimidad e ilegitimidad (enunciadas por Ferrero) y que persiguen poner de manifiesto la multiplicidad de fenómenos y situaciones que la categoría legitimidad encierra. Al respecto, sostiene Botana que, en los tres casos existe legitimidad en crisis, que en última ratio, no significan más que los diferentes grados que puede alcanzar la atribución de legitimidad de un sistema de poder.

La generalidad de los autores, sitúan el punto, en relación a la estabilidad -los sistemas de legitimidad- ó respecto a la crisis, los regímenes donde la atribución de legitimidad hace falta. ¿No será posible que un régimen pueda funcionar con una legitimidad parcial ó déficit de legitimidad? Y aquí nos encontramos con aquello que Ferrero denomina distintos grados de legitimidad. En los hechos, esas categorías intentan manifestar la multiplicidad de fenómenos y de situaciones que la noción de legitimidad apunta a explicitar y que señalan toda una serie de casos intermedios entre la legitimidad completa por una parte y la legitimidad en crisis por la otra. No se trata de reducir la política a un concepto único sino por el contrario de precisar el concepto analítico de legitimidad, a fin que él pueda aclarar uno de los numerosos aspectos que, en conjunto, constituyen el dominio de la política. 
Por lo expuesto, reiteramos el carácter plausible de la noción operacional de legitimidad adoptado, teniendo en cuenta, el hecho que la atribución de legitimidad puede alcanzar grados diferentes (Botana, 1968:212) ${ }^{87}$, mientras que, paralelamente, el proceso de legitimación presenta distintos tipos (participación, valores o elementos, conf. Barbé, 1973:65 y ss.). Resultando, ambos conceptos, aplicables a la praxis de la formación política argentina.

\footnotetext{
${ }^{87}$ Considera el autor que: "A primera vista podemos avanzar sobre la idea que los tres casos constituyen en los hechos, las tres fuerzas de un mismo tríptico y que bautizaremos con el nombre de legitimidad en crisis. Hay una crisis de legitimidad si la obediencia del principio es rechazado, por el mismo poder, pleno de buenas intenciones (pre-legitimidad). Hay una crisis de legitimidad si la obediencia dada a una fórmula híbrida es obtenida parcialmente, porque ni uno ni otro de los principios acoplados por el poder, son capaces de lograr la unidad del cuerpo político (cuasi-legitimidad). Hay, en fin, una crisis de legitimidad si el poder ensaya imponer obediencia por la fuerza o el miedo, porque carece de una legitimidad de reemplazo (ilegitimidad)."
} 


\section{CAPÍTULO I}

\section{3-1860. La legitimidad vigente y la adoptada.}

Génesis de la formación política argentina: Sociedad Civil y Estado.

1. A modo de introito.

La formación política argentina cimentada durante los años 1853-1860, surgió como un sistema de alianzas que no pudo evitar reproducir, a nivel nacional, las dialécticas interestructurales provinciales, y en la que actuó -como vínculo orgánico- la élite intelectual encargada de canalizar y transmitir mediante sus escritos y obras literarias, los intereses específicos del grupo hegemónico terrateniente-hacendado-militar. Para, más tarde, ya convertido ese bloc no sólo en clase dominante sino dirigente, establecer, a través del derecho, las 'reglas de juego' válidas para el colectivo. Esto es, establecer desde su posición prevalente, la dirección cultural, definitivamente, la ideología de la formación toda.

Entendiendo por formación política, el ensamble existente entre sociedad civil y sociedad política (o estado propiamente dicho), toca interrogarnos sobre la dialéctica que existió entre ambas; cuál fue la mediación pretensa y/o lograda por la dirigencia argentina, en tanto nódulo de conformación de la sociedad civil, así como el predominio de una u otra, en el devenir histórico.

Considerando que la apropiación territorial ideológicamente hablando, vale decir, la generación de lazos identitarios, es un requisito de todo estado que pretenda ser "fuerte" (v.g.: todos los estados provinciales, así como sus elites dirigenciales en búsqueda de la organización nacional) fue necesario que políticos e intelectuales se situaran frente a la cuestión de la identidad nacional y de sus formas de constitución, dando paso a una elite internalizada en los valores sociales de este bloque hegemónico: familias de "nombre", acompañadas por antecedentes históricos que trasvasaban la hegemonía política llegando a la cultural a través de periódicos fieles a su ideología. 
Bloque que, lejos de quitar la vista de Europa, ignoró la propia realidad, olvidando de tal modo, la búsqueda y análisis de peculiaridades regionales. De modo que, al no mediar acciones comunes aglutinantes en lo social y carentes de creencias colectivas identitarias, se exacerbaron los regionalismos locales obedeciendo, diríamos hoy, a la carencia de "capital social" (Putnam, 1993). Entendiendo por tal, aquel basado en la "confianza" que debe mediar en todo entramado social que pretende constituirse en Sociedad Civil.

Veamos el "escenario".

La Argentina de mitad del siglo diecinueve, guardaba en su territorio, idéntica situación conflictiva a la que, por entonces, había caracterizado a la sociedad civil occidental de la época.

Sin duda, la asimetría existente en el espacio geográfico, de alguna manera condicionó a sus habitantes, llevándolos a adoptar posturas actitudinales variopintas que, poco a poco y andando el tiempo, se agudizaron aún más.

No obstante lo apuntado, la polarización de fuerzas colectivas -iniciada con la diáspora entre morenistas y saavedristas- seguida por el enfrentamiento entre unitarios y federales durante la poliarquía y/o anarquía culminó, prima facie, con el dictado de la Constitución Nacional y el surgimiento del Estado-Nación.

Pero, ¿fue esto así? Creemos que no. En rigor, lo fue "formalmente" pero no en el relacionamiento interestructural acaecido en las distintas instancias regionales. Ello, toda vez que -las turbulencias infraestructurales, canalizadas, en principio, por la naciente dirigencia para lograr así impactar en la escena política y proveer de acuerdo y conforme a las demandas de la sociedad- no tuvieron fin.

Preguntarnos cuál fue el proyecto político del bloque hegemónico, implica, pues, escudriñar acerca de si lo hubo en el '53, en el '60, en el '80, ó en 1916. ¿Acaso medió otro a partir de 1930, con la primer fractura del orden constitucional? o ¿solo se trató, de un mero artilugio político?

$\mathrm{Si}$ observamos, la complejidad aparece a poco que se analice el proceso de "conformación del estado argentino": mezcla de diversos grupos étnicos, convivencia de burguesía-terrateniente-hacendada con "peonadas" y procesos de ascenso social 
(movilidad) solo para algunos. Tal estado de cosas, puso en evidencia una lógica de organización política y social bien diferenciada y, a decir verdad, poco virtuosa.

La incorporación expresa al texto constitucional de la "forma federal", también lo fue solo formalmente -vale decir como ideal, nunca en la praxis- permitiendo la hegemonía de las provincias que habían tenido éxito desde el punto de vista económico. Por lo que, una vez más, se puso de manifiesto que, el bloque constituido por la oligarquía terrateniente-hacendada no estuvo dispuesto a someter sus intereses específicos de clase a los intereses nacionales, sino, todo lo contrario.

Interrogarnos cómo fue el mundo, mediato e inmediato, de aquellos que fueron los representantes encargados, a nombre del pueblo de la Nación Argentina, de otorgar el marco normativo que posibilitó la organización nacional; indagar cuáles fueron las creencias de esta flamante dirigencia, dado que, en tanto legitimados, actuaron como depositarios de la legitimación de quienes los habían elegido, vale decir, pretensos detentadores del sistema de creencias vigente en el pueblo, y por ende, directos 'hacedores' de la dirección cultural, constituye pues nuestra tarea.

En su discurso inaugural - "Ojeada filosófica sobre el estado presente y la suerte futura de la Nación Argentina”- pronunciado en el Salón Literario cuando corría el año 1837, Marcos Sastre, fustigaba esa dirección, decididamente ideológica, que introducía instituciones foráneas ignorando la idiosincrasia de nuestra trama social. (Levene, 1958:235) ${ }^{88}$

Tiempo hacía que, en un intento por conciliar los intereses regionales, el Congreso General Constituyente reunido en 1816, había prometido estudiar las condiciones naturales de las provincias como paso previo a la organización. En tal sentido, en el Manifiesto, aprobado en la sesión del 3 de agosto de dicho año, sentenció:

“[...] Si al tirar las líneas las condujéramos por donde la naturaleza las señaló con límites visibles, donde el suelo se baste a sí mismo, donde presente las conveniencias y comodidades necesarias, densas o medios que las proporcionen a la seguridad, donde el clima, el lenguaje, el

\footnotetext{
${ }^{88}$ Señalaba Sastre que el "[...] rumbo nacional de la cultura del país, caracterizado por el plagio político, científico y literario que había imperado entre nosotros por entonces, tornaba necesario adoptar una política y legislación propia del ser argentino, cuanto un sistema de instrucción pública acomodado a él, así como una literatura propia y peculiar de su ser. Genéricamente hablando, pensaba que se había puesto en evidencia "el extravío de una marcha política guiada sólo por teorías exageradas y alucinada con el ejemplo de pueblos de otra civilización, que no había hecho más que imitar formas e instituciones extranjeras, cuando todo se debía buscar en el estudio de la naturaleza de nuestra sociedad, de sus vicios y virtudes, de su grado de instrucción y civilización, de su clima, de su territorio, de su población y sus costumbres.
} 
genio y carácter, las habitudes, los usos y costumbres no induzcan diferencias chocantes, fijaremos la demarcación, y diremos: la naturaleza ha llenado su designio y nosotros hemos conformado nuestra obra a sus planes”. (Alvarez, 1984:40).

A su turno, el 15 de diciembre de 1819, la Gaceta de Buenos Aires, también expuso las ideas del gobierno central sobre tan delicada materia:

“[...] Los federalistas quieren no solo que Buenos Aires no sea la capital, sino que, como perteneciente a todos los pueblos, divida con ellos el armamento, los derechos de aduana y demás rentas generales: en una palabra, que se establezca una igualdad física entre Buenos Aires y las demás provincias, corrigiendo los consejos de la naturaleza que nos ha dado un puerto y unos campos, un clima y otras circunstancias que le han hecho físicamente superior a otros pueblos, y a la que por las leyes inmutables del orden del Universo, está afectada cierta importancia moral de un cierto rango. Los federalistas quieren, en grande, lo que los demócratas jacobinos en pequeño. El perezoso quiere tener iguales riquezas que el hombre industrioso; el que no sabe leer, optar a los mismos empleos que los que se han formado estudiando; el vicioso disfrutar el mismo aprecio que los hombres honrados [...]" (Alvarez, 1984:41)

\section{Espacio y población.}

Una rápida mirada sobre el territorio abierto a las expectativas de sus habitantes, permitió visualizar el cómo y dónde de una geografía y un grupo poblacional que habría de convertirse, bajo los mandatos de la modernidad, en Estado.

Así, el espacio geográfico sobre el que se erigió -entre los años 1810/1820, primeros donde medió un intento de existencia 'autónoma' respecto de la metrópoli- la formación política argentina, constituyó en realidad un importante eje dinámico ocupado por una ancha franja extendida desde el N.O. hasta Cuyo y desde el centro hasta el S. del Litoral y la Banda Oriental. Fuera de él, quedó gran parte del N.E. y la Patagonia al no reconocer el poder de los blancos, y continuar bajo el dominio de las colectividades indígenas. (Bagú y Weinberg, vol. 2, 1974: 255-256). ${ }^{89}$

\footnotetext{
${ }^{89}$ Características éstas que, por otra parte, subsistieron hasta la época de la independencia y que así describieron los autores: "a) desde el NE hasta Córdoba, una población indígena de cultura quechua sedentaria agrícola-artesanal, con apreciable densidad demográfica en muchos valles fértiles; b) en el NE, indígenas de cultura guaraní también sedentaria agrícola-artesanal, pero de menor densidad demográfica; c) el Litoral y la banda oriental, con tribus nómadas belicosas, ya casi totalmente en dispersión a principios del siglo XIX; pocos africanos y sus descendientes, una población mestiza con tendencia al aumento y un sector blanco europeo y nativo; d) el sur, con gran predominio de población indígena, sobre todo araucana (agricultores, sedentarios en Chile, que atraídos por la riqueza pecuaria de la pampa, se hacen nómadas
} 
Algunos registros de la época indicaron que la población en dicha área -cuando corría el año 1810- fluctuó en torno a los 500.00 habitantes (el dato proporcionado por De la Fuente en 1809, es de 406.000); según la misma fuente, en 1839 ascendía a 768.000 habitantes, registrándose en 1849, 935.000 habitantes. Lo cual señaló, para esta última década, un $22 \%$ de aumento puramente vegetativo, considerando el fracaso obtenido por el proceso de inmigración escocesa fomentada por B. Rivadavia cuando corría el año 1826, debido a la hostilidad del vecindario y la falta de apoyo político.

No todos los inmigrantes llegados a partir de 1840 -fuerzas que llamaríamos espontáneas- entre los que se encontraban irlandeses, gallegos, italianos, ingleses, vascos franceses y vascos españoles, en su mayoría agricultores, artesanos, algunos profesionales y pequeños capitalistas, tuvieron la misma suerte. Los ingleses fueron los privilegiados: dueños de estancia, ganaderos definitivamente, que se vieron beneficiados por la política impositiva de Rozas. (Sáenz Quesada, 2001:326 y ss.)

En 1862, sin considerar la Banda Oriental, la población ascendía a 1.300.000 aproximadamente. Excluyendo, en dichas cifras, la población indígena rebelde, el crecimiento vegetativo y la corriente inmigratoria que, a lo largo de esa fase, resultó de poco volumen. Buenos Aires fue la única ciudad que llegó a superar los 100.000 habitantes.

Vale decir que, en términos de relacionamiento interestructural, estos datos, volcados al ámbito geográfico, produjeron los siguientes fenómenos: a) tipos tradicionales de economía doméstica de subsistencia (ejemplificado en un porcentaje apreciable de población defendiendo $s u$ estilo de vida); b) un asimétrico régimen alimentario (desigual por cierto, conforme las variopintas regiones) pero no seriamente deficitario; c) hiperpoblación urbana generadora de la consiguiente problemática de hacinamiento.

Peculiaridades, que, sin duda, demostraron la existencia de situaciones de inclusión y exclusión y que, con el correr de los tiempos, resultaron determinantes en lo referente a la fragilidad de los lazos humanos sobre los que se gestó nuestra débil sociedad civil.

La presencia en Buenos Aires, Montevideo y el Litoral, de una población activa conformada -además de la fuerza de trabajo aportada por mestizos, negros y criollos- por el bloc au pouvoir terrateniente-hacendado, dedicado a la explotación del conjunto "estancia-

cazadores de vacunos y equinos) que no se incorporó nunca ni al sistema colonial ni al nacional, aunque mantuvo con éste algunos intercambios de bienes y servicios." 
saladero-comercio exterior“, conformó una peculiar sub-región. Zona que, al contar, prácticamente, con puerto propio, concretó los negocios más significativos para la época, complejizando y diferenciando, aún más, ese auténtico damero regional.

No obstante lo señalado, tampoco esta sub-región presentó, al interior, idéntico perfil. Mientras en el Litoral y la Banda Oriental, la estructura productiva sufrió el cimbronazo provocado por las guerras civiles y la guerra de los orientales contra Portugal (1816/1825) respectivamente, que desorganizaron las actividades pecuarias; en Buenos Aires, los bloqueos - francés (1838/1839) y anglo-francés (1845/1848)- estimularon, por el contrario, la multiplicación de sus existencias de ganado "en pie" al cerrar, prácticamente, la salida al exterior.

Por ello, oportunamente, el incremento de la demanda del mercado internacional posibilitó ampliar el área de influencia ganadera mediante las llamadas "campañas del desierto" que, plasmadas como maniobra militar, financiadas por el Estado y comandadas durante este período- por los estancieros-gobernadores Rodríguez y Rosas, lograron óptimos resultados en beneficio del bloc terrateniente-hacendado, afianzando, aún más, su hegemonía en las instancias regionales de lo económico y político.

Lanzada Europa en busca de materias primas existentes en esta periferia, se intensificó el comercio con el viejo continente, provocando migraciones, desde el Noroeste y el Oeste hacia la zona del litoral. Tendencia que se agudizó aún más a partir del año 1880, considerando que, al tradicional ménage, se sumaron actividades tales como, la proveniente de la explotación de la vid y la elaboración de bebidas, el aprovechamiento de nuevos espacios agrícolas de la zona templada y el desarrollo de la ganadería. Aspectos que sustentaron la hegemonía de la aduana de Buenos Aires, por entonces, la principal fuente de ingreso público.

\section{La formación social argentina.}

El examen hasta aquí realizado, permitió ubicarnos ante una estructura social estratificada en cuya praxis se posicionaron: a) terratenientes-hacendados, fundamentalmente bonaerenses, priorizando sus intereses específicos (ganadería-saladerosexportación); b) pequeños terratenientes, cuya mayor o menor incidencia derivaba de la importancia regional, dedicados a la explotación de la tierra, como también a la artesanía, intermediación y transporte; c) comerciantes (españoles y británicos) que paulatinamente se 
transformaron en terratenientes y criadores; d) artesanos y agricultores, prácticamente sin relevancia en las instancias regionales de lo económico-político; e) sectores representativos de lo que llamaríamos hoy, clase media, que actuó bajo la égida colonial; f) intelectuales bonaerenses, provenientes de familias de terratenientes y propietarios urbanos, que cobraron relevancia pública por medio de la prensa y la política; g) mano de obra nómada, proveniente principalmente del campo y que, reducida mediante la fuerza por el poder público, se convirtió en un sector asalariado destinado a la producción urbana y rural; y h) esclavos negros que, en las ciudades, constituyeron la servidumbre doméstica de las familias acomodadas.

De manera que, pese a tener claramente definidos los roles a desempeñar, la dirigencia emergente de ese tejido social, debió superar distintas coyunturas para conservar, efectivamente, el poder económico y político. Las guerras, primero por la independencia y luego las civiles, provocaron disturbios en el entramado social, ante el obligado desplazamiento de los actores sociales. También la inexistencia de una eficaz estructura de producción, acompañada de escasa movilidad social y el analfabetismo, constituyeron un freno en el esfuerzo de aquella 'primigenia' dirigencia, por difundir la educación y la cultura.

Esto llevó al enfrentamiento del campo y la ciudad. La emergencia de una minoría urbana culta y educada, que pugnó por construir lazos que contribuyeran a forjar una gesta nacional, marcó, al propio tiempo, el fracaso de la dirigencia política en su inicial ideario, de plantear la participación popular como un mecanismo hábil para la conformación de una sociedad civil fuerte.

Sostiene Álvarez, al respecto, que

“[...] iniciado el movimiento separatista de 1810 por una minoría cuyas principales bases de operaciones eran las rentas públicas y el gobierno, fue imposible abandonar éste a las contingencias del sufragio libre y popular. A la primera renovación, el voto de las mayorías semibárbaras o ignorantes de lo que se proyectaba, hubiese podido ahogar la audaz empresa [...] ella 
no favoreció a los gauchos. Solo votaron, pues, algunos amigos políticos, y únicamente se admitió en el gobierno a los miembros del partido separatista." (Alvarez, 1984:125) ${ }^{90}$

A resultas de ello, el caudillo manejó sus peones como un señor feudal. Tierra y hacienda se convirtieron en elementos fundamentales para la fracción hegemónica, por lo que, desde el "poder", se sucedieron los duelos entre gobernadores-estancieros.

Los conflictos suscitados en orden a la distribución y la organización del poder fueron pues, prevalentemente, aquellos provocados por enfrentamientos entre regiones, o, en su caso, luchas entre fracciones y/o categorías dentro del bloc -numéricamente reducidoque ya ejercía el poder.

4. La formación política como expresión de sistema de alianzas sociales.

La precedente y breve descripción, pretendió servir de soporte -otorgando un marco fáctico- para explicar (en términos schusterianos), el por qué, de la relación existente entre legitimados (instituidos) y legitimantes (instituyentes).

¿Estaban los representantes, cuando corría el año 1853, realmente imbuidos de las necesidades, expectativas y demandas del pueblo? ¿Acaso percibieron cómo compensar los recursos escasos, cómo reconocer valores para otorgar, desde el Estado, sentido? ¿Comprendieron quizás, que no resultaba condición suficiente para obtener lealtad de masas, la adopción de una ideología universalista o planetaria como fundamento de un régimen, si éste se basaba en una desigual y asimétrica distribución de la riqueza social?

Mientras la dirigencia porteñista estaba integrada por hacendados, generales y abogados del rosismo -acompañados por periodistas y tribunos del Partido Liberalsupuestos legitimados (Sáenz Quesada, 2001:343), menester es preguntarnos ¿qué pasó con y entre aquellos que debían otorgar legitimación? ¿Acaso, existía un pueblo?

A estar del pensamiento de Mariano Moreno y en orden a la teoría de la retroversión de la soberanía - argumento expuesto en el año 1810- la respuesta no puede

\footnotetext{
${ }^{90} \mathrm{Y}$ añade (1984:126) “[...] El primer parlamento argentino fue disuelto por un golpe de estado (noviembre de 1811). Para constituir el segundo, se aceptó teóricamente el sufragio universal, pero en la práctica, el cabildo de Buenos Aires efectuó las designaciones por sorteo [...] El Congreso de 1816, 1819, la Constitución de 1826, el gobernador de Bs. As. decía en 1837, asentando las bases del derecho electoral aplicable por entonces: 'Mucho se ha escrito y hablado entre nosotros acerca del sistema constitucional; pero en materia de elecciones, como en otras, la práctica ha estado bien distante de las doctrinas más ponderadas..."
} 
ser más que afirmativa, al sostener: "La disolución de la Junta Central [...] restituyó a los pueblos la plenitud de los poderes, que nadie sino ellos mismos podían ejercer[...]" Postura que refuerza, ante el nuevo escenario político, al manifestar: "Los vínculos que unen al pueblo con el Rey son distintos de los que unen a los hombres entre sí mismos: un pueblo es un pueblo, antes de darse un Rey [...] los vínculos que unen a un hombre con otro quedaron subsistentes [...] los pueblos no debieron tratar de formarse pueblos pues ya lo eran [...]". De manera que el mecanismo a reconsiderar, desde el acto revolucionario, fue el problema de la "representación"- necesario para regenerar la unidad del entramado social a través del vínculo moral- de la que estuvieron investidos los representantes enviados por cada uno de los pueblos, en la consecución de la formación política argentina. 91

Mariano Moreno cerraría el interrogante, en 1810, al sostener que la reunión de los diputados a la Junta:

“[...] concentra una representación legítima de todos los pueblos, constituye un órgano seguro de su voluntad, y sus decisiones, en cuanto no desmientan la intención de sus representados, llevan el sello sagrado de la verdadera soberanía de estas regiones. " (Roldán, 2003:38)

En el mismo sentido, el Ministro Agüero -en su intervención en la sesión de la Asamblea Constituyente del 15 de febrero de 1826- sostuvo:

"Por una fatalidad, los vínculos de unión que componían la nación se disolvieron y la nación dejó de existir de hecho, y dejó de existir contra los deseos, contra la voluntad, contra los clamores y contra los sentimientos de los pueblos [...] "' (Roldán, 2003:39)

\footnotetext{
${ }^{91}$ Debemos aclarar, por razones metodológicas, que al hablar de "pueblos" se hace referencia a la teoría de la 'retroversión de la soberanía' puesta en vigencia en España, y receptada por los revolucionarios de mayo, en relación al concepto político de "ciudad", ante la invasión y ocupación napoleónica. Pueblos -como sinónimo de provincia o estado- soberanos que reinvindicaban derechos y eran reacios a renunciar a ellos [...] y que participaban de asambleas y congresos, mediante representantes portadores de instrucciones (mandato imperativo). Ello no obsta mencionar las palabras de Moreno que -derivadas de su formación como jurista en la Universidad de Charcas- lo conducen, como a muchos otros protagonistas del proceso independentista, a utilizar criterios políticos heterogéneos y difíciles de compatibilizar [...] Así, la realidad llevará -aún en muchos de los que se adherían a un concepto de nación, a imagen de la Revolución francesa, con una soberanía única y un pueblo compuesto de individuos- a la conciliación con la existencia de múltiples soberanías y la conformación de muchos pueblos soberanos". (Chiaramonte, 2003b: 94-116) Es a partir de la segunda mitad del s. XIX que el concepto pueblo recibe su acepción actual -en tanto depositario del poder constituyente- como noción que caracteriza a los ciudadanos, en su condición de electores y poseedores de mandato libre, en lo que a elección de representantes se refiere.
} 
$\mathrm{Si}$ bien las revueltas habidas, destruyeron los "vínculos" con el nivel superestructural, no ocurrió lo propio en el ámbito del tejido social. La permanencia de los Cabildos, durante algunos años más, y la restringida aunque activa "presencia" de los pueblos, fortaleció la voluntad del colectivo de mantenerse unidos, circunstancia ésta que, junto a la comunidad de intereses compartidos, hizo que el problema a dilucidar fuere el de encontrar un principio de legitimidad, que reemplazara al "tradicional-monárquico".

El interrogante no lo fue, pues, en lo aparencial de sus manifestaciones, sino que nuestra pregunta apuntó a conocer si medió, en la relación representado-representante, la suficiente acción comunicativa capaz de hacer nacer roles identitarios en una comunidad que pretendió constituirse en Nación. Esto es, si existieron -entre el sistema de poder legitimado (representantes) y aquellos que legitimaron el sistema (representados)comportamientos genéticos predispuestos, socialmente hablando, esto es, interacción, representaciones comunes, valores compartidos, sentido de pertenencia y esa nostridad, el necesario reconocimiento en el alter. No obstante, la integración del entramado social, se vio siempre amenazado por problemas de autogobierno.

\subsection{Hitos: Años 1810/1820 y 1826/1837.}

Si bien no constituye nuestra finalidad realizar un detallado análisis historiográfico de los hechos que marcaron el nacimiento del estado/nación argentino, inevitable resulta fijar algunos mojones determinantes, en el devenir de la formación política, dado que el acontecer político que registra la historia patria, ilustra acerca del común objetivo que lo signó: la organización nacional.

De tal modo, ciertos hitos que llamaremos temporales, resultaron determinantes para sustentar el proceso contextural de la formación política argentina. Por ello, el análisis del subistema político que, como centro diferenciado de auto-gobierno, ocupa una posición supra-ordinada respecto de los subsistemas económico (despliegue de fuerzas productivas) y el socio-cultural, permitirá una primera aproximación interpretativa del ciclo “1810/1853” y es precisamente esa sinergia la que, a nuestro juicio, coadyuvará en la tarea.

El período 1810 a 1820 se caracterizó, luego de la Primera Junta de Gobierno Patrio -y el ideario de Mariano Moreno- por las luchas en pos de la independencia, cuyo desenlace lo constituyó el Congreso de 1816 -plus la solución monárquica- y la conflictividad 
interregional. El lapso que corre desde 1820 a 1852, estuvo signado por una multiplicidad de sucesos: las disputas y combates entre unitarios-federales y el fenómeno de los caudillos; el afianzamiento de las provincias, con el correlato de los Gobernadores y el fracaso de los intentos centralizadores (1819/1826) -señaló la aparición institucional de Buenos Aires, su posterior hegemonía, seguida de la promoción pública de Juan Manuel de Rosas y sus sucesivos mandatos (1829/1852), la Ley de Aduanas y la consagración definitiva de la producción agropecuaria bonaerense favorecida por la posición prevalente de Gran Bretaña en el mercado internacional; ya en el transcurso que va de 1852 a 1862, la batalla de Caseros y sus consecuencias, pusieron de manifiesto la impostergable necesidad de organizar el sistema político, mediante el dictado de una Constitución; el surgimiento de la Confederación -sin Buenos Aires- otorgando legitimidad a la figura de Justo José de Urquiza no lograría, sin embargo, cerrar el interrogante acerca de, si durante el señalado devenir historiográfico, medió un auténtico proceso de legitimación en el seno de la sociedad civil, que operara a modo de legitimante de los actores que se desempeñaron en la Asamblea Nacional Constituyente de 1853. El acaecimiento de Pavón, la secuelas y condicionantes que le siguieron, ilustran sobre el camino que aún bastaba recorrer en la consecución del propósito común, cual era la unión nacional.

Por ello, menester es preguntarnos ¿cómo surgieron esos legitimados? ¿Cuáles fueron las herramientas, los mecanismos mediante los que fueron investidos como representantes?

Así:

a) Durante la primera década de nuestra primigenia formación política, la elección de los representantes ante las Juntas, Asambleas, Congresos, se realizó en forma indirecta mediante un grupo de compromisarios que, designados a priori, designaban un ciudadano.

b) En un intento por abandonar esas prácticas y para favorecer la participación del pueblo -aunque continuando con la elección indirecta- en el año 1821, la provincia de Córdoba dictó la primera normativa específicamente electoral.

Similar conducta adoptó la Provincia de Buenos Aires en agosto de 1821, pero consagrando la elección directa de representantes por todo hombre libre mayor de 20 
años.(González Bernaldo, 2003b:142) ${ }^{92} \mathrm{Si}$ bien y a efectos de conformar la Sala de Representantes, la norma estableció la división en distritos (la ciudad de Buenos Aires se dividiría en parroquias -Catedral, San Ignacio, San Nicolás, el Socorro, la Piedad, Montserrat, Concepción y San Telmo- para elegir doce diputados; en tanto la campaña, elegiría once representantes en actos comiciales a realizarse en Luján, Morón, Flores, Pilar, Ensenada, Arrecifes, San Nicolás, Chascomús y Patagones, incluyendo los pueblos ubicados en derredor a las mencionadas localidades), no fijó el "espacio físico" en que los ciudadanos emitirían su voto (por lo que algunos fueron formulados en las habitaciones del cura párroco, otros dentro del propio recinto parroquial, para, más tarde, expresarlos en el atrio de la parroquia) aunque el sistema no presentó mayores dificultades se prestaba a toda clase de matufias [...] sin embargo ello no obstaculizó su paulatina reforma y mejoramiento. (Luna, 1995:29). ${ }^{93}$

La crisis del año '20 permitió visualizar tanto en las prácticas sociales, cuanto en la representación simbólica, la importancia del rol desempeñado por la plebe y por el Cabildo de Buenos Aires. Plebe, bajo pueblo, chusma, populacho, fueron categorías conceptuales con las que, la elite ciudadana, calificó a los sectores bajos de la sociedad porteña. (Di Meglio, 2003: 173-174) ${ }^{94}$ Plebe que contó con líderes populares y dirigentes "intermedios" llamados "tribunos de la plebe"-, posiciones éstas, ocupadas por empleados del Estado y vecinos influyentes, verdaderos " [...] articuladores de la participación plebeya y en

\footnotetext{
${ }^{92}$ Señala la autora que " [...] el caso rioplatense es paradigmático [...] en lo que se refiere al sistema representativo, ya que el establecer el principio de la democracia electoral: un hombre, un voto [...] creyó dejar sentado que las elecciones parecen jugar un papel considerable en la legitimidad del régimen y ya nadie podrá prescindir de ellas. Este aparente adelanto democrático de la joven república no se traduce, sin embargo, en una democratización del poder. Debe plantearse, entonces, para qué sirven las elecciones. El caso del régimen de Rosas muestra que éstas servían menos como técnica de selección o medio de expresión política que como forma de plebiscitar la selección de candidatos efectuada por el gobierno".

${ }_{93}$ Agrega Luna (1995:30): "Imperfecto y atravesado por malos hábitos, el sistema electoral inaugurado en 1821 en la provincia porteña abrió, con todo, la posibilidad de un gradual perfeccionamiento. Dejaba, además, de lado (y para siempre) toda forma de calificación del voto, adelantándose en este sentido a la legislación contemporánea de Francia y Gran Bretaña, donde el ejercicio del voto estaba condicionado a la calidad de propietarios o a la renta [...]".

${ }_{94}^{94}$ Menciona el autor que "el término plebe era empleado por la elite de Buenos Aires para denominar a los sectores bajos de la sociedad porteña, un conjunto muy heterogéneo de personas que compartían su condición social subalterna, su pobreza material, su lejanía de las áreas de gobierno y sus espacios de sociabilidad. En buena parte eran analfabetos[...] y sus ocupaciones eran muy variadas: jornaleros, vendedores ambulantes, changadores, artesanos y aprendices, peones, transportistas de diverso tipo, mozos de pulpería, lavanderas, planchadoras, domésticas, matarifes, pequeños labradores de las quintas suburbanas, aguateros, costureras, prostitutas, mendigos [...]". En algunas oportunidades también ingresaban a esta categoría los esclavos.
} 
general de la política porteña decimonónica”, escena política a la que también ingresaron los militares.

La alianza de estos tres actores del momento postrevolucionario (plebe, líderes populares y Cabildo) fue desarticulada en octubre de 1820, toda vez que el temor al saqueo y a los tumultos, llevó a la elite a perseguir la destrucción de la plebe.

Por ello, el intento de organización dado en 1826 aportó tranquilidad. Rivadavia pensó que una Constitución unitaria daría forma a un país anarquizado: ignoró que la unidad, es decir la organización en lo jurídico, debía ser la resultante de un proceso en el cual todas las partes, sin excepción, debían reconocerse como sentidamente integradas. No obstante, el nuevo sistema electoral y la reforma militar trasformaron la forma de participación de la plebe urbana en la política porteña. (Di Meglio, 2003: 189) ${ }^{95}$

La estructura feudal no solo de la provincia de Buenos Aires, sino también del interior, había facilitado el surgimiento de regiones no competitivas. Clara herencia del aislamiento y proteccionismo de Rosas, los saladeros señalaron el camino de una preindustrialización, en demérito del interior. Por lo que, el desarrollo de un capitalismo tardío embretado en los límites estrechos de la oligarquía porteña, ligada a terratenientes y ganaderos, forzó el camino a seguir. El conflicto al que había intentado poner fin Bernardino Rivadavia afloró nuevamente. Pero ¿en qué sentido podía propugnarse un desarrollo capitalista si no existía unidad nacional ni formas jurídicas aceptadas por todos? De hecho, nada se podía ofrecer: ni a los capitalistas extranjeros, ni a los argentinos, desde el momento en que las formas proto-capitalistas, continuaban ejerciendo presión.

La falta de conectividad y la inconsistencia del tejido social observable en el imaginario colectivo de la época, permitieron, entonces, la continuidad de viejas prácticas económicas basadas en la ganadería, estableciendo, de esta manera, la diatriba inclusión/exclusión.

Existió también, vinculado con el interior, el problema de la integración del territorio nacional, ocupado en gran parte por indios que si bien se mantuvieron indolentes con Rosas, se sublevaron apenas se produjo el cambio.

\footnotetext{
${ }^{95}$ En palabras del autor: "Los plebeyos siguieron actuando en ella [...] pero sus prácticas se redefinirían con el cambio de escenario que puso fin a sus modos de participación en la década de la revolución"
} 
Los problemas a los que hemos hecho referencia fueron, pues, los emergentes de una inexistente formación económico-social y de la falta de acuerdo sobre la estructura política a lograr, así como también, aquellos nacidos de una incompleta integración territorial. Problemas que presentaron un constante solapamiento, singularizando, de ese modo, una disputa permanente entre Buenos Aires y el interior y entre tendencias a una más estrecha vinculación con Europa y los obstáculos existentes que facilitaran el intercambio comercial.

La existencia de "facciones" desmesuradas y sectarias en su accionar -y siendo Rozas quien detentaba el poder absoluto- permitieron que, a partir de 1835 los incipientes mecanismos electorales fueran liquidados. En su lugar, se estableció una innovadora "forma" de democracia basada en el sentimiento experimentado por las masas hacia Rozas, así como también, el constante hostigamiento para con la oposición.

Respecto a los "alrededores" de Buenos Aires, el sistema impuesto consistía en enviar a los jueces de paz de la campaña -desde Palermo- la lista conteniendo los nombres de los representantes a la Legislatura que debían ser votados y que, va de suyo, eran devueltas sin modificación.

En la ciudad, directamente no existían comicios, limitándose a una mera formalidad escrita. Queda claro pues, que hasta 1852 se eclipsó la costumbre del colectivo ante el acto comicial -que surgiera en 1821- y que, aún con todos sus extravíos, significó, a no dudar, un comienzo promisorio. (González Bernaldo, 2003: 199-200) ${ }^{96}$

También refiriéndose a las formas de representación y la paralela participación del pueblo en la espacio público, M. Ternavasio transcribe en el inicio de su artículo -referido a la "unanimidad" del régimen establecido por Rosas sobre la base de la coacción y el terror (2003b: 119)- palabras de Domingo Faustino Sarmiento:

\footnotetext{
96 Necesario es realizar algunas referencias en relación a los "mecanismos de politización" utilizados por Rosas durante su segundo gobierno, en derredor a la denominada "Santa Causa de la Federación". En tal sentido, moviliza "[...] a los morenos mediante las Naciones Africanas, otorga nuevas atribuciones políticas a los jueces de paz y echa mano de los curas que deben predicar la 'santa causa' a los parroquianos [...] la sociabilidad en las pulperías no será ajena a esta política proselitista. Aquí son los comisarios de policía y los jueces de paz los que deben velar para que la de vecindad se conjugue con una identificación sin fallo a la federación [...]Esto implica que la particular modalidad de encuentro de los habitantes con la política no solo lleva a una fuerte y obligada identificación de la población con la 'santa causa', sino que también otorga a las autoridades una mayor presencia en la vida cotidiana de los habitantes, un fenómeno que confirma la literatura antirrosista de la época”"
} 
"Rosas era un republicano que ponía en juego todos los artificios del sistema popular representativo. Era la expresión de la voluntad del pueblo, y en verdad que las actas de elección así lo muestran. Esto será un misterio que aclararán mejores y más imparciales estudios que los que hasta hoy hemos hecho [...]", 97

De todos modos, durante el intervalo señalado, fueron tantos y violentos los fraudes cometidos -circunstancia agravada por la obligada emigración de los opositores a la dictadura- que la desaparición de las elecciones no generó demasiada nostalgia en el colectivo elector. (Luna, 1995:32) ${ }^{98}$

Analizando las instancias regionales del ámbito económico-social, necesario es reconocer que los criollos fueron, en su estereotipo, el producto de un lento y arduo proceso de descomposición de todo aquello que caracterizaba al europeo en estas tierras y que claramente describiera Marcos Sastre (v. supra nota 89)

Conocedores de ello, los intelectuales orgánicos de los referidos tempos, se precipitaron a la conquista y educación de las masas.

En la consecución de tal finalidad, la creación del Salón Literario por Marcos Sastre contó con la colaboración de hombres como Esteban Echeverría, Vicente López, Juan María Gutiérrez, Juan Bautista Alberdi y Pedro de Angelis, quienes organizaban reuniones destinadas a lecturas 'científicas' a las que eran invitados -mediante la prensa- los

\footnotetext{
${ }^{97}$ Como menciona la autora al finalizar el aludido capítulo (2003b: 141): "La noción de unanimidad, lejos de asociarse a los valores del universo liberal, se vincula con una concepción organicista y jerárquica de la sociedad y con el predominio del ideal de unidad por encima de la diversidad de funciones. En este marco, la división de poderes es reemplazada por la absorción en manos del poder ejecutivo de las atribuciones de los otros dos poderes, [...] reemplazando la idea de constitución [...] por una antigua práctica de tipo pactista. El punto clave para Rosas fue imponer este ideal de representación en el espacio urbano porque en la campaña ya estaba presente desde el momento mismo en que se instrumentó la nueva representación; el voto por unanimidad, casi generalizado en el campo desde 1821, es una muestra de ello. Por lo tanto, el problema fue siempre la ciudad: escenario de disputas que mostraban la diversidad y pluralidad de una opinión pública en ciernes. En este contexto, el fenómeno del caudillismo en el Río de la Plata -estigmatizado en la figura de Rosas- y su corolario inmediato, el proceso de ruralización y militarización de la política, lejos de asimilarse al modelo clásico, que supone la ausencia de legalidad, muestra una tendencia a absorber la legalidad liberal heredada del espacio urbano, para institucionalizarse con el signo inverso: una representación invertida que prefigura la noción de un gobierno elector -tal como dejó señalado Natalio Botana- en vez de la noción de un pueblo elector. Este tránsito fue indudablemente complejo y deja al desnudo la distancia que separa a Rosas de la más moderna experiencia competitiva de la etapa precedente como, asimismo, de la más lejana representación estamental del Antiguo Régimen”.

${ }^{98}$ Señala Luna: "Es posible que las legislaturas provinciales fueran, tal como ocurría en Buenos Aires, razonablemente representativas de los sentimientos mayoritarios, pero el largo paréntesis de Rosas no favoreció, reiteramos, la formación de una tradición democrática, ni mucho menos estimuló la formación de partidos políticos".
} 
estudiantes, con el propósito de promover un intenso movimiento de ideas, a fin de elevar el nivel público de la cultura y esclarecer la conciencia nacional. (Levene, 1958:236)

Así, en "La Gaceta Mercantil” y en el "Diario de la tarde" de 1837, se publicaban los anuncios de las conferencias a realizarse. Marcos Sastre mantenía relación constante con el público y pedía a los suscriptores que le enviasen los títulos de algunas obras que consideraban importantes para enriquecer la Biblioteca del Salón, a efectos de hacer venir de Europa los libros que deseaban leer en español, francés, inglés, italiano o latín. (Levene, 1958:240) 99

Pese a la innegable nobleza y visión perseguida, esto provocó un primer enfrentamiento cultural, seguido por una encarnizada guerra civil, como fue la lucha desatada entre unitarios y federales.

Llevado por la fuerza de sus ideales y en pro de conformar una Nación, en carta de fecha 28 de septiembre de 1837, Sastre ofreció a Echeverría la dirección del Salón Literario y le transmitió su opinión en el sentido de transformarlo en un Instituto o Sociedad Literaria.

Creía que Esteban Echeverría,

"[...] estaba llamado a presidir y dirigir el desarrollo de la inteligencia en este país, consideraba que era quien debía encabezar la marcha de la juventud”.' (Palcos, 1940: 306 y 1941: 29)

No obstante el reconocimiento formulado -y siendo E. Echeverría el auténtico creador e iniciador de la "Asociación de la Joven Generación Argentina"- en rigor, fue Juan B. Alberdi (1810/1884) quien continuó como orador en el Salón, luego de M. Sastre.

Alberdi también fue director de la revista "La Moda" (editada durante 1837 hasta abril de 1838) y publicó su obra Fragmento preliminar al estudio del Derecho, en 1837.

En su discurso "Doble armonía entre el objeto de esta Institución con una exigencia de nuestro desarrollo social; y de esta exigencia con otra general del espíritu humano”, enunció conceptos fundamentales de orden filosófico e histórico -desarrollados ya en el "Fragmento preliminar [...]”- manifestando que habíamos empezado nuestra revolución por la acción y no por el pensamiento lo cual explicaba las anomalías existentes

\footnotetext{
${ }^{99}$ Recuerda Levene que: "Entre los últimos avisos publicados en septiembre de 1837, se informaba acerca de la impresión de algunas producciones literarias que se realizarían y entre ellas, traducida del italiano 'Los deberes del hombre' de Silvio Pellico”.
} 
“[...] la amalgama bizarra de elementos punitivos con formas perfectísimas, la ignorancia de las masas con la república representativa”. (Levene, 1958:237)

Entendió también, que la misión de las nuevas generaciones debía otorgar a la obra material una base inteligente. Para ello, era preciso investigar, por una parte, los elementos filosóficos de la civilización humana -cometido éste que obligaba recurrir a lo europeo- a la par que, estudiar las formas en que estos elementos inficcionarían respecto a las influencias particulares de nuestra edad y nuestro suelo (esto no había que consultarlo a nadie, sino a nuestra razón). El estudio de lo nacional era un trabajo nuevo, porque no se sabía suficientemente “que lo nacional era un elemento necesario de nuestro desenvolvimiento argentino". (Levene, 1958:238)

Además, y considerando las frustraciones habidas en los intentos por elaborar una constitución, sostuvo, en orden al sistema para elegir a quienes serían los "representantes" del pueblo que,

"El sistema electoral es la llave del gobierno representativo. Elegir es discernir y deliberar. La ignorancia no discierne, busca un tribuno y toma un tirano. La miseria no delibera, se vende. Alejar el sufragio de manos de la ignorancia y de la indiferencia, es asegurar la pureza y acierto de su ejercicio" (Alberdi, 1917: 121)

También Esteban Echeverría, con el propósito de profundizar la búsqueda por "lo nacional", decía que, si bien en su momento, integramos, fuimos parte de la sociedad española, ello no fue impedimento para reconocer que, por entonces, España era la más atrasada de las naciones de Europa. Afirmó que la "independencia" no fue suficiente pues no teníamos leyes ni derecho propios que respetaran nuestras costumbres en defensa y como garante de la libertad. No obstante, al manifestar "Hemos sabido destruir pero no edificar”, elogiaba sin proponérselo, al decir de Levene, a España:

"Nuestro pueblo se hallaba en la mejor condición para organizarse" considerando que la “[...] sociedad de entonces era homogénea, ni había clases, ni jerarquía, ni vicios, ni preocupaciones profundamente arraigadas [...] La revolución pudo casi al principio concentrar toda su fuerza al objeto de constituirse y tenía todo por sí; un pueblo dócil y despreocupado; potencia moral y física; todos los elementos necesarios para realizar sus miras y los encargados de dirigirla se hallaron en la mejor actitud para haber dado al cuerpo social como a un pedazo de cera la forma que hubiesen querido. El pueblo argentino no era como el de París o Londres, que se matan por pan, decía combatiendo el materialismo histórico, y al toque de asonada se regocijan; 
gozaba del bienestar que apetecía. Si lo llamaba el tambor, iba lleno de ardor y entusiasmo, pasaba los Andes, batallaba y vencía; si lo dejaban quieto se entretenía en su pacífica labor. Sólo deseaba paz, orden y libertad. A los gobernantes que no le dieron nada de lo que el pueblo pedía, les había faltado capacidad, ideas, y no ideas vagas, incompletas, que producen la anarquía moral." (Levene, 1958:239)

Palabras que, a nuestro juicio, fueron la 'piedra de toque', ya que generaron toda una actitud que, marcó, en lo esencial, la necesidad de imprimir una orientación nacional a la cultura política y jurídica argentina.

El fundador de la "Asociación de la Joven Generación Argentina", redactó las "Palabras Simbólicas" y el programa del "Dogma Social de Mayo" al que juraron obediencia el 9 de julio y que se publicó por primera vez en el número final de " $E l$ Iniciador" de Montevideo, en 1839, con el título de "Código o declaración de los principios que constituyen la creencia social de la República Argentina”. Es evidente que en esta obra, existen, a no dudar, influencias ideológicas provenientes del exterior -por ende alejadas de las influencias iluministas propias de la época rivadaviana- pero la matriz de los hechos y de las ideas de E. Echeverría provienen de la fuente dinámica de la revolución de Mayo, así como el "Código o declaración de los principios [...]" fue expresión del pensamiento y de la realidad nacional. (Levene, 1947: 35) ${ }^{100}$

Por caso, en la palabra 9": "Contribución de las tradiciones progresivas de la revolución de Mayo", se refirió, especialmente, a los decretos y leyes improvisados en medio de los azares de la lucha y el estrépito de las armas, y en los que se hallan consignados "los principios eternos que están en el Código de todas las naciones libres" (declaraciones y garantías, libertad individual, publicar las ideas sin censura previa, afianzamiento de los derechos del hombre, la necesidad de aliviar la miseria y desgracia de los ciudadanos, propender a su prosperidad e instrucción [...]). Lúcido programa, pero sin posibilidad de pronta realización. Fueron principios santos, que no lograron trasuntarse en la normativa legal a pesar de la voluntad de algunos legisladores.

De allí lo expuesto en su palabra $10^{a}$, referida a dos de los legados de España: sus costumbres y su legislación. Se pronunció acerca de la necesidad de educar al pueblo, para,

${ }^{100}$ Continuó diciendo Levene (1947:245) que: “La etapa constituyente es un nuevo momento original de la inteligencia argentina. Sin duda existieron influencias filosóficas y jurídicas exteriores [...], pero como en la etapa del fecundo estremecimiento de la Revolución de Mayo, las de carácter vertebral y formativo nacieron de las fuentes vivas del paisaje y la historia argentina”. 
de esa manera, estar en condiciones de organizar los elementos hábiles que posibilitaran dictar una legislación conforme con nuestra estructura social, dado que las leyes positivas debían guardar armonía con los principios del derecho natural.

La $12^{\mathrm{a}}$ descansa en la igualdad y la libertad pues define la democracia como el régimen de la libertad fundado sobre la igualdad de clases y -siguiendo a Alexis de Tocqueville- erige el desenvolvimiento gradual de la igualdad de clases en "ley de la providencia".

El realismo de Echeverría, le llevó a considerar que, si los gérmenes de una Constitución no estaban diseminados en las costumbres del pueblo y en sus instituciones, la obra de establecerla era irrealizable. (Levene, 1958: 241/248).

\subsection{La década de 1850.}

Vaciadas pues, las enseñanzas de vida tomadas de Europa, en los moldes de nuestra realidad, -y declarada la lucha a Rozas y a su entorno- aquellos que decidieron continuar bregando por la concreción del ideario levantado en la Revolución de Mayo, debieron hacerlo expuestos a persecuciones y/o, la mayoría de las veces, desde el exilio.

\subsubsection{Aparición de "ideas fuerza".}

Ejemplificando la efervescencia reinante en el entramado social, en enero de 1851, un periódico entrerriano, La Regeneración, publicaba que “ese año”, se llamaría

“[...] en esta parte de América La Organización.

Obra de una admirable combinación de ciencia, patriotismo y firmeza, habrá paz general y gloria en la república y con la República.

El buen derecho y el valor son bases incontrastables que Dios protege.

El gran principio del sistema federal, consagrado por la victoria, quedará consolidado en una asamblea de delegados de los pueblos. De su seno saldrá un mandato de fraternidad, y abrazándose todos los hermanos victoriarán reconocidos un nombre gloriosos que designa a un hombre grande, que simboliza: la constancia en el orden, la firmeza en el designio, el coraje en la lucha, la grandeza en los medios, el heroísmo en los hechos, el patriotismo y la civilización en los fines.

Para nosotros, la única faz del año 51 es La Organización” 
Señala F. Luna que, ante tales expresiones,

“[...] la prensa de Buenos Aires replicó que no era tiempo de dar constituciones, y diversas personas vinculadas con el dictador procuraron que el gobernador de Entre Ríos reprendiera al autor del artículo. Urquiza se negó [...]”' (Luna, 2004a:53).

Ciertamente, las ideas publicadas en La Regeneración, tornaron evidente, hicieron notorio que, la unidad despótica sobre la que Rosas construyó su poder, había llegado a su fin. (González Bernaldo, 2003b: 142) ${ }^{101}$ Ello permitió sostener a Jitrik que,

“[...] La caída de Rosas -3 de febrero de 1852- tiene una primera significación indudable: se rompe un sistema en el cual un hombre -su principal protagonista-, y detrás de él un grupo que por el momento representa inorgánicamente las fuerzas productivas de la provincia de Buenos Aires, trata de modelar la fisonomía del país entero." (Jitrix, 1968:23).

Por lo que, la meta originaria, causa eficiente y suficiente, se reiteraba para la dirigencia política. Una matriz común concitaba los espíritus libres: la organización de la nación, que debía realizarse a través de dos ideas "madres", diríamos de "fuerza": federalismo y constitución.

Atendiendo las diferentes instancias regionales en juego y teniendo en cuenta los disímiles objetivos que persiguieron los sectores en pugna, imprescindible resulta indagar en el nivel de lo 'ideológico', sin que ello implique desconocer la importancia de lo "económico".

¿Se encontraba acaso la temática 'instalada' en el pensamiento de los habitantes? ¿Se escuchaba en boca de la naciente sociedad civil conceptos como unión nacional, justicia, paz, bienestar, libertad? o ¿solo era patrimonio de una dirigencia? Vale decir, de las hoy denominadas minorías de mediación.

En su caso, ¿quiénes fueron, qué perseguían, para qué y por qué, cuándo, cómo? Además ¿qué valores compartían y cuáles fueron los grupos de pertenencia y referencia de aquellos hacedores y formadores de opinión?

\footnotetext{
${ }^{101}$ Completando la idea acerca del sistema de representación y el régimen electoral que se generara el año 1821 en Buenos Aires (cit. 93) y las tropelías cometidas por Rosas contra tales mecanismos, manifiesta González Bernaldo que, "La situación parece cambiar con la caída de Rosas. Entonces asistimos a una verdadera 'explosión asociativa' y un desarrollo sin precedentes del debate público [...] Vemos surgir nuevas formas organizativas: los clubes electorales, destinados a movilizar la opinión en torno a las candidaturas."
} 


\subsubsection{Los hombres de la Asamblea Constituyente.}

Aquellos que la integraron, nacieron a fines del s. XVIII y comienzos del s. XIX. Por lo que, la "obra" constitucional obedeció a la labor desplegada por dos generaciones que se imbricaron 'generacionalmente', vale decir fueron contemporáneas (1842 es el año de "contacto").

Una generación 'anterior-decisiva', (Vanossi, 1970:10) que comprende los años 1828/1842, nucleada en torno a Juan Bautista Alberdi, inspirador de la Carta Magna -cuyo artífice, fue Esteban Echeverría- y formada por Justo José de Urquiza, Marcos Sastre, Juan María Gutiérrez (quien junto con Alberdi creían conveniente establecer una constitución de transición) Domingo Faustino Sarmiento y Florencio Varela; y otra 'posterior', años 1842/1857, encolumnada tras el redactor de la Constitución, José Benjamín Gorostiaga e integrada por Vicente Fidel López, José María Mármol y Bartolomé Mitre.

Sin duda alguna, todos. Tanto los poseedores de medios de expresión, como los intelectuales y/o con ellos relacionados -quienes resultaron forjadores de íconos y consignas- fueron, auténticos generadores de una raison de vivre.

Indagar pues, en cada período lo acontecido, estos es, qué hechos condicionaron una u otra actitud nos permitirá explicar -para después comprender- los distintos comportamientos habidos.

Si bien es durante el período post-rosista en que se gestó un proyecto nacional, indudable es que el ideario que lo generó traía tras de sí toda la carga que individuos y/o generaciones enteras habían imaginado al comenzar el siglo XIX. La lucha, la exigencia de unidad fue enunciada mediante la propuesta de un congruente sistema de principios cardinales en torno a los cuales debía concebirse la mencionada unidad, y que resultaba el obligado cimiento no solo para elaborar proyectos necesarios para la transformación nacional, sino, también, para otorgar firmeza a los incipientes lazos sociales. Era preciso hallar algo más que un conjunto de verdades [...] se necesitaba [...] un dogma. Sus ideas, pues, pretendieron convertirse en acción política, capaz de dotar a la Argentina de un estructura que no fuese tan solo el resultado de luchas habidas en una abrumada formación política, sino que respondiese a un "[...] modelo previamente definido por quienes toman a su cargo la tarea de conducción política." (Halperin Donghi, 1995:15). 
Para ello, menester fue abocarse al análisis de los problemas y aspectos peculiares de la realidad nacional, tendiente a -v.g.: Zuviría, Frías- consolidar un estilo de convivencia social y política basado en la religión.

También fue motivo de preocupación el progreso económico, circunstancia por la que, diversas posturas planteaba la novel dirigencia: ¿puede un cambio en el aspecto económico influir en lo social y político? ¿Cómo conciliar cambio “posible” y "deseable”? ¿Debía lograrse en primera instancia el progreso económico o sería el progreso sociocultural el requisito insoslayable en la consecución del progreso económico?

El acaecimiento de hechos que, por su originalidad, habían resultado definitorios, como la supresión del tirano y la abdicación de diferencias que hasta entonces parecían irreconciliables, fueron puntos de partida para algunos, no todos, pero sí para la mayoría que se hizo escuchar. Hombres provenientes de distintas regiones, portadores de diferentes ideologías -reiteramos, aún no podía hablarse de partidos- discutieron, sancionaron y finalmente acataron el texto constitucional. Para ellos, no fue suficiente garantizar la no agresión, sino bregar por la unión, por la comunión de ideas matrices que permanecían inmaturas; por la celebración de un "contrato social", en el que se abandonaran las mezquindades de momento, reemplazándolas por la firme voluntad de constituirse en estado/nación mediante el dictado de un contrato fundacional.

Pero, ¿puede quizás discurrirse acerca de la existencia de un "contrato fundador” de una nacionalidad?, ¿de un "contrato moral" constructor de sentido identitario? Acaso ¿constituyó un acto fundacional el Acuerdo de San Nicolás? A no dudar el "capital social” conque contó nuestro formación política registró variables respecto a otras estado-céntricas y la historia demostró que no fue suficiente lo 'formal', lo 'explícito', para dotarla de valor y de sentido.

De manera que, en lo aparencial, los problemas habidos desde la Revolución de Mayo, fueron más importantes que los principios por los cuales se había luchado durante treinta años. Se diría que, pese a los ingentes esfuerzos y debates, para algunos la desunión fue un hecho, toda vez que, la inexistencia de roles identitarios había frustrado la unidad nacional.

Tal situación llevó a sostener que 
“[...] El acuerdo que llevó a Caseros (federales provincianos, unitarios, ideólogos románticos, caudillos, etc.) se rompió en seguida, apenas Urquiza pisó Buenos Aires y trató de poner en ejecución un programa de reconciliación [...]” ( Jitrik, 1968:.24)

Sin embargo y sin desconocer la objetividad del hecho histórico en sí, formalizada en la mencionada cita, creemos que -definitivamente, más acá y más allá de disquisiciones que podamos formular entre significante-significado- la existencia del texto constitucional como resultado de arduas discusiones, es el producto de la irrenunciable decisión de, pese a todo, construir un futuro común.

La historia nos entregó una “obra” que fijó límites al otorgar, por una parte, una declaración de derechos y garantías y establecer, por otra, una forma representativa, republicana y federal.

Refiriéndose a ello, sostuvo N. Botana que cada potestad, cada derecho, así como las instituciones u órganos creados por la Constitución Nacional,

“[...] hunde sus raíces en una historia que reúne en torno suyo períodos de consenso y de impugnación, diversas épocas en las cuales quedó retratada nuestra larga discordia entre la libertad y la igualdad.” (Botana, 1988:30)

\subsubsection{El acuerdo de San Nicolás.}

Con relación al acuerdo -cuya finalidad fue "asegurar la organización y funcionamiento del congreso general que, en ejercicio del poder constituyente, sancionara una constitución definitiva" (Zarini, 1981:143) diremos que, fue firmado por los gobernadores de diez provincias el 31 de mayo de 1852 -con posterioridad adhirieron Salta, Jujuy y Córdoba- siendo ratificado por todas las legislaturas provinciales, con excepción de la de Buenos Aires.

La legislatura de Buenos Aires debatió el Acuerdo durante varios días -en las llamadas jornadas de junio- durante los que se enfrentaron opositores (V. Sársfield, Mitre, Portela, Madariaga, Pirán, Montes de Oca, Estévez Saguí, Escalada Riestra) y defensores del mismo (V. F. López -hijo del Gobernador-, Pico, Gorostiaga, Juan María Gutierrez) produciéndose, finalmente, la secesión de Buenos Aires. 
La importancia del Acuerdo de San Nicolás fue determinante para analizar cuestiones previas al Debate propiamente dicho, sea por las manifestaciones a su favor, cuanto las formuladas por sus detractores, esto es, por los habitantes de Buenos Aires.

Por de pronto, el pueblo de Buenos Aires estaba decidido a defender no solo a los Diputados, sino también al recinto de la Sala si Urquiza hacía uso de la fuerza armada para impedir las sesiones. Desde el inicio de las mismas, el pueblo se instaló en la barra y ocupó las calles aledañas a la Sala.

"Cada hombre estaba armado, dispuesto a rendir su vida si los Representantes fuesen atacados. Estos comprendían el peligro que los rodeaba, pero estaban también decididos a arrostrar todo compromiso del género que fuere antes que sancionar el Acuerdo de San Nicolás. La opinión de la Sala era uniforme, y ella iba a dar el primer ejemplo entre nosotros de un cuerpo deliberante que no retrocede al aspecto de las bayonetas con que se ve amenazado; [...] La prensa toda seguía o iniciaba la tumultuosa agitación de estos días [...] "Los Debates”, diario redactado por el Sr. Mitre, se expresaba así el 19 de junio en el artículo 'La Organización Nacional - El Acuerdo de San Nicolás [...]' La organización nacional, formada sobre bases sólidas, eternas, irreprochables, es indudablemente el gran remedio, el único remedio salvador, después de tan largos años de tiranía y guerra fratricida. Pero ¿El Acuerdo de San Nicolás es un remedio o un específico? Sea dicho con el respeto debido al General Libertador que lo ha iniciado y encabeza los nombres de los signatarios: -no, el acuerdo no se funda sobre bases sólidas y eternas; no, no es un remedio eficaz para curar el mal que nos aqueja, y los defectos esenciales que el mismo Gobierno de Buenos Aires le ha tachado, lo colocan en el número de los especificos ineficaces para restituir la salud al cuerpo argentino...” (Ravignani, 1937: 308-309).

En idéntico sentido, sostuvo Halperin Donghi (1996:50)

“[...] Ese esfuerzo de definición de una política (que lleva implícita una imagen de la actividad política distinta de la elaborada antes de 1852) inspira los artículos con que Mitre llena no escasas columnas de su primer diario porteño, 'Los Debates'. En ellos encontramos en el lugar de honor al personaje que Alberdi había querido desterrar para siempre de la vida argentina: el partido".

Mitre lejos de negar la organización nacional, también la deseaba, pero fundada "sobre principios imperecederos, para que los medios estén de acuerdo con el fin [...]."

(Ravignani, E., 1937:309) 
Entendió, al respecto, que el Acuerdo era inaceptable porque las facultades y atribuciones que otorgaba al Directorio Provisorio eran excesivas, por lo que se establecería, a no dudar, una dictadura

“[...] irresponsable, sin contrapeso y sin antecedentes [...] He aquí la razón porque votaré en la Asamblea, como representante del pueblo, por la no admisión del tratado de San Nicolás [...]Nada de específicos - Régimen y Sistema. Todo lo que no sea adoptar esta divisa es desviarse del verdadero objeto, y si aparece un documento que no esté basado sobre esos principios, el pueblo soberano debe decir a sus lictores: -Tomad la esponja y borrad!’ (Ravignani, 1937:.309-310)

También en contra, desde el periódico "El Nacional”, en su artículo "El Tratado de San Nicolás y la Opinión Pública” (19/06/1852), Dalmacio Vélez Sársfield había sostenido que, el poder que detentaba Urquiza, era un

“[...] poder que el pueblo no hubiera votado [...] ya que era un hecho que la opinión de todo el pueblo de Buenos Aires está elocuentemente pronunciada contra el Tratado de San Nicolás [...] La opinión pública, en materias como las del Tratado de San Nicolás, es el sentimiento íntimo de cada hombre por el destino de su patria, sentimiento invencible desde que no puede decirse que el poder que se ha creado por el tratado sea un poder votado en las formas legales, teniendo el pueblo en su constitución toda la parte que debe tener un pueblo que no puede reconocer por su soberano una reunión de Gobernadores, Congreso sin ejemplo para constituir los poderes públicos, Cuerpo Legislativo que el pueblo de Buenos Aires no ha elegido, y cuya voz le es enteramente extraña y desconocida [...] si este juicio es errado, muéstresele al pueblo que él por sí o por sus Representantes, podrá siquiera hacerse escuchar por el Director Provisorio: muéstresele al pueblo, que debe perder todas las instituciones que crió (sic:e) desde 1810 para librar esos grandes poderes públicos a la dirección de un solo hombre [...] La opinión pública lo ha condenado [...] ¿Para qué serviría, pues, un poder como el que constituye el tratado, destituido de toda opinión pública, obligado a alejar de sí a los primeros hombres del país [...]?[...] cualquiera que sea la opinión de los Diputados sobre el tratado de San Nicolás; cualesquiera que sea la opinión del Gobierno de la Provincia, hay una opinión superior que debe vencer a todas las opiniones particulares, cual es la opinión general del pueblo, elemento indispensable en todo orden político, que no debe reconocer verdades absolutas, ni hechos consumados. Un pueblo violentado no es posible gobernarlo: mañana se emancipará. Será a toda hora un poder inmenso que esté amenazando al poder existente. Lo vencerá al fin, porque al fin los pueblos siempre vencen." (Ravignani, 1937: 311-312). 
Coincidente con ello, para Alberdi, tanto la tacha del acuerdo, cuanto el posterior alzamiento del 11 de septiembre de 1852, tuvieron por objeto frenar el establecimiento de un gobierno federal que despojaba a Buenos Aires del ejercicio de los poderes nacionales $\mathrm{y}$, con ello, de los ingresos provenientes de la aduana y el paralelo monopolio de la navegación de los ríos. (Zarini, 1981:146). Con dicha revolución, la provincia de Buenos Aires se liberó del dominio y autoridad de Urquiza, pero ella no obedeció al sentir del colectivo provincial sino que fue el resultado de la insubordinación de tropas comisionadas para vigilarla (Lettieri, 2003:99). ${ }^{102}$

Para legitimarse y en la consecución de establecer una continuidad simbólica entre la revolución de septiembre y la mítica Revolución de Mayo, la élite dirigencial porteña se abocó a la búsqueda de dispositivos que permitiesen crear, en el imaginario social, creencias, usos y costumbres, con la finalidad de obtener "construcciones intencionadamente selectivas" capaces de demostrar el rol fundamental que este vínculo pareciera haber desempeñado en la atribución de legitimidad al régimen político bonaerense en el siglo XIX. (Lettieri, 2003a:97/102)

La existencia de

“[...] una afinada sintonía entre una elite autodesignada y una opinión pública dispuesta a prestar su consenso no solamente a su liderazgo, sino también a los canales propuestos para expresar ese acuerdo" por lo que "Los mecanismos de legitimación del poder de autoridad en los orígenes de la nueva república porteña se correspondieron, fundamentalmente, con la inestabilidad e imprevisión de un 'tiempo acelerado' de la historia, como el que se vivió en Buenos Aires entre la batalla de Caseros y la derrota de los sitiadores de la ciudad". (Lettieri, 2003:114)

\subsection{Año 1852 - Elecciones - Análisis de la Asamblea General Constituyente.}

Hasta aquí, las decisiones políticas -también el "Acuerdo de San Nicolás”- pasaron por la determinación, no exenta de arrojo, de aquellos que ejercían funciones ejecutivas de gobierno, por lo que

\footnotetext{
${ }^{102}$ Añade el autor que "[...] ese alzamiento no fue el producto de una reacción generalizada de la población de Buenos Aires, ni una expresión contundente de esa opinión pública provincial que el liberalismo en la oposición se había abrazado el derecho de ilustrar y representar durante las jornadas de junio [...]".
} 
"Ni la ciudadanía argentina ni la ciudadanía bonaerense hicieron su aparición en la primera mitad del siglo pasado." (Chiaramonte, 2003b: 116)

A partir de 1852, el protagonismo pasará -en principio y 'formalmente'- al pronunciamiento popular para la elección de aquellos que fueran sus "representantes" a la Asamblea Constituyente. A juzgar por las palabras que comentásemos en el punto anterior y en tanto formadores de opinión pública en Buenos Aires respecto al Acuerdo, toca analizar si medió legitimación activa en términos de relativa "participación política". Sin duda que, teórica y doctrinariamente, es decir, conforme el análisis formalizado en nuestra Introducción, el "poder" del Congreso Constituyente tuvo una confusa melànge de legalidad-legitimidad pero no contó, en nuestra concepción, con legitimación activa.

¿Existió, quizás, sólo legitimación pasiva, toda vez que la participación política estuvo condicionada por factores contingentes?

Si ello fue así y en términos de eficacia, de resultado, ¿cuáles fueron los elementos legitimados?

A no dudar, la gesta en la consecución de la unidad nacional, tuvo una cara revolucionaria y otra reaccionaria que originó una nueva sociedad, ordenada conforme a razón y que priorizó el progreso socio-cultural como requisito del progreso económico. Hecho que fue patentizado -después de 1852- a través del surgimiento de los partidos políticos (fuerzas que -como dijéramos con antelación- en su época condenara Alberdi)

Insoslayable deviene, entonces, conocer cuáles fueron los instrumentos electorales con que contaron aquellos que constituyeron el iceberg del proceso de legitimación habido en el colectivo y, en su consecuencia, capaz de dotar -mediante el voto- de legitimidad a los elegidos.

La circunstancia de resultar aceptado a partir de la segunda mitad del siglo XIX el principio electivo -como forma para designar o transferir el poder público- puso al descubierto la presunción de potencial capacidad virtuosa que poseen los electores precisamente para seleccionar, escoger, votar, a quienes han de ejercer el mando. Y si bien no se trató de elegir un "gobernante", pensamos que la elección tuvo mayor relevancia político-institucional toda vez que el pueblo otorgó mandato a quienes en su nombre y representación estuvieron encargados de dictar la norma mediante la cual habría de concretarse la organización nacional. Mandato que, a nuestro juicio, constituyó un valor 
agregado toda vez que puso en ejercicio el poder constituyente originario, la soberanía popular.

Lo señalado no constituye -aunque resulte obvia la aclaración- un absoluto, ya que no invalida la circunstancia, ya enunciada, de encontramos ante un legitimidad heredada (Bragoni, 2003: 205) ${ }^{103}$ toda vez que la Constitución de la Nación deriva de distintas fuentes. Circunstancia que no empece mencionar los procedimientos electorales que fueron utilizados para otorgar mandato, esto es conferir legitimidad, a los Diputados convencionales.

Luego de los, ya mencionados, inicios en el quehacer electoral (v. 4.1. a y b) toca indagar cuáles fueron las leyes vigentes en dicha materia a nivel nacional -desde el año 1852 a 1880- y durante cuya vigencia se desarrollaron tres líneas directrices nacidas a partir del liderazgo de sendas figuras de la escena patria: Urquiza, Mitre y Alsina. Leyes que -en un intento por perfeccionar el ejercicio de los comicios- aunque semejantes en la generalidad de las disposiciones establecidas, fijaron algunas diferencias.

Recordemos cómo se expresaba el pueblo desde la separación -fuere de hecho o de derecho- de la metrópoli. Siempre se recurrió a técnicas electorales que, a lo largo de diez años, presentan designaciones de representantes por vía indirecta: se elegía un cuerpo de 'compromisarios' quienes estaban encargados de nombrar a un ciudadano para integrar un cuerpo colegiado (Junta Grande, Asamblea del Año XIII o Congreso de Tucumán). A tales efectos, y como también mencionáramos, las convocatorias se realizaban generalmente en los respectivos Cabildos -a excepción de Buenos Aires en que se celebraban asambleas seccionales- firmándose un acta en la que se listaban los presentes.

En tren de discernir como se vivenciaron y dirimieron los procesos electorales habidos en nuestra formación social, fuerza es enfatizar los cambios acaecidos -en el año 1821- en la técnica aplicable: primero en la provincia de Córdoba, más tarde en la provincia de Buenos, ya que -el establecer el voto universal- significó un intento por aproximarse

\footnotetext{
${ }^{103}$ Observa la autora que "Vale recordar que para la mayoría de las comunidades políticas herederas del poder colonial, el constitucionalismo liberal se convirtió en la única ideología legitimadora para organizar los nuevos Estados. Pensada la sociedad como pactos de individuos y pensado el poder como producto de la elección de ciudadanos, todo hacía prever que [...] el desenvolvimiento de la política se despegaría para siempre de las amarras corporativas del antiguo régimen e inauguraría en su lugar una tradición republicana afirmada en la costumbre revolucionaria."
} 
hacia un quehacer democrático (Luna, 1995:28-29) ${ }^{104}$ Característica que la generación romántica cuestionaría luego, considerando que en dicho mecanismo radicaba uno de los obstáculos principales para la estabilidad institucional argentina durante la primera mitad del siglo XIX.” (Bragoni, 2003: 208) ${ }^{105}$ De manera que "las elecciones formaban parte de una parodia en la que podía conocerse desde el escenario hasta sus protagonistas y que, por consiguiente, desnaturalizaba la democracia. En cambio, en la actualidad, la idea de pensar las elecciones como instrumento político ha arrojado resultados novedosos en la experiencia porteña del siglo XIX." (Bragoni, 2003: 206).

Las "listas" que posibilitaban el posterior escrutinio -más aquí y más allá del cómo y quiénes- existieron en la formación política argentina desde que se pensó en la organización nacional, considerando que la aptitud de los “elegidos" guardaba íntima adhesión con la de quienes resultaban "electores".

El Congreso de la Confederación dictó las leyes 140 y 207, en los años 1857 y 1859. Por la primera, se estableció el voto calificado -aceptando la doctrina expuesta por Alberdi, "de la pureza del sufragio”- facultativo, personal y no secreto (podía emitirse de modo verbal o escrito), para los varones mayores de 21 años; se votaba por una lista de candidatos a simple mayoría; autorizaba el uso de la fuerza pública contra "elementos indeseables" que se atrevieran a inscribirse en el padrón. El acto comicial -que se efectuaba en las Iglesias- se extendía por tres días (cada día se realizaba un escrutinio provisorio y el último día el definitivo o final). La Ley 207, estableció la lista completa y el voto público, no obligatorio.

En el año 1863, consolidada la unión, el Congreso de la Nación, dictó la Ley 75, estableciendo cómo debía formarse el padrón electoral y el mecanismo de funcionamiento de las Asambleas Electorales; los comicios se realizaban un solo día; el voto era público y

\footnotetext{
${ }^{104}$ Expresa F. Luna que "La primera norma específicamente electoral fue el Reglamento Provisorio de la Provincia de Córdoba, sancionado en enero de 1821, según el cual todo hombre mayor de 18 años podía votar. También podían emitirlo los extranjeros con un mínimo de cuatro años de residencia, así como los hombres de color nacidos en el país si eran hijos de padres libres; más aún, los negros podían ser elegido para cargos concejiles si fueran nietos de negros libres. Por el contrario, se negaba el derecho al voto a los españoles mientras su gobierno no reconociera la independencia de estas provincias. Esta norma estableció el sistema de elección indirecta -por electores- y el sufragio podía ser verbal o escrito".

${ }^{105}$ En ese sentido, ante el repudio al acuerdo de gobernadores -por el que se habilitó la apertura de la asamblea constituyente de 1853- manifestado por la Legislatura de Buenos Aires, J.B.Alberdi, ratificaba su desconfianza sobre el voto popular: "Los escándalos de junio en Buenos Aires son resultado del sistema de 1821, que Alsina y López, tuvieron el desacierto de restablecer en nombre de una libertad mal entendida. Ha dado esta vez, el fruto que entonces y que dará siempre: mientras la ley llame a elegir al populacho, el populacho elegirá niños que dicen lindas frases, porque lo representan".
} 
no obligatorio; la edad mínima para ejercer el derecho a sufragar, se redujo a 18 años. La Ley 623 (1873) disminuyó la edad a 17 años y eliminó el voto oral, pero siguió siendo público. Las leyes electorales 209 (1866), 893 (1877), 1012 (1879), 1024 (1880) у 2742 (1890) no alteraron el mecanismo sustantivamente, aunque fijaron algunas modificaciones. En todas rigió el sistema de "lista completa" y la nota característica de los actos electorales fue el fraude. 1881,1890 y 1895). ${ }^{106}$

El análisis de las manifestaciones vertidas por los congresales -elegidos conforme la normativa de la Ley 140- durante el desarrollo de las sesiones, nos permite inferir que existió margen para el patriotismo y el disenso -que caracterizó todas y cada una de las intervenciones, sólidamente dotadas de fuertes y polémicas expresiones- interpretando, a nuestro juicio, el sentir del pueblo. Insistimos, no sólo el pensamiento, sino el sentimiento nacional y, por ende, el por qué de la búsqueda de un Poder Nacional. Búsqueda que se tradujo, como no podía ser de otro modo, en la necesariedad de dictar la Constitución como modo de satisfacer, al menos en el plano del deber ser el vacío institucional.

Así, la respuesta de quienes se consideraban depositarios del poder soberano, fue dada $a b$ initio de las sesiones de la Convención, al sostener -desde la fórmula de juramento con que se aprestaron a cumplir con la tarea- la profunda responsabilidad y 'creencia' en su cometido, por lo que debían convertirse en auténticos representantes de la "nación” abandonando la mera condición de representantes de una "provincia". (Ravignani, 1937: 406) ${ }^{107}$

Por ello, encontrar los valores democráticos formulados en nuestra carta magna, nos reconduce, insoslayablemente, a interrogarnos respecto a cómo se formó -entre nosotros- la constitución de la libertad, para luego indagar qué acaeció con la constitución de la igualdad.

\subsubsection{Los Diputados constituyentes.}

\footnotetext{
${ }^{106}$ Ver ANEXO I (destacamos que el tema será tratado más detalladamente en el Capítulo II).

107 En referencia a ello manifestó “[...] hoy más que nunca -en los momentos solemnes en que se halla la República y cuando una Provincia había dado el escándalo de la desunión, convenía que el juramento no fuese una vana fórmula repetida-Que el diputado, al tomar posesión de su cargo, debía jurar sostener a toda costa la integridad del territorio contra toda usurpación, sostener la unión y la nacionalidad argentina -desprenderse de todo sentimiento mezquino de localidad, y al tomar posesión de su cargo, dejar de ser representante de una Provincia para ser representante de la Nación.".
} 
Teniendo por cierto que las creencias no pueden ser objetivamente examinadas, para explicar las conductas que originaron el cambio, hemos de considerar en primer término, los sucesos observables que las engendraron.

Para ello, analizaremos el pensamiento político-jurídico de los diputados enviados por las provincias (trece de las catorce) a la Asamblea General Constituyente, partiendo de la premisa que, la distinta procedencia de los mismos implicó, prima facie, -y teniendo en cuenta las relaciones acaecidas en las instancias regionales, como así también el examen geo-demográfico sintéticamente esbozado- que, a pesar de tener clara la finalidad que los concitaba, acudieran dotados de diferentes sistemas de creencias, costumbres, valores y objetivos a lograr.

Desde el inicio, 15 de noviembre de 1852 -en que comenzaron las sesiones preparatorias- se tornaron evidentes las pulsiones de vida que habrían de generarse en las discusiones de fondo. La mayoría de los Diputados, con lógicas diferencias, intervinieron poniendo de relieve una y otra vez, los argumentos esgrimidos en los pactos pre-existentes, fundamentalmente, el Pacto Federal y el Acuerdo de San Nicolás.

Tampoco faltaron -y a los que ya hiciésemos referencia- reproches cruzados, entre los Diputados de la Sala de Representantes de Buenos Aires y los enviados provinciales acreditados por ante el soberano Congreso, en lo que hace a la organización, número y funcionamiento de las distintas Comisiones, así como a la relación del Cuerpo con el Ejecutivo Nacional.

En tal sentido, resultan ilustrativos los dichos de Díaz Colodrero (Diputado por Corrientes), formulados en la Quinta sesión preparatoria del 19 de noviembre,

“[...] la esencia de este cuerpo constituyente consiste en la soberanía de los poderes conferidos a los mandatarios que lo forman, por los pueblos a quienes representan” (Ravignani, 1937:410)

Pese a las diferencias, instalado el Soberano Congreso Constituyente a partir del 20 de noviembre de 1852, un sentir compartido, como lo manifestaron en sus intervenciones, unió a los constituyentes: la profunda convicción que, aún con percepciones opuestas, debían superar cuarenta años de guerra civil y dar a la Patria un instrumento de organización política capaz no sólo de fundar una Nación sino de lograr la reconciliación de espíritus. Sentir éste último, al que muchos dieron en llamar "orden social". 
No ignoraron, y se notó con claridad en todas y cada una de las intervenciones, que debía lucharse por legitimar su accionar para que esa norma no se transformara en 'una hoja lanzada al viento'. En ese orden de ideas, su Presidente -Diputado Facundo Zuviríarespondió al discurso inaugural del Ministro de Relaciones Exteriores -quien acompañó al Delegado del Poder Ejecutivo- manifestando que las deliberaciones estarían substancialmente reducidas a los deseos, las ideas y los sentimientos de los pueblos que representamos. (Ravignani, 1937:412)

Procedentes de las trece provincias llegaron a Paraná desde:

Catamarca: Pedro Ferré y Pascual Centeno

Córdoba: Juan del Campillo (que sustituyó a Derqui), Santiago Derqui y Clemente José Villada (sustituido en febrero por Derqui).

Corrientes: Pedro Díaz Colodrero y Luciano Torrent

Entre Ríos: Juan María Gutiérrez y José Ruperto Pérez

Jujuy: José Quintana y Manuel Padilla

La Rioja: Regis Martinez

Mendoza: Martín Zapata y Agustín Delgado

Tucumán: Salustiano Zavalía y Fray José Manuel Pérez

Salta: Eusebio Blanco y Facundo Zuviría

Santiago del Estero: José Benjamín Gorostiaga y Benjamín Lavaysse

San Juan: Salvador María del Carril y Ruperto Godoy

Santa Fe: Manuel Leiva y Juan Francisco Seguí

San Luis: Delfín Huergo, Adeodato Gronda (sustituido por Juan Llerena).

\subsubsection{Comisión de Asuntos Constitucionales.}

Instalado el Congreso y luego de las sesiones preparatorias, el 24 fue designada la Comisión de Asuntos Constitucionales -encargada de redactar el Proyecto de Constituciónintegrada por los diputados:

-Manuel Leiva (por Santa Fe), universitario, católico, perteneciente a la clase media, conservador, federal y antirrosista, que además de participar en el "Acuerdo de San Nicolás", se desempeñó como senador nacional y ministro con Urquiza; 
-Pedro Ferré ( por Catamarca), universitario, clase media, militar y estadista de larga militancia contra Rosas, nacido en Corrientes fue su gobernador durante tres períodos, colaboró en los pactos provinciales del litoral y, al igual que Leiva, desplegó funciones en los poderes del estado provincial al que representó;

-Salustiano Zavalía (representó a Tucumán), universitario, dedicado a la actividad industrial, suplantó a P. Ferré mientras duró su licencia, siendo de destacar -aunque, dado el regreso de Ferré, no firmase el despacho- su dialéctica y la sabiduría demostrada, como también la nobleza moral habida en sus intervenciones;

-Martín Zapata (por Mendoza), universitario, jurisconsulto y liberal, fue todo un representante de la "estirpe patricia". Exiliado, vivió en Chile y fue miembro del "Comité de Emigrados Argentinos" -contrarios a Rosas-, como también del Comité Constitucional Argentino, con sede en Valparaíso;

-Juan del Campillo (en representación de Córdoba), universitario, doctor en jurisprudencia, de ideología liberal y vinculado a la "Asociación de Mayo", se desempeñó como magistrado, funcionario y diplomático. Ingresó a la Convención en reemplazo de su comprovinciano Santiago Derqui y ejerció la Secretaría, integrando -considerando su gran versatilidad- distintas Comisiones, para más tarde -finalizada su misión en el Congresoejercer el cargo de Ministro de Hacienda y luego de Justicia, Culto e Instrucción Pública durante la presidencia de Justo José de Urquiza y, posteriormente, Ministro Plenipotenciario ante el Vaticano;

-Pedro Díaz Colodrero (por Corrientes), universitario, actuó en la política desde el año 30, junto a Ferré, Cabral, Berón de Astrada, Madariaga y Pujol, joven aún, ilustrado y de sereno juicio fue, muchas veces, el espíritu conciliador que puso paz en los conflictos que amenazaban las relaciones de Urquiza y Pujol;

-Juan María Gutiérrez (porteño y en representación de Entre Ríos), universitario, de ideología liberal, escritor y periodista, fue cofundador de la Asociación de Mayo con Echeverría, Alberdi y López. Exiliado en Montevideo, Europa, Lima, Guayaquil, Santiago y Valparaíso, fundador de la escuela naval de Chile, investigador histórico y literario, miembro corresponsal de la Facultad de Filosofía y Humanidades de la Universidad de Chile (25/06/1859), miembro de número del Instituto Histórico-Geográfico del Río de la Plata (San Juan, 1856); su vida era su blasón y su programa; sobresalió como diputado 
constituyente, como ministro de la Confederación, como diputado al Congreso de la misma y como Rector de la Universidad. Hizo una subestimación rotunda de España en su "Fisonomía del saber español, cual debe ser entre nosotros", negándole toda intervención en el desarrollo de las ciencias, las letras y las artes, exposición que por su espíritu de combate mucho se asemeja al "Manifiesto de las Naciones" que aprobó el Congreso de 1818 redactado durante la guerra de la Independencia por el Pbro. Doctor Antonio Sáenz y, -José Benjamín Gorostiaga (representante por Santiago del Estero), universitario y liberal, fue partidario de una amplia tolerancia y libertad de cultos; laico, rico, razonador, orgulloso, profundamente calculador y práctico, reconocido públicamente como un joven de talento y austeridad cuando, conjuntamente con el presbítero Benjamín Lavaysse fue llamado a desempeñar el cargo de diputado constituyente; desempeñó la cartera de Hacienda en el breve gobierno de don Vicente López y Planes, luego de Caseros, y actuó con Gutiérrez y López en la defensa del Acuerdo de San Nicolás en las célebres sesiones de junio de la Sala de Representantes de Buenos Aires. En el breve paso por el Ministerio de Hacienda reorganizó literalmente la economía y las finanzas provinciales, tratando de arrancar de cuajo el régimen monopolista, de privilegio y persecución que había caracterizado el despotismo de Rosas. Posterior y sucesivamente fue constituyente, ministro del Interior, senador y presidente de la Corte Suprema de Justicia de la Nación. Groussac, poco inclinado a la serena estimación de los hombres del Congreso de Santa Fe, lo destaca con gran respeto y le asigna el papel principal en el proyecto y defensa de la Constitución de $1853 .{ }^{108}$

Si consideramos que la Comisión de Asuntos Constitucionales estuvo integrada por representantes de ocho provincias -de un total de trece que conformaron la Asamblea Constituyente- concluimos que casi el $62 \%$ de los pueblos, esto es de los estados provinciales miembros de la Confederación, debatieron específicamente el tema, por lo que el abanico regional formado por el N.O., Cuyo, Centro y Litoral -la cuasi-totalidad del país-estuvo representado en la misma.

Por ello, en el Informe de la Comisión de Asuntos Constitucionales que acompañó el Proyecto de la Constitución Nacional elevado al Congreso el 18/04/1853, consta que

\footnotetext{
${ }^{108}$ Datos obtenidos de distintas obras, fundamentalmente las mencionadas en la "Bibliografía", pertenecientes a Levene, R., Vanossi, J.R.A., López Rosas, J. y Gentile, J.
} 
“[...] el Proyecto que la Comisión tiene la honra de someter a examen de V.H. no es obra exclusiva de ella. Es la obra del pensamiento actual argentino, manifestado por sus publicistas y recogido en el trato diario que los miembros de la Comisión mantienen con sus dignos colegas [...]” (Vanossi, 1970:37)

También la fórmula adoptada para formalizar el Juramento en calidad de Diputados Constituyentes, y a la que ya hiciéramos referencia (v. supra nota 108), expresamente consagró ese sentido identitario, así como la 'ideología de la modernidad', propia del estado-nación.

Señala en tal sentido Halperín Donghi, que fue una característica generalizada de los hombres que se incorporaron al proceso constituyente de 1853, el mostrarse más interesados por los principios de la libertad y el orden, que por la integridad nacional.

Aludiendo al despotismo español que nos negaba la libertad, había dicho don Facundo Zuviría en 1852:

“[...] El entusiasmo por la libertad creyó al fin asegurarla, creando gobiernos ilustrados, que nuestra independencia pretendía consolidar con máximas metafísicas y exageradas [...]”' (Pérez Ghilou, 1984:24-25) ${ }^{109}$ El pueblo, las masas, que desconocían tales resortes y empezaron por desconfiar de la autoridad que los manejaba, apelaron a su instinto, que no engaña, que es superior y más seguro que toda política, y más fácil de conocerse que todas las teorías de la razón y exageraciones de la demagogia[...]no podían mirar sino con ojo torvo esos gobiernos que ocupados del exterior, de la prensa anárquica, de la tribuna y formas parlamentarias, del lustre y ornato de las ciudades, descuidaban todo lo que existía fuera de ellas y no satisfacían una sola de las exigencias reclamadas por la campaña[...]¿Qué remedios a nuestros males podrá esperarse de gobiernos y de hombres que, por más sabios y virtuosos que fuesen y conducidos por las más sanas y patrióticas intenciones, creían factible plantear en nuestra patria la constitución y leyes inglesas, modificadas con las teorías de la Revolución Francesa e incrustadas con muchas de las instituciones norteamericanas?" (Pérez Ghilou, 1984:.25) ${ }^{110}$

109 "Discurso pronunciado el día 25 de abril de 1852, en la solemne inauguración de la Vigésima Segunda Legislatura de la provincia de Salta, por su honorable presidente, el señor Dr. Don Facundo Zuviría”.

${ }^{110}$ Está claro, que aquí existió una fuerte autocrítica a su actuación y a las ideas vertidas en los años 1821 y 1831. 
4.3.3. Las sesiones - Análisis de la Minuta - Discurso del Presidente de la Asamblea - Intervenciones significativas - Aprobación de la Constitución Nacional.

La discusión en particular del proyecto se desarrolló durante trece sesiones (siete dedicadas a debatir las relaciones con la Iglesia).

Pese a la rapidez con que se examinó, las actas ilustran acerca de la profundidad y dedicación otorgada por los Diputados Constituyentes al tratamiento de las cláusulas. Cabe destacar el esmero, la prudencia y eficacia puestos de manifiesto en el análisis de las cuestiones acerca de la problemática organizacional de la formación política en la que, todos y cada uno, estuvieron empeñados, más aún, considerando que no poseían mayores antecedentes en la escena pública.

Sin duda, José Benjamín Gorostiaga y Juan María Gutierrez en su carácter de miembros

"[...] de la Comisión que preparó el proyecto, son las grandes figuras del Congreso Constituyente, cuyas actas ponen de relieve la preparación jurídica del uno y la perspicacia política del otro" (Vanossi, 1970:43) ${ }^{111}$

Afirmación, que no implica desmerecer la sapiencia y el accionar del resto de quienes integraron la Comisión, pues todos pusieron de manifiesto un profundo conocimiento del derecho público. Muchos de los que pertenecieron a la generación del '37 -Alberdi, Sarmiento y Gutiérrez- lograron esa formación debido a los viajes que realizaron, lo que les permitió no solo formarse en la cultura europea, sino cotejar la efectividad humana inherente a la misma.

“[...] Pero -continúa Vanossi- en el caso de otros argentinos, Gorostiaga entre ellos, se necesita buscar otra fuente ajena a los viajes y a los estudios en el exterior, ya que no se tienen noticias de que hayan realizado tales viajes o estudios [...] Toda su cultura y su formación profesional fueron adquiridas en el trajín de la vida y en suelo patrio..." (Vanossi, 1970:57-59)

Reunido el Congreso fue elegido Presidente, por ser el de más edad, Facundo Zuviría.

Pérez Guilhou muestra a través de su obra, la arraigada creencia cristiana del diputado por Salta, su respeto a la legalidad básica (especialmente con relación a la

111 Se refiriere el autor a manifestaciones vertidas por González Calderón. 
Constitución) su clara preferencia por la forma unitaria de gobierno, y, ya bajo el federalismo constitucional, su inclinación por una práctica centralista. Esto último es fruto de su ferviente deseo de alcanzar la unidad nacional, bajo la égida de un liberalismo firme pero pragmático, adaptable a las vicisitudes de los tiempos. Todo ello permite ubicar a F. Zuviría dentro del eclecticismo que caracterizó el período previo al proceso de la organización constitucional y que permitió identificar los ideales compartidos por “[...] un grupo de notables que cimentó días prósperos de la Patria, días que ellos sólo alcanzaron a vislumbrar”. (Tau Anzoategui, 1988:.XI)

Su presencia en la vida pública del país, marcada por ese eclecticismo,

"[...] lo condujo a ciertas incoherencias por la dificultad de no poder conciliar siempre sus viejas lecturas, de un liberal extremo como Constant, con un tradicionalista reaccionario como De Maistre”. (Pérez Ghilou, 1988:18)

En el análisis de la Minuta y dirigiéndose al "Delegado" del P.E.N., el presidente de la Asamblea Constituyente manifestó que constituían los "Principios" de los Representantes del Pueblo Argentino consolidar el programa de

“[...] unión, orden, libertad, olvido y confraternidad...como único lema digno de la época y de los Pueblos argentinos” (Ravignani, 1937:412)

Pueblos que manifestaron adhesión a Urquiza, porque en él encontraron a quien representaba leal y dignamente su ideario de vida, sus sentimientos, interpretando fielmente sus expectativas y enalteciendo a principio y realidad la idea y sentimientos de la nación [...]" (Ravignani, 1937:412)

Sostuvo también que no había que sentir temor de la anarquía, pues -finalizado su proceso de evolución- ella moría, mientras la nación quedaba.

Al manifestar su dolor por lo que significaba el vacío que proporcionaba la ausencia de los representantes por Buenos Aires, señaló que los pueblos jamás abusan de su razón y fuerza si no son arrastrados a ello y que

“[...] si ha habido extravios, errores y aún crímenes...estos nunca son colectivos, sino actos individuales, de cuya responsabilidad los pueblos están exentos ante la justicia y la razón ilustrada. Una constante experiencia acredita que aún en el más desfavorable de los casos, ellos son las víctimas, nunca los causantes de las desgracias" (Ravignani, 1937:414) 
A favor del texto del proyecto y respondiendo a las palabras de Zuviría, expresó Huergo que

"[...] la adhesión entusiasta de los pueblos Argentinos, había demostrado ya que el programa escrito por la mano del general Urquiza en las banderas libertadoras que triunfaron en Caseros; era también el programa de los pueblos, era el eco fiel de sus sentimientos ardientes pero sofocados, y la expresión verdadera de las necesidades del país” (Ravignani, 1937:420)

Conteste con lo antes expuesto, agregó Seguí que

“[...] la minuta de comunicación [...] contendría en ella gran parte del credo político del Congreso [...]" por lo cual era menester analizar dos aspectos sobre los cuales habría de recaer

“[...] la soberana resolución de la Asamblea Constituyente - a saber, el pensamiento y la expresión que le sirve de forma", estando "plenamente de acuerdo con el pensamiento político dominante en aquella” (Ravignani, 1937:422) y, analizando los sucesos acaecidos en Buenos Aires, expresó que similares incidentes se repiten en

“[...] los mejores cuerpos deliberantes del mundo civilizado - Donde hay hombres, hay miserias - hay debilidades - hay vicios - suele también haber crímenes - Es necesario marcar la diferencia - La política consiste en neutralizar su acción, en desvirtuar su influjo, en utilizarlo todo para el bien común." (Ravignani, 1937:427)

El Presidente de la Asamblea retomó el uso de la palabra, diciendo que

“[...] el trabajo -de la minuta- era excelente considerado filosófica y literariamente, pero no así bajo su aspecto político, porque aparecían resueltas cuestiones de la más vital importancia, y arreglados puntos constitucionales de que el Congreso debía ocuparse con oportunidad y con más calma [...] que la minuta era esencialmente política, como indirectamente acababa de probarlo el honorable Diputado por Salta” (Ravignani, 1937:421) y que

“[...] la incorporación de Buenos Aires a la gran familia argentina era uno de sus primeros deberes, uno, una de las primeras necesidades, y uno de los más vehementes deseos de las Provincias Argentinas representadas por el Congreso [...]” (Ravignani, 1937:425) 
A su turno, afirmó Gorostiaga que la minuta establecía diferencias -en lo que hace al "antes y después" del 3 de febrero- respecto a la conformación de la Sala de Representantes, dado que

“[...] la Sala de Buenos Aires era la única que se había separado de la voluntad argentina formulada en ley por el Acuerdo de San Nicolás de los Arroyos [...] (por lo que) no existe injuria al decir que la actual Sala ha entronizado la anarquía en aquella Provincia, como su predecesora divinizó el despotismo[...]" (Ravignani, 1937:425)

En igual sentido se expresó Gutierrez quien, aludiendo a los vicios de los poderes públicos (directa referencia a las Salas) mencionó que

“[...] se habían aplicado con generalidad [...] y que mientras no hubiese una Constitución que llenase el vacío de las instituciones actuales, estaríamos siempre en el desorden, y que aun cuando no lo hubiese, habría siempre el peligro mientras existiesen las causas que lo motivaban”. (Ravignani, 1937:425-426). Agregando que, los

"principios generales de politica desarrollados por la Comisión habían sido mal interpretados haciendo de ellos aplicaciones inoportunas [...]” y que cuando había resaltado "el vicio radical de nuestras instituciones [...]" lo había hecho creyendo que "cuando se trataba de organizar, era más que nunca político confesar francamente nuestras miserias, y poner sin embozo la mano sobre las llagas de nuestra sociedad para mostrarlas a los pueblos y a los gobernantes, y hacer sentir la urgente necesidad de remedio;[...] que al hablar sobre la Sala de Buenos Aires [...](la Comisión) lo había hecho como de un cuerpo político con abstracción completa de las personas" (Ravignani, 1937:428). Cuerpo político que "por el vicio de su origen no representaba en realidad a la Provincia de Buenos Aires, porque había comprometido su dignidad y desconocido sus intereses [...] por cuanto, como había sostenido la Comisión, 'bajo la administración de Rosas (las Salas) no eran sino un instrumento de dominación en manos de los Gobernantes' ", (Ravignani, 1937:429)

Nuevamente tomó la palabra Huergo, sosteniendo que, en la minuta, no había sido valorado

“[...] el alto concepto político que contenía - que la Comisión había dicho con profunda verdad que en el vicio orgánico de nuestras instituciones estaba la raíz de nuestros males y el germen de desmoralización que había producido unas veces el avance del despotismo, y otras los 
desbordes de la anarquía [...] que se vulgarizaba el pensamiento de la Comisión no viendo sino entidades personales donde ella había colocado una entidad moral, no viendo sino personas donde ella había visto un cuerpo político [...] que antes que todo era necesario hacer ver a los pueblos la necesidad urgente de que la Constitución viniese a llenar el vacío y la insuficiencia de instituciones que podían degenerar en instrumentos de desmoralización al embate de las pasiones ...que al hablar de la Sala de Buenos Aires, la Comisión no había sido impolítica, porque no puede clasificarse de este modo la verdad que se dice a los pueblos por dolorosa que ella sea[ ...] que estaba seguro que la decisión de enfrentarse con el Congreso no era ni podía ser el voto del noble pueblo de Buenos-Aires, que tenía necesidad de descansar en la paz afianzada por la Constitución, y de estrechar los vínculos rotos de confraternidad con las demás Provincias Argentinas" (Ravignani, 1937:428).

Más adelante y compartiendo el sentir favorable a la aprobación de la minuta en examen, Fray Manuel Pérez, opinó que

“[...] no podían comprender como desconocían verdades tan obvias [ ...]que la misión del Congreso no era lanzar al viento una hoja de papel escrita (como había dicho Gondra, al rechazar la minuta precedentemente) sino preparar el terreno [...] (porque) la parte sensata y culta de nuestras poblaciones era muy pequeña en comparación de las masas incultas aún y sin costumbres - que en nuestras instituciones representativas no habían entrado hasta hoy todos los elementos sociales que deben formarlas, para que sean la verdadera expresión de las necesidades de los pueblos - que la riqueza, la industria, la fuerza, el clero y todos los demás elementos sociales debían tener allí su órgano y su voz - que los pueblos estaban todavía en la infancia y que las instituciones debian estar en relación con sus costumbres” (Ravignani, 1937:429)

A renglón seguido y demostrando, una vez más su ferviente oposición al dictado de la norma fundamental, en el discurso del 20 de abril de 1853, sostuvo Zuviría que

“[...] los Diputados de un pueblo libre deben a su Patria sus acciones su ser y su misma vida. Le deben también hasta el sacrificio de su crédito y popularidad que es el mayor esfuerzo del patriotismo y el signo más elocuente de la propia convicción- Más no le deben el sacrificio de su conciencia, sino es para servirla con ella por medio de la noble y leal expresión de sus dictados [...] Toda reserva todo temor, en la franca expresión de nuestras opiniones [...] comprometería [...] el crédito de nuestra libertad e independencia individual, tan necesarias a la legalidad de nuestros actos. En uso pues y ejercicio de esa libertad, paso a llenar por mi parte el mayor de los 
deberes que me impone la misión de que estoy encargado, y creo llenarla, no lisonjeando ni a mi misma Patria; no disculpando sus errores, encubriendo sus faltas, alabando sus extravíos, ni disimulando con sombras el lamentable cuadro de su situación-Lisonjear a los pueblos como a los gobiernos, en vez de ilustrarlos en la marcha que deben seguir; antes que servicio, es una traición; porque solo se les puede lisonjear con el objeto de seducirlos para corromperlos[...]) Se dice[...]QUE LOS PUEBLOS DESEAN CONSTITUCIÓN. QUE PIDEN CONSTITUCION. QUE LA EXIGEN DE SUS REPRESENTANTES. Si esto es cierto sin condición alguna, será porque en la Constitución crean ver el remedio de los males que los aquejan, el término de sus prolongadas desgracias, el sepulcro de la tiranía y anarquía que los han devorado, la fuente de un inmenso y feliz porvenir, el verdadero y único garante contra las revoluciones y crímenes que forman su sangriento cortejo [...] Sin embargo creyó inoportuno el dictado de la Constitución, ya que [...] La ciencia del Legislador no está en saber los principios de derecho Constitucional y aplicarlos sin más examen que el de su verdad teórica; sino en combinar esos mismos principios con la naturaleza y peculiaridades del país en que se han de aplicar; con las circunstancias en que este se halle, con los antecedentes y acontecimientos sobre que se deba y pueda calcular: está en saberse guardar de las teorías desmentidas por los hechos ya sea por la falsedad de ellas, o su mala aplicación- Está también en conocer todos los elementos materiales y morales que encierra la sociedad sobre que va a legislar- Está finalmente, en saber juzgar y combinar todas las pretensiones e intereses discordantes de los Pueblos que constituyen dicha sociedad [...] Empíricos políticos siempre hemos querido aplicar remedios prontos y heroicos sin examen de la calidad de ellos y del estado del paciente-Los resultados han correspondido a nuestra imprudencia[...]Aún no han acontecido entre nosotros un cambio de Gobierno que quizá no haya sido sino de personas, no de ideas, principios ni costumbres que no cambian en un día; cuando en el acto, atribuyendo los males pasados a esas personas y no a causas reales permanentes y ligadas a intereses de otro orden se ha convocado a un Congreso para que dictase una Constitución, quizá sin más variantes que los motivos prominentes que han servido de causa o pretexto a la revolución a que debe su origen. Y qué ha resultado de esta aberración, sino lo que está consignado en nuestros fastos de sangre? Ni qué otra cosa podía resultar de Constituciones, que como dictadas a consecuencia de una revolución, vienen a ser el Eco de ella, el resultado genuino del principio o partido victorioso y no de la Nación que se compone de vencedores, vencidos y neutrales? Qué, de una obra nacida del foco de las pasiones en ebullición y sin el apoyo de esa aquiescencia general de los espíritus sobre la que no se puede contar en medio de fuertes conmociones políticas, ni aún después de ellas, sin dar treguas a la calma que solo se obtiene después de corrido algún tiempo que pasó la tempestad? Ni como suponer esa calma de los Pueblos, cuando sus mismos conductores participan del fuego de 
la revolución de que han nacido y a que quizá deban su existencia?[...]resulta indefectiblemente que toda Constitución dictada en medio de fuertes sacudimientos o a consecuencia de ellos, participará de su extremada energía, de la energía de las revoluciones que por justas que sean, siempre son el resultado de una violenta explosión, cuyos efectos serán revolucionarios por el espíritu que los anima y la violencia de su acción[...]la Constitución que de ellos emane, no será sino la enérgica expresión de esas pasiones, de esos sacudimientos, que si fueron útiles para destruir lo preexistente, no lo serán para desenvolver el caos que ellos dejan, para despejar el terreno del montón de ruinas que queda y empezar a edificar con la calma de la razón y de la sabiduría, único molde en que deben ser vaciadas las leyes y en especial las fundamentales. Siendo pues revolucionarios y violentos los actos que de dicha Constitución emane, no será extraño que perezca al nacer, sin dar otro resultado que aglomerar materiales para nuevos y frecuentes incendios. De aquí resultan las incuestionables verdades siguientes, comprobadas con nuestra propia historia:[...] oportunidad,[ ...]cada frustración hace retroceder[...], aceptar la misión de constituir un país sobre montones de ruinas y cadáveres sin previa preparación del terreno, o en medio de las tempestades y las olas embravecidas sin esperar que ellas calmen, no importaría otra cosa que aceptar la responsabilidad de la anarquía y del mayor de los escándalos que se pueda ofrecer: 'sacar el mal de la misma fuente del bien',[...]que cuando no hay costumbres republicanas, la República es la peor de las formas, así también, cuando los Pueblos no están preparados para recibir una Constitución, la Constitución es el peor de los remedios que se puede aplicar; [ ...] que esa preparación no ha de buscarse en la mente de los Legisladores, sino en las costumbres, opinión, hábitos públicos y en la disposición de los espíritus para recibirla, observarla y acatarla, como el símbolo de su fe social y política[...] $]_{\zeta} Y$ nuestra Patria se halla en tal estado?[...]El hombre público y en especial el Legislador, no puede dejar de prestar atención al tejido de antecedentes y circunstancias de que se compone la historia de cada país, de cada época y aún de cada individuo influyente en la sociedad-Solo ese tejido revela el verdadero carácter de los Pueblos, de los sucesos, de las épocas, de los individuos y de su influencia social- Solo el conocimiento y examen de ese tejido puede avisar la oportunidad de constituir una Nación y fijar su incierto y vacilante destino. Sin ese examen, todo será aventurado, todo será un ensayo, y las Constituciones no son una materia de ensayo sino el término de ellos[ ...]El objeto de toda Constitución[ ...] debe ser unir y conciliar los derechos, intereses y fueros de los Pueblos e individuos para que todos vivan en pacífica comunión[...] es preciso no olvidar, que el Congreso[ ...]tiene que medirse[ ...] con toda la revolución en la plenitud de su desarrollo[...]tiene que luchar con todos los vicios acumulados en tantos años de anarquía y despotismo; con vicios elevados por el tiempo al rango de virtudes e instituciones; con intereses distintos y quizá encontrados de los 
mismos Pueblos que va a constituir, con justos o injustos derechos prescriptos por una larga y pacífica posesión[...]Debe también advertir que va a dar una Constitución[...] sin haber podido ilustrar a los Pueblos con anticipación sobre las más graves cuestiones y nuevos problemas que debe resolver la Constitución que se dictare[...]Para creer llegada la oportunidad de constituirnos, parece que no hubiéramos contado con otro antecedente que haber triunfado del Dictador; sin advertir que triunfando de él, no hemos triunfado de la Dictadura- Aún pesan sobre nosotros la dictadura de los vicios que él nos ha legado; la dictadura del crimen y de la corrupción; la dictadura de la anarquía y guerra civil que con tanto furor han sucedido a su caída; la dictadura de la fuerza armada que a falta de otros medios morales, decide entre nosotros de todo nuestro ser social y político; la dictadura en fin de la crisis y de la situación a cuyo nombre callan todas las leyes y se legitiman todos los abusos y excesos[ ...] los excesos después de Caseros[ ...] nos revelan que nuestra Patria aún no había acabado de recorrer los últimos períodos revolucionarios, y que los Pueblos no estaban aún cansados de revoluciones y anarquía como se había creado, sin calcular en que las generaciones que se renuevan, no se cansan con sufrimientos ajenos, porque las fatigas y desengaños son personales[...]Las instituciones no son sino la fórmula de las costumbres públicas, de los antecedentes, de las necesidades, carácter de los Pueblos y expresión genuina de su verdadero ser político. Para ser buenas y aceptadas deben ser vaciadas en el molde de los Pueblos para que se dicten. ¿Y cuáles son nuestras costumbres, nuestros antecedentes, nuestro verdadero ser político y normal, para que lo traslademos a una Constitución, o que esta sea vaciada en aquel?[ ...]aún subsisten la agitación en los espíritus, la discordia en las ideas y pretensiones, los vicios legados por el despotismo, y que aún nos domina la fiebre de la anarquía con otros elementos disolventes y corrosivos de toda Constitución [...]Casi todos los Gobiernos antiguos y estables, se han formado, no por actos simultáneos sino sucesivos, que con el tiempo han venido a formar una Constitución- Las Capitulares de Carlo Magno, la Gran Carta de Inglaterra, la Bula de Oro de Alemania, el poder Papal, y los Códigos eclesiásticos; la antigua Constitución Española; los fueros de sus provincias y Reinos; todo ha sido el resultado de hechos sucesivos y no simultáneos[...]Alquimistas de la política, dogmatizadores de ella en toda América, somos los únicos que no hemos visto realizados uno solo de sus principios liberales - Estimándonos por sabios, políticos, diplomáticos y hombres de Estado, somos los únicos que no hemos gozado una sola época de paz, de libertad práctica, de felicidad, de abundancia, de orden interior, ni de respeto exterior; los únicos que en toda línea retrocedemos cada día, en vez de progresar; somos en fin, los únicos que en vista de nuestro estado, la América y la Europa nos compadecen, nos desprecian o insultan[... $]_{\zeta} Y$ por qué tanta desgracia? Porque de todo hemos abusado, y más que todo, de la oportunidad para nuestros ensayos. Aspirando siempre a la primacía en estos, solo 
hemos obtenido amargos desengaños y ser los últimos en las realidades...la anarquía y el despotismo no se sofocan ni dominan con leyes escritas: [...] las hondas llagas que ellas abren, no se curan en un día ni con un remedio [...] ]solo después de dominados aquellos monstruos por un poder fuerte, justo y vigoroso, es que se necesita de leyes fuertes, justas y vigorosas para evitar su regreso. La Constitución es planta nueva para el Pueblo Argentino: pide un terreno abonado antes por la paz y calma de las pasiones, por algunas leyes preexistentes, por algunos hábitos de orden y de una racional obediencia - Pide sobre todo, miramientos prolijos y estación oportuna para plantarla[...]antes de dictar la Constitución debemos sofocar la anarquía, cortar la guerra civil y restablecer la paz en toda la república, si no queremos que una nueva anarquía y más sangrienta guerra civil sea el Te Deum que los Pueblos canten a nuestra obra[ ...] Como representante de la Nación, no puedo ver la cuestión de constituir mi Patria ni con la voluntad, ni con la imaginación porque todo lo visto con ellas, pierde sus formas naturales, todo se altera[...]debo ver la cuestión con la lente del juicio, del raciocinio, y de la previsión fundada en la experiencia que le sirve de antecedente[...]me enseña que sin previa paz en que se conquisten algunos bienes en el orden social que debe preceder al político[...] es de todo punto arriesgado establecer esta, que siempre supone la preexistencia de aquel y la posesión práctica de algunas garantías inherentes al hombre en sociedad[...] ¿Daremos Constitución en los mismos momentos en que tenemos que tolerar, legitimar y aún aplaudir los excesos consiguientes al mismo estado de guerra, que es el peor de los efectos y el mayor de los males que ella envuelve?[...]para que la honra, la vida, la hacienda y otros derechos del hombre antes que del ciudadano, puedan ser consignados en una Constitución, es preciso que se empiece por respetarlos prácticamente si no se quiere que sean luego violados con la Carta que los consigue.[ ...]¿Cuál es el destino político de los Pueblos sino el de ser oprimidos como súbditos para que en provecho de sus opresores, expresen la voluntad como soberanos y legitimen sus mismas cadenas? Pero ¿ni qué otra Soberanía real les ha quedado, que la de alternar entre la esclavitud apoyada en nuestra abyección, o la anarquía provocada con nuestras exageraciones de Libertad?[...] la la sombra de la paz, en vez de habitantes desgraciados, porque carecemos aún de los derechos de hombres, empezaremos a ser Ciudadanos de nuestra Patria, y gozar de las garantías de tales[...]La fuerza moral de las leyes y costumbres recobrará su imperio usurpado por la fuerza física, enemiga del orden cuando no emana de aquellas.[ ...]los Pueblos prefieren la paz a la libertad porque solo en la paz ven goces presentes que son por los que obran[...]"

También y respecto al Acuerdo de San Nicolás, Zuviría había sostenido en 1852 que la 
“[...]política no es otra cosa que la ciencia de conciliar los recíprocos intereses de la sociedad, y éstos no se concilian sino a costa de nuestras concesiones y aún sacrificios, (Pérez Ghilou, 1988:3 ${ }^{112}$ [...]la ciencia o tino político está en comparar lo sensible de los sacrificios con la utilidad que ellos produzcan; está en conciliar un mayor número de intereses discordantes o encontrados; está en fin, en calcular lo que se deba a las circunstancias y a las personas, sin mayor lesión de los principios y derechos de la justicia[...] (Pérez Ghilou, 1988:.3-4) 113 “[...]Sea por nuestro permanente estado de guerra ó por otras causas[...] es una amarga y desconsolante verdad que entre nosotros se carece de toda idea práctica en orden á seguridad de las personas y respeto a las propiedades[...]”. Se pregunta: ¿qué derecho es respetado?, ¿con qué seguridad se cuenta?, ¿qué igualdad se conoce en nuestros Pueblos? Consideró que muchos lo culparán por exagerar la situación por la que, entiende, atraviesa la Patria, pero - a contrario sensupiensa que [...] "En política como en moral, ocultar la verdad, disfrazarla o negarla, es perpetuar el error alejando su remedio" (Ravignani, 1937:.469-478) ${ }^{114}$

Su intervención fue seguida por la réplica de Juan M. Gutiérrez quien manifestó

“...muy al principio de este siglo, dijo un distinguido político, que solo había dos modos de constituir un país; tomar la Constitución de sus costumbres, carácter y hábitos, o darle el Código que debía crear ese carácter, hábitos y costumbre, sino los tiene - Si pues el nuestro carece de ellos, si como el mismo señor Diputado de Salta lo expresa en su discurso, "la Nación es un caos", la Comisión en su Proyecto presenta el único medio de salvarla de él. La Constitución no es una teoría, como se ha dicho; nada más práctico que ella; es el Pueblo, es la Nación Argentina hecha ley, y encerrada en ese Código que encierra la tiranía de la ley, esa tiranía santa, única a que yo y todos los Argentinos nos rendiremos gustosos - Los pueblos nos la piden con exigencia, porque ven en ella su salvación; y es por otra parte la oportunidad más aparente para dársela; debemos

112 "Informe sobre el Acuerdo de San Nicolás".

113 "Moción de Paz y Unión con Buenos Aires".

114 Cabe señalar que, la circunstancia de haber reproducido casi en su totalidad el meduloso discurso de Facundo Zuviría -pese a que no integró la Comisión de Asuntos Constitucionales- reside en que, a nuestro juicio, fue quien más se detuvo en el análisis del ejercicio del poder constituyente en lo que a justificación del poder se refiere, esto es, de otorgar legitimidad a la construcción del Estado-Nación. Posteriormente, tanto nuestra concepción de legitimidad cuanto la detenida lectura de los debates habidos nos llevó a una disímil conclusión, ya que, no obstante utilizar en su argumentación la categoría conceptual legitimidad en rigor aludió a legalidad o se refirió a legitimidad jurídica no legitimidad política. Esto así, dado que en casi todas sus intervenciones, en tanto Presidente del Congreso, su respeto por la legalidad básica, ejemplificada a través de las nociones de oportunidad, mérito y conveniencia -más allá de su expresa mención- estuvieron presentes en ellas. Registrándose por otra parte, pocas o ninguna referencia a la conceptualización adoptada por nosotros como resultante del análisis realizado en la Introducción. 
hacerlo sin pérdida de tiempo; y pretender su aplazamiento es una acción que no me atrevo a calificar” (Ravignani, 1937:479/480)

También, Zavalía, en respuesta a Zuviría, analizó los argumentos de fondo sobre los que giraran las reflexiones de éste último señalando, a nuestro juicio, con decidido espíritu irónico, que habían sido "elaboradas con el brillo de su talento y las ventajas de la calma del bufete!!!":

En cuanto al "orden y la paz”, sostuvo que

"[...] Con las imperfecciones propias de nuestro modo de ser político existen los Pueblos por lo general, subordinados a sus Gobiernos; [...] piden a gritos la organización nacional [...] y si el orden no es completo es porque falta la Constitución y esperar que todo esté en orden y en paz para darla es como esperar a que sane el enfermo, para aplicarle los remedios."

Tocante a la "falta de costumbres republicanas" para promulgar la Carta, expresó

“[...] por lo mismo que nuestros pueblos no están educados, es preciso ponerlos cuanto antes en la escuela de la vida constitucional[...]ni la anarquía ni el despotismo en que se vivió desde la Independencia 'no es a propósito para formar buenos ciudadanos' (ejemplos de Chile y Perú que marchan por un camino de prosperidad) [...] el ejemplo tomado de Estados Europeos (constituidos por actos sucesivos) "tienen con el nuestro muy poca analogía", guardando grandes diferencias en lo que hace a origen racial y antecedentes históricos se refiere.

Refiriéndose a la "falta de un poder suficiente", mencionó que la Constitución lo crea

“[...] y será robustecido por el poder incontrastable de la opinión nacional [...] recuérdese que, en tiempos anteriores, la resistencia a la organización solo ha emanado de los Gobernantes, y nunca de los Pueblos; ” por el contrario [...]hoy están todos de acuerdo” (Ravignani, 1937:480/481)

Por su parte Zapata -en contra de lo sostenido por Zuviría- a la par que mencionó la irrevocabilidad del mandato dado a los Convencionales Constituyentes manifestó que no cumpliría con su deber

“[...] ]sino protestase expresamente contra la oposición que ha hecho el Sr. Diputado por Salta[...] por considerarla antiparlamentaria[...] dado que la cuestión sobre la oportunidad 
del dictado de una Constitución está resuelta ya por este mismo Soberano Congreso desde el 24 de diciembre último[...] ]esa resolución más que una ley del Congreso, es una ley anterior y superior á las facultades de nuestro mandato mismo; porque fue sancionada ya por los Pueblos que representamos aquí- Esa ley, en fin, fue firmada hace cerca de un año en San Nicolás de los Arroyos[...] y para cuyo cumplimiento se instaló este Congreso [...] ¿Con qué derecho podríamos hoy volvernos contra nuestros comitentes?. Sin desconocer la conveniencia del Directorio Provisorio [...] "porque las lecciones de nuestro pasado abogaban por la urgencia de una Autoridad Nacional Provisoria anterior a la Constitución que se diera al pueblo Argentino[...] consideró que [...] el único y grande objeto de ese Directorio Provisorio estará satisfecho con la sanción y promulgación de la Carta Constitucional, y la elección que con arreglo a ella se haga del Poder Ejecutivo Nacional permanente- ¿Para qué se quiere entonces prolongarlo?[...]Nuestras Provincias están cansadas ya de ser gobernadas por estatutos provisorios, por tratados provinciales, [ ...]Cuarenta y tantos años de amarga experiencia[...] le han servido de enseñanza [...] Ellas quieren una Constitución que ponga término a todo eso: nosotros estamos obligados a dársela, y el Congreso debe también á la Nación y al Mundo civilizado la expresión completa de su pensamiento consignado en este Código" (Ravignani, 1937:481-483)

El Diputado Huergo, refutando los argumentos de Zuviría y las razones invocadas acerca de la inoportunidad reaccionó con profunda sorpresa y -considerándolo como un grosero insulto a la faz de los Pueblos- sostuvo que

“[...]la República Argentina necesita un Gobierno fuerte y vigoroso, pero quiere un Gobierno nacido de la Constitución, armado con todo el poder que ella le dé, porque es mejor, como ha dicho muy bien un eminente publicista Argentino, en vez de dar el despotismo a un hombre dárselo a la ley[...] y, al fundamentar la continuación del Directorio Provisorio, sustentó la idea que "el Poder Nacional debe tener su origen y su fuerza en la libre elección de los Pueblos Confederados: a ellos, y no a nosotros corresponde su elección por el Acuerdo de San Nicolás[...]las Constituciones son unas veces el resultado y muchas otras la causa del orden moral de las Naciones - En Inglaterra, en los EE.UU., ella ha sido el resultado del orden y de las buenas costumbres - Entre nosotros, como en muchas otras partes, ella será la causa, ella será la que morigere nuestros hábitos y la que eduque nuestros Pueblos”. (Ravignani, 1937: 483-484)

En idéntico sentido, al tomar la palabra el Sr. Seguí, enfatizó, 
“[...]Estoy dispuesto a suscribir una Constitución cualquiera, antes que conformarme con el modo de ser actual de la República, con la prolongación de (este) estado de cosas[...]Esas convulsiones locales, esos movimientos de círculo, esas revoluciones de intereses personales, en que se disputa el bastón del mando, porque todos se creen con derechos iguales para empuñarlo, no son más que el fruto del aislamiento provincial, y de la falta de una ley general que declare y haga efectivos los derechos y los deberes de todos, que determine y marque las atribuciones y órbita del poder, así como los límites de la obediencia y las obligaciones que impone. Así es que, una Constitución como la que en Proyecto se discute, debe ser aclamada con enajenamiento patriótico por todos los que quieran mandar con dignidad a los Pueblos y ser garantidos en sus altas funciones administrativas, así como por los que quieran ser mandados con arreglo a su calidad de hombres libres[...]"

Y, refiriéndose a la situación que se vivía en la ciudad de Buenos Aires, manifestó que

“[...]ojalá fuera posible desparramar en la Ciudad de Buenos Aires, medio millón de ejemplares de ese Proyecto para vulgarizar más y más los principios de eterna verdad que en él se contienen[...] que la situación presente, es la única que en el período de 43 años ha ofrecido la República para constituirse. Lo creo así, desde que observo, que los poderes personales han desaparecido del suelo Argentino. Hoy nadie puede encontrar prosélitos para oponerse a una Constitución generosa y libre, como la que se ha presentado al Congreso. El pensamiento nacional se robustece de día en día; el sentimiento constitucional se agiganta, y sería inevitable la caída del que enarbolara una bandera de oposición a esa ley, en que se funda las seductoras esperanzas de todos los argentinos”. (Ravignani, 1937:486-487)

En su intervención, el Sr. Lavaysse se dirigió a Zuviría diciendo

“[...]Deseo que el señor Diputado por Salta, al aconsejar en su discurso[...]que se suspenda el Proyecto de Constitución por un tiempo indefinido; nos muestre alguna medida más aceptable y más conveniente que la Constitución, para presentarla a los Pueblos[...]No creo que[...] quiera sustituir a una Constitución ilustrada y liberal, como la que contiene el Proyecto de Constitución presentado por la Comisión, una Dictadura irresponsable, en la que manifestemos a los Pueblos nuestros mandantes, que les ofrecemos, en vez de un Gobierno riguroso y fuerte por la razón, por la ley y por la justicia, algún Gobierno despótico, armado de la suma del poder; burlando de este modo las esperanzas y el vehemente deseo de los Pueblos por recibir cuanto antes la ley fundamental, que asegure la prosperidad y el engrandecimiento de la República[...]" (Ravignani, 1937:484-485) 
Acto seguido Zuviría solicitó la palabra para explicar algunos conceptos de su discurso -fundamentalmente, “inoportunidad”- y esgrimir su defensa, cerrándose a continuación el uso de la palabra, con la intervención del Diputado Seguí quien, después de algunas consideraciones consecuentes con las mencionadas supra, pidió se procediese a votar.

De modo que, finalizado el debate, el Proyecto de Constitución presentado por la Comisión de Negocios Constitucionales,

“[...] resultó unánimemente aprobado, y aclamado por una mayoría de catorce contra cuatro en la sesión del 20 de abril de 1853”. (Ravignani, 1937:488)

En la sesión del 5 de mayo de 1853 se discutió en general la Minuta de comunicación al Director Provisorio, entre otras ideas se expresó:

“[...] El Congreso obligado por la naturaleza de sus graves tareas a meditar sobre el destino de las sociedades y sus revoluciones se ha imbuido de la idea, de que las revoluciones sólo son legítimas, cuando salvan las ideas, los pueblos, sus intereses esenciales, la honra entre ellos, y los derechos que la humanidad emancipada por el cristianismo, ha afirmado por la civilización - Nuestro lúgubre pasado, antes de Mayo de 1851, justificaba una revolución, si hay alguna que pueda ser necesaria. Pero legitimarla solo podía el intento y la reparación - El Congreso encontró aquel en el válido programa del $1^{o}$ de Mayo de aquella fecha - En el Acuerdo de S. Nicolás de los Arroyos ha visto el medio; y el Congreso instalado, reuniendo al fin y objeto el poder, debió hacer que la obra correspondiese al designio, y la egecución al intento - La Constitución, Señor, de la Confederación Argentina, ha legitimado vuestra revolución[...]Dios crió al hombre bueno y sociable bajo todas las latitudes. El Argentino lo es, y por serlo, su sangre generosa ha corrido a torrentes - El sentimiento de lo justo lo ha hecho reclamar, tal vez con exageración, la justicia; el sentimiento de su dignidad, los derechos de libertad, seguridad y propiedad - Sus instintos de progreso lo hacen reclamar con impaciencia todas las mejoras y todas las relaciones morales, intelectuales y comerciales - La Constitución llena estos conatos - Y porque los atiende cumplidamente, el Congreso espera que la Confederación Argentina restituida al goce de todos sus derechos, por medio de una Constitución que garante todas las aspiraciones, todos los intereses, todas las ambiciones y partidos legítimos, bajo la sumisión a la ley, y a las autoridades que los moderan, imprimiéndoles su acción legal y útil - puede y debe bajo tales condiciones, entrar en la carrera de los Pueblos democráticos y civilizados[...]” . (Ravignani, 1937:547-549) 
4.3.4. La Constitución Nacional llega a la Provincia de Buenos Aires - Panorama político, social y económico- La Convención de la Provincia de Buenos Aires - Las Sesiones.

La Comisión que llevó la Constitución sancionada a la Provincia de Buenos Aires, estuvo constituida por los Señores del Carril, Gorostiaga y Zapata.

Cabe señalar que, ante la consulta que el Presidente formuló a la Soberana Asamblea

“[...] sobre si la Constitución debería mandarse imprimir aún antes del Cúmplase del Ejecutivo Nacional[...] el Diputado Zapata señaló que la impresión que se trataba de hacer no era de un carácter oficial, como la que se haría después que el Director Provisorio la mande cumplir, sino al solo objeto de generalizarla y ponerla al alcance de todos (moción que resultó aprobada)". (Ravignani, 1937:550)

El disenso experimentado en el seno de la asamblea constituyente no fue otra cosa que un epifenómeno surgido de la intrínseca debilidad del entramado social. Dado que, si bien el congreso significó la reafirmación del federalismo, ello no alcanzó a ocultar la profunda necesidad de encontrar un nuevo punto de inflexión que operase como una alternativa a las creencias facciosas que, desde siempre, habían teñido la ideología y la praxis de nuestra historia.

Insistimos. En tanto seres dotados de razón y de principios de vida ('façon de vivre' ) quienes pergeñaron el estado argentino, aún con matices diferenciales señalados ya en la reproducción de los debates y si bien detentaron disímiles ideologías, persiguieron una única finalidad: conformar un sistema político único, sobre la base y el respeto de las pluralidades provinciales.

Definido pues el objetivo, los diputados constituyentes fundieron sus ideas aún, y sin duda, a costa de mutuas concesiones ya que, la télesis concitante, resultaba nutriente necesaria y suficiente.

Una rápida recorrida por los siete años de discordia y enfrentamientos -transcurridos desde la sanción de la Constitución y el correlato de la Confederación hasta la incorporación de Buenos Aires y la reforma de 1860- permitirán visualizar el panorama 
político, económico, social y cultural de la Provincia de Buenos Aires, así como lo acontecido a partir de la firma del llamado Pacto de Familia celebrado entre Mitre y Urquiza, el 11 de noviembre de 1859.

Los negociadores del Pacto, fueron auténticos tributarios de las ideas y leyes germinadas durante el señalado discurrir temporal -tanto en la dirigencia cuanto en la opinión pública- respecto a la meta que los instigaba: la unión nacional y, por ende, la indivisibilidad del territorio de la república. (Heras y García, 1961: XIV)

Luego de la firma de dicho Pacto, la política interna de la Provincia de Buenos Aires, atravesó por un momento de desorientación, hasta que el triunfo de la lista del "Club Libertad" -en la elección de convencionales realizada el 25 de diciembre de 1860- polarizó una poderosa y dinámica corriente de opinión, continuadora de la política del 11 de noviembre en sus proyecciones nacionales, cuyo jefe indiscutible fue Mitre.

La línea Mayo-Caseros, tuvo en Urquiza -portador de un federalismo constitucionalista y, en principio, anti-porteño- y en Mitre, sus máximos forjadores. Sin desconocer, va de suyo, a quienes junto a ellos, realizaron ingentes esfuerzos por concretar la unidad nacional basándose en postulados populares, en tanto recipendarios de la soberanía popular. Se trató de dos políticas en pugna: a) la originada en el Acuerdo de San Nicolás -que legara la Constitución Nacional- y b) la de la revolución septembrista, que culminara la magna obra con la Reforma de 1860.

Indagaremos pues, los acontecimientos políticos habidos intra Buenos Aires, así como las relaciones mantenidas con la Confederación, después de la firma del mencionado instrumento.

En principio, los objetivos a lograr, esto es, la paz, la integridad y la reconciliación constituyeron preceptos medulares conducentes a la firma del mencionado Pacto de San José de Flores o Pacto de Familia.

En el pacto, sostuvieron C. Heras y C. García,

“[...] no hubo imposición ni sometimiento, sino encuentro de dos políticas rivales que desde 1852 se habían disputado la hegemonía nacional. Fueron ellas la política del Acuerdo de San Nicolás y la política de la revolución del 11 de septiembre. La primera legó al país la Constitución de 1853; la segunda perfeccionó la obra con la reforma de 1860[...] La lucha, ha escrito Ramón J. Cárcano, respondió a la existencia de dos antagonismos históricos, resultado de la topografía del 
país, de intereses, ideas y tradiciones diversas. No hubo en ningún momento tendencias pronunciadas contra la integridad nacional [...] Las cláusulas fundamentales del Pacto no surgieron durante la complicada tramitación del mismo. Desde el día siguiente de la secesión se lanzaron fórmulas para volver a la unión. Los negociadores recogieron ideas y normas que habian hecho camino en el ánimo de los dirigentes y sedimentado en la opinión pública [...] Las partes en lucha nunca perdieron de vista la unidad nacional; la división era pasajera y siempre persistió como hecho inconmovible la indivisibilidad territorial de la república.

Por esto, bien se pudo llamar al Pacto del 11 de noviembre, Pacto de Familia, porque él no sancionó sometimiento ni imposiciones humillantes, sino que anudó mediante una honrosa transacción, el hilo roto de la integridad nacional. Así lo interpretó Urquiza en el Manifiesto al pueblo de Buenos Aires, datado el 11 de noviembre: 'En una lucha de familia debe preferirse toda transacción a una batalla [...] Ha triunfado la nación y ha triunfado la campaña y ciudad de Buenos Aires. Esta paz es para mí el mayor de los triunfos, porque es el triunfo de todos los argentinos'.

El leal cumplimiento del pacto exigía el previo desarme moral; concluía la etapa marcial y se iniciaba la de la legalidad, cuya realización imponía arrojar el lastre del belicismo." (Heras y García 1961: XIV-XV-4).

El "Pacto", complementado por el Convenio de Unión, fue considerado en sesiones secretas a partir del 6 y aprobado el 12 de junio de 1860.

Se analizaron en él, dos problemas fundamentales: 1) la reunión de una Convención Nacional ad-hoc, para considerar las respuestas propuestas por Buenos Aires y 2) la determinación de un régimen provisorio en materia rentística, hasta que Buenos Aires enviase sus representantes al Congreso Federal encargado de dictar la legislación permanente. Asimismo, recomendaba que los Convencionales fueren preferentemente nativos o residentes de las provincias que representaren. Se reuniría en Santa Fé, debiendo concluir sus tareas dentro de los treinta días de su instalación.

Cabe destacar que desde el gobierno de la Confederación, las indicaciones dadas, más que instrucciones eran una enumeración de principios; todo debía subordinarse a la unión nacional. También se contemplaron cláusulas económicas, fundamentalmente las concernientes a la Aduana.

Aprobado por aclamación en ambas Cámaras del Congreso el 6 de junio, al recibirlo en Buenos Aires el gobernador Mitre, solicitó la reunión de la Asamblea Legislativa en 
sesión secreta para su consideración, resultando aprobado el día 12. (Heras y García, 1937:XLIII, cit.33) ${ }^{115}$

Además, con la visita a Buenos Aires del Presidente Derqui -acompañado por Urquiza- finalizó la política de hostilidad, reemplazándolo por cordialidad y acercamiento, constituyendo una verdadera cita de la fraternidad.

"Un ambiente de alegría contagiosa se apoderó del pueblo porteño que rindió a los huéspedes, y muy especialmente a Urquiza, homenajes de toda naturaleza [...] El abrazo de Mitre y Urquiza simbolizó el olvido del pasado y la fusión de las dos políticas que durante siete años habían disputado la hegemonía nacional [...]"

Así, al inaugurar la Escuela Primaria de la Parroquia de Catedral Norte (conteniendo una importante efigie de B. Rivadavia) y

"[...] Como un signo de los tiempos nuevos, los antiguos adversarios sellaron la reconciliación bajo el techo de una escuela pública [...]” (Heras y García, 1961: XLIV).

También el periodismo de la época, del cual, como mencionásemos, constituyó un claro ejemplo Bartolomé Mitre, desempeñó un importante rol, resultando eficaz instrumento en tanto auténtico forjador de opinión pública en pro de la unión nacional. Unión nacional, que sólo podía lograrse mediante la consolidación de la paz. (Heras y García, 1937: XV) ${ }^{116}$

${ }^{115}$ Aclaran los autores que: "Las Actas secretas faltan tanto en los archivos de ambas cámaras como en el HISTÓRICO DE LA PROVINCIA. En el de la Cámara de Diputados se conserva el borrador que publicamos correspondiente a la sesión del 10 de junio. Pese a nuestras búsquedas no las hemos podido ubicar en otros repositorios, ignorándose cuándo desaparecieron".

${ }^{116}$ Más adelante agregaron que: "Como lo afirmó Nicolás Avellaneda en EL NACIONAL, '[...] La política del 11 de septiembre[...] había terminado su ciclo histórico, pero dentro del clima creado por ella debía cumplirse el Pacto. La nueva política exigió el retiro de quienes habían impulsado la guerra. Juan Carlos Gómez abandonó la dirección de EL NACIONAL; lo sustituyó el joven Nicolás Avellaneda, quien, conjuntamente con Vélez Sarsfield y Sarmiento, integró el formidable triunvirato defensor de la causa porteña. En LA TRIBUNA, en reemplazo de los Varela, asumió fugazmente la dirección el poeta José Mármol, quien de acuerdo con arraigadas convicciones, bregó por el pronto cumplimiento del Pacto, sin declinar por ello su posición de porteño nacionalista. Reapareció la combativa REFORMA PACÍFICA, siempre dirigida por Nicolás A. Calvo, subvencionada por el Gobierno de Paraná. El versátil Lucio V. Mansilla, venido a menos en los círculos áulicos de la Confederación, por su oposición a la candidatura presidencial de Derqui, intentó abrir nueva senda con la fundación de LA PAZ, cuyo título involucraba su programa, y en el COMERCIO DEL PLATA, de noble tradición montevideana en la lucha contra la tiranía (Miguel Cané, fue uno de sus directores y entusiasta fogonero de la incorporación de Bs. As.) En la Confederación, EL NACIONAL ARGENTINO, periódico oficial dirigido por el chileno Francisco Bilbao, se adaptó a las necesidades de la hora; el 17 de noviembre cambió el lema: 'Defendemos la ley federal jurada.' 'Son traidores los que la combaten' por el de "Integridad-Fraternidad”, y, a poco andar, Juan F. Seguí, ex constituyente de 1853, ocupó la dirección" [...] La nueva entidad se basó en la fusión y el olvido total. 'A este 
Frente a los septembristas, surgió una nueva fuerza política. El programa de la nueva entidad política -que contó entre sus filas con Félix Frías y el coronel Conesa, así como con antiguos federales pertenecientes a distinguidos y prestigiosos ambientes- fue acogido entusiastamente por gran parte de los porteños. Por lo que, más allá de lo "acordado" por ambos gobiernos en el Pacto, los enfrentamientos entre los grupos en pugna tornó inevitable su traslación a la esfera institucional. (Heras y García, 1937: XVI) ${ }^{117}$

Sarmiento, uno de los que reaccionó frente a la importancia y al efecto logrado por la Asociación de la Paz ante la sociedad, llegó incluso a descalificar para el ejercicio de la función pública a quienes no ostentaran una limpia trayectoria septembrista.

La prensa toda, fue quien acometió la discusión acerca de la viabilidad de aprobar la Constitución a libro cerrado entre el 22 de noviembre y el 3 de diciembre.

La polémica la inició Avellaneda desde “El Nacional”. La réplica fue encabezada por Sarmiento -en tanto partidario del candidato opositor, don Mariano Fragueiro- quien escribió sobre la necesidad de impedir que Santiago Derqui fuese proclamado Presidente ya que se había mostrado como el más decido partidario de someter a Buenos Aires por la fuerza. El enfrentamiento entre la "Asociación de la Paz" y el "Club de la Libertad" -entre los que Mansilla intentó terciar desde las columnas de La Paz- fue, entonces, decididamente evidente y, de alguna manera, promovieron la formación de elites políticas. (Heras y García, 1937: XVII) ${ }^{118}$

\footnotetext{
anhelo obedeció la publicación del periódico LA PAZ por Mansilla y la creación de la Asociación de la Paz, (Félix Frías) sin que el periódico fuera el vocero oficial de la misma. ”.

${ }^{117}$ En ese orden de ideas, destacan que "El 21 de noviembre hubo un importante debate en la Asamblea Legislativa, de profunda repercusión en la marcha ulterior del proceso político [...] Sarmiento pronunció una notable pieza oratoria, en la que bosquejó con la agudeza propia de su talento, las líneas directrices a que debía ajustarse la nueva política. Según él, la prolongada lucha de siete años había "creado una masa de hechos, de intereses de hombres y de cosas", que no podian desplazarse de inmediato sin causar un gran desequilibrio; tampoco podía crearse de improviso una fuerza nueva, una nueva opinión, ni dar nuevas bases al gobierno. Todos anhelaban, decía, la unión nacional; pero cada uno 'quiere su unión personal'. La paz alcanzada era entre los gobiernos, pero no entre los pueblos representados por sus partidos; el ambiente estaba cargado de desconfianza, el Poder Ejecutivo se movía indeciso sin lograr la concordia interna, base fundamental del Pacto del 11 de noviembre."

${ }^{118}$ Manifiestan al respecto Heras y García que "El programa del Club, aparecido en EL NACIONAL del 3 de diciembre, era de repudio a la política de fuerza y apoyo a la del derecho; llamaba a estrechar filas unidos, a los antiguos pandilleros y chupandinos, para defender mejor los derechos históricos de la provincia y repudiaba con vehemencia a los federales históricos, sindicados de responder a influencias de Derqui y aún de Urquiza."
} 
- Los pasos que precedieron la puesta en marcha de la Convención Provincial para revisar la Constitución Nacional.

Es evidente que el clima político se había vuelto a enrarecer, avizorándose una acalorada campaña electoral entre los integrantes de la Asociación de la Paz y los pertenecientes al Club Libertad. Para evitar el fraude, se levantó un padrón en las parroquias, ya que la ley vigente -dada durante el gobierno de Rivadavia- al no establecer ese requisito o "condición", de alguna manera facilitaba el "voto transeúnte" de quienes procedían de la campaña, cuando no el voto fraudulento del mismo ciudadano en la misma o distintas parroquias.

Pese a ello y frente al escaso apoyo obtenido, la Asociación de la Paz, se retiró de las mesas y reclamó garantías.

En lo referente al desarrollo del acto existieron alteraciones e incidencias varias en Balvanera y La Piedad, como también en San Telmo y Pilar; se suspendieron en San Fernando y se realizaron en Lobos, Monte, Navarro, Saladillo, 25 de Mayo y Bragado; Patagones comunicó su no realización por falta de tiempo.

La Ciudad eligió veintidós (22) diputados-convencionales universitarios, once (11) sin título y tres (3) militares, treinta y seis (36) en total; en la campaña, por su parte, sobre un total de treinta y cuatro (34) convencionales resultaron electos trece (13) universitarios, diecinueve (19) sin título y dos (2) militares.

- Realizando un fugaz y formal balance de la Convención, diremos que se celebraron quince (15) sesiones, cuatro (4) preparatorias y once (11) ordinarias para analizar la Constitución aprobada en Paraná. Se instaló el 5 de enero -día en que se celebró la 1ra. Sesión Preparatoria- en tanto durante los días 23, 25 y 31 de enero fueron llevadas a cabo la segunda, tercera y cuarta, respectivamente.

En ellas se discutieron los títulos, la ciudadanía de quienes la integraban (caso Cnel. Wenceslao Paunero), el juramento, el nombre que debía tener (¿Convención del estado o de la provincia? ¿Pueblo o Estado?), y cuestiones de forma como el número de vicepresidentes, si los Secretarios, taquígrafos y empleados en general debían ser pagos o no, el origen de los gastos a realizar, entre otros temas.

La 5ta. Sesión fue la primera de las ordinarias y se llevó a cabo el 6 de febrero. Ante las dilaciones producidas, sin ingresar al debate, sostuvo Sarmiento, 
“[...] objeto y misión es examinar la constitución y en su caso, aceptarla (art.4) o reformarla (art. $\left.5^{\circ}\right)$, no tratar un proyecto de reforma que presente una comisión [...] agregando que "[...] los pueblos no tomaron parte en el debate [...] fue mandada obedecer desde un campamento [...] el Pacto de Noviembre nos ordena examinar la Constitución [...] siempre me he ocupado de la unión nacional. No soi 'separatista' ni lo seré jamás [...]” (Reforma Constitucional de 1860, 1961:72-77)

En tal sentido presentó una moción para que la convención toda se constituyera en Comisión, la cual, sometida a votación, fue rechazada por veintiocho votos contra veintiseis.

De todos modos y como el Pacto disponía (artículo $2^{\circ}$ ) [...] la necesidad de examinar la Constitución antes de su aprobación e introducir las enmiendas que correspondieren, dicho análisis fue aprobado por treinta y dos (32) votos contra diecisiete (17). (Heras y García, 1961:XXIX)

Ante la evidencia normativa, se nombró una Comisión que integraron, a propuesta de B. Mitre, siete (7) miembros, resultando electos: Dalmacio Vélez Sarsfield, Domingo Barros Pazos, Domingo Faustino Sarmiento, Bartolomé Mitre, José Mármol, D. L. Domínguez y D. A. C. Obligado.

En la 6ta. Sesión ( $2^{a}$ ordinaria reunida el 24 de abril) celebrada en minoría y no siendo posible considerar los asuntos que constituían el orden del día, se decidió considerar y aceptar las renuncias presentadas por los Diputados Alsina, D. Valentín, y Gamboa, electos por la ciudad; y la del Cnel. Emilio Conesa y el señor Domingo Olivera, que habían resultado electos, el primero por la $10^{\mathrm{a}}$ y el segundo por la $1^{\mathrm{a}}$ Sección de campaña.

Al realizarse la $7^{\mathrm{a}}$ Sesión $\left(3^{\mathrm{a}}\right.$ ordinaria realizada el 25 de abril), la Comisión Examinadora manifestó al elevar su informe -y entre otras consideraciones- que,

“[...] consultando la paz y el decoro de los pueblos, a la vez que los principios fundamentales de las so[/]ciedades que se gobiernan por instituciones democráticas, la comisión reconoció que, la necesidad de reforma era imprescindible, para que la paz fuese fecunda y duradera, y para que la unión fuese sólida y ajustada al principio de la soberanía popular”. (Reforma Constitucional de 1860, 1961:107)

Decidida la reforma, fueron propuestas veinticinco (25) enmiendas, divididas en cinco (5) secciones sistematizadas: $1^{\mathrm{a}}$ Declaraciones, Derechos y Garantías; $2^{\mathrm{a}}$ 
Composición de los Poderes; $3^{\mathrm{a}}$ Atribuciones de los Poderes; $4^{\mathrm{a}}$ Materias económicas y $5^{\mathrm{a}}$ Reformas del Pacto -ó que deriven de ellas- las que resultaron informadas por Vélez Sársfield. Habiéndose procedido a la votación, el Proyecto de reforma fue admitido, en general, por treinta y dos (32) votos contra diecisiete (17). (Universidad Nacional de La Plata, 1961:107).

El 27 de abril se llevó a cabo la 8va. Sesión (4ta. Ordinaria) Sarmiento dirigió una larga alocución contra diecisiete convencionales que se pronunciaron por la abstención negándose no solo a votar, sino a participar en el debate- entre los que se encontraban Ugarte, Frías, Irigoyen, Esteves Saguí. Entendiendo que faltaban a su deber, expresó

“[... ] Esta Convención, Sr. Presidente, fue nombrada en medio de la humareda que había dejado el cañoneo de Cepeda. No nos conocíamos los unos a los otros; todo el mundo sabe que había entonces una tentativa de reacción, pero apenas se disipó el humo, la ciudad supo mui bien donde estaba y eligió a sus Representantes, según su voluntad [...] un pueblo ha dicho: así lo quiero [...] Es importante este hecho porque demuestra la nueva fuerza moral que se desarrolla en el país[...]la nacionalidad se hace con los hechos, no con las abstenciones. Los hechos, las discusiones forman los sentimientos del público, y no el silencio [...]" (Reforma Constitucional de 1860, 1961:154-158)

Mediaron, entonces, las intervenciones de Ugarte y Frías, pidiendo este último que se respete su derecho de guardar silencio, rogando a la Convención le otorgue su licencia para hablar, después de terminada esta discusión. (Reforma Constitucional de 1860, 1961:163)

Luego de lo señalado se entró al orden del día, debatiéndose diversas reformas a los artículos 5 y 6 , los que, producida su discusión, resultaron aprobados.

Durante la $9^{\text {a }}$ Sesión (5 $5^{\text {a }}$ Ordinaria del 30 de abril) se discutieron las reformas a los artículos 9 (el que pasó a Comisión con una enmienda propuesta por el Sr. Elizalde) 12, 15 y 18 , los que, practicada la porfía, fueron aprobados.

En la $10^{\text {a }}$ Sesión (6 $6^{\mathrm{a}}$ Ordinaria del $1^{\circ}$ de mayo) fueron aceptados los artículos 30, 33 (intervención de Sarmiento en defensa de los derechos del pueblo no establecidos en la Constitución "federal"; similares intervenciones de Mitre enfatizando que no se legisla para cada individuo sino para ese 'ser moral que se llama sociedad [...] para ese ser colectivo que se llama humanidad), y 36 (Sarmiento y Mitre, [...] es preciso que el Diputado sea de la Provincia). 
Cabe señalar que ésta fue la última sesión en que estuvo Mitre como convencional, porque fue elegido Gobernador.

La elección de Senadores, Atribuciones del Congreso, del Poder Ejecutivo y del Poder Judicial, así como las potestades y reservas de los estados provinciales, se debatieron en la $11^{\mathrm{a}}$ ( $7^{\mathrm{a}}$ ordinaria celebrada el 7 de mayo).

En la $12^{\mathrm{a}}$ Sesión ( $8^{\mathrm{a}}$ ordinaria del 8 de mayo) fue aprobado, con adiciones, el artículo 31 - agregados emergentes de considerar el impacto inmigratorio, el tema de la ciudadanía y las consecuencias que podrían provocar algunos tratados internacionales firmados por la Confederación sin la presencia de Buenos Aires-; también se retomó la cuestión relativa a Régimen aduanero, sin concluirlo.

La $13^{\mathrm{a}}$ de las Sesiones ( $9^{\mathrm{a}}$ ordinaria del 9 de mayo) continuó con el debate de las atribuciones del Congreso sobre Aduanas, habiéndose aprobado el inc. $1^{\circ}$ del artículo 64 (luego de un arduo y dilatado debate sobre derechos de exportación e importación, la conformación del tesoro nacional, la emisión de papel moneda, entre otros); también fue considerada, la realización de elecciones para convencionales por la $13^{\mathrm{a}}$ Sección de campaña (Patagones) por las que resultaron electos los Sres. Dres. Manuel R. García y Manuel Quintana.

Examinadas las actas de la referida elección, en la 14ta. Sesión Ordinaria $\left(10^{\mathrm{a}}\right.$ ordinaria del 11 de mayo) fueron aprobadas, resolviéndose la incorporación de los convencionales elegidos por Patagones.

Asimismo, en uso de la reserva formulada en la 8va. Sesión (abstención), el diputado Frías manifestó:

"Yo había pensado votar en silencio contra todas las enmiendas propuestas a la Constitución[...] Al alzar hoy mi voz en este recinto, no lo hago con la mira de convencer a nadie[...]Aunque por diversos caminos, vamos todos al mismo puerto, al puerto de salvación para la nacionalidad argentina[...]Entendiendo que la aceptación sin enmiendas no significa de ninguna manera entender que ella sea perfecta pues ninguna obra sale perfecta de las manos del hombre ya que carece de las virtudes necesarias para darles vida. 'Las instituciones, se ha dicho con razón, no tienen más valor que el de los hombres destinados á practicarlas; ' y a mi juicio lo que convendría corregir entre nosotros, no son las instituciones, sino a nosotros mismos [...] Un pueblo[...]no es libre por sus leyes, sino por sus costumbres[...]” (Reforma Constitucional de 1860, 1961:314/323) Por último y dirigiéndose a la mesa de la Secretaría, entregó lo que constituyó 
su "propuesta de reforma": establecer como religión de estado la Católica, Apostólica y Romana.

Sarmiento contestó esta intervención sosteniendo, entre otras argumentaciones que "la base de la libertad, es la libertad de conciencia [...]" y en referencia a la "persecución" o, en su caso, "matar" todo pensamiento contrario a su filosofía de vida, que durante siglos había realizado el catolicismo, agregó

"La libertad de los pueblos, pues, no se consigue con la persecución; se consigue por la tolerancia y por la libertad de conciencia [...]”" (Reforma Constitucional de 1860, 1961:324/336).

Intervinieron otros Diputados Constituyentes y, ante la moción de J. Mármol, la reforma propuesta por F. Frías fue rechazada.

Antes de cerrar la sesión fueron aprobadas las llamadas 'reformas indirectas' (arts. 4, 34, 97) y finalizado el debate sobre las mismas, Vélez Sársfield, propuso reemplazar el nombre con que fuere designada la República hasta el momento: "Confederación Argentina". Entendió que las categorías conceptuales utilizadas tanto por el Tratado del 4 de enero de 1831 cuanto la que nombró a Urquiza 'Director', habían sido adoptadas por gobiernos absolutos, por lo cual debía retomarse su nombre legítimo, su nombre de honor: "Provincias Unidas del Río de la Plata", ya que marcaba el momento en que se perfeccionaba la unión, para constituir una sola nación. También, con fundada argumentación, Mármol apoyó las palabras de Vélez Sársfield y con los señores Convencionales y la "barra" puestos de pie y prorrumpiendo en gritos, fue declarada por aclamación la reforma.

En la 15ta. (11 a ordinaria del 12 de mayo), el presidente de la Convención procedió a leer la invitación al Te Deum formalizada por el gobierno de Buenos Aires (suscripta por Mitre y Sarmiento), en acción de gracias al Todo poderoso, por el feliz resultado de los trabajos de la Convención.

Por último, se dio lectura al Acta final de la Convención la cual destacó que, se había dado fiel cumplimiento al mandato recibido del pueblo de Buenos Aires, interpretando la voluntad y consultando en todos sus actos las conveniencias del mismo a quien representó, y con ella las de los demás pueblos sus hermanos. Agregando en el proyecto de comunicación al Poder Ejecutivo del Estado que, 
“[...] a nombre de la patria común, la Convención Nacional pondrá su sello augusto a esos trabajos y a la unión definitiva de la familia argentina, conquistada por la libertad y afianzada por el derecho -y tal es la esperanza con que este Cuerpo termina sus sesiones, y tal es el generoso sentimiento con que abraza a nombre de Buenos Aires a los demás pueblos [...]” (Reforma Constitucional de 1860, 1961:355).

Importa señalar, a modo de colofón, la importancia que tuvo para la ilustración del pueblo todo y en la consecuente formación de opinión pública el "Redactor de la Constitución”, encargado de publicar los debates de modo paralelo a la realización de las sesiones.

4.4. Reforma Constitucional de 1860 - La Convención Nacional ad hoc - Los Diputados - Las Sesiones.

Tendiente a concretar la Reforma Constitucional, la opinión de Urquiza era favorable a la aprobación de las reformas formalizadas por la Convención provincial y, en tal sentido, remitió una circular a varias provincias proponiendo candidatos.

El presidente Derqui, por su parte, se mostraba reticente, en virtud de lo cual organizó actos de clara intromisión -que motivaron la reacción de Sarmiento- en la provincia de San Juan. Conducta esta que llevó a Mitre a consultarlo y, si bien negó los cargos, admitió, la existencia de esfuerzos dirigidos a

“hacer del asunto de las reformas una cuestión de 'unidad' y 'federación' y explicó la necesidad de asociar sus trabajos a prohombres del llamado partido liberal." (Heras y García, 1961: XLVI)

Por otra parte, y en virtud de los acuerdos existentes, se encomendó que aquellos que resultaren electos fuesen de preferencia nativos o residentes en las provincias cuya representación invistiesen y que no desempeñaran cargos gubernamentales.

De allí que, el mismo Urquiza que, en principio, había aceptado su elección como convencional por la provincia de Entre Ríos, luego renunció, eligiéndose en su lugar a Juan F. Seguí. Elección, esta última, que produjo gran impacto en Buenos Aires puesto que Seguí -desde “El Nacional Argentino”, órgano oficial del gobierno de Paraná- se había manifestado en contra de las reformas. No obstante y declinando actitudes personales, 
Seguí contribuyó a la aprobación de las reformas, cumpliendo expresas instrucciones de Urquiza. También, y por similares razones, Vélez Sársfield -elegido por Córdoba- renunció al cargo, que luego terminó aceptando ante la presión de sus amigos, especialmente Mitre.

Además, ambos, en su comunicación epistolar habían puesto de manifiesto sus inquietudes ante el nombre de alguno de los convencionales. (v.g: los dos Alsina -padre e hijo- a quienes reprochaban haber fomentado la guerra civil).

Cabe destacar que, el ambiente de concordia existente entre Mitre, Urquiza y Derqui no fue adoptado por sus seguidores -sobre todo por los partidarios de Derqui- situación plasmada tanto en lo que hace a la elección de los Convencionales nacionales, cuanto a la campaña, como se señalara, emprendida por el periodismo (v.g.: desde El Nacional Argentino).

Considerando las suspicacias suscitadas, Mitre, Urquiza y Derqui mantuvieron una profusa correspondencia en tren de paliar la situación. (Heras y García, 1961: XLIX). ${ }^{119}$

Ejemplo de ello, constituyó lo expresado por Mitre a Urquiza, al anunciarle la finalización de los trabajos de la Convención: las reformas

"tienen en vista la mayor felicidad de los pueblos, la mayor dignidad de los gobiernos provinciales, a la par que la mayor estabilidad del Gobierno nacional” y reclamándole su efectiva cooperación "para complementar la grande obra de la organización nacional, propendiendo a que las reformas a la Constitución sean aceptadas libremente por los pueblos", (Heras y García, 1961: XLVIII) palabras decididamente fructíferas en la consecución del objetivo buscado.

De esta suerte, el 23 de junio ambas Cámaras del Congreso aprobaron la convocatoria de la Convención Nacional ad-hoc,

"al sólo efecto de que tome en consideración las reformas que la Convención de Buenos Aires propone se hagan a la Constitución Nacional y decida definitivamente sobre ellas". (Heras y García, 1961: XLVIII-XLIX)

\footnotetext{
${ }^{119}$ Así, Urquiza escribió a sus amigos de la Convención: "La Constitución de 1853, que ha sido la tabla de salvación, el iris de paz, el símbolo de la alianza y de la fraternidad, saldrá de vuestras manos perfeccionada para recibir el juramento de un pueblo ilustre. No podría ella en ninguna de sus prescripciones contener nada que estorbase lo que con cuidado buscaron los patriotas que la sancionaron: La integridad de la Patria [...]". A su vez, Mitre se dirigió a Derqui, expresándole la ansiedad que reinaba en Buenos Aires, vaticinándole que la unión no será posible si se rechazan las reformas, y que "haría todo lo que le fuese posible a fin de robustecer [...] mi poder moral, para estar mejor habilitado de este modo para sellar la grande obra de la unión."
} 
- Los Diputados.

El número de diputados que representaría a cada provincia fue establecido por el P.E. y la elección de los mismos -toda vez que no existían censos- se rigió conforme lo establecido por el artículo 34 de la Constitución.

La Confederación llamó a elecciones con arreglo a la Ley del 1 de junio de 1859, las que debían realizarse los días 5, 6 y 8 del mes de agosto. El gobierno de la provincia de Buenos Aires convocó, asimismo, para el 5 de agosto.

Buenos Aires estuvo representada por doce convencionales: cinco universitarios (Valentín Alsina, Adolfo Alsina, Rufino de Elizalde, Francisco de las Carreras y Nicanor Albarellos); seis ciudadanos sin título, pero aquilatado renombre tanto por sus dotes intelectuales como por su actuación pública (Domingo Faustino Sarmiento, José Mármol, E. Castro, I. Portela, M. Ocampo y Juan María Gutiérrez) completaba la lista, un militar; Wenceslao Paunero.

Las elecciones realizadas en Córdoba, Santiago del Estero, Tucumán, Salta y Jujuy, dieron como resultado la conformación de una corriente liberal acorde con la existente en Buenos Aires. Enfrentada a ella, las provincias de Cuyo, La Rioja, Catamarca y Corrientes tuvieron como mayor exponente al Diputado Pujol. Entre Ríos y Santa Fé estaban alineadas detrás de Urquiza.

- Las sesiones.

Se realizaron ocho (8) sesiones (cuatro (4) preparatorias del 14 al 22 de septiembre y cuatro (4) ordinarias del 22 al 25 de septiembre. (UNLP, IV- Convención Nacional Ad-Hoc, 1961:575-602).

Desde el inicio se perfilaron dos fracciones antagónicas: liberales y conservadores, pero ello no fue en desmedro de los leales y sinceros deseos que guiaban a los convencionales. Los temas substanciales en los que se focalizó el debate fueron: "los tratados" y “derechos de exportación”. Sin embargo, ambos fueron llevados prudentemente, lo cual no aconteció con cuestiones "formales": la validez de las elecciones (por requisito de residencia) y la incompatibilidad de aquellos funcionarios (gobernadores y ministros) 
para desempeñarse como convencionales (cuyo debate justificó las reuniones particulares previas, en un intento por de evitar discusiones "de forma” en el seno de la Convención).

En la 1ra. Sesión preparatoria (14 de septiembre) fue elegido presidente, don Mariano Fragueiro; habiéndose procedido a designar una comisión -integrada por J. Mármol, F. Frías y J. Posse- encargada de la redacción del Reglamento. También fue nombrada otra comisión -formada por Paz, Portela, J. Posse, Cáceres y Castro- con la finalidad de analizar los poderes de los señores convencionales.,

La 2da. Sesión preparatoria (17 de septiembre), registró el ingreso de la documentación referida a las elecciones, el protocolo de las negociaciones habidas y el Acta final de la Convención de Buenos Aires. Habiéndose procedido a su consideración, se aprobó el proyecto de Reglamento.

En la 3ra. Sesión preparatoria (19 de septiembre), fueron aprobadas las elecciones realizadas en Córdoba, Catamarca, Corrientes, Entre Ríos, Jujuy, Mendoza, La Rioja, Salta, Santiago del Estero, San Luis, Santa Fe y Tucumán, lo cual importó la aprobación de cuarenta y cinco (45) diputados. El tema de la "residencia" generó discusiones las que fueron subsanadas por la Comisión, al señalar que el requisito establecido en el artículo $4^{\circ}$ del convenio de junio -conforme la circular del ministerio- no era "preceptiva", sino de recomendación.

El número de treinta y cuatro (34) votos contra catorce (14) por los que fue aprobado el dictamen, puso de manifiesto que las dificultades habían sido superadas, (San Martino de Dromi, 1995: 192) ${ }^{120}$ resolviéndose, en consecuencia, que la Convención comenzara el día 21 de septiembre (aunque en rigor, se instaló el 22 por la tarde).

Las cuatro (4) sesiones ordinarias, tuvieron lugar durante los días 22, 23 y 25 de septiembre. En la segunda, es decir el 23, y a propuesta de Victorica, fueron aprobadas por aclamación las reformas propuestas, con algunas modificaciones.

La Convención -por mayoría- decidió designar una Comisión de siete miembros, resultando electos los señores: José Mármol (41 votos), Juan Francisco Seguí (39 votos), Rufino de Elizalde (31 votos), José Benjamín Gorostiaga (39 votos), Dalmacio Vélez

\footnotetext{
${ }^{120}$ La circunstancia de haber logrado la unidad nacional quedó explicitado en el discurso que pronunciara J.F. Seguí: "[...] la organización definitiva de la República va a realizarse [...] y hoy asistimos al magnifico espectáculo de la unión de los pueblos [...]", estando dispuesto al sacrificio de ideas individuales, "siempre que él se me exija en nombre de la unión, de la paz y de la fraternidad de los pueblos argentinos [...]".
} 
Sársfield (33 votos), Luis Cáceres (39 votos) y Salvador María del Carril (39 votos), para el tratamiento del proyecto y elaboración de un dictamen.

El Dictamen fue considerado en la 2da. Sesión ordinaria del 23, aconsejando: a) “ Aceptar, en vez del cambio del título de Confederación Argentina, este artículo: 'Las denominaciones adoptadas sucesivamente desde 1810 hasta el presente, a saber -Provincias Unidas del Río de la Plata, República Argentina, Confederación Argentina,- serán en adelante nombres oficiales indistintamente para la designación del Gobierno y Territorio de las catorce Provincias, empleándose las palabras Nación Argentina en la formación y sanción de las leyes"; b) "Modificar la reforma propuesta al artículo 31, del modo siguiente: "Salvo para la Provincia de Buenos Aires los tratados ratificados después del Pacto de 11 de noviembre de 1859”; c) “Modificar la propuesta al artículo 64, inciso $1^{\circ}$, del siguiente modo: 'Suprimir estas palabras: En cuya fecha cesaran como impuesto nacional"; d) "Modificar la reforma propuesta al artículo 91 del modo siguiente: "El Poder Judicial de la Nación será ejercido por una Corte Suprema de Justicia y por los demás Tribunales inferiores que el Congreso estableciese en el territorio de la Nación"; e) "La Comisión ha creído también deber proponer a la Convención la aclaración de la parte final del artículo 97 en estos términos: $Y$ entre una Provincia o sus vecinos contra un Estado o ciudadano extranjeros".

La Comisión se excusó de fundar las razones de su dictamen, considerando la publicación de la discusión de las reformas propuestas por Buenos Aires y los importantes debates que habían tenido en aquella Convención y en la prensa del país. Ofreciéndose a proporcionar los antecedentes y explicaciones que fueren solicitadas sobre aquellas reformas que susciten alguna discusión”. (UNLP, IV- Convención Nacional Ad-Hoc, 1961: 591-592)

El dictamen no se debatió, habiendo admitido la Comisión las sugerencias de varios convencionales respecto a, las ya referidas 'ser natural o residente', así como también las relacionadas al artículo 64, agregándose "en cuya fecha cesarán como impuesto nacional, no pudiendo serlo provincial." (UNLP, IV-Convención Nacional Ad-Hoc, 1961:593)

Terminadas estas breves acotaciones, Victorica pidió la palabra y manifestó aquello que fue considerado como la expresión del sentimiento de una época-:

"La integridad de la nación Argentina no se discute entre argentinos: se hace". (UNLP, IV- Convención Nacional Ad-Hoc, 1961:593). 
Acto seguido, pidió la aclamación del dictamen, el que resultó apoyado por todos menos uno, según reza el acta. Constituida la Convención en Comisión de redacción, solo restó dar "forma" a lo sancionado. El mismo día, en horas de la noche, se realizó la tercera sesión para considerar el proyecto elaborado por la comisión, el cual -luego de algunas observaciones- se procedió a firmar.

En la última sesión del 25 se trató el dictamen de la comisión encargada de concordar las reformas de la Constitución, tarea que, como lo señalara Sarmiento, estuvo a cargo de Vélez Sársfield.

La Constitución de la Nación Argentina fue jurada en la ceremonia del 21 de octubre en la Plaza de la Victoria.

Mitre al hacer uso de la palabra dijo:

“[...] después de medio siglo de afanes y luchas, de lágrimas y de sangre”, vamos a cumplir el testamento de nuestros padres, ejecutando su última voluntad en el hecho de constituir la nacionalidad argentina bajo el imperio de los principios”. (Reforma Constitucional de 1860, IVConvención Nacional Ad-Hoc, 1961:638-639)

Añadió que esta Constitución, además de la Constitución de 1816 y 1825, fue también la del Congreso Federal de Santa Fe e interpretando cabalmente el proceso histórico que allí se cerraba, señaló:

“[...] complementada y perfeccionada por la revolución de Setiembre en que Buenos Aires reinvindicó su derechos y como tal, esta es la constitución definitiva [...]”. (Reforma Constitucional de 1860, V- Jura de la Constitución Nacional, 1961:639)

Las dos políticas rivales de la etapa de la Organización Nacional, conciliadas en el Pacto del 11 de noviembre, protocolizaron con aquella ceremonia la unión indisoluble de los argentinos,

"[...] que al fin vuelven a encontrarse en este lugar en días más serenos, para abrazarse como hermanos bajo el amparo de una ley común". (Reforma Constitucional de 1860, IV- Convención Nacional Ad-Hoc, 1961:639) 


\section{ADDENDA DEL CAPÍTULO I.}

La incorporación de esta addenda, obedece a que, el desarrollo histórico hasta aquí manifestado -y que nos condujo al año 1860- puso de relieve que debíamos completar nuestra primigenia planificación estructural, dada la importancia que, para nuestra pesquisa, revistieron los sucesos acaecidos durante el interregno 1860-1890.

1. 1860 -La República y el Estado de Buenos Aires: normalidad-normatividad.

Una cuestión preliminar: las divisiones (cleavages) que marcaron la periodización histórica en Argentina a nivel socio-político, estuvieron claramente demarcados desde la independencia. Mientras "ciudad", "centro" y "sectores vinculados a las economías de exportación", constituyeron factores propios de los unitarios; las variables "campaña", "periferia" y "sectores amenazados por la economía de exportación" lo fueron respecto de los federales (con la excepción del gobierno de Rozas, en tanto representante de los hacendados de la provincia de Buenos Aires). (Barbé-Olivieri, 1972:138-139)

Los vaivenes parecieron no tener fin: si bien la perseverancia de Urquiza había logrado una Constitución, luego fue Buenos Aires la que se separó de la Confederación. 
De hecho, fue la falta de integración económica y política lo que postergó el problema institucional y el país quedó una vez más, nuevamente dividido: Confederación, por un lado, y Estado de Buenos Aires, por otro.

No obstante, luego de la batalla de Pavón, transcurridos diez largos años de conflicto y desacuerdo y con un "tironeo histórico" que asumió formas muy diversas, Buenos Aires absorbió el resto de la Confederación. Los agrupamientos políticos tradicionales empezaron a mostrarse retóricos: ya no tenía sentido ser unitario y estaba dejando de tenerlo ser federal en el sentido partidista.

Sí subsistía, por hallarse profundamente arraigado en el sentir del pueblo todo, el federalismo como aspiración y reivindicación. Vale decir que, cuando Buenos Aires recuperó su capacidad directiva nacional después de 1860 al derrotar al interior, lo que aún permaneció vívido, fue la existencia de intereses antagónicos bien definidos.

Por ello, los enfrentamientos entre porteños perduraron, después del gobierno de Mitre, como las únicas opciones legales en las que el incipiente entramado social de los argentinos podría reconocerse y encontrarse: crudos y cocidos primero, autonomistas y nacionalistas después fueron estableciendo los canales que permitieron lograr los acuerdos que dieron forma al P.A.N, última unificación partidaria del siglo XIX. Fusión que trató de sintetizar, soterradamente, los enfrentamientos y localismos en pugna, en la consecución de esperadas reivindicaciones capaces de otorgar apoyo y cohesión al ordenamiento constitucional.

Constituida la República, toca preguntarnos cuál fue la realidad por la que siguió transitando la nueva formación política y las transformaciones que sufrió.

Para "comprender", no solo "explicar", cómo fue transformándose, necesario es plantearse qué se entiende por realidad, esa efectividad humana de la que habla H. Héller.

Así, concebimos como "realidad" todo aquello que existe en el terreno de lo fáctico, vale decir, que "es", más allá que "deba o no", que "corresponda" o resulte "procedente", que se ajuste a "derecho o moral" alguna.

En ese sentido, las transformaciones experimentadas, si bien no lo fueron en orden "global", tampoco acontecieron inaudita parte, sino que formaron parte de un proceso asincrónico y asimétrico en que la formación económico-social hegemónica se generó 
sobre el MPC y, en nuestro caso particular, en el estadio del denominado capitalismo tardío o tardo capitalismo.

A no dudar, conciliar libertad e igualdad fue uno de los problemas que signó al signó XIX, pretendiendo armonizar nuevas sociedades y nuevas civilizaciones. Dialéctica ésta que abordaron, en modo recurrente, distintos pensadores, entre otros Tocqueville y Sarmiento. (Levene, 1958:.272) ${ }^{121}$

Un ciclo que contó con datos positivos, aconteció pues en lo político desde la caída de Rosas en Caseros hasta 1880. La 'organización nacional' si bien por un lado, señaló el momento de 'construcción del Estado', por el otro marcó el inicio de modo sistemático de la socialización de los valores de la élite dominante definitivamente consolidada. Esto es, la “construcción de la nacionalidad" que a diferencia de la construcción estatal no cristalizó en una sola etapa, sino que supuso un renovado proceso de interacción entre gobernantegobernado. (Barbé-Olivieri, 1972:142) ${ }^{122}$

A imagen de la formalidad vigente en el sistema norteamericano, los hombres moldeados para ocupar la escena política (v.g.: Mitre, Sarmiento) buscaron la constitución de Partidos Políticos como un ideal para luchar y destruir el despotismo sobre la base de elecciones y libre opinión, gestándose así “una ficción republicana...” (Luna, 1995:33)

Paralelo a ello, el período presentó una faz negativa caracterizada por la multiplicación de Partidos Políticos inorgánicos, personalistas, vaciados ideológicamente, dado que no fueron grandes las diferencias existentes entre las tres tendencias que por entonces se perfilaron: la federal, la corriente reunida en torno a Mitre y los autonomistas. Décadas, las señaladas, que pueden caracterizarse como "pre-partidarias”.

Al igual que aconteciera en la Revolución Francesa, las fuerzas políticas comenzaron a funcionar en clubes (Sanguinetti, 1986:373) circunstancia por la cual, parte de la ciudadanía comenzó a participar en ellos (el "Club de la Libertad" -origen del Partido Liberal- y el “Club del Pueblo”, germen del Partido Nacionalista).

\footnotetext{
${ }^{121}$ De acuerdo a lo manifestado por el autor y en lo que imaginamos como una auténtica liaison ideológica, decía el sanjuanino en "Facundo" que a la América del Sur le hacía falta un Tocqueville para revelar este nuevo mundo de las instituciones. En tal sentido, recordamos también la influencia de las ideas de E. Echeverría quien, por entonces, preparaba una obra sobre "La democracia en el Plata" siguiendo los lineamientos trazados por Alexis de Tocqueville en "La democracia en América".

${ }^{122}$ Señalan estos publicistas que, toda vez que implica la legitimación del sistema, se explica que Sarmiento años después, e iniciado el proceso inmigratorio, "lanza[...] el grito de alarma frente al fenómeno de vastas masas de inmigrantes que quedan marginadas, sin insertarse en el sistema político"
} 
La existencia de instrumentos que, en principio, "hacen" a una democracia, tornaron factible la expresión de la ciudadanía con la participación del pueblo, plus el dictado de leyes electorales y la documentación periodística y epistolar de la época -llena de costumbres y estilos, donde el ejercicio habitual de la calumnia, la invectiva o el rumor tendencioso constituyeron moneda corriente- hicieron plausible esa "ficción republicana". (Luna, 1995:34-37)

De manera que, la literatura clásica -tanto la procedente de la teoría del estado, la politología, cuanto la historia- consideró que la república nos puso frente a una forma de gobierno creada "por deliberación y consentimiento", por lo que, los gobernantes de la nación argentina debieron contar con una legitimación que, en tanto noción operativa, a nuestro juicio y stricto sensu, reiteramos, no existió.

Circunstancia ésta, a la cual debe agregarse, la coexistencia con un país dividido por el "feudalismo" regional. Por lo que, la Constitución que se formó "volcada en el molde de la de los Estados Unidos de Norteamérica" -según el decir de algunos autores- y con la influencia determinante de la creación alberdiana (sus "Bases y Puntos de partida para la Organización Nacional") sin dejar de mencionar la potencial y, por momentos, real guerra civil por la que atravesó nuestra formación política, fue una solución ecléctica entre principios contradictorios: centralismo y federalismo; religión del Estado y libertad religiosa; orden colonial y una nueva sociedad constituida sobre la base de inmigración y educación pública.

Por ello, los denominados cuatro presidentes "fundadores", debieron enfrentarse a

“[...] una geografía sin cultura indígena ni barroca y escasa ilustración colonial, que había madurado un fruto que, hacia 1876, Mitre no dudó en calificar de igualitario”. (Botana, 1988:31).

2. La formación social base de la formación política (1862/1868, 1868/1874,1874/1880, 1880/1886, 1886/1890) - Censos y regímenes electorales.

La concreción del Estado Argentino, dejó al descubierto la formación social subyacente que presentó como rasgo distintivo, la relación asimétrica existente entre porteños y provincianos, ejemplarmente representada y, por qué no, en cierto modo, formalmente 'superada' durante los debates habidos en la Asamblea Constituyente. 
Y decimos formalmente, porque muy diversa fue la efectividad humana desde entonces hasta nuestros días.

Por de pronto, si analizamos los veintisiete años que corren desde 1862 a 1889, la ciudad-capital (Buenos Aires) cambió sus caracteres patriota, semi-sencillo, semi-tendero, semi-curial y semi-aldea, transformándose en una ciudad con pretensiones europeas en distintos aspectos e instancias regionales, tanto en lo urbano, en lo socio-económico, en lo político, como también en lo religioso y literario.

- $1862 / 1868$.

El General Bartolomé Mitre (1821/1906) -quien murió a los 84 años y fue Presidente de la Nación, gobernador, legislador, periodista, militar e historiador- notorio adversario de Urquiza, peleó contra la Confederación -fue vencido en Cepeda en 1859- y resultó finalmente triunfante en Pavón (1861). Destacado estadista, su realismo político le llevó a responder de modo concluyente a quienes reclamaban la secesión y castigo para los vencidos, que correspondía comprender que la República Argentina debía tomarse como la habían hecho Dios y los hombres y que, con la ayuda del Creador, los hombres la irían mejorando. Sus ideas, plasmadas a través de sus obras, ilustran sobre el legado de las fuentes del pasado hispánico, de la Revolución de Mayo y de las épocas subsiguientes. En tal sentido,

“impresiona que Mitre haya podido escribir [...] en tiempos revolucionarios que el Código de Indias era más dulce y humano que el actual de los norteamericanos, que las crueldades de los conquistadores para con los indios habían sido atroces. Así como que la falta de historia propia es una de las causas más eficaces de la falta de fuerza moral y de espíritu público en nuestras Repúblicas.” (Levene, 1958:358).

Suscribiendo el sistema de ideas que había cobrado nueva vida en 1810, y que al decir de Moreno, provocara "una feliz revolución de las ideas”, Mitre declaró, fundadamente, su admiración por Moreno y Rivadavia. Admiración que, posteriormente, trasladaría a San Martín y Belgrano, en tanto fundadores de la Independencia argentina y americana.

La impronta política impresa por Mitre, llevó a N. Jitrik a sostener: 
"Derrotado políticamente el interior después de Pavón, el importante fervor cultural y transformista iniciado por Urquiza se detiene y Buenos Aires se lleva todas las energías progresistas del país, es decir que cuenta con los medios para un desarrollo 'Sarmientino' que no irradia por el momento sino que queda reducido a la provincia y a la ciudad. Buenos Aires refleja lo más importante del proceso nacional y deviene modelo único. En primer lugar, de ella, desde la primera presidencia de Mitre (1862) en adelante sale toda la política nacional, en ellas se concentra toda la inteligencia argentina y allí se instala, también, el laboratorio de las transformaciones concretas" (Jitrik, 1968:30).

Ya en 1839, desde El Iniciador, había proclamado la dignidad de la vida del espíritu, poniendo sus esperanzas en la juventud americana, a la que convocó a la unión y al trabajo.

También en sus escritos publicados en La Nueva Era -como "La montonera y la guerra regular", "La montonera sistematizada" y la "Necesidad de la disciplina en las Repúblicas"- investigó acerca de las instituciones de la sociedad civil y la vida de los pueblos.

A partir del $1^{\circ}$ de abril de 1846 y desde encendidas columnas en Los Debates, protagonizó todos los sucesos que acaecían junto al pueblo y sus dirigentes, preocupándose y ocupándose por la problemática que suscitara la violenta caída de la tiranía.

Un fragmento de la carta escrita por Sarmiento a Mitre -el $1^{\circ}$ de octubre de 1852 desde Santiago de Chile- señala la firme orientación política de Mitre:

“¿Qué hacen, qué piensan hacer? Trasluzco de los diarios hasta setiembre que he visto, que vuelve a presentarse la cuestión del año pasado. ¿Somos argentinos? ¿Somos porteños? Usted respondió, somos argentinos [...]” (Levene, 1958:362).

A no dudar, Mitre fue un cabal representante de la dialéctica existente, así como de la efectiva imbricación de lo histórico en lo jurídico, como lo demuestra al mencionar los tres ciclos que identificaron la conformación de lo nacional: lógica, sistema y régimen. (Levene, 1958:387).

Tanto su "Profesión de Fe", cuanto sus escritos complementarios en "Los Debates" ilustran acerca de las preocupaciones que aquejaban el sentir de Mitre en materia política y social, sin por ello dejar de destacar el carácter histórico de su contribución a la organización constitucional tanto de la provincia de Buenos Aires, como de la Nación. 
Poniendo de manifiesto su profundo idealismo -sin dejar de reconocer las sufrientes demandas del colectivo social, es decir de la ansiedad y el desconsuelo popular- bregó por introducir en el entramado social, una imagen alentadora sobre el destino y el genio moral de la nación argentina. Entre esos ideales figuraba en primer término el de la organización nacional, para lo cual era necesario que las provincias volvieran a la normalidad, restableciendo sus poderes propios, y que el pueblo pudiera expresarse libremente por el órgano de sus legislaturas, como en esos días lo hacía la Legislatura de Buenos Aires. Pensamiento que le llevara a decir,

“[...] el amor a la patria es un árbol siempre verde y cuyas hojas nunca son arrancadas por los vientos del otoño" (Levene, 1958:363).

El progresismo de sus ideas -por ejemplo, el pronunciarse a favor de la elección directa de los gobernantes- resultaron valiosos antecedentes históricos de nuestro derecho público electoral.

De la misma manera, la decidida lucha por la consecución de una real articulación social, quedó plasmada en su obra "Las garantías recíprocas" del 7 de abril, la que constituyó, al propio tiempo, una reacción contra el sectarismo y una ardorosa defensa de los derechos de los habitantes. (Levene, 1958:375) ${ }^{123}$

Una nueva legalidad nació, pues, tras la batalla de Pavón (Fayt, 1962: 481) ${ }^{124}$ ya que después de un período sin autoridad nacional legítima por haberse declarado en receso el poder ejecutivo de la Confederación y disuelto el legislativo- Mitre asumió por ley de la Legislatura de Buenos Aires las facultades constitucionales del ejecutivo y mantuvo las

\footnotetext{
${ }^{123}$ Dichas "garantías" constituyeron el escrito sobre Baldomero García, que había agraviado a la sociedad civil en la época de Rosas. Mitre al escribirlas, entendió que, precisamente en defensa del colectivo social y del derecho común de los partidos, debía reaccionarse contra tendencias sectarias. En tal sentido manifestó que Baldomero García debía dejar de ser considerado como el partidario de la dictadura de Rozas y convertirse en un ciudadano igual a los demás "[...] Queremos evitar -dice con amplia visión- que la República Argentina no se divida en dos sociedades distintas: una con derechos civiles y otra sin ellos, y que el manto de la libertad abrigue a todos sin excluir al último de sus hijos [...]"

${ }^{124}$ Acaecida el 18 se septiembre de 1861, produjo el primer gobierno de facto. La C.S.J.N., fijó los principios que otorgaron debido marco a las facultades ejecutivas y legislativas que debía desempeñar el gobierno. En tal sentido, y en relación a las atribuciones del Gral. Mitre en su carácter de encargado del poder ejecutivo nacional, decidió in re "Baldomero Martínez y otro", "que el gobernador de Buenos Aires [...] fue autoridad competente para conocer y decidir en esa clase [...] por ser quien ejercía provisoriamente todos los poderes nacionales después de la batalla de Pavón, con el derecho de la revolución triunfante y asentida por los pueblos y en virtud de los graves deberes que la victoria le imponía".
} 
relaciones exteriores de la Confederación Argentina, hasta la reunión del Congreso Nacional.

Establecido el mencionado Congreso, Mitre fue designado como "Encargado del Poder Ejecutivo Nacional", para, posteriormente, materializados ya los comicios de “electores para Presidente de la Nación”, ser elegido como presidente por el período 18621868.

Mitre estableció una creciente centralización del poder; creó instituciones nacionales; sancionó la ley de territorios nacionales; nacionalizó el "Código de Comercio" vigente en el Estado de Buenos Aires- y encomendó a Dalmacio Vélez Sarsfield la redacción del Código Civil; organizó también la Justicia Federal; intentó salvar el problema pendiente de la capital mediante la "ley de compromiso", aunque la misma perdió vigencia sin resolver la cuestión.

A efectos de formar élites dirigentes -y sin desconocer la importancia que revestía la educación primaria para el crecimiento de un país- optó por instituir el Colegio Nacional de Buenos Aires (ex Colegio de Ciencias Morales) y otros similares en Salta, Tucumán, Catamarca, San Juan y Mendoza, con la finalidad de fomentar los estudios universitarios y la acción política.

Estableció el Ejército Nacional, que actuó, cuando corría el año 1865, en la guerra con el Paraguay. Guerra que -como sostuviere algún autor- no contó con la anuencia del pueblo argentino que siempre había considerado al pueblo paraguayo como parte de las Provincias Unidas. Esto generó conflictos en las provincias, a lo que se sumó entre los años 1866-1867, el estallido de la Guerra Civil.

No obstante, los resultados obtenidos en la política interna de la provincia, permitieron ratificar el pensamiento y la acción de Mitre, coyuntura ésta que condujo a que el colectivo todo debiera subordinarse a la unión nacional.

$-\quad 1868 / 1874$.

Luego de intensos cabildeos habidos entre B. Mitre y Lucio V. Mansilla, entre otras figuras, la fórmula integrada por Domingo Faustino Sarmiento-Adolfo Alsina, fruto de un acuerdo entre el Partido Liberal de seis provincias y el Partido Autonomista de Buenos 
Aires, resultó triunfante para desempeñar la presidencia y vice-presidencia de la República por el período $1868 / 1874$.

Sarmiento, a la sazón en misión diplomática en los Estados Unidos de Norteamérica, supo del resultado de las elecciones durante el viaje de regreso, asumiendo el cargo el 12 de octubre de 1868.

El ejercicio de la primera magistratura, puso en sus labios un lema "Provinciano en Buenos Aires, porteño en las provincias y argentino en todas partes" que expresa fielmente la mencionada confluencia de fuerzas. Aunque sus ideas "progresistas" tuvieron como epicentro a Buenos Aires, su situación de 'mediador' (en tanto provinciano) le permitió introducir sus reformas también en el interior lo cual supuso el surgimiento de determinadas esferas sociales de apoyo, ya que creó “lazos simpáticos con los sectores urbanos, cultos y burgueses" (Jitrik, 1968:37).

La Guerra con el Paraguay, provocó su enfrentamiento con Buenos Aires. Ello, por cuanto si bien la conducción fue esencialmente porteña ya que estuvo en manos de Mitre, las tropas que constituían el ejército, se reclutaron en las provincias. Esta situación ocasionó, asimismo, su decidida enemistad con Alberdi, reflejada en El crimen de la guerra. (Eggers-Brass, 2006:334). ${ }^{125}$ Escenario que hizo crisis cuando Sarmiento impuso como su sucesor otro provinciano: Nicolás Avellaneda.

Preocupado por el fomento de la ciencia y la enseñanza y entendiendo la educación como instrumento prevalente en el proceso de cambio y modernización del estado, a través del ministro Nicolás Avellaneda, puso en práctica una nueva y pujante política educativa. Ello, no sólo en el convencimiento del rol indelegable del Estado en esta materia, sino en repuesta a las cifras emanadas del Censo realizado en el año 1869, señalando que el $82 \%$ de la población era analfabeta.

\footnotetext{
125 Sostiene Eggers-Brass al respecto: "Quedaban para lamentar -además de la masacre injusta del pueblo paraguayo y la destrucción de su pujante economía- decenas de miles de muertos argentinos, una gran deuda contraída debido a la guerra y el pésimo estado de salud de la población. Los liberales festejaban el aniquilamiento de las montoneras federales, porque la guerra fue una buena excusa para mandar al frente a los gauchos legales.".
} 
En la implementación de dicha política, se inclinó por contratar mujeres como docentes, así como por traer maestras de los Estados Unidos; en 1870 creó la Escuela Normal de Paraná y estableció un sistema de becas para pobres. (Eggers-Brass, 2006:337). ${ }^{126}$

Entendió que en los Colegios Nacionales habrían de formarse las élites dirigenciales, en tanto las Escuelas Normales resultaban aptas para educar a las clases medias y bajas.

Al respecto señala J. Alvarez, que enviar al colegio solo una parte de la población escolar no significaba resolver el problema de conflictividad potencial vigente en el colectivo, ya que la enseñanza de la lecto-escritura y el conocimiento matemático adquirido en la escuela primaria, no fue suficiente para crear lazos solidarios entre los argentinos. No bastaron para suscitar o consolidar el sentido patriótico en el entorno de 'lo' nacional, ni contar con héroes comunes.

En rigor,

"la escuela exagera las ventajas del país, ocultando sus defectos y necesidades [...] en verdad así entendida, la escuela primaria no evitará las guerras civiles." (Álvarez, 1984:130-135)

Fundamental deviene mencionar otras problemáticas que presentó el 'escenario social': a) la 'cuestión del indio' -que intentara solucionar Alsina mediante el trazado de una 'zanja' y al que diera finiquito Roca mediante el Ejército- y b) la discusión sobre el establecimiento de la 'capital federal', que tuviere como principales hitos los años 1778 y 1813, hasta su definitiva dilucidación por obra de Avellaneda.

Del mismo modo, la fiebre amarilla en 1871 y el cólera de 1877, fueron dos sucesos que impactaron sobremanera sobre el tejido social, promoviendo preocupación por la higiene y salubridad públicas, y que obligaron a vastos sectores de la población a migrar, fundamentalmente, desde el Riachuelo.

Los hombres de color que coexistieron junto a los gauchos, padecieron similares abusos, en lo que se refiere a su incorporación forzada a las fuerzas que defendían la frontera luchando contra los indios, en resguardo de ganaderos y latifundistas. La guerra

\footnotetext{
${ }^{126}$ Y agrega: "Sarmiento afirmaba: 'Hay, es verdad, becas para pobres, pero estos pobres son los de la democracia decente. Pídelas un diputado, un amigo, alguien; pero este alguien es de buena familia" ".
} 
con el Paraguay, de la que también debieron participar obligadamente, como también la aludida fiebre amarilla, devastaron esta minoría. (Eggers-Brass, 2006:350). ${ }^{127}$

Pese a todo, y sin que importase el lugar en el que acaecían los hechos, los provincianos se vieron obligados a entender una nueva forma de política nacional superando los conflictos interprovinciales, bregando por la unidad nacional. Unidad nacional que, lejos de considerar los intereses provinciales, contempló como prevalentes los de la clase hegemónica confundiendo sus objetivos específicos de clase con los existentes en todo el país.

Sintetizando esa realidad, expresó Jitrik (1968:43)

"A partir de la superación de estos escollos, el camino le queda abierto, nada se opone a que la unidad, la oligarquía nacional, realice su gran experiencia de transformación para lo cual se valdrá del pensamiento liberal, amasado a partir de las especulaciones socialistas de los jóvenes de la Asociación de Mayo y consolidado teóricamente por hombres como Alberdi, Mitre, Sarmiento y Avellaneda que, desde el poder, fueron creando las condiciones para que dicho pensamiento pudiera encarnarse en la realidad".

- $1874 / 1880$.

Al igual que Sarmiento, Nicolás Avellaneda llegó a la presidencia como resultado de una alianza constituida entre fuerzas políticas del autonomismo porteño y las habidas en diferentes provincias. No contó, en rigor, aunque ese fue su anhelo, con un partido político unificado. Circunstancia a la que se agregó la necesidad de imponer roles de autoridad dado el enfrentamiento armado con el interior.

Además, su pugna con el Partido Nacionalista continuaba aún y ello le llevó a modificar la ley electoral. Con la abolición de la lista única y el establecimiento del sistema de circunscripciones uninominales, otorgó a los partidos minoritarios la posibilidad de lograr bancas en el Congreso.

Este escenario político sufrió cambios, cuando "parte" del grupo mitrista aceptó la conciliación. Y decimos "parte" porque algunos: los más jóvenes y progresistas, se

\footnotetext{
${ }^{127}$ Señala Eggers-Brass que, "Diezmados por las guerras o las pestes, los que sobrevivieron comenzaron a luchar por sus derechos a través de periódicos como La raza africana o sea El demócrata negro, o El proletario. En la Constitución se había reconocido finalmente la igualdad y libertad de todos los habitantes de la Nación argentina, pero en salones y cafés continuaba la segregación. Actualmente muchos de sus descendientes, mezclados por generaciones con otros criollos, mestizos e indios, ya no se distinguen del resto de la población nativa”.
} 
escindieron del autonomismo, estableciendo el Partido Republicano, entre quienes se distinguieron Leandro N. Alem, Pedro Goyena, Aristóbulo del Valle, Roque Sáenz Peña, Lucio V. López, y José M. Estrada. Partido que, por otra parte, tuviere efímera duración ya que la muerte de Adolfo Alsina, Ministro de Guerra de Avellaneda, señaló su fin.

Fracturada entonces la conciliación inicial entre mitritas y oficialistas, numerosos ex republicanos retornaron al autonomismo reagrupándose en una nueva fuerza política, que fuera denominada por Sarmiento como Partido Autonomista Nacional (P.A.N) y que llevó como candidato presidencial a Julio A. Roca, quien desempeñaba -desde el fallecimiento de Adolfo Alsina- el cargo de Ministro de Guerra.

Como no podía ser de otro modo, la crisis internacional habida a nivel económico en el año 1873, tuvo sus efectos en nuestro país durante los siguientes años. Ello incrementó el déficit en el comercio exterior e interrumpió las inversiones, llevando a la quiebra a muchas entidades. Situación ésta, que originó distintos comportamientos, entre los que señalaremos: i) el regreso de muchos de los inmigrantes, a sus países de origen; ii) el cuestionamiento del pago de la deuda externa (cuyo cumplimiento Avellaneda defendió ante el Congreso); iii) la reducción de sueldos y pensiones; iv) la demora en el pago de los haberes correspondientes a los empleados públicos; v) decretándose, por último, el curso forzoso del papel moneda, para, posteriormente, realizar una emisión monetaria magüer la obligada depreciación.

Con relación a la política exterior, bajo su presidencia se firmó el tratado definitivo de paz con Paraguay; continuándose las tratativas -por cuestiones de límites- con Chile que habían comenzado durante la presidencia de Sarmiento y que finiquitaran durante el mandato de Roca con el acuerdo de 1881.

También cobró auge durante su gestión el desarrollo de las bellas artes, la literatura, y el teatro, lo que trajo aparejado la transformación de la ciudad capital.

Tocó a Nicolás Avellaneda, ocuparse principalmente de la inmigración. La Ley dictada en 1876

"trató de proteger al inmigrante, estableciendo comisiones dependientes del Departamento Central, intentando controlar los fraudes y asegurándole alojamiento durante cinco días después de arribado al país y trasladado hasta el punto de residencia." (Eggers-Brass, 2006:348). 
Además fueron mejor aceptados -tanto en la estancia como en los puestos- que los nativos del país, vale decir los gauchos, pues cuando se movilizaba la guardia nacional o acontecía una campaña electoral, el hacendado podía verse privado de ellos ya que los peones eran inexorablemente reclutados.

De allí que los inmigrantes pioneros, integrantes de las clases populares y equiparados a los criollos pobres, poco a poco fueron logrando que sus hijos comenzaran a ocupar puestos dentro la emergente clase media.

Finalizando su mandato, Buenos Aires fue declarada capital de la República por Ley $\mathrm{N}^{\circ}$ 1029, del 21 de septiembre de $1880{ }^{128}$, declaración que Alberdi consideró como el primer y auténtico hecho revolucionario.

El mensaje del P.E. Nacional con que elevara el proyecto consignó en uno de sus párrafos

“[...] La ley que declara a Buenos Aires Capital de la República no hace sino ratificar un hecho que es el resumen y una de las causas a la vez de toda nuestra historia”. (Alberdi, 1964:225) 129

No obstante -y fundamentalmente, porque ofreció soluciones concretas a los problemas debatidos durante los treinta últimos años- el año 1880 comenzó a cobrar sentido al cerrarse -después de Caseros- el período nacido con, si no antes, la Revolución de Mayo. Sin embargo, no fue lo suficientemente fuerte, para aliviar la problemática en que se encontraba sumergida la débil y fragmentada sociedad civil argentina.

- $\quad 1880 / 1886$.

El último cuarto de siglo XIX constituyó para nuestra formación el segundo pacto colonial (imperialismo y dependencia) ya no con España sino con Inglaterra, encaminando a las élites locales a producir las materias primas destinadas a ser transportadas y comercializadas por la metrópoli.

\footnotetext{
${ }^{128}$ Sancionada por el Congreso Nacional el día 20 de septiembre de 1880 y promulgada el día siguiente por el Poder Ejecutivo, presidido por Nicolás Avellaneda.

${ }^{129}$ Refiriéndose a la importancia de las hostilidades mantenidas por Tejedor contra Roca, expresó Alberdi que: "La erección de la ciudad de Buenos Aires en Capital definitiva de la República Argentina[...] es la primera revolución real y efectiva que se hace a la Constitución que tenia este país, cuando era Colonia de España [...] La soberanía popular de la Nación existió de nombre, como idea, como principio de derecho[...]" toda vez que la Ordenanza de Intendentes creó la institución Provincia-Metrópoli que desapareció con el dictado de la Ley de Capitalización y el debido correlato de la Ley por la que la Legislatura Provincial cedió la Ciudad de Buenos Aires (26 de noviembre de 1880).
} 
Situación ésta que permitió al imperio apropiarse de gran parte de los medios de producción (tierras, minas, fábricas) existentes a la época. (Eggers-Brass, 2006:372)

Luego de cruentos enfrentamientos con Carlos Tejedor -gobernador y representante de los intereses de la provincia de Buenos Aires- quien también aspiraba a la presidencia de la Nación (v. supra n.130) ${ }^{130}$, el año 1880 -llamado de la Organización Nacional- señaló la llegada al poder de Julio Argentino Roca, a no dudar, cabal representante de las propensiones del interior.

Así, reunido el colegio electoral, ciento cincuenta y seis (156) miembros votaron por Roca, en tanto Tejedor sólo contó con los votos de Buenos Aires y Corrientes. Tejedor no aceptó la derrota, alzándose en armas. Situación que, luego de intensas luchas, finalizó con su rendición y posterior renuncia.

Roca -quien había llegado a la presidencia de la mano del Partido Autonomista Nacional (P.A.N.)- asumió el 12 de octubre de 1880, convirtiéndose dicho Partido en

“una suerte de partido único, dominado por el presidente de la nación”. (Eggers-Brass, 2006:372).

Para llegar a la primera magistratura, y producto de su inventiva, se valió Roca de un aparato de poder útil al ideario: "la Liga de Gobernadores" que marcó el comienzo de una clase nacional: la oligarquía, conformada por propietarios, terratenientes, ganaderos, y que, en sus orígenes, ya denominásemos "burguesía terrateniente vacuna". (Linchetta, 1988). Clase ampliamente vinculada con Europa y, por ende, cultora y práctica de la idea de 'progreso indefinido'.

En aras de concretar su pensamiento propuso el "rearmado" de la sociedad civil, sin, en apariencia, cuestionar el origen político. Pese a ello, y dado su liberal-positivismo, recibió la negativa del grupo católico, sobre todo en temas de educación, familia y concepción de la persona humana (lo que condujo a romper relaciones con la Santa Sede).

De origen provinciano (tucumano) al igual que sus dos inmediatos antecesores, heredero de la Generación del '37 y un militar 'estilo europeo', Roca impuso a su gobierno

\footnotetext{
${ }^{130}$ Completando la n. 129, cabe señalar que en septiembre de 1887 la Legislatura de la provincia de Buenos Aires cedió -mediante la Ley provincial $N^{\circ} 1889$ - los municipios de San José de Flores y Belgrano para ensanchar la Capital Federal. Por Ley Nacional N ${ }^{\circ} 2089$, fueron federalizados esos territorios incorporándolos al municipio de la Capital de la Nación.
} 
una impronta progresista, aunque decididamente positivista y liberal, lo cual introdujo un enorme respeto por la ciencia y un paralelo demérito por la metafísica, esto es, por lo relativo a la religión y la moral. (Jitirk, 1968:195) ${ }^{131}$

Iniciado bajo el lema “Administración y Progreso”, este plan persiguió, en esencia, el avance de la frontera a cualquier precio, enfatizando la valorización territorial y el desarrollo regional.

Bregó, asimismo, por un estado "modernizado", creando un aparato burocrático, decididamente imprescindible para una formación política formalmente "descentralizada", aunque políticamente "unitaria".

En su programa de gobierno, la educación ocupó un lugar destacado. Para concretar tal cometido, reunió el Congreso Pedagógico (1882/1884) cuyos encendidos y encontrados debates culminaron con la elevación al Congreso de la Nación de un "proyecto" y la posterior sanción de la Ley 1.420 estableciendo la educación laica, común y obligatoria.

Sin embargo, ello no evitó que continuaran formándose, mayoritariamente, aquellos que pertenecían a la clase dirigente, dificultando la concreción del propósito perseguido, ya que sólo una parte de la población estaba escolarizada, por lo que -esa deficiencia estructural- no alcanzó a resolver la cuestión del potencial votante.

Es evidente que esta generación estuvo dedicada a implementar medidas conducentes a lograr la "socialización" de la comunidad. La impronta de la innovación y transformación constituyeron su ideología en relación a lo político, en tanto actividad tendiente a la realización del hombre. De allí, la enjundia puesta en la creación de instituciones y su visión de futuro, como así también el lugar dado a la "cultura". Desde el momento que, contar con "ella", el ser "culto" configuró un testimonio distintivo de la intelectualidad, formada, en su mayoría, por quienes detentaron roles dirigenciales.

\footnotetext{
${ }^{131}$ Refiriéndose al lenguaje científico utilizado por esta generación, señala Jitrik, la fisura con el pasado regido por el pensamiento de la Iglesia, para lo que recurre a fragmentos de la tesis para el doctorado, publicada en 1884, de Ramón J. Cárcano, "De lo hijos adulterino, incestuosos y sacrílegos", "[...] El espíritu de la ley y el espíritu del pueblo marchan, pues, paralelos, armónicos, sin adelantar el uno y quedarse el otro. Pero hay veces que las leyes por su acción, suelen oponerse al progreso de las ideas, y permanecen como sepulturas abiertas al pensamiento que avanza. Entonces las sociedades retroceden, se paralizan, sufren y se nubla y oscurece su desarrollo. La misión del legislador es por eso delicada y difícil, llena de peligros que salvar y de responsabilidades que cubrir [...]"
} 
Sin embargo, no todos fueron intelectuales. Muchos ricos ganaderos o comerciantes que vivían de la mera ostentación tratando de imitar al grupo que flanqueaba a Roca, formaron parte de la élite del régimen. (Jitrik, 1968:78) ${ }^{132}$

Unos y otros adoptaban actitudes dualistas y hasta contradictorias -reiterando conductas habidas desde el comienzo de nuestra historia- oposición entre campo y ciudad, entre materia y espíritu o civilización y barbarie. Por lo que, mientras la ciudad fue considerada, en su momento, como sinónimo de cultura y realización del espíritu, el campo constituyó el último refugio al que podía apelarse. (Jitirk, 1968:197) ${ }^{133}$

Al igual que el ritmo adoptado para el sub-sistema político, Buenos Aires, impuso al Estado todo, su estructura económica -sinónimo de expansión de la oligarquía- guiada por un accionar fundamentado en que el país no podía mantenerse aislado, ni pretensamente autónomo, sino, por el contrario, debía integrarse y formar parte de un orden económico fuerte (pro-británico).

Establecido, pues, internacionalmente, el rol a desempeñar por nuestra formación política, Argentina debió cumplimentar ciertos requisitos, llenar determinados recaudos, a saber: 1) contar con una ganadería óptima (cría y engorde) y con el crecimiento de la agricultura (la vieja estancia se transformó y el alambrado cobró presencia); 2) los ferrocarriles no sólo debían valorarse como modo de comunicación y civilización del país, sino que, per se, constituían un negocio capaz de introducir al país en la revolución industrial y 3) en relación a la mano de obra, no bastaba la de los nativos del país (gauchos), sino que debía agregarse la de los inmigrantes (postura ya asumida por Mitre). (Jitrik, 1968:56 y 224) ${ }^{134}$

\footnotetext{
${ }^{132}$ Dice este autor que "El signo más evidente de este grupo es la estridencia y el mal gusto, la más perfecta contrafigura de los padres de esta generación, los héroes de la independencia y de la proscripción, de los intelectuales que dieron forma a la Argentina que se apoya en ellos, y aun de los representantes más dotados que, como Cané, se avergüenzan de sus contemporáneos: 'Nuestros padres eran soldados, poetas y artistas; nosotros somos tenderos, mercachifles y agiotistas' ",.

${ }^{133}$ Manifiesta al respecto, "La ciudad es el paradigma vital de la alta burguesía, no se puede vivir en el campo, que es la 'antivida'. Y la vida en la ciudad está hecha de superficialidad, de dudosa moral” haciéndose eco de las palabras que Eugenio Cambaceres escribiera en "El campo: un narcótico inaguantable", en Silbidos de un vago, cap. XII, ed. Castellví, 1956. En tanto señala en p. 259, refiriéndose a los dichos de Cambaceres en "El regreso al campo", Sin rumbo, cap.XXV, ed. Castellví, p.182: "Si en un momento la ciudad era el único recinto aceptable hoy se está tornando irrespirable, mefítico, infecto. Todo el mundo se ahoga en el hacinamiento y la incomodidad, en el lujo y el hastío. Estamos llegando al final de una experiencia y hay que buscar aire puro, respiración. Se impone el regreso al campo".

Sostuvo Jitrik que: "Los inmigrantes fueron traídos o alentados a venir para realizar tareas agrarias, ganadería y agricultura. Para lo primero, tropezaron con la hostilidad proletaria y un sistema de explotación que no exigía mucha mano de obra, para lo segundo con la falta de tierras y de una estructura agraria en la
} 
Con todo, ni el hecho de finalizar la "ocupación" o conquista de los territorios habitados por los indígenas -lucha que comenzara con la "zanja" establecida por A. Alsina durante la presidencia de Avellaneda- y que registrase hitos durante los años 1879, 1881 y 1885; ni el mejoramiento en los establecimientos de campo por la tecnificación; ni las inversiones; como tampoco las obras públicas y urbanísticas en el sector público, lograron una 'total' inserción en la economía-mundo, decididamente liderada por Inglaterra.

Por otra parte la adquisición de roles identitarios, de valores y creencias compartidos -en el sentido profundo de argentinidad- se encontraban, aún, inmaturos. Eduardo Wilde, en 'Fígaro', del 30 de septiembre de 1884, señaló en 'Ser Argentino',

“[...]Todavía es una preeminencia subjetiva eso de ser porteño[...]En política[...]es necesario ser porteño y argentino, o más bien, ser argentino antes que localista. Ahora no debe haber porteños en el sentido de la palabra, como no hay catamarqueños, sanjuaninos, ni cordobeses. Hay argentinos; hay una capital en la República y hombres libres, no localistas en todas partes [...] Tenemos la capital legal, la organización política del país sancionada y convertida en hecho, pero no tenernos aún la posesión de estado hecha conciencia, dato íntimo que no necesite ya de la afirmación ni de la ratificación" (Jitrik, 1968) ${ }^{135}$

- $\quad 1886 / 1890$.

A pesar de favorecer Buenos Aires la candidatura de Dardo Rocha, un porteño, Roca logró imponer como Presidente a un cordobés -su concuñado Miguel Juárez Celmanquien asumió en 1886.

\footnotetext{
que pudieran insertarse. Además, no siempre los inmigrantes tenían formación agraria o les interesaba la tierra". Agregando más adelante: "Los inmigrantes ponen la nota desagradable en tanto distinción, en tanto matiz. No sólo están ahí sino que crean problemas sociales, obligan a pensar después de haber hecho sentir: hacinamiento, miseria, enfermedad, delito, todo se junta para descolocar al hombre del 80, tan seguro de sus modales". (De Santiago de Estrada en "El Conventillo",en Viajes y otras páginas literarias, ed. Estrada, Primera edición, Barcelona, 1889, p.111).

${ }^{135}$ El autor cita la obra de Wilde, reproducida por Florencio Escardó, Wilde, ed. Santiago Rueda, 1959, pág. 123. También Jitrik (1968:194), al referirse a qué significa vivir en Buenos Aires para las facciones encontradas señala que "La enemistad entre porteños y provincianos es ahora, en sus sobrevivencias, unilateral: los provincianos no quieren mal a Buenos Aires, la consideran suya, se sienten apegados a ella, trabajan por su grandeza y, sinceramente, desearían que la gran ciudad y sus hombres reconocieran sus esfuerzos", y se apoya en los sostenido por E. Wilde, en un fragmento de su discurso sobre 'Arrendamiento de las obras de salubridad', 1887, p.14, en el que manifiesta su amor por la ciudad de Buenos Aires: "[....no puedo ser sospechado yo tampoco de no tener amor a este pueblo. En él puede decirse que he aprendido a vivir; en él me he desenvuelto; lo conozco intimamente [...]lo conozco desde el hospital hasta la más alta aristocracia, hasta la más alta sociedad, ya que aquí no hay aristocracia. Pienso vivir en él toda mi vida."
} 
Los desacuerdos habidos entre Roca y Juárez, condujo al alejamiento del primero, convirtiéndose Juárez Celman en el "único", por lo cual su gobierno recibió el nombre de Unicato.

Durante su gestión, acentuó las medidas laicas comenzadas por Sarmiento. En tal sentido, dictó un conjunto de leyes que modificaron la fisonomía de la sociedad argentina, como la creación del Registro Civil, la institución del Matrimonio Civil y la secularización de los cementerios.

En la faz económica, pese a que se privatizaron los ferrocarriles -al igual que otras empresas estatales- el Estado continuó otorgando concesiones alimentando su construcción, todas con garantía estatal de ganancias aseguradas, liberación de impuestos y cesión de tierras fiscales. (Eggers-Brass, 2006:385).

Existía, más allá de las públicas declaraciones formuladas, una importante deuda interna y externa, acompañada por el fomento de la especulación y el aumento de empréstitos, lo cual solo generaba ganancias para un acotado número de terceros y comisionistas; la emisión monetaria, provocó, asimismo, inflación. Lamentable contexto que se completó, con un perturbador proceso de especulación que tuvo como escenario la Bolsa -por lo que fue clausurada en 1889- y operaciones fraudulentas en tierras.

Aunque Juárez Celman intentó restarle importancia, la crisis en Europa -affaire Baring Bros de Inglaterra- constituyó el definitivo detonante en la ya golpeada situación de nuestra formación política,

Recopilando la década del ' 80 , diremos que en lo socio-económico, y como consecuencia de la alianza conformada entre algunos intelectuales y grupos económicos, durante el 'régimen' surgió la alta burguesía porteña de neta raigambre liberal, la oligarquía.

Y, como manifestase Jitrik, si bien en un comienzo,

"la relación entre dirigentes e intereses económicos directos había permitido un modo de vida patriarcal, modo de vida que vendría a ser la síntesis entre "aldea" - con sus connotaciones de pobreza material- y sentido heroico de la existencia, ello no constituyó impedimento alguno para establecer el contacto directo entre dignatarios y pueblo: la vida es sencilla pero espiritual, la cultura europea no interfiere hábitos criollos". (Jitrik, 1968:30). 
No obstante, nuevos vientos llevaron a que la economía comenzara a planificarse por el surgimiento de esa oligarquía- y a que los intelectuales -detentadores de roles de autoridad- asumieran la responsabilidad desde el gobierno.

Las turbulencias generadas al interior de la nueva clase social y su incidencia en el colectivo, modificaron, necesaria e inexorablemente, las relaciones del proceso de producción ante el surgimiento de una nueva comprensión de la realidad socio-económica.

Se abandonó el sencillismo patriarcal, reemplazándolo por un modo de vida aristocrático -que cada día cobró mayor fortaleza- y cuyos caracteres distintivos fueron:

"el origen criollo, los méritos intelectuales o militares de cercanos antecesores, la incidencia en la vida pública y las responsabilidades que se asumen...” (Jitrik, 1968:31)

El hecho que Buenos Aires se hubiese transformado en el polo de gravitación del país, no constituyó obstáculo alguno para que mediaran históricas demandas, como tampoco, para licuar, o al menos esclarecer, sus propias contradicciones (v.g.; estructura ganadera vs. estructura agraria). (Jitrik, 1968:33) ${ }^{136}$

De manera que, son esas contradicciones -existentes $a b$ initio de nuestra formación y no superadas- plus, la atmósfera de descontrol económico-financiero (deuda externa e interna, inflación desmandada, especulación) con las que finaliza esta última década, las que otorgan obligado contexto a la crisis que se aproxima en el subsistema de poder y el consiguiente, aunque fracasado, acto revolucionario.

Habida cuenta de lo expuesto, la formación política argentina (conf. doctrina de Ferrero, 1943 a) establecida bajo un poder "cuasi-legítimo", fue portadora de un pre-anunciado déficit de legitimidad, toda vez que, al igual que los diferentes fenómenos de deslegitimación -manifestados por los legitimantes a través de concretos y efectivos comportamientos desviados o apáticos- suscitaron, a lo largo del período analizado, una sensación de incertidumbre e inestabilidad proporcionando una legitimidad parcial, por inexistencia de integración social e, insistimos, la falta -por carencia y/o fraude electoralde un proceso de legitimación que "reconociese" el concreto poder.

\footnotetext{
136 Señala Jitrik que las relaciones materiales de producción muestran que: "La estructura básicamente ganadera de Buenos Aires constituye una base indudable de los planes liberales pero no es su sustento absoluto porque de pronto los gobernantes creen que se puede diversificar la economía por medio de la agricultura; lo que hay, entonces, son coincidencias parciales que se rompen cuando, de una manera u otra, el intento de diversificación se manifiesta”.
} 
Ecuación que dio, como resultado final -dado el solapamiento existente entre el ordenamiento jurídico y la carencia de una auténtica y real participación popular- el sometimiento del colectivo a una legitimidad "adoptada".

\section{CAPÍtULO II}

\section{Crisis por déficit de legitimidad.}

1. La década.

En palabras de H. Sábato (2003b: 14),

“[...] las prácticas de poder concretas que desarrollaron las propias elites con frecuencia 
violaron aspectos fundamentales del ideario que estaba en la base de su legitimidad, provocando tensiones y contradicciones en el seno mismo de las clases dirigentes" 137

Situación que, en una suerte de ósmosis, enturbió la única relación existente -el sufragio- entre representante y representado. La prístina elección de instituciones y "formas" republicanas al separarnos de la monarquía, condujo a interrogarnos sobre ¿Cuáles fueron los detonantes socio-políticos que forzaron el cambio habido en las prácticas políticas, impactando en la representación? Y ¿cuáles las habidas en el proceso de legitimación y el lógico correlato de la atribución de legitimidad al concreto poder?

A no dudar, las variaciones provocadas en el entramado social, surgieron como lógico corolario de una mayor actividad asociativa (profesionales, logias masónicas, clubes sociales y culturales) que permitió, en nuestros lares, la formación de una incipiente sociedad civil -a través del ejercicio de la acción comunicativa- y su aparición en la esfera de "lo" público. Postura que, como racional y prudente respuesta, llevó a los firmantes del Acuerdo de San Nicolás a suprimir el "mandato imperativo", propio de las desigualdades jurídico-políticas existentes en la sociedad colonial, sustituyéndolo por el "mandato libre".

Planteado el tema, realizaremos entonces, un breve análisis y cotejo sobre temas que guardan íntima relación con los regímenes electorales y censos ocurridos durante el período transcurrido entre los años 1821/1914. Especial énfasis ocupará la etapa que va desde 1852 a 1880 (o pre-partidaria) a efectos de esclarecer cómo y quiénes podían elegir y ser elegidos en la segunda mitad del siglo XIX, a nivel nacional.

Como dijésemos en el capítulo anterior, la legislación electoral había nacido en 1821, en el afán de dotar de publicidad y visibilidad al procedimiento electoral a construir, basado en la pública deliberación. Prístinos ensayos que finalizaron a partir de 1835, con la entronización de Rosas, sus adoradores y el paralelo y desmesurado accionar faccioso y sectario que caracterizara a sus seguidores. Proceder embretado en un tipo de visibilidad plebiscitaria "que negaba toda posibilidad de disenso con el objeto de resaltar, casi

\footnotetext{
${ }^{137}$ Indica Sabato (2003b:21): “En algunos casos, la relación entre dirigentes y bases estaba cimentada en vínculos de dependencia social; en otros, se trataba de lazos creados en función de la vida política; pero en todos ellos las prácticas electorales, heterogéneas y complejas, contribuyeron de manera decisiva a la articulación de redes políticas que incorporaron a distintos sectores de la población al juego electoral, así como a la creación de liderazgos y tradiciones especificamente políticos."
} 
exclusivamente, la adhesión unánime al jefe de gobierno” (Ternavasio, 2003:59) ${ }^{138}$ y obviamente alejada de la vinculatibidad aristotélica. (Linchetta, 2005: 555-556 y cc.)

El promisorio intento de formar una ciudadanía hábil quedó trunco, al menos en lo referente a la creación de conciencia cívica por medio del sufragio ya que, como tenemos dicho el ciudadano no nace, sino que se hace. (Guerra, 2003b: 33) ${ }^{139}$

Durante este lapso (1821/1835), fueron tantos y violentos los fraudes (Ternavasio, 2003a:73) ${ }^{140}$ cometidos en los pseudo-comicios -circunstancia agravada por la obligada emigración de los opositores a la dictadura- que, el no contar con el acto eleccionario, no generó demasiada nostalgia. Pensamos, sin embargo, que la desaparición de ese mecanismo anuló la incipiente práctica democrática y con ello la formación, más temprana, de partidos políticos -primigeniamente entendidos como formas de asociación política, grupos e individuos que en ejercicio de la política plenaria, ambicionaban llegar al poderfavoreciendo el accionar de las elites dominantes, en función de herramientas de presión y manipulación electoral (facciones).

Semejantes en la generalidad de las disposiciones establecidas, las distintas leyes introdujeron -en un intento por perfeccionar el ejercicio de los comicios- algunas diferencias específicas que el momento propiciaba. Por ello, aunque sesgadamente, importante deviene conocer cómo fueron los mecanismos electorales a través de los cuales pudo expresarse el entramado social.

Por otra parte, comparando los censos llevados a cabo desde el año 1849 (elecciones de 1853), y como ya señaláramos, con el comienzo de la inmigración, la población se duplicó entre censo y censo.

Así, con el Censo de la Confederación 1857 (1.210.000 habitantes) y el dictado de la Ley 140 (5/10/57), fue organizado el primer régimen electoral por el cual se estableció el sistema de lista completa. El sufragio -que podía emitirse en forma escrita o verbal- era

\footnotetext{
${ }^{138}$ Destaca la autora (en nota 3) que con los conceptos de publicidad y visibilidad "se busca detectar los sentidos de tales nociones en relación a los procesos electorales y la configuración del espacio público, entendido éste como el ámbito de disputa por el poder en el que se entrecruzan prácticas formalizadas en la normativa con otras no contempladas en la letra de la ley"

${ }^{139}$ Sostiene el historiador: "Ser y sentirse ciudadano no es algo "natural", sino el resultado de un proceso cultural en la historia personal de cada uno y en la colectiva de una sociedad". V. de igual modo Linchetta (2006a).

${ }^{140}$ Fraude, dice Ternavasio, entendido como '[...] el 'ocultamiento' de mecanismos tendientes a adulterar materialmente los resultados de los votos"; y su paralela "[...] aceptación como mecanismo de producción de poder político".
} 
personal (masculino y mayor de 21 años), facultativo y no secreto. Esto es, de clara inspiración "alberdiana" sobre la base de la doctrina de la pureza del sufragio o voto calificado. No podían votar los sordo-mudos, ni los eclesiásticos, como tampoco aquellos que no cumplieren con los requisitos de ciudadanía. ${ }^{141}$

Dicha norma fue modificada por la Ley $N^{\circ} 207$ del 4 de julio de 1859 que también estableció el sistema de lista completa y el voto público, pero no obligatorio. Ese año se efectuó un nuevo censo (De la Fuente), marcando un ligero crecimiento poblacional que ascendió a 1.304.000 de habitantes.

En noviembre de 1863 se dictó la Ley 75, variando la anterior en algunos aspectos: determinar cómo debía fijarse el registro electoral y realizarse las asambleas electorales. Se permitió el voto a mayores de 18 años, agregándose requisitos que, discrecionalmente, inhabilitaban sufragar.

La Ley $\mathrm{N}^{\circ} 209$ dada en octubre de 1866, solo reformó temas vinculados a los procedimientos para la realización del acto eleccionario.

A esta norma se agregaron otras leyes $-\mathrm{N}^{\circ} 623$ del año 1875, $\mathrm{N}^{\circ} 893$ del año 1877 , $\mathrm{N}^{\circ} 1012$ del año 1879, $\mathrm{N}^{\circ} 1.024$ del año 1880 y Ley $\mathrm{N}^{\circ} 2.742$ del año 1890- completando detalles de orden procedimental. Fue eliminado el voto oral, aunque continuó siendo público, lo cual permitió mantener el "control” del desarrollo comicial.

Como corolario, cabe mencionar que el sistema de representación estuvo signado por el régimen de "lista completa" -establecido por la Ley 140- hasta el año 1912, aunque sufrió una excepción entre 1903 y 1905, período éste en que -como lo desarrollaremos infra- fue reemplazada por la Ley $\mathrm{N}^{\circ} 4.161$.

Sostiene F. Luna que si bien los mecanismos implementados a través del quehacer legislativo constituyeron una invitación a cometer "trampas y fraudes", lo promisorio estuvo dado por el surgimiento de la

\footnotetext{
${ }^{141}$ Fundamentando su postura, Alberdi (1974:160) expresó en 1852 que "La inteligencia y la fortuna en cierto grado no son condiciones que excluyan la universalidad del sufragio, desde que ellas son asequibles para todos mediante la educación y la industria [...] Para olvidar los inconvenientes de una supresión brusca de los derechos de que ha estado en posesión la multitud podrá emplearse el sistema de elección doble y triple, que es el mejor medio de purificar el sufragio universal sin reducirlo ni suprimirlo, y de preparar las masas para el ejercicio futuro del sufragio directo”. Cabe señalar que el sistema fue decididamente discrecional, permitiéndose el uso de la fuerza pública para impedir la emisión del voto de aquellos que resultaren "indeseables". De modo que sus notas destacables fueron las típicas de la época: fraude y violencia (tal como lo sostuviese Sarmiento en carta dirigida a Domingo de Oro el 17 de junio de 1857).
} 
“pasión por la cosa pública, fundamento posible para una vida cívica que hiciera viable con el tiempo un sistema orgánico de partidos al servicio de formas institucionales sólidas, perdurables. (Luna, 1995:38-40).

Va de suyo que, con tan limitado procedimiento, la eficacia electoral no fue mucha, ya que sólo reflejó de soslayo la realidad del sentir de la ciudadanía. Esta cuestión no es menor, dado que, si bien los "no" argentinos solo constituían en 1869 la octava parte de la población total, en 1895 llegaron a ser la cuarta del total. (de la Fuente, 1898) ${ }^{142}$

Por otra parte, muchos inmigrantes se incorporaron al país ya adultos, en tanto que los nativos censados incluían grandes masas de población menor de dieciocho (18) años. De manera que, cuando corría el año 1895, la población masculina que había alcanzado la mayoría de edad, representaba un cuarenta y siete por ciento (47\%) de extranjeros;

“[...] y del cincuenta y tres por ciento restante de argentinos con derecho al voto, por lo menos la mitad no sabían leer ni escribir [...]”' (Álvarez, 1984:131-132).

Cierto es que, desde 1880, se incrementó la incorporación de niños a la escuela, hecho que se dio en consonancia con el aumento de la agricultura, atrayendo población hacia campos que, aún, se encontraban desocupados. (Álvarez, 1984:134) ${ }^{143}$

${ }^{142}$ Además de señalar las asimetrías existentes en las distintas provincias en lo referente a migraciones y la 'penosa' educación primaria en algunas de ellas, y con la finalidad de buscar diferentes recaudos para suprimirlas, expresa de la Fuente (1977: 392) que ello debe llamar la atención de magistrados y legisladores: "[...] bajo el punto de vista étnico, moral y económico del pueblo de los Estados. La homogeneidad, bajo aspectos diversos, en condición nacional y de familia; y responderá en todo caso a estrechar los vínculos que aproximan a los individuos y consolidan la solidaridad política. Entre los hechos relevantes del censo puede consignarse, asimismo, el que se refiere a los extranjeros, que, englobando todas las nacionalidades, aparecen en primer término, impulsando todos los adelantos, dueños de casi toda la viabilidad férrea, de la navegación exterior e interior, de las mejores propiedades, de la mayoría de las industrias, comercios, bancos, etc., apareciendo el hijo del país [...] en situación relativa bastante inferior. Resulta, por fin, de la comparación de ambos censos, 1869 y 1895, una impresión de progreso evidente en el conjunto, pero sin uniformidad para todas las agrupaciones; a punto de no poder establecerse en muchos casos, términos medios 'razonables'; tales son de diferentes y enormes las distancias que acusan entre sí los términos extremos."

${ }^{143}$ Sobre esa base, sostuvo el autor "[...] serenamente, sin gestos heroicos, sin volcar raudales de elocuencia en el parlamento, se ha podido hacer en pocos años bastante más que durante el período 1810 a 1880. Con las reservas consiguientes a este género de cálculos, es admisible que los gastos de instrucción pública representaron los siguientes porcentajes sobre el total de lo invertido por el gobierno nacional:
Año 1865 $1,7 \%$
“ 1870 $2,0 \%$
“ 1875 $6,1 \%$
“ 1880 $4,0 \%$
“ 1912 $12,7 \%$ " 
El panorama característico de esos tempos estuvo representado, pues, por la carencia de cultura política. Erigiéndose como principal manifestación, el deficitario conocimiento acerca del sufragio, sus implicancias y consecuencias ya que, la dirigencia política consideraba normal que los electores sufragaran conforme a sus conveniencias personales, más allá que concordaran con las del colectivo, esto es, pensando en el bien común. Ello en la creencia que, los así electos, no perseguirían su propio beneficio en el manejo de los recursos públicos. Convicción ésta que llevó al entramado social a otorgar carácter de irrevocable al mandato, con lo cual dispensaba de toda responsabilidad a los mandatarios respecto de sus mandantes.

La cantidad de extranjeros que habitaban el país, había promovido en la Convención Reformadora de 1898, un extenso debate acerca de quienes tenían derecho a voto.

Pese a la trascendencia que revestía el tema, la ley Sáenz Peña -si bien, y en principio, aventó el fraude electoral- al otorgar el voto a los argentinos o naturalizados, no logró dar solución a la desigualdad existente respecto a cientos de miles de extranjeros que continuaron excluidos del padrón electoral.

La Constitución Nacional estableció que cada 33.000 (treinta y tres mil) habitantes se elegiría un diputado; pero, mientras en el interior del país, esos habitantes eran casi todos argentinos (varones), en el litoral, siendo extranjeros en su mayoría, no tuvieron participación en los comicios, vale decir, acceso directo a las urnas (los guarismos que arrojan los Cuadros 3,4 y 5 -obrantes en el Anexo III- resultan ilustrativos y acreditan lo expresado).

La Ley $\mathrm{N}^{\circ} 4.161$ (1903) reemplazó a las anteriores pero no medió un nuevo censo poblacional hasta el año 1914. La normativa no solo se refirió al Régimen electoral, sino que abordó el tratamiento de las calidades, derechos y deberes de los electores. Formación del registro cívico nacional. Asambleas electorales. Elecciones de senadores y electores presidenciales. Y, lo más importante, estableció el sistema de circunscripciones uninominales, reemplazando el de lista completa.

Modificada por la Ley $\mathrm{N}^{\circ}$ 4.578, en junio de 1905, reimplantando el sistema electoral de lista completa, también fue reformada por las Leyes $\mathrm{N}^{\circ} 4.719$ (sept./1905), 6.015 (sept./1908, sobre formación del padrón cívico nacional) y 8.130 (julio/1911, elaboración de un padrón electoral). 
1.1. Como grafican los Cuadros que conforman los Anexos II y III, el resultado de la política inmigratoria significó que durante el período que va desde 1880 hasta 1890, ingresaron al país de cien (100) a doscientos (200) mil extranjeros. Las colonias agrarias implementadas para su admisión no resultaron suficientes, por ello un importante porcentual se quedó en la ciudad de Buenos Aires, lo cual incrementó excesivamente el crecimiento de su población.

En 1889 la ciudad capital contaba con quinientos (500) mil habitantes de los cuales trescientos (300) mil eran extranjeros, explicación que avala la difusión del ‘conventillo' levantado sobre las grandes mansiones abandonadas por la oligarquía- y, como corolario, el hacinamiento y las graves consecuencias en salud (falta de higiene, déficit de alimentación, carencia de cultura y prevenciones).

De modo que el ingreso indiscriminado de personas al país y el correlato de la falta de trabajos "fijos", constituyeron, entre otras causas, caldo de cultivo para el delito. Por otra parte, cuando el inmigrante fue 'obligado' a salir de los alrededores del Riachuelo, vale decir, a dejar el ghetto del sud -como también lo hiciere, obvio que en distintas condiciones, la aristocracia tradicional ante la fiebre amarilla y el cólera- aparecieron los "barrios", constituyendo un escenario socio-urbanístico representativo del quehacer porteño donde se entremezclaron lo viejo y las nuevas corrientes, aunque éstas últimas, sobreentendido resulta, no entendidas y mucho menos digeridas. (Jitrik, 1968:107) ${ }^{144}$

Las mencionadas circunstancias, reflejaron claramente el inconformismo social que fue socavando al liberalismo enquistado en el poder.

Ante las dificultades existentes, el P.A.N. comenzó a fragmentarse incapaz de sortear sus propias contradicciones, generando una oposición -intra filas- deseosa de incorporar nuevos estilos para visualizar la realidad política de aquellos días.

Acabado ejemplo de ello, constituyen las palabras que Aristóbulo del Valle expresara en "Qué es la soberanía nacional" -discurso parlamentario, pronunciado en la sesión del 8 de julio de 1887, ante el H. Senado de la Nación- :

\footnotetext{
${ }^{144}$ Dice Jitrik (cit. a Cúneo): “Los barrios -y no el campo- se llenan de inmigrantes, y la ciudad extiende su caserío hacia las nuevas orillas, en donde amanecían -vanguardias del urbanismo criollo-el 'boliche' y 'el piringundín'. Y añade: Caos y mezcla en donde nadie sabe nada ni se da cuenta de que se van engendrando tensiones afectivas muy fuertes cuyo primer escape va a ser la crisis del 90, en la que el plan roquista trastabilla y el edificio amenaza con venirse abajo".
} 
“[...] la soberanía nacional, señor Presidente, implica una gran masa de derechos y facultades para el que la ejercita, porque, entiéndase bien, la soberanía nacional en los pueblos constituidos como el nuestro, no reside, no la posee como dueño el Poder Ejecutivo de la Nación ni ningún otro de los poderes públicos del estado; la soberanía nacional reside en el pueblo de la República y todos los poderes que desempeñan aquellas facultades, las desempeñan única y exclusivamente por delegación constitucional de ese pueblo [...] ") (Jitrik, 1968:258) ${ }^{145}$

Dicha lectura política, puso de manifiesto que el slogan anunciado a comienzos de la década -sinónimo de progreso y desarrollo- se había tornado ilusorio para el colectivo. Los 'públicos' negociados, perturbaron de tal modo el relacionamiento interestructural, que solo favorecieron a unos pocos elegidos [...] hay un 'único' hambriento, es decir, muchos que están fuera del festín." (Jitrik, 1968: 253) ${ }^{146}$

Estado de cosas que agudizó aún más el déficit de legitimidad, vale decir la falta de reconocimiento del poder establecido, de un acuerdo entre todos los integrantes del colectivo social, es decir, de la inexistencia de un verdadero proceso de legitimación.

Ello permitió visualizar que el fenómeno "legitimación” -base del mecanismo de institucionalización de un determinado "diseño de vida" y, por ende, de la consecuente "legitimidad"- se había quebrado, tanto por la existencia de un débil "consenso", cuanto por la consecuente circunstancia de ser éste, un consenso no legitimante.

${ }^{145}$ El autor vuelve a citar a Aristóbulo del Valle -al referirse a la falta de probidad, planificación y racionalidad del gobierno en las concesiones y garantías respecto de los ferrocarriles y empresasmencionado el discurso del 21 de octubre de 1887, pronunciado ante el H. Senado de la Nación, 'El negociado de los ferrocarriles', oportunidad en la que hiciera referencia a las concesiones otorgadas sin subvención, ni garantía alguna, "[...]he tenido ocasión de intervenir en mi calidad de abogado en una propuesta presentada al P.E. de la provincia de Buenos Aires, que hoy está sometida a la Legislatura, en que una empresa colonizadora ha pedido como una concesión, como un derecho, que se le reconozca la facultad de construir líneas férreas sin subvención ni garantía de ninguna especie. En presencia de estos hechos, es injustificable que la Nación esté acordando las cantidades que acuerdan a todas estas líneas que se inventan para hacer negocio. Porque es necesario decir la verdad: no son los capitales extranjeros, sino los negociantes de concesiones los que vienen a solicitar garantías para hacer fácil fortuna, obteniendo una concesión del Congreso argentino para ir en seguida a negociarla en Europa y hacer fortuna con el crédito de la Nación".

${ }^{146}$ Señala Jitrik, que Manuel T. Podestá (1924: 57) describe la calle Florida, los paseantes, los desocupados, los mirones, mujeres hermosas, corrillos de empleados, la fila de carruajes, joyas, perlas, tejidos, brocados, muebles, estatuas, bustos, bronce en los escaparates, concluyendo que:[...] La concurrencia se había hecho inmensa; por momentos había que detenerse, porque se hacía difícil el tránsito; las conversaciones eran más animadas y por todas partes no se oía más que hablar del ruidoso descalabro de la Bolsa. Era la noticia de última hora que había llegado a la calle Florida como el preludio de una catástrofe agigantada por el miedo o por el arrepentimiento de los que habían expuesto su caudal, su crédito y tal vez su pan de cada día, en la ruleta disimulada." 


\section{Esbozo de revolución.}

El escenario social de 1880, tornó visible la presencia de una significativa masa popular -conformada por la fusión de sectores criollos e inmigrantes- que, sometida y desdeñada por la oligarquía, padecía las secuelas del "régimen".

Considerando el comprometido contexto económico en que aconteció la presidencia de Juárez Celman, no resultó extraño que, tal estado de cosas, provocara el deseo de intervenir en el manejo de la res publica, de quienes resultaban los nuevos argentinos -hijos de inmigrantes- cualesquiera fuere la finalidad perseguida.

Ciertamente, los vaivenes de dicha presidencia también sufrieron embates exógenos derivados del generalizado y perverso brote especulativo, produciendo grave daño en las arcas públicas que -en el transcurso del año 1890- se intentó paliar mediante la emisión clandestina de papel moneda. Decisión gubernamental que fuera reprobada por el senador Aristóbulo del Valle, al sostener -finalizando su intervención- :

“[...] No soy de los que creen que hay males que se curan con estos medios que envenenan el organismo social. Estamos carcomidos por una enfermedad de corrupción moral, de una gran corrupción moral pegada a nuestro cuerpo como lepra, que no se salva con otro procedimiento sino con cauterio, haciendo buena y debida justicia como corresponde hacer en el caso actual" (Romero, 1969:207-208) ${ }^{147}$

Expresiones éstas, que provocaron fuertes turbulencias no solo en el concreto poder, sino, y substancialmente, en la opinión pública.

\footnotetext{
${ }^{147}$ A efectos de esclarecer la dialéctica significante-significado, completamos las palabras finales del Senador del Valle, con las que pronunciara al inicio de su alocución: "Los hechos anteriores se han agravado con uno de último momento, que seguramente no está en conocimiento de la cámara y que la va a sorprender como me ha sorprendido a mí [...] se ha hecho una emisión clandestina de cuatro millones y medio de pesos para entregarlos al Banco Nacional, no ya bajo la presión de los depositarios aglomerados a la puerta del Banco que pudieran poner en peligro la existencia de aquel establecimiento, sino para salvar necesidades cuyo carácter no puedo apreciar, pero que entraría en el movimiento ordinario de la institución bancaria [...] La Cámara debe comprender [...] que comprometiendo mi responsabilidad de hombre y de senador con ellas, debo tener todos los antecedentes que bastan para formar, más que un juicio, la certidumbre moral de un hombre [...] Entre lo que se llaman exigencias de la administración y lo que impone la conciencia honrada de hombre público en cumplimiento de los deberes que ha jurado, no puede haber vacilaciones para mí. No justifico ninguna de las emisiones clandestinas que se han hecho por el gobierno nacional con el sello de la Nación; no justifico tampoco las emisiones lanzadas a la circulación por el Tesoro público, ni justifico tampoco las que se han hecho para salvar al Banco Nacional, ni al Banco de la Provincia, que peligraba cerrar sus puertas, porque antes de ver al gobierno de mi país falsificar el sello de la Nación, preferiría que quebraran el Banco Nacional y el Banco de la Provincia."
} 
Al respecto, y transcurrida una década desde el comienzo del "régimen”, expresó Jitrik

"El 90 es un sintoma de la congestión que se ha producido por la acumulación indiscriminada de elementos que se ha venido haciendo durante 10 años. Y una advertencia que es imposible recoger porque el movimiento ha desencadenado tantas cosas que nadie puede sensatamente integrar en el sentido de una conducción”. (Jitrik, 1968:107)

Las referidas transformaciones, incorporaron costumbres, valores y disvalores que, al integrarse a la 'orientación general' del colectivo, impregnaron, como no podía ser de otro modo, la realidad política.

Influidos, conducidos y/o directamente llevados por las elites dirigenciales, la nueva significación de sentido que tiñó la escena de la formación socio-política, motivó distintos comportamientos en el ciudadano común, reiterando la sempiterna lucha entre los 'genios invisibles de la ciudad'. Situación que generó el natural revulsivo en las distintas instancias regionales no solo del plano infraestructural, sino también, filtrándose por los intersticios hacia el nivel superestructural suscitando, como no podía ser de otro modo, un estado de cosas que se tradujo en lo que más adelante fue un esbozo de revolución.

Como sostiene Habermas las crisis surgen cuando la estructura de un sistema de sociedad, admite menos posibilidad de resolver problemas que las requeridas para su conservación.

Así, en el período transcurrido entre la caída de Rozas y el año 1910, y considerando la existencia formal de un "Pacto social" -dans le sens roussoniano- en el país se consolidó, a contrario sensu de la lógica, diríamos de la racionalidad económica, un modelo de desarrollo económico cuyos resultados fueron, al menos en un principio, óptimos. Y decimos “en principio”, porque constituyó el mejor ejemplo de la parábola del hijo pródigo. No sólo con la ninguneada que se realizó al dilapidar los recursos escasos, sino también, por sus consecuencias, toda vez que, a la postre, ello trajo aparejado hipotecar el futuro de la incipiente formación política argentina.

Germen, por qué no, de la decadencia que, históricamente, nos acompañaría y que tendría un decisivo proceso contestario -caracterizado por signos de desobediencia en el colectivo- en la conformación de nuestra gelatinosa sociedad civil, plus la insoslayable 
incidencia que el eclipse de "la educación cívica" generó, provocando crisis en la credibilidad institucional.

Como hiciésemos referencia ya, no todos los inmigrantes vinieron por idéntica razón: hubo quienes soñaban con una tierra mejor, próspera, de paz y tranquilidad huyendo de situaciones cruentas. También lo hicieron trabajadores que debieron dejar el viejo mundo por razones políticas y gremiales "y que reiniciaran aquí la lucha secular contra la explotación[...]imbuidos de ideas anarquistas y socialistas[...]por ello italianos, españoles, alemanes $y$ franceses [ ... ${ }^{148}$ comenzaron a establecer organizaciones obreras para hacer frente mancomunadamente a la explotación y la miseria. Y lo hicieron por la simple razón que no había industria y, en consecuencia, tampoco existía el concepto de obrero. (Jitrik, 1968:251-252) ${ }^{149}$

A la importancia que revistió el proceso inmigratorio y, más allá de la valoración que sobre el mismo se realizara, debe agregarse el cambio producido en el entramado social por el surgimiento de una renovada clase media fuerte, pretendiendo ingresar a la universidad, a la lucha política y a la cultura, como modo de crecer en la estratificación social y, por ende, intervenir en la economía. Por ello, el año 1895 encuentra a esta clase con sus propias fuerzas políticas: radicalismo y socialismo- controlando gran parte del comercio minorista, mediante intelectuales, escritores y conspicuos profesionales.

Continuando con las turbulencias en la formación social, más adelante y como no podía ser de otro modo -no obstante encontrarse instalada en el liberalismo de la época una estrecha ligazón con la manufactura inglesa- la impronta estuvo dada por la emergencia de una incipiente industria y, como lógica consecuencia, el surgimiento de la clase obrera. Temas éstos que, si bien visualizados por la literatura de la época, aún estaban alejados de

\footnotetext{
${ }^{148}$ Al respecto agrega Jitrik, (1968:107), “En 1887 habia 4 trabajadores por establecimiento industrial (Dardo Cúneo), índice muy expresivo de la falta total de estructura básica [...]". El surgimiento de las organizaciones obreras provocó en el régimen una nueva xenofobia [...] y son advertidos por el sistema que los empieza a vigilar y a reprimir, a la par que en 1896 nace el Partido Socialista, que pretende un fundamento obrero, y la interiorización, por parte de muchos intelectuales de origen no oligárquico, de la temática de la disconformidad y la protesta anarquista".

149 Considerando la coexistencia de 'nuevas' y 'viejas' prácticas, manifiesta el autor, como introito a un fragmento tomado de Fray Mocho, (1961: t. II, pág. 292): “Disconformidad es el signo predominante, incomodidad. Hay una nueva clase media que cree posible y factible vivir como las altas clases en un tironeo de lo criollo que se siente legítimo pero perdido en la promiscuidad”.
} 
la realidad estructural argentina aletargada en las instancias regionales de los estados provinciales. (Jitrik, 1968: 262) ${ }^{150}$

\subsection{0 - La Unión Cívica.}

Respondiendo a la agitación de aquellas horas, en 1889 Francisco Barroetaveña había lanzado desde el diario La Nación, un exacerbado artículo -Tu quoque Juventud-que conmovió el sentir cívico-popular. (Romero, 1969:208) ${ }^{151}$

Ante este estado de cosas y con el postulado ético como bandera, una nueva ideología ingresó a la escena política. Mitristas, antiguos autonomistas y republicanos; jóvenes sin afiliación anterior; católicos resentidos con las leyes laicas de Roca y Juárez Celman; la clase media cuantitativamente fortalecida; grupos obreros -con conciencia de clase-, se reunieron en el Jardín Florida cuando corría el año 1889 en la consecución de un sistema democrático. (Romero, 1969:209) ${ }^{152}$

Como instrumento de expresión de una corriente principista que renegaba del exacerbado capitalismo impuesto a la sociedad civil argentina, el movimiento de neta afiliación kraussista, contó en sus filas con la presencia de hombres como Leandro N. Alem, ${ }^{153}$ Bernardo de Irigoyen, Juan B. Justo y Lisandro de la Torre. ${ }^{154}$ Corriente de opinión

\footnotetext{
${ }^{150}$ Registra Jitrik palabras de Joaquín V. González: "Estamos en condiciones de examinar un proceso. No tenemos de qué quejarnos porque en lo intelectual hemos hecho grandes progresos pero también estamos lejos de la homogénea ortodoxia liberal y positivista. Hay un anhelo de volver a las fuentes, se insinúa cierto espiritualismo, se busca el 'nudo' de lo argentino en lo tradicional. Oligarquía y pensamiento liberal se separan, la oligarquía necesita actualizarse." ('Un año de historia literaria argentina', O.C.).

151 Menciona Romero algunas de las expresiones de Barroetaveña que provocaran la agitación y estremecimiento de la civilidad : "La designación del jefe único del Partido Nacional, hecha en la persona del presidente de la república, que constitucionalmente no puede ser jefe de partido; la docilidad del congreso; el aplauso que se le dirige desde todas las provincias cuando se cometen atropellos como el cierre de la Bolsa; la supresión del sistema electoral; las adhesiones incondicionales como la de esta noche por un grupo de argentinos de la decadencia cívica, ¿no son síntomas que nos demuestran un intenso retroceso moral del pueblo y una completa perversión de ideas?".

${ }^{152} \mathrm{El}$ autor cita a Mitre quien -refiriéndose a gran parte del cuerpo social que había quedado fuera del "unicato"- manifestó: "Toda la sociedad está aquí genuinamente representada [...] sin más aspiraciones que el bien común".

${ }^{153}$ También menciona Romero, lo expresado por Leandro N. Alem (presidente del nuevo partido):"Una vibración profunda conmueve todas mis fibras patrióticas al contemplar la resurrección del espíritu cívico en la heroica ciudad de Buenos Aires".

${ }^{154}$ En similar sentido, manifestó de la Torre en Rosario:"Yo no digo, señores, que esté la batalla ganada, pero sí digo y sostengo que hay ya soldados para trabarla, mentes que irradian el entusiasmo, pechos y sangre que no se excusan; digo que el pueblo enervado es ya pueblo que siente, y que ante un coloso de pie no quedan intrigas ni miserias que amparen y sostengan a los tiranos de decadencia, que los desprecian y apostrofan dormidos"
} 
que, con su pujanza, logró constituir -el 13 de abril de 1890, mediante el mitin realizado en el frontón Buenos Aires- la primer fuerza política surgida de un heterogéneo poder social: la Unión Cívica.

\subsection{Revolución del Parque.}

La lucha contra la corrupción, el fraude electoral y el unicato fueron las bases fundacionales de la Unión Cívica que -ante la severa crisis económica y los desajustes de la administración- en julio de 1890, de algún modo encabezó la "Revolución del Parque". Levantamiento éste, que contó con dos importantes avales: un decidido apoyo militar y el ardiente respaldo del pueblo.

A través del manifiesto revolucionario, fueron explicitados los fundamentos que condujeron a la insurrección:

"El movimiento revolucionario de ese día, no es la obra de un partido político. Esencialmente popular e impersonal, no obedece ni responde a las ambiciones de círculo u hombre público alguno. No derrocamos el gobierno para separar hombres y sustituirlos en el mando; lo derrocamos para devolverlo al pueblo a fin de que el pueblo lo reconstituya sobre la base de la voluntad nacional y con la dignidad de otros tiempos, destruyendo esta ominosa oligarquía de advenedizos que ha deshonrado ante propios y extraños las instituciones de la república”. ("Historia de las elecciones argentinas", 2011:47) ${ }^{155}$

Si bien los rebeldes no lograron su cometido, esto es, el derrocamiento del régimen, ya que fueron controlados desde el gobierno, (Romero, 1969:210) ${ }^{156}$ la "revolución" fue el resultado objetivo del nuevo proceso de legitimación existente en la sociedad civil que -no obstante su intrínseca "debilidad"- buscaba, perseguía, para, finalmente lograr, nuevos caminos en la conquista de una legítima representación de aquellos que serían sus mandatarios.

Al respecto expresó Jitrik, prologando palabras de Juan Balestra,

\footnotetext{
${ }^{155}$ Dirigidos por el general Manuel J. Campos, los rebeldes dominaron el Parque de Artillería (lugar que actualmente ocupa el Palacio de Tribunales), mientras otras fuerzas ocupaban lugares estratégicos en esquinas y balcones, a efectos de favorecer el desplazamiento de las fuerzas y acosar al contrincante. Luego de tres días el gobierno logró neutralizar al grupo revolucionario.

${ }^{156}$ Menciona Romero, la frase con que el senador Pizarro, sintetizara el corolario de la sublevación: "La revolución está vencida, pero el gobierno está muerto".
} 
"Los prohombres argentinos juzgan la situación: es insostenible. Una marea cuyo momento inicial no se quiere considerar envuelve los actos y los juicios; se siente la necesidad de una corrección del rumbo que recupere viejos valores oscurecidos. Errores imperdonables han hecho temblar la estructura. Se necesita, sin duda, un chivo emisario”. (Jitrik, 1968:274).

Refiere Balestra (1959) analizando el caos económico por el que atravesara el Estado, que el doctor García, Ministro de Hacienda de ese entonces, había manifestado

“[...] es preciso que sepan ustedes que el 15 del corriente tenemos que pagar en Europa 500 mil libras esterlinas, por el servicio de la deuda externa y la garantía de los ferrocarriles, y no disponemos, en total, de más de 35.000 pesos moneda nacional [...]" palabras con las que no había hecho más que preanunciar el estado de quiebra en que se encontraba la República.

Bancarrota que el poder ejecutivo pretendió ocultar al Congreso, al sostener en el mensaje que dirigiera en oportunidad de inaugurar las sesiones de prórroga del año 1889:

“[...] tenemos depositado en Europa el servicio de la deuda hasta el año 91; tenemos recursos a la mano por 154 millones" iy la realidad era esa bancarrota! Se maldecía del favoritismo que había desparramado el dinero de los bancos a cambio de papeles incobrables; se recordaban las predicciones, antes maldecidas, de la prensa; se blasfemaba de la ocultación oficial y de la mentira, sobre todo de la mentira, encubridora del derroche y compañera de la soberbia. Algunos clamaban contra la rebelión desatentada que había agravado la crisis, convirtiendo las dificultades momentáneas en una posibilidad de ruina". (Balestra, 1959, en Jitrik, 1968:274-275)

Crisis ésta, que también Juárez Celman evitara mencionar al presentar su renuncia, refiriéndose al frustrado 'golpe' como

“[...]un motín de cuartel ha ensangrentado las calles de la capital y llenado de dolor al pueblo argentino, que descansaba tranquilo en la seguridad de sus altos destinos[...] El motín ha sido vencido y una amnistía general y absoluta ha amparado en el olvido a sus autores; y para sellar[...] mis sinceros propósitos [...] he invitado a los hombres más respetables y representativos a formar parte del Gobierno[...] Mis nobles esfuerzos han sido inútiles[...] dejo a otros la tarea[...] y presento a V.E. la renuncia de Presidente de la Nación [...]” (Jitrik, N., 1968:275) ${ }^{157}$

\footnotetext{
${ }^{157}$ En relación a tal momento, manifiesta Eggers-Brass, T. (2006:385): "Después de la caída del presidente, el Weekly Bulletin de Londres reveló que la Casa Baring le había pagado a Juárez Celman 100.000 libras, y 80.000 a su ministro Wilde para obtener el contrato de obras sanitarias (citado por Tur, 1971)”.
} 
Lógicas desavenencias producidas en el P.A.N. produjeron una escisión en torno a quien sería el sucesor de Julio A. Roca como presidente del partido. La "junta de notables", aunque no formalmente, actuaba desde 1892 como órgano de selección del candidato y postuló para el cargo a Carlos Pellegrini, en tanto la decisión de Roca pasaba por promover a Manuel Quintana. La pugna originó, dentro de la ideología conservadora, nuevas fórmulas políticas: los "autonomistas nacionales" o roquistas -proclives a continuar con el fraude electoral- , y los "autonomistas" o pellegrinistas -fracciones separadas del P.A.N.decididamente movilizados por distintas representaciones acaecidas en el escenario político, como las revoluciones radicales, las huelgas obreras y las conjuras anarquistas. Turbulencias que, si bien aún no incidían en el concreto poder, señalaban la necesidad de incorporar estos nuevos actores sociales a la escena política para que este sentir social, portador de nuevas demandas, ingresara al parlamento debidamente canalizados a través de la U.C.R., primera fuerza opositora, y del Partido Socialista, debilitando a las dos grandes "fuerzas" de la época: los obreros y el anarquismo.

Tras la renuncia de Juárez Celman, asumió el poder su vice-presidente, Carlos Pellegrini, quien había nacido en 1846, en un hogar de sólida fortuna inmobiliaria, rural y urbana. Extranjero (de origen saboyano) y acriollado en Buenos Aires, tuvo una juventud sin tropiezos y se doctoró en Jurisprudencia en 1869.

Aunque las leyes electorales vigentes desde 1857 hasta la elección que le permitiere llegar al poder, hubieren concedido voto a cuantos argentinos llegaren a cierta edad, casi todos los presidentes de la nación habían sentido el deber de confesar "oficialmente" que el fraude y la violencia impidieron al sistema teórico producir sus efectos normales.

La coyuntura de una crisis internacional, había permitido que el país ingresara a la modernidad y al sistema capitalista, pero esa incorporación la había hecho "con todos los vicios: dependencia y confusión". (Jitrik, 1968:275)

Ya en la "era aluvial" (Romero, 1969), y no obstante lo acontecido intrapartidariamente, Pellegrini perteneciente a la oligarquía y, por ende, partidario del autoritarismo que caracterizara tanto al P.A.N como al Unicato -y en plena crisis económica- había decidido no hacerse cargo de la primera magistratura si previamente no recibía el apoyo expreso de quienes podían, por su solvencia, facilitarle el dinero imprescindible para afrontar las obligaciones más inmediatas. Convocó, entonces, a los 
banqueros y les hizo saber que necesitaba ocho a diez millones para pagar un compromiso que vencía a los nueve días de su asunción, de los cuales no contaba con nada. De la respuesta que recibiera dependía la aceptación o renuncia al cargo de presidente. Los dejó solos y volvió al poco rato. Sumó y exclamó: "18 millones!!! Bueno, ahora soy presidente.”. (Sabsay, F., 2004). Cabe señalar que gran parte de los historiadores se pregunta cuáles habrán sido los logros, franquicias, negocios u otras "recompensas", que recibieron aquellos que tan solidariamente acudieron en defensa del país. (Eggers-Brass, 2006:403)

Acerca de la ley de amnistía que promovió, fijó su significado en "levantar la ley y los principios por sobre todas las cosas, sobre todas las aspiraciones". Solo habrá ley de olvido, solo habrá ley de paz, sólo habremos establecido la unión de la familia argentina el día en que todos los argentinos tengamos iguales derechos.

Buscó mantener en el poder al P.A.N y evitar el desarrollo de la otra fuerza opositora -la Unión Cívica- que amenazaba alterar el panorama político con un nuevo factor: la voluntad popular.

Durante la presidencia de Pellegrini, Roca se desempeñó como Ministro del Interior, procurando integrar al país con tres elementos: inmigración, educación y transporte. Para ello la clase gobernante -también económicamente dominante- eligió el sistema liberal, centralizando el poder político. Por lo que, no obstante la pretensa vigencia de una fluida impronta en lo social, esa concentración impidió el ingreso de la sociedad civil al reducido, minúsculo, círculo de las decisiones políticas tomadas por la elite enquistada en el poder.

\subsection{Unión Cívica Nacional - Unión Cívica Radical.}

Cuando corría el año 1891, la Unión Cívica se dividió formando dos Partidos: la Unión Cívica Nacional (cívicos) y la Unión Cívica Radical (radicales).

La primera, encabezada por Mitre, accedió a contemplar la posibilidad de concretar un acuerdo con la oligarquía gobernante (la llamada conciliación).

Para las elecciones presidenciales de 1892, la Unión Cívica Nacional presentó la fórmula: Bartolomé Mitre-Bernardo de Irigoyen.

Ambos integrantes presentaban notorias diferencias ideológicas. Mitre se había manifestado como antirrosista y liberal; Bernardo de Irigoyen, había servido, siendo joven, 
al régimen instaurado por Rozas y provenía del autonomismo. Antecedentes estos, por los que Roca se opuso a su nominación, siendo reemplazado por José Evaristo Uriburu.

A su turno y liderada por Leandro N. Alem, la Unión Cívica Radical tomó como norma política, la intransigencia, y eligió como candidatos a Hipólito Yrigoyen y Juan M. Garro.

Sustentó su comportamiento político en dos postulados: revolución y abstención electoral, en respuesta al no establecimiento del voto secreto, considerado como llave maestra del sistema democrático. La U.C.R fue organizada a escala nacional, con comités abiertos en todos los barrios de las grandes ciudades; contó también, con periódicos -al igual que otros partidos- a través de los que se expresaba ante la opinión pública; y si bien sus organismos, comités y convenciones, se reunieron programáticamente, no participó en las elecciones.

¿Qué pretendía con su estrategia/táctica? Su programa se redujo, nada más y nada menos, a pedir moralidad pública, pureza electoral y vigencia del sistema federal. Lo que llevó a Carlos Pellegrini a expresar que “[...] más que un partido, era una sentimiento”.

En respuesta, sostuvo Yrigoyen que la misión del radicalismo -como cruzada cívicaera tan importante, que pedirle que descendiese a las pequeñeces de una visión puramente economicista -proteccionismo o librecambio- era insultar la grandeza de su misión.

Su prédica fue: el cumplimiento de la constitución.

Estas características dieron al movimiento una enorme fuerza e identidad, contrastando con los demás partidos del régimen -el roquismo, el pellegrinismo, el modernismo, el mitrismo- que se repartían el poder con distintos nombres.

La ética que esgrimió el nuevo partido, lo hizo interesante frente a la opinión pública, sobre todo a la juventud.

No contó solo con una adhesión de clases, sino que concitó elementos muy heterogéneos. De allí que, a nivel de estructura social, nucleó tanto a hombres del patriciado argentino y estancieros, cuanto a sectores de trabajadores urbanos y peones rurales; también la clase media, a la que se agregaron elementos populares, mestizos e inmigrantes anarquistas y socialistas; finalmente, los grupos católicos, todos defendiendo sus ideales democráticos, por lo que constituyó un fenómeno sociológico desbordando toda idea de pertenencia o posicionamiento de clases. (Romero, 1969) 
La aparición en la escena política del Partido Modernista (autonomistas, juaristas) y de su líder Roque Sáenz Peña, concomitante con su afán de no permitir la llegada del movimiento popular a la vez que asegurar los resultados de la elección a favor de Luis Sáenz Peña -hijo de Roque- llevó a Pellegrini a tomar distintas medidas: acusar al radicalismo de conspiración, imponer el estado de sitio, detener a la dirigencia radical excepto a Yrigoyen- y a los militares sospechados, a la vez que clausurar periódicos y revistas satíricas.

Medidas que provocaron, una vez más, la abstención de la Unión Cívica Radical y el paralelo triunfo del "acuerdismo", representado por el binomio Luis Sáenz Peña-José Evaristo Uriburu.

3. 1893- 1895: nuevos intentos revolucionarios.

En el año 1892 comenzó la débil presidencia de L. Sáenz Peña, acompañado por J. E. Uriburu. Frágil ya que no contaba con un partido político que la apadrinara, resultando la llegada de la fórmula al gobierno, fruto de un acuerdo inter-pares por encima y muy lejos de la voluntad popular. Esta debilidad del presidente le obligó a dejar el poder en manos de personalidades -M. Quintana, M. Cané, A. del Valle- quienes, a modo de primer ministro, coordinaban el gabinete.

La formación política, presentaba una manifiesta inestabilidad, por lo que durante el año 1893 el radicalismo se sublevó en algunos puntos, con resultado variopinto. En Buenos Aires, por ejemplo -y al contrario de lo acontecido en San Luis y Santa Fe- A. del Valle pudo contener el levantamiento y luego de algunos cabildeos y vacilaciones Quintana asumió la singular función de coordinador de secretarios de estado y, en ejercicio del mismo se encargó, al igual que sus antecesores en el poder, de reprimir a la oposición, restableció el estado de sitio, intervino las provincias sublevadas y sofocó nuevas insurrecciones.

El llamado a elecciones en algunas provincias (Catamarca, 1893 y Buenos Aires, 1894) dio el triunfo a los radicales. Sin embargo, no pudieron tomar posesión de sus cargos por espurias causales -anulación y acuerdos- circunstancia que, una vez más, indujo a la conspiración radical. 
Por lo expuesto, en julio de 1893, la revolución estalló en la provincia de Buenos Aires, expandiéndose a Santa Fe, San Luis y Tucumán.

Sofocados los núcleos revolucionarios, en 1894, el ministro Manuel Quintana restableció el orden en el país, pero al no contar con apoyo parlamentario renunció.

En 1895, Sáenz Peña -luego de haberse negado a amnistiar a los revolucionariospresentó su renuncia. La presidencia -hasta completar el mandato- fue asumida por el vicepresidente José Evaristo Uriburu.

4. Roca y su segunda presidencia.

El estado de permanente convulsión política, trajo de regreso -aunque en rigor de verdad nunca se habían alejado- como potenciales presidenciables a Roca (que desplazó a Pellegrini) y Mitre (del Valle y Alem habían muerto en 1896).

Por entonces, la población -conforme el Segundo Censo Nacional realizado en 1895- marcó la presencia en nuestro territorio de 3.954.911 habitantes. Cantidad ésta, que casi triplicaba a quienes habían actuado en el proceso de constitución del Estado cuando corría el año 1853 (ver detalle en punto 6 infra). Situación que, por ende, si bien multiplicó de modo exponencial los conflictos -auténticos generadores de identidad- no registró demasiadas variables en sus representaciones y significados considerando los "auténticos" actores políticos y las instituciones, en que fue contextualizada dicha conflictividad.

Mitre se negaba a un segundo mandato de Roca y propició desde el diario "La Nación" un accionar opositor: la denominada política de las paralelas, integrada por cívicos y radicales.

La propuesta fue desechada por Hipólito Yrigoyen, quien se abocó a reorganizar el Partido. Para ello, en 1904 constituyó el Comité Nacional y fue preparando la revolución que estallaría en 1905, manifestando, al fundamentarla, que

"Las revoluciones están en la ley moral de las sociedades, y ni es dado crearlas ni es posible detenerlas sino mediante reparaciones tan amplias como intensas son las causas que las engendran.”. (Romero, 1969:.213)

Los postulados del radicalismo habían sido denunciados como insuficientes -desde el punto de vista de las necesidades económicas y sociales del proletariado- por el fundador 
del Partido Socialista, constituido en junio de 1896, Juan B. Justo, quien por primera vez concurrió a elecciones.

Julio A. Roca comenzó su segunda presidencia en el año 1898, integrándose la fórmula con Quirno Costa como vicepresidente.

Refiriéndonos a la política interior, diremos que, completando la labor iniciada contra las montoneras y los indígenas, Roca desplegó una feroz represión contra los obreros y sus organizaciones sindicales (ya con la inserción de anarquistas y partidarios del socialismo); asimismo y contando con mayoría propia en el Congreso, sancionó la "Ley de Residencia" la cual le permitía expulsar del país a los extranjeros -que perturbaran el orden público- o impedir la entrada de aquellos que -por sus antecedentes- tuviesen la posibilidad de colocarlo en situaciones de peligro; en 1901, al sancionarse la Ley Orgánica del Ejército, estableció el servicio militar obligatorio.

También debió enfrentar importantes temas en materia de política exterior: cuestiones limítrofes con Chile (pendientes desde 1881); restablecimiento de las relaciones diplomáticas con el Estado Vaticano (interrumpidas durante su primer mandato, v. supra Addenda Capítulo I) y la labor desempeñada por el ministro de Relaciones Exteriores, Luis María Drago (Doctrina Drago) quien planteó la ilegitimidad del uso de la fuerza tanto para el cobro de deudas, o como medio de presión para forzar diferentes perjuicios de contenido económico.

\subsection{Sistema electoral: Ley $N^{\circ} 4.161$ (1903).}

Importa mencionar -dentro del gabinete que acompañó a Roca en esta segunda etapa- el destacado lugar que ocupó Joaquín V. González como Ministro del Interior, quien no vaciló en manifestar su preocupación por lo que dio en llamar "el ambiente de subversión que se percibía latente en el país". Inquietud esta, que expusiera con antelación en su tesis doctoral "Estudio sobre la revolución". En ella señaló, el "santo" derecho a la revolución que detentaban los pueblos ya que, su ejercicio, permitiría la evolución social, necesaria para lograr la prosperidad y el adelanto, definitivamente, el florecimiento de la humanidad. Expresó, asimismo, la necesidad de otorgar instrucción a ese pueblo para 
morigerar las consecuencias políticas de una población "poco disciplinada". (Di Tella, 1998:113-114) ${ }^{158}$

Su plan de transformación política, contempló la reforma de la ley electoral a nivel nacional, estableciendo el voto secreto y la creación de circunscripciones electorales pequeñas en las que solo se elegiría un diputado. Con ello se pretendió garantizar que -aún triunfando los candidatos opositores- ello no afectaría el concreto poder existente en las jurisdicciones provinciales, como tampoco en el orden nacional. Manifestaba sobre el particular que

"la causa de las profundas perturbaciones del día es que las clases obreras no tienen sus representantes en el Congreso".

Agrega Di Tella, que se perseguía la desaparición del caudillaje tradicional, como también la aparición de "nuevos" liderazgos. (Di Tella, 1998: 115-116) ${ }^{159}$

En orden al sistema electoral, Pellegrini, siendo senador y refiriéndose a la historia de las elecciones argentinas desde 1853, había manifestado:

“[...] no conocimos, en la práctica, el ejercicio del sufragio libre por todos los electores. Media, sin embargo, un atenuante: cincuenta y nueve años después de la Revolución de Mayo el censo reveló que sobre cada seis de esos votantes teóricos, solo uno sabía leer y escribir. En 1904, aún restaban tres. De aquí el peligroso dilema: o entregar el gobierno a los ineptos, o gobernar con prescindencia de la mayoría [...]”" (Sabsay, F., 2004)

${ }^{158}$ Glosa el autor, palabras de J. V. González, al expresar: "Sólo la educación haría imposible que cada soldado fuera 'instrumento ciego de las pasiones demagógicas y anárquicas de los partidos exaltados',". Ello en directa referencia al pensamiento de anarquistas y socialistas (con influencia marxista).

${ }^{159} \mathrm{Al}$ enumerar a qué tipo de liderazgos hacía referencia, dijo el Diputado Vedia, miembro informante de la Comisión: "Anoto en primer [lugar] al patrón de la fábrica, al dueño de la viña, al propietario del ingenio, al estanciero, al explotador de minas, al colono, al terrateniente, al afincado, a todos los que, manejando cuantiosos intereses, de cualquier género, tienen a su servicio grandes masas de hombres. Anoto en el segundo al hombre útil a sus convecinos, capaz de molestarse por ellos, curioso de sus necesidades, gran amigo del cura, del juez de paz, del boticario, del periodista, y del maestro de escuela; que el lunes solicita la libertad del pobre trabajador que se embriagó el domingo; que a éste le paga la multa cuyo perdón no obtuvo; que al otro le procura un empleo; que llama a todos sus hijos y como a tales los trata; que no se cansa de pedir para su circunscripción y que lo pide todo: el telégrafo, el ferrocarril, el tranvía, la luz eléctrica, el pavimento. En el mismo grupo puede anotarse al que llamaremos intelectual -médico, abogado, político de raza o de ocasión- que imita al tipo que acabo de esbozar, que va como él al comité y al atrio, y que compensa con imaginación y con cierta habilidad su inconstancia, realizando por temporadas lo que constituye el trabajo permanente, la verdadera esclavitud en que el otro vive y goza". Pensamiento que también expusiera Sarmiento exhortando a los propietarios a ocuparse en forma más comprometida de los intereses que le eran propios, más allá de los aparatos partidarios que, utilizando el clientelismo, movilizaba sus punteros para intimidar al ciudadano común. 
Tal el origen de la Ley $N^{\circ} 4.161$ (1903) que, si bien consagró las circunscripciones uninominales no incorporó -en virtud de la intervención del senador Pellegrini- al quehacer electoral las iniciativas presentadas por Joaquín V. González en su proyecto: disminución de la edad para alcanzar la ciudadanía y consagración del voto secreto. (Di Tella, 1998:117) ${ }^{160}$

No obstante, su vigencia en las elecciones del año 1904 y el acceso de Alfredo Palacios como Diputado -por el distrito de La Boca- señaló el inicio de la representación del socialismo en el Congreso Nacional. Vale decir que, además, rompió el círculo cerrado de la "lista completa" lo cual, de alguna manera, significó un avance sobre la oligarquía, toda vez que, además del Partido Socialista, resultaron también elegidos algunos representantes de la U.C.R.

\subsection{5 - Revolución.}

Finalizado su mandato, una vez más Roca fue el gran elector, supliendo al pueblo. Si bien su maniobra -proponer que el presidente fuese designado por una Asamblea de Notables- fracasó, ello no fue obstáculo para desplazar nuevamente a Pellegrini, resultando electo Manuel Quintana.

Desdeñando el fraude y fieles a sus principios, los radicales se abstuvieron de participar en los comicios.

Quintana asumió como presidente en el año 1904 y José Figueroa Alcorta lo acompañó desde la vicepresidencia. Este contubernio, al igual que los habidos con anterioridad y en los que habría de reincidir el régimen, acrecentaron aún más las profundas diferencias existentes entre quienes poblaban nuestro territorio.

\footnotetext{
${ }^{160}$ Expresa Di Tella el argumento que -en la sesión del 20 de diciembre de 1902- proporcionó Pellegrini:"El voto secreto es contrario a ciertas bases fundamentales de nuestro régimen político. Una de las condiciones más importantes para que este régimen funcione con regularidad es la existencia de grandes partidos políticos con sus programas, con sus tendencias, con sus hombres representativos; y son estos grandes partidos políticos los que vienen a remediar, en la práctica, los inconvenientes del sufragio universal; pues este sería el caos, la anarquía, si no existieran estos partidos, que lo disciplinan y que lo hacen servir a ideas y propósitos determinados. Pero un partido supone la acción pública: el meeting, la discusión del candidato, la discusión del programa. Todos los actos preparatorios de la elección son actos públicos, en que cada ciudadano hace profesión de fe, de principios, de simpatía. ¿Qué significaría la publicidad de todas estas opiniones en el momento de condensarlas en un voto, si se quisiese convertirlas en un secreto? Se me dirá que es para resguardar a algún ciudadano que no tiene bastante independencia política para resistir a las influencias que pesarán sobre él. Pero no podemos trastornar toda una legislación para dar un escudo a la cobardía cívica".
} 
En esa convicción, sostuvo J. Álvarez,

"Nuestro pasado demuestra que librar la previsión a los resultados naturales de la lucha por la vida, no defiende suficientemente a los débiles o a los menos aptos, esto es, a quienes más lo necesitan. Si el Estado aspiraba a formar una nueva nacionalidad atrayendo a su seno a los desheredados del planeta ¿cómo olvidó prevenir la enfermedad, la vejez y la falta de trabajo? Hoy mismo, un obrero nuestro se alimenta mejor y está más respetado que en la Edad Media; pero vive al día y suele carecer de arraigo. No parece razonable ofrecerle aquí, para que se quede, un sistema idéntico al que le obligó a emigrar de su patria” (Álvarez, 1984:120)

Queda demostrado que, si bien a comienzos del siglo XX los derechos individuales eran "formalmente respetados" y cientos de extranjeros llegaban huyendo de la miseria y la intolerancia; y aunque se enseñase la Constitución Nacional en las escuelas públicas como un dogma que, en cuanto tal, per se y demiúrgicamente, fuera capaz de asegurar progreso e igualdad para el colectivo todo, ello no fue suficiente para que un sentimiento subjetivo de igualdad -entre inmigrantes y nativos- se instalara en la sociedad civil, trasuntándose a la sociedad política.

Para el pensamiento y accionar de los gobernantes, ninguno de los temas mencionados constituía un problema digno de merecer su atención y, por ende, ser considerados. Tal estado de cosas provocó -como lo adelantásemos- el levantamiento popular en el año 1905, cuyo detonante fue el cansancio, la irritación popular frente al método de supervivencia planteado por el modelo de 1880, basado en el fraude. Revolución que -si bien contó con el respaldo del ejército- abortó ante la declaración del estado de sitio. Situación que permitió al presidente, vencer al radicalismo y restaurar el régimen.

Poco tiempo después de morir Quintana, asumió José Figueroa Alcorta y buscó el aval de una coalición de fuerzas políticas -el Partido Republicano, fundado por Mitre; los viejos autonomistas y otras organizaciones políticas independientes- para el desempeño de su cargo.

A su turno, Pellegrini habida cuenta de su postura antagónica con Roca, imprimió desde su rol de legislador, significativos cambios en sus maniobras políticas.

Contrariamente a la conducta mantenida hasta entonces, se mostró como un irrestricto guardián del libre juego electoral -al igual que los radicales- manifestando que el radicalismo se veía forzado a consumar revoluciones porque no se les permitía la libre 
participación y, anticipándose a la ley de amnistía que seguramente, y como en oportunidades anteriores, dictaría el Congreso, atacó al gobierno. (Eggers-Brass, 2006:409) ${ }^{161}$

Su pronto fallecimiento, acaecido en 1906, al igual que el deceso de Mitre, Quintana y Bernardo de Irigoyen, posibilitó que Roca, nuevamente, ocupara un rol protagónico al obstaculizar -valiéndose de su mayoría parlamentaria- el accionar del presidente.

Esto condujo, junto a la falta de aprobación del presupuesto, a que Figueroa Alcorta diera por finalizadas las sesiones extraordinarias. Sin llegar a "clausurar" el Congreso, prohibió la reunión de legisladores, dentro y fuera del parlamento y se dedicó a preparar los actos previstos para el centenario de la Revolución de Mayo. Para garantizar la celebración y ante las turbulencias sociales que continuaban sucediéndose, recurrió a las rutinas de aquellos que le precedieron en el mandato: represión y estado de sitio.

\section{Las coyunturas revolucionarias.}

Las "revoluciones" hasta aquí analizadas, permitieron poner en evidencia la íntima relación que medió entre las oscilaciones del ingreso per cápita y el acaecimiento de las tres revueltas, por lo que, prima facie, no fueron acompañadas por el pueblo con idéntico espíritu ciudadano.

Distintos autores coinciden en señalar que en tanto las insurrecciones armadas de 1890 y 1893 fueron eminentemente populares, acompañadas de una masa que las siguió con simpatía, formada en su mayoría por jóvenes y una clase media en formación, la ocurrida en el año 1905 tuvo escasa repercusión.

Para explicar el por qué de ese comportamiento, J. Álvarez utilizó un índice estadístico: "la cantidad de artículos importados que registró nuestra balanza, en comparación con la de Estados Unidos de Norteamérica”.

\footnotetext{
${ }^{161}$ Expone Eggers-Brass, que Pellegrini dijo, en un discurso en el Congreso, que el régimen imperante: "no era representativo por las prácticas viciosas que constituían a los gobiernos en grandes electores, no era republicano porque no existía independencia de poderes, ni era federal por las constantes intervenciones a las autonomías provinciales".
} 
El análisis realizado le permitió señalar que, mientras el episodio del 1890 se produjo en un declive, los acontecimientos de 1893 acontecieron en un período de estabilización a bajo nivel, acaeciendo el de 1905, en una -denominada por Bagú (1984:9$10)-$

“[...] curva ascendente muy rápida, aunque en una altura inferior a la de 1890. No debemos dudar que el factor económico estuvo presente en el primer plano de los acontecimientos, aunque los hombres que redactaron las proclamas revolucionarias no lo comprendían, ni, por lo tanto, lo traducían en ellas. ${ }^{162}$

A no dudar, el escenario ofrecido en el año 1905, mostró grandes diferencias con la visión que ofrecieron las últimas décadas del siglo XIX. Una suerte de bonanza y prosperidad había dado comienzo por estos lares y los inmigrantes europeos llegaban nuevamente a nuestras costas en grandes contingentes. Debido al auge de las exportaciones, el bloque de poder de los ganaderos bonaerenses hacía gala de las ventajas comparativas que gozaba en la pirámide estructural, por lo que el lujo y despilfarro signaron sus conductas.

Situación, la descripta, que dejó al descubierto la asimetría socio-económica que existió -y coexistió- no solo con el hacinamiento de los habitantes de los conventillos ubicados a la vera del riachuelo porteño, sino también con la severa desocupación imperante en los centros urbanos. El despiadado marco especulativo que guiaba a los grandes terratenientes al fijar el precio de las tierra -sobre todo en la pampa húmeda- muy por encima de las posibilidades de los humildes trabajadores rurales (chacareros, campesinos, pequeños arrendatarios) completó, a no dudar, el panorama que se ofrecía al imaginario colectivo.

Otro emergente fue el movimiento obrero, reunido en torno a la Federación Obrera Regional Argentina (F.O.R.A) portador de ideales anarquistas-libertarios y la Unión General de Trabajadores (U.G.T) asociación que nucleaba al sector socialista. Si bien se trató de militantes, en su mayoría extranjeros, que se mostraban renuentes a cualquier

\footnotetext{
162 Añade el citado autor: "Pero el hecho cierto fue [...] que cuando los radicales volvieron a levantarse en 1905, los pequeños estancieros bonaerenses, los hijos jóvenes de familias ricas y la incipiente clase media no los escuchó con tanto entusiasmo como en la década anterior. Por vía del sufragio, en cambio, esos mismos grupos sociales iban a llevar al radicalismo al poder en 1916, con el concurso de algunos sectores de clase obrera.".
} 
injerencia de orden político considerando la experiencia habida en los gremios de los distintos países de procedencia, buscaron su fortaleza en estas organizaciones. El enfrentamiento habido con el régimen llevó a que se produjeran intensas luchas obreras durante los años 1906 (se registraron treinta y nueve huelgas), 1907 y 1908 (huelga general durante varios días, contra la Ley de Residencia).

En el año 1909 los obreros propusieron -unificando ambas asociaciones- la constitución de la Confederación Obrera Regional Argentina (C.O.R.A). Esto no fue aceptado por los anarquistas quienes agudizaron su intransigencia por medio de la prensa, a través del diario matutino "La Protesta" y de "La Batalla" -diario vespertino-, conducta que, como venimos viendo, fuera adoptada por la sociedad civil toda, desde el inicio de nuestra formación política. Así, "La Vanguardia" fue el órgano de expresión de los socialistas, en tanto la C.O.R.A apareció con "La Confederación”.

Lo descripto permite concluir, que este "cambio" en el aspecto social operado durante la década, solo fue en lo aparencial de la vida cotidiana y para unos pocos, ya que no fue acompañado por la existencia de una estructura de producción capaz de otorgar respuestas hábiles a la cuestión económica. Fundamentalmente, porque, reiteramos, la propiedad de las tierras más aptas ya estaba -deliberada y fatalmente- consumada y, paralelamente, no mediaba atisbo alguno acerca de buscar la industrialización del país.

6. Años 1910-1914: regímenes electorales - Censo de 1914.

Pese a que nada cambió en las elecciones de 1910, lo cierto es que, la muerte de Roca (1914), selló el fin del "régimen", es decir, de todo un ciclo cuyo común denominador estuvo constituido por el fraude y la violencia.

Repudiando este estado de cosas, hecho carne en gran parte de la población, el radicalismo reiteró su postura abstencionista dada la continuidad del régimen electoral.

Roque Sáenz Peña, candidato de los 'notables', ocupó la presidencia, desempeñándose en calidad de vicepresidente Victorino de La Plaza.

Una nueva muestra del referido inconformismo de la población en lo referente al nivel socio-económico, se puso de manifiesto con el llamado "Grito de Alcorta". La desigual relación existente entre terratenientes, campesinos medios y pequeños 
arrendatarios -posicionamientos estructurales a los que ya hiciéramos referencia- se vio incrementada en 1911 debido a las importantes pérdidas derivadas de una nefasta cosecha. Como consecuencia, en el año 1912 y pese a una cosecha redituable, a contrario sensu, los precios no acompañaron ese resultado, por lo que los agricultores no pudieron afrontar el pago de las deudas existentes, derivando ello en un reclamo que -iniciado por un grupo residente en Alcorta (Pcia. de Santa Fe)- generó un movimiento que se expandió no solo por el sur de Santa Fe, sino que pasó a Entre Ríos, Córdoba, norte de Buenos Aires y La Pampa. (Eggers-Brass, 2006:412) ${ }^{163}$

Respecto a las relaciones habidas en el concreto sistema de poder, debemos destacar de la presidencia de Sáenz Peña que, en febrero de 1912, promulgó la Ley $\mathrm{N}^{\circ} 8.871$ estableciendo el voto universal, secreto y obligatorio, y a la que se la llamó por su nombrela cual, sin duda, constituyó un mojón trascendental para la ciudadanía.

Además de introducir modificaciones en el régimen electoral en cuanto al control que debía ejercer el Poder Judicial, la confección de los padrones, distritos electorales y lista incompleta, como colofón y para crear al sufragante -ya que el pueblo dado el fraude no concurría a votar- instituyó el voto obligatorio. Con el nuevo régimen electoral la Unión Cívica Radical abandonó su postura abstencionista.

Ante la muerte de Roque Sáenz Peña, asumió el vicepresidente Victorino de la Plaza, quien, continuando con la impronta política dada por Sáenz Peña, mostró, ante la opinión pública, preocupación por la marcha de las instituciones y la reorganización de los partidos (Eggers-Brass, 2006:413) ${ }^{164}$, cuestiones a las que sumó, intentando adoptar una actitud "reformista", su interés por introducir modificaciones en la instancia regional de lo económico-financiero.

Lo hasta aquí expuesto, reiteramos una vez más, tornó evidente que no fue suficiente incorporar "formalmente" -en la consecución de una mentalidad ciudadana

\footnotetext{
${ }^{163}$ Destaca la autora que "[...] el radicalismo progresista de Santa Fe formó una comisión mediadora representando al gobierno [...]" que obtuvo positivas respuestas. Y agregó, "[...] es por ello que el radicalismo tuvo muchos votos en la región cerealera, y en 1912 la UCR le gana a Lisandro de la Torre [...] ex radical escindido en 1987, que tenía arraigo en los comerciantes de Rosario y en los colonos del sur de la provincia de Santa Fe".

${ }^{164}$ Opina, Eggers-Brass, en ese sentido, que V.de la Plaza "[...] fue visto [...] como 'un conservador resignado a llevar adelante una política reformista que no compartía'. Insistió en la necesidad de 'reconstruir los partidos tradicionales' a fin de contribuir a la 'estabilidad de las instituciones', cumpliendo el deseo de Pellegrini y de Sáenz Peña de permitir elecciones limpias, 'satisfaciendo así una ansiada aspiración nacional' (Floria y García Belsunce, 1971)".
} 
progresista, capaz de superar esa atonía- el principio teórico del sufragio universal, como tampoco la garantía republicana de la periodicidad propia de los cargos gubernativos, toda vez que la escuela argentina -en su carácter de “aparato del estado"- no preparaba suficientemente, ni en calidad ni en cantidad, los hombres necesarios capaces de bregar por una acabada articulación de ambos sistemas. (Álvarez, 1984:135) ${ }^{165}$

Queda claro que el régimen y la oligarquía abrazaron la causa del liberalismo en materia económica pero no hicieron lo propio en el plano político, sub-sistema en el que se manejaron con un cerrado posicionamiento conservador destinado a retener el concreto sistema de poder. Esto evidenció las contradicciones básicas que originó la pretensión del gobierno de insertar aceleradamente al país en el concierto mundial de la modernidad, sin considerar la fragilidad del colectivo y, por ende -y al interior de la formación política argentina- su propia debilidad. (Gorostegui de Torres, 1974:225) ${ }^{166}$

El pensamiento de Juan Álvarez, asimismo, destacó la relación existente entre la impronta económica y los conflictos armados acaecidos en el proceso de constitución de nuestra formación política, sin que ello implicara desconocer la existencia de factores de otra naturaleza.

Al respecto, expresó Sergio Bagú,

"En este gran emporio del trigo y de la carne, más de la mitad de la población vivía en núcleos urbanos cuando se levantó el censo de 1914. No por vocación, sino porque el campo argentino, con sus latifundios y su producción extensiva, solo necesitaba mano de obra escasa y barata. La consecuencia de todo esto fue una sucesión de hechos violentos, de huelgas reprimidas

${ }^{165}$ En 1910, sostuvo Álvarez que "[...] enviar al colegio solo una parte de la población escolar significa no haber resuelto el problema; y además, aún respecto de lo ya logrado, parecería necesario corregir un poco el rumbo, antes de seguir adelante. Nuestras escuelas superiores siguen siendo insuficientes para preparar la cantidad de estadistas que exige el turno incesante de los cargos públicos nacionales, provinciales y municipales; y la escuela primaria, si bien enseña a leer, escribir y contar, no crea ni afirma suficientemente el sentimiento de la solidaridad entre los argentinos. Como si el patriotismo solo hubiera de cimentarse en la vanidad nacional y en la existencia de héroes comunes, la escuela exagera las ventajas del país, ocultando sus defectos y necesidades. Deja entrever a los niños que solo aquí pueden hallarse tierras fértiles, clima suave, libertad, fácil riqueza y soldados animosos; con lo cual, produce ciudadanos para quienes los problemas nacionales no tienen más explicación que la inepcia de los gobiernos. La revolución de Mayo con sus héroes y sus glorias, es la estrella polar de nuestra ruta: sin otro bagaje histórico, los jóvenes deben distinguir cuáles revoluciones por parecerse a aquélla son sagradas, y cuáles han de reducirse a la categoría de vulgares delitos castigados por la ley de la materia. Interín lo averiguan, constituyen buena presa para cuantos necesiten revolucionarios apasionados y dispuestos a luchar gratis. En verdad, así entendida, la escuela primaria no evitará las guerras civiles".

${ }^{166}$ Y agrega la autora: "Esta dualidad se manifiesta a poco que se compare la política de modernización jurídica o de laicización con la resistencia opuesta a toda legislación progresista en materia laboral y, sobre todo, a cualquier intento de participación democrática de la población en el gobierno". 
con mano dura, de levantamientos de chacareros empobrecidos, de gran ampliación del movimiento sindical, de vasto arraigo del pensamiento anarquista, sindicalista y socialista en la masa urbana [...] la 'Semana trágica' de enero de 1918, alborada roja en un país confundido, cuyo gobierno aún se manejaba con un esquema liberal novecentista y cuya masa obrera urbana carecía de programas adaptados a su momento histórico [...] Para explicarlo, de nada servía el tipo de historia que se encontraba en los textos escolares (ley 1420 y colegios nacionales creados por Mitre) [...] la estrecha conexión entre los salarios insuficientes y la huelga sangrienta o entre los arriendos rurales y el grito de Alcorta, que cualquier político secundario conocía por vía empírica, no aparecía en el planteamiento historiográfico habitual, como si se tratara más bien de episodios periodísticos.” (Bagú, 1984:7)

La reforma electoral de 1912, definitivamente, tuvo por finalidad iniciar una larga marcha en pos del aprendizaje de la ciudadanía, a efectos de lograr "cultura política" capaz de generar comportamientos de lealtad. Comportamientos entendidos como virtuosos, esto es, como manifestación de conciencia cívica, en el entendimiento de que, la participación de todos debería ser, al propio tiempo, un logro común y el único medio de garantizar la democracia, aún desde el disenso. (Álvarez, 1984:130) ${ }^{167}$

Por lo cual, al posibilitarse la libre participación popular, las recurrentes crisis vividas hasta entonces y que llevaran a un déficit de legitimidad dada la carencia del necesario e insoslayable proceso de legitimación, en teoría, deberían haber tenido finiquito.

\footnotetext{
${ }^{167}$ Expresó así, que "Hasta entonces, el fraude y la violencia, habían producido una apatía del cuerpo electoral teórico, favorable al voto calificado, esto es, a la eliminación de los manifiestamente ineptos, de tal suerte, que, sin gran esfuerzo, pudo normalizarse el gobierno de las minorías cultas, lo que hubiera significado adaptar la ley a las costumbres, aun corriendo el albur de exponer el país a nuevas revoluciones. Por ello, se optó el voto de verdad, vale decir, con representación de las minorías, aún en la certeza de todos los inconvenientes que generaría entregar a las mayorías ineducadas una herramienta de esas características. Así, desde la independencia, recién en 1912 pudo empezar a saberse lo que tales mayorías esperaban del ejercicio del sufragio.".
} 


\section{CAPÍTULO III}

1916. Nueva legitimidad por legitimación del sistema y de los elementos del sistema.

Principio electivo-democrático. Sistema de Partidos. Primer gobierno popular.

Como mencionásemos en el capítulo anterior, en plena "era aluvial" y en clara y explícita disconformidad con la ideología impuesta por el liberalismo conservador, en 1880 comenzó a gestarse una nueva dirección política: la democracia popular. Régimen que surgió a la escena política, en respuesta a la crisis que representó el sistema político durante el unicato de Miguel Juarez Celman.

Así, esta novísima generatriz que conmovió el tejido social todo,

"nació como una aspiración en el seno del conglomerado criollo-inmigratorio y adquirió forma y sentido de movimiento político por obra de otros grupos que se aprestaron a la lucha contra la oligarquía encabezando aquella masa, informe e insegura en sus convicciones e ideales..." (Romero, 1969:205)

Ideales que -aunque confusos e inciertos- estaban latentes en el pueblo y que lograron concreción -acaecida la revolución de 1890- a través de las reinvindicaciones de la Unión Cívica Radical. Partido que, históricamente, señaló el derrotero de la libertad, la ética y el camino de las urnas obteniendo como respuesta la empatía popular y del que, cual crisol, fueron despegando hombres y grupos generando distintos movimientos políticos cada uno con sus propios anhelos, sueños y pretensiones.

1. El principio electivo-democrático.

Lo hasta aquí señalado, permite concluir que durante las ya analizadas etapas de nuestra historia política y hasta el año 1916, la inexistente legitimación -en la conceptualización por nosotros adoptada- pseudolegitimó, una sociedad política constituida por unos "pocos", una élite encargada de decidir formalmente ("legalmente") el destino de una formación política en ciernes.

Así, el mensurar la legitimación del sistema político a través de la legitimación de sus elementos, presupone una jerarquización de los mismos ya que, "algunos", resultan más relevantes pues, su justificación, repercute en todo el sistema (v.g.: accionar de Partidos Políticos y sindicatos, frente a los inputs/outputs de la instancia regional de lo económico) que, por ser elementos contingentes, proporcionan un transitorio bienestar económico. 
Lo propio acontece con el mero sostenimiento de los denominados "factores secundarios de legitimación”. Ninguno se basta a sí mismo para superar las crisis.

Teoría que hemos convalidado a través del decurso de nuestra historia -abordada en los capítulos anteriores- permitiéndonos concluir en que, un sistema de poder o alguno de sus elementos se legitima en base a un modelo socio-económico-político, (ó diseño de vida). (Barbé, 1968:43-44) ${ }^{168}$

Lo que nos interesa reiterar, es que existe un poder legitimado por la creencia, que supone la internalización previa del sistema de valores. Definitivamente, no existe un sistema político legítimo o ilegítimo, sino un proceso de constante interacción entre legitimado -sistema político, a través de un concreto poder- y legitimante, los actores, la sociedad civil, al que, siguiendo a C. Barbé denominaremos proceso de legitimación.

\subsection{Aplicación de la Ley Sáenz Peña.}

Como dijésemos, el estado de ebullición por el que atravesó la sociedad civil, permitió que el lento y farragoso proceso culminara en el año 1916, “con” y "gracias" al dictado de la Ley Sáenz Peña en el año 1912. Ley que fue "algo" más que el iceberg del nuevo proceso de legitimación, ya que generó una nueva legitimidad al consagrar el voto universal, secreto y obligatorio (aunque sin participación femenina). (Historia del Radicalismo, 1982:164-165) ${ }^{169}$

Las palabras pronunciadas por R. Sáenz Peña, al fundamentar el mensaje con el que acompañó el proyecto de ley, resultan esclarecedores de su postura y pensamiento,

\footnotetext{
${ }^{168}$ Sostiene el autor que debe quedar claramente explicitado que la legitimación se verifica a través de concretos y efectivos comportamientos (que no se reducen a la esfera de lo económico) los cuales -en su mutuo y recíproco contralor- constituyen la auténtica "historia de vida" o "diseño de vida". Cita en tal sentido a Smelser (1968:237, tit.orig. Theory of Collective Behavior, New York, 1963), quien manifiesta que el modelo de vida implica "el puesto ocupado por el hombre en la naturaleza, la relación entre los hombres, en fin, lo deseable y lo no deseable en el ámbito de las relaciones humanas". Refiriéndose a N. Poulantzas, (1971, vol.II: 28-29), agrega que, también queda comprendido en esa noción, el proceso de simbolización, la transposición mítica, el 'gusto', el 'estilo', el 'modo' de vida' en general..."

${ }^{169}$ Enuncia entonces, A. Rouquié que, evaluando el accionar político argentino: "Las circunstancias de la vida política resultaron considerablemente modificadas por la nueva ley (Sáenz Peña). Las posibilidades de participación política, hasta entonces muy limitadas, se ampliaron considerablemente [...] A partir de entonces, las capas populares que habían permanecido al margen de los juegos electorales reservados a la elite tradicional y a sus clientelas pasivas, entraron progresivamente en la vida política. Se pasó de una 'democracia limitada' a un sistema de 'participación ampliada': los individuos de transformaron en ciudadanos. En lo sucesivo, los estratos populares estarían en condiciones de movilizarse en pos de objetivos políticos $[\ldots]$ "..
} 
"Esto que se ha dado en llamar la quimera de un romántico, es una verdad tan práctica y un precepto de ejecución tan sencilla que cuando la sintamos realizada, recordaremos como un anacronismo los regímenes que la han desconocido”. Ya promulgada, y explicitando el sentido de la norma, se dirigió al país diciendo: “QQuiera el pueblo votar!” (Historia del Radicalismo, 1982:143)

Consagrando normativamente el principio de legitimidad "electivo-democrático" por cuyo logro se había luchado desde los comienzos de la organización política, la Ley $\mathrm{N}^{\circ}$ 8.871 -“Ley Sáenz Peña”- estableció el régimen electoral, fijando las calidades, derechos y deberes de los electores. Al instituir las elecciones parlamentarias y presidenciales, organizó colegios electorales; dispuso las características del sufragio (secreto, universal y obligatorio) para todos los argentinos varones mayores de 18 años y su específico procedimiento, como también el funcionamiento de las juntas escrutadoras o electorales, con fiscalización de los partidos; adoptando el sistema de representación de lista incompleta (mayoría y minoría). Finalmente regló la forma del escrutinio y el régimen de sanciones, precisando normas procesales como también disposiciones complementarias. (Digesto constitucional, electoral y municipal de la República Argentina, 1924:39). ${ }^{170}$

Sin embargo, fue necesario mucho más que una norma para educar al ciudadano y de ese modo terminar con los entuertos generados por el régimen y el consabido fraude. Por una parte, los hombres del radicalismo, demostrando su credo marchaban mostrando sus documentos y manifestando a viva voz “iNo se vende!”. Al propio tiempo, y en función docente la Unión Cívica Radical, luchaba por formar políticamente al ciudadano ${ }^{171}$ así como también, bregar por la observancia de lo que Yrigoyen llamara la reparación, vale decir, "la corrección de los vicios políticos y administrativos propios del régimen conservador".

En ese orden de ideas, manifestó en su mensaje de 1922,

"Hemos venido a las representaciones públicas acatando los mandatos de la opinión y estimulados por el deber de reparar, dentro de nuestras facultades y en la medida de la acción del

\footnotetext{
${ }^{170}$ Sancionada el 10 de febrero y promulgada el 13 de febrero de 1912, fue reglamentada mediante Decretos del 21 de marzo y 3 de abril de 1912 y publicada en el B.O. el 26 de marzo de 1912. En el lapso transcurrido entre 1912 y 1930, hubieron reformas legislativas: Leyes 9.147 (1913), 10.267 (1917), 10.269 (1917), 11.050 (1920) y 11.387 (1926), que no modificaron sustancialmente el sistema de la Ley 8.871 (se introdujeron reformas en los cuadros burocráticos y procedimentales, v.g.: creación de una Secretaría Electoral en cada Distrito).

${ }^{171}$ De modo que en muchos comités funcionaban las denominadas academias de enseñanza electoral, circunstancia que se daba a conocer por intermedio de los diarios de ese entonces.
} 
tiempo, todas las injusticias morales y políticas, sociales y positivas, que agraviaron al país durante tanto tiempo. Por esto no habremos de declinar, en ningún caso ni circunstancia, de tan sagrados, porque ellos constituyen la salud moral y física de la Patria”. (Romero, 1969:219).

Ante la réplica que formulara Lisandro de la Torre, respecto a que el radicalismo no contaba con un programa de acción para remediar las dificultades y contrariedades por los que atravesaba el estado, Yrigoyen había expresado que, intrínsecamente, la U.C.R. representaba la Nación. Esto es, que simbolizaba per se un sistema, dotado de lineamientos doctrinarios que señalaban la conducta a seguir para otorgar soluciones a la problemática estatal. (Romero, 1969:220) ${ }^{172}$

1.2. El rol de los partidos políticos y de la U.C.R. El surgimiento del ciudadano y de la voluntad popular como elementos del sistema político.

La dinámica de las fuerzas políticas analizadas en capítulos anteriores, permitió visualizar la significativa importancia que los años Noventa imprimieron a la escena política. Esa década, señaló el origen de los tres partidos políticos que intentaron responder a las demandas formuladas por el entramado social ante la emergencia de cierta conciencia de clase.

Apunta Galletti (1961) que las líneas de nuestra política obedecieron, pues, al "Liberalismo Ilustrado" de Urquiza, Mitre y Sarmiento. Seguido de la "Oligarquía Liberal”, en sus disímiles representaciones: a) la “Conciliación” de Avellaneda (1874-1880); b) el "Unicato" de Roca y Juárez Celman hasta 1890, momento en que se produjo la llamada primera gran ruptura en la marcha hacia la organización nacional; c) el "Acuerdo", inicio de un diferente modo de hacer política, determinado por "conciliaciones", "paralelas", "acuerdos", "contubernios" (período que comienza con Carlos Pellegrini, finalizando J. E. Uriburu); d) la nueva política de Roca y formación del Partido Autonomista Nacional (ensayo de "partido único").

${ }^{172} \mathrm{Y}$ justificando sus dichos, agregaba: "Extraviados viven los que piden programa de gobierno a la causa reinvindicadora. Como exigencia legal y como sanción de justicia me hace el efecto del mandatario pidiendo rendición de cuentas al mandante o del reo interrogando y juzgando al juez. Sería lo mismo que pretender el ejercicio de instituciones que no se han fundado o la aplicación de una constitución que no se ha hecho". Tal vez, si bien pueden entenderse estas palabras con pretensión mesiánica (como algunos mencionaron), nosotros preferimos hablar de postura idealista, propia del romanticismo-histórico, y como resultado del incipiente Sistema de Partidos (en términos de Yrigoyen instituciones que no se han fundado) . 
La presencia de "fuerzas de tensión" durante los mencionados períodos y enclaves, fue debilitando y disgregando la "oligarquía liberal” cuyo punto de inflexión lo constituyó, a no dudar, la Ley Sáenz Peña y la posterior llegada del Radicalismo al gobierno, momento en que se produjo la segunda ruptura (Galletti, 1961) con el advenimiento de la clase media al poder (1916).

Los disímiles ciclos por los que atravesó el Partido Radical -intransigencia con Yrigoyen durante su primer presidencia; la "línea conservadora" que imprimió Alvear a su gestión; finalizando con la "época de crisis" que signó el segundo mandato de Yrigoyencondujeron a la tercera ruptura que significó el golpe de 1930 y el retorno al "fraude electoral". (Galletti, 1961:11-18)

A su turno, los grupos en pugna que, paulatinamente fueron imbricándose y cimentando, por ende, la desunión en diferentes agrupaciones políticas ${ }^{173}$-aún las pertenecientes a la oligarquía- estuvieron constituidos por inmigrantes, en su gran parte ideológicamente formados en el anarquismo (Gilimón, 1997:531-538) ${ }^{174}$ y socialismo, y que, con el decurso del tiempo, resultarían fundamentales en la consecución de nuevos comportamientos y prácticas políticas.

Entre las principales y que perdurarían, aún con cambios, en el historial partidario de la formación política argentina, se encuentra el Partido Demócrata Progresista, organizado en torno a la figura de Lisandro de la Torre (que abandonase el Partido Radical por disidencias con Yrigoyen).

El Partido Socialista de Juan B. Justo, creado en junio de 1896, también fue desmembrándose hasta que se produjo la separación al comenzar el año 1918. En enero del mencionado año, el grupo disidente constituyó el Partido Socialista Internacional, más tarde convertido en Partido Comunista.

Con la aparición de Alfredo Palacios -quien llegara como Diputado Nacional en representación del socialismo en 1904- en el año 1915, nació a la faz política el Partido

\footnotetext{
173 A las que hiciésemos referencia en la Addenda al Capítulo I .

174 El "anarquismo", movimiento cuantitativamente integrado por obreros, tuvo como mayor exponente a la F.O.R.A. (Federación Obrera Regional Argentina) constituida en el año 1901. Así como en Europa se habían dividido en colectivistas y comunistas, el pragmatismo americano llevó a la conformación de dos ejes: organizadores y antiorganizadores. Poco a poco los primeros constituyeron el movimiento. Las huelgas, la violencia y el rechazo por la acción política (lo que provocó el definitivo alejamiento de sectores socialistas) caracterizaron su accionar.
} 
Socialista Argentino. Una última escisión se produjo en 1927 dando paso a la formación del Partido Socialista Independiente.

Definitivamente, la gente toda, cualesquiera fuere su origen y creencia, el "pueblo" que desde el inicio existió -aparencial y potencialmente- pero que hasta el dictado de la Ley Sáenz Peña no adquirió identidad institucional, pareció -a través del accionar de la Unión Cívica Radical- haber encontrado el modo, el camino para dejar de lado las lógicas diferencias y cerrar filas al servicio de un propósito mayor que podría resumirse en considerar a la política como una acción de carácter ético y entender el concepto del federalismo como una forma de soberanía institucional de la Argentina y de libertad personal.(del Mazo, 1951:11). ${ }^{175}$

Conteste con ello, andando el tiempo y refiriéndose más a un estilo de vida que a una forma de gobierno, sostiene Habermas, que no hay democracia sin escuchar y reconocerse en el otro, lo que conduce a la afirmación clásica según la cual los juicios morales y sociales son los medios de conservación y de reproducción de valores culturales, de normas sociales y de mecanismos de socialización [...] que la sociedad no es solamente un conjunto de producción, sino un colectivo que exige integración social y el mantenimiento de sus valores culturales tanto como los de producción; en términos más concretos, donde la educación y la justicia son tan importantes como la economía y la política. (Touraine, 1993:389)

2. Hipólito Yrigoyen: primer gobierno popular y legítimo.

La llegada del radicalismo al gobierno, representó una auténtica revolución. Teniendo como postulado esencial el orden basado en la vigencia de la Constitución, la U.C.R. promovió una nueva época en la política argentina, al penetrar profundamente en las instituciones de nuestra formación política toda.

175 Dijo H. Yrigoyen, al cumplirse un año de la revolución de 1905: 'La Nación, en todos sus ámbitos, fortificó la frente de los vencidos y compensó sus pesares, demostrando en todo sentido y de la manera más imponente que registran sus anales, que no son, precisamente, triunfos los que requiere de sus hijos, sino superiores abnegaciones y luchas fecundas, concordantes con sus aspiraciones y con los solemnes deberes de las horas por las que atraviesa. Por eso también el movimiento radical fue más grande al día siguiente del contraste y sigue siendo en tales proporciones que es corto el tiempo para incorporar todas las decisiones que quieren alistarse en sus filas". 
Significó también, abandonar la concepción existente hasta fines del siglo XIX en el sentido de entender la política como un signo de distinción y privilegio de unos "pocos" poseedores de poder económico y de una mayor cultura- quienes gerenciaban el sistema político como si fuere un bien propio.

Los comicios celebrados, dieron como resultado la elección de Hipólito Yrigoyen como presidente de la república. El año 1916 constituyó la génesis de una coyuntura que, a no dudar, configuró el umbral generador de la depuración ideológica habida en el pueblo, que buscaba contar con una democracia representativa y terminar con el sectarismo del régimen.

Hijo de Martin Yrigoyen un vasco inmigrante cuidador de caballos -nacido en la aldea del Sare enclavada en los Bajos Pirineos- y de Marcelina Alem -hermana mayor de Leandro Alem- Juan Hipólito del Sagrado Corazón de Jesús Yrigoyen, fue el mayor de cinco hermanos. Su origen popular, su pensamiento innovador por fuera de las estrechas fronteras del régimen, fue innegable. Ningún elemento lo unía a la oligarquía, representada por el liberalismo conservador.

Las elecciones de 1916, marcaron pues un hito, ya que incorporó a la noción líquida (Baubam, 2009) de "ciudadano" -candidatos y/u "ocasionales" electores y/o "grandes" electores- la participación de todos aquellos que hasta ese momento se habían abstenido de participar ante la presencia del "régimen". ${ }^{176}$

Esta incipiente participación y, como ya dijésemos, la tibia emergencia de un "Sistema de Partidos", junto con la consagración normativa del principio electivodemocrático, dieron como resultante la irrupción del primigenio gobierno popular.

Gobierno que -elegido por primera vez en la historia de la Nación Argentina, mediante elecciones legítimas además de legales- puso énfasis en los valores democráticos, sin abandonar las ideas de desarrollo y "progreso". Progreso no contemplado como pensamiento único y desde un punto de vista positivista (“hacer"), sino priorizando el "ser" y el "valer" del hombre, de la persona-humana en la conformación del pueblo y de su

\footnotetext{
176 Como presentáramos en el capítulo anterior, y resultando que las mujeres no gozaban del derecho a sufragar, cabe señalar que el total de argentinos varones representó un 30,3\% de la población total, mientras los extranjeros varones aumentaron al 35,7\%, registrándose un descenso en la tasa de masculinidad (v. Cuadro 5 en Anexo III) respecto a la década anterior.
} 
importancia respecto a "la" política y "lo" político, como condiciones necesarias para arribar a las otras instancias.

\section{Ejercicio del concreto poder.}

El retorno a la escena política de la Unión Cívica Radical -dando fin a su larga abstención- y, reiteramos, como primer gobierno popular, fue acompañado por nuevos grupos que, procedentes de los tiempos revueltos habidos en el entramado social y hasta ese momento ignorados, se incorporaron a "lo" político. De tal modo, a la fuerza de una clase media en gestación y de un proletariado industrial, se unió el aporte inmigratorio, como también una juventud amante del progreso. Segmentos constitutivos del tejido social que, portadores de nuevas demandas, exigían mayor participación y que en amplio abanico provenían

"[...] de todos los estratos sociales, desde el peón al estanciero, desde el proletario al comerciante; tanto el moderno empleado como el profesional liberal. Todas las capas sociales le prestaban su aporte, interpretada su honda protesta de renovación institucional." (Etchepareborda,R., 1986:15)

Profusas fueron las declaraciones de H. Yrigoyen en el sentido de avizorar el triunfo en las urnas de la Unión Cívica Radical, así como su paralela no aceptación a ser candidato a Presidente, teniendo por premisas el poder legítimo y la existencia de un pueblo soberano. (Historia del Radicalismo, 1982:158) ${ }^{177}$

Aunque nunca fue un movimiento, mucho menos un partido político, de unanimidades -lo cual motivó una intensa vida al interior partidario con disímiles puntos de vista y divergentes actitudes- Hipólito Yrigoyen fue elegido por la Convención Nacional de la U.C.R como candidato del partido para ocupar el cargo de Presidente. Al ser anoticiado de tal decisión en su domicilio de la calle Brasil (barrio de Constitución de la Capital Federal), respondió con un "no" y entregó a sus interlocutores una carta proporcionando las razones por las que declinaba el ofrecimiento, expresando, al propio tiempo, su reconocimiento y excusas ante la Convención.

177 Sostuvo al respecto, "[...] cuando hayan desaparecido todas las opresiones que ha soportado el país, dando paso a los gobiernos legítimos que exalten y cimenten la voluntad popular [...] Y reorganizada la República sobre una representación veraz de la democracia, los poderes ejercerán sus funciones con la más alta autoridad y el aplauso unánime de los pueblos, porque el respeto y el cariño que éstos profesan a las magistraturas legítimas determinan el enaltecimiento de la investidura de la misma”. 
En algunos de sus párrafos, manifestaba

“[...] Mi pensamiento no fue jamás gobernar el país [...] Tengo la convicción de que haría un gobierno ejemplar, pero un gobierno no es más que una realidad tangible, mientras que mi apostolado es un pensamiento [...] una espiritualidad que perdura a través de los tiempos, cerrando un ciclo histórico de proyecciones infinitas [...]” (Historia del Radicalismo, 1982: 160)

Su negativa llevó a la Convención a insistir y, ante una nueva resistencia, los delegados respondieron amenazando con regresar a sus provincias y disolver la U.C.R.

La alternativa y complejidad del tema, llevó a H. Yrigoyen a expresar:

“Hagan de mi lo que quieran” (Historia del Radicalismo, 1982: 160)

No fue un momento fácil. Por primera vez se utilizaría con alcance nacional, el voto universal, secreto y obligatorio.

La oligarquía presionaba sobre Victorino de la Plaza y los fraudes denunciados tenían como meollo la provincia de Buenos Aires, responsabilizando de ello al entonces Ministro de Gobierno, Marcelino Ugarte. A esta situación, se agregaba que la U.C.R hacía cuatro años que lograba triunfar en comicios provinciales -piénsese que, en esa época, era la única agrupación de dimensiones nacionales que contaba con organización en las catorce provincias- y que, prácticamente no había existido campaña electoral ya que H. Yrigoyen no hablaba en actos públicos. No obstante, tal conducta, no impidió movilizaciones populares y que el 29 de marzo disertara, entre otros, en un teatro de la ciudad de Rosario (Pcia. de Santa Fe) el candidato a vice-presidente Pelagio Luna.

De todos modos pese a los favoritismos políticos y prácticas fraudulentas, el pueblo deseaba ejercer su soberanía en las urnas. Ya hemos analizado cuantitativamente los guarismos a que ascendía la población y el importante número de extranjeros que la integraba por lo que no debe extrañarnos que el padrón electoral -por cierto nuevo por lo cual resultó plausible encontrar algunas imperfecciones- no llegara al millón doscientos mil (1.200.000) de ciudadanos. Si a ello agregamos la inexperiencia de los votantes, las maniobras disuasorias y el sempiterno "fraude", el resultado fue que sólo el $64 \%$ de los inscriptos (759.000 ciudadanos) acudió a las urnas: 339.332 votos correspondieron a la U.C.R., lo cual representó 143 electores. La cantidad alcanzada, no garantizó el triunfo en el Colegio Electoral ya que, para obtener la mayoría, era necesario contar con 151 votos y 
existían disidentes dentro de la U.C.R. que representaban a la Pcia. de Santa Fe (28.267 votos, 19 electores).

Finalmente primaron los principios por sobre los hombres y la fórmula de la U.C.R., Yrigoyen-Luna, recibió 152 votos (uno más de los que necesarios para la mayoría absoluta); el Partido Conservador (Rojas-Serú) 153.406 votos, 65 electores; el Partido Demócrata Progresista (de la Torre-Carbó) 123.637 votos, 65 electores y el Partido Socialista (Justo-Repetto) 52.895 votos, 14 electores. (Etchepareborda, 1986: 17-19)

4. Sentido ético y establecimiento de políticas de estado.

Más allá de la opinión de sus biógrafos, Yrigoyen marcó hechos objetivamente incontrastables acerca de sus convicciones éticas y morales, tendientes a demostrar al colectivo social -que había otorgado legitimidad a su mandato- que la construcción de un nuevo diseño de vida gestado durante el proceso de legitimación, no sería defraudado.

Poniendo de manifiesto la ética krausista, renunció, por ejemplo, a sus futuros sueldos de Presidente a favor de la Sociedad de Beneficencia -reiterando la actitud mantenida durante diecisiete años en los que también había donado sus sueldos de profesoral ser elegido para presidir la fórmula, esto es, antes de ser designado como primer mandatario. Ello, convalidando su sentimiento de respeto a la civilidad, como también los esfuerzos no exentos de sacrificio, realizados con el objetivo de reintegrar a la Nación la integridad que forja el contenido espiritual y la dirección cultural de un pueblo.

Un nuevo testimonio de cómo regiría los destinos de aquellos que habían depositado su confianza en el nuevo proyecto de vida, legitimándolo, lo proporcionó la conformación del gabinete ministerial: no solo habían desaparecido los apellidos perpetuados durante décadas por la oligarquía, sino que, para conducir los ministerios de Guerra y Marina fueron nombrados civiles.

Constituyeron el gabinete inicial: Interior, doctor Ramón Gómez, Relaciones exteriores, doctor Carlos A. Becú; Hacienda, doctor Domingo Salaberry; Obras Públicas, doctor Pablo Torello; Justicia e Instrucción Pública, doctor José S. Salinas; Agricultura, 
doctor Honorio Pueyrredón; Guerra, señor Elpidio González y Marina, ingeniero Federico Alvarez de Toledo. (Historia del Radicalismo, 1982: 174-175) ${ }^{178}$

Reiterando su concepción ética acerca del quehacer político, manifestaba Yrigoyen en el mensaje que dirigiera el 15 de octubre de 1921 al Congreso Nacional,

“Cada vez es más imperioso hacer del ejercicio cívico una religión política, un fuero inmune, al abrigo de toda contaminación, hasta dejar bien cimentadas las prerrogativas inalienables e imprescriptibles de la nacionalidad [...] y agregaba con mayor rigor: "Es indispensable fijar como condición irreductible que la moral política es la base de todos los progresos y de todas sus formas eficientes”. (Historia del Radicalismo, 1982: 230)

La impronta rectora del quehacer yrigoyenista, llevó a Carlos Ibarguren, decidido censor del radicalismo, a sostener

"Ese gobierno de Yrigoyen fue, en nuestra historia, muy representativo, no porque significara el de una mayoría electoral, sino porque entregó la suerte del estado y de sus resortes políticos al dominio de un vasto estrato de la sociedad argentina que hasta ese momento jamás había gravitado ni ascendido al poder, y que constituía una de las capas básicas en que se asentaba la nueva Argentina de la inmigración [...] El historiador debe considerar que fue necesaria, en su momento, esa importante evolución, resultado de la reforma electoral hecha por el presidente Sáenz Peña, quien con su honda mirada de estadista vio que en los renovados cimientos de nuestro país estaba comprimida una enorme represa de ciudadanía a la que era indispensable darle salida en la vida cívica para que no rompiera con violencia y rebeliones el dique que la sofocaba" (cit. en Etchepareborda, 1986:20)

No vamos a detenernos en los detalles de la asunción, el juramento y el frenesí popular que rodeó la ceremonia. Sólo a modo de ejemplificar la objetiva presencia de un proceso de legitimación al interior del colectivo, mencionamos que la multitud desenganchó los caballos de la carroza que condujo a Yrigoyen, Luna y los más altos jefes del Ejército y la Armada, y tiró de ella desde el Congreso hasta la casa de Gobierno.

\footnotetext{
${ }^{178}$ Pese a ello, no todo el periodismo acompañó esa decisión. En su editorial del 13 de octubre, sostuvo "La Nación": "Apresurémonos a decirlo: la impresión pública es mala. Algunos de los nombres que figuran en la lista podrían aparecer en cualquiera de las siete carteras restantes, sin más ni menores títulos que en aquella para la cual han sido designados. Los antecedentes de su eficacia electoral han influido en una forma exclusiva para su consagración ministerial, de modo que llegan al gobierno muy ejercitados en las lides del Comité, pero totalmente ajenos a las funciones en que les tocará actuar". Sin embargo, en la praxis y durante los seis primeros años, la realidad puso de manifiesto los pocos cambios producidos y, paralelamente, la eficacia demostrada en el desempeño de sus funciones.
} 
Conducta que mereció el disgusto de Yrigoyen pero, ante la imposibilidad de controlar al pueblo sin que mediera el ejercicio de la fuerza, ordenó a la custodia no intervenir.

La lucha agonal no había resultado fácil para la U.C.R., ni para Yrigoyen. Tampoco lo fue el ejercicio del poder.

Ya en el concreto poder y heredera de un Congreso no renovado, la U.C.R. representaba la "minoría" en la Cámara de Diputados (45 bancas frente a 70 de la oposición) y contaba con cuatro (4) representantes en el Senado, siendo veintiséis (26) los pertenecientes a la oposición. (Historia del Radicalismo, 1982: 180)

Lo cierto es que, al abandonar la abstención, Yrigoyen no sólo había elegido sino también aceptado una legalidad 'heredada' del régimen. Circunstancia que -además de impedirle 'purgar', desbaratar, las trasnochadas prácticas existentes en los tres poderes- lo sumió en un entrañable desasosiego, según lo confesara a Ricardo Caballero, con estas palabras:

“'El poder! ;Llegar al poder! No le oculto que lo he ambicionado, pero por el camino de la revolución, con las características con que yo conducía el movimiento, cuando ustedes los de Santa $F e$, se me cruzaron y me obligaron, con la vehemencia de su buena fe, a tomar el de las vías comunes, tan lleno de dificultades para realizar una obra limpia, a causa de la maraña de intereses que crecen en él. (Etchepareborda, 1986:20).

En las provincias, sólo tres Gobernadores respondían a su ideología: Córdoba, Santa Fe (aunque con disidencias) y Entre Ríos. El resto (once provincias) se mantuvieron leales al "régimen" ya que no estaban dispuestas a desafiarlo, permitiendo el voto libre y limpio de la ciudadanía, toda vez que eso significaba poner en peligro sus particulares situaciones distritales.

Dialéctica, la plasmada entre los poderes nacionales y las situaciones provinciales, que fue resolviéndose mediante "intervenciones", (Romero, 1969:222) ${ }^{179}$ las cuales, ante un parlamento en franca minoría, fueran declaradas por decreto del Poder Ejecutivo Nacional.

Fundamentando su postura doctrinaria, sostuvo en los considerandos del decreto del 24 de abril de 1917- por el que dispuso intervenir la provincia de Buenos Aires:

\footnotetext{
${ }^{179}$ El origen espurio -no legítimo- de casi todos los gobiernos provinciales, obligó a Yrigoyen a utilizar el mencionado instituto con el fin que, más adelante y establecidas las debidas condiciones, la ciudadanía pudiera expresar su voluntad soberana. Sostuvo en 1918, "No habría habido poder humano que me hiciera desistir de la reorganización de todos los gobiernos ilegítimos, detentadores de la soberanía de los pueblos”.
} 
"El pueblo de la República, al plebiscitar su actual gobierno legítimo, ha opuesto la sanción soberana de su voluntad a todas las situaciones de hecho y a todos los poderes ilegales. En tal virtud, el Poder Ejecutivo no debe apartarse del concepto fundamental que ha informado la razón de su representación pública, sino antes bien, realizar como el primero y el más decisivo de sus postulados, la obra de reparación política que alcanzada en el orden nacional, debe imponerse en los estados federales, desde que el ejercicio de la soberanía es indivisible dentro de la unidad nacional y desde que todos los ciudadanos de la República tienen los mismos derechos y prerrogativas".

Asimismo y esclareciendo su punto de vista y en oportunidad de aprobar las elecciones realizadas en la provincia de La Rioja, el 26 de febrero de 1919, el gobierno nacional manifestó,

"La renovación que se lleva a cabo en todos los poderes de gobierno de los estados de la República obedece a un mandato sancionado por el pueblo argentino y definitivamente consagrado en su historia; el poder federal cumple la fe jurada de dar a los Estados sus gobiernos verdaderos. Una vez legítimamente constituidos ellos quedan incorporados dentro de los preceptos de la Constitución y de sus leyes correlativas y sólo podrán ser intervenidos cuando concurran las circunstancias que la Carta Fundamental menciona y que deberán ser interpretadas y aplicadas restrictivamente por los poderes federales[...] En cuanto a las autonomías provinciales ellas son atributos de los pueblos y no de los gobiernos [...] La autonomía es la que recién ahora se ha de consagrar; y cuando ello se consiga habrá llegado el momento de amparar a sus gobiernos y respetar sus leyes”. (Etchepareborda, 1986:21-22).

Debe recordarse que, además de las catorce provincias, integraban el país diez gobernaciones ó territorios nacionales, constituidos como tal en razón de su reducido desarrollo y exigua población. Escenario éste, que, decididamente, no les permitía llegar a un nivel superior de institucionalización política. Ante ello, y decidido a recomponer las jurisdicciones territoriales, a partir del año 1919 el gobierno nacional comenzó a enviar al Congreso proyectos de ley que contemplaban -en razón del paulatino incremento poblacional, de la cultura y del crecimiento económico- la posibilidad de convertir en provincias, alguna de las gobernaciones. Comenzó con La Pampa y Misiones, a las que siguieron Chaco, Río Negro y Chubut. Ninguno tuvo tratamiento parlamentario. 


\subsection{Política económico-social.}

El poseer sólidos principios morales, generó en Yrigoyen y su gabinete, el respeto a sus semejantes, el ayudar al débil, suscitando conductas honestas en el ejercicio de la función públicas y en la consecución de una política distributiva.

De igual forma -entendiendo que la política económica resultaba la piedra angular sobre la que descansaba el crecimiento de los países desarrollados- su formación moral lo llevó a buscar la reconstrucción económica con sentido nacional, por lo que, juzgó que todo gobierno debía afrontar de modo preceptivo el cimentar y construir sensatas y estratégicas medidas para lograr tal cometido.

En 1917 el Poder Ejecutivo proyectó la creación de un Banco del Estado, que significaba, ya en esa época, la creación del Banco Central de la República Argentina, teniendo por valor internalizado como diseño de vida, la importancia de la moneda y el régimen bancario. (Historia del Radicalismo, 1982: 197) ${ }^{180}$

Notorio resultó el contenido social, la búsqueda del desarrollo nacional y soberano que orientaba el pensamiento yrigoyeniano, el cual trasuntado en proyectos de ley, caía ante las mayorías legislativas controladas por el régimen y por ende, objetivamente dotadas, reiteramos una vez más, de un obstruccionismo reaccionario. (Historia del Radicalismo, 1982: 196) ${ }^{181}$

Un significativo hito del sentido que pensaba otorgar el gobierno radical al ejercicio del concreto poder, lo constituyó el importante cambio impreso a las relaciones entre el capital y el trabajo.

Sin embargo y aunque el poder dejó de estar al servicio de los bloc au pouvoir constituidos por las oligarquías nacional y extranjera- erigiéndose en auténtico regulador de los conflictos sociales existentes en el nivel infraestructural, ello no impidió el recurrente uso de medidas de acción directa por parte de los trabajadores, como la realización de

\footnotetext{
${ }^{180}$ Argumentó Yrigoyen, que, a esos dos fundamentos, “[...] están supeditados la vida, el desarrollo y la producción nacional".

${ }_{181}$ Prueba de ello ofrecen unas palabras tomadas del Mensaje dirigido al Congreso el 11 de diciembre de 1916, solicitando autorización para la emisión monetaria, empréstito destinado: "[...] a) constitución del Banco Agrícola Nacional; b) creación de la Marina Mercante Nacional; c) explotación de los yacimientos petroliferos de Comodoro Rivadavia”. Petición que, sintetizara Yrigoyen sosteniendo que, con tales medidas, el Poder Ejecutivo perseguía concretar tres cuestiones prioritarias para el pueblo " [...] el desarrollo de la producción agrícola, el de la explotación petrolera nacional y el de una flota mercante que sirviese soberanamente al comercio exterior argentino [...]"
} 
numerosas huelgas durante los años 1916, 1917 y 1918, manifestaciones que, en muchas oportunidades, culminaron con la intervención policial, la cárcel y muertes.

Pese a ello, la mayoría de la conflictividad obrera fue canalizada mediante reinvindicaciones (reducción en la jornada laboral, condiciones de vida dignas, mejoras salariales, atención sanitaria, entre otras) logradas por las organizaciones sindicales, a través del diálogo propuesto por el gobierno -en su rol de legítimo y efectivo árbitro- con la parte patronal. (Historia del Radicalismo, 1982: 186) ${ }^{182}$

No obstante, existieron episodios en que el pretenso diálogo no fue comprendido y mucho menos aceptado. Tal el caso de los sindicatos ferroviarios. Las huelgas se sucedieron encadenadamente (protagonistas de la "La semana trágica") y debieron ser controladas por la policía. Policía -heredada del "régimen"- a la que, si bien no siempre el gobierno radical recurriera, hubo momentos en que se tornó inevitable su intervención. ${ }^{183}$

Dispuesto a concretar en actos, la creencia que el pueblo había depositado en su programa de gobierno y guardando la lealtad debida al proceso de legitimación que lo había llevado al ejercicio del poder, Yrigoyen -aún con las huelgas habidas en el período transcurrido desde 1916 a 1919- luchó por responder a las justas demandas. Para ello, no trepidó en dialogar con laboristas, sindicalistas e intelectuales, con quienes comenzó a elaborar proyectos de ley. Consecuente con ello y basándose en la necesidad de poner en marcha una justicia distributiva orientó en tal sentido el ámbito económico-social. ${ }^{184}$

\footnotetext{
${ }^{182}$ La conflagración mundial entablada en 1914, repercutió en la dirigencia e ideólogos de la FORA, organización que nucleaba por una parte (quintista) a anarco-libertarios, renuentes al arbitraje estatal y por otra (novenaria) guiada por socialistas y sindicalistas que, en definitiva, aceptó la mediación del gobierno y el paralelo establecimiento de una "reglamentación del trabajo" que, sin duda, significó para la historia una decisiva conquista laboral y puso un freno a la prepotencia del capitalismo extranjero, en su mayor parte inglés”. El triunfo de la Revolución Rusa en el año 1917, convulsionó definitivamente los ánimos revolucionarios de ambas organizaciones obreras, en sintonía con los trabajadores rusos y alemanes. De modo que, cuando los obreros de un establecimiento metalúrgico comenzaron una huelga persiguiendo mejoras y ante la intransigencia patronal, las dos centrales dispusieron una huelga general. El aumento del número de muertos, de una y otra parte, llevó a que al escenario se incorporaran fuerzas militares: las tropas de Campo de Mayo, al mando del general Luis J. Dellepiane, salieron para restablecer el orden alterado, respetando y haciendo respetar al gobierno popular e Yrigoyen facilitó el entendimiento. Similares hechos se repitieron en el noroeste, el Chaco santafesino y el litoral.

${ }^{183}$ El hecho que el gobierno no apelara a dicho factor, es decir que evitara el "choque", el enfrentamiento para sofocar las turbulencias habidas, obedeció, fundamentalmente, a que se trataba de una policía, de una corporación educada, formada para servir sólo a gobernantes y privilegiados, a pesar de estar integrada por padres, hijos o hermanos de obreros o ciudadanos de modesta condición social.

${ }^{184}$ Entre los mencionados proyectos, subrayamos los referidos a las ocho horas de trabajo, sueldo mínimo, regulación de los artículos de primera necesidad, percepción de salarios en moneda nacional, observancia del descanso dominical, mejoras en los contratos de trabajo, conciliación y arbitraje, jubilaciones y pensiones, casas para obreros, cooperativas, etc.
} 
En orden a los proyectos de ley presentados por el gobierno -estimulando la instalación de astilleros para la construcción naval y el transporte comercial- la mayoría parlamentaria reiteró, una vez más, su postura obstruccionista. Ello, en abierta y decidida omisión obscurantista, en franca ignorancia de las necesidades surgidas en razón de la crisis mundial provocada por el estado de beligerancia en que se debatía el orbe y la problemática que ello aparejó para el comercio.

Más adelante y con relación a la integración regional y con países vecinos, anticipó en un mensaje de 1922, la conveniencia de fomentar el desarrollo de ferrocarriles destinados a buscar una salida al Océano Pacífico para las provincias del Norte y centro del país (el Huaitiquina); otro paso hacia Chile (propiciando la unión con la Patagonia a través del Trasandino del Sur) y una comunicación con Bolivia (por Yacuiba) atendiendo la situación económica de los territorios del Chaco y Formosa.

Las propuestas ferroviarias interesaron al Congreso, pero obligó a Yrigoyen a vetar una ley ya que toda la planificación ferroviara quedaba subordinada "a la organización de una compañía privada" que recibiría en propiedad la red de ferrocarriles Nacionales permitiendo, además, negociar la fusión con el resto de los ferrocarriles existentes en el país, constituyendo una compañía accionaria.

Fundamentando el veto, Yrigoyen consideró que la pretensa norma resultaba un verdadero despojo del patrimonio soberano, ya que entregaba a los manejos privados el patrimonio de los Ferrocarriles Nacionales recibiendo a cambio

“[...] papeles de un valor dudoso que solo permitirán favorecer las conveniencias de los tenedores de acciones de empresas determinadas, a costa de los sagrados intereses de la Nación”. (Historia del Radicalismo, 1982: 196-197)

De todos modos, la mayoría de los proyectos sucumbieron como tales. Entre ellos los tendientes a fomentar la explotación petrolera y al dictado de la ley orgánica del petróleo (Historia del Radicalismo, 1982:198) ${ }^{185}$; así como, los referidos a la exportación agropecuaria que, en esa época, constituían una realidad tangible. En este último caso debió enfrentar dos temas: incrementar la producción mediante el fomento y colonización

\footnotetext{
${ }^{185} \mathrm{Ni}$ bien asumida la Presidencia, Yrigoyen "[...] trató de arbitrar fondos para la explotación de los yacimientos de petróleo de Comodoro Rivadavia. A ellos se agregarían, en 1918 los descubiertos en Plaza Huincul. Años más tarde, en 1927, el autor radical José Bianco, alertaba sobre la forma 'con que el capital extranjero se adueña de los resortes oficiales' y calificaba al tema del petróleo -adviértase la época-como 'nudo gordiano de la política mundial'",
} 
agrícolo-ganadera y, al propio tiempo, mejorar el régimen de distribución de la tierra pública a fin de llevar progreso a zonas del interior para de ese modo atenuar las desigualdades regionales y el inevitable crecimiento asimétrico. (Historia del Radicalismo, 1982:194-195) ${ }^{186}$

Como en el ya abordado caso del transporte, los proyectos no se transformaron en ley, puesto que la oligarquía persistió en su accionar antipopular, entorpeciendo la implementación de políticas de estado.

Para contrarrestar las conductas antidemocráticas en áreas muy sensibles como la explotación energética, el gobierno recurrió a legítimos resortes respecto a la creación de Y.P.F. Así, cuando corría el año 1922, estableció administrativamente -en el ámbito del Ministerio de Agricultura- la Dirección General de Yacimientos Petrolíferos Fiscales. Organismo éste que dirigiera el general Enrique Mosconi, y que meses más tarde, al llegar a la Presidencia Alvear, se transformara en la gran empresa nacional.

A esta altura de la exposición, deviene significativo estar al corriente de la opinión que un legislador socialista tuvo sobre la postura opositora reaccionaria, al expresar,

"Derrotado el Partido Conservador por el radicalismo [...], a sus dirigentes no se les ocurrió la única idea sana que cabía, en esas circunstancias, concebir y realizar a un partido oligárquico de terratenientes que había dominado el país durante un siglo y que caía del poder deshecho y desprestigiado por la victoria de otro partido que representaba las clases medias: la idea de modernizarse y convertirse en un organismo que, si bien no debía volver al gobierno, podía ser aún de alguna eficacia pública como partido de moderación y colaboración [...] Lejos de esto, el conservadorismo sólo pensó en la reconquista del poder, y como su índole oligárquica y el número reducido de sus elementos no le permitían aguardar un futuro triunfo con sus propias fuerzas, imaginó primero la fórmula del antirradicalismo, el antiyrigoyenismo después, para reunir en torno a esa bandera negativa y estéril, no sólo a los conservadores sino también a todos los

\footnotetext{
${ }^{186}$ Debe tenerse en cuenta las depredaciones a que fueran sometidas - "campaña del desierto" mediante- las tierras fiscales durante tantas décadas. Por eso en el año 1916 el gobierno ordenó un relevamiento catastral en varios territorios nacionales; por otro Decreto de 1921, dispuso "[...] establecer un plan orgánico de colonización que, velando por los intereses del Estado y haciendo de la tierra pública un factor de progreso y no de especulación, arraigue las poblaciones que han de formar los futuros núcleos de nuevas provincias". Pero no se trataba solo de distribuir extensiones determinadas, porque a los colonos "[...] no es posible abandonarlos en las tierras que se les entregan, sin garantirles el desenvolvimiento provechoso de su trabajo dentro de direcciones económicas acertadas". También fueron contemplados aspectos relacionados a la tecnificación de las labores, a la educación del hombre de campo y a su bienestar, "tratando de resguardar al colono de los monopolios expoliadores" (v.g.: los referidos a la falta de arpillera, bolsas e hilo sisal, elementos indispensables al momento de la cosecha).
} 
demás partidos, o fracciones de partidos, que decidieran hacer una política de oposición sistemática al radicalismo [...] Para fomentar el surgimiento de estos elementos opositores en el Partido Socialista y en el seno mismo del Partido Radical, los conservadores adoptaron como línea de conducta permanente, en los distritos electorales donde sus propias fuerzas no tenían predominio, votar los candidatos de otros partidos que se declarasen antirradicales o hicieran política antirradical [...] Adoptaban formas hábiles y cautelosas. Una de ellas era aconsejar al 'electorado independiente' que hiciese antiyrigoyenismo votando por sus candidatos. Esto ocurría en particular en vísperas de elección de algunos candidatos a senador, pues los conservadores siempre tuvieron especial interés en evitar que los radicales alcanzaran a formar mayoría propia en la Cámara Alta, lo que en efecto consiguieron, ayudados por el sistema electoral y la duración del mandato establecido para aquel cuerpo en la Constitución”. (Etchepareborda, 1986:23-24)

\subsection{Política exterior.}

En el orden internacional, la Primera Guerra ya llevaba dos años cuando asumió Yrigoyen, cuyo gobierno si bien conservó la neutralidad declarada por los conservadores, lo hizo bajo otros postulados.

Dijo H. Yrigoyen,

"La paz es el estado normal de las naciones. Todo pueblo,[...] tiene la obligación de mantener la paz y de resguardarla. La desesperación de los gobiernos por 'declarar' la neutralidad frente a conflictos que a lo nacional no afectan, procede de que desde lo más íntimo les mueve un espíritu de dependencia: un espíritu rendido de antemano, o bien por intereses, o bien por una idea o sentimiento de inferioridad fruto de un tipo de política sin fe ni principios". (Historia del Radicalismo, 1982: 202)

Diferentes también fueron las actitudes mantenidas por los gobernantes antes del 12 de octubre de 1916, ante algunas consecuencias sufridas por la Nación Argentina a raíz del conflicto armado.

A título de ejemplo mencionaremos lo acaecido con dos naves argentinas que habían padecido los efectos del accionar bélico, al igual que alguna representación consular. V. de la Plaza por entonces Presidente, reaccionó en esas oportunidades pero no con la energía que la opinión pública esperaba. 
Cuando Alemania en 1917 comunicó que iniciaba una guerra submarina sin restricciones, otra fue la actitud con que respondió nuestro país, aunque sin romper relaciones diplomáticas. Motivo por el que se lo acusó de "atropellar las instituciones y no acatar a la opinión pública" ya que tal había sido la decisión de las Cámaras. (Etchepareborda, 1986:24).

Decididamente más intransigente y severa fue la respuesta cuando, en distintas oportunidades, la armada alemana hundió dos buques de bandera argentina. En ambos episodios Alemania presentó excusas y ofreció las debidas reparaciones y en Berlín, las autoridades alemanas realizaron una ceremonia pública de desagravio al pabellón argentino (cumplida en la base naval de Kiel).

Finalizada la guerra, firmado el Tratado de Versalles y ante la constitución de La Liga de las Naciones, se suscitaron las inveteradas divergencias entre Yrigoyen y Alvear embajador en Francia- en lo referente al carácter de la aparición de la Nación Argentina en el concierto internacional y la no aceptación de las enmiendas introducidas al Tratado por nuestro país.

Resumiendo su postura y sorprendido por la actitud de Alvear -proclive a aceptar los condicionamientos de EEUU y algunos estados europeos- cuya propuesta era integrar la Liga aunque no se respetaran las propuestas del gobierno argentino, dijo Irigoyen

"Debiamos reintegrar a la patria a la plenitud de su autoridad moral, al ejercicio soberano de sus fueros [...] Así como en una poderosa concepción política nos propusimos redimirla de todos sus males y desgracias, así por magnos juicios y actitudes concordantes buscamos afirmar y consolidar su personalidad en el orden internacional, elevándola nuevamente al templo del honor, de la razón y de la justicia universal" (Historia del Radicalismo, 1982: 213).

Referido al plano latinoamericano, Yrigoyen expresó su inalterable línea de conducta al enunciar su "credo americano". De esta suerte, en mensaje dirigido a la Cámara de Representantes del Uruguay, el 29 de marzo de 1918, manifestó,

"Afirmo mi credo americano por la sustentación fundamental de la soberanía de las naciones, en su consagración inmanente e inmutable, tal como la divina providencia las discerniera y el espíritu de cada una de ellas las culminara, constituyendo unidas una de las más 
poderosas entidades del mundo en el concierto de los bienes universales" (Historia del Radicalismo, 1982:205-295) ${ }^{187}$

\subsection{Educación,}

En lo que hace a la política educativa, la difusión de la cultura nacional constituyó una de las mayores preocupaciones del Poder Ejecutivo, circunstancia que puso de manifiesto en su Mensaje dirigido a los legisladores en 1918.

De allí la necesidad, en primer término, de resolver los problemas de la educación primaria, como esencia y bien supremo de la democracia, tendientes a combatir el analfabetismo en el país. Preocupación que se extendió a las instituciones docentes de la instrucción secundaria y normal, enfatizando el rol de los directivos y la paralela colaboración de profesores y maestros, todos con una finalidad común: forjar el carácter y modelar el espíritu de la juventud argentina con virtudes ejemplares.

Volcados los enunciados en el proyecto de Ley Orgánica y presentados en 1918 al Congreso de la Nación, sufrió idénticas consecuencias que otras iniciativas -como la de construcciones escolares- debido a la oposición de los representantes de la oligarquía que al conformar mayoritariamente el cuerpo, nuevamente impidieron la sanción de la propuesta. (Historia del Radicalismo, 1982: 220-222). ${ }^{188}$

\footnotetext{
${ }^{187}$ Baste el ejemplo mencionado por Manuel Gálvez y Gabriel del Mazo, en el que el propio Yrigoyen instruyó al capitán del Crucero "9 de Julio" que saludare -durante su paso por el Caribe y América Central- a la bandera de la República Dominicana (país ocupado militarmente por los EEUU de Norteamérica)- hecho que fue muy bien recibido por el pueblo dominicano. Tal actitud soberana fue reiterada respecto al Brasil (durante el centenario de su independencia); llegando su proyección latinoamericana a tener decidida manifestación al plantearse la "cuestión del Pacifico" entre Bolivia, Perú y Chile. Su visión le llevó a concebir la convocatoria a un "Congreso Latino Americano" ya que Argentina constituía, en el extremo sur del continente americano, un faro al que no podía dejar de mirarse. Congreso que no llegó a materializarse debido a la presión que la potencia ejerciera sobre diversos estados. No obstante, el núcleo concitante de la temática acerca de la hermandad latinoamericana, quedaría definitivamente plasmada en los considerandos del Decreto del 4 de octubre de 1917, al establecer el 12 de octubre como "Día de la Raza".

${ }^{188}$ En cuestiones que no se supeditaban a la aprobación de las Cámaras, el Consejo Nacional de Educación llevó a cabo una importante obra: "[...] de 7.856 escuelas en 1916 (918.468 alumnos), se pasó a 10.982 escuelas en 1922 (con 1.324.215 alumnos). Se fundaron 37 institutos de enseñanza secundaria a lo largo de los seis años del período y 12 escuelas de artes y oficios" (no se consideran las instituciones educativas provinciales que, sin duda, incrementarían los guarismos). Por ello, al finalizar su mandato, dijo Yrigoyen en el mensaje de 1922 dirigido al Congreso Nacional, respecto a las orientaciones dadas respecto a la instrucción cívica: “[...] La obra del gobierno no se limitó [...] a crear o fomentar la creación de nuevos centros de enseñanza: les imprimió también modernas orientaciones, [...] mejoró métodos y procedimientos didácticos, fijando otros rumbos a los estudios de la juventud y marcándoles un señalado carácter regional. Acentuó [...] la tendencia nacionalista y práctica. Manteniendo vivos en los escolares, como en el alma ciudadana,
} 
Se pronunció también Yrigoyen, sobre el régimen universitario y la necesidad de introducir modificaciones en los sistemas de gobierno y administración, como también en los métodos de enseñanza predominantes,

“...rompiendo los viejos moldes a efectos de evitar la concentración en pocas manos, y sin solución de continuidad, del manejo de los respetables intereses encomendados a estas instituciones, dando intervención en la elección de sus autoridades directivas y cuerpos docentes a todos los elementos constitutivos de las diferentes facultades que las componen”. (Historia del Radicalismo, 1982: 219)

Uno de los hitos más significativos en materia educativa, lo constituyó, a no dudar, la "Reforma Universitaria".

A partir del año 1890 fue generándose en el país, un movimiento de disconformidad respecto a la enseñanza universitaria. Lucio Vicente López denunció un excesivo "profesionalismo", manifestación que fue imitada en 1894 por Aristóbulo del Valle. Durante los años 1903, 1904, 1906, 1908, 1912, 1915/1917, se produjeron desórdenes en distintas Facultades, a raíz de demandas insatisfechas que evidenciaban los Centros de todas las universidades nacionales.

La Universidad de Córdoba se erigió en el principal foco de descontento y acusaciones estudiantiles, frente a sectores clericales reaccionarios, irreductibles al ingreso del liberalismo y la modernidad en sus aulas. Protesta que se agudizó con la actitud adoptada por el Rector, quien resolvió no receptar solicitud alguna del estudiantado, a la par que suspender toda actividad en el ámbito universitario.

El gobierno no aceptó la decisión adoptada e Yrigoyen, junto con el ministro Salinas, decretaron la intervención de la Universidad, designando en tal cargo al doctor José Nicolás Matienzo. (Historia del Radicalismo, 1982: 221-222) ${ }^{189}$

los sentimientos de amor y glorificación de la Patria con actos democráticos de civismo [...] al celebrar las grandes festividades históricas con entusiastas manifestaciones populares [...]”

${ }^{189} \mathrm{Si}$ bien la intervención modificó los estatutos, con el propósito de democratizar el gobierno universitario, la finalidad perseguida no se logró pues los consejeros elegidos por los profesores, nombraron rector al candidato de la asociación clerical "Corda Frates". Los consejeros estudiantiles sintiéndose traicionados, abandonaron la sala con el objeto de impedir que el acto se consumara, y declararon la huelga general, la que se extendió a nivel nacional, como también al sector secundario, recibiendo la adhesión de algunos gremios. La "revolución" declarada por el estudiantado tuvo como principal consecuencia la redacción del "Manifiesto Liminar de la Reforma" (21 de junio de 1918). La situación planteada provocó temor entre los representantes del clero ultramontano y alguno "dejó caer su estola, y de allí surgieron las cintas que fueron distintivo de la Reforma, el tradicional color morado". No obstante, Nores volvió a clausurar la universidad, por lo que el P.E.N designó un nuevo interventor que no logró asumir ante la resistencia y trabas de las autoridades 
Paralelo a ello en Buenos Aires se constituyó, el 11 de abril de 1918, la Federación Universitaria Argentina (F.U.A.) que contó con delegados de las federaciones estudiantiles de las universidades existentes en la época y hasta allí llegaron los principios reformistas dados en Córdoba en junio de ese mismo año.

En agosto la Universidad de Buenos Aires (U.B.A.) reformó su estatuto, estableciendo la libre asistencia a clase e instituyendo la representación estudiantil en el Consejo Superior. Lo propio ocurrió en la Universidad de La Plata (U.N.L.P.) en el año 1920 y luego de varias revueltas estudiantiles.

El motivo, la intención que hemos perseguido con esta reseña sobre el aspecto universitario, fue demostrar el "núcleo de coincidencias" y la fluida comunicación que había nacido entre Yrigoyen y los estudiantes. En una entrevista con un grupo de ellos el Presidente había manifestado,

"[...] que su gobierno pertenecía al espíritu nuevo; que se identificaba con las justas aspiraciones de los estudiantes y que la Universidad argentina debía nivelarse con el estado de conciencia alcanzado por la república” y agregaba, en un nuevo cónclave, que "[...] veía en la reforma Universitaria la posibilidad de una decisiva contribución al renacimiento idealista de la República”. (Historia del Radicalismo, 1982: 223)

En dicho encuentro, al proporcionar sus reclamos al Presidente, los estudiantes manifestaron que deseaban para la Universidad, un gobierno democrático legítimo, atributo al que consideraban como auténtico método en la consecución del cambio esperado. Se refirieron también, al 'demos' universitario, soberano, y, en consecuencia, al derecho de los estudiantes de darse un gobierno propio. Palabras que conmovieron a Yrigoyen y que, al comprender el significado republicano y educativo de la proposición, lo llevaron a indagar sobre el fundamento jurídico del pensamiento reformista.

Entusiastamente los alumnos respondieron,

"El estudiantado universitario [...] es titular de derechos cívicos en la vida institucional de la república. Si tiene capacidad y puede concurrir a la elección de presidente de la nación, tiene

encabezadas por Nores. En septiembre un grupo de estudiantes tomó la Universidad, anunciando la reanudación de las clases. Instaurado nuevamente el conflicto, el ministro Salinas fue designado como interventor, quien acogió varias demandas del estudiantado, reformó el estatuto de la Universidad e incorporó profesores reformistas al claustro docente. Las medidas adoptadas lograron la paulatina y debida normalización. 
capacidad y podrá concurrir a la elección de decano o consejero de su propia Universidad". (Historia del Radicalismo, 1982: 223)

Con la firma del primer presidente de la Unión Cívica Radical, quedaron consagrados pues, los principios liminares de las Universidades, siendo los más significativos: régimen de participación estudiantil, asistencia libre, docencia libre, periodicidad de la cátedra, publicidad de los actos universitarios, extensión universitaria y asistencia social de los estudiantes. (Historia del Radicalismo, 1982: 223). ${ }^{190}$

La Universidad no había hecho más que reiterar el clima, el nuevo diseño de vida por el que atravesó, a partir del año 1916, la formación política toda,

"[...] desde que dejó de ser gobernada para gobernarse por sí misma”. (Historia del Radicalismo, 1982: 224) ${ }^{191}$

La concepción ética que signó la presidencia de Yrigoyen, fue puesta una vez más de manifiesto, en el mensaje que el 15 de octubre de 1921, casi al finalizar su primer mandato, dirigiera al Congreso,

"Cada vez es más imperioso hacer del ejercicio cívico una religión política, un fuero inmune, al abrigo de toda contaminación, hasta dejar bien cimentadas las prerrogativas inalienables e imprescriptibles de la nacionalidad [...]” y agregaba, en modo más contundente, "[...] "Es indispensable fijar como condición irreductible que la moral política es la base de todos los progresos y de todas sus formas eficientes” (Historia del Radicalismo, 1982: 230)

En idéntico sentido -y como lo expresara al asumir el gobierno- (Historia del Radicalismo, 1982: 231) ${ }^{192}$ puso de relieve que detentar el concreto poder no significaba

\footnotetext{
${ }^{190}$ Dijo F. Luna en su "Yrigoyen": "Así como durante las agitaciones sociales había estado abierta la Casa de Gobierno a los obreros para escuchar la expresión de sus anhelos, del mismo modo acogió Yrigoyen la estudiantina, confió en ella, le otorgó responsabilidades y le dio una personería como nunca había tenido antes y como pocas veces gozó después". Por ello en su mensaje anual al Congreso de la Nación, decía el Presidente en 1922: "[...] La nacionalización de la Universidad de Tucumán, ha satisfecho una necesidad sentida por juventud de la zona norte de la República [...] servirá eficazmente los intereses económicoindustriales de la región y llevará su saludable influencia hasta los cuerpos obreros y el seno mismo de los hogares." También y con referencia a la creación de la Universidad Nacional del Litoral, sobre la base de la Facultad de Derecho de Santa Fe, sostuvo que "[...] El nuevo organismo, ya vigoroso [...] abarcará, principalmente, el territorio de tres provincias argentinas y contribuirá poderosamente al desarrollo y progreso de la República, identificándose con su desenvolvimiento político, institucional y social y con sus necesidades económicas, industriales y comerciales".

${ }^{191}$ Palabras extraídas del discurso que el Dr. José S. Salinas, Ministro de Justicia e Instrucción Cívica, pronunciara el 12 de agosto de 1921 -en nombre del Presidente H. Yrigoyen- al celebrarse el centenario de la U.B.A. (Historia del Radicalismo, 1982: 224).
} 
disfrutar de "cualquier tipo de privilegios" por eso en una carta enviada a los representantes de la provincia de Jujuy (año 1921) y aludiendo a su "vuelta al llano", manifestó

“Cuando asumí el Poder Ejecutivo de la República (previendo lo que habría de suceder, dados los prestigios con que estaban revestidos los ciudadanos que designé para ser mis colaboradores y dándome cuenta de que habrían de acentuarse en el conceptuoso desempeño del gobierno), entre las reglas de conducta que fijamos, fue una de ellas que desde los estrados del poder pasaríamos directa y únicamente a nuestras casas y de allí a las filas de la opinión que ha de cimentar y custodiar los esplendores alcanzados por nuestra patria para hacerla cada vez más eminente y grandiosa” (Historia del Radicalismo, 1982: 231). ${ }^{193}$

Entendió que no bastaba con buscar buenos "fines", sino que resultaba primordial la honestidad de los "medios" utilizados para alcanzar el objetivo (el "que se rompa pero que no se doble" de Alem). En tal sentido, dijo en su Mensaje dirigido al Congreso de la Nación, en julio de 1922,

"[...] todo lo que no sea de origen legítimo tiene necesariamente que derrumbarse en el abismo que debe existir entre el derecho y la usurpación [...]" (en Historia del Radicalismo, 1982: 230).

Lo hasta aquí manifestado no nos exime de mencionar que, pese al reconocimiento formulado al pensamiento y accionar de Yrigoyen, muchas fueron las disidencias de legisladores radicales con relación al excesivo 'personalismo', y desaire institucional con que manejara al radicalismo el Presidente, como también a cierto aire populachero que se estaba imprimiendo a la acción partidaria. (Etchepareborda, R., 1986:25). Circunstancia que fue evidenciada en la elecciones de abril de 1922, en que se produjo la escisión partidaria

\footnotetext{
${ }^{192}$ En el mensaje que la revista Proteo publicó el 12 de octubre de 1916, Yrigoyen manifestó: "Asumir la contienda reparadora, desde el llano a la cumbre, renunciando a todas las posiciones y resguardos para remontar la abrupta montaña a pura orientación de pensamiento, a puro vigor de virtudes y a pura entereza de carácter, y llegar a la cima pasando por sobre todos los poderes oficiales y las conjuraciones conniventes, es empresa que no conciben los mediocres ni alcanzan los pigmeos y que ni siquiera comprendieron los grandes ni afrontaron los poderosos".

${ }_{193}$ Poniendo de manifiesto sus convicciones morales, envió un proyecto al Congreso de la Nación estableciendo: "Los magistrados, secretarios y empleados de la Justicia Federal y de la ordinaria de la Capital, acogidos a los beneficios de la jubilación, no podrán ejercer la profesión de abogado, escribano o procurador durante el término de diez años, contados desde la fecha en que dejaren el cargo."

También respecto al nivel militar, su anhelo principista, sus ansias de justicia que alcanzara a la totalidad del entramado social, le llevó a buscar la aplicación de similares normas, de un trato igualitario, entre aquellos que continuaron prestando servicio y quienes hubieren pasado a situación de retiro por haber participado en los movimientos revolucionarios de 1890, 1893 o 1905.
} 
con las siguientes fórmulas: U.C.R.: Marcelo T. de Alvear - Elpidio González y U.C.R. Principista: Miguel Laurencena - Carlos F. Melo.

Disidencias que habrían de profundizarse y por las que la oposición adoptó tácticas que le permitieron -no obstante la mayoría radical obtenida en los comicios- además de fortalecer determinados cotos provinciales, detener sus políticas públicas de cambio y movilidad social obstaculizando el quehacer legislativo. Por ejemplo, pese a contar con mayoría absoluta en Diputados -lo que le permitió imponer la nacionalización del petróleoel Senado trajinó su sanción hasta el desenlace revolucionario. (Etchepareborda, R., 1986:25)

\section{Nuevo gobierno popular: Alvear.}

La plena vigencia libertaria del principio electivo-democrático, como también la existencia de "un consenso residual de legitimación" que anidaba en el colectivo en torno al radicalismo, posibilitaron, una vez más, que este movimiento resultara claro vencedor en la escena política. Y sostenemos nuestro decir en la circunstancia que, en ésta oportunidad, no fue el liderazgo o la figura carismática de una fuerza individual -como lo fuera anteriormente Hipólito Yrigoyen- la que concitó el voto de la ciudadanía sino que, por sobre la personalidad del candidato se levantaron los principios de un partido: la Unión Cívica Radical. ${ }^{194}$

Es que Marcelo Torcuato de Alvear -candidato electo por la Convención Nacional del partido- no mostró similar preocupación por "la" y "lo" político que pusiera de manifiesto Yrigoyen.

Miembro de una de las familias patricias más acaudaladas de la época, prontamente logró una sólida formación intelectual y cultural que le llevó a constantes viajes por el exterior. Ello no fue impedimento para que participara en el mitin Jardín Florida, aunándose a la cruzada en pos de la moral administrativa y la integridad del sufragio propuesta en el Manifiesto. Militancia que le llevó a acentuar su posición contra el Unicato,

\footnotetext{
${ }^{194}$ Siguiendo a C.Barbé (1973) denominamos consenso residual de legitimación, al aval que se le proporciona a un concreto poder por el solo hecho de ejercitarse dentro de los límites del sistema de poder ya legitimado. En ese sentido, "El que triunfaba era el radicalismo cuya figura principal y querida era el mandatario saliente." (Historia del Radicalismo, 1982: 249)
} 
como también a enfrentar el escarnio que sufría la soberanía nacional y el profundo quebranto económico en que había caído el país por obra del Régimen.

Lo acaecido en el mitin del Frontón del Parque (1890) lo contó entre uno de los principales instigadores. Más tarde y desde su exilio en Montevideo, que compartió con Alem y otros, lideró un grupo que sufriera idéntico destino y juntos firmaron un manifiesto contra Pellegrini -publicado en el diario "El Siglo" de esa ciudad- mencionando que su gobierno dictatorial, sólo constituía una variable del pasado unicato juarista. En el año 1905, condujo las agrupaciones revolucionarias que ocuparon las estaciones ferroviarias de Temperley y Lomas (baluartes de los insurrectos).

Elegido Diputado en 1912, su actuación como legislador no resultó sobresaliente, si bien pudo considerarse como acertada. (Historia del Radicalismo, 1982:244) ${ }^{195}$. Después del 12 de octubre de 1916 y ya durante la presidencia de Yrigoyen, se desempeñó como embajador en Francia.

Mucho se ha escrito sobre las relaciones que existieron entre Yrigoyen y Alvear. Algunos las consideraron "opuestas", para otros de extrema confianza. (Historia del Radicalismo, 1982: 244) ${ }^{196}$

Quizás una frase expresada en 1920 entre sus íntimos por el primero, baste para cerrar el enigma:

"Alvear es radical. Le falta apostolado, pero es radical”. (Historia del Radicalismo, 1982: 244)

La Convención Nacional de la Unión Cívica Radical, continuando con los ritmos de la democracia, y pese a las divergencias existentes -la mayoría de los convencionales aguardaba una sugerencia puntual de Yrigoyen, quien se limitó a manifestar cierta estima por Alvear- consagró la fórmula Marcelo T. de Alvear- Elpidio González. El candidato a

\footnotetext{
$195 \mathrm{Al}$ respecto, podemos señalar que "participó de los proyectos de reglamentación de empleos civiles y organización del ejército así como de la confección de la ley de casas baratas que intentaba entonces erradicar los conventillos".

196 Aquellos que abonan la tesis de "extrema confianza" se basan en el hecho que Alvear fue padrino de Yrigoyen en el duelo que éste mantuvo con Lisandro de la Torre. Quienes los ubican en posiciones opuestas en la vida intrapartidaria, lo señalan como "galerita" dado el fluido contacto con los ambientes oligárquicos; refiriéndose también, al momento en que, en su rol de representante diplomático en París, manifestó su adhesión a los aliados ignorando las banderas de neutralidad e igualdad jurídica de los estados, esgrimidas por Yrigoyen.
} 
vicepresidente se había desempeñado como Ministro de Guerra y Jefe de Policía durante la presidencia de Yrigoyen.

Cuando fue el acto eleccionario, incluso cuando fue elegido por el Colegio Electoral, el presidente Alvear se encontraba en Europa, planificando -auxiliado por su amigo Le Breton- su futura acción de gobierno y la conformación del gabinete ministerial.

Pocas semanas antes de finalizar su mandato H. Yrigoyen recibió -en el puerto de Buenos Aires- al electo presidente, quien manifestó,

"Hipólito, usted sabe que yo siempre seré su amigo fiel”. (Historia del Radicalismo, 1982: 258).

Poseedores de fuerte carácter, ambos presentaron disímiles personalidades, lo cual provocó distintas reacciones en el entramado social. Así, operada la transmisión del poder, cuando H. Yrigoyen abandonó la Casa Rosada el pueblo se volcó hacia él, lo cual no le permitió llegar a su antigua vivienda debiendo desviarse hacia el domicilio de amigos.

Pese a las disidencias internas y la breve campaña electoral, el triunfo radical fue contundente logrando mayoría absoluta en el Colegio Electoral: doscientos treinta y cinco (235) miembros, contra ochenta y ocho (88) del resto de las fórmulas que participaron en el acto comicial. (Historia del Radicalismo, 1982: 250)

Ya en el efectivo ejercicio del concreto poder, Alvear fue acompañado por algunos radicales que, abandonando las tendencias yrigoyenistas, encauzaron su acción hacia, lo que podría denominarse, una nueva forma de liberalismo conservador. ${ }^{197}$

El partido radical se escindió entonces en "personalistas" -leales a H. Yrigoyen- y "antipersonalistas" -adeptos al Presidente Alvear- que fomentaron la reacción de la aletargada oligarquía. Si algún error o negligencia cabe imputar a Alvear, es la elección de un gabinete integrado por hombres mayoritariamente opuestos al pensamiento radical; así como también, el haber estimulado en el Congreso la constitución de un 'espacio' destinado a legisladores ostensiblemente anti-irigoyenista y, por ende, anti-personalista, que finalizara unido a la oligarquía. Tal irreflexión, mezcla de frivolidad y desidia, resultó el hilo

\footnotetext{
${ }^{197}$ El período 1922-1928, tal vez pueda definirse como “una época de libertad” ya que a los inquebrantables principios de libertad enarbolados por los radicales, debemos agregar un matiz liberal en las costumbres de la época. Resultó innegable el clima de ventura y bonanza, originado durante la presidencia de Yrigoyen y que si bien no exento de lujos y extravagancias en algunos sectores, fue propicio para la renovación intelectual y la producción artística. "Años locos", que no sólo acontecieron en la Argentina sino que tuvieron su impronta también en EEUU, en algunas capitales de Sudamérica y parte de Europa.
} 
conductor de la escisión de la U.C.R, dando lugar al nacimiento de la Unión Cívica Radical Antipersonalista. (Historia del Radicalismo, 1982: 275) 198

Alvear deseaba rodearse de ministros de "lujo", que atenuaran sus responsabilidades en el ejercicio de la Presidencia -al estilo europeo, no presidencialista como el norteamericano o el argentino- por lo que integró su gabinete con José Nicolás Matienzo, en el Ministerio del Interior; Rafael Herrera Vegas, en Hacienda; Angel Gallardo en Relaciones Exteriores, todos cercanos al Partido Conservador. El Ministerio de Justicia e Instrucción Pública fue encomendado a Celestino Marcó -próximo al ala de la disidencia principista-; el área de Agricultura quedó en manos de Tomás Le Bretón -un viejo amigo de Alvear, casi "galerita" o "azul”-; Eufrasio Loza, vicepresidente del Comité Nacional de la U.C.R, fue nombrado para el Ministerio de Obras Públicas. Los Ministerios de Guerra y Marina no fueron civiles, ambos fueron cubiertos por hombres pertenecientes a las fuerzas armadas, designándose al general Agustín Justo -ex Director del Colegio Militar- y al almirante Domecq García.

No cabe duda que, en su accionar, el gobierno de Alvear se apartó de la dirección que tradicionalmente caracterizara a la U.C.R y que, enunciada por Alem, llevara a la "praxis" política Yrigoyen.

Fuerza es reconocer que, si bien existieron el juego democrático y las libertades públicas; que hubo "sentido social" para afrontar las reinvindicaciones laborales y gremiales -recordemos el "Laudo Alvear" destinado a los trabajadores de la caña de azúcaral utilizar el arbitraje como una solución justa de controversias que se aplicaba desde 1916, estas medidas carecieron de esa inalterable fuerza interior que otorga la práctica del sentido ético sobre el cual, el radicalismo, había legitimado el diseño de vida pergeñado por la sociedad civil durante el proceso de legitimación. (Historia del Radicalismo, 1982: 273-274) 199

El favorable clima social -considerando el crecimiento y el bienestar- permitió al flamante gabinete aquietar el dinamismo que caracterizara el período anterior y establecer su impronta personal en materia universitaria -las universidades reformistas fueron

\footnotetext{
198 “De cualquier manera [...] Alvear nunca llegó él personalmente-ni tampoco su gobierno- al extremo de la fractura [...] por ejemplo, no cedió a las presiones para que interviniese la provincia de Buenos Aires; así tampoco dio su apoyo a la fórmula antipersonalista Melo-Gallo para el comicio del $1^{\circ}$ de abril de 1928 ”.

199 "Más que una actitud casi religiosa del quehacer político, había en Alvear como un espíritu apenas deportivo y quizás en esto radicó la diferencia de fondo[...] Ser radical 'en todo y hasta el fin' según la expresión de Yrigoyen, exigía firmeza de convicciones y fortaleza de espíritu”
} 
intervenidas-; en política exterior -falta de respaldo de las posturas anti-imperialistas sustentadas por Honorio Pueyrredón, en la Sexta Conferencia Panamericana de La Habana; en materia militar la designación de dos ministros vinculados con la ultra-derecha, marcó su máximo nivel durante "la semana trágica". (Historia del Radicalismo, 1982: 259) 200

A modo de justificar estos retrocesos en materia de políticas públicas, la oligarquía utilizando distintas herramientas -periódicos propios y manipulación de sectores políticos y/o periodísticos pseudo-progresistas, que terminaron siendo funcionales al "régimen"urdió la existencia de un gobierno paralelo creado desde la sombra por Yrigoyen.

Esta falacia fue creída por algunos militares afines a Yrigoyen, llevándolos a proponer un golpe para destituir a Alvear e instalar al ex presidente como gobernante de facto.

Narró Félix Luna, que la propuesta fue rechazada en estos términos

"Ustedes no me conocen si me creen capaz de destruir la obra de tantos años" (Historia del Radicalismo, 1982:260)

Tal vez, también ayudó a incrementar esta fabulación la circunstancia de no encontrarse Alvear preparado para enfrentar las circunstancias del momento. Esto es, no por desnaturalizar principios básicos del entramado social, erigidos en contenidos esenciales del radicalismo, sino por la falta de seguridad, de solidez en sustentarlos.

Ya lo dijimos, desde su gestación la U.C.R no poseyó un pensamiento dogmático, ni único -propio de totalitarismos- sino que, muy por el contrario, erigida en fuerza política popular y de mayorías, las divergencias habidas en el seno entre sus partidarios y militantes fueron naturales y esperables. Se suscitaron de manera espontánea ante la existencia de disímiles enfoques, aunque encuadrados en comunes y esenciales creencias habidas en el colectivo.

Los problemas por los que había pasado Yrigoyen en el parlamento, lejos de superarse se agudizaron. No sólo continuaron subsistiendo en la Cámara de Senadores sino que -dada la escisión operada entre "yrigoyenistas" y "antipersonalistas"- el enfrentamiento

\footnotetext{
${ }^{200}$ El general Justo no disimuló sus apetencias "presidenciables". En tal sentido incitó el surgimiento de logias que años más tarde se lanzarían a la conspiración anti-irigoyenista".
} 
recrudeció trasladándose a la Cámara de Diputados, originándose así, el llamado “contubernio". (Historia del Radicalismo, 1982:261) 201

Contubernio consumado entre "radicales antipersonalistas" (azules o galeritas) y "conservadores", a los que se sumó el resto de los representantes del régimen y la oligarquía, generando una serie de perjuicios en el normal funcionamiento del Congreso por desconsideradas actitudes parlamentarias (v.g.: las habidas en el tratamiento de proyectos de ley en materia de política de preservación petrolera nacional; (Historia del Radicalismo, 1982:264-265) ${ }^{202}$; el destrato al que fuera sometido el vicepresidente Elpidio González, en su carácter de presidente del Senado, a efectos de forzar la aprobación de pliegos viciados, promoviendo la designación de senadores por la provincia de Jujuy; como también en negarle, en el desempeño de dichas funciones, la posibilidad de designar a los miembros de las distintas comisiones que integraban el cuerpo).

Conductas, las adoptadas por la "liga" (contubernio), que obligaron a los “yrigoyenistas" a faltar a varias sesiones y/o retirarse y no dar quórum. Medidas que fueron acentuando las discrepancias durante el transcurso del año 1923.

Las disputas se acentuaron en 1924 al realizarse las elecciones de Diputados, por lo cual el vicepresidente no concurrió a la Asamblea Legislativa, hecho que destacó el diputado conservador Sánchez Sorondo, al calificar esa actitud de 'extemporánea'. Tal aseveración mereció la réplica -en la primera sesión de la Cámara de Diputados y en nombre del bloque radical- del doctor Andrés Ferreyra, quien expresó,

"Llevamos a la presidencia de la República al doctor Alvear, que sintetizaba nuestros ideales pero, luego las luchas internas hicieron desviar a ese presidente. ¿Pero qué sucede hoy? ¿Cuál es el peligro? El peligro que veo venir es que sin consultar a las mayorías populares, el gobierno surgido de nuestro propio esfuerzo se entregue al conservadorismo, que ha sido repudiado en los comicios argentinos [...] Por eso protesto; porque entiendo que se arrebata al pueblo lo que legítimamente el pueblo ha dado al radicalismo. No protesto porque vayan a

\footnotetext{
${ }^{201}$ Sinónimo de "alianza o liga vituperable", "maridaje ilegal", o "cohabitación ilícita".

202 Designado el Cnel. Enrique Mosconi como Director de YPF, manifestó la conveniencia de crear una empresa mixta, de capitales privados y estatales, ambos nacionales, para monopolizar -en todos sus niveles- la actividad petrolera. En 1928, ante la falta de capital privado nacional interesado, se pronunció por "adoptar el monopolio del estado, pero en forma integral es decir, en todas las actividades de esta industria: la producción, elaboración, el transporte y el comercio”. Los debates parlamentarios se sucedieron, pero los proyectos de la U.C.R haciendo suyas las palabras de Mosconi no tuvieron total recepción. La Cámara de Diputados con la bancada del alvearismo, optó por una ley admitiendo la explotación mixta.
} 
desempeñar posiciones públicas. Protesto, sí, porque habiendo nosotros conquistado en los comicios el gobierno de la Nación, no tienen derecho los conservadores de gobernar ni dirigir los destinos de la República. (Etchepareborda, R., 1986:26)

En su intervención, con la que respondió a las palabras de Ferreyra, el diputado “antipersonalista” José P. Tamborini, utilizó una categoría conceptual que tuvo fuerte arraigo en la historia de nuestro país al señalar,

"Aqui estamos advertidos contra la diatriba y dispuestos al combate, frente a los que creen que el título político de radicales sólo puede obtenerse castrando la voluntad y cayendo 'genuflexos' ante la de un caudillo poderoso [...] Que no se nos venga con esa palabra mal aplicada y de mal gusto, contubernio”. (Etchepareborda, R., 1986:26-27)

Las divergencias estaban planteadas y no existió regreso. Los disidentes decidieron reorganizar el nuevo partido Antipersonalista.

A partir de ello, varias provincias fueron intervenidas

"tanto para mantener el control del Senado como para instrumentar los mecanismos del fraude con vistas a las elecciones de sucesión presidencial de 1928”. (Historia del Radicalismo, 1982: 262)

Herramienta que, por motivos contrapuestos, no pudieron aplicarse en Córdoba ni en Buenos Aires.

En la primera porque gobernaba Julio A. Roca, quien acompañaría a Justo como vicepresidente, por lo que el Senado no tomó ninguna medida.

La provincia de Buenos Aires, por el contrario, constituyó un baluarte de Yrigoyen y pese a la presión que la oligarquía ejerciera sobre Alvear desde la Cámara Alta para que fuere intervenida, éste se negó. A ello se agregó el triunfo del “yrigoyenismo" en las elecciones para gobernador realizadas en 1926, las que, de alguna manera, garantizaron elecciones limpias para las presidenciales de 1928.

Confirmando su táctica cismática, fueron los "antipersonalistas" quienes -con más de un año de antelación a dichos comicios- comenzaron la praxis política con miras a la sucesión de Alvear.

En abril de 1927, la Convención Nacional del sector proclamó la fórmula Leopoldo Melo y Vicente C. Gallo (cabe acotar que, ante las disputas surgidas acerca del orden que ocuparían ambos candidatos, Alvear fue quien decidió la posición de cada uno). 
Las turbulencias partidarias no sólo acontecieron dentro de la U.C.R.

Respondiendo al convite de Julio A. Roca se fusionaron partidos conservadores constituyendo una Confederación de Derechas, fuerza que se unió al antipersonalismo.

Dentro del Partido Socialista, algunos disidentes decidieron aliarse a los antipersonalistas, constituyendo, en el año 1927, la base fundante del Partido Socialista Independiente.

El Partido Provincial de Buenos Aires, que contó con las adhesiones de los antipersonalistas de las provincias de San Juan, Mendoza y Santa Fé, otorgó también su apoyo a la fórmula Melo-Gallo. Uniones estas que prácticamente unificaron todas las derechas.

El "cierre" de posiciones de la derecha, no constituyó impedimento alguno en la labor desplegada por Yrigoyen con la finalidad de preservar las estructuras de la U.C.R. Esto posibilitó que en las elecciones para gobernador realizadas en las provincias de Salta, Tucumán, Santa Fe y Córdoba, triunfara el partido radical.

Restaban semanas para las elecciones presidenciales y aunque no contaba con candidato, la U.C.R. -debido al acaecimiento de varios hechos de violencia desatados por los conservadores en la Capital Federal y algunas provincias- decidió suspender su campaña proselitista.

Sabía que contaba con el apoyo del pueblo y

"no quería dar lugar a las provocaciones que pudiesen frustrar el acto comicial o contribuir al clima golpista que ya comenzaba a insinuarse”. (Historia del Radicalismo, 1982: 281)

Circunstancia que llevó a la Convención Nacional, reunida el 22 de marzo, a constituir una comisión con el objeto de entrevistarse con el presidente Alvear y solicitar garantías ante los apremios e intimidaciones electorales observadas en algunas provincias (v.g.: Mendoza, San Juan y Córdoba). Reclamo ante el cual Alvear aseguró "las máximas garantías de limpieza electoral".

El día 24 y por aclamación -no fue necesario votar- Yrigoyen fue elegido candidato para encabezar la lista de la U.C.R. (Historia del Radicalismo, 1982:282) ${ }^{203}$ Para completar la fórmula fue elegido Francisco Beiró.

\footnotetext{
${ }^{203} \mathrm{Al}$ aceptar su candidatura dijo Yrigoyen: “Ante la eminente y solemne expectativa del pueblo argentino, que repercute en todos los ámbitos de su territorio con las más intensas vibraciones cívicas, y bien
} 
El pueblo participó mayoritariamente en el acto eleccionario y los resultados fueron: U.C.R. Yrigoyen-Beiró, 838.583; Frente Unico Antipersonalista Melo-Gallo, 414.026; Partido Socialista, Mario Bravo-Nicolás Repetto, 64.985 y dos fórmulas comunistas (encabezadas una por Rodolfo Ghioldi y la otra por José F. Penelón) que, sumadas, lograron unos 30.000 votos.

Más de los tres cuartas partes de los sufragantes se inclinaron por la fómula de la U.C.R. Los Colegios Electorales confirmaron el pronunciamiento popular, con 271 electores para Yrigoyen-Beiró y 71 para Melo-Gallo. (Historia del Radicalismo, 1982:286) ${ }^{204}$

En forma inesperada y antes de asumir murió Beiró, hecho por el cual nuevamente debió reunirse la Convención Nacional de la U.C.R a los efectos de elegir un candidato para completar la fórmula. Elegido Enrique Martínez -gobernador electo de Córdoba-, fue consagrado como vicepresidente por el Colegio Electoral.

\section{1928. Segunda Presidencia de Yrigoyen.}

Creemos que el pueblo legitimó el concreto poder. El liderazgo de Yrigoyen, depositario de la 'creencia' popular, logró posicionarlo nuevamente en la escena política.

Pese a ello, los dos años de su presidencia no fueron similares al primer mandato. Tampoco debían serlo. Cada momento, cada instante es irrepetible: distintas resultaban las coordenadas de tiempo y, por qué no, de espacio, para quienes habían sido elegidos.

Tal estado de cosas, llevó a F. Luna a decir que

"Entre los muchos mitos enquistados en nuestra historia, uno de común aceptación es el que descuenta el fracaso del segundo gobierno de Yrigoyen. El concepto no es totalmente exacto, y hay en él un resabio de la pertinaz propaganda antirradical de aquellos años”. (Historia del Radicalismo, 1982: 294)

compenetrado de que ellas condensan en suprema unción todas las idealidades del presente, esperanzas del futuro e infinitas irradiaciones de los destinos de nuestra nacionalidad, no puedo menos que inclinarme reverente a tan honrosísima designación, que me hace intérprete de los más fervorosos y sagrados anhelos patrióticos".

${ }^{204}$ La cantidad de sufragios logrados por la UCR, demostró "el firme propósito de los sectores populares en frenar todo intento de restauración oligárquica fecundado por los que se decían 'antipersonalistas', por los conservadores o por los seudo nacionalistas que alentaban para el país un proyecto corporativo [...]". 
Señalemos algunas diferencias. En el año 1916, la U.C.R. llegó al poder desde el llano, habiendo mantenido largos períodos de abstención y portando las banderas de una oposición principista totalmente alejada de los gobernantes del 'Régimen'. Ello imprimió, en una primera etapa, un nueva dirección cultural al entramado social que no fue suficiente para lograr similar revulsivo en la sociedad política.

Circunstancia ésta que se tornó evidente durante el segundo período constitucional de H. Yrigoyen, donde contó con una dirigencia política sin credibilidad, pero enquistada en el poder.

Cierto es que, en 1928, Yrigoyen volvió a detentar el concreto poder, encabezando el partido que -durante dos períodos completos- gobernara el país, momento en que volvió a reiterarse, una vez más, la problemática con la que debió presidir y administrar desde 1916 a 1922: la inexorable mayoría opositora desplegada por los partidarios del 'régimen' desde el Senado de la Nación. (Historia del Radicalismo, 1982:294) ${ }^{205}$

Debemos resaltar que muy otra fue la respuesta de la Cámara de Diputados a las iniciativas de los legisladores yrigoyenistas, por ejemplo, al aprobar íntegramente el proyecto de nacionalización del petróleo. Norma a la que el general Enrique Mosconi, consideró de vital importancia para la futura estructura económica.

Acompañamiento que no resultó eficaz, dado lo esporádico, confuso y paradójico de las conductas desarrolladas por la sociedad política. Dirigencia que -si bien estuvo capacitada ya que los mismos personajes que sobresalían en la política lo hacían en el mundo de la cultura- manifestó, perdida en rencillas intra o extra-partidarias, escasa, o ninguna sensibilidad por las dificultades propias de la heterogeneidad del entramado social que caracterizara al colectivo social. Sociedad civil que aguardaba las debidas respuestas socio-económicas, vale decir, las que los convulsionados tempos exigían, no aquellas que sólo otorgaran respuestas a las convicciones facciosas de la dirigencia política, desprovistas de todo sentido de patria.

\footnotetext{
${ }^{205}$ Considerando la duración del mandato de los Senadores, el radicalismo irigoyenista, contó con siete (7) bancas, nueve (9) ocuparon los conservadores, nueve (9) siguieron perteneciendo a los antipersonalistas y una (1) al socialismo. Situación que, aunque cambió ya avanzado el año 1930 -al lograr la UCR una mayoría popular en la Cámara Alta- quizás fue el detonante del golpe fascista de José E. Uriburu. El panorama de la Cámara de Diputados fue totalmente distinto. Los triunfos logrados por el radicalismo, durante los años 1927 y 1928, bajo la conducción personal de Yrigoyen y con antelación al 12 de octubre, le permitieron contar con una amplia mayoría: noventa y una (91) bancas; treinta y seis (36) pertenecieron a los conservadores; veintiuna (21) al antipersonalismo y diez (10) al socialismo.
} 
No obstante, el obrar del radicalismo que acompañara el quehacer presidencial, ratificó que constituía una corriente popular basada en concretas acciones, destinadas a conformar una auténtica democracia social que priorizara 'lo' nacional.

Tal finalidad llevó a Amable Gutiérrez Diez, a expresar

"Una nueva izquierda se está formando en el radicalismo y ella no se conforma con estas conquistas semirrealizadas (cumplimiento de la Constitución, sufragio, etcétera) sino que adquiere una conciencia más esencial de la misión histórica del partido y prevé una programación de renovación institucional en la que son factibles todos los progresos, aun los más avanzados”. (Etchepareborda, 1986: 32)

Por ello, en el gabinete del que Yrigoyen se rodeó, también fue puesto de manifiesto la dimensión nacional que imprimiera a su gobierno, ya que más de la mitad de sus colaboradores pertenecían al interior del país.

Al reprobar la administración alvearista y enfatizando el sentido de bien común para la nación toda -en el sentido antes referido- expresó Yrioyen en el discurso de Apertura de 1929 ,

"La legislación social es inferior a las exigencias de la sociedad [...] nuestra estructura económica no está suficientemente tutelada [...] las realizaciones en el derecho positivo, en la legislación obrera, se han detenido inopinadamente [...] es necesario mejorar la legislación protectora de los que trabajan”. (Etchepareborda, R., 1986:33).

Además de modernizar el trato dispensado a las relaciones laborales, se otorgó especial atención a las fracciones sociales relacionadas con la producción y el transporte agropecuario, tanto el destinado al consumo interno como el correspondiente al sector exportador.

El comercio con el mercado inglés, con marcadas diferencias de subordinación en nuestra balanza, llevó a contemplar la necesidad de abrir nuevos mercados a las carnes argentinas.

Por ello, en conversaciones mantenidas en el año 1928, con Herbert Hoover, presidente electo de los Estados Unidos de Norteamérica -quien visitó nuestro país en el marco de una gira por Latinoamérica- Yrigoyen solicitó además de la 'no' intervención de ese país en otros estados, la necesidad de concordancia y reciprocidad en las relaciones económicas en vista del alza operado en las importaciones de productos manufacturados 
que ingresaban a nuestro país, y el correlato de la caída en los precios de las exportaciones agropecuarias.

Más adelante, y pese al importante apoyo del pueblo, la crisis mundial provocó -al interior de nuestra formación política- una fuerte convulsión a nivel productivo, originando la retracción de la economía interna debido a la mengua registrada en el comercio exterior.

Situación que repercutió tanto en las ciudades como en las zonas rurales, dando paso a una despiadada desocupación que no pudo ser contrarrestada por el sindicalismo (por entonces dividido en tres centrales).

Las huelgas y la violencia -impulsada por la Liga Patriótica- resultaron las respuestas brindadas por los trabajadores, reclamando una mejora salarial y condiciones dignas de labor. Reconocieron, no obstante, que el arbitraje a nivel gubernamental mostraba una sensibilidad social que dignificaba a la condición humana. Ante tal estado de cosas, y pese a las presiones provenientes de las "extremas" -izquierda y derecha-, el movimiento obrero logró unificarse constituyendo, el 27 de septiembre de 1930, la Confederación General del Trabajo (CGT).

A la caótica coyuntura económica -depreciación del peso y baja del precio de nuestros cereales; disminución de salarios y desocupación, entre otros- y el accionar sindical, se sumó la actividad desplegada por los grupos oligárquicos y la prensa adicta persiguiendo -ya en la escena política- la fractura constitucional.

Pareciera que, ni unos (obreros) ni otros (políticos), supieron comprender el civismo con el que se manejó el gobierno de Yrigoyen, quien, haciendo gala del progresismo y el respeto por la libertad vigente, no sólo respetó el derecho de huelga, sino que veló por la vigencia de normas éticas, y la observancia de la soberanía popular.

Definitivamente, por la convicción que

"[...] los hombres deben ser sagrados para los hombres y los pueblos para los pueblos [...]” (Historia del Radicalismo, 1982: 287, 297) ${ }^{206}$

La conducta principista y popular de Yrigoyen, su pertenencia irreductible a la "Causa" del pueblo enfrentando al "Régimen" oligárquico, si bien le permitió conquistar la lealtad y apego de las mayorías nacionales, alimentó, al propio tiempo, el odio y la

\footnotetext{
${ }^{206}$ Cabe señalar que solamente los anarquistas advirtieron -desde su órgano de prensa "La Protesta"- el avance dictatorial.
} 
violencia de las minorías privilegiadas y de inequívocos intereses 'no' nacionales. Alianzas y bloc au pouvoir que, entendieron, debían acelerar la conjura creando el clima propicio para el golpe. Para ello, fue menester difamar y desprestigiar al presidente manifestando su incapacidad para ejercer las funciones de gobierno; combatir y refutar la acción de sus colaboradores y, como "broche" del complot, instaurar la violencia en las calles.

El actuar con rapidez era esencial para el triunfo del golpe. Con ello, se evitaba que el gobierno incentivara su conducta popular, ya que, las elecciones en San Juan y Mendoza darían mayoría en el Senado, en desmedro de las clases privilegiadas, de modo que el Proyecto de Ley de Nacionalización del Petróleo -que contaba con media sanción en Diputados y que no había sido sancionada por la Cámara Alta por intereses espurios, ajenos a 'lo' nacional- se convertiría en Ley.

La conspiración comenzó en 1922, cuando la “Logia General San Martín” principió a hostilizar a Yrigoyen, apoyados por objetivos específicos de la oligarquía y no nacionales, como también por ideólogos de izquierda, tornados prontamente en fascistas. (Historia del Radicalismo, 1982: 302-303) ${ }^{207}$ Entre sus logros figuran, el nombramiento del entonces coronel (luego general) Agustín P. Justo como ministro de Guerra durante la presidencia de Alvear y el establecimiento, a partir de 1923, de la "cena de camaradería" de las fuerzas armadas. Si bien sus miembros no encontraron eco entre los oficiales del ejército y fue disuelta en el año 1926, su acción conspirativa continuó.

Contubernio que, en 1927, llevó a Matías G. Sanchez Sorondo, uno de los 'notables' del partido conservador, a expresar

“Ayer fueron los alquileres, hoy es el petróleo, mañana será la propiedad rural amenazada de ser distribuida” (Etchepareborda, R., 1986: 33).

Todo era válido, poco importaba el por qué, la finalidad era una: la conjura para socavar las bases populares del oficialismo.

Por eso, a pesar de ser reducido el grupo de militares que participó de la conspiración, la acción psicológica ejercida por la propaganda golpista, revistió suma

\footnotetext{
${ }^{207}$ Tal el caso del poeta Leopoldo Lugones que reclamó "la hora de la espada", contra el "obrerismo" que según él, desarrolló el gobierno de Yrigoyen, conducta que -a su criterio- constituyó "una dilapidación sistemática”. Fue, además, quien redactó la proclama del 6 de septiembre para el golpe encabezado por Uriburu. El Tte. Cnel. José María Sarobe consideró el documento sumamente reaccionario, procediendo a corregirlo.
} 
importancia en el golpe encabezado por José E. Uriburu, quien se había retirado del servicio activo en el año 1929.

Tal vez, el error de Yrigoyen radicó en consentir su reelección, pero el escenario político nacional no admitía otra salida. Era el único que podía hacer frente a "las derechas" unificadas.

"Su grave falta quizá haya residido en no haber querido, o no haber sabido, formar un sucesor de sus propios quilates”. (Etchepareborda, R., 1986:34)

De todos modos la violencia y provocación desatadas en algunas provincias asesinato en Mendoza del caudillo Lencinas- que incluso se hiciera sentir en la persona del presidente Yrigoyen -caso del atentado sufrido el 24 de diciembre de 1929 al salir de su domicilio de la calle Brasil- obligó a incrementar las medidas de seguridad. Esto fue sinónimo de pérdida del contacto que existía entre Yrigoyen y la ciudadanía. Ambas partes -pueblo y presidente- estaban acostumbrados a que el automóvil fuera rodeado, permitiendo saludos, entrega de cartas y demandas expresadas espontáneamente.

La circunstancia de producirse cambios en materia de seguridad, que ya no permitieron el acercamiento con los ciudadanos, aislándolo, fue aprovechada por los golpistas para iniciar una operación plagada de falacias y desvaríos, siendo la fantasía más utilizada que

"el presidente, ya reblandecido, era ocultado por su círculo intimo" (Historia del Radicalismo, 1982:304)

Por cierto, el episodio del atentado había conmovido profundamente a Yrigoyen (Historia del Radicalismo, 1982:304) ${ }^{208}$

Los tiempos habían cambiado, el estado en que había dejado Alvear la presidencia no fue precisamente de bonanza. La "Caja de Conversión” y la no renovación de los cuadros administrativos, configuran alguno de los desaciertos cometidos. A ello se agregaron los desgatados años (76/77) de Yrigoyen que ya no le permitían ejercer la presidencia con el meticuloso rigor con que había atendido cada cuestión, cualesquiera fuere el organismo y el nivel jerárquico. Su deseo de estar, de ver, de solucionar todos los temas -como lo hiciera durante su primer mandato- estaba por encima de sus posibilidades.

\footnotetext{
${ }^{208} \mathrm{Al}$ declarar en la Comisaría que levantaba el sumario, manifestó: "El convencimiento infinito que tengo de no haber hecho jamás mal a nadie, en sentido alguno, y sí todo el bien que estuvo a mi alcance".
} 
Al contrario del criterio de Alvear que delegaba, Yrigoyen concentraba las decisiones. En consecuencia, y como no podía ser de otro modo, los procedimientos fueron lentificándose. (Historia del Radicalismo, 1982:308) 209

Muy a su pesar, los radicales debieron asumir la realidad -no obstante las victorias electorales obtenidas en La Rioja, Jujuy y Buenos Aires- que se reflejó notoriamente en las elecciones de renovación parlamentaria.

Los guarismos para la U.C.R. se redujeron de modo exponencial y en la Capital Federal, ganaron los socialistas independientes. Y, aunque un diputado socialista mencionara que los triunfadores eran "conservadores y reaccionarios" (Historia del Radicalismo, 1982:308) ${ }^{210}$, y que la prensa, los periódicos en general, las revistas junto a los intereses foráneos, había conseguido confundir al electorado, la realidad mostraba palmariamente la presencia de errores, fallas y defectos no subsanados por el gobierno radical.

También resultó evidente la paralela ausencia y atonía popular. Así como, la invariable conducta en nuestra historia nacional, de los sectores conservadores que no quisieron o no supieron, saberse, definitivamente, "sentirse" nacionales.

Fueron pocos los funcionarios leales con los que el presidente Yrigoyen contó en ese estadio de su gestión. Su Ministro de Guerra, el Gral. Luis J. Dellepiane -el mismo que durante "la semana trágica" de 1919 doblegando los extremismos en juego, restableciera el orden, disciplinando a la policía y sosteniendo al orden legitimado- lo alertó sobre ello, hasta que, desautorizado por Elpidio González, Ministro del Interior, quien sostuvo que reinaba la tranquilidad, se vio obligado a renunciar. (Historia del Radicalismo, 1982:311) ${ }^{211}$

\footnotetext{
${ }^{209}$ Ello no impidió que continuara con su obra popular: la defensa de la tierra pública; la creación del Instituto Nacional de la Nutrición; la sanción de la Ley de Jubilaciones y Pensiones para Bancarios; la creación del Instituto Nacional del Petróleo; la paulatina devolución legislativa reformista a las Universidades, que fuere parcialmente abandonada durante la presidencia de Alvear; el establecimiento legislativo de la jornada laboral de 8 horas; el cierre de la Caja de Conversión (para contener el endeudamiento externo); un presupuesto de $18,5 \%$ para el ítem Educación, entre otras.

${ }^{210}$ Refiriéndose al resultado electoral -en un crónica escrita en la revista "Claridad"- manifestaba el diputado socialista Joaquín Coca que se había "producido en el país un cambio político de singular importancia para su porvenir" Uno de ellos "el descenso de la influencia del Partido Radical", sobre todo en la Capital Federal, siendo el Partido Socialista Independiente, una hoja de parra tras el que se ocultaban los ricos, los privilegiados, los burócratas, los burgueses: las fuerzas sociales de conservación y de reacción".

${ }^{211}$ En su renuncia -dirigida al presidente Yrigoyen- expuso: "He visto y veo alrededor de V.E. pocos leales y muchos intereses. Habría que nombrar un tribunal que analizara la vida y los recursos de algunos de los hombres que hacen oposición a V.E., y de otros que gozando de su confianza, hacen que V.E [...] sea
} 
De allí en más, los hechos desencadenantes de los conflictos fueron sucediéndose sometiendo la formación política a un mar de tribulaciones. En consonancia con nuestros dichos, se sostuvo

“La opinión pública, azuzada por los partidos y por la prensa, se aleja decepcionada del radicalismo. No debe olvidarse que, si bien la misma acompañó plebiscitariamente a ese partido en los comicios de 1928, lo hizo más como reacción frente al antipersonalismo y a las derechas, considerados por las clases media y popular como un instrumento de reacción aristocratizante que por adhesión al radicalismo y a su líder”. (Etchepareborda, R.,1986:35-36)

Pensamos que como en tantos otros momentos de nuestra historia institucional, el triunfo del radicalismo en 1916, que, a no dudar, imprimió una nueva dirección cultural al entramado social, no fue suficiente para lograr similar revulsivo en la sociedad política.

La presencia de "personajes" formalmente insertos en la ideología del régimen, ya enquistados en el poder, logró que la presidencia iniciada en 1922 significara el comienzo de un nuevo período constitucional de gobierno. Con el transcurso del tiempo, las posturas adoptadas por los nuevos detentadores del poder, permitieron advertir que una gradual brecha fue gestándose entre ambos niveles estructurales.

El inicio de un tercer período constitucional en 1928, nos ubicó frente a una crisis que, con el transcurso del tiempo, fue agudizándose hasta estallar.

Por ello, y al no contar la frágil sociedad civil con un sistema de valores alternativos, se generó -promediando el año 1929- el "principio de un 'fin' anunciado”, ya que en el año 1930, con el "golpe" de Uriburu, se produjo el primer quiebre de legitimidad democrática, por un aparencial déficit de legitimación. Y decimos "aparencial” toda vez que, a nuestro juicio, el proceso de deslegitimación fue pergeñado, aumentado y dirigido por el contubernio integrado por facciones reinvindicatorias del régimen, plus la nueva postura fascistizante, que terminó anulando el débil civismo cuya titularidad residió en una gelatinosa, sectorizada y confundida sociedad civil argentina.

presentado al juicio de sus conciudadanos en la forma despectiva, que es marea que nada detendrá si V.E. no recapacita”. 


\section{CAPÍTULO IV}

1930. Deslegitimación del sistema. Fractura institucional. Gobierno de facto.

Rémoras de una legitimidad de origen democrático, plus la existencia de una apatía -comportamiento indicador de falta de estabilidad- el inicio de un tercer período constitucional en 1928, volvió a ubicarnos frente a una crisis que fue agudizándose hasta estallar.

En postura que compartimos, y destacando la importancia del elemento 'estructura', Barbé-Olivieri entienden que siendo la crisis de legitimación consecuencia directa de la crisis del modelo "agro-exportador" -basado en la división internacional del trabajo- ${ }^{212}$ producido ese desequilibrio en nuestra formación política, ésta desembocó, como no podía ser de otro modo, en inestabilidad política.

Por lo que, “una burocracia relativamente 'eficiente', la 'diferenciación' partidaria o la autonomía de los subsistemas no fueron suficiente para garantizar la estabilidad política" (Barbé-Olivieri, 1972:171).

Considera Lipset, que un mayor desarrollo económico se corresponde con un sistema de "democracia política", esencialmente entendida, reiteramos, como estabilidad de las instituciones constitucionales. Resulta pues, innegable la vinculación de un régimen democrático con el desarrollo económico, de allí que la democracia "política" debe completarse, ineluctablemente, con la democracia "económica".

En consonancia con lo expresado, Barbé-Olivieri (1972:151) destacan que, el acaecimiento de los golpes militares, mostró la validez de la legitimidad política. Ello, toda vez que, el carecer, el estar falto de ella, provoca que no se alcance la debida estabilidad. Situación que se incrementó por una paralela crisis en el crecimiento económico, acentuando aún más la crisis de legitimación que a su vez es una de las causas -pero no la única- de la crisis económica"

\footnotetext{
${ }^{212}$ Ideología "importada" de los países centrales (desarrollados) que consideraba a la Argentina como "el granero del mundo" por lo que debía proporcionar al concierto internacional dicha materia prima, abandonando cualesquiera emprendimiento de industrialización. Manifiesta Lipset (1977:30) que desde Aristóteles hasta nuestros días, se tiene dicho que solo en una sociedad rica y poderosa en la que existieren pocos ciudadanos en situación de pobreza, marginados o excluidos del sistema, podría vivirse una situación en que la totalidad de la población (no solo una élite) participase inteligentemente en política y desarrollase la autocontinencia necesaria para evitar sucumbir al llamado de demagogos irresponsables. Reflexiones que, sin duda, no se compadecen con la realidad vivida en la etapa que describimos.
} 
Como dijésemos anteriormente, el estado argentino suscitó, al igual que en otras formaciones políticas, problemas de legitimación propios del capitalismo tardío. Por lo que, reconocida la distribución asimétrica de la riqueza, el sub-sistema político, la incipiente dirigencia se abocó a obtener una lealtad de masas, buscando restablecer la carencia de 'sentido' con 'valores'. Ya que, de no darse este proceso, se producirían las denominadas "crisis", como la que hemos venido recorriendo a lo largo de los capítulos.

En tal sentido, advierte Habermas que

"El sistema político requiere un input de lealtad de masas lo más difusa posible [...] las crisis de input tienen la forma de la crisis de legitimación [...] que es, directamente, una crisis de identidad...Déficit de legitimación significa que con medios administrativos, no pueden producirse, o conservarse en la medida requerida, estructuras normativas pertinentes para la legitimación”. (Habermas, 1995:64-65)

Enunciados algunos de los componentes capaces de provocar un déficit de legitimación, toca analizar las coordenadas de tiempo y espacio que generaron tal escenario histórico-político.

La disconformidad con que la oposición recibió los resultados electorales -auténtico "plebiscito" dotado de legitimidad cuanto de legitimación- que llevara en 1928 a Yrigoyen a su segunda presidencia (Ciria, A., 1985:16) ${ }^{213}$, fue evidente y compartida por casi la totalidad de la dirigencia política partidaria.

En relación a ello, sostuvo F. Pinedo, que en esas elecciones no sólo pudo hablarse de plebiscito -entendido en su significado clásico, vale decir, como sinónimo de una abultada y significativa victoria- sino también, como el

“...pronunciamiento de la plebe, de la masa popular desheredada, que acompañó al caudillo con inequívoca decisión y que pudo sentirse representada por gran cantidad de los electos radicales”. (Ciria, A., 1985:16)

Pese a ello, la réplica a la voluntad popular no se hizo esperar. El contubernio establecido entre J. E. Uriburu (fascista) y A. P. Justo (liberal), firmemente unidos en la coyuntura antipopular y anticonstitucional, con el agregado de un Congreso opositor, y

${ }^{213}$ Los resultados fueron: U.C.R.: 838.583 votos; Frente Único: 414.026; P.S: 64.985; “muy distanciados”: P.D.P. y P.C. 
demás factores reaccionarios -infelizmente articulado con la falta de reacción del radicalismo para enfrentar la conspiración- resultaron decisorios. (Ciria, A., 1985:16) ${ }^{214}$

Con el transcurso del tiempo, Yrigoyen confesaría que

"No obstante sus amenazas agresivas, tampoco llegué siquiera a suponerlas en la certidumbre que la tranquilidad de la Nación era inconmovible e inexpugnable”. (Historia del Radicalismo, 1982: 308)

Innegable deviene que la conspiración fue apoyada por otros importantes segmentos del colectivo, como lo fueron el periodismo -cuyo frontis fue Crítica-; las agrupaciones estudiantiles centralizadas en la Federación Universitaria; el Senado de la Nación y su incansable acción antagónica; como también, las tradicionales fiestas de la Sociedad Rural Argentina, convertidas en eventos dedicados a exteriorizar -en el acto inaugural- "silbatinas y tumultos" contra el representante del gobierno. ${ }^{215}$

Cónclave opositor al que el oficialismo no pudo, o no supo, oponer resistencia, ocupado en la lucha librada al interior del partido por la sucesión de H. Yrigoyen. Lucha intestina que no solo debilitó la imagen presidencial, sino también dificultó adoptar las previsiones -que la compleja y comprometida situación del concreto poder- ameritaba.

De todos modos, la insurrección no realizó referencia alguna al logro de objetivos económicos, sociales o políticos, por lo que, lejos de ser un movimiento popular, la sublevación fue la consecuencia del revulsivo opositor habido desde que Yrigoyen llegara al poder en 1928, hasta la jornada en que el Ejército marchó hacia la Casa de Gobierno. Vale decir, se mantuvo en el plano de la (mera) crítica. Actitud destituyente que dio sus frutos ya que, a esa altura de los acontecimientos, en 1930 la adhesión del pueblo al partido gobernante se había desgastado a punto tal que el brío y la potencia popular se encontraba fuera de combate, desgastada y sin posibilidad de reacción o desobediencia ante la facticidad impuesta.

La ideología del movimiento revolucionario -originada en la prédica antiliberal que llegase al país desde Italia y Alemania, cuanto en el contexto económico-social de

\footnotetext{
${ }^{214}$ La feroz oposición de Uriburu, no parece "casual”, pues -aunque descreía de la clase política- no debe olvidarse que con antelación perteneció a "esa" clase: representó a su provincia como diputado por el Partido Conservador; buscó alianzas con otras fuerzas políticas; a la par que bregó por la escisión del radicalismo y el desmembramiento del socialismo.

${ }^{215}$ Provocativo estado de situación cuyo punto culminante lo constituyera el triunfo obtenido por la U.C.R en las elecciones para diputados en marzo de 1930.
} 
desarrollo y crecimiento que caracterizara la década de 1920- fue explicitada por el teniente coronel Ramírez, mediante conceptos sumamente claros.

Sostuvo, al respecto, la necesidad de cambiar el sistema, no solo el gobierno, para lo cual era preciso modificar algunos matices y orientaciones de

“[...] la vida política del país; ya que [...] la Ley Sáenz Peña, con ser excelente, parece no ser la que mejor se adapte a una población que contiene el cuarenta por ciento de analfabetos. El sistema parlamentario actual no es el más adecuado al progreso o intereses de las fuerzas vivas de la Nación...” (Etchepareborda, R., 1986: 58)

1. El golpe. Prisión y reclusión de Yrigoyen.

Por causa de la implacable gripe-neumonía que sufriera Yrigoyen, el 5 de septiembre los ministros se reunieron, solicitándole que pidiera licencia por razones de salud. Si bien se resistió a la petición, finalmente delegó el mando en Martínez, quien, en la certeza que sería el lógico sucesor en la presidencia de la República, esa misma noche estableció el estado de sitio -instituto al que nunca había recurrido un gobierno radical(Sanguinetti, 1981:172) ${ }^{216}$ y pospuso el llamado a elecciones en las provincias cuyanas a celebrarse el 7 de septiembre. Prevención que adoptara, ya que, considerando el sentir ciudadano, se descartaba el triunfo de la U.C.R. que -por primera vez en catorce años- daría mayoría en el Senado, de allí la imperiosa necesidad de postergarlas.

Civiles y militares de la conspiración se reunieron la madrugada del 6 de septiembre, intentando sublevar distintos regimientos y guarniciones de la Capital, objetivo que no lograron. (Etchepareborda, 1986:44-45) ${ }^{217}$

\footnotetext{
${ }^{216}$ Expresó el autor que el diario "Libertad" en su edición del 6 de septiembre prevenía que "Martínez está echando pólvora en la hoguera, sin advertir, en su temeridad o en su inconsciencia, que puede ser él mismo la primera víctima. A él, a su gobierno [...] le decimos todavía hoy: si no están ciegos, abran los ojos y miren: verán convulsionado al pueblo; si no están sordos, pongan atento el oído y escuchen: oirán la voz inconfundible de la Nación que dice ibasta!, y no espera más."

${ }^{217}$ Cuenta el Gral. Mosconi que, como encargado de transmitir a E. Martínez las novedades, le comunicó que las fuerzas de Campo de Mayo, Liniers y del Arsenal se encontraban a la espera de sus órdenes. Palabras a las que Martinez respondió: "Que su renuncia era espontánea y definitiva, que sus deseos eran evitar que se derramara una sola gota de sangre y que nos pedía que se entregara el Arsenal y las tropas al nuevo gobierno y que nos solicitaba a los generales que estábamos en el Arsenal que nos retiráramos tranquilamente a nuestros hogares, porque todo había terminado".
} 
Lo único que obtuvieron fue el levantamiento del jefe y los cadetes de la Escuela Militar -fuerzas a las que se unió parte del cuerpo de Comunicaciones- las que, al mando del general retirado Uriburu marcharon hacia el centro de la ciudad.

Sólo con la fuerza policial, los insurrectos hubieran podido ser reducidos, pero el vice-presidente Martínez, ordenó no hacerlo. De donde, la presunción acerca de su intención de permanecer en el concreto poder se tornó evidente, circunstancia ésta que, cabe aclarar, no había sido siquiera considerada por Uriburu quien continuó, imperturbable, su marcha hacia Plaza de Mayo. Sólo encontró una débil resistencia cuando, al pasar frente a Plaza Congreso, se produjo un fugaz tiroteo. (Sanguinetti, 1981:176) ${ }^{218}$

Al llegar Uriburu, E. Martínez hizo colocar una bandera blanca en el mástil externo de la Casa Rosada. No resistir la sublevación y además rendirse -si bien resultaron hechos inéditos- fueron realizados por el vice-presidente, al ver que todas las guarniciones del Ejército estaban bajo el control de Uriburu.

De esa manera, el 6 de septiembre de 1930 resultó consumado el segundo golpe, ocasionando una nueva fractura constitucional que instauró al Gral. Uriburu en el ejercicio del concreto poder.

Interesa destacar que el sábado 6 por la tarde, el vice-presidente recibió la visita 'amistosa' de L. Colombo -presidente de la Unión Industrial Argentina- en carácter de emisario de los golpistas, comunicándole que debía abandonar el gobierno. (Historia del Radicalismo, 1982: 325, 315) ${ }^{219}$

Mientras tanto, Yrigoyen y sus colaboradores se trasladaron a la ciudad de La Plata. Allí, y en compañía de las autoridades provinciales, Hipólito Yrigoyen se dirigió al cuartel del Regimiento 7, lugar en que firmó su renuncia, a última hora del sábado 6 de septiembre de 1930, solicitando refugio y atención para su crítica enfermedad. Alojado en una

\footnotetext{
${ }^{218}$ Hecho que nunca fue debidamente aclarado. Según narró uno de los protagonistas, lo que ocurrió fue que existió una refriega entre los propios revolucionarios, creyendo escuchar y ver salvas de ametralladora provenientes de una ventana que, supuestamente, pertenecía al bloque 'personalista'. Luego se constató que el Congreso se encontraba desocupado, que la ventana pertenecía a la Comisión de Presupuesto y que el ruido obedeció al estruendo causado por una araña, al precipitarse pulverizada por los disparos de la formación insurgente.

${ }^{219}$ Hubo muchos otros insurrectos que, erróneamente, fueron convencidos que el accionar de la ultra-derecha estuvo determinado por el llamado personalismo yrigoyenista y que el alejamiento de Yrigoyen, garantizaría la continuidad institucional. Uno de ellos fue Alfredo Palacios, decano de la Facultad de Derecho, que tuvo la "lealtad de reconocer su equivocación a las pocas horas, renunciando inclusive a su cargo". Fácticamente, cabe mencionar, que la acción desplegada por la oligarquía fascista, despertó odios que se volcaron contra el domicilio de la calle Brasil, lugar al que $\mathrm{H}$. Yrigoyen ya no regresaría.
} 
habitación del casino de oficiales, fue atendido por su médico personal y médicos del regimiento, permaneciendo hasta el 10 de septiembre. Ese día, siendo las once de la noche, una Junta Médica autorizó su traslado a un buque de la Armada que lo condujo -en calidad de prisionero- a la isla Martín García. (Historia del Radicalismo, 1982: 340) 220

2. La conspiración: ¿sólo ensayo fascista-corporativo? - El contubernio.

Variadas resultaron las investigaciones realizadas acerca de la "crisis" que los desequilibrios habidos en 1930 provocaron en nuestro sistema político y, por ende, también diferentes las opiniones vertidas.

Unas hicieron apología de la revolución septembrista; otras entendieron que se trató de una aventura "típicamente fascista" y algunas la catalogaron como una "democracia fraudulenta", cuando, en rigor, consideramos fue la sumatoria de dichos emergentes.

La revolución estuvo caracterizada por dos sectores bien definidos.

Uno, decididamente de impronta militar y encabezado por José Evaristo Uriburu, contó con el apoyo de grupos nacionalistas y algunos dirigentes conservadores.

El otro segmento revolucionario se nucleó tras la figura de Agustín P. Justo, apoyado por conservadores, radicales antipersonalistas y el socialismo independiente (instancia que, fundada en razones de orden lógico analizaremos infra en 6)

No dudamos que el gobierno de José E. Uriburu sembró -en el escenario político argentino- la semilla del pensamiento nacionalista aristocratizante. Ratificó, también, e intensificó la presencia de los militares en la instancia regional de lo ideológico, constituyendo, en sus inicios, un incentivo para el accionar del movimiento universitario argentino.

Claramente, Uriburu expuso sus objetivos de gobierno:

“ $\left.1^{\circ}\right)$ Sanear y reconstruir rápidamente la administración y las finanzas;

$\left.2^{\circ}\right)$ Poner en orden el país y las universidades;

\footnotetext{
${ }^{220}$ En realidad, y conforme lo prometido se lo iba a trasladar a Montevideo, pero continuó detenido en el "Belgrano" hasta que fue llevado a otro buque, el "Buenos Aires". La precariedad de esta embarcación forzó el regreso al "Belgrano". A los pocos días volvió al "Buenos Aires". Durante un mes y medio fueron provocados estos cuatro cambios de buque, hasta que, finalmente, llegó a la isla Martín García en la que permaneció detenido casi dieciocho meses.
} 
$3^{\circ}$ ) Preparar la reorganización institucional de la república mediante reformas a la Constitución que nos defiendan en el futuro de los peligros del personalismo, del centralismo, de la oligarquía y de la demagogia;

$4^{\circ}$ ) Estimular la formación de grandes fuerzas cívicas que deben dar las soluciones para volver a la normalidad, sin que mi gobierno tome bandera partidaria." (Ciria, 1985: 31-32)

Propósitos, los enunciados, que -lejos de hacerse realidad- fueron diametralmente tergiversados.

En relación al primer punto, no solo se extrajo el $40 \%$ de la existencia de oro de la Caja de Conversión, sino que también aumentó la deuda flotante del Tesoro y se emitió papel moneda en gran escala. Completándose el cuadro financiero con la creación de nuevos impuestos equivalentes a más del $15 \%$ del presupuesto nacional.

En cuanto al segundo, los intentos de sublevación e indisciplina llevados a cabo por suboficiales en las provincias de Córdoba, Corrientes y Tucumán, como también la rebelión de civiles levantados "en armas" registrada en Entre Ríos, fue la respuesta al autoritarismo que pretendió imponer el dictador.

La instauración de la "ley marcial", la tarea legiferante reducida a "bandos" sobre delitos, el restablecimiento de la "pena de muerte" -expresamente excluida del Código Penal- la sucesión de fusilamientos, persecuciones, torturas y deportaciones; el retorno del "fraude" en los comicios presidenciales; la intervención a las Universidades -con la insubstancial excusa de subsanar la anarquía existente en ese ámbito- acompañada de estatutos retrogradando la autonomía lograda en 1918, hasta llegar a la asechanza y detención de dirigentes estudiantiles, fueron otras tantas maneras de desarrollar sus planes de "orden".

La "reorganización nacional" pomposamente anunciada en el tercer objetivo persiguió la reforma sustancial del régimen democrático vigente, reemplazándolo por un gobierno corporativista.

Como lo sostuviera Carlos Ibarguren, su plan se sustentaba en

“[...] hacer una revolución verdadera, que cambie muchos aspectos de nuestro régimen institucional, modifique la Constitución y evite se repita el imperio de la demagogia que hoy nos desquicia. No haré un motín en beneficio de los políticos, sino un levantamiento trascendental y constructivo con prescindencia de los partidos". (Etchepareborda, 1986: 40). 
Insistimos, además de la reforma constitucional, se proclamaba la necesaria derogación de la Ley Sáenz Peña reemplazándola por un sistema de voto calificado.

El cuarto y último objetivo, estaba direccionado contra el radicalismo yrigoyenista, fuerza política que había evidenciado una formidable resistencia y eficacia opositora, y que -fuere por acción o por omisión- en su rol de auténtica mediadora entre las demandas populares y el concreto poder, proporcionara suficientes muestras de solidez y empeño como emergente de la sociedad civil y del sentir cívico.

No fue ese tipo de fuerza la pergeñada por el gobernante de facto, quien otorgó sus preferencias a la "Legión Cívica". Grupo paramilitar que -cual guardia pretoriana, articulada "por" y "desde" el Ministerio de Guerra- finalizado el período del gobernante de facto, presentó fuerte resistencia al ser eliminado. ${ }^{221}$

Enunciados los cuatro objetivos -que no se cumplieron- la denominada línea fascista inaugurada por el general José Félix Uriburu, contó con un vice-presidente civil, Enrique Santamarina (quien falleciera pocos meses después). Vice-presidente que, ante la advertencia realizada por el periodismo acerca de: "si no hay pueblo, las tropas no saldrán", sugirió que los legisladores opositores

“[...] fueran en masa a los cuarteles y solicitaran, en nombre del pueblo, el concurso de jefes y tropas". (Sanguinetti, 1981:173)

Aceptada la "sugerencia”, varios fueron los destinos elegidos. Quien más resistencia presentó al deseo de los revolucionarios, fue el general Elías C. Álvarez mostrándose dubitativo y vacilante ante el verdadero carácter del movimiento, manifestando que sólo acompañaría a una corriente revolucionaria "civil” para derrocar al gobierno, si contaba con la seguridad

"[...] de que mi actitud de jefe militar, completamente desinteresada, no va a iniciar un período en que otros militares crean que pueden servirse del ejército con fines ambiciosos ilimitados [...] esto es, que no pensaba alentar a su tropa en esa aventura [...] si el ejército

\footnotetext{
${ }^{221}$ Otorgándole raigambre argentina y en contra de su desmembramiento, sostuvo Ibarguren, que la "Legión Cívica" "[...] no tuvo tiempo de desarrollarse en toda la República ni de adquirir la importancia y magnitud de una poderosa fuerza capaz de realizar los objetivos perseguidos por el jefe del gobierno provisional" (Ciria, 1985: 33)
} 
entraba a convertirse en el árbitro de los destinos nacionales, atribuyéndose el derecho de crear y destruir gobiernos”. (Sanguinetti, 1981:175)

Hábilmente, los políticos que lo rodeaban lograron convencerlo que ello no ocurriría y tal expeditiva maniobra, marcó el fin del ideario democrático y popular, sellando el destino de la República y la desbordada efervescencia septembrina.

Debe mencionarse, asimismo, la total inercia y atonía, como también las posturas ambivalentes, vale decir, en pro y en contra, demostrada por los partidos políticos autoproclamados "neutrales" -Partido Socialista, Demócrata Progresista y Partido Comunista- frente a "vencedores" (conservadores, socialistas independientes y antipersonalistas) y "vencidos" (radicales irigoyenistas), ante el autoritarismo de Uriburu.

Vaya, a título de ejemplo, una declaración dirigida al pueblo el 7 de septiembre por el socialismo independiente pidiendo "respeto por los vencidos",

“[...] corresponde ahora a los vencedores desterrar de su corazón las persecuciones y venganzas. Si hay lugar a sanciones legales por delitos cometidos, ;que se apliquen! Pero que no se desaten los odios políticos infecundos. El partido vencido, cuyos hombres han sido depuestos de sus cargos, forma parte de la nación, y sus componentes deben gozar de las mismas libertades que todos y ser protegidos, en el goce de ellas, por el gobierno provisional” (Sanguinetti, 1981:177)

El presidente provisional José E. Uriburu, acompañado por sus Ministros, prestaron juramento el 8 de septiembre de 1930. (Historia del Radicalismo, 1982:326) ${ }^{222}$ Anunciando, que habían concretado una revolución libertadora para salvar las instituciones.

Refiriéndose a los integrantes del gabinete, sostuvo Manuel Gálvez,

"El ministerio, intelectual y socialmente, no puede ser mejor; pero llama la atención que tres de los ocho ministros estén vinculados a las compañías extranjeras de petróleo, y todos, salvo dos o tres, a diversas empresas capitalistas europeas y yanquis. Los primeros actos del gobierno de Uriburu no dejan duda de que la revolución será, si no lo es ya, una restauración del régimen. El 6 de Setiembre es una especie de Termidor de nuestra historia” (Ciria, 1985:20)

3. Acordada de la Corte Suprema de Justicia. Validez del gobierno de facto.

\footnotetext{
${ }^{222}$ Los integrantes del gabinete ministerial fueron: en Interior, Matías G. Sánchez Sorondo; Relaciones Exteriores y Culto, Ernesto Bosch; Hacienda, Enrique S. Pérez; Guerra, Gral. Francisco Medina; Marina: contralmirante Abel Reard; Obras Públicas: Octavio S. Pico; Agricultura: Horacio Beccar Varela. Como secretario de la presidencia fue designado el teniente coronel Emilio Kinkelin.
} 
El Gral. Uriburu comunicó oficialmente a la Corte Suprema de Justicia de la Nación el derrocamiento de H. Yrigoyen y su acceso al poder, circunstancia que condujo a la Excma. Corte a dictar la Acordada de fecha 10 de septiembre de 1930 reconociendo al gobierno provisional como gobierno de facto al expresar:

"En Buenos Aires, [...] reunidos en acuerdo extraordinario los señores Ministros de la Corte [...], doctores don José Figueroa Alcorta, don Roberto Repetto, don Ricardo Guido Lavalle y don Antonio Sagarna y el señor Procurador General de la Nación, doctor Horacio Rodríguez Larreta, con el fin de tomar en consideración la comunicación dirigida por el señor Presidente del Poder Ejecutivo Provisional, Teniente General don José F. Uriburu, haciendo saber a esta corte la constitución de un gobierno provisional para la Nación dijeron:

“1 $\left.{ }^{\circ}\right)$ Que la susodicha comunicación pone en conocimiento oficial de esta Corte Suprema la constitución de un gobierno provisional emanado de la revolución triunfante de 6 de septiembre del corriente año.

“2०) Que ese gobierno se encuentra en posesión de las fuerzas militares y policiales necesarias para asegurar la paz y el orden de la Nación, y por consiguiente para proteger la libertad, la vida y la propiedad de las personas, y ha declarado, además, en actos públicos, que mantendrá la supremacía de la Constitución y de las leyes del país, en el ejercicio del poder.

"Que tales antecedentes caracterizan, sin duda, un gobierno de hecho en cuanto a su constitución y de cuya naturaleza participan los funcionarios que lo integran actualmente o que se designen en lo sucesivo con todas las consecuencias de la doctrina de los gobernantes de facto respecto a la posibilidad de realizar válidamente los actos necesarios para el cumplimiento de los fines perseguidos por él.

"Que esta Corte ha declarado, respecto de los funcionarios de hecho 'que la doctrina constitucional e internacional se uniforma en el sentido de dar validez a sus actos, cualquiera que pueda ser el vicio o deficiencia de sus nombramientos o de su elección, fundándose en razones de policía y de necesidad y con el fin de mantener protegido al público y a los individuos cuyos intereses puedan ser afectados, ya que no les sería posible a estos últimos realizar investigaciones ni discutir la legalidad de las designaciones de funcionarios que se hallan en aparente posesión de sus poderes y funciones.(Constantineau, Public Officers and the Facto Doctrine, Fallos: 148:303)'

"Que, el gobierno provisional que acaba de constituirse en el país, es, pues, un gobierno de facto cuyo título no puede ser judicialmente discutido con éxito por las personas en cuanto ejercita la función administrativa y política derivada de su posesión de la fuerza como resorte de orden y de seguridad social. 
“Que ello no obstante, sí normalizada la situación, en el desenvolvimiento de la acción del gobierno de facto, los funcionarios que lo integran desconocieran las garantías individuales o las de la propiedad u otras de las aseguradas por la Constitución, la administración de Justicia encargada de hacer cumplir ésta las restablecería en las mismas condiciones y con el mismo alcance que lo habría hecho con el Poder Ejecutivo de derecho.

"Y esta última conclusión, impuesta por la propia organización del Poder Judicial, se halla confirmada en el caso por las declaraciones del gobierno provisional, que al asumir el cargo se ha apresurado a prestar el juramento de cumplir y hacer cumplir la Constitución y las leyes fundamentales de la Nación, decisión que comporta la consecuencia de hallarse dispuesto a prestar el auxilio de la fuerza de que dispone para obtener el cumplimiento de las sentencias judiciales.

"En mérito de estas consideraciones, el Tribunal resolvió acusar recibo al gobierno provisional en el día, de la comunicación de referencia mediante el envío de la nota acordada, ordenando se publicase y registrase en el libro correspondiente, firmando por ante mí de que doy fe [...] Raúl Giménez Videla. Secretario”. (Ciria, 1985: 24-25)

Ante el fallo, A. Ciria manifestó, citando a Gabriel del Mazo, que existieron sobrados argumentos para aseverar que, en el pronunciamiento, medió

"[...] presión oficial sobre los miembros de la Corte Suprema, bajo amenazas de ser puestos en comisión junto con todo el Poder Judicial”. (Ciria, 1986: 36)

Destaca H. Zarini que el reconocimiento de los gobiernos de facto ha dado lugar a la elaboración de diversas teorías: la tesis legitimista, del reconocimiento popular, de la prescripción, del error común, de la necesidad, del hecho consumado. Y que, en su fallo, la Corte aceptó, en los considerandos $2^{\circ}$ y $5^{\circ}$, la teoría del hecho consumado; en el $4^{\circ}$ la teoría de la necesidad y fundado en ella, permitió al poder ejecutivo el ejercicio de la función legislativa, inaugurando el régimen de los decretos-leyes, (instituto decididamente extraño al orden constitucional). (Zarini, 1981: 213-215)

Al referirse a los principios constitucionales y su crisis en un gobierno de facto, menciona J. Vanossi (1975:585-586) en relación a los “representantes", que

"[...] ninguna autoridad es legítima si no se la ejerce en representación del pueblo que es la fuente originaria de toda autoridad y de todo poder."

Agregó que se trata de un problema de "actitud mental", de interpretación, por lo que, desconocerla o negarla, carece de sentido. 
Ingresando al tratamiento de la legitimación, manifestó que sin perjuicio de existir diferentes "medios" para lograr su consecución, todos tienen una raíz común: la 'fuerza de convicción'. Cualesquiera fuere el medio utilizado, debe detentar esa "fuerza" capaz de ratificar el pretenso proceso de cambio toda vez que la problemática de la sociedad política, es la "convivencia". (Vanossi, 1975:601)

\section{José E. Uriburu. Manifiesto del $1^{\circ}$ de octubre de 1930.}

Si alguna duda subsistiera sobre el objetivo y el proyecto a implementar por el gobierno de facto, la finalidad corporativa de Uriburu quedó explicitada en el manifiesto que brindó al pueblo el $1^{\circ}$ de octubre. En él se refirió, a la precipitación y alarma que manifestaran diversas fuerzas políticas por ver cumplida sus expectativas y negó que hubiere contraído compromiso alguno -prescindiendo tanto de las masas, cuanto de los partidos políticos- más allá de la reorganización de la administración pública:

“[...] Si el gobierno de la revolución se limitase a sustituir hombres en el poder, es seguro que recogería el aplauso de los partidos beneficiados, pero la revolución no se ha hecho para cambiar valores electorales. Colocados por encima de los partidos, tenemos un pensamiento político que no pretendemos imponer, pero que estamos en el deber de hacer público para que se lo considere y se lo discuta [...] No consideramos perfectas ni intangibles ni la Constitución ni las leyes fundamentales vigentes, pero declaramos que ellas no pueden ser reformadas sino por los medios que la misma Constitución señala [...] Creemos que es necesario que la Constitución sea reformada, de manera que haga posible la armonización del régimen tributario de la Nación y de las provincias, la autonomía efectiva de los estados federales, el funcionamiento automático del Congreso, la independencia del Poder Judicial, el perfeccionamiento del régimen electoral, de suerte que él pueda contemplar las necesidades sociales, las fuerzas vivas de la Nación. Consideramos que cuando esos intereses puedan gravitar de una manera efectiva, no será posible la reproducción de los males que ha extirpado la revolución. Cuando los representantes del pueblo dejen de ser meramente los representantes de los comités políticos y ocupen las bancas del Congreso obreros, ganaderos, agricultores, profesionales, industriales, etc., la democracia habrá llegado a ser entre nosotros algo más que una bella palabra. Pero será el Congreso elegido por la ley Sáenz Peña quien declarará la necesidad y extensión de las reformas, de acuerdo con lo preceptuado en el artículo 30 de la Constitución Nacional” (Romero, 1969: 229-230). 
5. El periodismo y la opinión pública.

Los contenidos que Uriburu vertiera en su manifiesto, promovieron cierta resistencia, fundamentalmente, en los políticos quienes desafiaron al gobierno de facto con dejarlo sin opinión pública.

El 4 de octubre, escribió de Tomaso en "Crítica",

"Reconozco que el manifiesto último dice una cosa importante: la Constitución y la ley Sáenz Peña no serán tocadas por el gobierno de hecho; si ellas deben sufrir modificaciones, como las prudentes que ya había aconsejado la experiencia, o como las catastróficas que desearían algunos trasnochados lectores de Mussolini que por aquí tenemos, sólo en el Congreso próximo elegido mediante la legislación electoral vigente en la Nación y en las provincias- podrían discutirse. Pero esa declaración era obligada. ¿Quién, que no sea un loco [...] ha podido suponer, ni durante un minuto, que estaba en las facultades del gobierno provisional modificar, por sí, a la elección de una Asamblea Constituyente? Si alguien lo ha supuesto o creído posible, querría decir que en la República Argentina hay todavía personas que padecen, políticamente hablando, de desvario mental".

Y, ratificando su postura, en la jornada siguiente, advirtió al gobierno que " [...] no se deje embriagar por sueños megalómanos" intentando establecer una "reforma fascista de la revolución”. Sumó a esos conceptos, que

“Si ésas son las 'nuevas ideas' que el partido nacional, cuya formación sería grata al gobierno provisional, inscribiría al frente de su programa, me atrevo a hacer un seguro vaticinio: ese partido morirá en estado de feto." (Sanguinetti, 1981:182)

Declaraciones éstas, que llevaron a Carlos Ibarguren, inspirador y colaborador del general Uriburu, a pronunciar, el 15 de octubre desde Córdoba, una conferencia que pretendió esclarecer -al propio tiempo que revalidar- los "principios" revolucionarios:

"[...] uno de los vivos anhelos que animan a la revolución es que en el estado actúen los representantes genuinos de los verdaderos intereses sociales, en todas sus capas, evitando así que elementos parasitarios del profesionalismo electoral que no significaban ningún valor, acaparen el gobierno, como ha ocurrido y se interpongan entre éste y las fuerzas vivas y trabajadoras del país $[\ldots] "$ 
"Por otra parte, en el Parlamento pueden estar representados los partidos por el sufragio universal y acordarse una representación parcial a gremios que estén sólidamente estructurados. La sociedad ha evolucionado profundamente del individualismo democrático que se inspira en el sufragio universal y del que se desprende la suma de intereses individuales a la estructuración colectiva que responde a intereses generales más complejos y organizados en forma coherente dentro de los cuadros sociales" (Galletti, 1961:93)

El establecimiento de una "representación funcional" -al margen de la Constitución Nacional y las leyes- quedó claramente explicitada en dicha conferencia al mencionarse explícitamente ciertas categorías conceptuales, a saber: "representantes de intereses sociales", "representación a los gremios", "cuadros sociales".

La finalidad de implementar un régimen corporativo, aun contra legem, fue evidenciado, no sólo por los individuos que integraron el gabinete, sino por el resto de los 'funcionarios' designados en lugares expectantes, puesto que pertenecían a los grupos más representativos de la oligarquía, y lograron tales posicionamientos gracias a la notoria participación en el bloc au pouvoir dominante (Historia del Radicalismo, 1982:326). ${ }^{223}$.

De donde y en consonancia con lo expresado, poco acercamiento tuvieron con el pueblo (para ellos la "masa") por lo que parecieron constituir un fascismo ilustrado.

\section{Respuestas del accionar corporativo.}

Una de las primeras acciones del gobierno de facto fue ordenar la intervención de la cuasi totalidad de las provincias. Hubieron dos excepciones: San Luis y Entre Ríos, cuyos gobernadores fueron ratificados en sus cargos por su manifiesta adhesión a los gobernantes de facto.

En la ciudad de Buenos Aires, fueron atacados el edificio del diario "La Época” y el domicilio de Yrigoyen. También se acometió contra el busto correspondiente a la primer

\footnotetext{
${ }^{223}$ Integraron el gabinete: en Interior, el Dr. Matías G. Sánchez Sorondo (conservador, abogado, diputado y senador, relacionado con intereses extranjeros); en Relaciones Exteriores y Culto, el doctor Ernesto Bosch (abogado, ex presidente de la Sociedad Rural); en Hacienda, doctor Enrique S. Pérez (abogado, con actuación en el gobierno de Alvear, directivo de la Sociedad Rural); en Justicia e Instrucción Pública, doctor Ernesto E. Padilla (abogado, ligado a la oligarquía azucarera de Tucumán y a la Cía. de Seguros Germano Argentina S.A.), en Obras Públicas, ingeniero Octavio S. Pico; en Agricultura, doctor Horacio Béccar Varela (abogado, ex asesor de la Cámara de Comercio Norteamericana y colaborador en empresas de capitales extranjeros); en Guerra, general Francisco Medina y en Marina, contralmirante Abel Renard.
} 
presidencia de Yrigoyen, que fue arrebatado de la Casa Rosada y arrastrado por las calles. (Historia del Radicalismo, 1982:326) ${ }^{224}$

Si bien, mediaron éstos y otros festejos de "unos pocos", la contrariedad y hostilidad de "los muchos" llevó -no obstante la vigencia del 'estado de sitio'- a que fuere implantada la ley marcial (que llegaba hasta la pena de muerte).

También "La Vanguardia" medio de prensa del Partido Socialista, sufrió los avatares provenientes del gobierno provisional. Así, en nota dirigida a su Director el 4 de octubre de 1930, el Ministro del Interior, doctor Matías Sánchez Sorondo decía:

"[...] Adjunto copia autenticada del decreto dictado en la fecha declarando en estado de sitio al territorio de la República. El gobierno provisional de la nación desea que el diario de su dirección se reduzca a publicar dicho decreto sin hacer comentarios de ninguna especie al respecto, pues entiende en esta forma garantizar la tranquilidad pública. Desea asimismo que se mantenga esta nota en la más absoluta reserva.

"Oportunamente remitiré a usted una declaración ['que no llegó nunca', según consigna en cita el autor] explicando los motivos que han determinado el decreto de referencia".

Más adelante y en respuesta, el periódico daba a conocer a la opinión pública que

"La última nota que recibiéramos del ministro Sánchez Sorondo, fechada el 2 de diciembre de 1930, dice así:

“"Tengo el agrado de dirigirme al señor director transmitiéndole el deseo del gobierno provisional de que no se publiquen informaciones de ninguna clase sobre el señor Hipólito Yrigoyen. En adelante el gobierno provisional dará sobre este asunto las noticias que juzgue conveniente publicar.

"Asimismo desea este gobierno que en cuanto al conflicto universitario se reduzca la información a dar a cuenta de los acontecimientos que se desarrollen sin publicar los discursos y sin comentarios.

“'Convencido este gobierno de que la prensa seria del país colabora con toda eficacia en la obra en que está empeñado, formula este deseo sabiendo que con su acostumbrada gentileza el señor director sabrá interpretar adecuadamente, manteniendo sobre esta nota la indispensable reserva." (Sanguinetti, 1981:193)

\footnotetext{
${ }^{224}$ Incidentes que -el capitán Juan D. Perón, activa figura de la conspiración y del 'golpe'- juzgó de
} “desmanes (del) populacho ensoberbecido". 
El aparato represivo en que se convirtiese el gobierno de facto ("legionarios" marchando por las calles; establecimiento de la picana eléctrica -“creación”, esta última que Leopoldo Lugones (h) incorporó a una "Sección Especial”- entre otras medidas) además de la "censura" a los medios de prensa, deterioró aún más la imagen de Uriburu.

Como no podía ser de otro modo, la crisis económica que sacudió al mundo, también se hizo sentir en nuestra formación política y las posibles "salidas" que se vislumbraron para escapar al destino certero de la doctrina que sentara Gunnar Myrdall, solo contemplaron los objetivos específicos de la clase hegemónica, vale decir, los "privilegios" de la minoría dominante.

7. Los intelectuales y la sociedad civil.

Además de las intrigas y componendas generadas al interior del radicalismo (Historia del Radicalismo, 1982:310 y ss.) ${ }^{225}$, situaciones coyunturales, de marcada inestabilidad y plagada de inequívocos rasgos provisionales caracterizaron pues, la dictadura del '30 que fuere iniciada con el golpe del 6 de septiembre.

Para Uriburu, las elecciones para gobernador del 5 de abril de 1930 realizadas en la provincia de Buenos Aires, provocaron una fractura en la "continuidad jurídica revolucionaria" por lo que tuvo que optar por dejar sus proyectos pro-fascistas en el presidente elegido -el general Justo- esperando que éste los pusiera en marcha a través de las instituciones constitucionales. Accionar que, reiteramos, señaló el inicio de la llamada “democracia fraudulenta" -reflotando el duelo entre la oligarquía y la democracia popularúnico modo en que -a nuestro criterio, en consonancia con la facticidad electoral- Justo podía llegar a triunfar.

Etapa que puede caracterizarse por: a) un marcado decaimiento del "civismo", plus la retracción de las fuerzas progresistas, aptas para generar la transformación del colectivo social; y b) un escenario fundado en el "fraude" sustentado por un acuerdo presidido por sectores conservadores, que contaba con el apoyo de factores de poder (Ejército e Iglesia) y

\footnotetext{
225 Como el mensaje transmitido a Eduardo Yrigoyen, hijo del Presidente, advirtiéndole del estallido revolucionario el día anterior a que aconteciera; la postura de E. Martínez, preparando un nuevo gabinete para el día siguiente; la actitud de los dos capitanes del Colegio Militar.
} 
sobre el que actuaban, cual extremos catalizadores, grupos fascistas. Agrupaciones éstas, decididamente inspiradas

“[...] en un principio por Maurras y Mussolini [...] y seducidas luego por la soberbia wagneriana de Hitler." Ideología y acciones que sólo perseguían, como dijera Federico Pinedo cambiar los fundamentos del poder político, haciéndolo reposar en la representación de corporaciones o gremios[...]” (Romero, 1969:235-236)

Como otros tantos sectores, la FUA acompañó en un principio a los revolucionarios. Posteriormente y luego de ver burlada la autonomía y los paradigmas de la "Reforma Universitaria”, sus integrantes pusieron de manifiesto su descontento ante el gobierno dictatorial.

Lo propio ocurrió -ya hemos mencionado algunos casos- con la prensa. De allí que, un allegado a N. Botana -director de "Critica"- José Gabriel confesara,

“[...] En fin de cuentas, si Yrigoyen erró, también hubo algo de desprevención (y eso es error) en la oposición no conservadora a Yrigoyen [...] No puedo pensar lo contrario conociendo a 'Critica' y sabiendo que nadie en aquella querida casa creyó fomentar con su anti-yrigoyenismo, quizá exaltado, ninguna dictadura."

Y agregaba más adelante,

“[...] El día en que la gente de 'Crítica' pueda hablar (y ha de ser pronto) se conocerá como debe conocerse la gestación y ejecución de la llamada revolución del 6 de setiembre de 1930, de la que resultó beneficiado en primer lugar quien menos había hecho por ella, el chino [así apoda, despectivamente, al general Uriburu]; en segundo, quien sólo había hecho un poquito, el ejército nacional; y en tercero, los que habían hecho más, sin hacer gran cosa, los conservadores de la provincia de Buenos Aires; perjudicados resultaron, en primer término, quien había hecho más, 'Crítica'; y en segundo, quien la seguía en méritos, el Partido Socialista Independiente, que, dicho sea fuera de la cuestión, no tiene nada de socialista”. (Sanguinetti, 1981:180)

A nuestro criterio, el juicio de valor sobre la revolución del ‘30, cuanto el sentido dado por Uriburu y Sánchez Sorondo a su gobierno, es severo y crítico, definitivamente, negativo. Es por ello que

“[...] Gran cantidad de sus mismos actores han deplorado lo ocurrido. Entre ellos, Perón manifestó, en su discurso del 8 de abril de 1953, que 'el presidente Yrigoyen fue el primer 
presidente argentino que defendió al pueblo' y por eso cayó 'ignominiosamente por la calumnia y por los rumores,", (Sanguinetti, 1981: 195-196).

Riguroso y mordaz, resultó el veredicto que sobre Uriburu expresara il Duce en una publicación 'auténtica' del fascismo italiano, dirigida por el propio Mussolini:

“El público americano está ávido de novedad,

"La novedad comenzaron a decirla algunos valientes que se llamaban Leopoldo Lugones y Manuel Gálvez en Argentina [...] Miremos a Roma para salvarnos de Moscú. Vayamos hacia el fascismo italiano para defendernos del comunismo ruso,

"Y así aparece la segunda y más peligrosa deformación del fascismo, dentro de cuyo naciente prestigio comenzaron a parapetarse los conservadores y los reaccionarios de cada república latinoamericana. Cada minúsculo tirano llegado al poder por un golpe cuartelero, colocaba delante suyo, bien a la vista en el despacho presidencial, una fotografía ecuestre de Mussolini, y se autoproclamaba, en entrevistas y discursos, admirador del genio del Duce. Entretanto, despojaba al pueblo de los pocos derechos obtenidos, y bajo cuerda vendía a los norteamericanos, junto con las concesiones petrolíferas, la independencia de la Nación. Estos epígonos han dañado más al fascismo que las campañas de los exiliados [...]

"El general Uriburu, jefe de un gobierno provisional, que significaba en Argentina la reacción de los latifundios conservadores contra la llegada al poder de los hijos de inmigrantes, o sea del pueblo, no oculta sus simpatías hacia el fascismo y consigue inclusive formar una Legión Cívica, o sea una milicia voluntaria armada e instruida por oficiales del ejército, con saludo romano, juramento y así de seguido. Tentativa que, sin embargo, usó un procedimiento totalmente opuesto al de la organización de los camisas negras. Mussolini conquistó el poder con sus legiones, y del poder se sirvió para refrenarlas y regimentarlas, transformándolas, de pueblo que eran, su Estado. Uriburu conquistó el gobierno con un golpe de Estado militar, y después impuso al ejército de sus empleados devenir pueblo fiel. Y así sucedió que de los doscientos mil 'legionarios' no se halló, una vez caído el jefe, ni siquiera veinte jóvenes dispuestos a jugarse el pellejo contra adversarios que hacían ludibrio y ejemplo de su nombre,

"Somos muy respetuosos de lo que ocurre en casa ajena, pero cuando Uriburu, hombre de casta más que de clase, reaccionario y oscurantista (el hombre que ha clausurado un tercio de las escuelas en Argentina), afirma en un mensaje presidencial que 'entre fascismo italiano y comunismo ruso preferimos fascismo italiano', es preciso tener el coraje de decir, nosotros fascistas, que se hacen deplorables confusiones [...] Preferimos la calidad a la cantidad y estamos 
persuadidos que para prestigiar la idea del fascismo sería mejor disponer de más estudiantes serios y de menos imitadores insuficientes [...]

“En Argentina [...] la prensa amarilla orquestada, ligada a los exiliados de París y a los grupos subvencionados por Moscú, hace una desesperada tentativa de sumergir, en la onda de desaprobación hacia el conservadurismo retrógrado, derrotado por los hijos de inmigrantes que han retomado el poder con renovada voluntad, la idea fascista, que a toda costa quiere presentar como inspiradora de las medidas y leyes impopulares y anti-obreras sancionadas por los ministros de Uriburu”" (Sanguinetti, 1981: 196-198).

Aún concediendo las inmoderadas explicaciones de los golpistas -referidas al "caos administrativo", la inmovilidad institucional, el "peculado" y la "impudicia"- el derrocamiento de Yrigoyen demostró cabalmente la regresión de las instituciones y la destrucción de la voluntad popular.

En ese sentido, sostuvo Rafael Bielsa,

"[...] Que la segunda presidencia de Yrigoyen empezara bien y luego se produjera una progresiva relajación funcional, sin que se pueda hablar, sin embargo, de inmoralidad del gobernante, y que diversos factores -algunos de los cuales ahora se olvidan- contribuyeron a facilitar la caída del gobierno, no es cuestión que interese más que para recordar el hecho. Lo que no puede negarse es que ese gobierno era de genuino origen popular y democrático, y que el sentido americanista del ciudadano que lo presidía había hecho de él como un hombre guión en el movimiento de restauración o de efectiva independencia de las naciones de América Latina. Hasta sus críticos más severos, lo juzgaron como auténtico americano, y gobernante que no cambalachea la soberanía ni el bienestar de sus conciudadanos. Fue presidente democrático y no demagogo; tenía fe en su pueblo, que ni siquiera aduló a la plebe” (Etchepareborda, R., 1986:45)

\section{Agustín P. Justo: segunda fase del contubernio.}

La segunda de las facciones conspirativas, se inspiró y reunió bajo la conducción de Agustín P. Justo (ex Ministro de Guerra durante la presidencia de Alvear) -quien tuvo el apoyo incondicional del teniente coronel José María Sarobe- concitando la adhesión de la mayoría de los oficiales comprometidos y manteniendo diferentes contactos con las cúpulas que conformaban el abanico opositor de centro-derecha (radicales antipersonalistas, conservadores y socialistas independientes). 
Si bien sostuvo la necesidad de derrocar a H. Yrigoyen, su objetivo no persiguió introducir cambios en el orden institucional, vale decir, en el régimen, sino reconquistar el concreto poder, (Ciria, 1985:20) ${ }^{226}$ preservando la estructura económico-social -contraria a los intereses del pueblo- que el radicalismo deseaba transformar.

Al igual que las dos caras de Jano, ambas corrientes continuaron enfrentándose en la lucha por la futura prevalencia en el poder.

Justo llegó a la presidencia en 1932, mediante el denominado "fraude patriótico", toda vez que, si bien en lo visible mantuvo formalmente el estereotipo democrático, mediante el fraude truncó el verdadero mandato popular.

Los "privilegios" constituyeron otro emergente de la denominada década infame.

Ambos caracteres fueron los que permitieron a Justo situar a la formación política argentina en directa dependencia "colonialista" de Gran Bretaña.

Lo cierto fue que la "aparencial" deslegitimación del sistema (¿o de uno de sus “elementos"?) llevó a los actores del golpe a ocupar el concreto poder, por déficit de legitimidad.

Los tempos transcurridos desde el acaecimiento de la revolución, claramente señalaron que se trató de una reacción contra la incipiente democratización de la vida política argentina, surgida de la reforma electoral impuesta por la Ley Sáenz Peña que, precisamente, concretara el principio de legitimidad electivo-democrático.

La candente efectividad humana intimidó al liberalismo, y el general Agustín P. Justo apareció en el escenario político acompañando al gobierno provisional, en un intento por rectificar no solo el perfil de Uriburu, sino también el del régimen, pretendiendo generar -en el imaginario colectivo- cierto matiz democrático.

Con esa finalidad y con el pensamiento puesto en que el radicalismo había "desaparecido", gradual y paulatinamente se llamó a elecciones provinciales.

En ese sistema que Pinedo llamó "mediana democracia", la prueba piloto fue la de la provincia de Buenos Aires -luego le seguirían Corrientes, Santa Fe y Córdobaentendiendo que en esas jurisdicciones el oficialismo lograría imponerse. Y no fue "casual", sino "causal" la elección de Buenos Aires, ya que en ella el fraude "patriótico" -

\footnotetext{
${ }^{226}$ Sostuvo Sarobe, que el objetivo de la revolución lo constituían los hombres. No las instituciones, ni los partidos.
} 
como lo denominaron los diputados "aliados"- fue celosamente organizado por el gobernador Manuel Fresco.

Las elecciones se fijaron para el 5 de abril de 1931. Más allá de las divergencias suscitadas en el radicalismo, en primer lugar sobre si se debía concurrir o abstenerse; tema seguido por "quiénes" serían los candidatos para componer la fórmula, lo cierto es que la U.C.R. resultó triunfante en las urnas. (Historia del Radicalismo, 1982:329) ${ }^{227}$

Pese a la victoria obtenida, las conjeturas acerca de cuál sería el resultado final, fueron varias. La mayor duda estribó en si los gobernantes permitirían que el Colegio Electoral se reuniese.

Recelos e inferencias que estuvieron justificadas ya que, haciendo caso omiso y en flagrante burla de la voluntad manifestada por el pueblo de la provincia de Buenos Aires, el general Uriburu en acuerdo de ministros, suspendió dicha convocatoria, como también la conformación de la Legislatura. (Historia del Radicalismo, 1982:330) ${ }^{228}$

Finalmente anuladas las elecciones en Buenos Aires, debido a la inesperada victoria del radicalismo -cuyos guarismos fueron humillantes para el gobierno provisional- Uriburu suspendió el resto de los comicios a celebrarse en las provincias anunciadas.

Cabe mencionar que, el candidato a gobernador, triunfante en las urnas, fue Honorio Pueyrredón y al cumplirse el décimo cuarto aniversario (5/04/1945) de esa histórica elección anulada por la dictadura militar, pronunció en su domicilio particular su último discurso -ante algunos amigos y bajo otra dictadura que irrumpió en su casa- manifestando que habían participado del acto eleccionario ante la palabra empeñada por un general de la nación, entendida como

“[...] palabra de honor del ejército al que él pertenecía. Sin embargo, ante el estupor del país entero y del mundo exterior que nos observaba, ese mismo gobierno anuló la consagración del veredicto popular y deportó a sus mandatarios electos [...] ¿Qué se ha conseguido con clausurar los comités? Aquí se cierra uno y allí se abre otro. Ni se ha conseguido ese objeto ni se ha

227 El resultado fue el siguiente: Radicales: 218.783; Conservadores; 187.083; Socialistas: 41.577; Antipersonalistas: 2.597; En blanco: 12.341. Situación realmente inimaginable ya que siete meses antes los vencedores habían sido expulsados del gobierno. De todos modos, siendo la elección para gobernador indirecta, en el Colegio Electoral los radicales no contaban con quórum propio: 55 electores pertenecían a la U.C.R. (a los que quizás se sumaran los antipersonalistas); los conservadores contaban con 49 y los socialistas con 9, posibles árbitros en la contienda.

${ }^{228}$ El 15 de abril, al conocerse el logro alcanzado por el voto popular, el Ministro del Interior Sánchez Sorondo había presentado su renuncia. Reflexionado en forma inequívoca ante el error de quienes calcularon que los radicales no podían ganar, manifestó, "La razón de los números no es la del entendimiento". 
impedido que sus autoridades funcionen. Si fueran clausuradas las iglesias y los sacerdotes obligados a retirarse de los templos ¿se habría suprimido a los creyentes? ¡No! Los creyentes verdaderos encontrarían siempre un rincón donde orar por la salvación de las almas [...] ;El Radicalismo encontrará siempre un lugar donde orar por la salvación de la República!” (Historia del Radicalismo, 1982:335)

Una vez más, quedó de manifiesto que los acontecimientos y referencias que se sucedieron desde 1916 a 1928, pusieron en evidencia que la U.C.R. llegó al ejercicio del concreto poder legítimamente, no solo en virtud de la legalidad y garantías establecidas por la Ley Sáenz Peña, sino que fue necesario contar con un plus: el hecho que los votos fuesen honestamente computados. (Snow, 1972:81)

9. Regreso y muerte de Yrigoyen.

En el mes de octubre de 1930 Yrigoyen se enteró, a través de los periódicos, que lo estaban procesando "[...] por supuestas irregularidades cometidas en el desempeño del gobierno [...]". Proceso acerca del cual no tenía conocimiento, vulnerando, en consecuencia, esenciales garantías constitucionales. (Historia del Radicalismo, 1982: 323) ${ }^{229}$

Habiendo sido indultado por Uriburu, el sábado 20 de febrero de 1932, Yrigoyen arribó -procedente de la Isla Martín García- al puerto de Buenos en el guardacostas "25 de Mayo". Dable es mencionar, que no aceptó el indulto, por lo que la litis continuó en sede judicial (habiéndose declarado falta de mérito en los cargos formulados).

La circunstancia de no contar ya con su vieja casa de la calle Brasil, hizo que fuese a vivir al domicilio de su sobrino, Luis Rodriguez Yrigoyen.

El 16 de diciembre de 1932 fue declarado el estado de sitio, lo que posibilitó las detenciones de Yrigoyen -que de ningún modo quiso volver a dirigir la U.C.R.Pueyrredón, Alvear y el general Dellepiane, entre otros.

Con la única excepción de Yrigoyen quien, una vez más, fue trasladado a Martín García, el resto de los prisioneros quedó detenido a bordo del crucero " 25 de Mayo".

\footnotetext{
${ }^{229}$ Manifestaba Yrigoyen, en su defensa presentada ante la C.S.J.N. (27/04/31) entre otras irregularidades, el dictado de su prisión preventiva sin llevar a su conocimiento las causas por las que fuere ordenada la medida y la posterior comunicación , vía secretaría del Juzgado del doctor Jantus, notificándole "[...] la confirmación por la Cámara, de la prisión preventiva basada en consideraciones que no he podido entender, sin conocer tampoco los casos a que se refieren, como podrá verlo V.H. pues me permito adjuntarle al presente escrito. Procediendo ambas entidades al margen de los más fehacientes mandatos humanos y muy especialmente aquél por el cual 'es inviolable la defensa en juicio de las personas y de los derechos, etc."
} 
Situación que se extendió hasta el mes de abril de 1933, fecha en que se levantó la medida de excepción, quedando en libertad los detenidos, a quienes, por otra parte, nada pudo probarse en su contra.

En rigor, Yrigoyen fue traído de regreso en enero de 1933, debido al deterioro de su salud. El avance de su enfermedad resultaba ya incontenible y su ánimo se encontraba sumamente afectado por lo injusto de su detención. Una acongojada, populosa y popular multitud, acompañó sus últimas horas. El deceso se produjo a las 19:21 hs. del 3 de julio de 1933.

La farsa democrática posibilitó el acaecimiento de sucesivas turbulencias en el tejido social, las que fueron ferozmente reprimidas por la dictadura registrándose cientos de detenidos, como también muertos y lesionados. El restablecimiento pacífico de la normalidad, esto es, de la democracia constitucional, resultó pues, una tarea harto azarosa, considerando la decidida reiteración de actos represivos por parte del ilegítimo gobierno de facto.

Golpes, quiebres y fracturas que, infelizmente, habrían de perpetuarse en el imaginario colectivo de nuestra ciudadanía, por lo que, la recurrencia cíclica y soterranea de las crisis signó el corsi e ricorse de nuestra historia. 


\section{EPÍLOGO}

1. Cierto es que en la evolución histórica de las formaciones políticas, un estado fuerte no siempre resultó epifenómeno de la sociedad civil que lo integró (Poulantzas, 1985:212/233), como tampoco achicar el estado significó agrandar la nación.

De ello dio prueba el papel cumplido por el primigenio Estado nacional argentino, al embretar las incipientes relaciones sociales estableciendo la prevalencia del M.P.C. a la difusa, gelatinosa, sociedad civil.

Queda claro entonces, que la construcción del estado argentino, cuanto su desarrollo no se originó gracias a la impronta de la sociedad civil, sino a la inversa: fue la sociedad política la que engendró a la sociedad civil. De tal modo, y refiriéndose a las diferentes formas de relacionamiento signadas por la represión, las revoluciones, la cooptación, los mecanismos de control ideológico, sostiene O.Oslak (2012: 275) que existió

"[...] un sino trágico en este proceso formativo. 'La guerra hizo al Estado y el Estado hizo la guerra' [...] la unidad nacional fue siempre el precio de la derrota de unos y la consagración de privilegios de otros [...]"

Si fue la "sociedad política" la que originó a la "sociedad civil", ¿Quién pone en duda que el Poder viene de arriba? ¿Acaso alguien se cuestiona el por qué aquellos que están en el llano obedecen? Por cierto la respuesta a ambos interrogantes, largamente tratados a lo largo de la historia, ya no resultan cuestionados.

El Poder viene de arriba y su ejercicio reside en una elite, en tanto su legitimidad proviene de abajo, dado que la creencia en él genera consentimiento, activo o pasivo, pero definitivamente sincero de quienes deben obedecer. Tal aserto, permite inferir que el pueblo debe estar espiritual e interiormente unido, no solo respecto al principio de legitimidad que comparte, sino también en lo referente a los grandes principios morales y religiosos que sustentan la vida, en una sociedad dada.

Para ello, es esencial cierta previsibilidad en el tejido social, al menos en lo cotidiano, acerca de las acciones y reacciones que recíprocamente adoptarán. (Ferrero, 1940:31-32 ${ }^{230}$ Extremos, los mencionados, sobre los que ninguna duda existe en sociedades

\footnotetext{
230 "La sociedad reposa entonces sobre la contradicción entre la libertad humana y la necesidad social de reacciones previsibles" manifiesta el autor.
} 
que llamaríamos "perfectas" (v.g.: hormigueros, colmenas), pero sobre los que no resulta fácil discurrir de igual modo frente a sociedades humanas ya que, siendo el hombre naturalmente imperfecto, también ellas devienen imperfectas y aproximativas. ¿Por qué siendo el hombre un ser eminentemente "social", lo cual lo lleva a vivir siempre en grupos, en ejercicio de su libre albedrío se torna un ser "insociable"? ¿Por qué esa contradicción, esa resistencia a cumplir con el deber ser, priorizando "su" querer? ¿Acaso el individualismo, el egoísmo y el espíritu de conservación de cada quien, devienen prioritarios y, en consecuencia, capaces de comprometer el orden social? ¿Radica en ello la “imperfección”?

También y expandiendo el interrelacionamiento de los grupos sociales hacia la faz política, señala H.Arendt (2012) que la esfera pública es el “potencial” espacio de aparición entre los hombres que actúan y hablan. En ese sentido, y enfatizando la importancia del lenguaje y del diálogo, considera que el poder solo es realidad cuando palabra y acto no se han separado, cuando las palabras no están vacías y los hechos no son brutales, cuando las palabras no se emplean para vetar intenciones sino para descubrir realidades y los actos no se usan para violar y destruir sino para establecer relaciones y crear nuevas realidades.

Aceptada la limitación, parcialidad, contingencia y reconociendo la extrema fragilidad de los principios de legitimidad, también del democrático, pensamos que respetarlo constituye el touch del contrato social que logra conformar toda formación política. Confianza y lealtad, deberían convertirse en la virtud cardinal de la civilización moderna (Ferrero, 1943:349), en lo que a la relación poder-ciudadano se refiere.

En ese sentido, se preguntaba Tayllerand ¿qué ocurre con aquellos gobiernos cuya legitimidad es puesta en duda? ¿Qué deben hacer para infundir al pueblo "confianza” en la legitimidad del poder que detentan y, así, asegurar su estabilidad? Y proporcionaba una sencilla respuesta: sólo es necesario que el poder se "constituya" de modo tal que no inspire temor brindando, además, garantías ya que, ${ }^{231}$

\footnotetext{
${ }^{231}$ Las garantías deben ser tanto para el soberano como para los súbditos. Talleyrand -las "Memorias" fueron publicadas en el año 1891- considera que se carecería de ellas: "[...] Si la libertad individual no fuera plenamente resguardada por las leyes, contra cualquier tipo de atropello; Si la libertad de la prensa no fuese garantizada plenamente, y si las leyes no se limitasen a castigar los delitos en que incurriesen; Si el orden judicial no fuese independiente, y para ello compuesto de miembros inamovibles; Si el poder de juzgar quedase reservado en ciertos casos a las administraciones o a cualquier otro cuerpo que no fuera el de los tribunales; Si los ministros no fuesen responsables solidariamente del ejercicio del poder del que son depositarios; Si a los consejos del soberano pudieran entrar otras personas que no fueran responsables; En
} 
"No basta que la confianza se funde en las virtudes y grandes cualidades del soberano, que como él son perecederas, sino que ha de fundarse en la solidez de las instituciones, que son permanentes [...]” (Ferrero, 1943b: 70-71)

Pero estas explicaciones no cierran el interrogante sobre la cuestión tematizada. Pareciera que existen constantes históricas en la marcha hacia la organización nacional. ¿Acaso existió una variable, una constante que tuvo “como premisa la inadecuación o el desencuentro inherente al argentino [...]? ¿Habría tal vez un dualismo hecho de tesis y antítesis, sin posibilidades de síntesis que cubriría toda la historia política del país? ¿Es que existen tesis y antítesis sin síntesis? Una negación no va seguida de una afirmación. ¿A qué obedeció la circunstancia de tantos desencuentros y frustraciones que cubrieron el cotidiano devenir histórico? [...] Nuestra historia política nos habla a menudo de la pérdida de la ruta en el preciso momento en que pareciera imponérsenos el camino más seguro. Cuando creemos en el cómodo tránsito, un brusco corte, y un cambio al parecer inexplicable se produce [...] y nuevamente retomamos los caminos cubiertos de fango. Una circunstancia provocada o no, pero sin duda en latencia [...] Tal vez, ¿Existe en el argentino una inadecuación de hondas raíces? (Galletti, 1961:20-25)

Insistimos, fuerza es reconocer que, si de redactar una Constitución se trataba, resultó insoslayable enmarcar "lo" político, vale decir el "poder" -y la inherente legitimación, o no, que traducía- dentro de una juridicidad que la legitimase. De donde, a nuestro juicio, "sociológicamente", y analizándola hoy día, la legitimidad como noción operativa-contingente, quedó embretada en "lo" jurídico, reduciéndola como muchos autores sostienen, a la mera legalidad. Entendimiento que, para 'esa' época, no podía ser otro.

G. Ferrero dijo, que el día en que descubrió la legitimidad, había comenzado a ver claro en la historia. Legitimidad que encuentra lógico correlato con la legitimación, que, definitivamente, continúa siendo uno de los conceptos claves de la problemática política.

Considerando que la legitimación posee una medida "cualitativa" no "cuantitativa dentro de la problemática política, y apelando a un principio de nuestros días -aceptado por

fin, si la ley no fuese la expresión de una voluntad formada por la reunión de tres voluntades distintas”. También le dice al soberano, que si bien es el rey legítimo de Francia, por sí solo no podrá sostener el peso del poder; ya no se cree en su infalibilidad; por ello debe rodearse de instituciones representativas y reconocer el derecho de oposición con las libertades que ello representa. 
todos, al menos declarativamente- cual es, el de "la mayoría", podremos decir que un elemento del sistema de poder está "legitimado" cuando recibe la legitimación de la mayoría de la población. (Barbé, 1973:73) Afirmación siempre generalizada, toda vez que admite interrogantes: por ejemplo, ¿cuál formación de tal legitimación está constituida por una legitimación activa y cuál otra, por una legitimación pasiva?

El tema va unido a la posibilidad de estabilidad (o permanencia) de un sistema de poder o de alguno de sus elementos, ya que no todos los eventuales legitimantes tienen el mismo peso a1 interior de un determinado sistema de poder. Vale decir, que no todas las des-legitimaciones significan el mismo peligro para un sistema de poder.

Eso es lo que piensa S. M. Lipset (1977:57) cuando indica, priorizando el sistema democrático en su faz política:

"La estabilidad de cualquier democracia dada depende no solamente del desarrollo económico, sino también de la eficacia y legitimidad de su sistema político”. Entendiendo por "efectividad", la eficiencia de hecho. Esto es, el modo en que e1 sistema resuelve las funciones básicas de gobierno, tales como las consideran la mayoría de la población y grupos tan poderosos dentro de ella como lo son las altas finanzas o las fuerzas armadas".

2. Las relaciones teoréticas hasta aquí establecidas, permitieron, pues, considerar a la legitimidad como un concepto operacional, es decir valorativo-axiológico, habilitándonos a percibir una serie de fenómenos políticos y su lógica interna, que posibilitaron determinarla -al interior del sistema político- como un atributo, con diferenciales grados, del elemento Poder y del régimen político por él establecido.

Ello obligó al necesario relacionamiento con el concepto de legitimación que, en tanto proceso, y los distintos tipos que puede presentar -considerando el nivel de participación, los valores priorizados y los elementos del sistema jerarquizados por la sociedad civil- supone la exigencia de una acción comunicativa a nivel popular.

Diagnósticos estos, que habilitaron posicionarnos frente a la observación de los hechos y valores que originaron la formación política argentina.

G. Ferrero (1943a) supo referirse al Poder como algo que se alza como una "montaña" y para cuyo análisis y justificación es preciso sortear sucesivas cortadas y mesetas. 


\section{Conclusiones.}

Nuestras definitivas conclusiones han de referirse, pues, al suceder de esas cortadas $y$ mesetas.

1853/1890. Como señaláramos, el análisis de los primeros años en que se gestaron los prístinos ensayos de vida institucional, ratificó que se trató de épocas en que, en la sociedad política, no solo no existió diferencia entre legalidad-legitimidad, sino que, a nuestro criterio, se llegó a confundir ambas categorías, utilizándolas con similar significado-significante que recién logró deslindarse cuando la legitimidad fue comprendida como un problema político.

En cualquier caso, tampoco la sociedad civil, reprodujo la activa participación de sus representantes, manejándose con un proceso de legitimación pasivo, por momentos manifiestamente apático.

Aunque a partir de 1852, el protagonismo -al menos formalmente- estuvo en manos del pronunciamiento popular para la elección de aquellos que fueran sus "representantes" a la Asamblea Constituyente, tampoco medió legitimación activa en términos de relativa "participación política". Solo existió, legitimación pasiva, ya que la "participación" sumó a la natural atonía "política- el estar condicionada por factores contingentes: los denominados factores secundarios de legitimación.

A no dudar, la gesta en la consecución de la unidad nacional, tuvo una cara revolucionaria y otra reaccionaria que originó una nueva sociedad, ordenada conforme a razón y que priorizó el progreso socio-cultural como requisito del progreso económico.

Dijimos también que el principio de legitimidad electivo -como forma para designar o transferir el poder público- puso al descubierto la presunción de potencial capacidad virtuosa que poseen los electores precisamente para seleccionar, escoger, votar, a quienes deben representarlos. Si bien el principio consagrado fue el electivo-democrático, -por lo que está indisolublemente unido al sufragio- cuando el ejercicio, la praxis está viciada, el principio no responde, no condice con el debido proceso de legitimación, sino sólo en lo "formal".

Lo señalado no constituye -aunque resulte obvia la aclaración- un "absoluto", ya que no invalida la circunstancia, ya enunciada, de encontramos ante un legitimidad 
heredada, más allá de compartir creencias, y de mediar consenso, en tanto especie de indicador empírico de legitimación.

Por lo que, legitimación -en tanto noción operativa, a nuestro juicio y stricto sensu-, no existió durante el período 1853/1890, de modo que la formación política argentina establecida bajo un poder "cuasi-legítimo", fue portadora de una crisis de legitimidad, toda vez que, al igual que los diferentes fenómenos de deslegitiminación -manifestados por los legitimantes a través de concretos y efectivos comportamientos desviados o apáticossuscitaron, a lo largo del período analizado, una sensación de incertidumbre e inestabilidad proporcionando una legitimidad parcial (origen de una democracia restrictiva), por inexistencia de integración social y, reiteramos, la falta -por carencia y/o fraude electoralde un proceso de legitimación que "reconociese" el concreto poder.

1891/1915. Los acontecimientos observados durante este período, admiten sostener que el desquicio existente en el nivel infraestructural -al que se sumó la violencia y el fraude de quienes detentaron el concreto poder- acentuó la crisis de legitimidad.

No existió creencia, acuerdo, acción comunicativa o discurso entre gobernantes y gobernados -esto es, un proceso de legitimación- para ser elector o elegido, ya que los medios empleados por la dirigencia hasta la sanción de la Ley Sáenz Peña, dejaron claramente explicitado que el poder legítimo, de aquella época, nunca pretendió obtener una lealtad popular, por lo que la crisis a que llegó el concreto sistema de poder fue totalmente predecible. La fragmentación social devino lógica resultante de las contradicciones que mediaron en la dialéctica gobernante-gobernado. Contradicciones que el gobernante de turno nunca se esforzó en superar y/o evitar, de allí la reacción, el escarmiento de los actores sociales y el insoslayable déficit de legitimación, generador a su vez de crisis de legitimidad. (Habermas, 1995:89)

El orden, la planificación administrativa, el progreso, enunciados en 1880 y reiterados por la oligarquía instaurada en el sistema, tuvo un nivel de autolegitimación que no fue suficiente para generar confianza en el pueblo. La educación, la salud, la riqueza sólo para algunos en detrimento de otros surtió, como era de esperar, efectos no queridos, debilitando la potencial justificación del poder.

Frente a tal situación crítica, la desconfianza imperante en el colectivo, llevó al actor social, a "apoderarse" de la tradición, de allí los actos revolucionarios. 
La legitimidad atribuida a una sociedad política autoritaria constituida por unos "pocos", originó una élite -estructural y económicamente posicionada como dominanteencargada de decidir formalmente el destino de una formación política, imponiendo obediencia por la fuerza, carente de una legitimidad de "reemplazo" lo cual nos ubicó frente a un poder ilegítimo, sinónimo de legitimidad en crisis por déficit de legitimación.

Déficit que se tradujo en crisis toda vez que, a nivel del sistema de poder y de su reflejo sobre el sistema político, provocó la crisis de un "proyecto de vida" sin mediar un proyecto "alternativo". Es decir, sin haber sido totalmente sustituido por otro proyecto o “diseño de vida". (Barbé-Olivieri, 1972:149)

De modo que la situación de crisis de legitimidad vivida desde 1880 hasta 1916, obedeció a la falta de un proceso de legitimación. No bastó, no fue suficiente contar con la legalidad de origen, en tanto pseudo génesis de la legitimidad del régimen fundada en la dominación hegemónica imperante en la estructura de clases, pues no medió un proceso previo de institucionalización y socialización de valores. No se luchó, cualesquiera sea el origen y la creencia de los actores, por dejar de lado las "particulares" diferencias, al servicio, en la consecución, de un propósito superador. Esto es, de "valores que se querían vivir" y compartir. Tampoco los gobernantes del período contaron con la creencia necesaria para aparecer con un líder, cuyo carácter de hombre "providencial" fuere indiscutido.

De allí la crisis, que denominamos déficit de legitimidad dada la carencia del necesario e insoslayable proceso de legitimación.

1916/1928. Tal como sostuviésemos, el año 1916 inauguró una nueva esfera pública en el devenir de la formación política argentina, a la par que significó la irrupción del primer gobierno popular, elegido por primigenia vez en la historia de la Nación Argentina, mediante elecciones legítimas además de legales. Esto es con participación del "pueblo" (cualesquiera fuese su creencia).

La reforma electoral de 1912, definitivamente, inició una larga marcha en pos del aprendizaje de la ciudadanía, a efectos de lograr "cultura política" capaz de generar comportamientos de lealtad. Comportamientos entendidos como virtuosos, esto es, como manifestación de conciencia cívica, en el entendimiento de que, la participación de todos debería ser, al propio tiempo, un logro común. (Álvarez, 1984:130) 
Sin embargo, fue necesario mucho más que una norma para educar al ciudadano. De allí el surgimiento de las denominadas academias de enseñanza electoral en aras de contar con una mayor participación de las capas populares y pasar, de una 'democracia limitada' a un sistema de 'participación ampliada'.

Teniendo pues, por premisas insoslayables, el poder legítimo y la existencia de un pueblo soberano, resultó evidente que los poderes desempeñarían sus funciones dotados de auténtica "autoridad", sólo cuando existieran gobiernos legítimos sostenedores de la voluntad popular y la República fuese sustentada por una verdadera representación democrática.

Fue notoria la recepción del nuevo diseño de vida por parte del concreto poder, a través del establecimiento de nuevas políticas de estado, como también la búsqueda de la consolidación de las reglas de juego mediante el “derecho” (Heller: 1987).

De manera que, el gobierno popular instaurado a partir de 1922, fue la resultante de un consenso residual de legitimación, que anidaba en el imaginario colectivo en torno al radicalismo. En ésta oportunidad, se levantaron los principios de un partido: la U. C. R. “El que triunfaba era el radicalismo cuya figura principal y querida era el mandatario saliente." (Historia del Radicalismo, 1982: 249; v.p. 228, n. 194)

Si bien ello significó el comienzo de un nuevo período constitucional de gobierno legítimo para la U.C.R., con el transcurso del tiempo, las posturas adoptadas por los nuevos detentadores del poder -aunque pertenecientes a esa misma fuerza política- no lograron evitar que una gradual brecha fuese gestándose entre los gobiernos de 1916 y 1922.

En las elecciones de 1928, creemos que el pueblo legitimó -dada su decidida participación demostrada a través de los guarismos que arrojara el comicio- el concreto poder. El liderazgo de Yrigoyen -'liderazgo’ que no implica desconocer los dichos de sus críticos y opositores- logró posicionarlo nuevamente en la escena política.

Pese a ello, los dos años de su presidencia no fueron similares al primer mandato. La disconformidad con que la oposición recibió los resultados electorales -auténtico "plebiscito" dotado de legitimidad cuanto de legitimación- que llevaran en 1928 a Yrigoyen a su segunda presidencia fue evidente (se llegó a mencionar -F. Pinedo- como auténtico plebiscito [...) como pronunciamiento de la masa popular desheredada, (Ciria, A., 1985:16) 
Las crisis suponen lógicas contradicciones en la dialéctica gobernante-gobernado, por lo que amenazan la integración social. En consecuencia, el Estado debe esforzarse en superarlas. Cuando fracasa en su intento, es castigado por los actores sociales produciéndose un déficit de legitimación, con lo que el campo de acción se restringe, justamente, cuando debería ser ampliado enérgicamente. (Habermas, 1995: 89)

La ausencia y/o la atonía de la ciudadanía popular fue notoria. El ciclo que había comenzado con un poder legítimo, culminaba con la ilegitimidad de un golpe gestando una nueva crisis.

1928/1930. Aún contando con una legitimidad de origen democrático, la apatía existente en la ciudadanía -comportamiento indicador de falta de estabilidad-signó el inicio de un tercer período constitucional en 1928, ubicándonos frente a una crisis que fue agudizándose hasta estallar.

Por ello, y al no contar la frágil sociedad civil con un sistema de valores alternativos, se generaron -promediando el año 1929- turbulencias económicas y sociales que desembocaron en el descalabro político y la consecuente zozobra que se adueñó de la vida cotidiana. Concretándose, ya en el año 1930, con el "golpe" de Uriburu, el primer quiebre de legitimidad democrática, por un aparencial déficit de legitimación.

En cualquier caso, lejos de ser un movimiento popular, la sublevación fue la consecuencia del revulsivo opositor (no popular) habido desde que Yrigoyen llegara al poder en 1928, hasta la jornada en que el Ejército marchó hacia la Casa de Gobierno, como consecuencia de la ideología de la época (sintetizada por C. Ibarguren - refiriéndose al plan que anunciara Uriburu al manifestar sus objetivos) propugnando la modificación del régimen institucional y por ende de la Constitución Nacional, prescindiendo de los partidos políticos.

También las palabras de M. Gálvez, ratificaron el accionar fascista-corporativo de los golpistas. Por ello, repetimos los conceptos enunciados -ante la presencia de un gabinete ministerial integrado por personajes ligados a intereses foráneos- sosteniendo que el golpe, la revolución, constituían una verdadera restauración del régimen y que "[...] El 6 de Setiembre es una especie de Termidor de nuestra historia". 
La convalidación de lo fáctico que significó el fallo de la C.S.J.N. llevó a que sólidos autores, manifestaran que existieron sobrados argumentos para aseverar que, en el pronunciamiento, medió

"[...] presión oficial sobre los miembros de la Corte Suprema, bajo amenazas de ser puestos en comisión junto con todo el Poder Judicial”."

La finalidad de implementar un régimen corporativo, aun contra legem, y constituir un fascismo ilustrado fue, pues, notorio y manifiesto.

Asimismo, la pretensión de establecer una "representación funcional" -al margen de la Constitución Nacional y las leyes- en paralelo con la llamada "democracia fraudulenta", reflotando el duelo entre la oligarquía y la democracia popular, presentó un marcado decaimiento del "civismo". Escenario sustentado por un acuerdo presidido por sectores conservadores, que contó con el apoyo de factores de poder (Ejército e Iglesia) y sobre el que actuaron, cual extremos catalizadores, grupos fascistas.

A nuestro criterio, el juicio de valor sobre la revolución del ‘30, cuanto el sentido dado por Uriburu y Sánchez Sorondo a su gobierno, es severo y crítico, definitivamente, negativo. Circunstancia también reconocida desde el exterior (v. opinión de B. Mussolini p. 261262) y, ya en la mitad del siglo XX, por uno de los más significativos líderes políticos de nuestra formación política (v.g. dichos de J. D. Perón, p. 258, n. 224)

El golpe contra el gobierno legítimo demostró cabalmente la regresión de las instituciones y la destrucción de la voluntad popular. Ello, ya que el gobierno de H. Yrigoyen contó con una legítima génesis popular y democrática.

La segunda de las facciones conspirativas -dirigida por A. P. Justo- significó el establecimiento del denominado "fraude patriótico", toda vez que, si bien en lo visible mantuvo formalmente el estereotipo democrático, mediante el fraude truncó el verdadero mandato popular, señalando la emergencia de la denominada década infame.

De modo que, la aparición de Justo, marcó el segundo paso de comedia del contubernio.

Dijimos antes, que la fractura constitucional de 1930 fue ocasionada por un aparencial déficit de legitimación. El momento de la legitimación, aquello que Almond llama la 'cultura política', ocupa un puesto determinante en el desarrollo político ya que es el momento esencial al servicio del cual se encuentran los elementos 'estructurales. 
Si bien resulta innegable, en el análisis de la política, la importancia de la denominada 'estructura' almondiana, cierto es que dicha estructura funciona al servicio de un concreto modelo de legitimación. Por ejemplo, en nuestra formación política, determinadas estructuras -como los partidos- evidenciaron suma importancia en la lucha por el sostenimiento de la estabilidad política;

“[...] pero no en la medida en que se presentaban más 'diferenciadas' -el caso de la Argentina hasta 1930 demuestra lo contrario- sino más legitimadas por la costumbre de los miembros de los respectivos sistemas políticos. Existen dos modos distintos para afrontar la incongruencia entre 'cultura política' y 'estructura'. Una consiste en afirmar que la institución política 'moderna' no puede desarrollarse en una sociedad culturalmente no preparada a recibirla. La segunda, para la cual el constitucionalismo ha fracasado en las naciones latino-americanas, porque fue artificialmente importado en una sociedad cuya evolución histórica era muy diversa de la europea. En ese sentido, Mariátegui había señalado cincuenta años atrás: 'En una economía semifeudal no pueden prosperar ni funcionar instituciones democráticas y liberales' ". (BarbéOlivieri, 1972:168-170) ${ }^{232}$

Señalando, como corolario, que "La legitimación es el único criterio científico con el cual juzgar la consistencia -y la eventual prestación futura- de un sistema político. (Barbé-Olivieri, 1972:171)

Si bien, una crisis de legitimidad constituye desde luego un proceso de cambio de creencia que se manifiesta por la amenaza que pesa sobre el estatuto de las grandes instituciones tradicionales, también es cierto que la relación de eficacia con que se desempeña el concreto poder, guarda íntima reciprocidad con el libre albedrío de

\footnotetext{
${ }^{232}$ Agregan Barbé-Olivieri que, "En el esquema parsoniano una sociedad dada es el sistema que resulta de los modos en los que los componentes del sistema total, están organizados en relación a una de sus funciones fundamentales, es decir a la acción colectiva útil para el logro de las metas de la sociedad. Consecuentemente, el desarrollo político no es otro que el proceso a través del cual se construye y se hace funcionar la organización necesaria, que determina los fines de la acción y moviliza los medios necesarios para alcanzar esos fines. ¿Cuál es la función del subsistema en lo interno de este esquema? Así como la función del subsistema económico está constituida por la producción, la del subsistema político es en cambio, la movilización de resortes sociales con el fin de lograr los fines colectivos [...] Pero para que tal poder sea generado se requiere la integración de la colectividad respecto a las metas o fines colectivos. $Y$ he aquí que la legitimación aparece como un elemento de especial relevancia en el esquema parsoniano. El rol de la legitimación es considerado por Parsons de gran importancia en el proceso de desarrollo político en una suerte de parangón entre la organización (en el subsistema económico) y la legitimación de la autoridad (en el sistema político). La legitimación de la autoridad, afirma, se encuentra en la base de las decisiones colectivas".
} 
satisfacción del colectivo. Es por ello que Offe y sus colaboradores indican que, en las formaciones políticas de tardo capitalismo,

"[...] la forma en que se procura legitimación obliga a los partidos políticos a entrar en una puja de programas, con el resultado de que las expectativas de la población se elevan cada vez. más. Ello podría generar un abismo insalvable entre el nivel de las pretensiones y el de los logros, que produciría desilusión en el electorado”. (Habermas, 1995: 95)

Desilusión que entendemos como "crisis de motivación", generada por la discrepancia entre la carencia, la falta de estimulación por parte del Estado y el paralelo síndrome de privatismo civil (Habermas, 1995:96) que experimenta el tejido social, al entender que lo público se ha despolitizado.

El concreto poder y el actor social deben reelaborar la cultura y la tradición que, en determinados momentos del devenir histórico, les llevó a obrar mancomunadamente. Deben reinventar esa acción comunicativa -en tanto sinónimo de interacción- y el discurso, entendido como un modo hábil para restablecer el acuerdo mediante una fundamentación, es decir, alegando razones, abandonando el monólogo o el mero relato. ${ }^{233}$

Hemos tratado, a lo largo de nuestro trabajo, de presentar los acontecimientos objetivamente, abordando diferentes andariveles de análisis en la observación de dos constantes: a) la heterogeneidad, lo revulsivo y la falta de madurez y cultura política que han caracterizado nuestra sociedad civil y b) la versatilidad y fragilidad, hasta, en ciertos casos, frivolidad, que constituyeron variables asumidas por la sociedad política, colocando a la ciudadanía, frente a la llamada regla de hierro de la oligarquía.

Consideramos que todas y cada una de las crisis por déficit de legitimidad, cuanto los disímiles procesos de legitimación, han sido signados -en la consecución de la formación política argentina y más allá de la lucha entre "los genios invisibles de la ciudad"- por un estado larval de "deslegitimación latente" protagonizado por las distintas fuerzas en pugna.

\footnotetext{
${ }^{233}$ Ampliando sus dichos, menciona Habermas (1995:91) que: “[...] Un límite sistémico para los intentos de compensar los déficit de legitimación mediante una manipulación deliberada consiste, entonces, en la disparidad estructural que media entre los ámbitos del concreto poder y la actividad que despliega y la tradición cultural. Pero a partir de allí puede construirse un teorema sobre la crisis sólo si se agrega otro punto de vista, a saber: la expansión de la actividad del estado tiene por efecto secundario un acrecimiento más que proporcional de la necesidad de legitimación."
} 
Cíclico acontecer que no solo conjugamos en tiempo pasado, sino que pareciera constituirse en el único presente (sin formular conjetura alguna en prospectiva, dado que no corresponde al quehacer científico vaticinar).

Por lo expuesto, entendemos que la dialéctica entre "legitimidad-legitimación" no siempre resultó condición veritativa y los solapamientos realizados entre dichas categorías han otorgado sustento a la originaria proposición confirmando nuestra hipótesis: la existencia de una deslegitimación latente -por déficit de legitimación- y las recurrentes crisis de legitimidad habidas en la formación política argentina, sea por situaciones de:

I. Cuasi-legitimidad (1853/1890) por incapacidad del concreto poder de concitar la unidad u obediencia del cuerpo político, debido a déficit de legitimación (por procesos de legitimación abortados y/o fraude electoral).

II. Ilegitimidad (1891/1915), derivado del anterior escenario protagonizado por la oligarquía intentando imponer obediencia mediante los llamados factores secundarios de legitimación: miedo, coerción y/o prestigio. Ello generó déficit de legitimación por apatía y/o comportamientos desviados por temor

III. Poder legítimo por debido proceso de legitimación (1916/1922): fijación de nuevas reglas de juego no solo consolidadas en el derecho, sino incorporadas y representadas en la ciudadanía a través de creencias y valores compartidos.

III.1. Legitimidad parcial por consenso residual de legitimación (1922/1928): obediencia, crédito que el pueblo proporcionó al sistema de poder ya legitimado, vale decir a la fuerza política, aún sin mediar liderazgo.

III.2. Poder legítimo (1928/1930) aún con aparencial déficit de legitimación -por crisis de motivación- y la circunstancia de sustentarse en un elemento: el liderazgo, de quien ejerce el concreto poder.

IV. Poder ilegítimo por golpe (1930) que ocasionó la fractura institucional del primer gobierno constitucional legítimo. El Poder se impone por miedo y fuerza, careciendo de legitimidad de reemplazo por déficit de legitimación. 
Creemos que los argumentos sostenidos resultaron pues, lógicamente validados en virtud del significado de las premisas de la que partiésemos y las conclusiones a las que arribamos.

Vayan estas reflexiones finales para expresar una vez más, la importancia del quehacer interdisciplinario en el abordaje de cuestiones politológicas. El interés selectivo (Prélot, 1984:57) en tanto "noción autónoma" de la Ciencia Política, nos permitió utilizar sus categorías conceptuales para indagar en la Historia, demostrando la trascendencia y eficacia de indagar los procesos de conocimiento abiertos en el meollo de nuestra investigación. 


\section{BIBLIOGRAFÍA.}

\section{De metodología}

BENSON, Oliver, El laboratorio de ciencia política, Amorrortu, Buenos Aires, 1974.

BLOCH, Marc, Introducción a la Historia, FCE, México, 1995.

CAMPILLO LORENZO, Rafael, "El método científico”, UEX, Cáceres, en (htpp://eleklektiko.files.wordpress.com/2008/09/el-metodo-cientifico.pdf).

CARDOSO Ciro F.S.-PEREZ BRIGNOLI, H, Los métodos de la Historia, Edit. CríticaGrijalbo, Barcelona, 1986.

ECO, Umberto-SEBEOK Thomas A., El signo de los tres- Dupin, Holmes, Peirce, Ed. Lumen, Barcelona, 1989.

ECO, Umberto, Cómo se hace una tesis, gedisa editorial, Barcelona, 2006.

FEBVRE, Lucien, Combates por la historia, Ariel, Barcelona, 1992.

FOUCAULT, Michel, Las palabras y las cosas, s. XXI editores, México, 1990.

FERNANDEZ SUAREZ, Jesús Aquilino, La filosofía jurídica de Eduardo García Máynez, Universidad de Oviedo- Publicaciones, 1991, en "htpp://books.google.com.ar/books?isbn= 847468285".

GARRAGHAN, Gilbert J., A Guide to Historical Method, Fordham University Press: New York, 1946.

MAGARIÑOS de MORENTIN, Juan A., El signo - Las fuentes teóricas de la semiología: Saussure, Peirce, Morris, Hachette, Buenos Aires, 1983.

MARRADI Alberto, ARCHENTI Nélida, PIOVANI Juan I., Metodología de las Ciencias Sociales, EMECE, Ciudad Autónoma de Buenos Aires, 2007.

MC CULLAGH, Behan C., Justifying Historical Descriptions, Cambridge University Press: New York, 1984.

OCHOA G., Ana B., “Métodos”, en (htpp://www.monografías.com/trabajos11/metods/

metods.shtm).

POPPER, Karl R., La lógica de la investigación científica, Tecnos, Madrid, 1962.

"A Pluralist Approach to the Philosophy of History", en The Myth of the

Framework, Routledge, London, 1996.

PRIGOGINE Ilya-STENGERS, Isabelle, La nueva alianza-Metamorfosis de la ciencia, Alianza Editorial, Madrid, 1994.

SCAVONE, Graciela M., ¿Cómo se escribe una tesis?, en LA LEY, Ciudad Autónoma de Buenos Aires, 2002, p.744

SHAFER, J., A Guide to Historical Method, The Dorsey Press: Illinois, 1974.

SCHUSTER, Félix G., Explicación y predicción - La validez del conocimiento en Ciencias Sociales, CLACSO, Buenos Aires, 1982.

(http://www.ispjae.cu/eventos/colaeiq/Cursos/Curso12.doc)

(htpp://www.es.scribd.com/doc/58663071/32/Metodo-genético)

(htpp://eleklektiko.files.wordpress.com/2008/09/el-metodo-cientifico.pdf)

\section{Específica}

BARBE, Carlos, Appunti per una teoria della legittimazione, G.Giappichelli editori, Torino, 1973. 
- Progresso e Sviluppo, Edizioni Giappichelli, Torino, 1974.

BARBÉ, C.-OLIVIERI, Mabel, Analisi in prospettiva storica comparata sull'inadeguatezza della teoría funzionalista per lo studio dell'instabilità política argentina: una proposta alternativa, Estratto dagli ANNALI della FONDAZIONE LUIGI EINAUDI, Vol.VI, Torino, 1972.

BASTID, P., BOBBIO N., CHEVALLIER J.J., POLIN, R., STERNBERGER D., "L'idée de légitimité", en Annales de Philosophie Politique", nº 7, P.U.F., Paris, 1967.

BERTIN, Hugo D.- CORBETTA Juan C., La noción de legitimidad en el concepto de lo político de Carl Schmitt, Editorial Struhart \& Cía., Buenos Aires, 1997.

BOBBIO, Norberto - MATTEUCCI, Nicola - PASQUINO, Gianfranco, Diccionario de Política, Siglo Veintiuno Editores, México, 2008.

BOTANA, Natalio, La légitimité problème politique, C.L.BROUSSE, Buenos Aires, 1968.

- "La crisis de legitimidad en Argentina y el desarrollo de los partidos políticos", en: Revista Criterio, $\mathrm{N}^{\circ}$ 1604, Buenos Aires, septiembre, 1970. COICAUD, Jean-Marc, Legitimidad y Política, Edic. HomoSapiens, Santa Fe, 2000.

DUVERGER, M., Sociologie politique, P.U.F., París, 1966.

- Introdution à la politique, Gallimard, Paris, 1964.

- "Sociologie des régimes politiques”, en G. Gurvitch, Traité de sociologie,

P.U.F., París, vol.II, 1963.

- Institutions politiques et droit constitutionniel, P.U.F., París, 1962 (cit. en

Botana, 1968:132).

- Méthodes des sciences sociales, P.U.F., París, 1961a.

- De la dictature, Juillard, París, $1961 b$.

- "Contribución à l'étude de la légitimité des gouvernements de fait", dans

Revue du droit public et de la science politique en France et l'étranger, T.60, París, 1945.

FERRERO, G., El Poder, Inter Americana, Buenos Aires, 1943a.

-Reconstrucción, Sudamericana, Buenos Aires, 1943b.

FOSSAERT, Robert, La societé. Les estructures ideologiques, Seuil-Paris, 1983.

GUARIGLIA, Osvaldo, Ideología, verdad y legitimación, CFE, Buenos Aires, 1993.

GODOY ARCAYA, Oscar "La amistad como principio político". Rev. "El Príncipe". Año 1, n.2 (Abril-Junio), La Plata, 1994, p.11-40.

HABERMAS, Jürgen, Après Marx, Fayard, París, 1985.

- Problemas de legitimación en el capitalismo tardío, Amorrortu edit.,

Buenos Aires, 1995.

KRIELE, Martín, Introducción a la teoría del estado. Fundamentos históricos de la legitimidad del estado constitucional democrático, ed. Depalma, Buenos Aires, 1980.

LINARES, Juan F., "Legitimidad y razón suficiente del poder", en JURISPRUDENCIA ARGENTINA, To. IV, p.71-74, Buenos Aires, 1963.

LOPEZ HERNANDEZ, José, "El concepto de legitimidad en perspectiva histórica", en http://ojs.uv.es/index.php/CEFD/article/view/116.

MANN, Michael, The Sources of Social Powers, University Press, Cambridge, 1992.

MARTINEZ-SICLUNA y SEPULVEDA, Consuelo, Legalidad y legitimidad: la teoría del poder, Ed. ACTAS, Madrid, 1991.

OPP, Karl D., "Einige Bedingungen für die Befolgung von Gesetzen”, in K. Lüdersen, F. Sack (ed.), Abweichendes Verhalten, vol. I, Francfort s/M, 1975.

PARSONS, Talcott, "Autoridad, legitimación y acción política", en La Autoridad, comp. de varios autores, (trad. Andrés M. Mateo), México, 1969. 
PEÑA, Roberto I., El pensamiento político del deán Funes, Universidad Nacional de Córdoba, Córdoba, 1953, caps. VII y VIII.

PEREZ GILHOU, Dardo, El pensamiento conservador de Alberdi y la Constitución de 1853, Depalma, Bs. As., 1984, cap. IV, pto. B, El conservadorismo político.

POLIN, Raymond, “Analyse Philosophique de l'lidée de légitimité”, en L'idée de légitimité, P.U.F., París, 1967 (cit. en Barbé, 1973: 21)

POULANTZAS, Nicos, Questions sur le pouvoir - Repères - Dialectiques, Máspero, París, 1980.

PRELOT, Marcel, La Ciencia Política, EUDEBA, Buenos Aires, 1984.

PRO, Diego F., "Periodización y caracterización de la historia del pensamiento argentino", en revista "Universidad", Universidad Nacional del Litoral, Santa Fé, n 51, año 1962.

ROUSSEAU, Jean-Jacques: Oeuvres complètes, Tome III, B. Gagnebin et M. Raymond (eds.), Gallimard, París, 1964

SABSAY, Fernando, Revista del Colegio Público de Abogados de la CF, Ciudad Autónoma de Buenos Aires 3/02/04.

SERRANO GOMEZ, Enrique, Legitimación y racionalización-Weber y Habermas: la dimensión normativa de un orden secularizado, U.N.A.M., ANTHROPOS, Barcelona, 1994.

SCHMITT, Carl, Legalidad y legitimidad, (Trad. J. Díaz), Edit. Aguilar, Madrid, 1971.

- El concepto de lo 'político' (texto de 1932). Con un prólogo y tres corolarios, Alianza Ed.(1ra. ed. 1932), Madrid, 1987.

STERNBERGER, Dolf, "Legitimidad", en: Sills, David (Director) Enciclopedia Internacional de Ciencias Sociales, Vol. 6. Madrid, Aguilar, 1970, p. 535-538.

SUVIRIA, José M., Los constituyentes de 1853, Lajouane, Buenos Aires, 1889.

VIALATOUX, Joseph, Le problème de la légitimité du pouvoir. Vichy ou De Gaulle?, Editions du livre francais, Paris, 1945.

\section{De contexto}

ACTON, Harry B., "Logique et casuisteque du pouvoir”, en Le Pouvoir, P.U.F., París 1957.

ALBERDI, Juan Bautista, Bases y puntos de partida para la organización política de la República Argentina, edit. Plus Ultra, Buenos Aires, 1974.

-La Revolución del 80, edit. Plus Ultra, Buenos Aires, 1964.

-Fragmento preliminar al estudio del Derecho, Fac.de Derecho y

Ciencias Sociales - UBA, Buenos Aires, 1942.

-Derecho público provincial argentino, La Cultura Argentina,

Buenos Aires, 1917.

ALVAREZ, Juan, Las guerras civiles Argentinas, EUDEBA, Buenos Aires, 1984.

ARENDT, Hanna, La condición humana, Paidós, Buenos Aires, 2012.

ARNAUD, Pierre., "L'idée de légitimité dans la Nouvelle Philosophie politique d'August Comte”, en L’idée de légitimité, n 7, P.U.F., París, 1967 (cit. en Barbé, 1973:55)

ARON, Raymond, La sociologie allemainde contemporaine, P.U.F, Paris, 1950.

-Immuable et changeante, de la IVe à la Ve République, Calmann-Lévy, París,1959.

AUZA, Néstor T., El periodismo de la Confederación, EUDEBA, Buenos Aires, 1978. 
AVILES, Víctor D., Gobernantes de Santa Fé, Instituto de Investigaciones Históricas Brigadier General Estanislao López, 1960.

BAGÚ, Sergio, Evolución histórica de la estratificación social en la Argentina, Fac. de Filosofía y Letras, Inst. de Sociología, Pub.Interna N 36, UBA, Buenos Aires, 1961.

-“Juan Álvarez", en ALVAREZ, J. Las guerras civiles Argentinas,

EUDEBA, Buenos Aires, 1984.

BAGÚ, Sergio y WEINBERG, Gregorio Weinberg, "La Sociedad Argentina - I (Síntesis Crítica de su desenvolvimiento durante una primera etapa de su historia") en De la Anarquía a la Organización Nacional, CEAL, vol. 2, 1974.

BALESTRA, Juan, "La república en quiebra", en El Noventa, una evolución política argentina, Capítulo XIII, Fariña, Buenos Aires, 1959

BARBANO, Filippo, Sociologia Strutturale, Giappichelli, Torino, 1966.

BAUMAN, Zygmunt, En busca de la política, FCE, Buenos Aires, 2001.

-Amor líquido, FCE, Buenos Aires, 2009.

BENDIX, Reinhard, Max Weber, Amorrortu, Buenos Aires, 1970.

BERLIN, Isaiah, en "Due concetti di libertà", in Passerin D'Entreves, A. (a cura di): La libertad política, Edizioni di Comunitá, Milano, 1974.

BIDART CAMPOS, Germán J., "Prólogo", en BERTIN, H.D.- CORBETTA J.C., La noción de legitimidad en el concepto de lo político de Carl Schmitt, Editorial Struhart \& Cía., Buenos Aires, 1997.

BIELSA, Rafael, "Práctica de la Constitución", en Anuario del Instituto de Derecho Público, t. VIII, Buenos Aires, 1948.

BOBBIO, Norberto, Estudios de Historia de la Filosofía: de Hobbes a Gramsci, Editorial Debate, Madrid, 1985.

BOTANA, Natalio, "Tradiciones e Instituciones en la democracia argentina" en GARZON VALDES, Ernesto, MOLS Manfred, SPITA Arnold (comp.) La nueva democracia argentina (1983-1986), edit. Sudamericana, Buenos Aires, 1988.

BOTANA, Natalio- GALLO, Ezequiel, De la República posible a la República verdadera (1880-1910), Ariel, Buenos Aires, 1997.

BOURDIEU, Pierre, Le capital social, en Actes de la recherche en sciencies sociales. Vol.31:2-3,1980. (http://www.persee.fr/web/revues/home/prescript/article/arss_03355322_1980_num.31 12069 )

BOURRICAUD, Francois., "Sur deux mécanismes de personnalisation du pouvoir”, en La personnalisation du Pouvoir, P.U.F., París, 1964.

BRAGONI, Beatriz, "Los avatares de la representación. Sufragio, política y elecciones en Mendoza, 1854-1881", en SABATO, Hilda-LETTIERI, Alberto (comp,), La vida política en la Argentina del siglo XIX-Armas, votos y voces, FCE, Ciudad de Buenos Aires, 2003.

BRAUDEL Fernand., La dynamique du capitalisme, Flammarion, Paris, 1985.

- Una lección de historia de Fernand Braudel, FCE, México, 1989.

BURDEAU, George, La Democracia, Ariel, Barcelona, 1960.

-Traité de Science politique, T.III, Librairie de Droit et de Jurisprudence, París, 1950.

-Méthode de la sciencie politique, Dalloz, Précis, 1959.

BUSSHOFF, Heinrich, Systemtheorie als Theorie der Politik, Munich, 1975.

CASASBELLAS, Ramiro de, "El fantasma de la lista sábana", Diario La Nación, Buenos Aires, 06/05/99.

CEAL, - De la Anarquía a la Organización Nacional, vol. 2, Buenos Aires, 1974. 
- Formación de un Estado Moderno, vol. 3, Buenos Aires, 1974.

- Las bases de la expansión, vol. 4, Buenos Aires, 1974.

- Crecimiento y desequilibrios, vol. 5, Buenos Aires, 1974.

- La clase media en el poder, vol. 6, Buenos Aires, 1974.

CIRIA, Alberto, Partidos y Poder en la Argentina Moderna, Hyspámerica, Buenos Aires, 1985.

COHEN, Jean y ARATO Andrew, Sociedad Civil y teoría política, FCE, México, 2000.

COLEMAN, James S., "Social Capital in the creaton of Human Capital", American Journal of Sociology, vol. 94, Suplement S95-S120, The University of Chicago, USA, 1988.

COTTA, Sergio, “La notion de constitution”, en L'idée de philosophie politique, Paris, P.U.F., 1965.

CROZIER, Michel., Le phénomène bureaucratique, Seuil, Paris, 1963.

CHIARAMONTE, Juan Carlos, "Ciudadanía, soberanía y representación en la génesis del estado argentino (C. 1810-1852)", en SABATO, Hilda (coord.), Ciudadanía política y formación de las naciones- Perspectivas históricas de América Latina, FCE, México, $2003 b$.

-“Una antinomia anacrónica", (en http://www.revistaenie.clarin.com/ideas/Porteñosprovincianos-enfrentamiento-siglo-XIX 0 887911217.HTML)

DE IPOLA, Emilio, Las cosas del creer- Creencia, lazo social y comunidad política, Ariel, Buenos Aires, 1997.

de JOUVENEL, Bertrand, Du pouvoir. Histoire naturelle de sa croissance, Geneve, les Editions du Cheval Ailé, 1947.

- De la souveraineté. A la recherche du bien politique, Th. Génin, Paris,1955.

- De la politique pure, Calman-Lévy, Paris, 1963.

de la FUENTE, Diego G., "Introducción. Segundo Censo de la República Argentina (1898)", en BOTANA, Natalio- GALLO, Ezequiel, De la República posible a la República verdadera (1880-1910), Ariel, Buenos Aires, 1997.

del MAZO, Gabriel, El radicalismo: ensayo sobre su historia y doctrina, Edit.Raigal, Buenos Aires, 1951.

DEMICHELI, Alberto, Formación constitucional argentina, Buenos Aires, 1971.

DIGESTO CONSTITUCIONAL, ELECTORAL Y MUNICIPAL DE LA REPÚBLICA ARGENTINA, Tomo II, Buenos Aires, 1924.

DI MEGLIO, Gabriel, "La consolidación de un actor político: los miembros de la plebe porteña y los conflictos de 1820", en SABATO, Hilda-LETTIERI, Alberto (comp,), La vida política en la Argentina del siglo XIX-Armas, votos y voces, FCE, Ciudad de Buenos Aires, 2003.

DI TELLA, Torcuato S., Historia Social de la Argentina contemporánea, Troquel, Buenos Aires, 1998.

EASTON, David, The political System. An Inquiry into the State of Political Science,New York, Alfred A. Knopf, 1964 (cit. en BOTANA, 1968:14)

ECO, Humberto- MARTINI, Carlo M., ¿En qué creen los que no creen?, Planeta, Buenos Aires, 1998.

ETCHEPAREBORDA, R., BAGÚ, S., ORTIZ, R.M.,ORONA, J.V., Crisis y Revolución de 1930, Biblioteca Argentina de Historia y Política, Hyspamérica, Buenos Aires, 1986.

ECHEVERRÍA, Esteban, Dogma Socialista, El Ateneo, Buenos Aires, 1947. 
EGGERS-BRASS, Teresa, "Historia Argentina: Una mirada crítica (1806-2006)”, Edit. Maipue, $3^{\text {a }}$ edic., Ciudad Autónoma de Buenos Aires, 2006.

ESCARDO, Florencio, Wilde, ed. Santiago Rueda, Buenos Aires, 1959.

FAYT, Carlos S., Derecho Político, Abeledo-Perrot, Buenos Aires, 1962.

FRAY MOCHO, "De baqueta a sacatrapo", en Obras Completas, ed. Schapire , t. II, Buenos Aires, 1961.

FREUD, Sigmund, Psicología de las masas, Alianza Editorial, Buenos Aires, 1989.

FREUND, Julien, L'essence du politique, Sirey, 1965.

- Sociología de Max Weber, Ediciones Península, Barcelona, 1967.

FRIEDRICH, Carl J., Man and his Government. Am empirical theory of Politics, Mc Graw-Hill, New York, 1963.

GALLETTI, Alfredo, La realidad argentina en el siglo XX -I- La Política y los Partidos. FCE, Buenos Aires, 1961.

-Historia Constitucional Argentina, Edit. Platense, La Plata, 1974.

GALVEZ, Víctor, Memorias de un viejo, Academia Argentina de Letras, Buenos Aires, 1990.

GARZON VALDES, Ernesto, MOLS Manfred, SPITA Arnold (comp.), La nueva democracia argentina (1983-1986), edit. Sudamericana, Buenos Aires, 1988.

GENTILE, Jorge H., El texto original de la Constitución de 1853, Córdoba, mayo de 2003 (en www.profesorgentile.com.ar)

GERMANI, Gino, Estructura social de la Argentina, Raigal, Buenos Aires, 1966.

GILIMÓN, Eduardo, "Un anarquista en Buenos Aires (1911)", en BOTANA, N.- GALLO, E., De la República posible a la República verdadera (1880-1910), Ariel, Buenos Aires, 1997.

GÓMEZ ORFANEL, Germán, Excepción y normalidad en el pensamiento de Carl Scmitt, Centro de Estudios Constitucionales, Madrid, 1986.

GONZÁLEZ BERNALDO, Pilar, "Sociabilidad, espacio urbano y politización en la ciudad de Buenos Aires (1820-1852)", en SABATO, Hilda-LETTIERI, Alberto (comp,), La vida política en la Argentina del siglo XIX-Armas, votos y voces, FCE, Ciudad de Buenos Aires, 2003.

GRAMSCI, A., Risorgimento, Editore Riuniti, Roma, 1971.

HALPERIN DONGHI, Tulio, Proyecto y construcción de una nación (1846-1880), Ariel, Buenos Aires, 1995.

HAMON, Léo, "Spécificité du pouvoir politique", dans Pouvoir et societé, Centre Catholique des Intellectueles Francais, Recherches et Débats $n^{\circ} 53$, Desclée de Brouwer, Bruges, 1966.

HEATH, Joseph, Communicative Action and Rational Choice, MIT Press, Cambridge (Mass.) 2003.

HELD, David, Modelos de Democracia, Alianza, Madrid, 2001.

HERAS, Carlos y GARCIA, Carlos F., "Introducción” en Reforma Constitucional de 1860, Facultad de Humanidades y Ciencias de la Educación-Universidad Nacional de La Plata, La Plata, 1961.

HELLER, Hermann, Teoría del Estado, FCE, México, 1987.

HISTORIA DE LAS ELECCIONES ARGENTINAS, vol. 02, “Clarín”, Ciudad Autónoma de Buenos Aires, 2011.

HISTORIA DEL RADICALISMO, Vol. 1/21, Edit. GAM, Buenos Aires, 1982.

HUIZINGA, Johan, El concepto de la Historia y otros ensayos, FCE, México, 1980, (trad. 
Wenceslao Roces).

INFORMACION PARLAMENTARIA, ELECCIONES, Vol. I, Serie Estudios e Investigaciones $\mathrm{N}^{\mathrm{o}}$ 7, Buenos Aires, Abril 1993.

JITRIX, Noe, El 80 y su mundo, edit. Jorge Alvarez, Buenos Aires, 1968.

KELSEN, Hans, Esencia y valor de la democracia, Guadarrama, México, 1977.

KLUCKHOHN, Clyde, Le concept de culture, en LASSWELL, Harold D. y LERNER, Daniel (comp.), Les Sciences de la politique aux Etats-Unis, Cahiers de la Fondation Nationale des Sciences Politiques, Armand Colin, París, 1951.

KLUCKHOHN, Clyde y KELLY, William H., The Concept of Culture, en LINTON R. (comp.), The Science of Man in the World Culture, New York, 1945.

KOHLBERG, Lawrence, Die kognitive Entwicklung des Kindes, Francfort s/M, 1975.

LEVENE, Ricardo, Historia del Derecho Argentino, To. X, Edit.Guillermo Kraft Ltda., Buenos Aires, 1958.

- Historia de las ideas sociales argentinas, Espasa-Calpe, Colección Austral, Buenos Aires, 1947.

Aires, 1960.

- La revolución de Mayo y Mariano Moreno, Edic. Peuser, Buenos

- El pensamiento vivo de Moreno, Edit. Losada, Buenos Aires, 1983.

LINCHETTA, María C., - "Participación: concreción democrática de Libertad-Poder", en II Congreso Internacional de Filosofía del Derecho, To. I, La Plata, 1987, págs.401-406.

- "Función de los Grupos de Presión en Países Centrales y

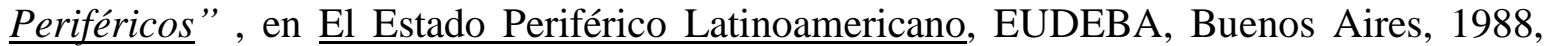
pág.291-301. (Co-autora).

-"Factores de poder: La burguesía terrateniente-hacendada en la Argentina”, en ANALES 31- Facultad de Ciencias Jurídicas y Sociales- UNLP, La Plata, 1988, págs.

- "Dicotomía y dialéctica entre normalidad-normatividad y legalidadlegitimidad”, en EL DERECHO CONSTITUCIONAL EN EPOCAS DE CRISIS, Instituto de Estudios Legislativos-H. Cámara de Diputados de la Pcia.de Buenos Aires. La Plata, 2001.

-“Reflexiones en torno al 'discreto encanto' de la representación”, en Revista "ANALES” - Año 4/ N 36 - Nueva Serie. CABA, 2005, p.552/563.

- "Democracia y ciudadanos 'hoy'”, mimeo en III Congreso Nacional de Derecho Político, AADP, Córdoba, 2006a.

- "Participación: ¿utopía o ideal?, en 6tas. Jornadas Nacionales de Filosofía y Ciencia Política, SLAVIN Pablo E. (compilador), Edic. Suárez, Mar del Plata, 2006b, p. 223/232.

- "Democracia e Instituciones en Argentina", en XI Jornadas Nacionales de Filosofía y Ciencia Política, Claudina ORUNESU y Pablo SLAVIN (compiladores) Facultad de Derecho, UNMar del Plata, 2011.

LIPSET, Seymour, El hombre político, EUDEBA, Buenos Aires, 1964.

- L'homme et la politique, Seuil, París, 1963.

LOPEZ, Lucio Vicente, La Gran Aldea, Huemul, Buenos Aires, 1965.

LOPEZ ROSAS, José Rafael, Historia Constitucional Argentina, Astrea, Buenos Aires, 1977.

LOBATO, Mirta Zaida (directora del tomo), Nueva Historia Argentina- El progreso, la modernización y sus límites (1880-1916), Edit. Sudamericana, Barcelona, 2000. 
LUNA, Félix, -Fuerzas hegemónicas y Partidos Políticos, Edit. Sudamericana, Buenos Aires, 1995.

- Cultura y población desde la Independencia hasta el Centenario (1816-1910), edit. Planeta, Buenos Aires, 2003.

- Justo José de Urquiza, edit. Planeta, Ciudad Autónoma de Buenos Aires, 2004.

- Bartolomé Mitre, edit. Planeta, Ciudad Autónoma de Buenos Aires, 2004.

- Domingo F. Sarmiento, edit. Planeta, Ciudad Autónoma de Buenos Aires, 2004.

- Julio A. Roca, edit. Planeta, Ciudad Autónoma de Buenos Aires, 2004.

MALLEA, Eduardo, Historia de una pasión argentina, edit. Sudamericana, Buenos Aires, 1984.

MANSILLA, Lucio V., Retratos y Recuerdos, El Ateneo, Buenos Aires, 1927.

MARITAIN, Jacques, "Démocratie et autorité", en Le pouvoir, Paris, P.U.F., vol. II, 1957.

MARTÍ, José Luis, La república deliberativa.Una teoría de la democracia, Marcial Pons: Barcelona, Madrid, 2006.

MAZO, Gabriel del, Breve historia del radicalismo, Coepla, Buenos Aires, 1964.

MAYER Jorge M., Alberdi y su tiempo, EUDEBA, Buenos Aires, 1963.

MERELMAN, R. M., "Learning and Legitimacy", in American Political Sciences Review, $\mathrm{n}^{\circ} 60,1966$.

MOSCA, Gaetano, "Elementi di Sciencia Politica", reproducido en La classe politica, Laterza, Bari, 1966.

MUÑOZ, Jacobo., "La alternativa del disenso", en: Figuras del desasosiego moderno, A. Machado, Madrid, 2002.

NEGRI, Antonio, Stato e política, Feltrinelli, Milán, 1970.

NIETZCHE, Friedrich, La genealogía de la moral, Alianza Editorial, Madrid, 1980.

ORTIZ, Tulio Eduardo, Los ciclos históricos argentinos, Plus Ultra, Buenos Aires, 1977.

OSLAK, Oscar, La formación del Estado argentino- Orden, progreso y organización nacional, Ariel, Ciudad Autónoma de Buenos Aires, 2012.

PALCOS, Alberto, Echeverría y la democracia argentina, Lib. "El Ateneo,Buenos Aires, 1941.

- "Prólogo", en Echeverría, Esteban Dogma Socialista, U.N.L.P., La Plata, 1940.

PARSONS, Talcott, "On the concept of political power", en: T. Parsons, Sociological Theory and Modern Society, Free Press, New York, 1967.

- "Authority, Legitimation and Political Action", en Structure and Process in Modern Societies, The Free Press, Glencoe, 1964,

- "Il concetto di Potere Politico", in Il politico, septiembre 1963 (título original,

"On the Concept of political power", en Proceedings of the American Philosophical Society, vol.107,n.3, junio de 1963.

- La struttura dell'azione sociale, Il Mulino, Bologna, 1962.

PATEMAN, C., "Political Culture, Political Structure and Political Change", in British Journal of Political Science, Luglio, 1971.

PEÑA, Roberto I., El pensamiento político del deán Funes, Universidad Nacional de Córdoba, Córdoba, 1953, caps. VII y VIII.

PEREZ GHILOU, Dardo, Facundo Zuviría y la Organización Nacional- Su nacionalismo liberal, Depalma, Buenos Aires, 1988.

- El pensamiento conservador de Alberdi y la Constitución de 1853, Depalma, Buenos Aires, 1984, cap. IV, pto. B, El conservadorismo político.

PICCIRILLI, Ricardo, Rivadavia, Edic. Peuser, Buenos Aires, 1952. 
PODESTÁ, Manuel T., 'El único hambriento', en Irresponsable, ed. Minerva, 1924.

PORTELLI, Hugues, Gramsci y el Bloque histórico, s. XXI, México, 1990.

POULANTZAS, Nicos, Poder político y clases sociales en el estado capitalista, s.XXI, México, 1985.

PUTNAM, Robert D., Makingh Democracy Work: Civic Tradition in Modern Italy. Princeton University Press, Princeton, 1993.

- Gesellschaft und Gemeisinn. Socialkapital im internationalen Vergleich. Gütersloh: Bertelsmaun, 2001.

- El declive del capital social: un estudio internacional sobre sociedades y el sentido comunitario. Galaxia, Gutemberg, 2003.

QUINTANA, Federico M., "En torno a lo argentino", Coni, Buenos Aires, 1941, cit. en "Antología de los Barrios", I, "La Nación”, Buenos Aires, 15/03/1959.

RAVIGNANI, Emilio, Asambleas Constituyentes Argentinas, To.4, Casa Peuser Ltda., Buenos Aires, 1937.

- Historia Constitucional de la República Argentina, Buenos Aires, 1930.

RECALDE, José R., Crisis y descomposición de la política, Alianza Universidad, Madrid, 1995.

RITTER, Joachim, "Politik und Ethik in der praktischen Philosophie des Aristoteles" in id. Metaphysik und Politik, Suhrkamp, Francfort s/M, , 1969 (cit. en Habermas, 1985: 253).

ROLDAN, Darío, "La cuestión de la representación en el origen de la política moderna", en SABATO, Hilda-LETTIERI, Alberto (comp,), La vida política en la Argentina del siglo XIX-Armas, votos y voces, FCE, Ciudad de Buenos Aires, 2003.

ROMANO, Ruggiero, Les conquistadores, Flammarion, París, 1972.

ROMERO, José Luis, Las ideas políticas en Argentina, FCE, Buenos Aires, 1969.

RUBINSTEIN, Juan Carlos, Crisis de la sociedad civil. Neofeudalización y Postfordismo, TRAMA, Madrid, 2002.

- "Reflexiones en torno a la sociedad civil", en Rev. "El Príncipe", Año I No 2, La Plata, 1994. Págs.53-79.

- Filiación histórica y sociopolítica de la enfiteusis rivadaviana, Fund. Bco. de la Pcia. de Bs. As., Buenos Aires, 1984.

SABATO, Hilda-LETTIERI, Alberto (comp,), La vida política en la Argentina del siglo XIX-Armas, votos y voces, FCE, Ciudad de Buenos Aires, $2003 \mathrm{a}$.

SABATO, Hilda (coord.), Ciudadanía política y formación de las naciones- Perspectivas históricas de América Latina, FCE, México, 2003b.

SABINE, George, Historia de la Teoría Política, FCE, Buenos Aires, 1990.

SABSAY, Fernando, "Revista del Colegio Público de Abogados de la CF", Ciudad Autónoma de Buenos Aires (03/02/04).

SAENZ QUESADA, María, La Argentina. Historia del País y de su gente, Ed. Sudamericana, Buenos Aires, 2001.

SAGARNA, Antonio, "La organización nacional. La Constitución de 1853", en Historia de la Nación Argentina, t. VIII, cap. IV, Buenos Aires, 1947.

SANGUINETTI, Horacio, Los socialistas independientes, EB, Buenos Aires, 1981.

SAN MARTINO DE DROMI, María Laura, Formación Constitucional Argentina, Edic. Ciudad Argentina, Buenos Aires, 1995.

SCHWAB, George, Carl Schmitt. La sfida dell'eccezione, Laterza, Bari, 1986.

SIERRA, Vicente, Historia de la Argentina, edic. Garriga S.A., Buenos Aires, 1962.

SMELSER, Neil J., Il comportamento collettivo, Vallechi, Firenze, 1968. 
SNOW, Peter G., Radicalismo Argentino, Edit. Francisco De Aguirre, Buenos Aires, 1972. TAU ANZOATEGUI, Víctor, Las ideas jurídicas en la Argentina (siglos XIX-XX), ed. Perrot, Cap. II, Buenos Aires, 1977.

- "Prólogo" en Perez Ghilou, D., Facundo Zuviría y la Organización Nacional- Su nacionalismo liberal, Depalma, Buenos Aires, 1988.

TEDESCO, Juan C., Educación y Sociedad en la Argentina (1880-1900), Pannedille, Buenos Aires, 1970.

TERNAVASIO, Marcela, "La visibilidad del consenso. Representaciones en torno al sufragio en la primera mitad del siglo XIX", en SABATO, H.-LETTIERI, A. (comp,), La vida política en la Argentina del siglo XIX-Armas, votos y voces, FCE, Ciudad de Buenos Aires, 2003a.

-"Hacia un régimen de unanimidad. Política y elecciones en Buenos Aires, 1828-1850", en SABATO, Hilda (coord.), Ciudadanía política y formación de las nacionesPerspectivas históricas de América Latina, FCE, México, $2003 \mathrm{~b}$.

TOKATLIAN, Juan Gabriel, "Ninguna caída es para siempre", Diario "Clarín", Ciudad Autónoma de Buenos Aires, 14/11/05.

TOURAINE, Alain, Critique de la modernité, Fayard, Paris, 1993.

- ¿Qué es la Democracia?, FCE, Montevideo, 1995.

UNIVERSIDAD NACIONAL DE LA PLATA, Reforma Constitucional de 1860-Textos y documentos fundamentales, Facultad de Humanidades y Ciencias de la Educación, La Plata, 1961.

VANOSSI, Jorge R.A., La influencia de José Benjamín Gorostiaga en la Constitución Argentina y en su Jurisprudencia, edic. Panedille, Buenos Aires, 1970.

-Teoría Constitucional I, Depalma, Buenos Aires, 1975.

WALLERSTEIN Immanuel, El moderno sistema mundial, siglo XXI, México, 1984.

WEBER, Max., Le savant et le politique, Union Générale d'Editions, París, 1963.

- Economía e Società, Comunita, Milano, 1968.

- The Theory of Social and Economic Organization, traduc. M. Henderson y

T. Parsons, The Free Prees, Glencoe, 1947.

ZARINI, Helio J., Historia e Instituciones en la Argentina, edit. Astrea, Buenos Aires, 1981. 
ANEXOS 
ANEXO I 


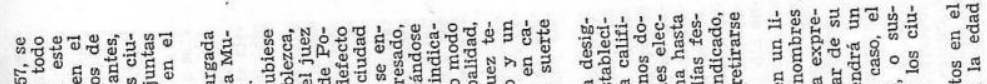

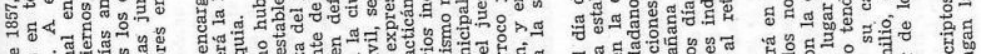

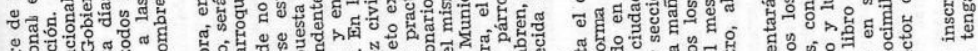

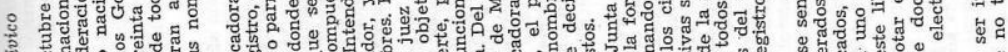

a

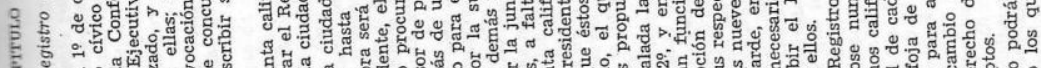

等

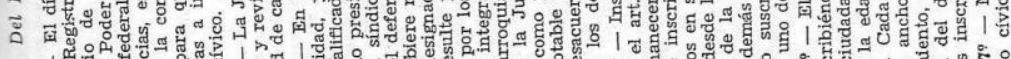

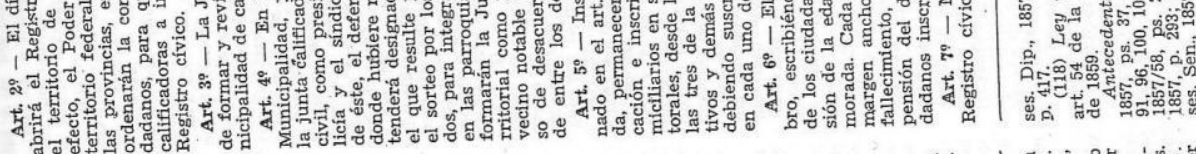

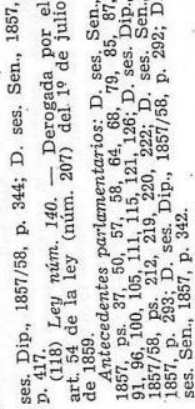

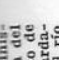

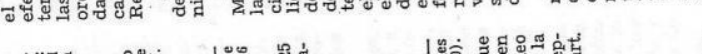

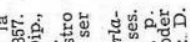

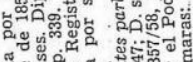

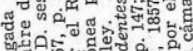

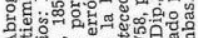

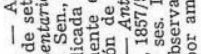

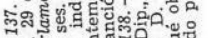

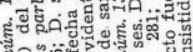

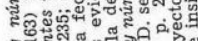

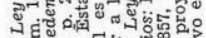

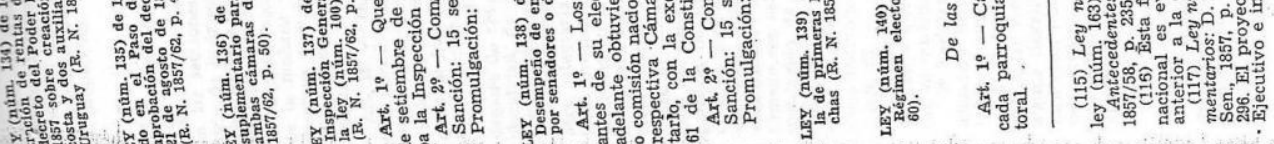

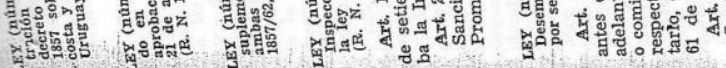

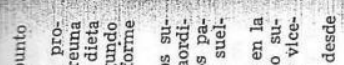

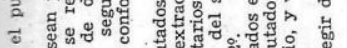

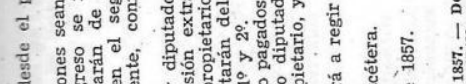

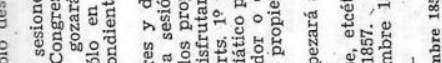

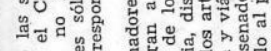
c.

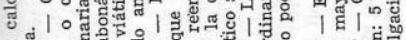

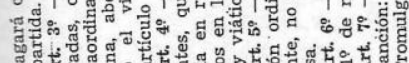

A. 원

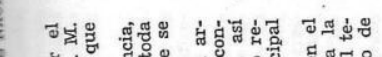

1.

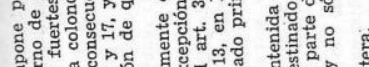

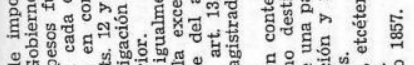

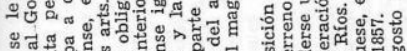

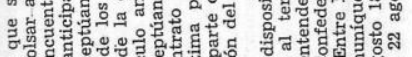
品年

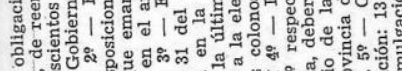

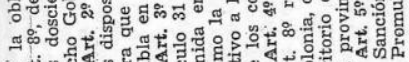

घ.

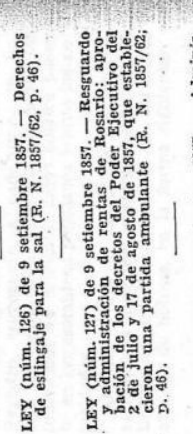

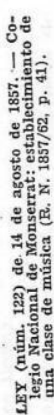

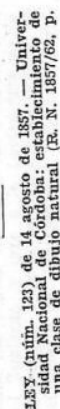

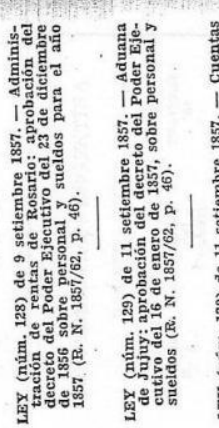

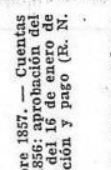

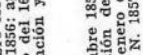

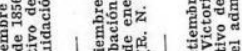

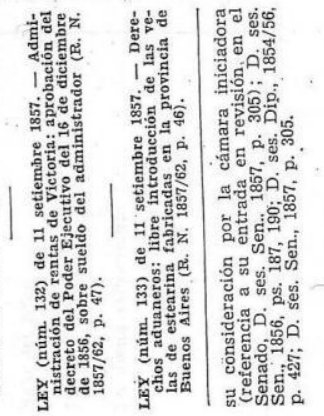

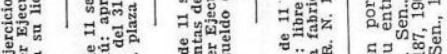

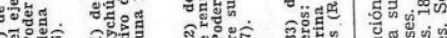

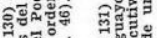
yु

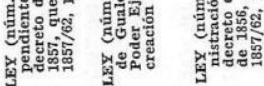

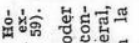

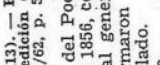
㩆

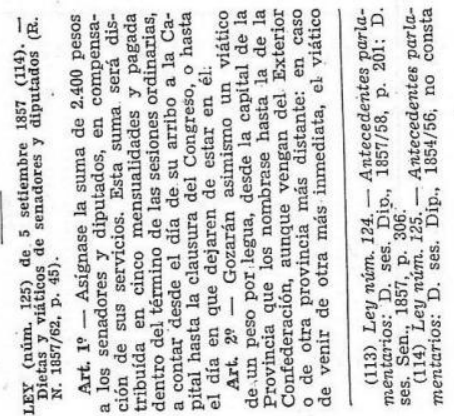
等

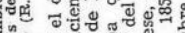
政觉 क g $\mid$ a.s.

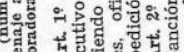

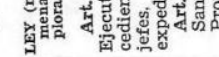




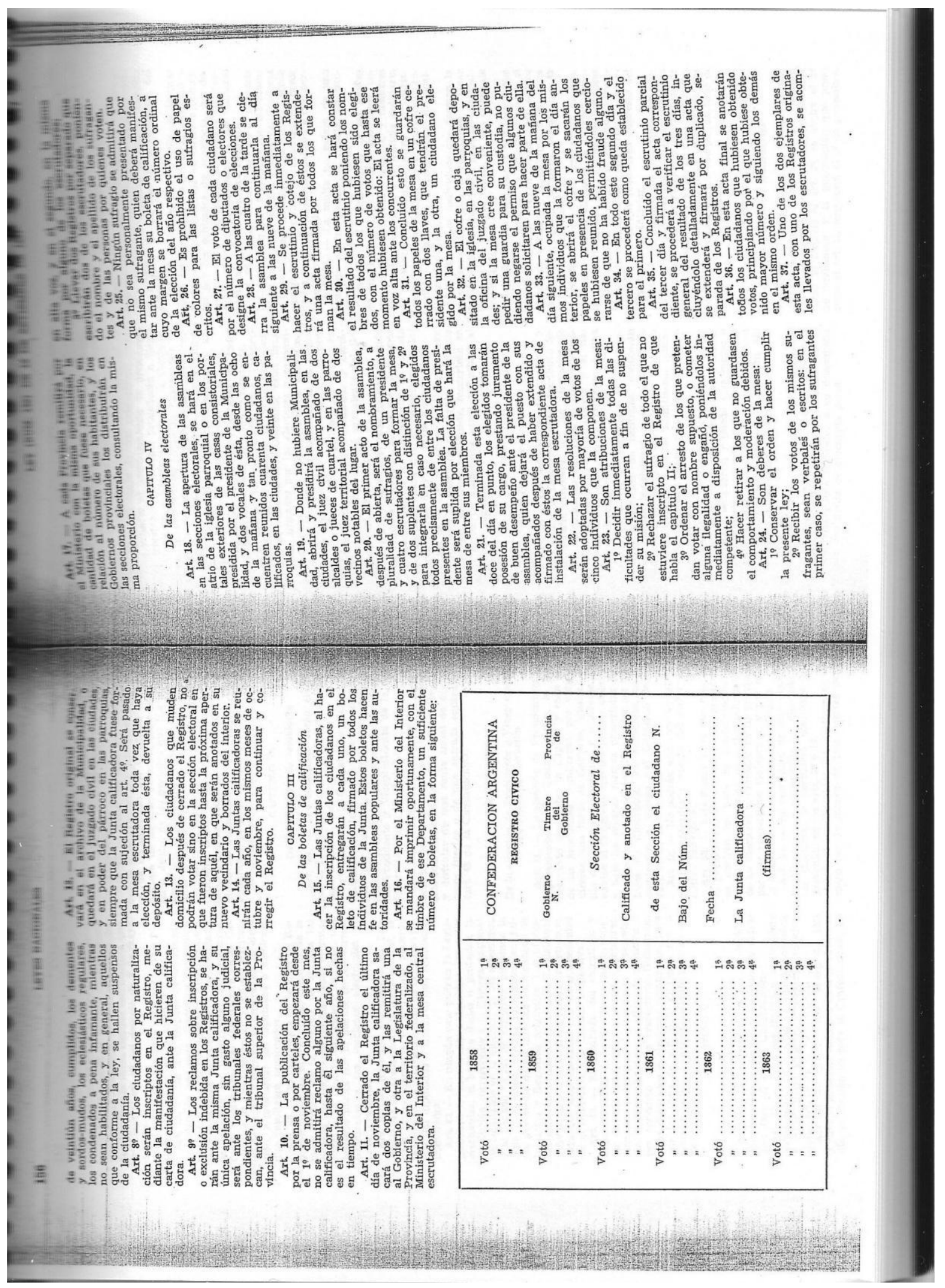




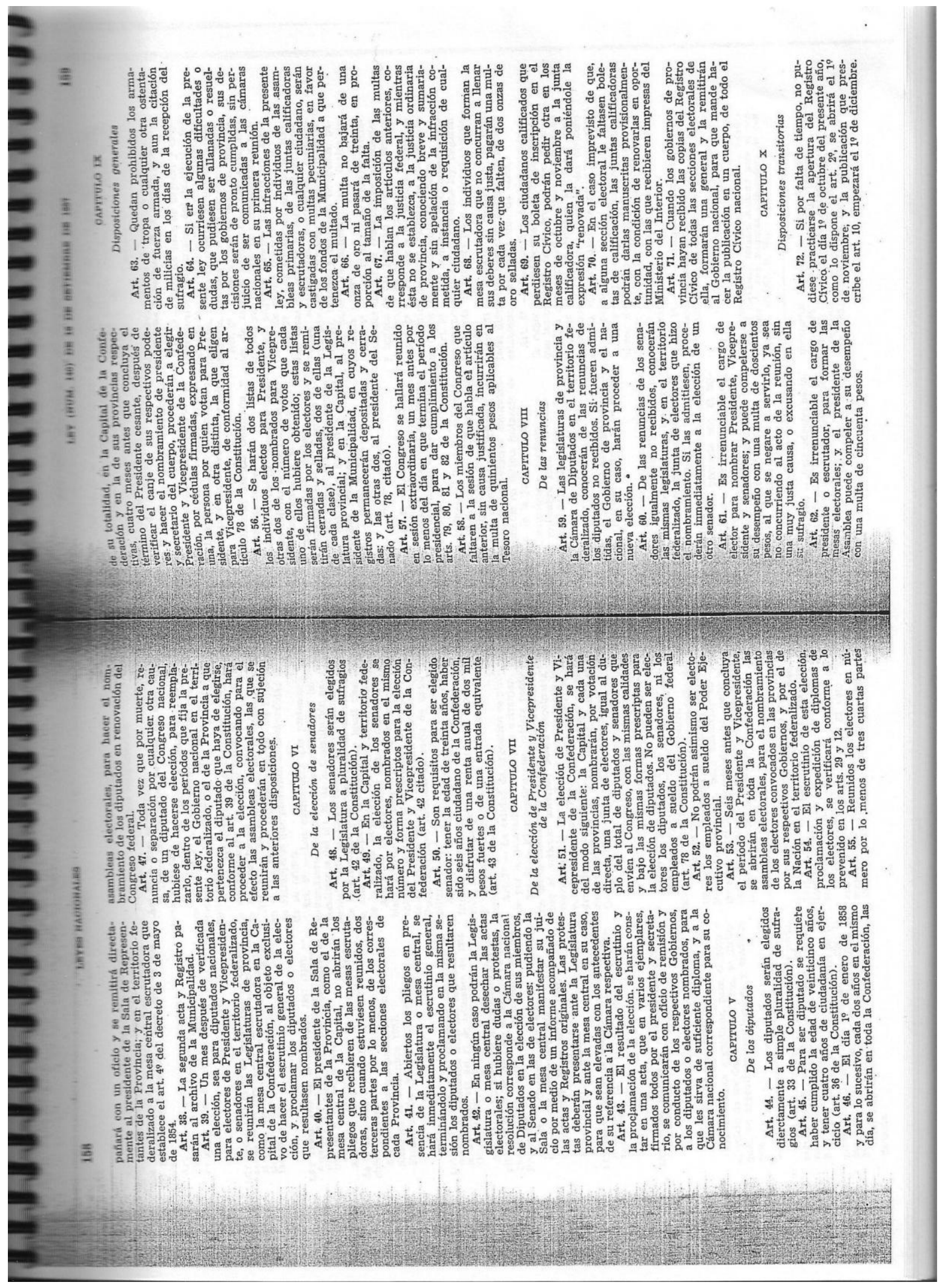




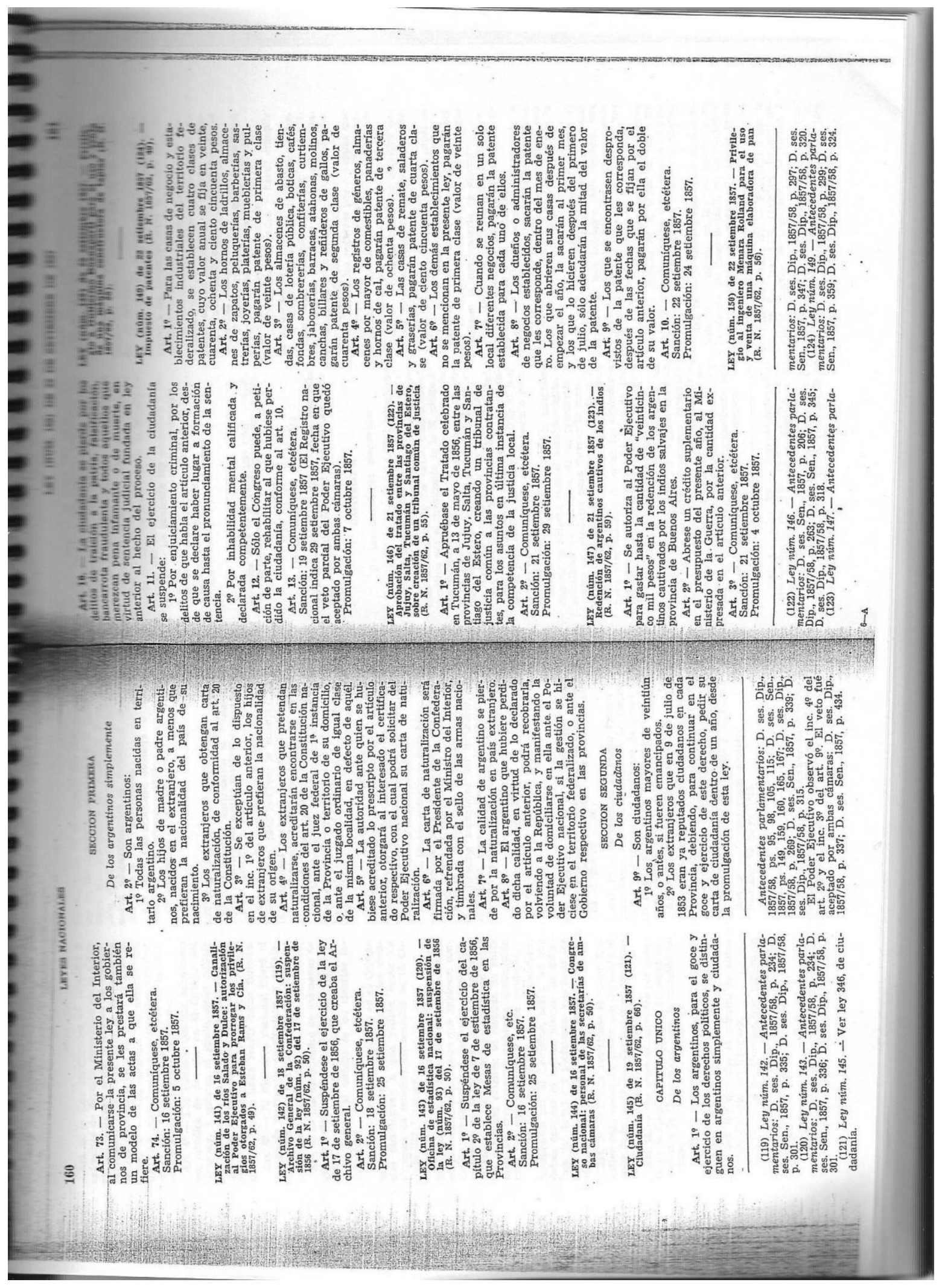




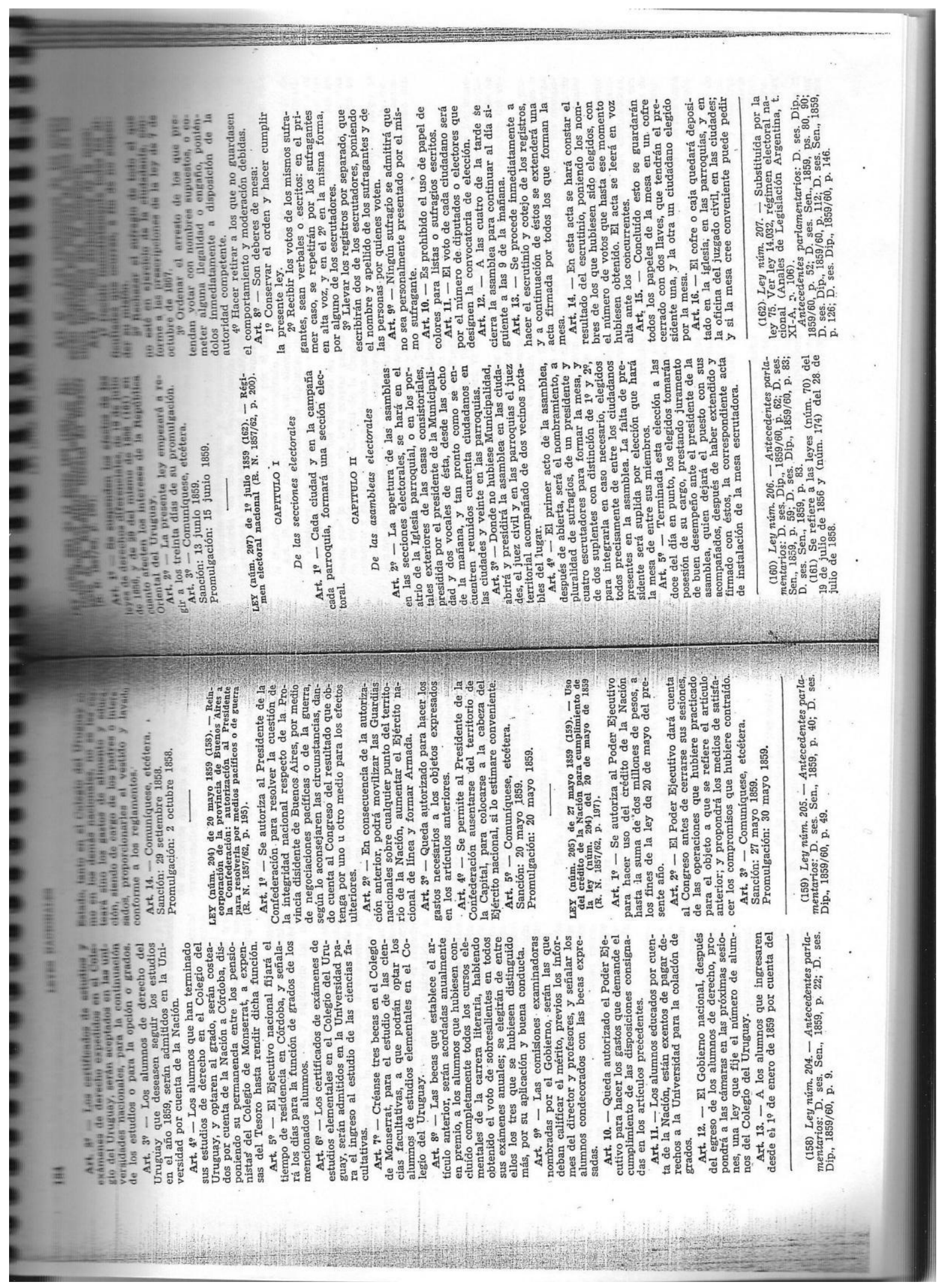




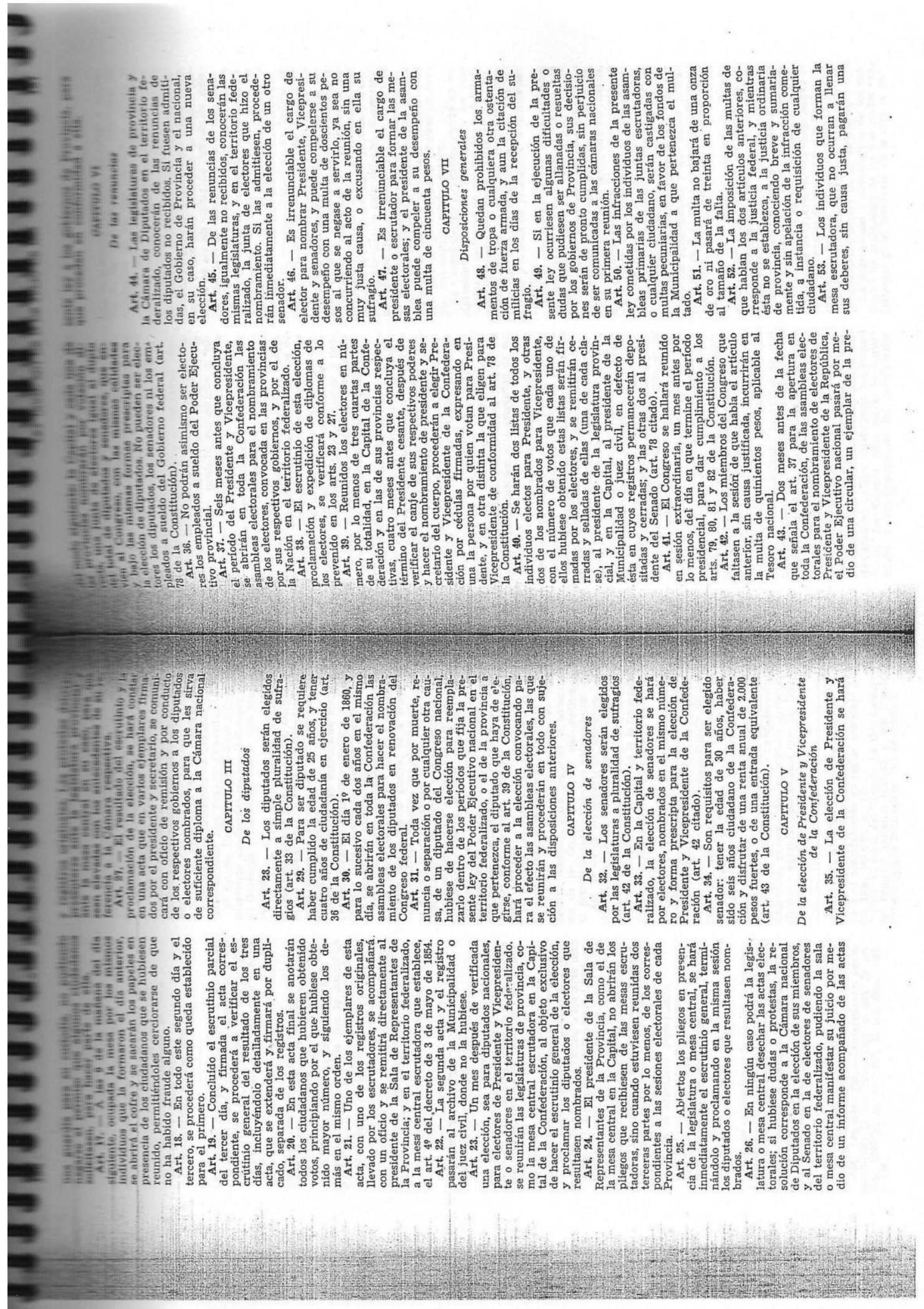




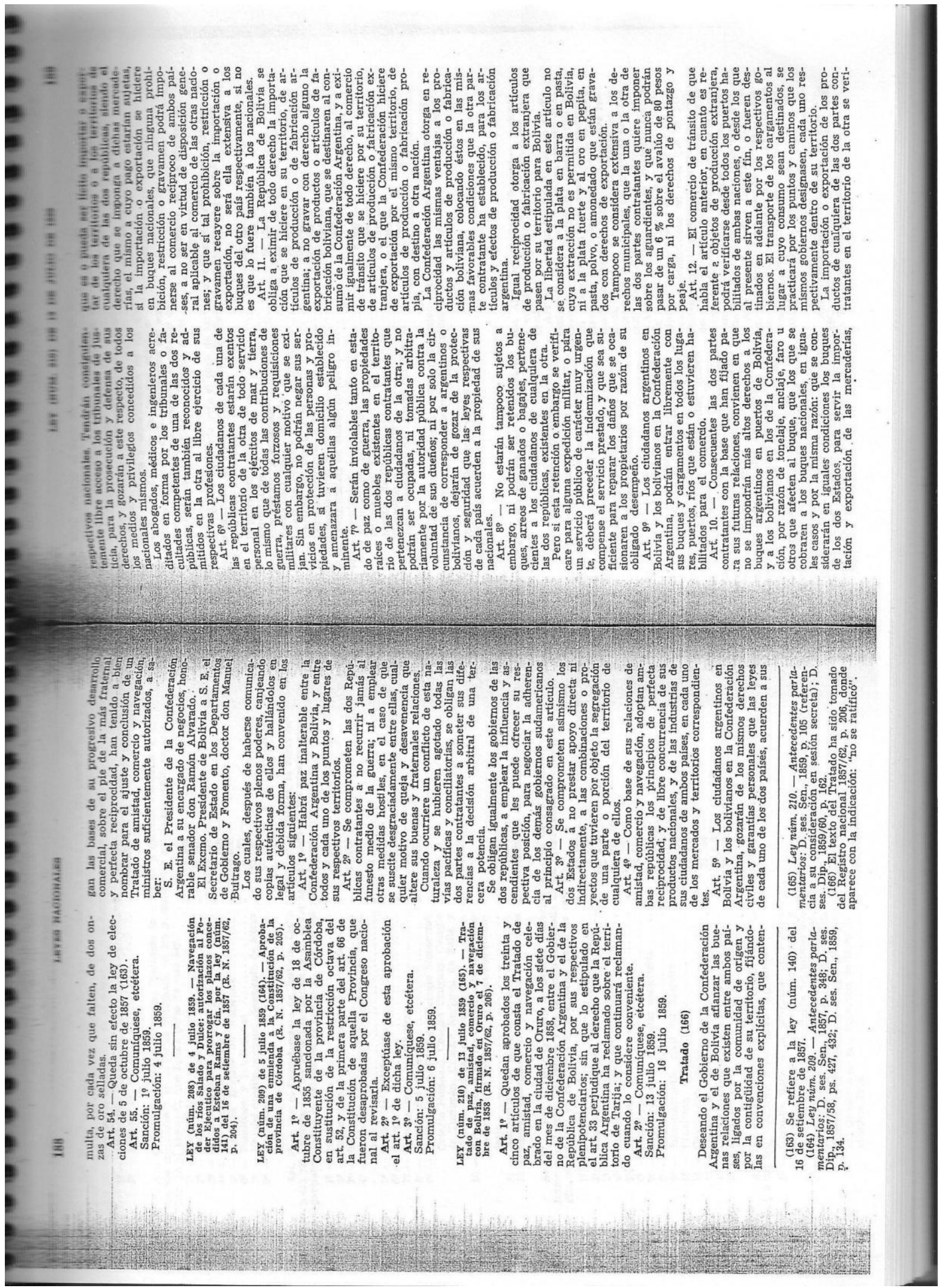




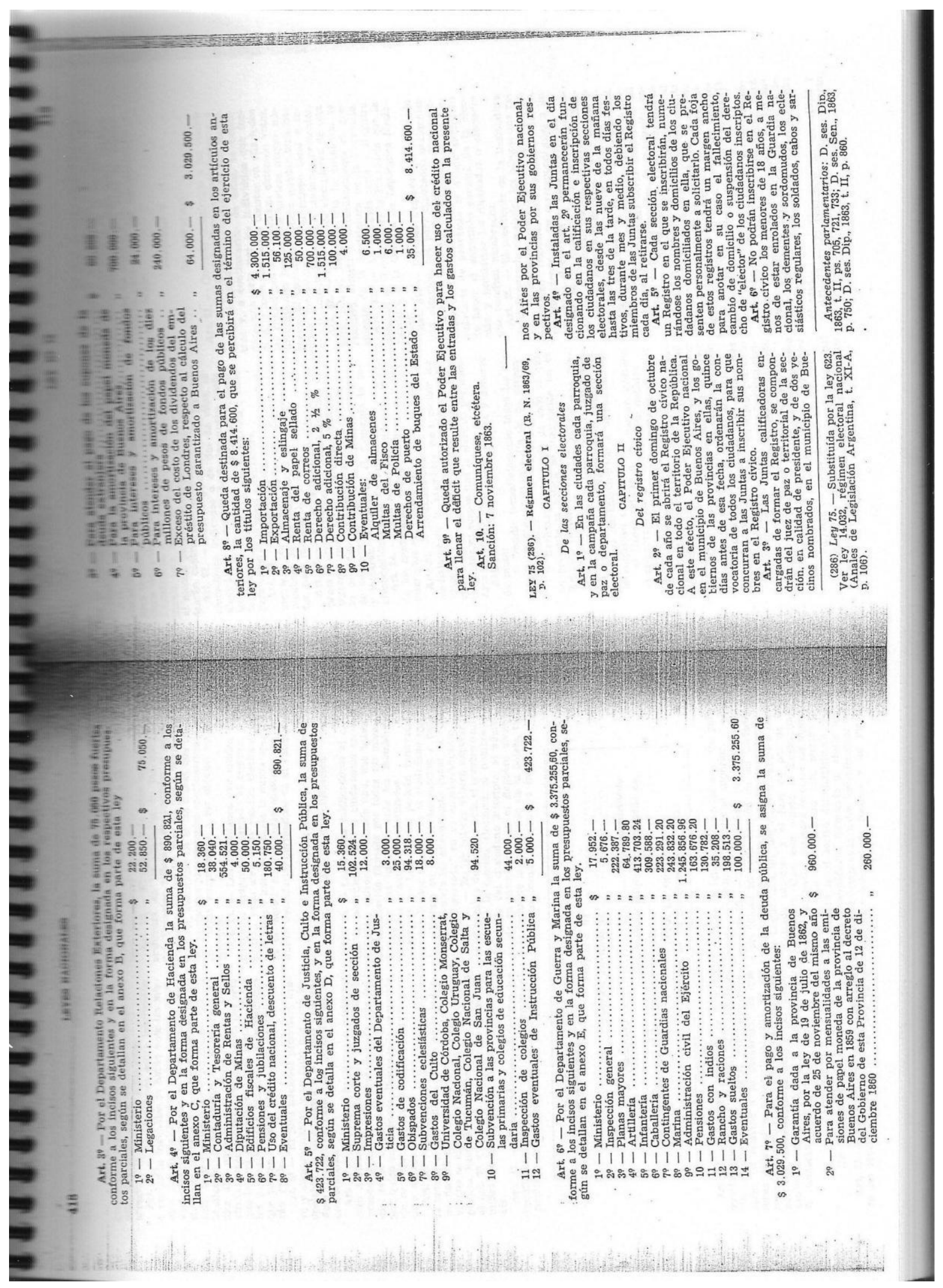




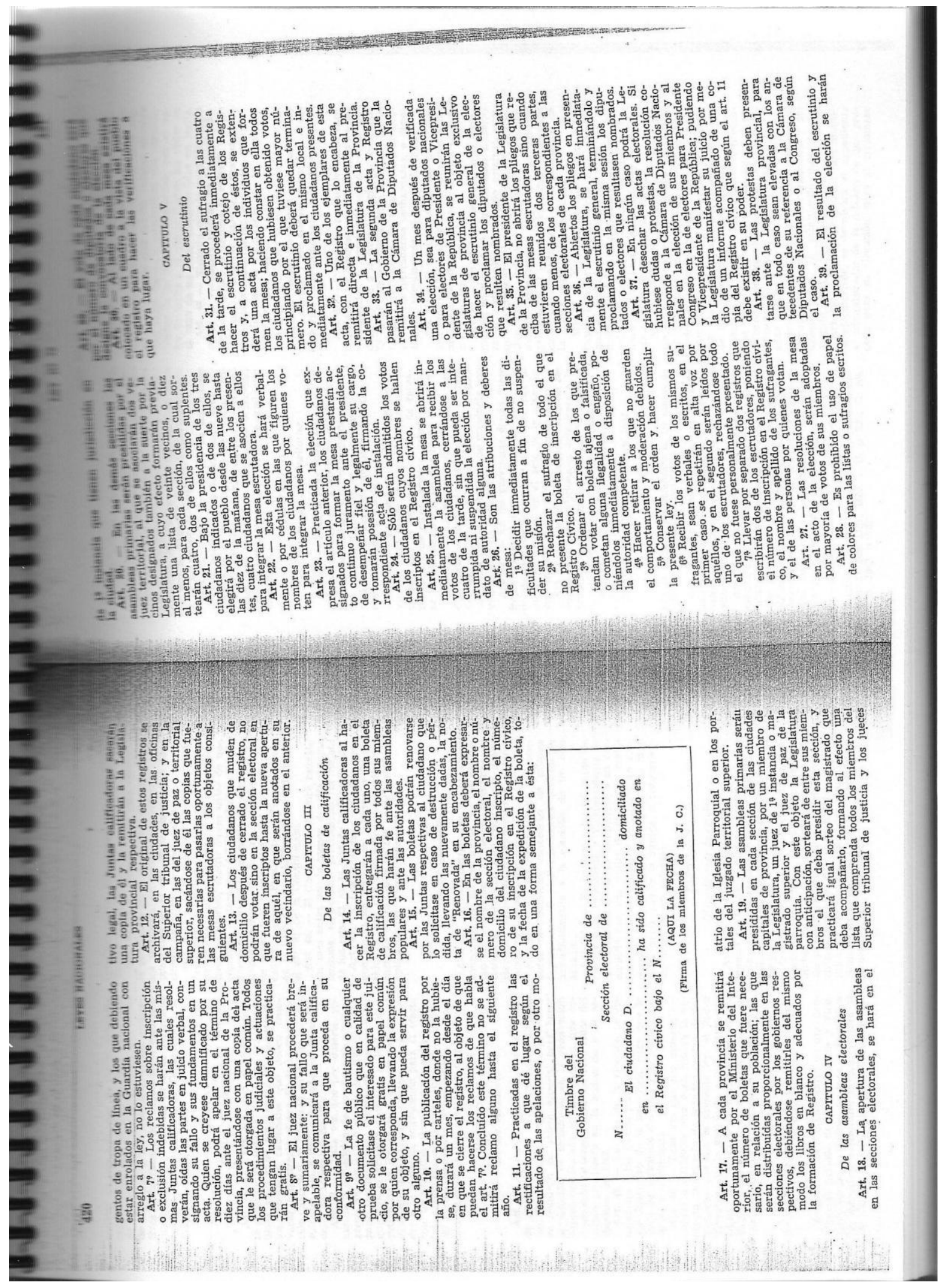




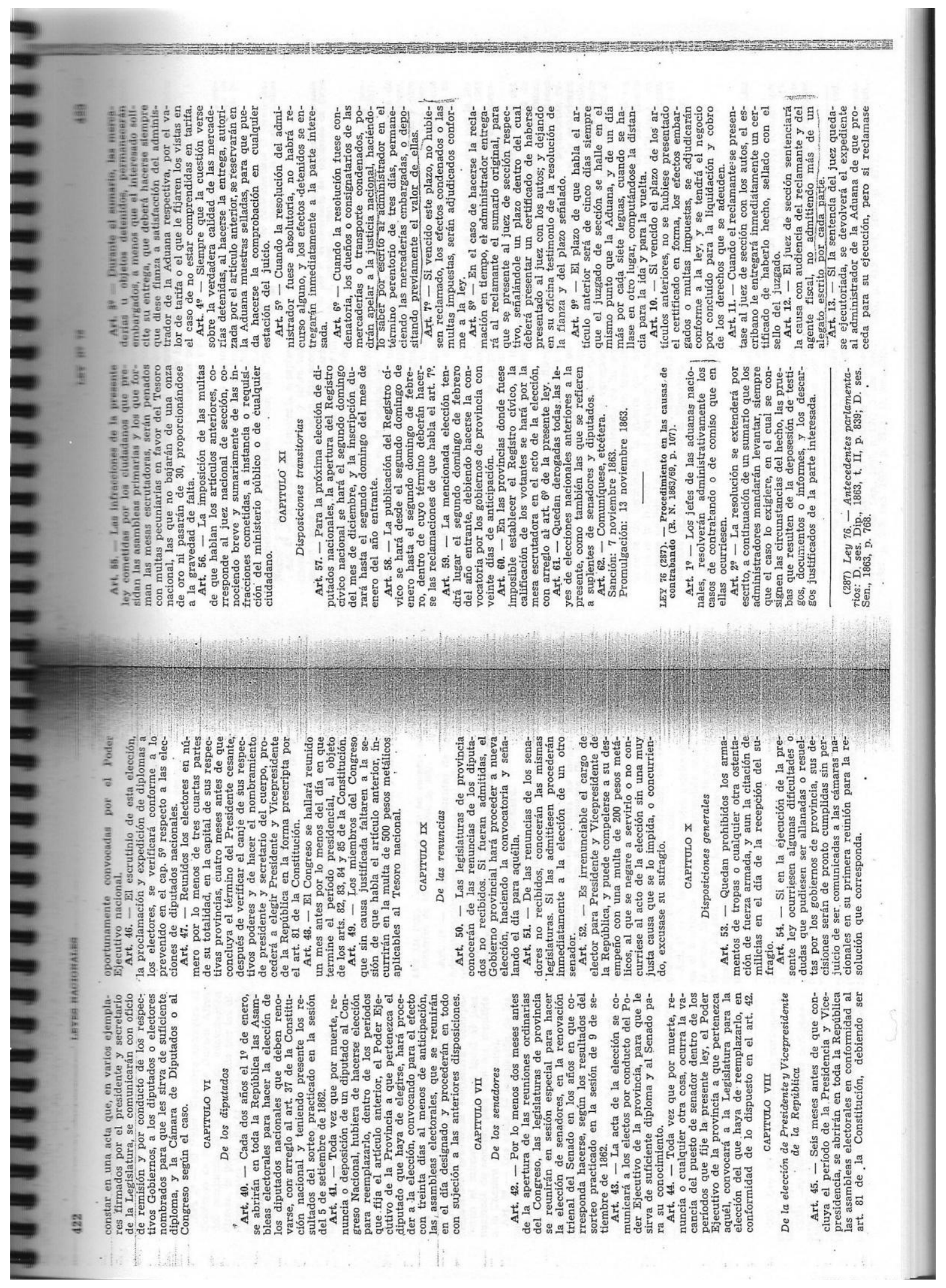




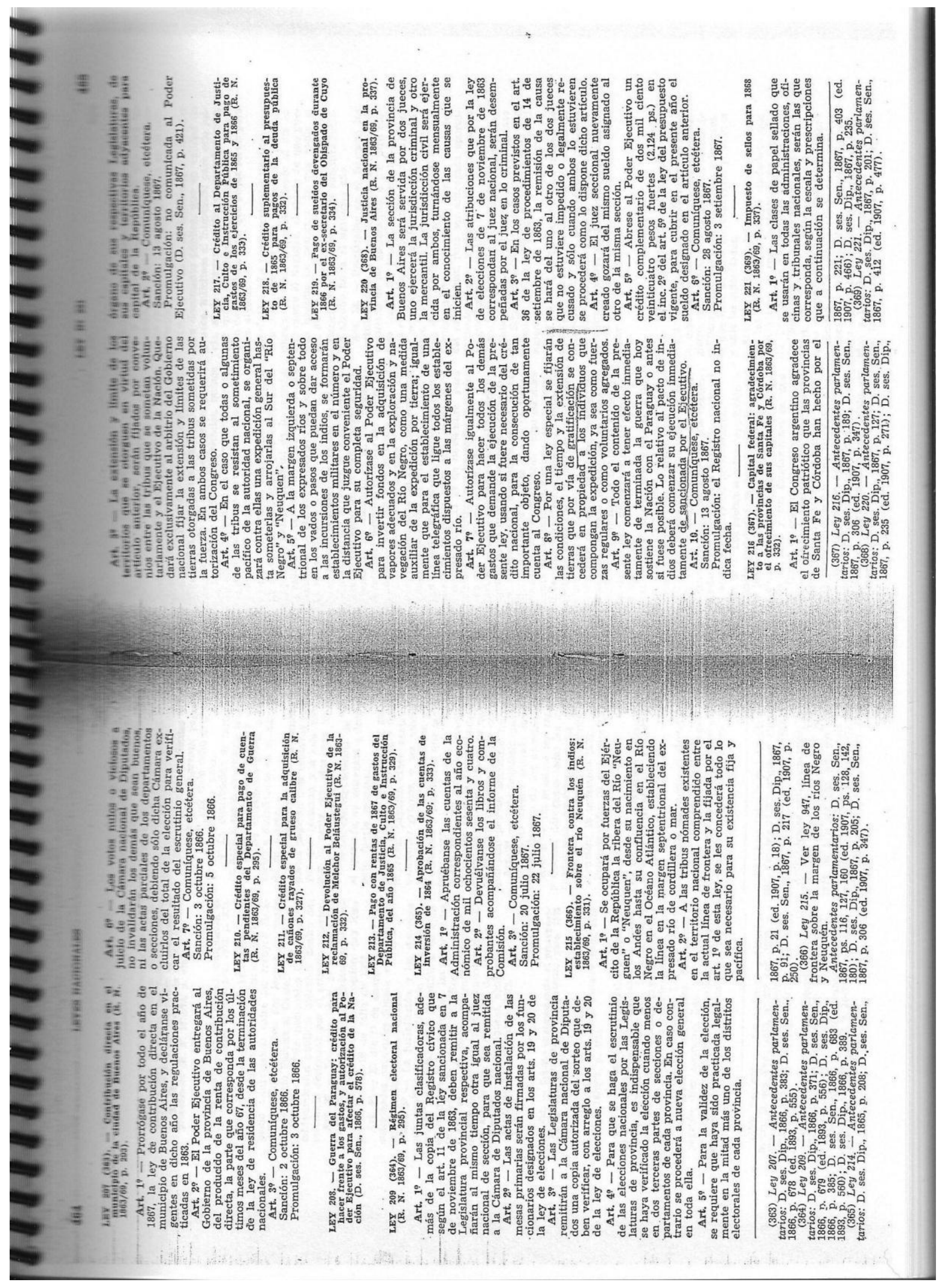




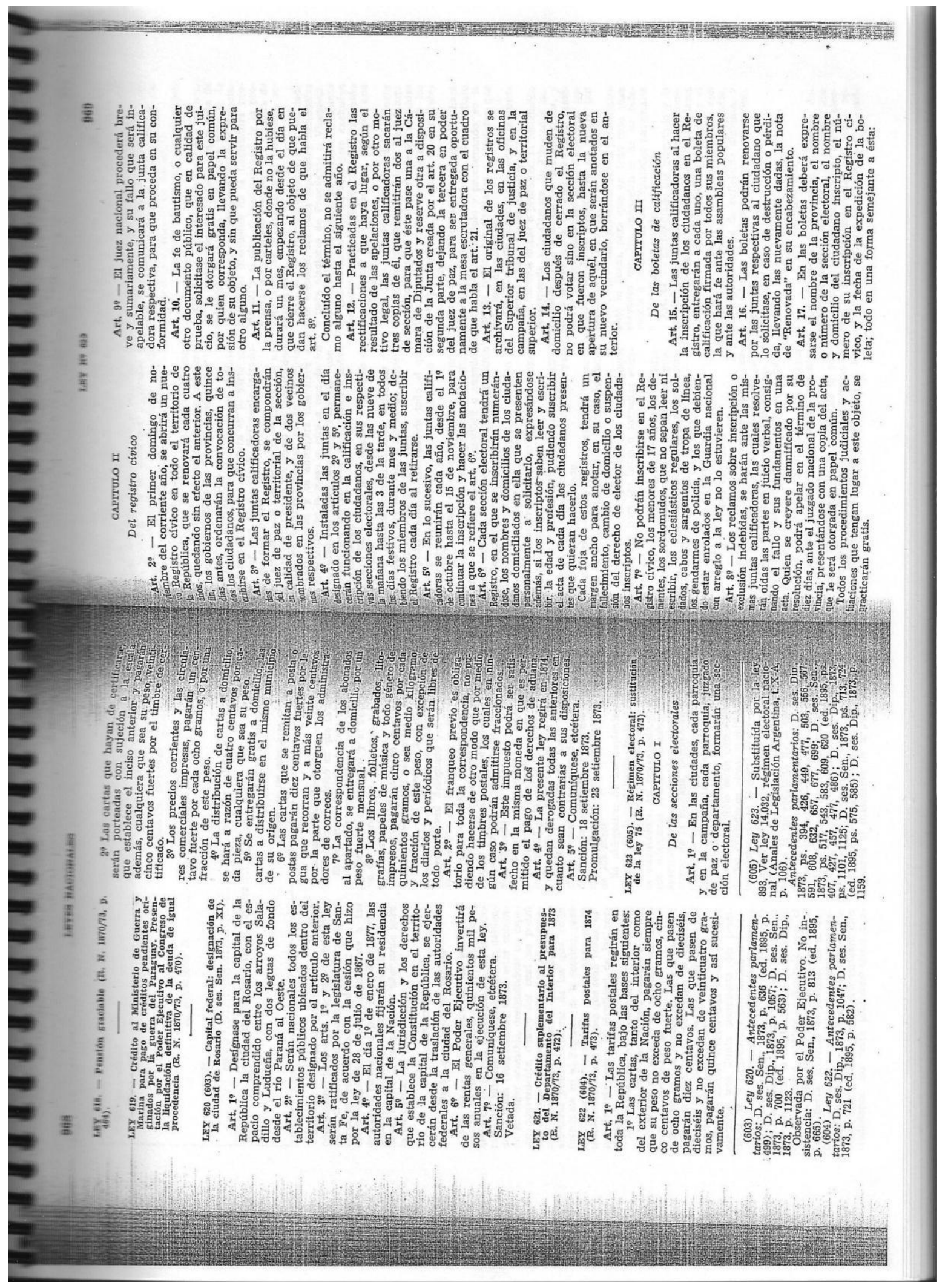




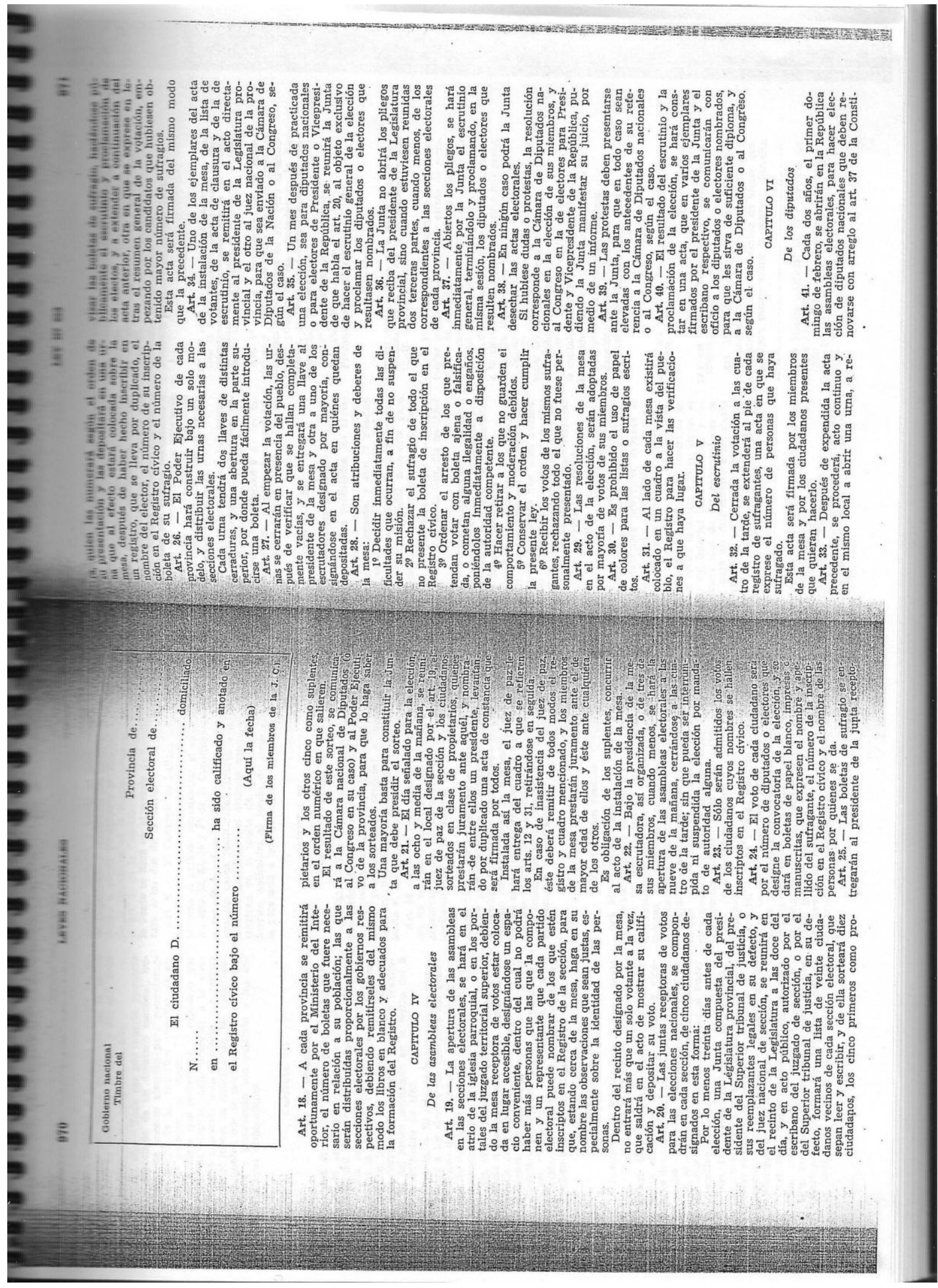




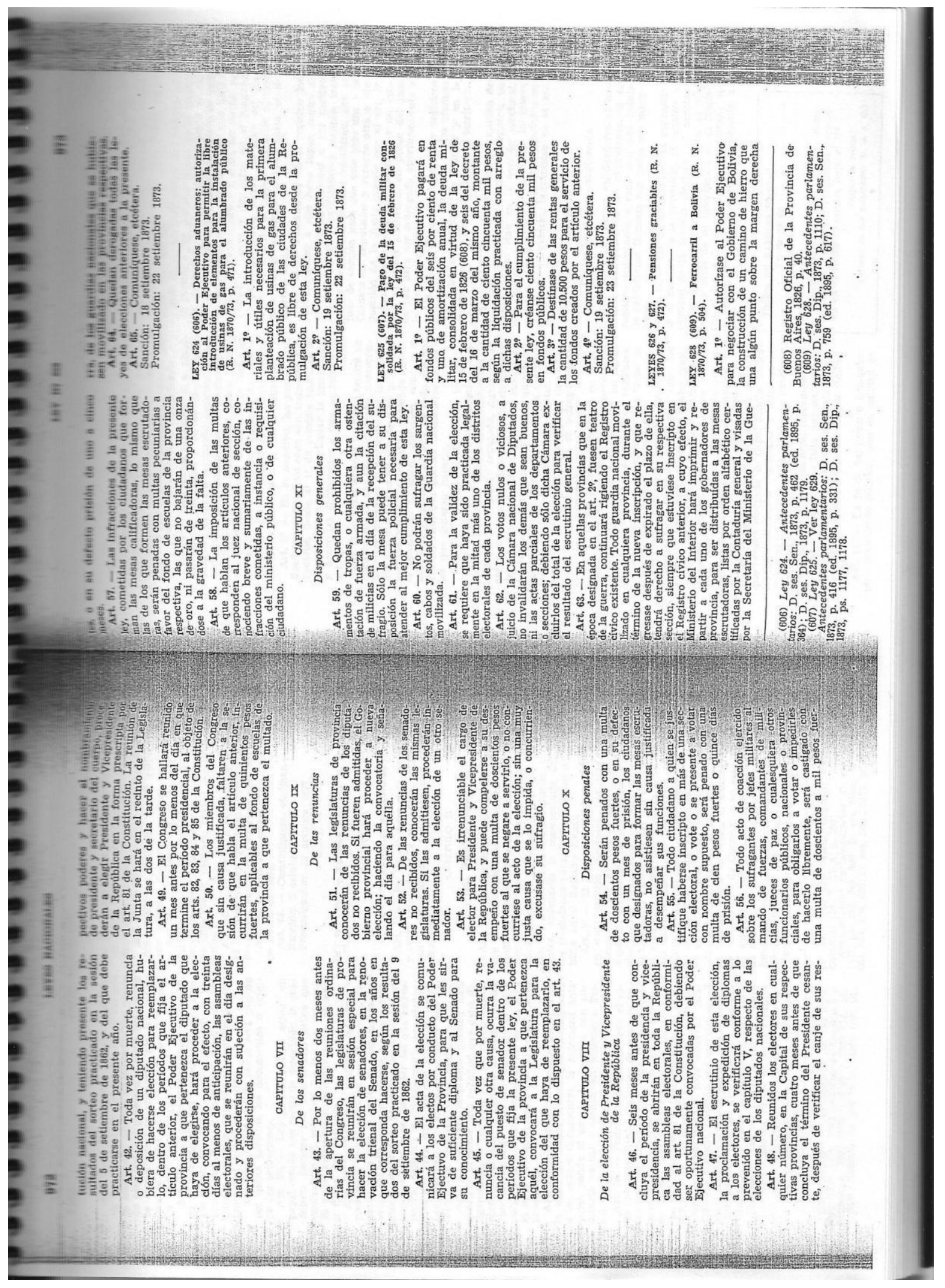




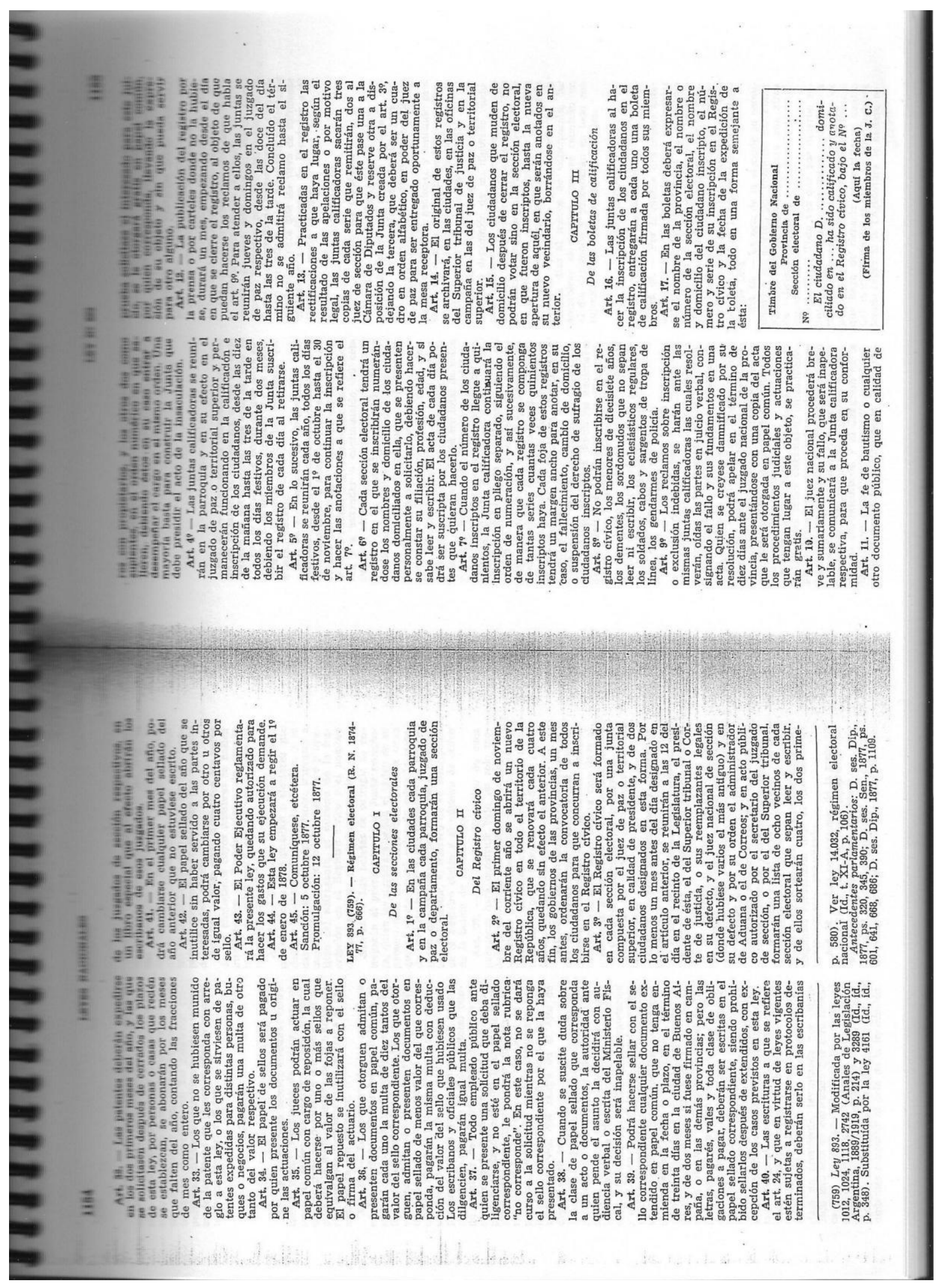




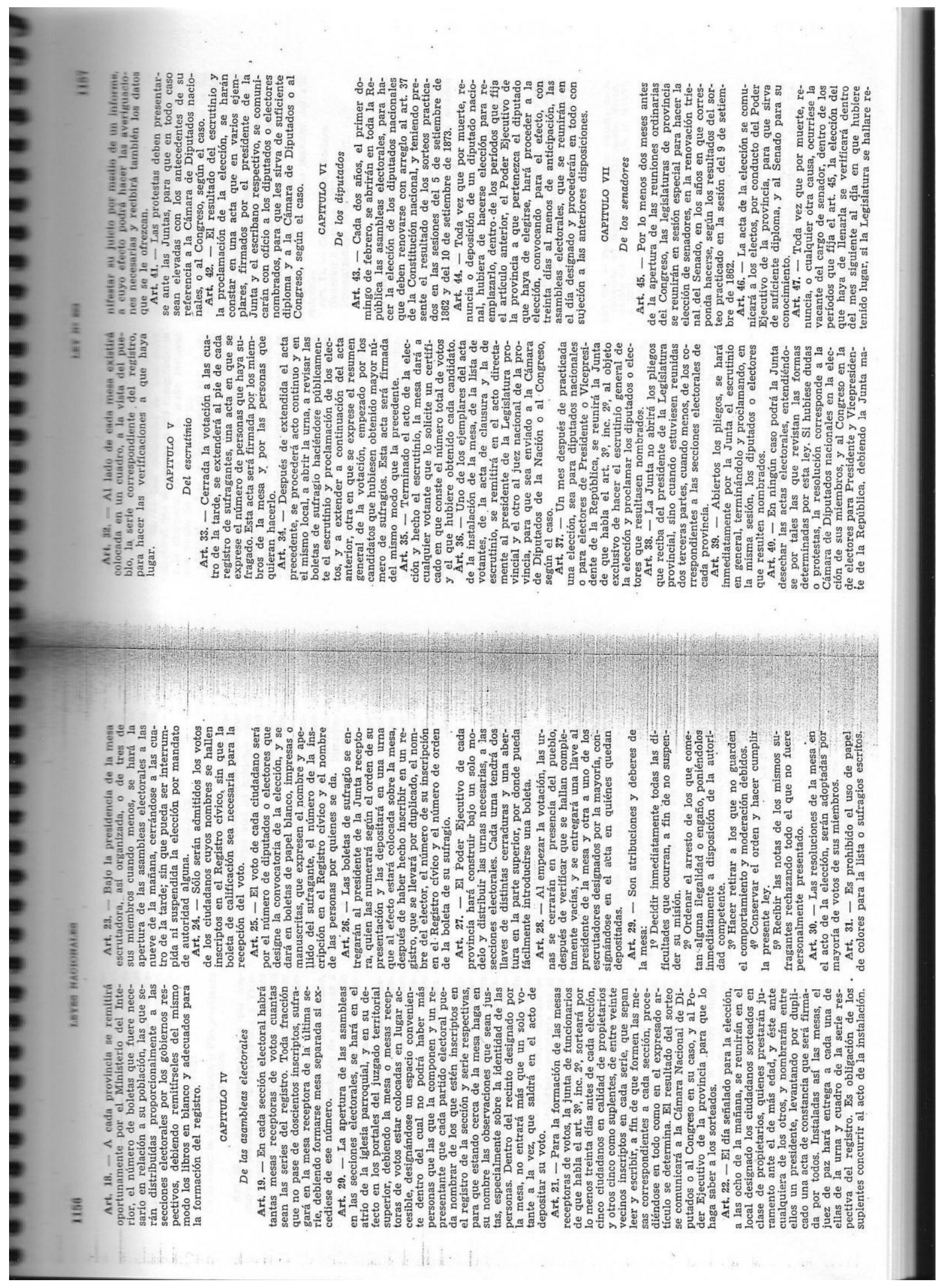




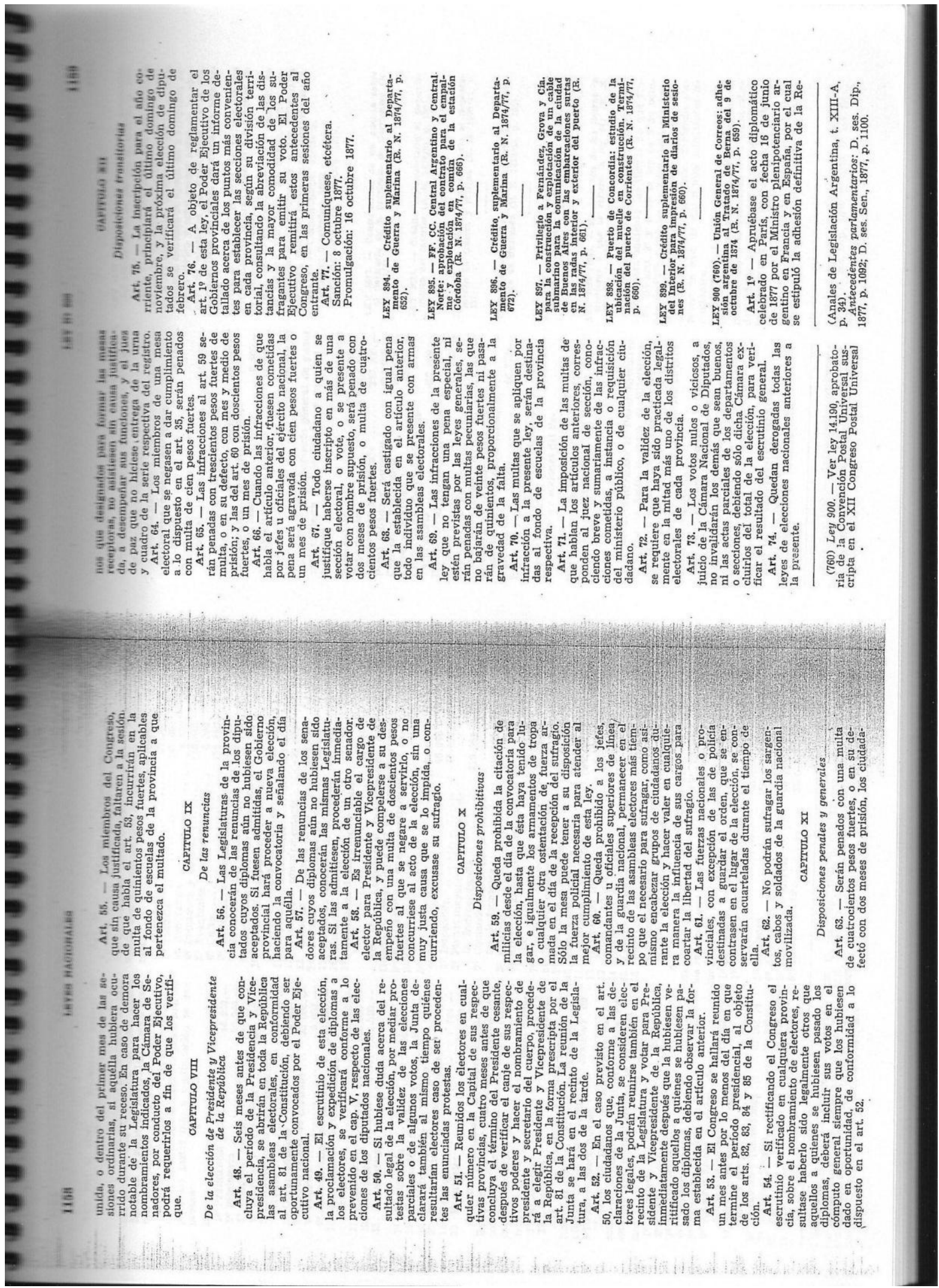




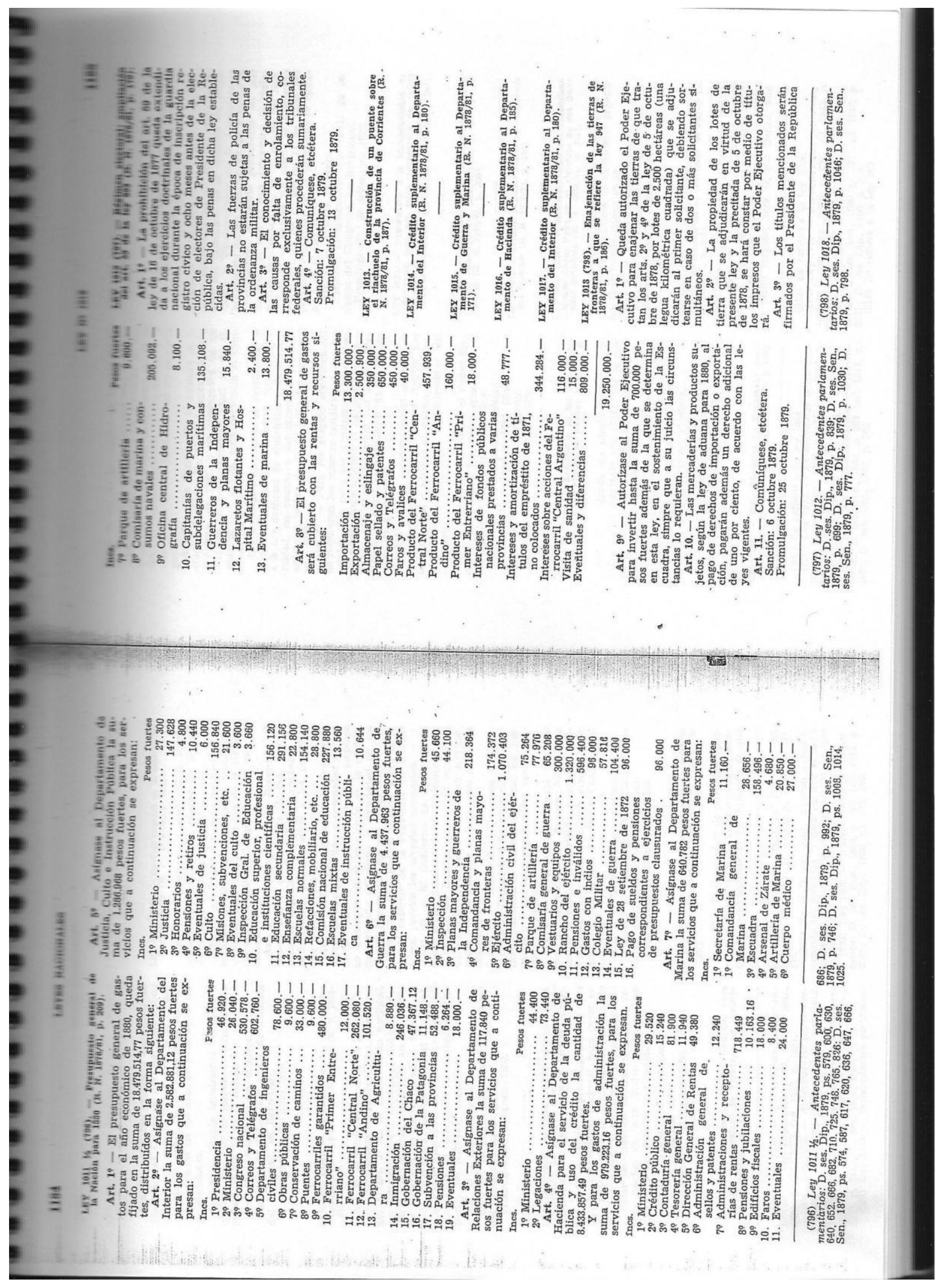




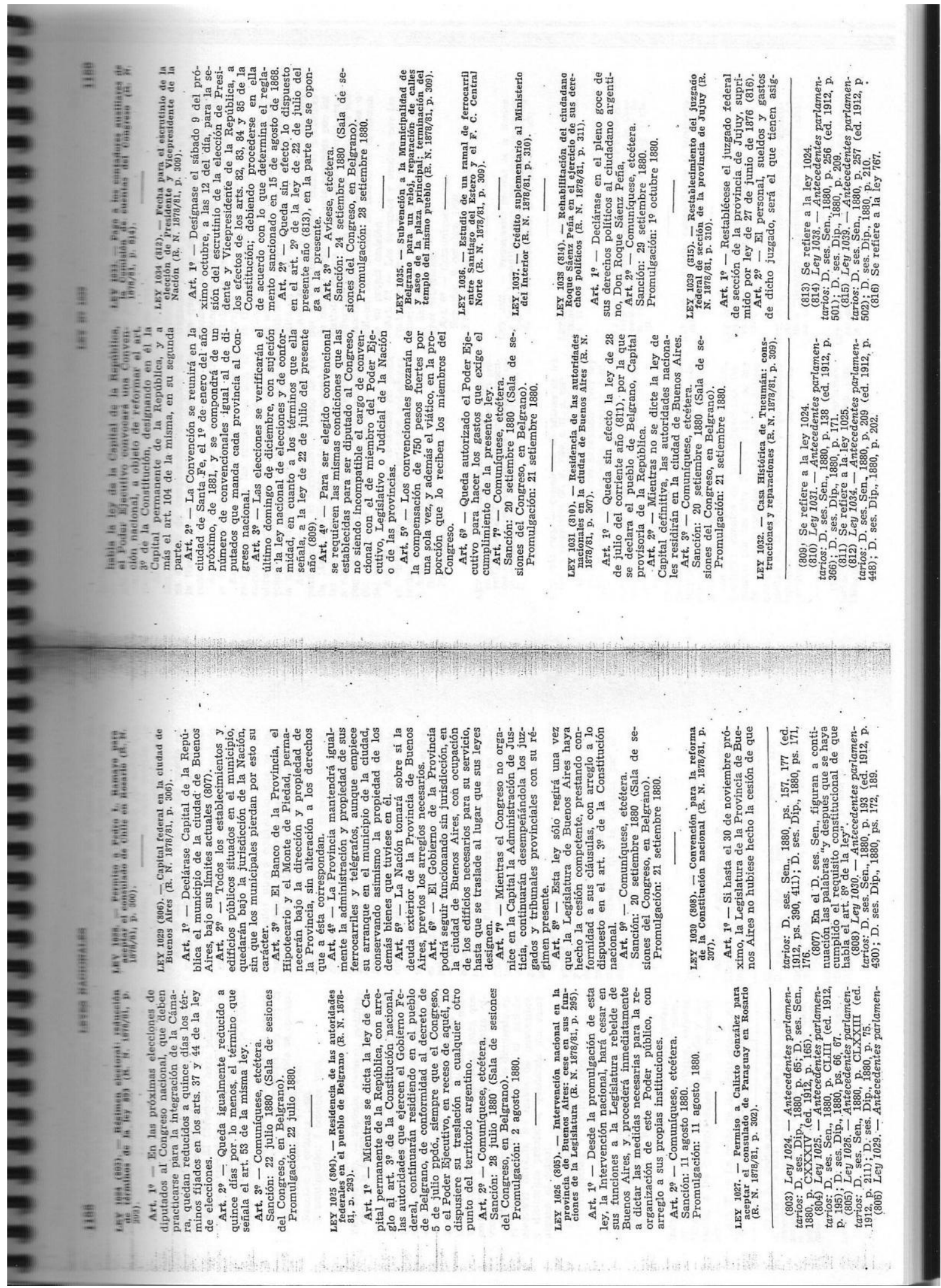




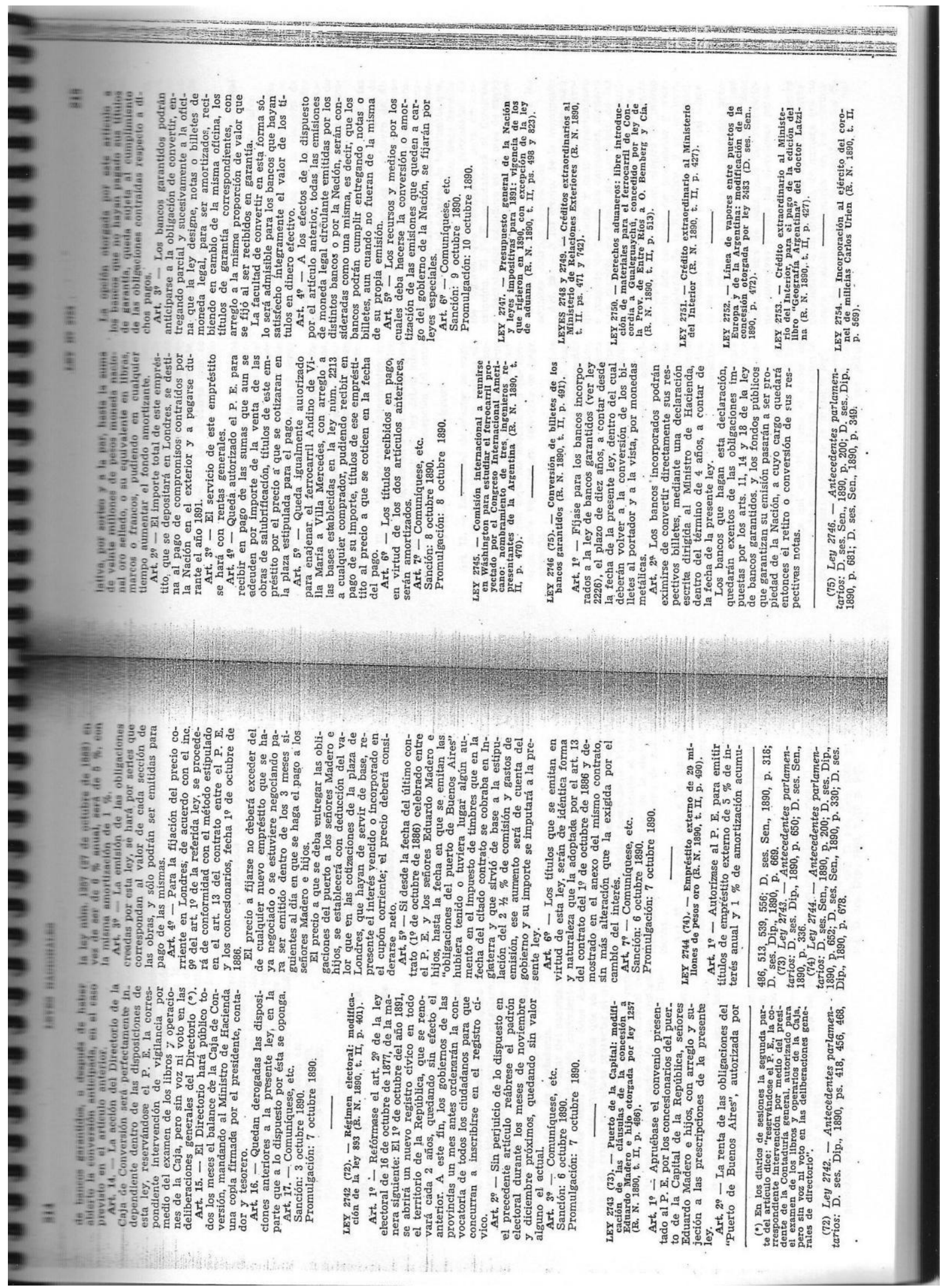




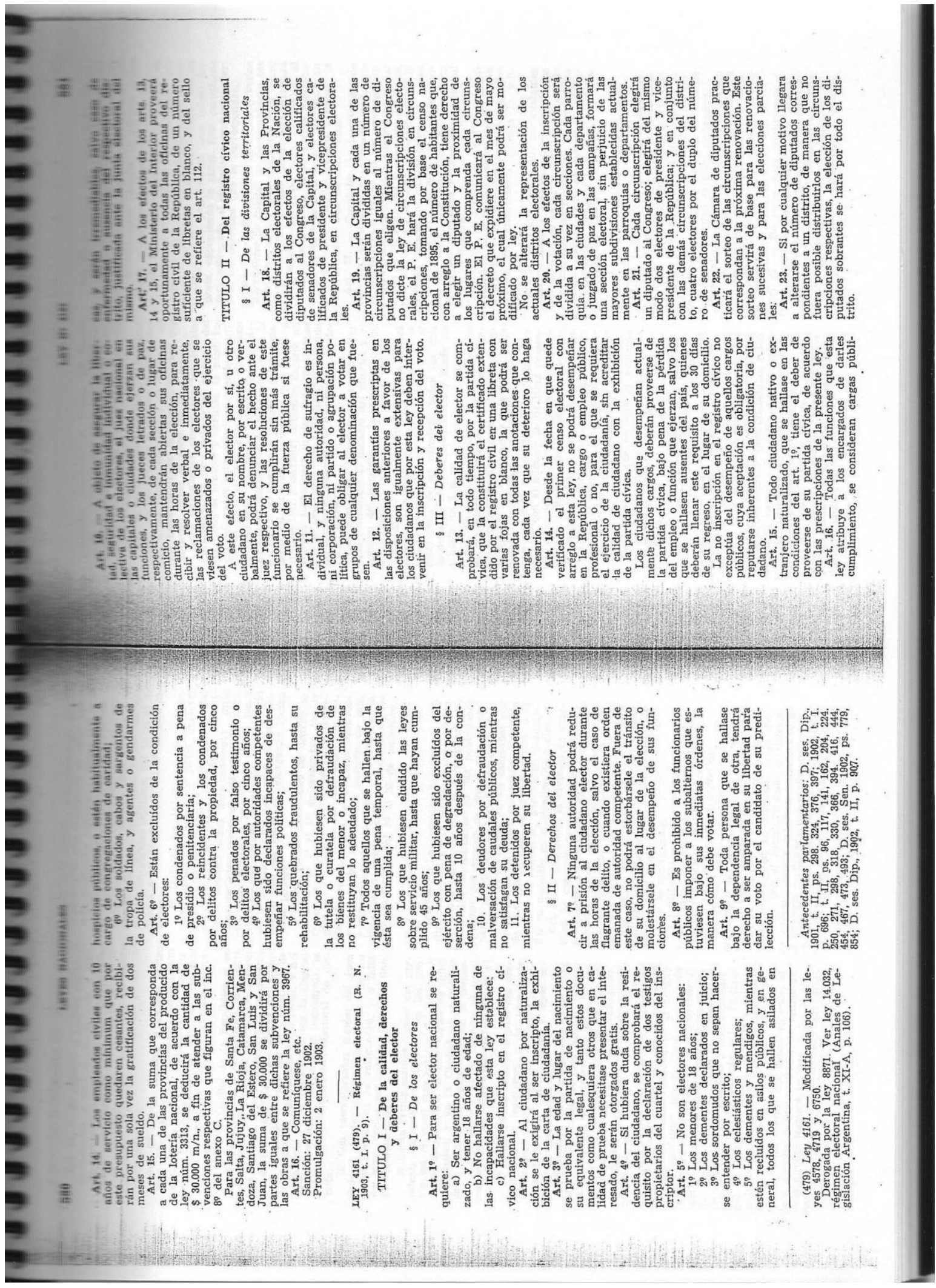




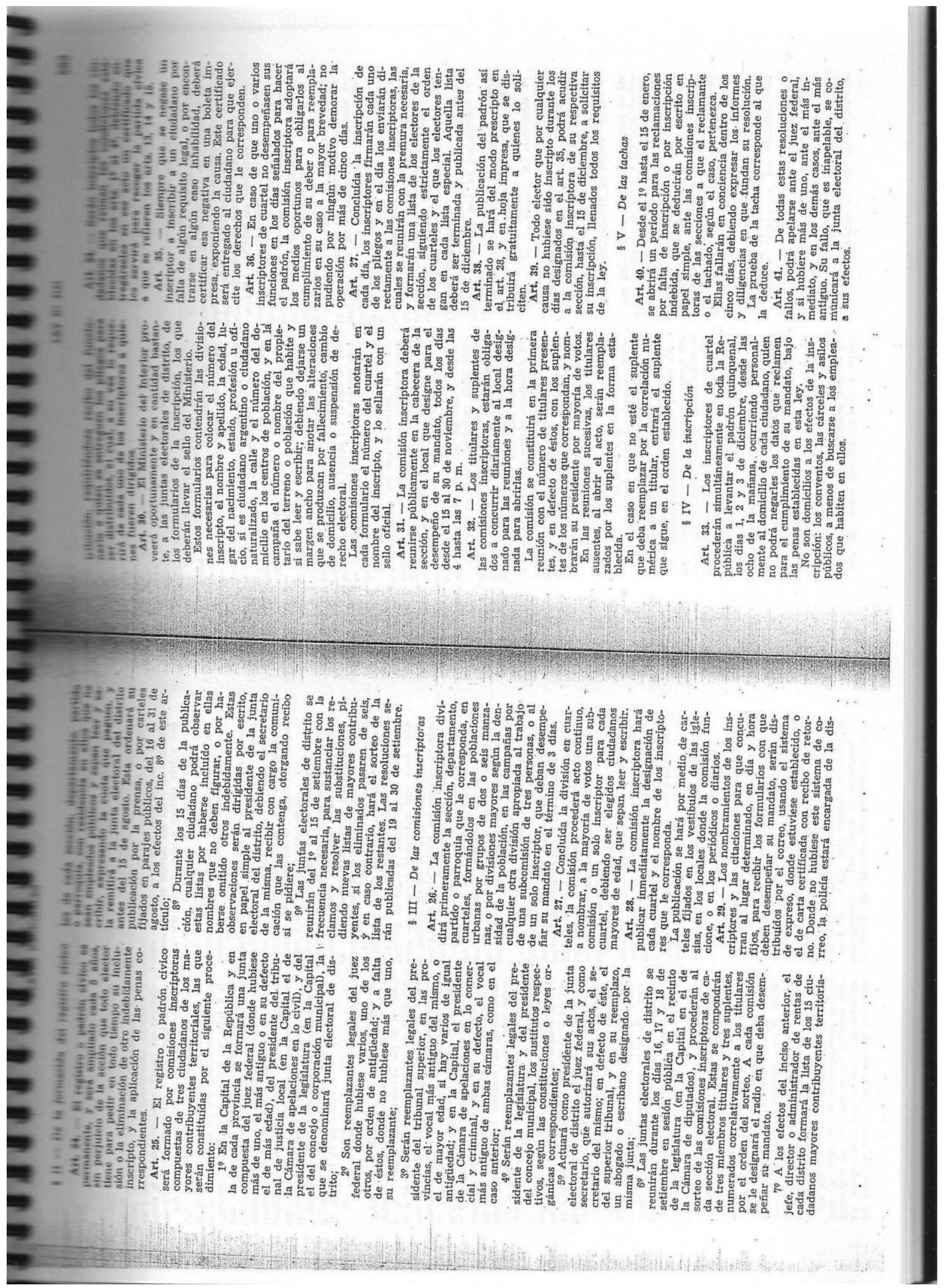




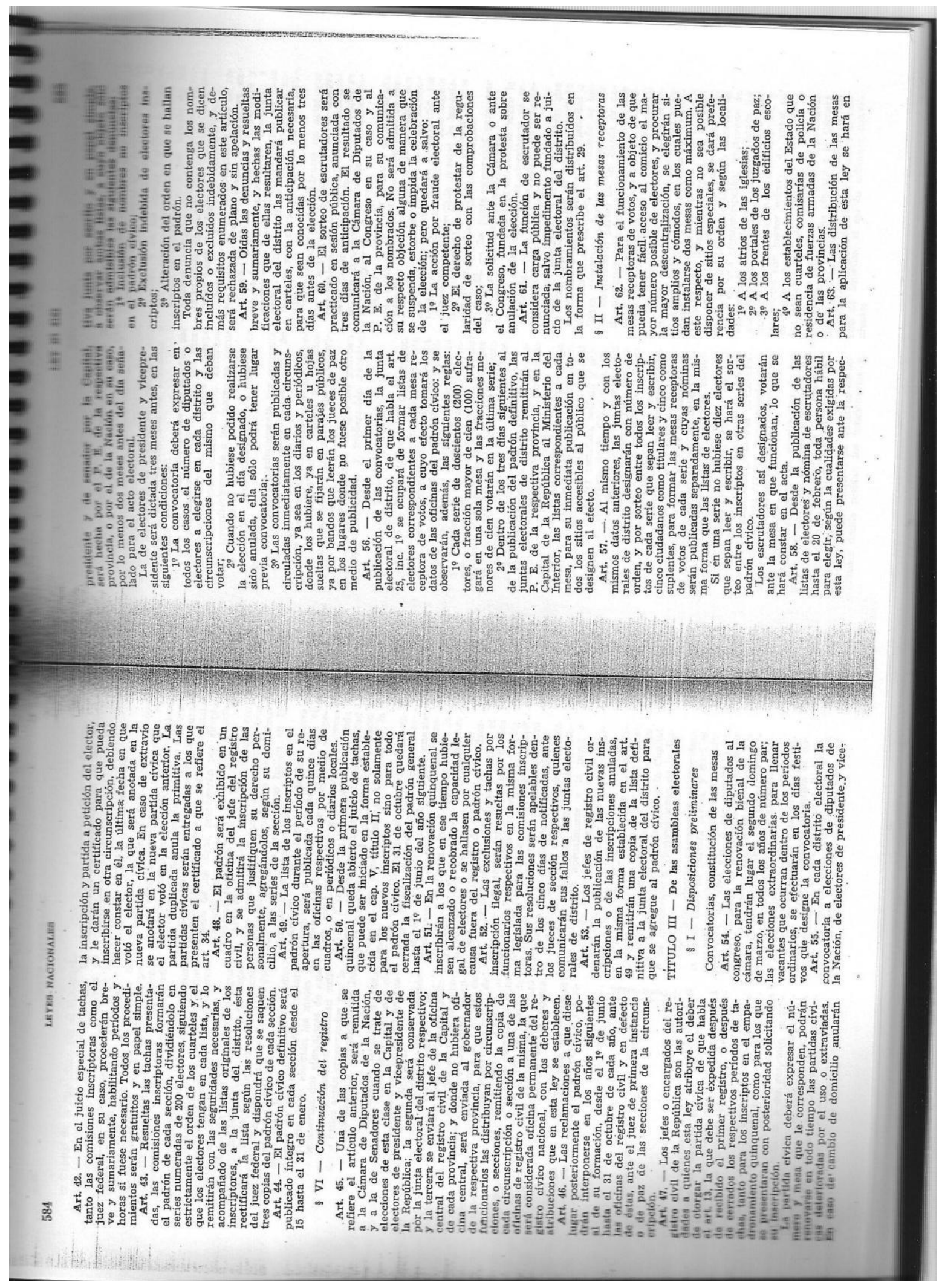




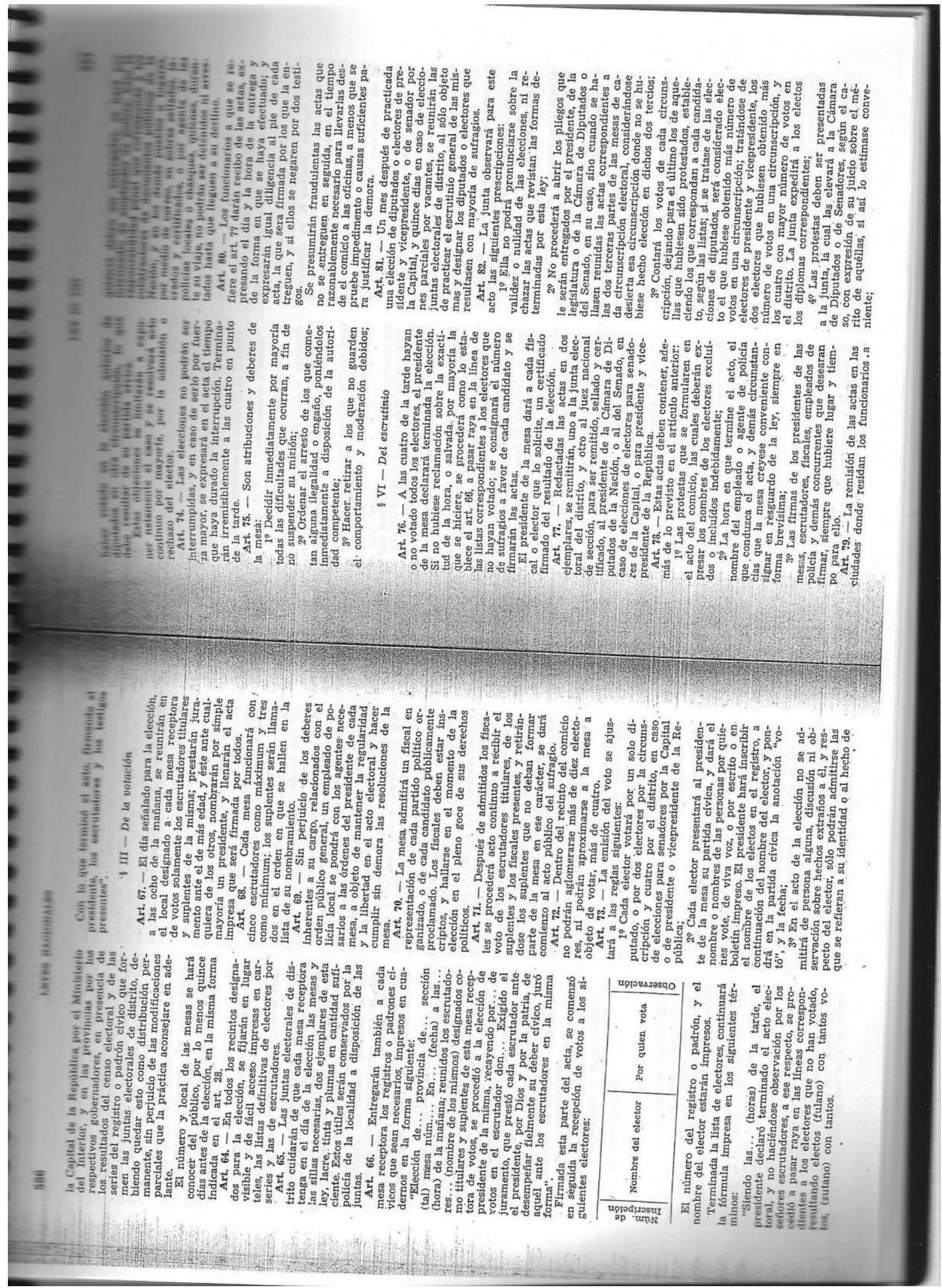




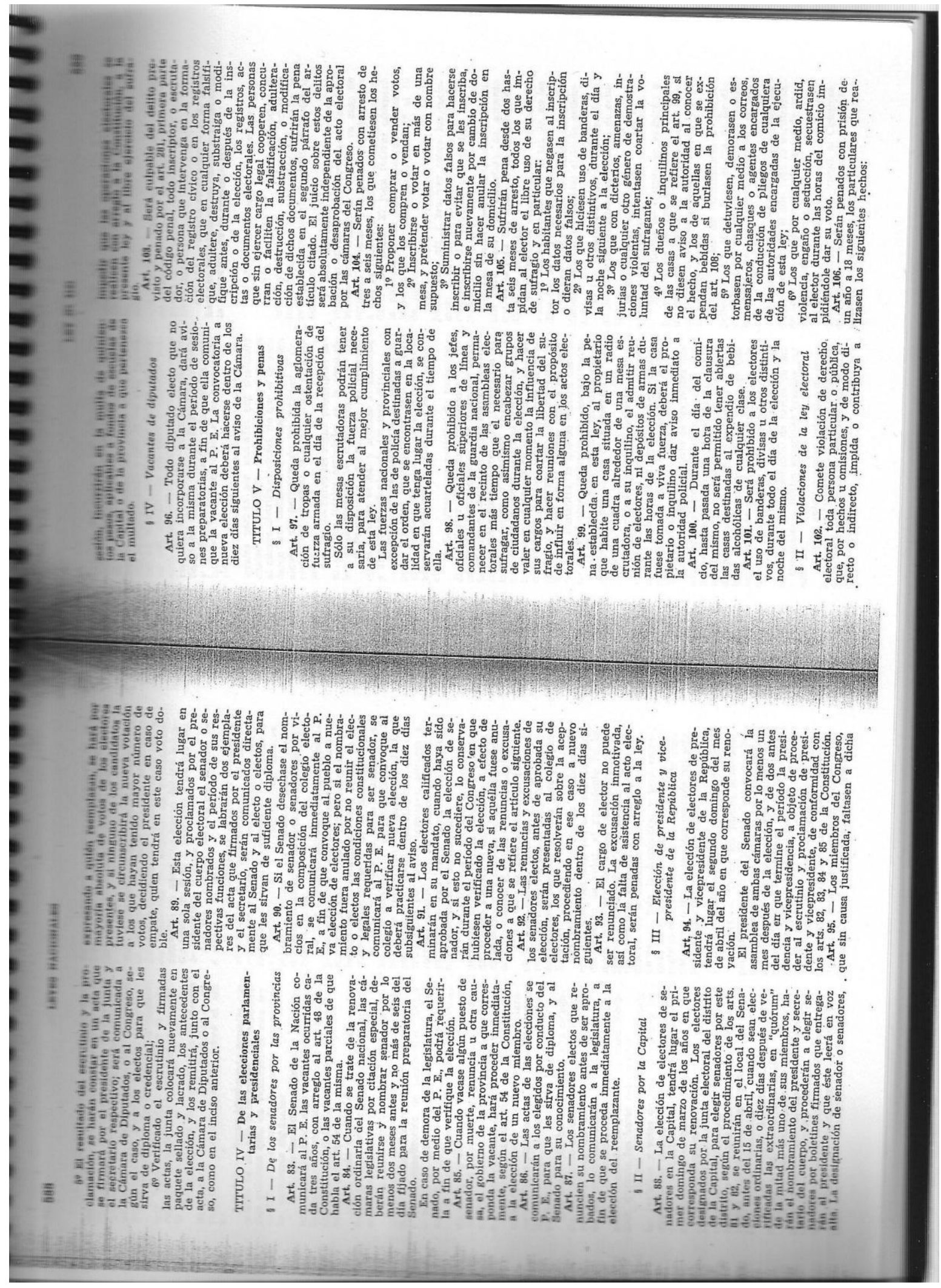




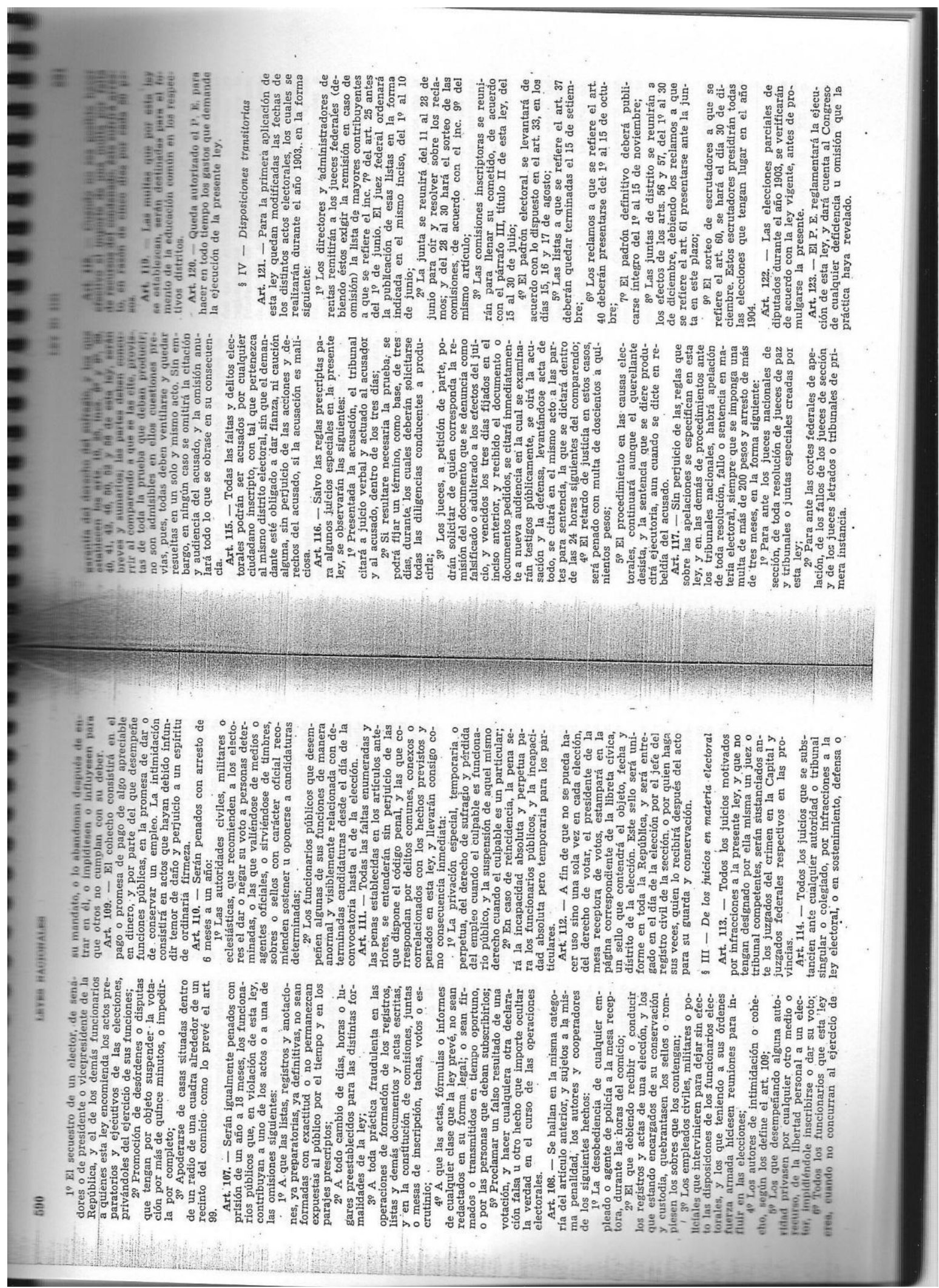




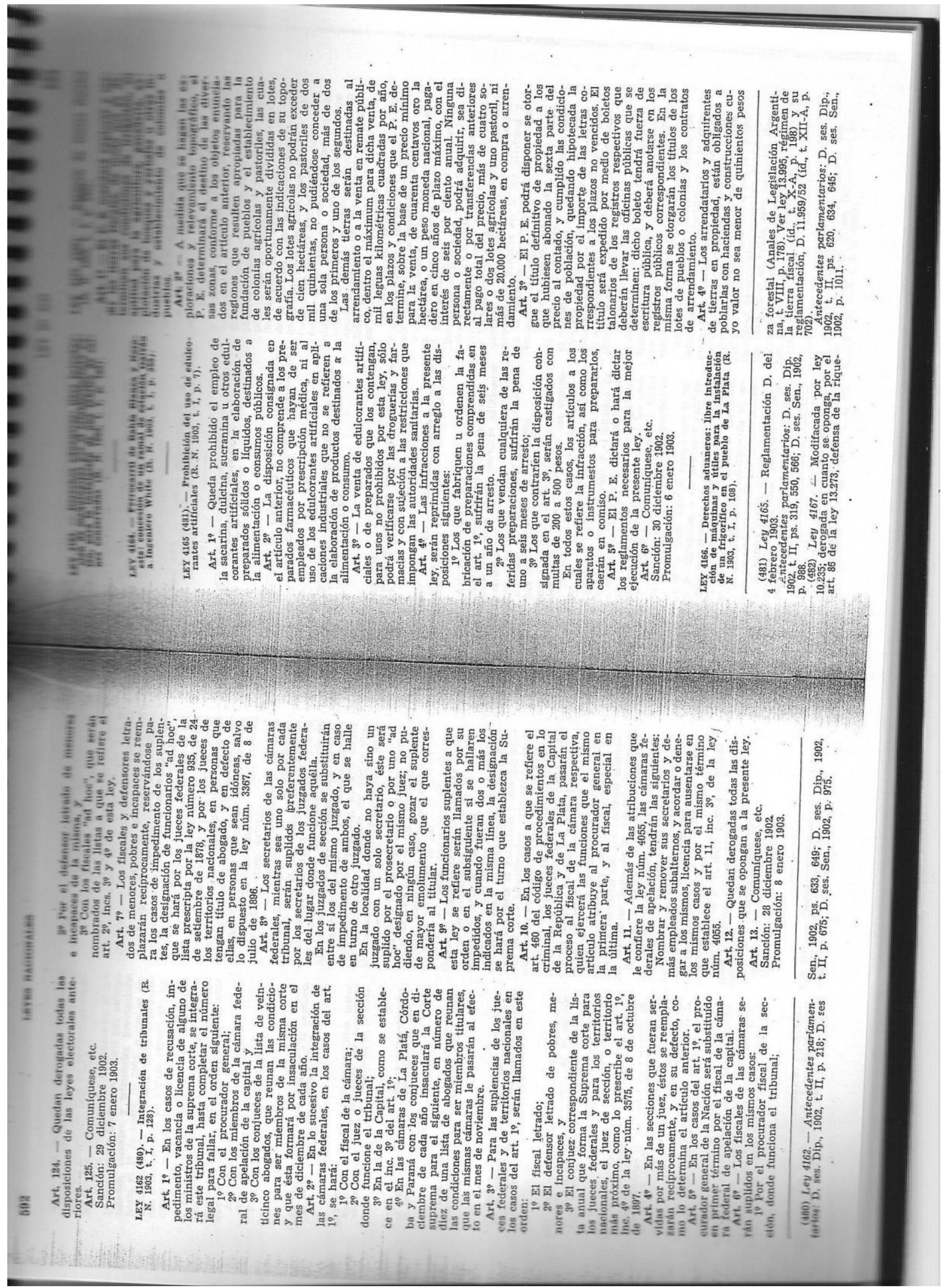




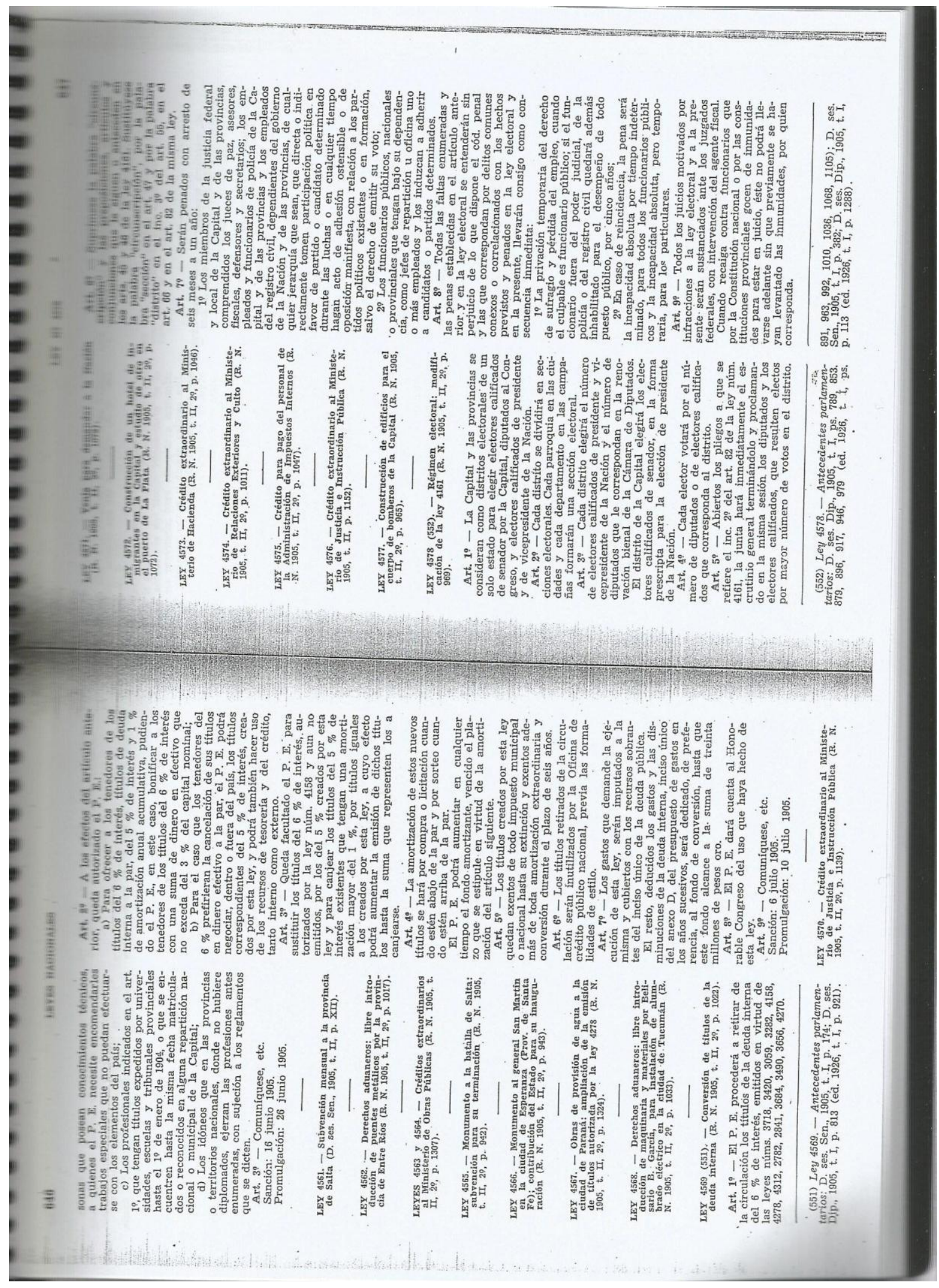




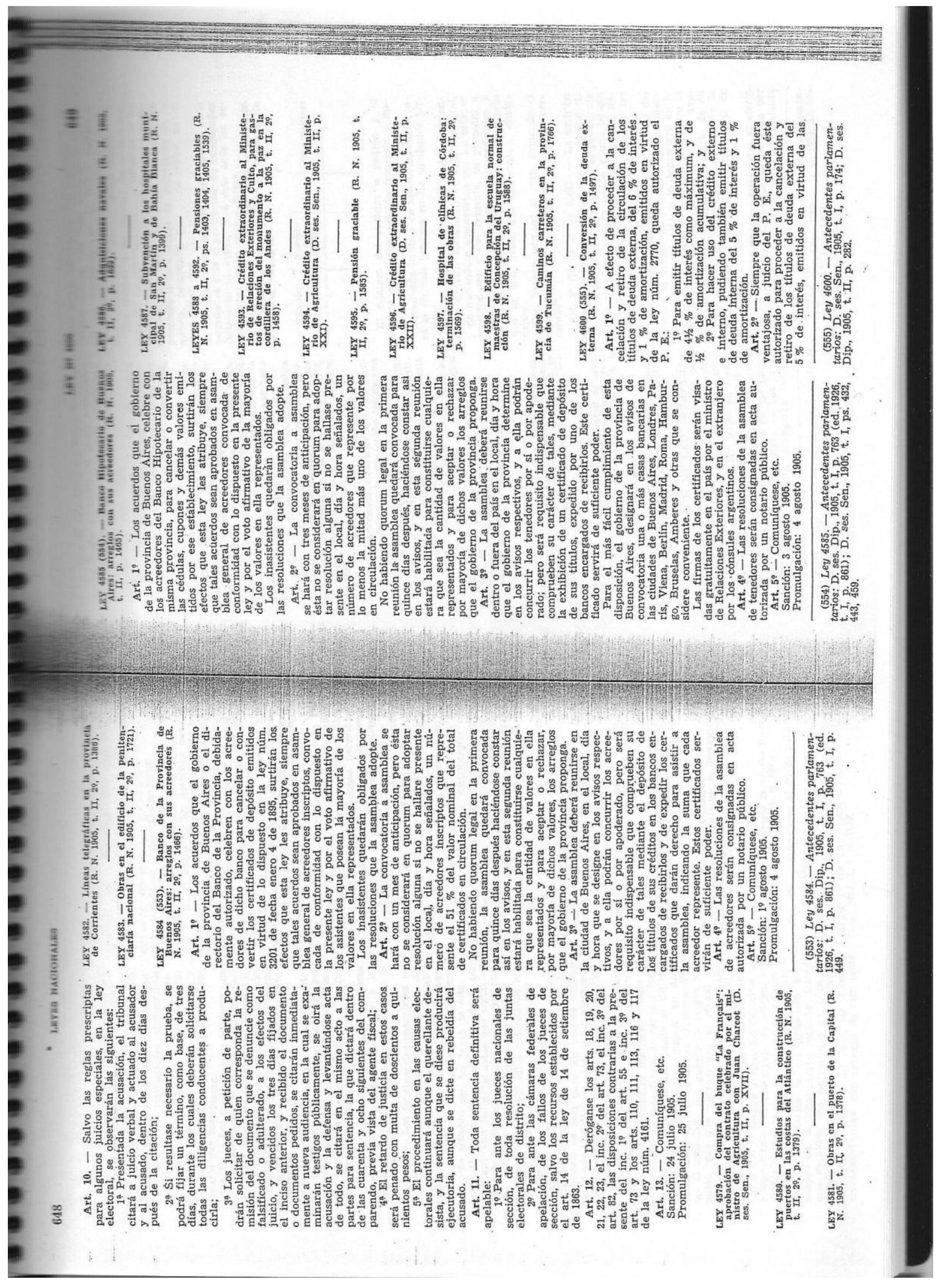




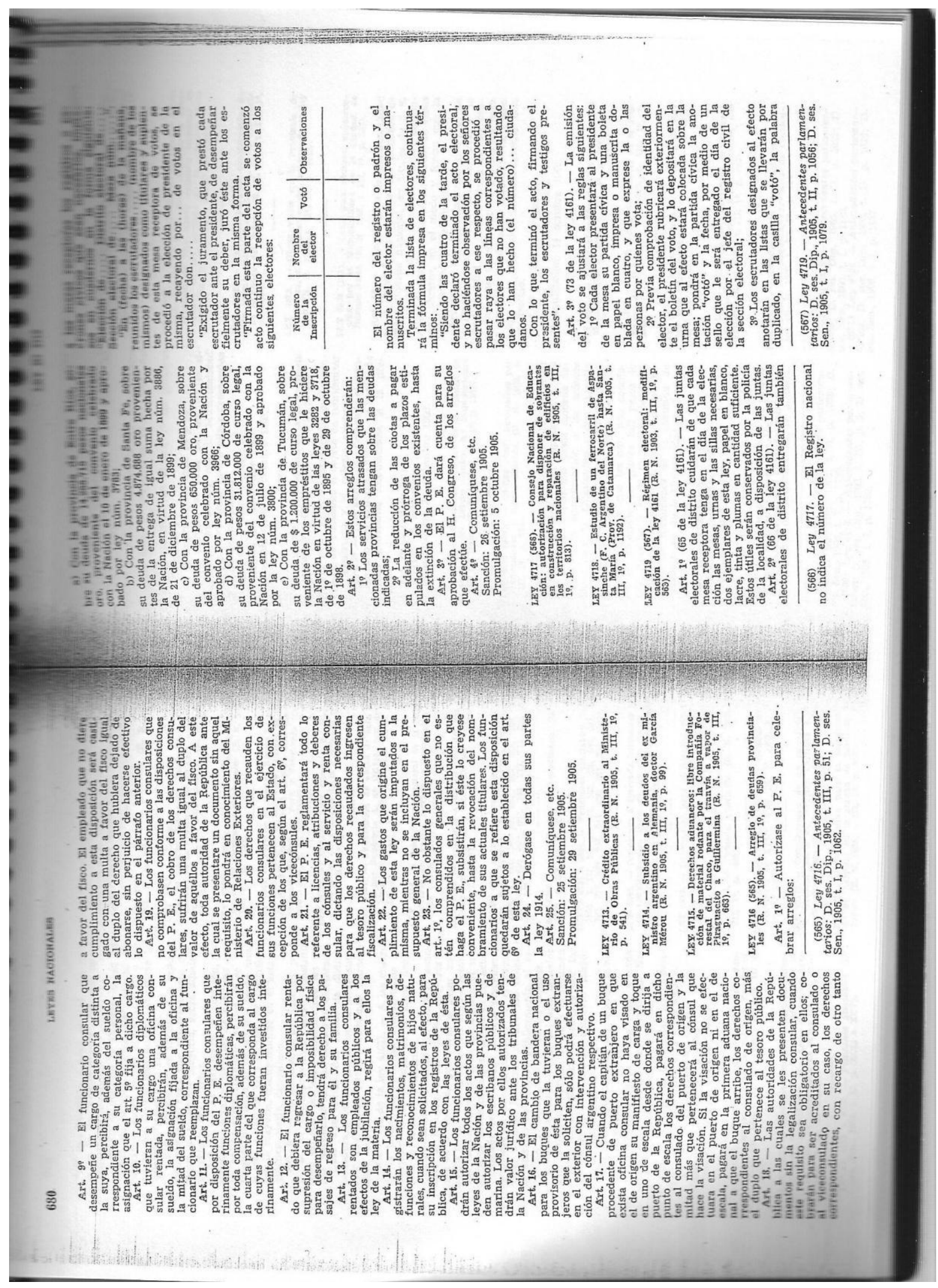




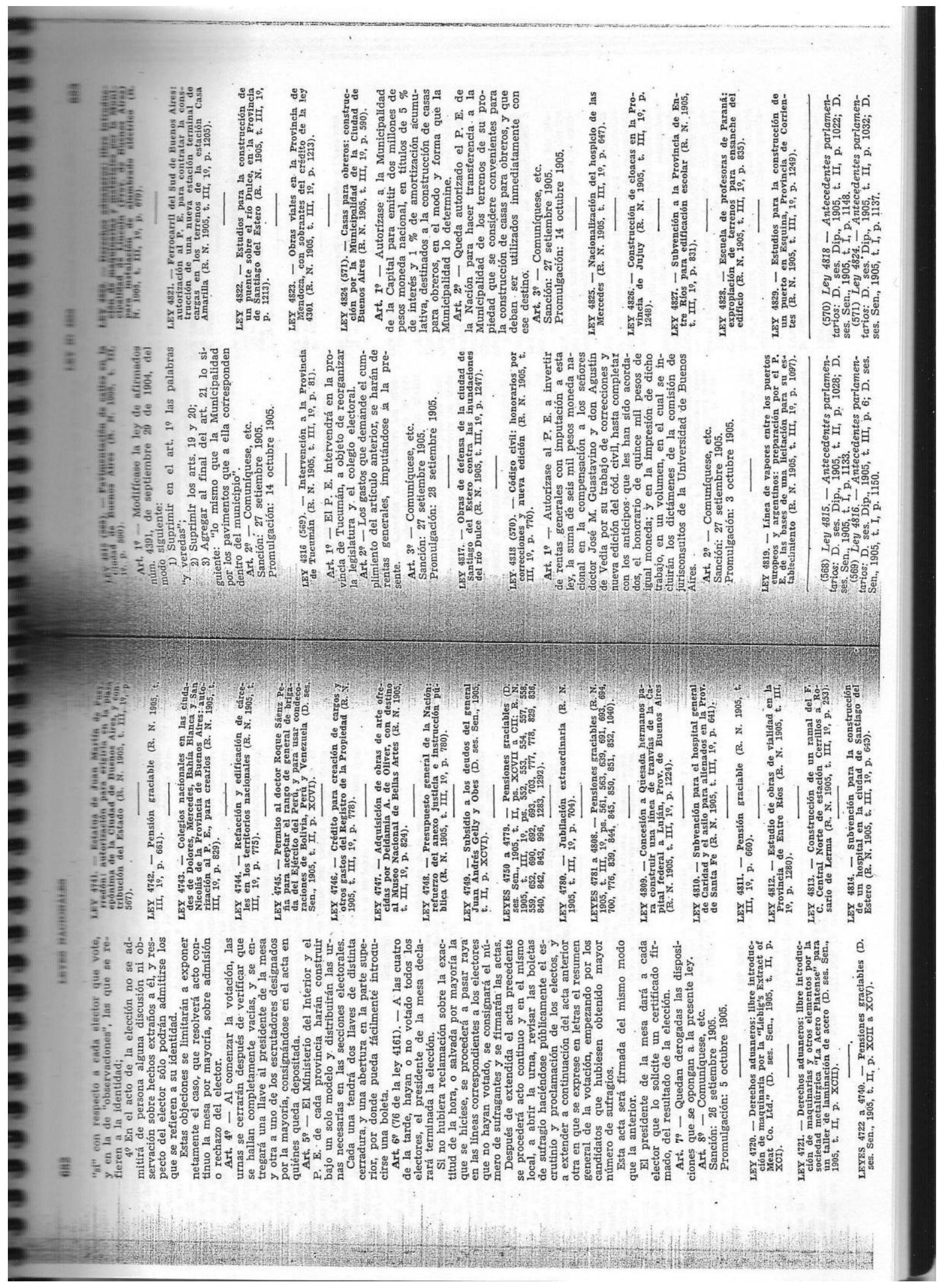




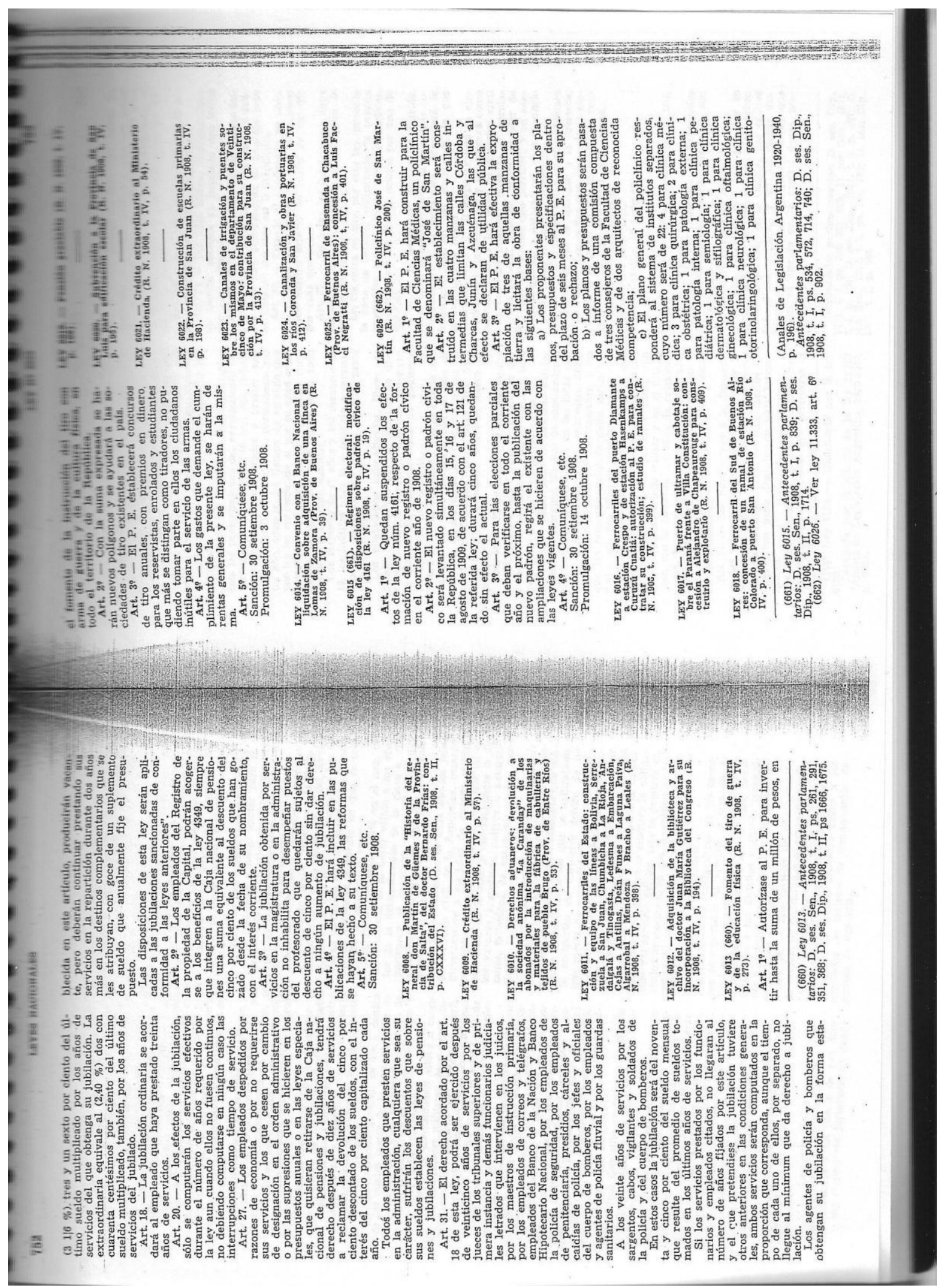




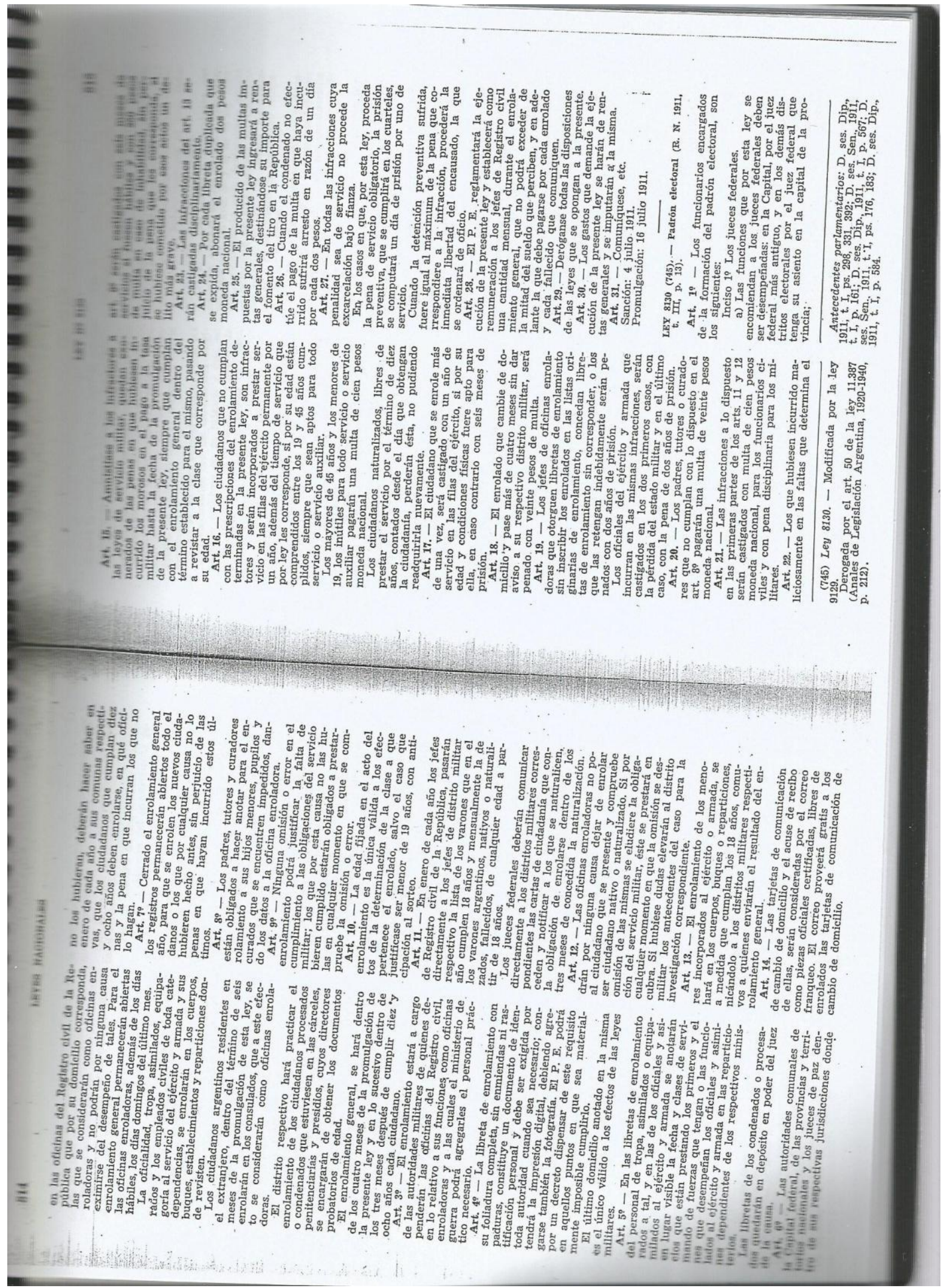




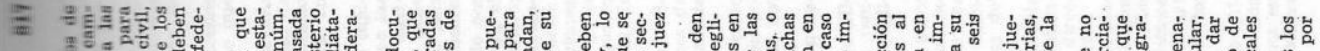

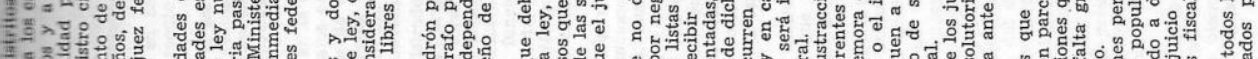

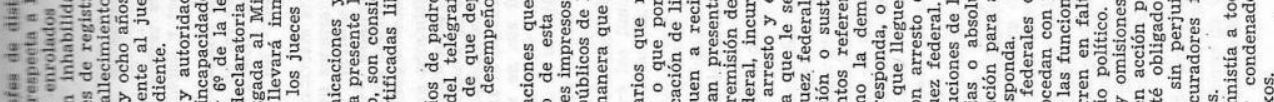

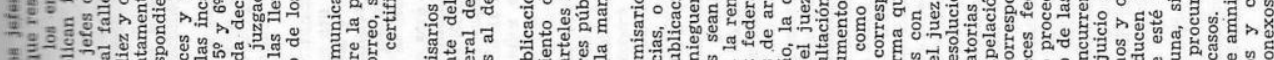
a

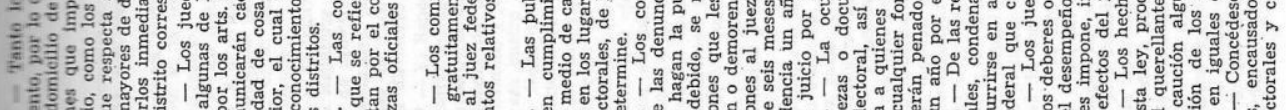
I

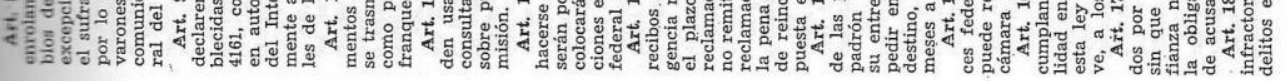

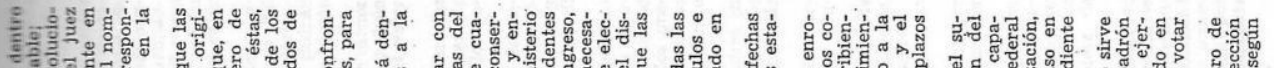

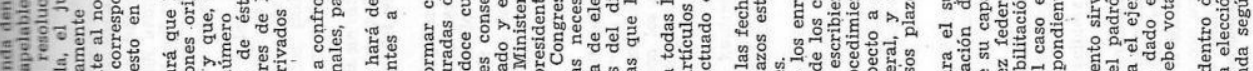

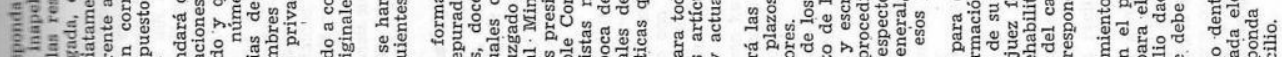

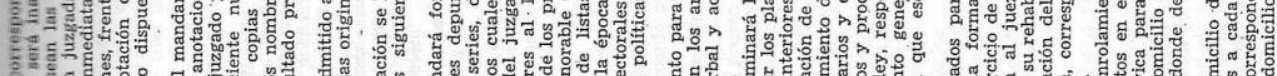
15.

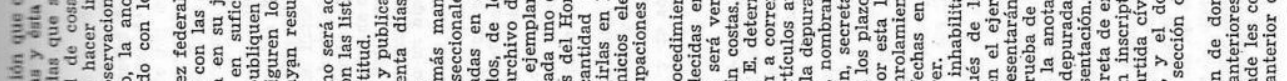

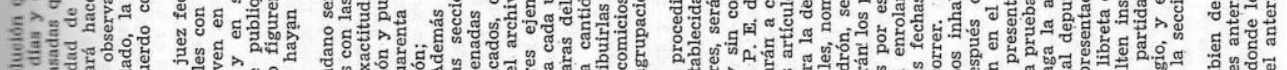

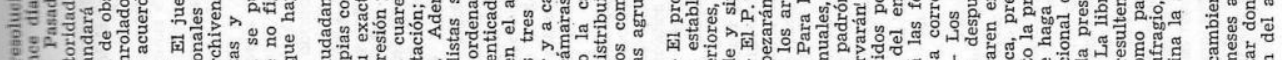

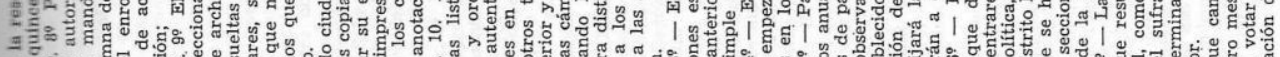

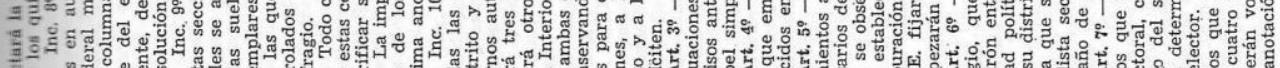

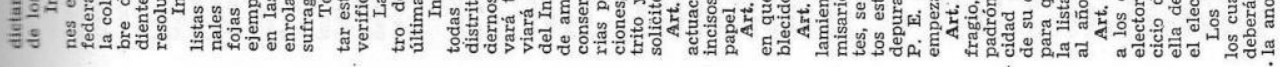

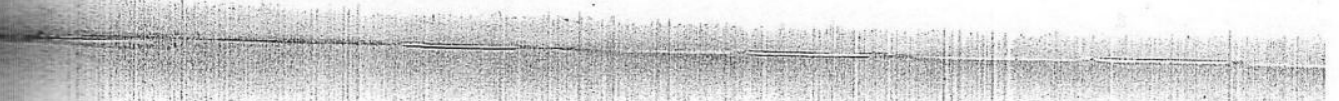

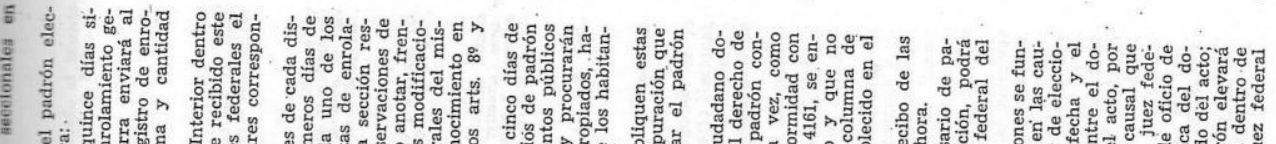

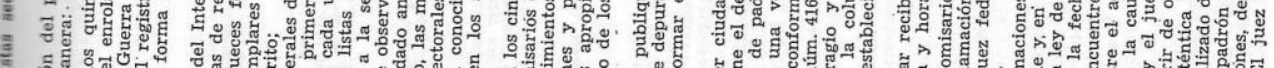

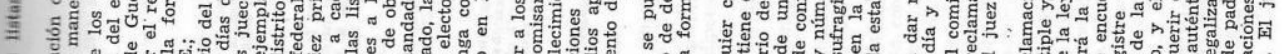
1

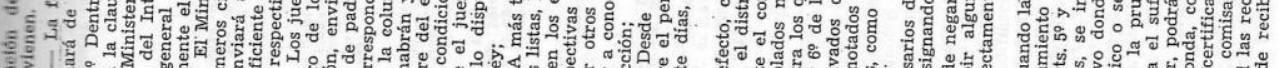

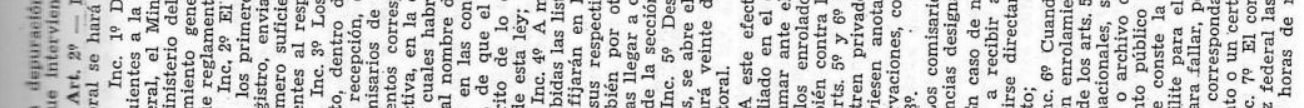
等

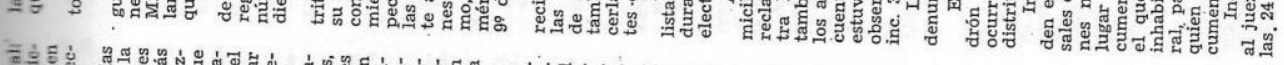

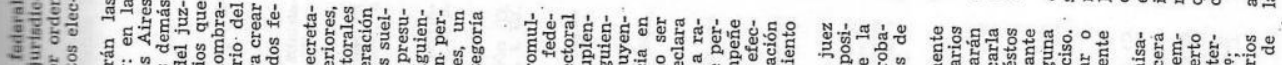
ing

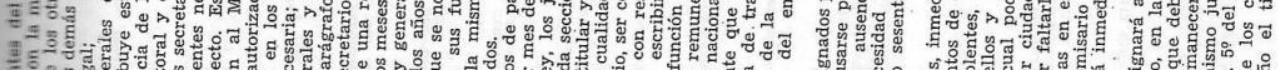
1

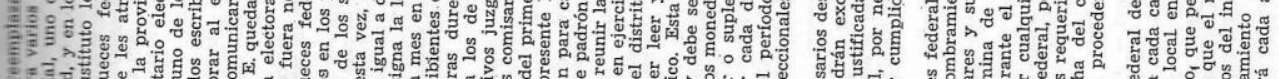

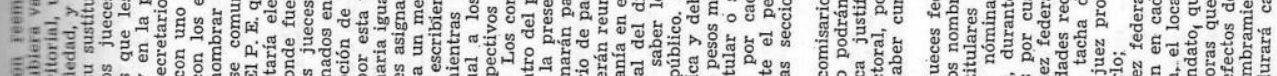

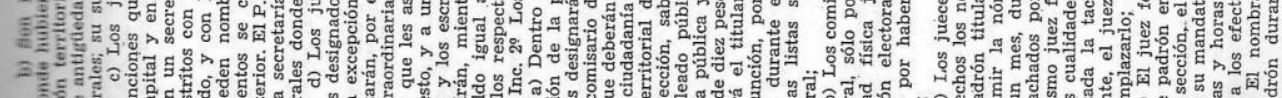

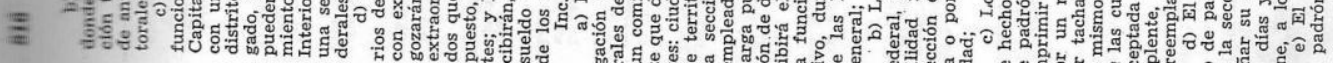

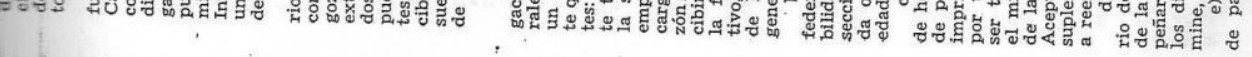




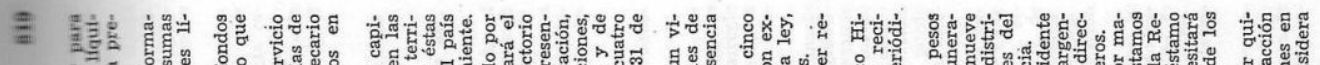

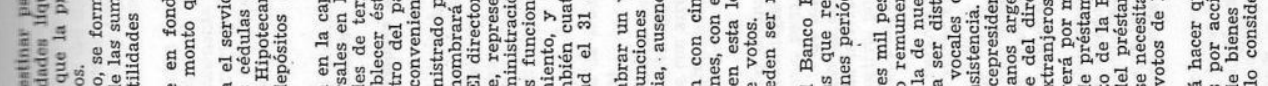

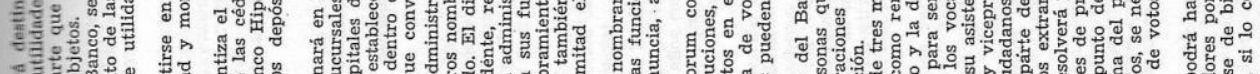

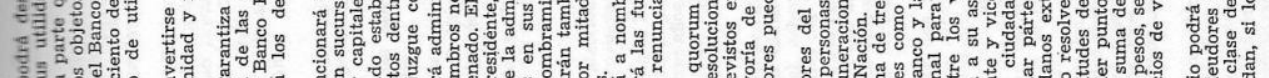

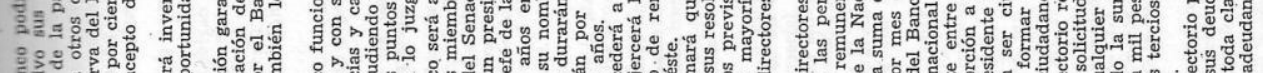

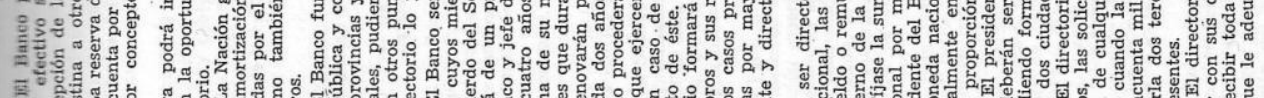

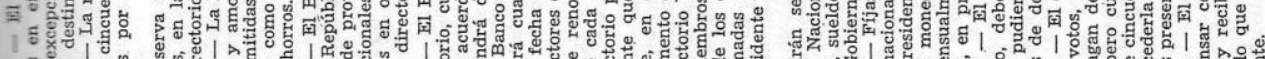
7.

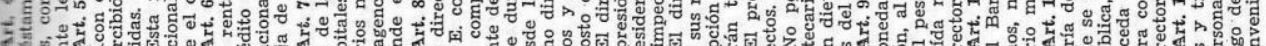

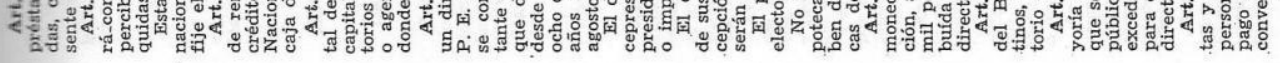

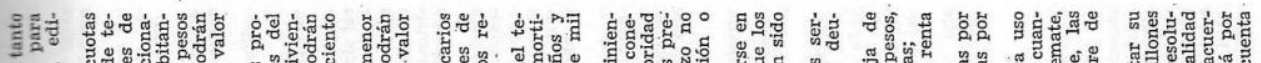

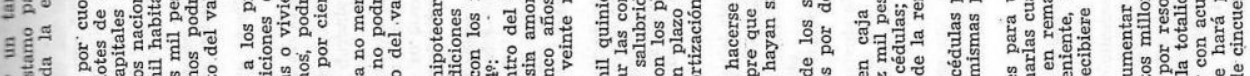

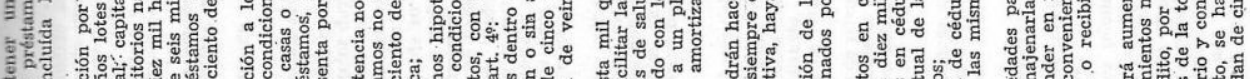

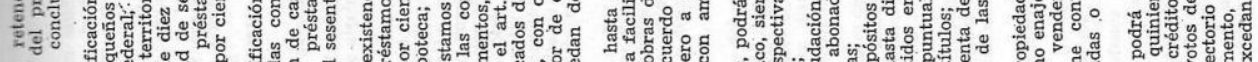

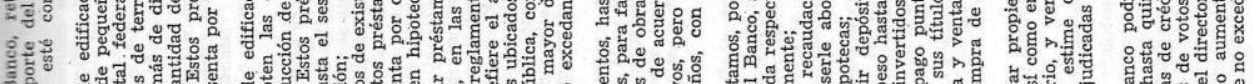

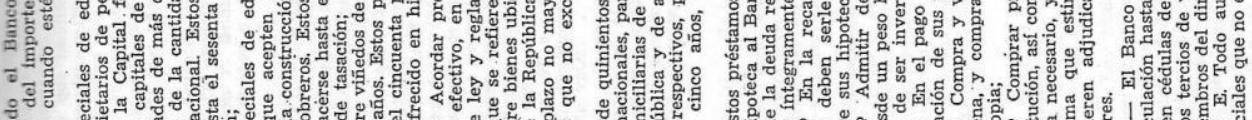

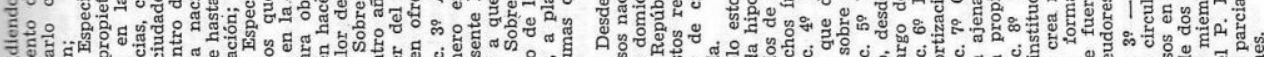

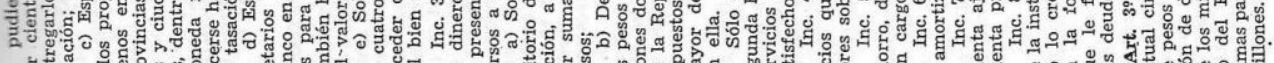

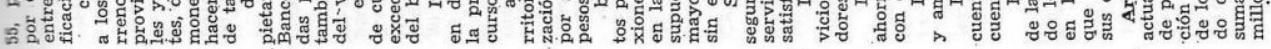

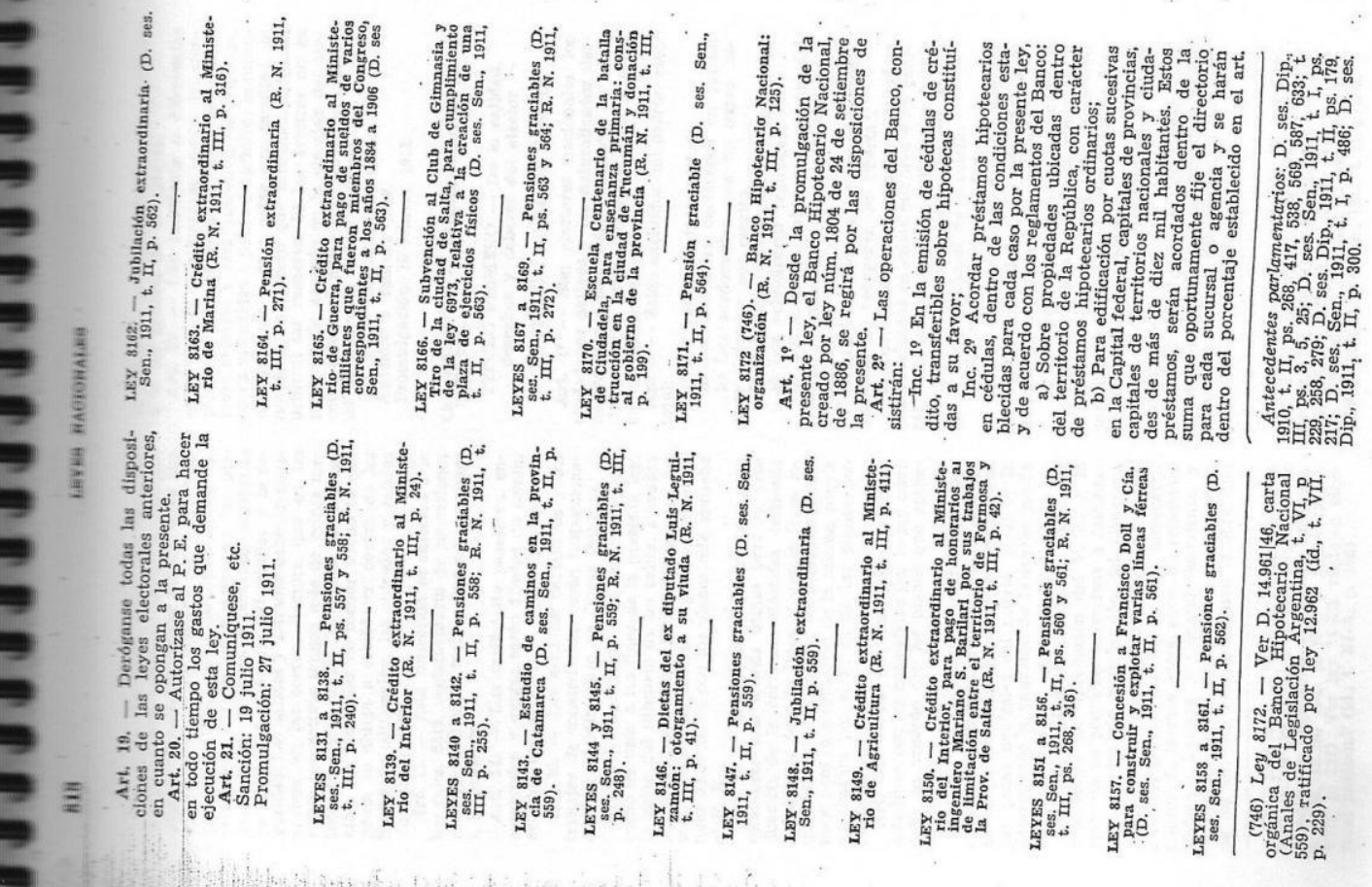




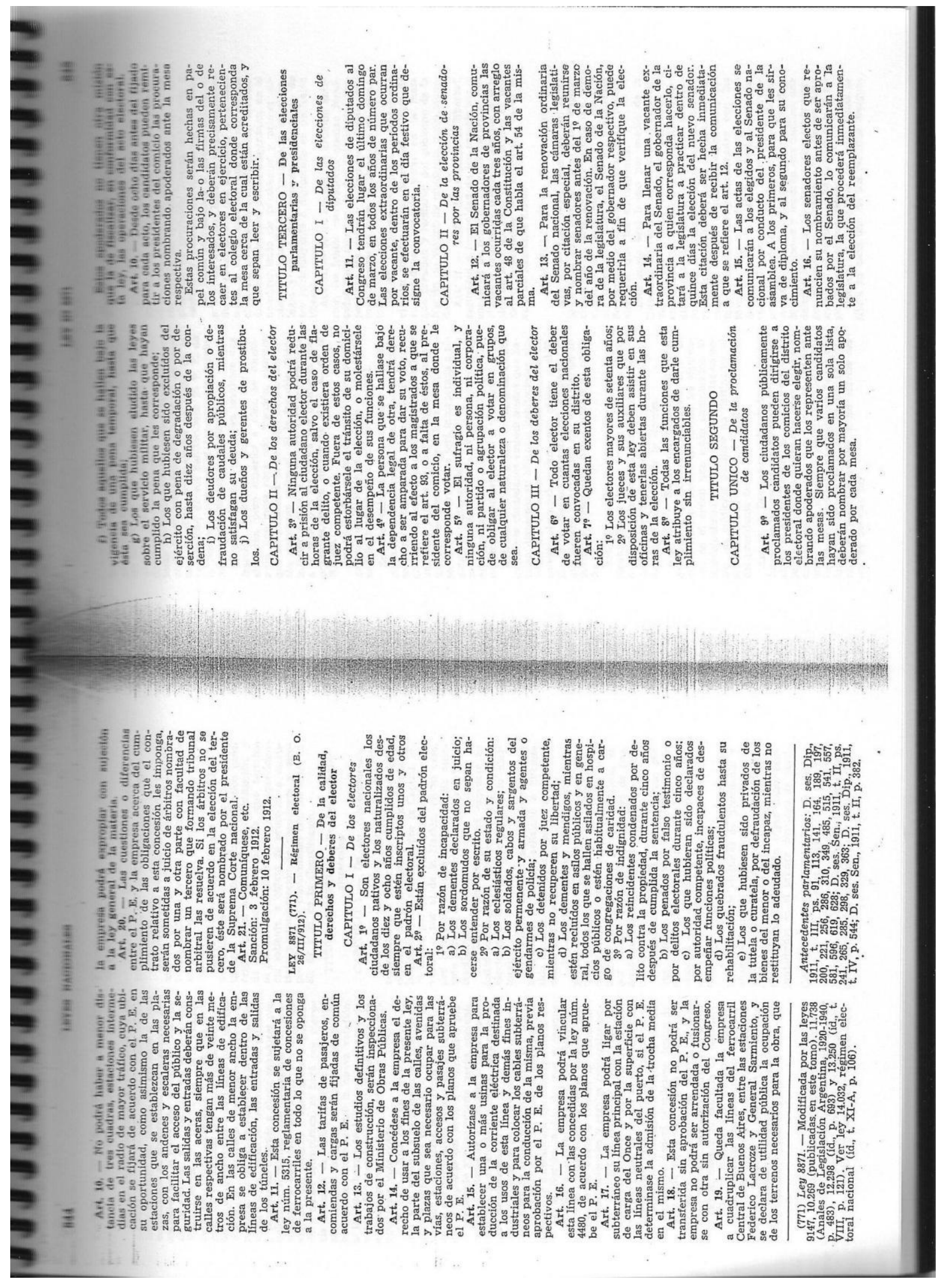




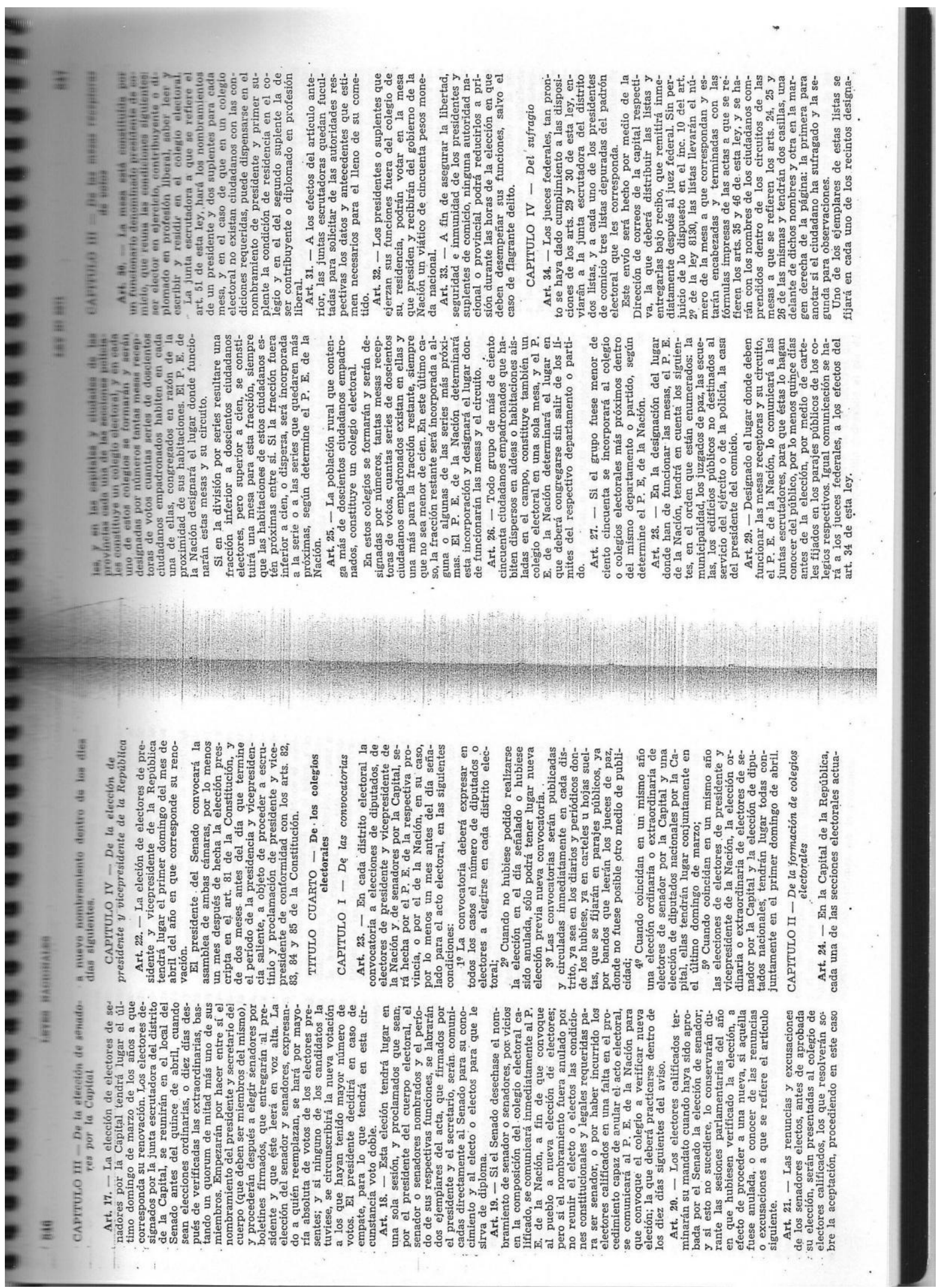




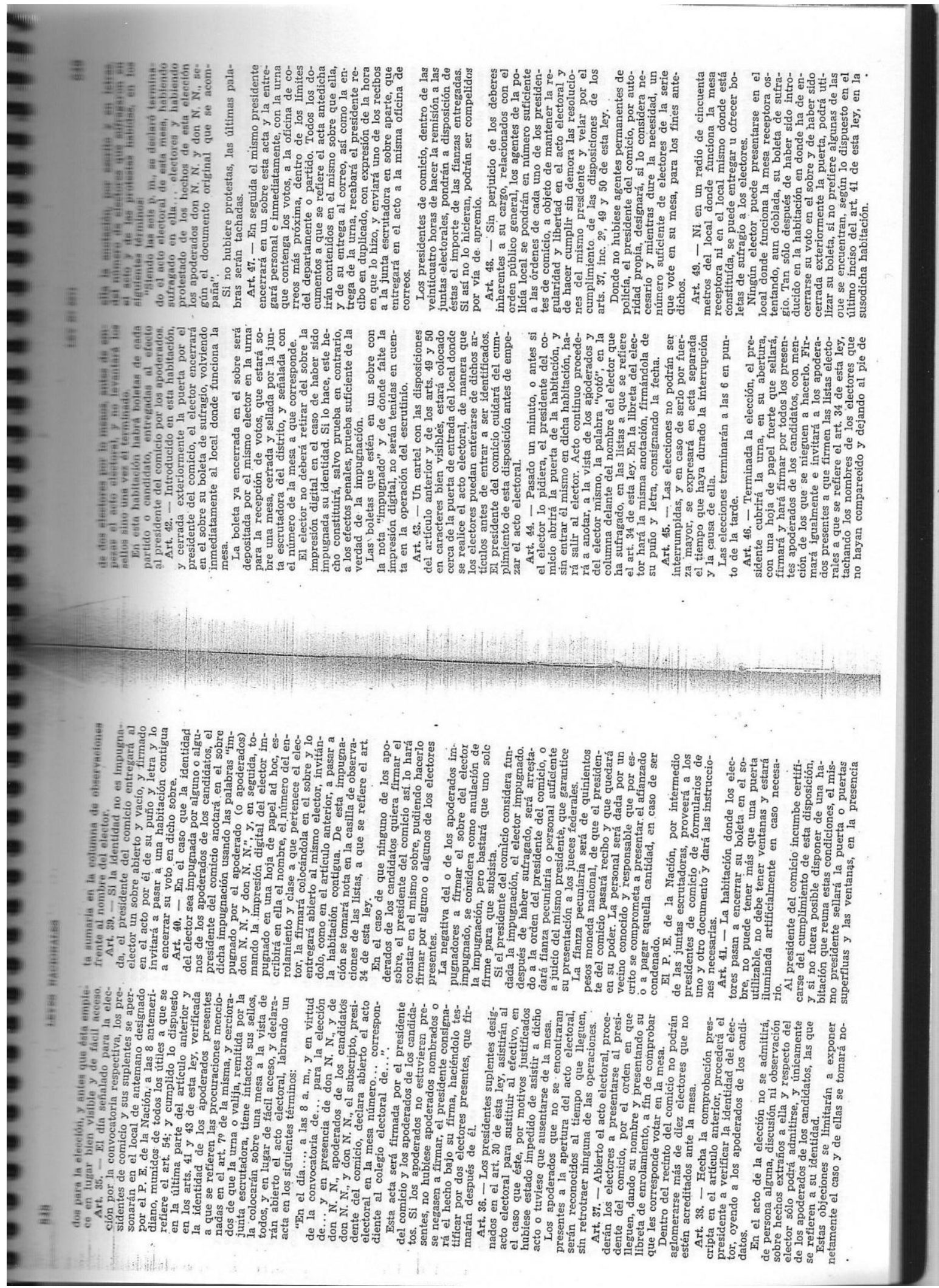




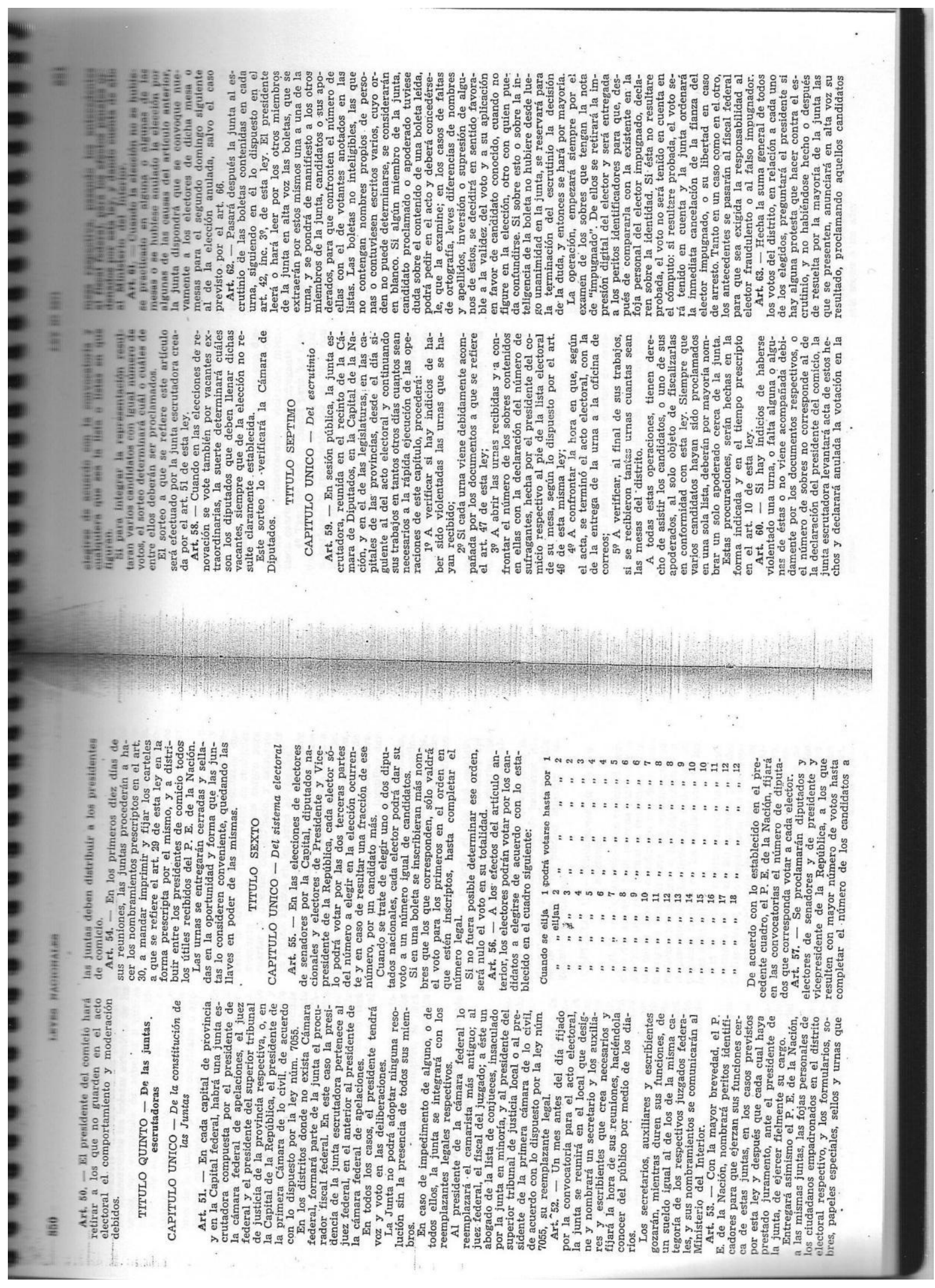




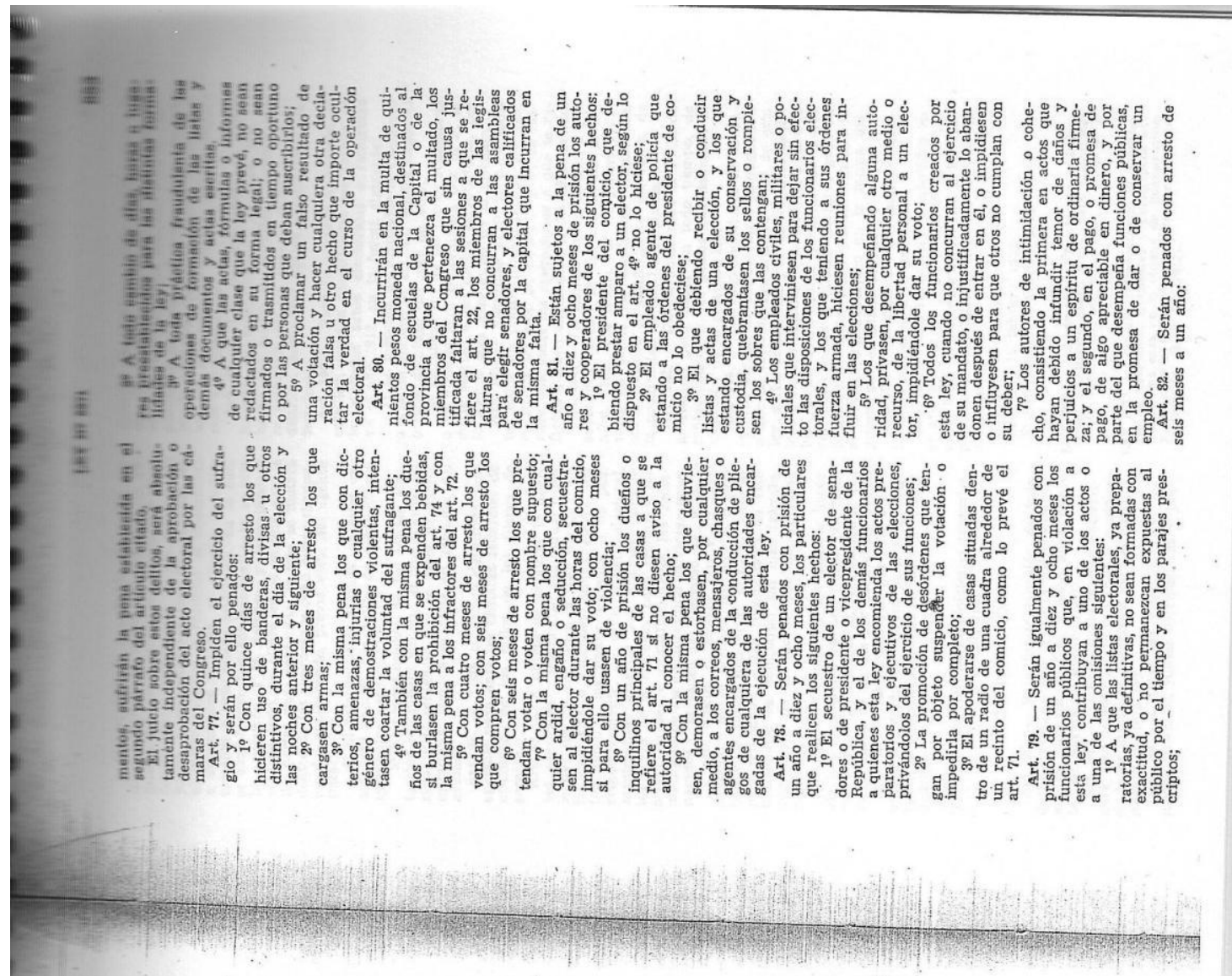

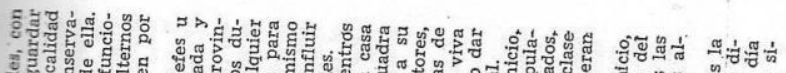

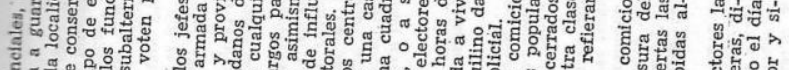

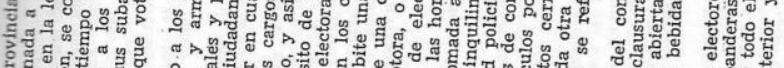
연

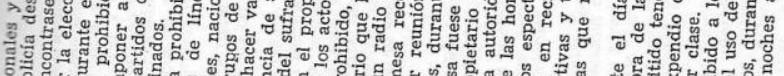

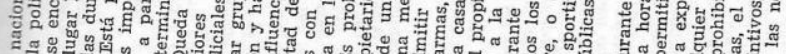

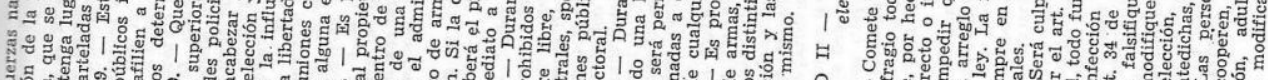

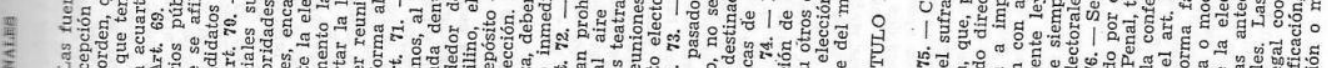

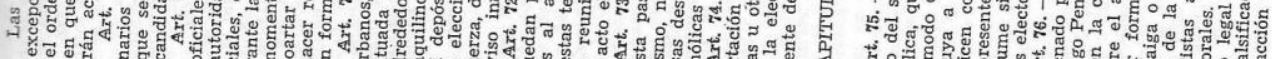

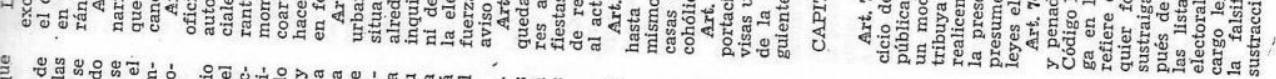

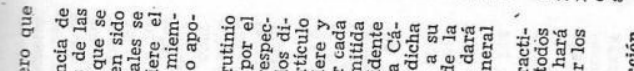

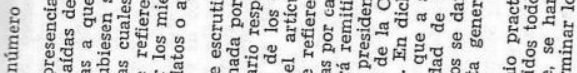
F

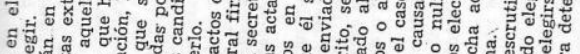

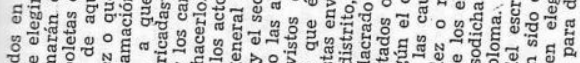
웜

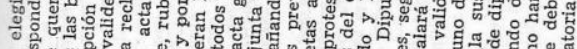

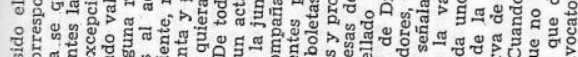
ติ

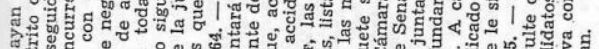

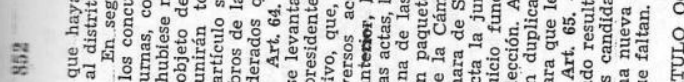

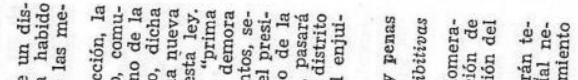

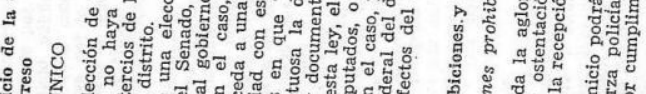

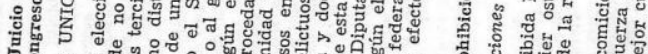

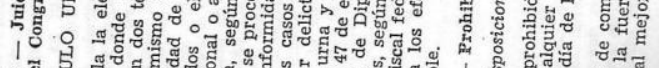

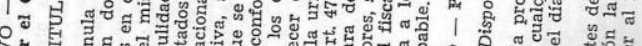

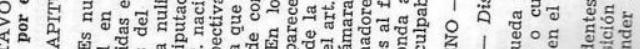

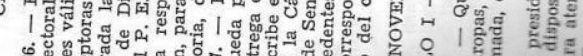
\&.

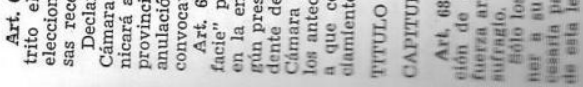




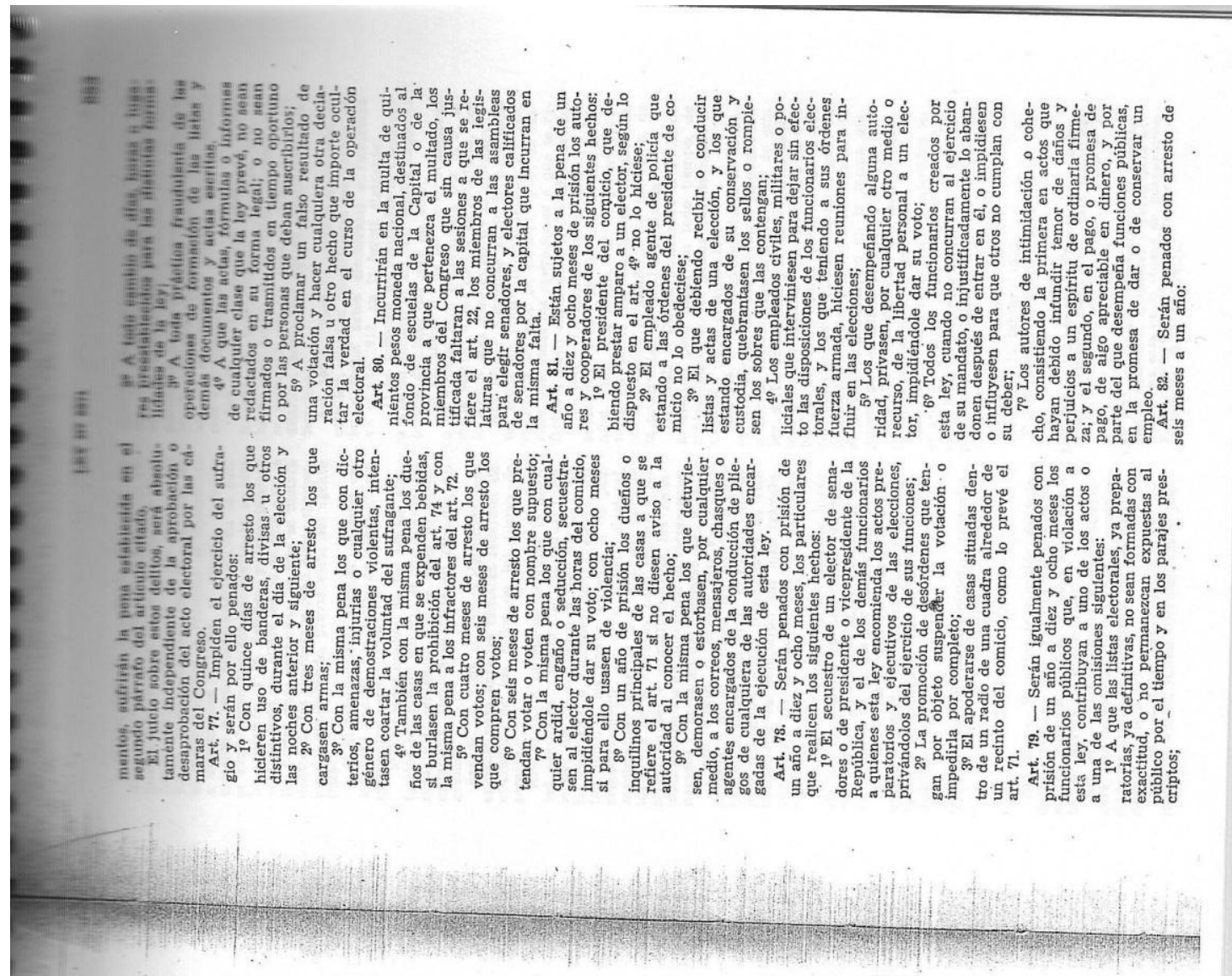

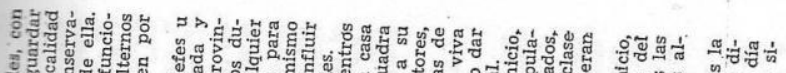

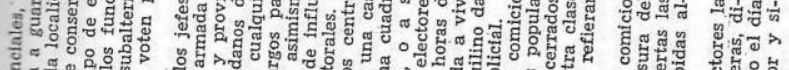

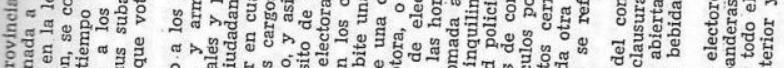

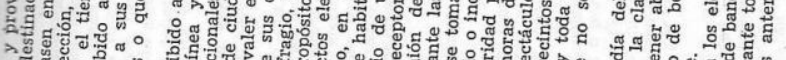

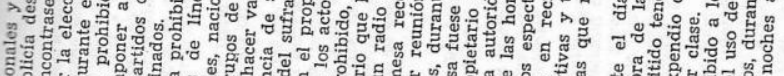

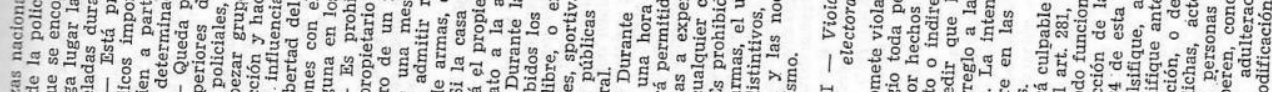
9.

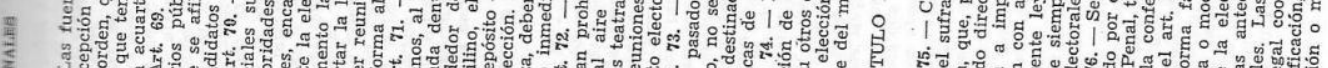

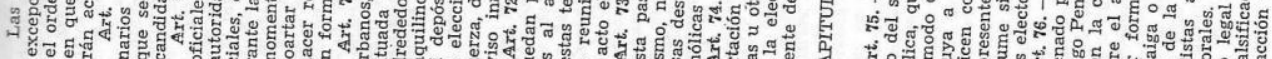

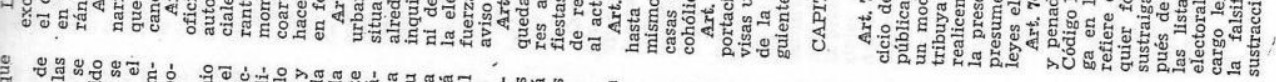

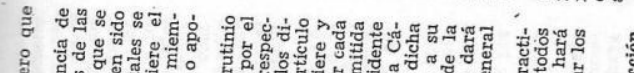

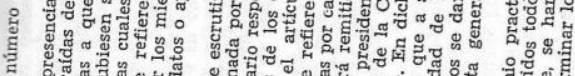

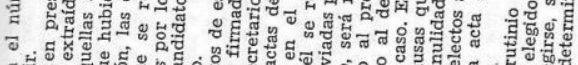

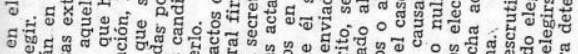

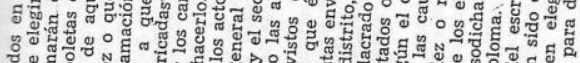
웜

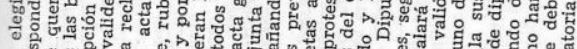

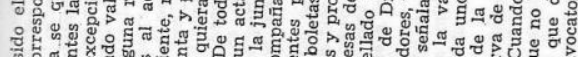
जิ

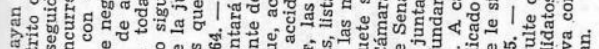

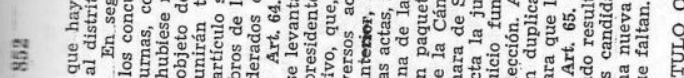

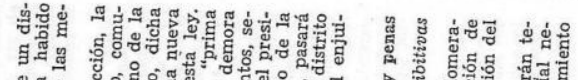

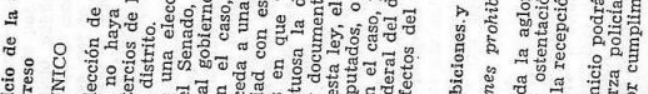

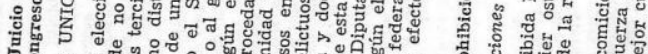

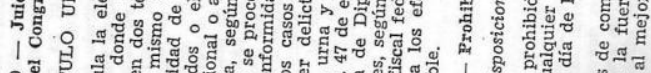

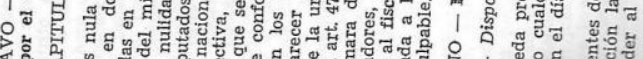

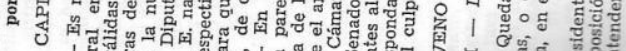

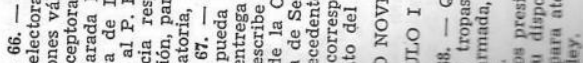
6.

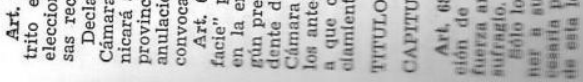




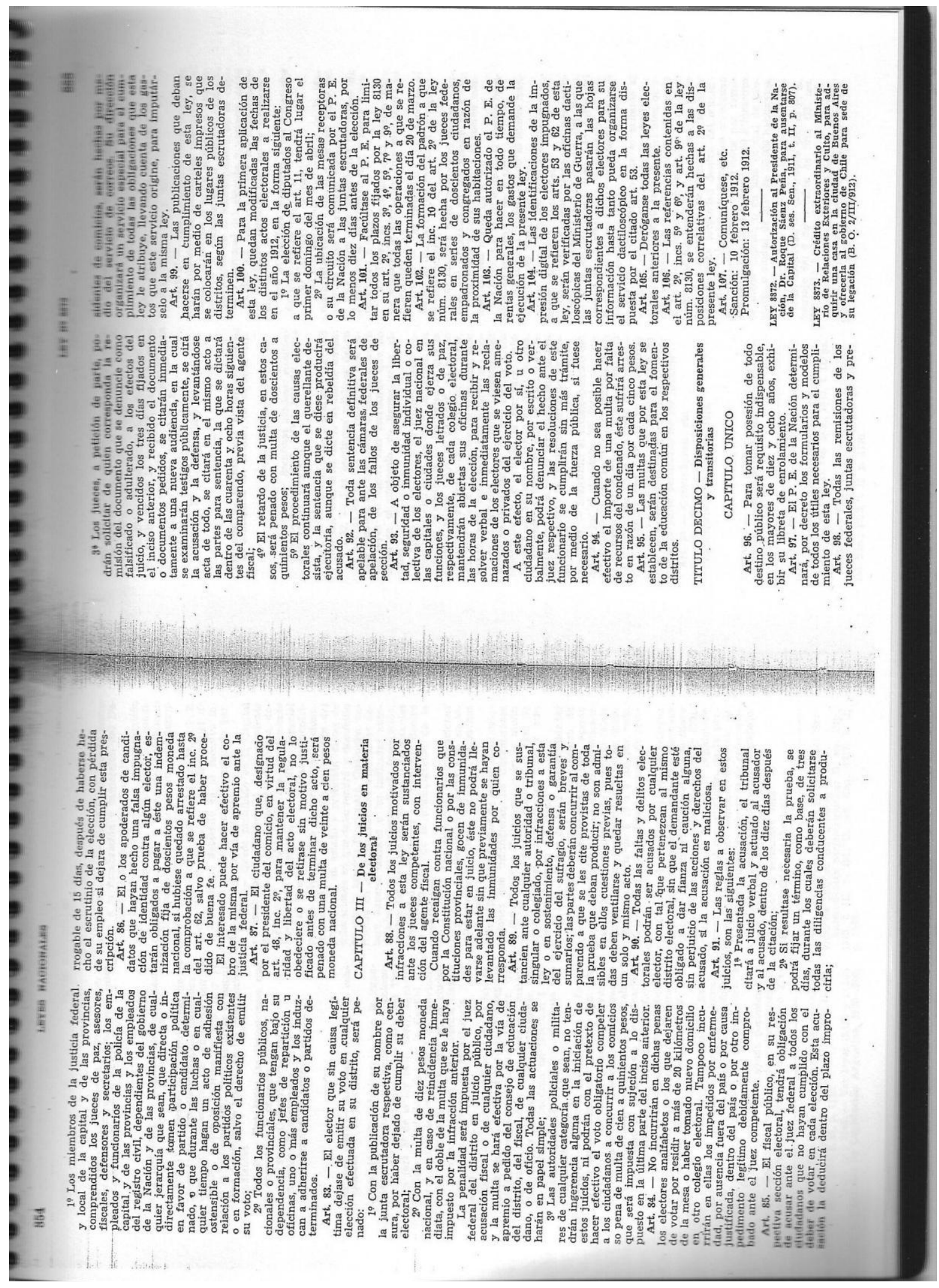




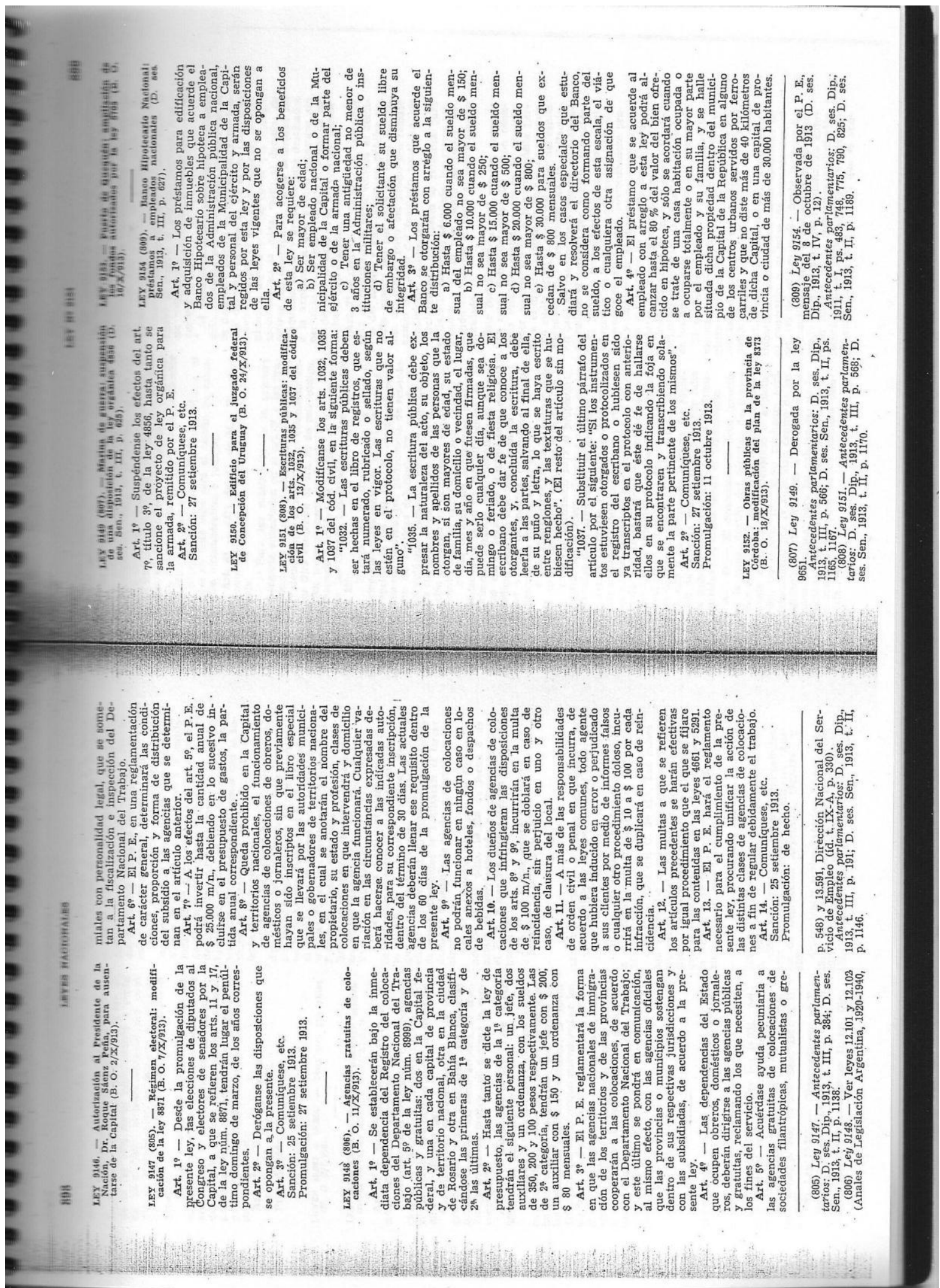




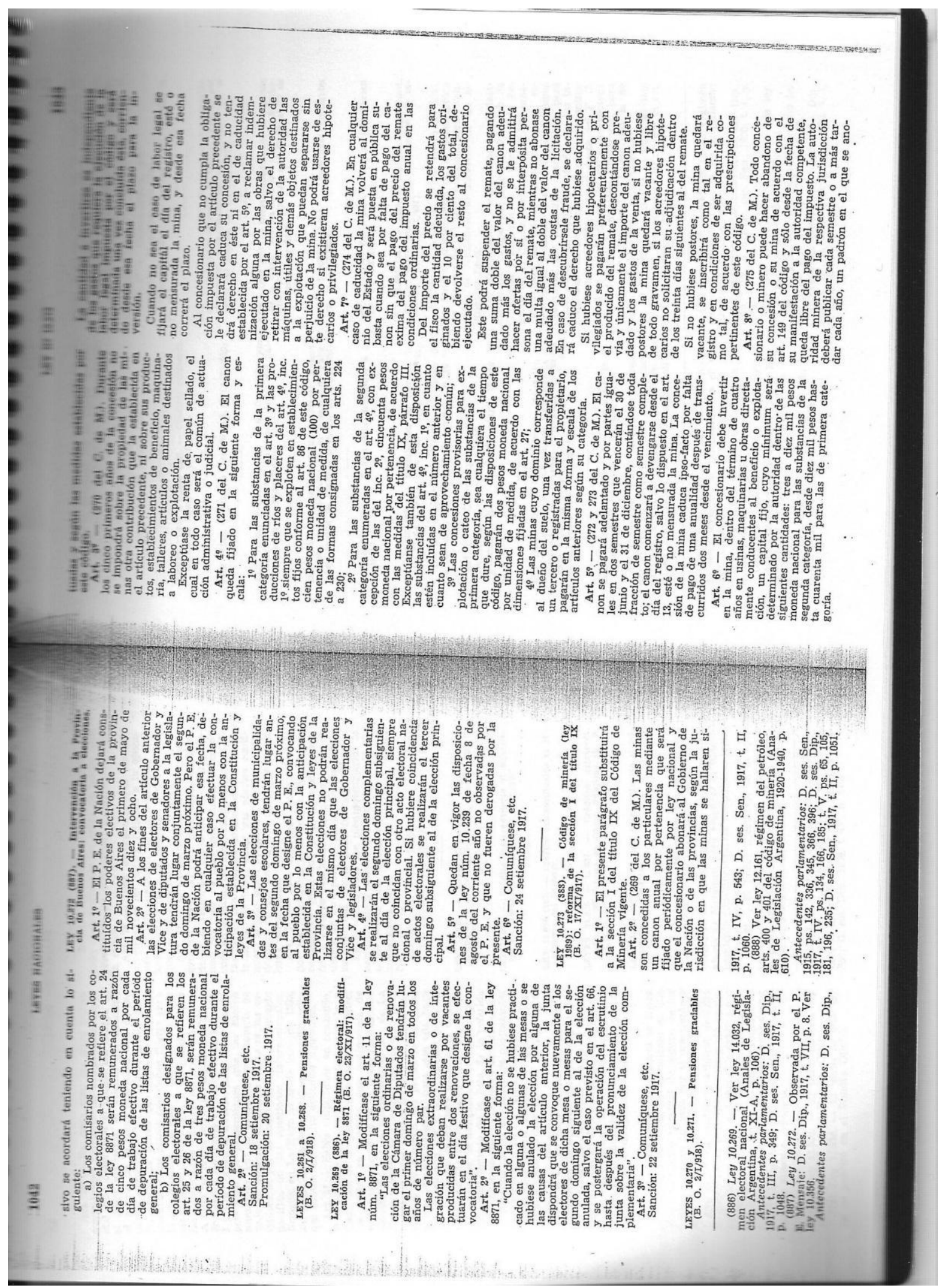




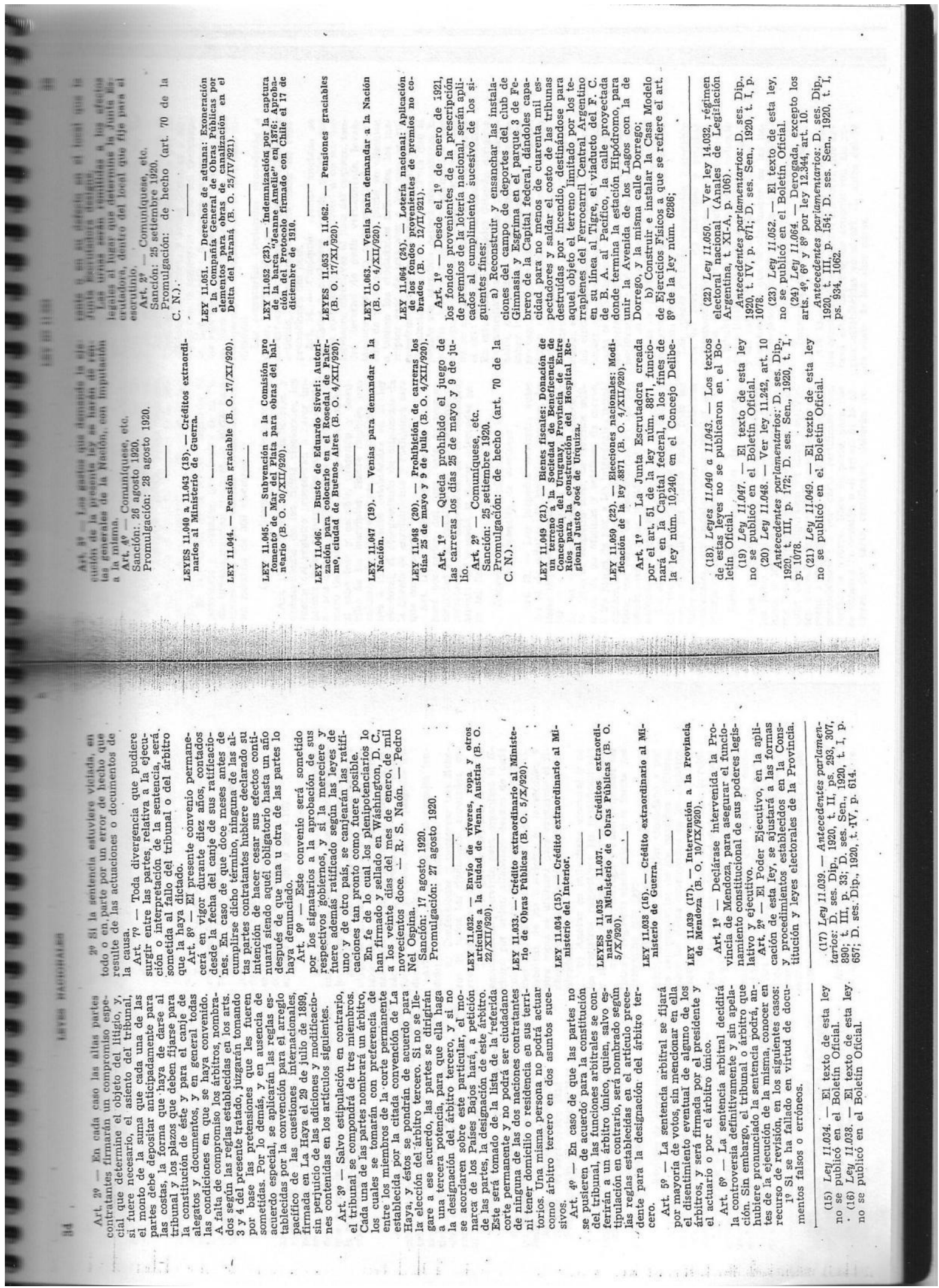




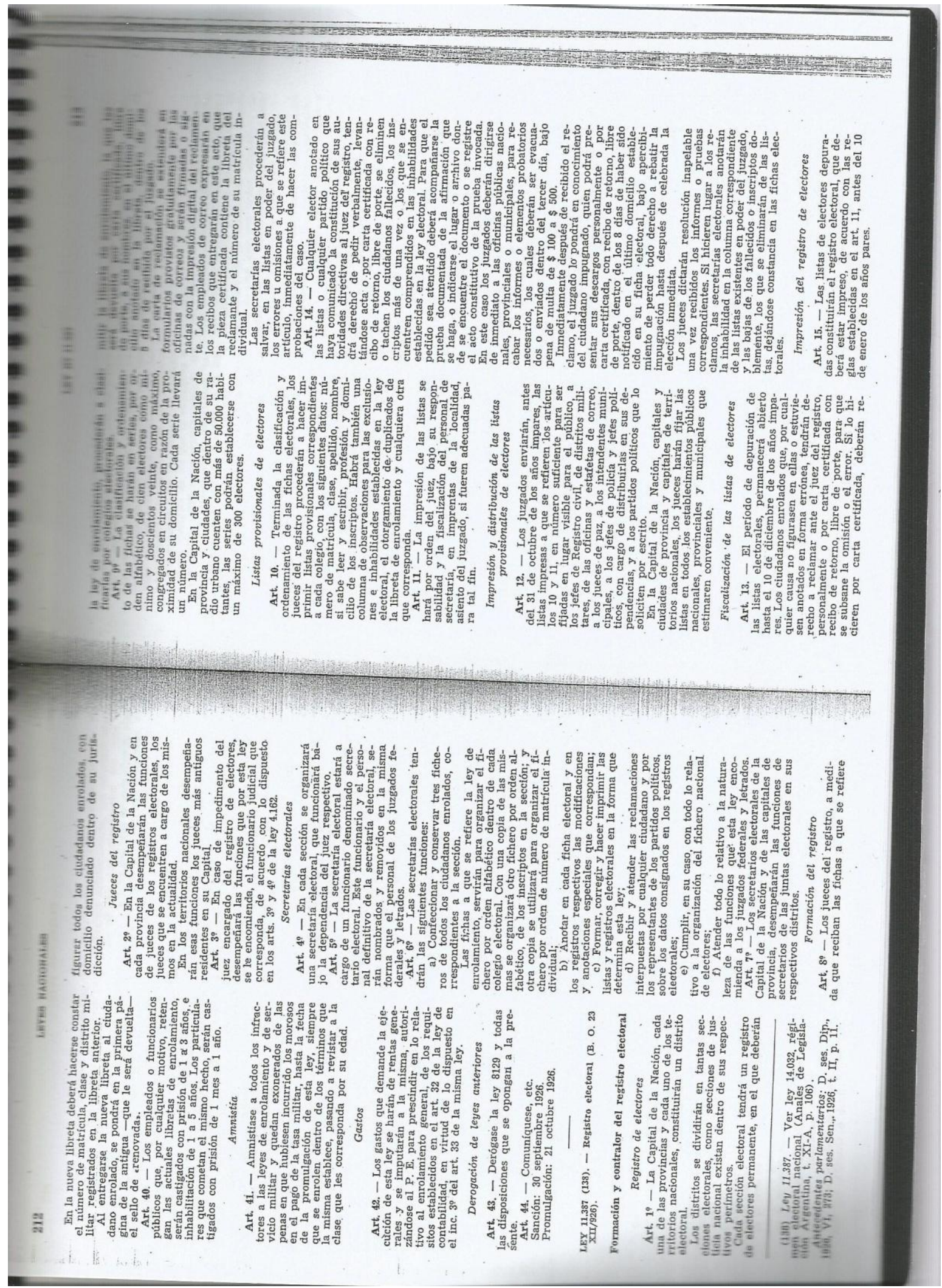




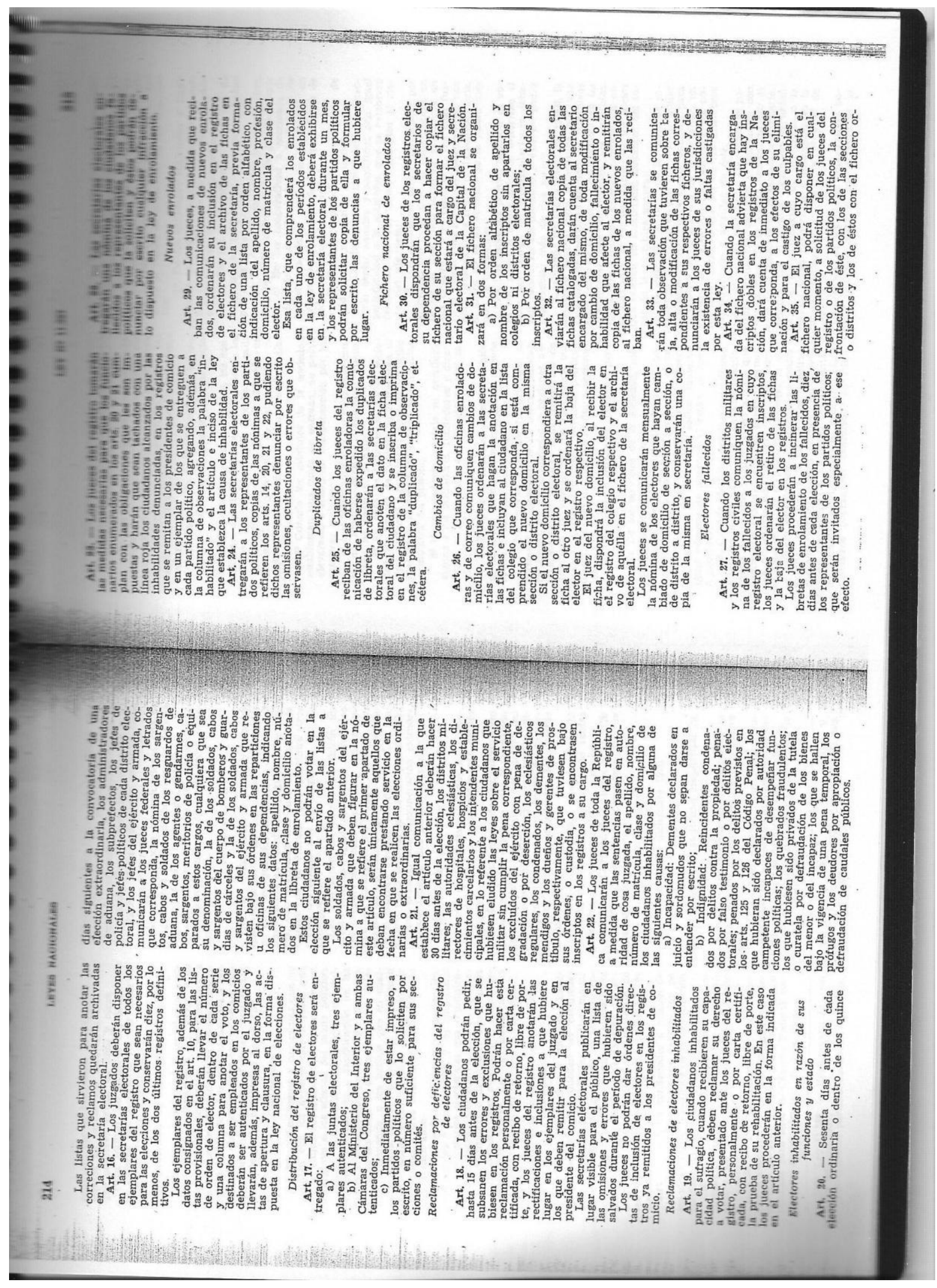




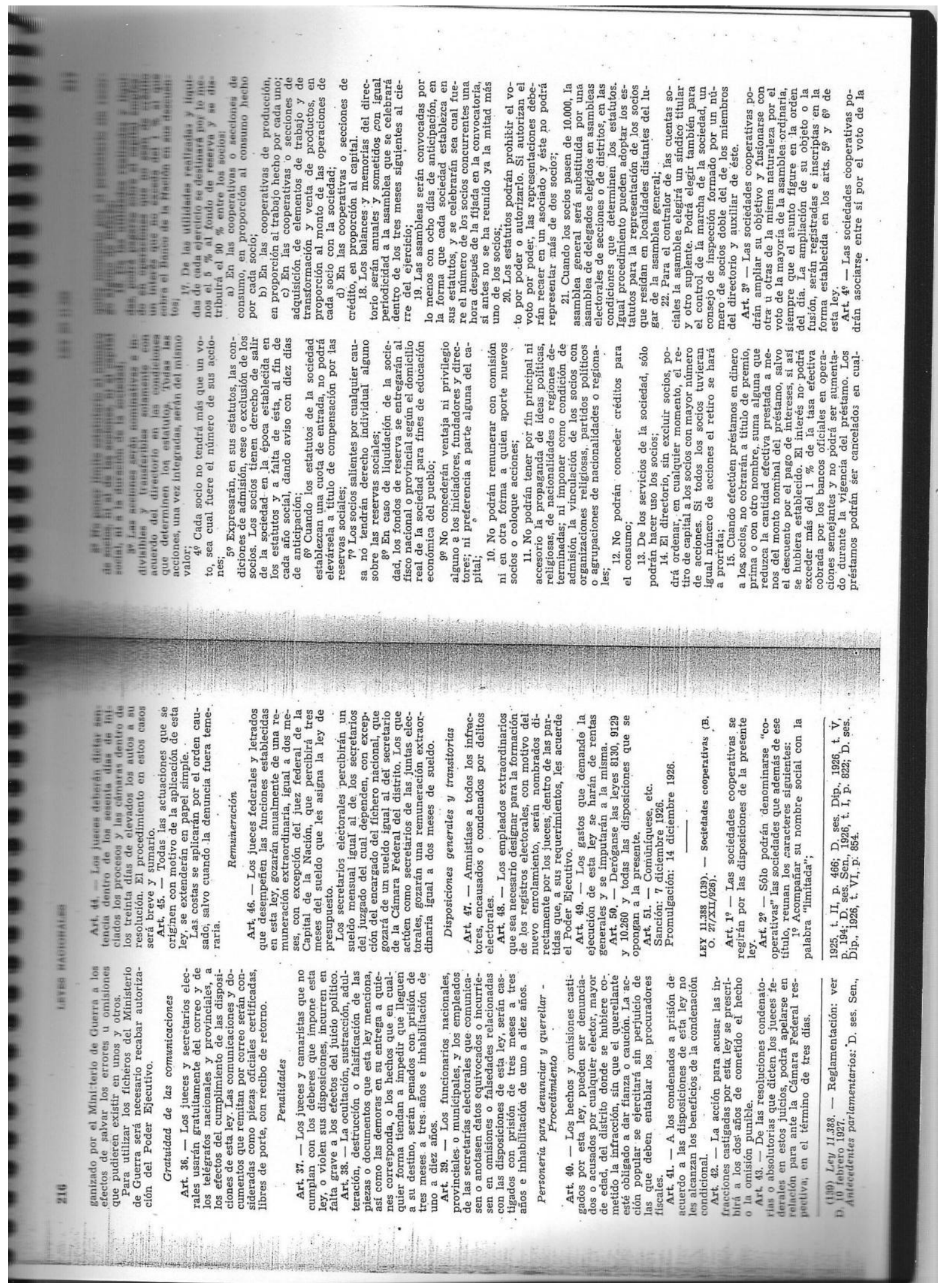


ANEXO II 


\begin{tabular}{|clc|}
\hline \multicolumn{2}{c|}{ CUADRO 1 } \\
& & \\
& & \\
& & 935.000 \\
1849 & De la Fuente & 1.210 .000 \\
1857 & Censo de la Confederación & 1.304 .000 \\
1859 & De la Fuente & 1.737 .076 \\
1869 & Primer Censo Nacional & 3.954 .911 \\
1895 & Segundo Censo Nacional & 7.885 .237 \\
1914 & Tercer Censo Nacional & \\
& & \\
\end{tabular}

\section{CUADRO 2}

\section{CRECIMIENTO ANUAL MEDIO POR CADA MIL HABITANTES SEGÚN CENSOS NACIONALES}

Período Crecimiento

$1869-1895 \quad 27,6$

$1895-1914 \quad 34,8$

${ }^{234}$ CEAL, vol. 5, p.200. Los datos extraídos de las fuentes son los correspondientes al período 1853/1916, criterio de análisis reiterado en todos los Cuadros.

${ }^{235}$ CEAL, vol. 5, p.200 
ANEXO III 


\begin{tabular}{|c|c|c|c|c|c|c|c|}
\hline \multicolumn{7}{|c|}{ CUADRO 3} & \\
\hline Censo & Total & Americano & & Europeos & & Otros & \\
\hline & Número & & $\%$ & Número & $\%$ & Número & $\%$ \\
\hline 1869 & 210.330 & 42.904 & 20,4 & 166.556 & 79,2 & 870 & 0,4 \\
\hline 1895 & 1.006 .838 & 118.068 & 11,7 & 881.121 & 87,5 & 7.649 & 0.8 \\
\hline 1914 & 2.391 .171 & 213.686 & 8,9 & 2.108 .261 & 88,2 & 69.224 & 2,9 \\
\hline
\end{tabular}

\begin{tabular}{|c|c|c|c|c|c|}
\hline \multicolumn{6}{|c|}{ CUADRO 4} \\
\hline \multirow[t]{3}{*}{ Censo } & \multirow[t]{3}{*}{ Total } & \multicolumn{3}{|c|}{ Población } & \multirow[b]{3}{*}{$\%$} \\
\hline & & \multicolumn{2}{|l|}{ Urbana } & Rural & \\
\hline & & Número & $\%$ & Número & \\
\hline 1869 & 1.737 .076 & 496.680 & 28,6 & 1.240 .396 & 71,4 \\
\hline 1895 & 3.954 .911 & 1.479 .452 & 37,4 & 2.475 .459 & 62,6 \\
\hline 1914 & 7.885 .237 & 4.157 .370 & 52,7 & 3.727 .867 & 47,5 \\
\hline at & os nacior & poblacic & & & \\
\hline
\end{tabular}

${ }^{236}$ CEAL, vol. 5, p.223

${ }^{237}$ CEAL, vol.5, p. 224 


\begin{tabular}{|c|c|c|c|c|c|}
\hline \multicolumn{5}{|c|}{ CUADRO 5} & \\
\hline \multirow[t]{2}{*}{ Censo } & \multirow[t]{2}{*}{ Total } & \multirow[t]{2}{*}{ Argentinos } & \multicolumn{2}{|l|}{ Extranjeros } & \multirow[b]{2}{*}{$\%$} \\
\hline & & & Número & & \\
\hline \multirow[t]{3}{*}{ 1869: } & TOTAL & 1.737 .076 & 1.526 .746 & 210.330 & 12,1 \\
\hline & Varones & 891.675 & 741.346 & 150.329 & 16,9 \\
\hline & Mujeres & 845.401 & 785.400 & 60.001 & 7,1 \\
\hline \multicolumn{2}{|c|}{ Tasas de masculinidad } & 105,5 & 94,4 & 250,5 & \\
\hline \multirow[t]{3}{*}{ 1895: } & TOTAL & 3.954 .911 & 2.948 .073 & 1.006 .838 & 25,5 \\
\hline & Varones & 2.088 .919 & 1.450 .838 & 638.081 & 30,5 \\
\hline & Mujeres & 1.855 .992 & 1.497 .235 & 368.757 & 19,8 \\
\hline \multicolumn{2}{|c|}{ Tasas de masculinidad } & 111,9 & 97,0 & 173,0 & \\
\hline \multirow[t]{3}{*}{ 1914: } & TOTAL & 7.885 .237 & 5.494 .066 & 2.391 .171 & 30,3 \\
\hline & Varones & 4.227 .023 & 2.719 .995 & 1.507 .028 & 35,7 \\
\hline & Mujeres & 3.658 .214 & 2.774 .071 & 884.143 & 24,2 \\
\hline \multicolumn{2}{|c|}{ Tasas de masculinidad } & 105,1 & 100,1 & 138,5 & \\
\hline
\end{tabular}

${ }^{238}$ CEAL, vol.5, p. 224 